\title{
Savannah River Site Environmental Report for 1999
}

by

M. Arnett

Westinghouse Savannah River Company

Savannah River Site

Aiken, South Carolina 29808

A. Mamatey

This paper was prepared in connection with work done under the above contract number with the U.S. Department of Energy. By acceptance of this paper, the publisher and/or recipient acknowledges the U.S.

Government's right to retain a nonexclusive, royalty-free license in and to any copyright covering this paper, along with the right to reproduce and to authorize others to reproduce all or part of the copyrighted paper. . 
MECEIVED

OCT 132000

\& STI

\section{Savannah River Site}

\section{Environmental Report for 1999}

Editors

Margaret W. Arnett

Albert R. Mamatey 


\section{Can We Make This Report More Useful to You?}

We want to make the Savannah River Site Environmental Report more useful to its readers. Please take a few minutes to let us know if the report meets your needs. Then fold and tape this page so the postage-paid notation and the mailing address are visible, and place it in the mail.

1. How do you use the Savannah River Site Environmental Report?

$\square$ to learn general information about the Savannah River Site

$\square$ to learn about doses received for the current year

$\square$ to learn about site compliance information

$\square$ to gather effluent data

$\square$ to gather environmental surveillance data

$\square$ other

2. What part(s) of this report do you use?
main report
$\square$ data book
summary pamphlet

3. Does the Savannah River Site Environmental Report contain

enough detail?

$\square$ too much detail? For example,

$\square$ too little detail? For example,

4. Is this report

$\square$ too technical?

about right technically?

not technical enough?

5. If you could change this report to make it more readable and useful to you, what would you change?

6. What is your affiliation?
DOE Headquarters
other DOE facility
$\square$ regulator
$\square$ other government office/agency
$\square$ environmental group
$\square$ elected official
$\square$ university/academy
$\square$ library/public reading room
$\square$ media
$\square$ industry
$\square$ other group
other individual

7. To help us identify our audience, please indicate your educational background.
$\square$ graduate degree in scientific field
$\square$ graduate degree in nonscientific field
$\square$ undergraduate degree in scientific field
$\square$ undergraduate degree in nonscientific field
$\square$ experience with science outside college setting
$\square$ little or no scientific background

If you are interested in attending a workshop to critique the 1999 report, please provide your name, address, and telephone number.

For more information, please call Bob Lorenz, Manager - Environmental Sampling and Reporting, at 803-725-3556, or send an e-mail message to robert.lorenz@srs.gov.

Savannah River Site Environmental Report for 1999 (WSRC-TR-99-00299) 


\section{DISCLAIMER}

This report was prepared as an account of work sponsored by an agency of the United States Government. Neither the United States Government nor any agency thereof, nor any of their employees, makes any warranty, express or implied, or assumes any legal liability or responsibility for the accuracy, completeness, or usefulness of any information, apparatus, product or process disclosed, or represents that its use would not infringe privately owned rights. Reference herein to any specific commercial product, process or service by trade name, trademark, manufacturer, or otherwise does not necessarily constitute or imply its endorsement, recommendation, or favoring by the United States Government or any agency thereof. The views and opinions of authors expressed herein do not necessarily state or reflect those of the United States Government or any agency thereof.

This report has been reproduced directly from the best available copy.

Available for sale to the public, in paper, from: U.S. Department of Commerce, National Technical Information Service, 5285 Port Royal Road, Springfield, VA 22161

phone: (800) 553-6847

fax: (703) $605-6900$

. email: orders@ntis.fedworld.gov ·

online ordering: http://www.ntis.gov/ordering.htm

Available electronically at http://www.doe.gov/bridge

Available for a processing fee to U.S. Department of Energy and its contractors, in paper, from: U.S. Department of Energy, Office of Scientific and Technical Information, P.O. Box 62, Oak Ridge, TN 37831-0062 phone: (865)576-8401

fax: (865)576-5728

email: reports@adonis.osti.gov 


\section{DISCLAIMER}

\section{Portions of this document may be illegible in electronic image products. Images are produced from the best available original document.}




\section{Acknowledgments}

- The editors acknowledge with deep appreciation the efforts of the following individuals, who-in addition to the chapter authors and compilers-reviewed and/or contributed valuable resources, information, or technical data to the Savannah River Site Environmental Report for 1999:

$\begin{array}{llll}\text { Linda Basinger } & \text { Robin Davis } & \text { Bobby James } & \text { Lindy Nowak } \\ \text { Janice Baynham } & \text { Chuck Dynarski } & \text { Mary Jamison } & \text { Matt Parker } \\ \text { Steve Bingham } & \text { Teresa Eddy } & \text { Paul Johns } & \text { Priscilla Patterson } \\ \text { Jim Bollinger } & \text { Dave Filler } & \text { Larry Koffman } & \text { Kevin Scaggs } \\ \text { Horace Bledsoe } & \text { Lynne Geary } & \text { Donna Martin } & \text { David Scott } \\ \text { Palmer Bowen } & \text { Bill Giddings } & \text { Robyn McBeath } & \text { Joe Shake } \\ \text { Sandra Boynton } & \text { Susie Grant } & \text { Larry McCollum } & \text { Barry Shedrow } \\ \text { de'Lisa Bratcher } & \text { Ferris Gunnels } & \text { Frank Melendez } & \text { Bob Steitler } \\ \text { Richard Brooks } & \text { John Haselow } & \text { Hal Morris } & \text { Roger Thomas } \\ \text { Chuck Brown } & \text { Robert Kemmerlin } & \text { Charles Murphy, Jr. } & \text { Gary Wein } \\ \text { Charlene Cochran } & \text { Chuck Hunter } & \text { Jim Novak } & \text { George Wingard } \\ \text { Brent Daugherty } & \text { Corn } & \text { Ker Carting }\end{array}$

Environmental Advisory Committee: Dr. Edgar Berkey, Dr. Keros Cartwright, Dr. Bernd Kahn, Dr. Dennis Paustenbach, Dr. Milton Russell, Dr. Bernard Sweeney, and Dr. Gordon Wolman

- Listed below are those who provided expert publications support.

$\begin{array}{lll}\text { Alan Clayton, } & \text { Steve Ashe, } & \text { Bernadette Hobbs } \\ \text { Stephanie Doetsch, } & \text { Bruce Boulineau, } & \text { and Icy Welcher } \\ \text { Lisa McCullough, } & \text { Ruth Hooper, } & \text { (customer service) } \\ \text { Ann Moser, } & \text { Emily Rooks, } & \text { Lynn Gleason } \\ \text { Yvonne Nixon, } & \text { Hugh Smith, } & \text { and Cherry Glisson } \\ \text { and Joan Toole } & \text { and Byron Williams } & \text { (forms) } \\ \text { (printing) } & \text { (photography) } & \end{array}$

Dennis Hendrix and Eleanor Justice (illustrating)

- A special thanks to Mary Baranek for coordinating the DOE-SR review and approval process. This process requires dedication and support from both DOE-SR and WSRC.

$\begin{array}{llll}\text { Ben Gould (DOE-SR) } & \text { Trish Baughman } & \text { Tom Coughenour } & \text { Sharon Lybrand } \\ \text { Mina Perrin (DOE-SR) } & \text { (WSRC) } & \text { (WSRC) } & \text { (WSRC) } \\ \text { Gail Whitney } & \text { Brent Blunt (WSRC) } & \text { Pat Dominey (WSRC) } & \text { Bart Marcy (WSRC) } \\ \text { (DOE-SR) } & \text { Randy Collins (WSRC) } & \text { Juli Hearn (WSRC) } & \text { Bob Shankle (WSRC) }\end{array}$

- Thanks to Karl Bergmann, John Ellinger, Chuck Harvel, Tracey Humphrey, and Marvin Stewart for providing computer support.

- Gratitude is expressed to the following for management, administrative, and other support:

$\begin{array}{llll}\text { Brenda Alejo } & \text { Tim Hartley } & \text { David Hughey } & \text { Mark Spires } \\ \text { Perry Allen } & \text { Jim Heffner } & \text { Jay Hutchison } & \text { Becky Sturdivant } \\ \begin{array}{l}\text { Daryl Doman } \\ \text { June Hall }\end{array} & \text { Dean Hoffman } & \text { Bob Lorenz } & \text { Brenda Walker } \\ \text { Calvin Hamilton } & \text { Tom Huckabee } & \text { Wayne Pippen } & \text { Robin Young }\end{array}$


The Savannah River Site Environmental Report for 1999 is prepared for the U.S. Department of Energy (DOE) according to requirements of DOE Order 231.1, "Environment, Safety and Health Reporting." The report's purpose is to

- present summary environmental data that characterize site environmental management performance

- confirm compliance with environmental standards and requirements

- highlight significant programs and efforts

- assess the impact of SRS operations on the public and the environment

SRS has had an extensive environmental monitoring program in place since 1951 (before site startup). In the 1950 s, data generated by the onsite environmental monitoring program were reported in site documents. Beginning in 1959, data from offsite environmental surveillance activities were presented in reports issued for public dissemination. SRS reported onsite and offsite environmental monitoring activities separately until 1985 , when data from both programs were merged into one public document.

The Savannah River Site Environmental Report for 1999 is an overview of effluent monitoring and environmental surveillance activities conducted on and in the vicinity of SRS from January 1 through December 31, 1999. It is prepared by the Environmental Monitoring Section (EMS) of Westinghouse Savannah River Company (WSRC). The "SRS Environmental Monitoring Plan" (WSRC-3Q1-2-1000) and the "SRS Environmental Monitoring Program" (WSRC-3Q1-2-1100) provide complete program descriptions and document the rationale and design criteria for the monitoring program, the frequency of monitoring and analysis, the specific analytical and sampling procedures, and the quality assurance requirements.

Variations in the environmental report's data content from year to year reflect changes in the routine program or difficulties encountered in obtaining or analyzing some samples. Examples of such problems include adverse environmental conditions (such as flooding or drought), sampling or analytical equipment malfunctions, and compromise of the samples in the preparation laboratories or counting room.

\section{Report Documents Available on Web \\ Readers can now find the SRS Environmental Report-as well as the accompanying data book and summary - on the World Wide Web.}

The address for access to these documents on the Web is as follows:

http://www.srs.gov/general/srenviro/endrpt/index.html

To inquire about the report documents, or to request hard copies, please contact

Bob Lorenz, Manager

Environmental Sampling and Reporting

Westinghouse Savannah River Company

Building 735-16A

Aiken, SC 29808

Telephone: (803) 725-3556

E-mail address: robert.lorenz@srs.gov

Unless otherwise indicated, the figures and tables in this report are generated using results from the routine monitoring program. No attempt has been made to include all data from environmental research programs. A more complete listing of data can be found in Savannah River Site Environmental Data for 1999 (WSRC-TR-99-00301).

The following information should aid the reader in interpreting data in this report:

- Analytical results and their corresponding uncertainty terms generally are reported with up to three significant figures. This is a function of the computer software used and may imply greater accuracy in the reported results than the analyses would allow.

- Units of measure and their abbreviations are defined in the glossary (beginning on page 239) and in charts at the back of the report.

- The reported uncertainty of a single measurement reflects only the counting error-not other components of random and systematic error in the measurement process-so some results may imply a greater confidence than the determination would suggest.

- An uncertainty quoted with means represents the standard deviation of the mean value. This number is calculated from the results themselves and is not weighted by the uncertainties of the individual results.

- All values represent the weighted average of all acceptable analyses of a sample for a particular 
analyte. Samples may have undergone multiple analyses for quality assurance purposes or to determine if radionuclides are present. For certain radionuclides, quantifiable concentrations may be below the minimum detectable activity of the analysis, in which case the actual concentration value is presented to satisfy $\mathrm{DOE}$ reporting guidelines.

- The generic term "dose," as used in the report, refers to the committed effective dose equivalent (50-year committed dose) from internal deposition of radionuclides and to the effective dose equivalent attributable to beta/gamma radiation from sources external to the body. 


\section{Contents}

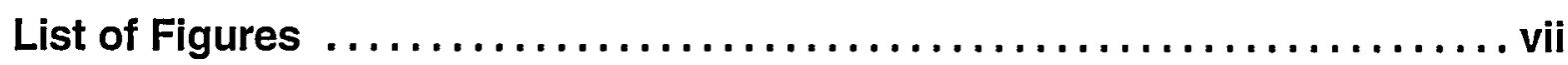

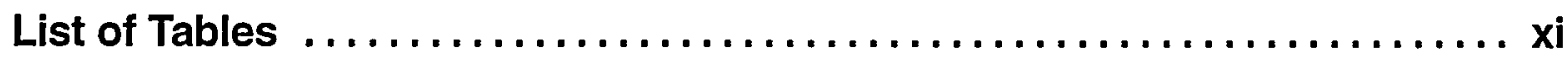

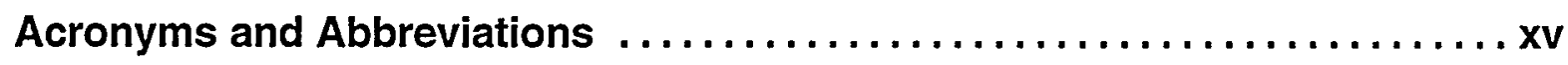

Sampling Location Abbreviations $\ldots \ldots \ldots \ldots \ldots \ldots \ldots \ldots \ldots \ldots \ldots \ldots \ldots \ldots \ldots$

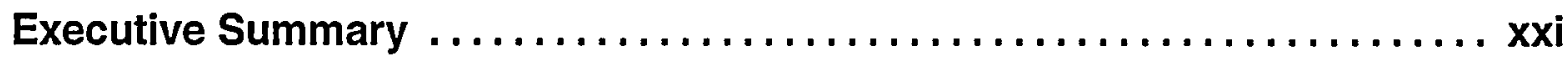

Potential Radiation Doses $\ldots \ldots \ldots \ldots \ldots \ldots \ldots \ldots \ldots \ldots \ldots \ldots \ldots \ldots \ldots \ldots \ldots \ldots \ldots \ldots$

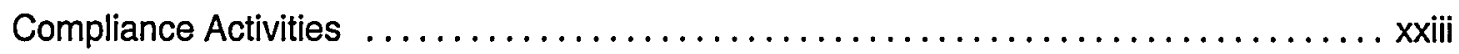

Radiological Effluent Monitoring $\ldots \ldots \ldots \ldots \ldots \ldots \ldots \ldots \ldots \ldots \ldots \ldots \ldots \ldots \ldots \ldots \ldots \ldots$

Radiological Environmental Surveillance $\ldots \ldots \ldots \ldots \ldots \ldots \ldots \ldots \ldots \ldots \ldots \ldots \ldots \ldots \ldots$

Nonradiological Effluent Monitoring $\ldots \ldots \ldots \ldots \ldots \ldots \ldots \ldots \ldots \ldots \ldots \ldots \ldots \ldots \ldots \ldots$

Nonradiological Environmental Surveillance $\ldots \ldots \ldots \ldots \ldots \ldots \ldots \ldots \ldots \ldots \ldots \ldots \ldots \ldots \ldots$

Groundwater $\ldots \ldots \ldots \ldots \ldots \ldots \ldots \ldots \ldots \ldots \ldots \ldots \ldots \ldots \ldots \ldots \ldots \ldots \ldots \ldots \ldots \ldots \ldots$

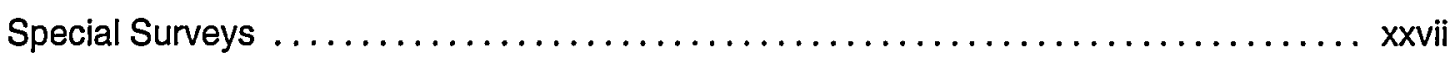

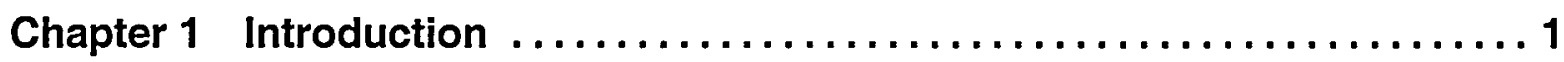

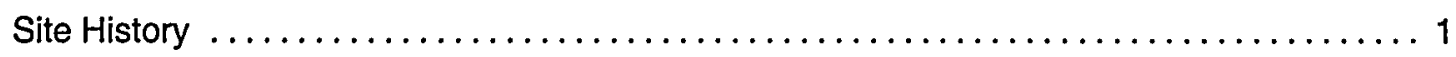

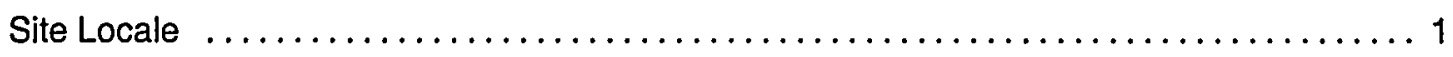

Site Mission ................................................ 5

Site Areas (Including Major Facilities, Operations, and Activities) $\ldots \ldots \ldots \ldots \ldots \ldots \ldots 5$

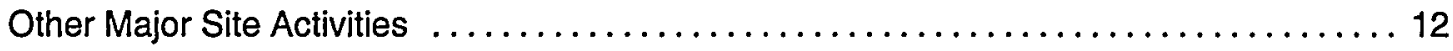

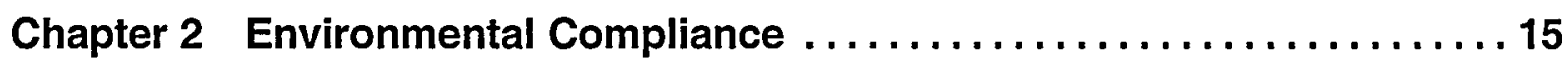

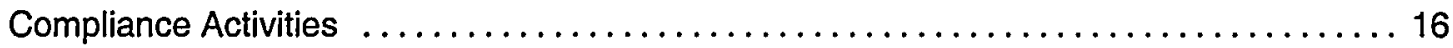

Environmental Release Response and Reporting $\ldots \ldots \ldots \ldots \ldots \ldots \ldots \ldots \ldots \ldots \ldots$

Assessments/Inspections . . . . . . . . . . . . . . . . . . . . . . . . . . . . 36

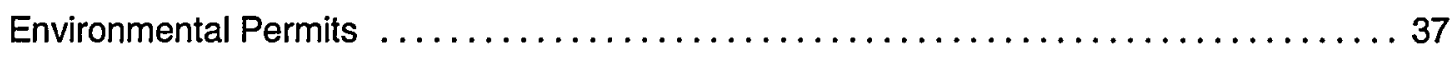

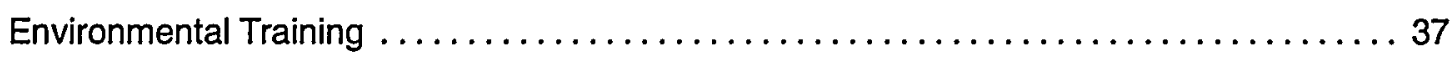

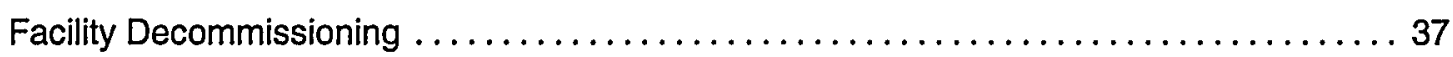

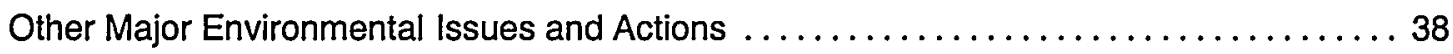


Chapter 3 Environmental Program Information $\ldots \ldots \ldots \ldots \ldots \ldots \ldots . \ldots 4$

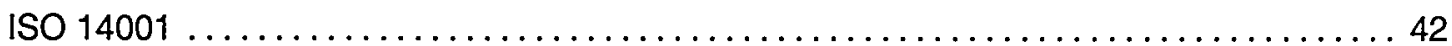

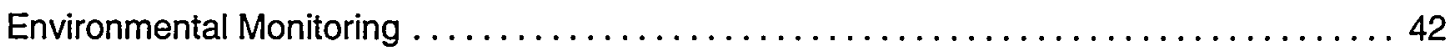

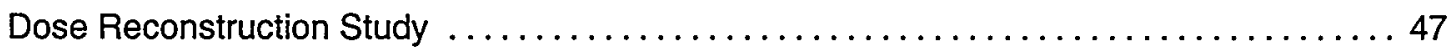

Pollution Prevention . . . . . . . . . . . . . . . . . . . . . . . . . . . . . . . . . . . 47

Public Involvement .......................................... 49

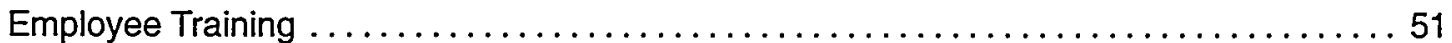

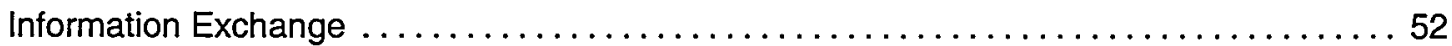

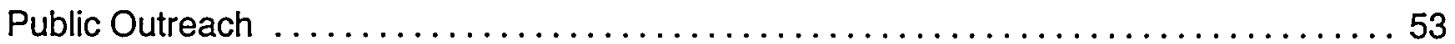

Chapter 4 Environmental Management $\ldots \ldots \ldots \ldots \ldots \ldots \ldots \ldots \ldots \ldots \ldots$

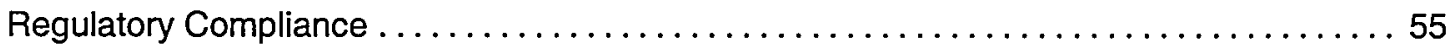

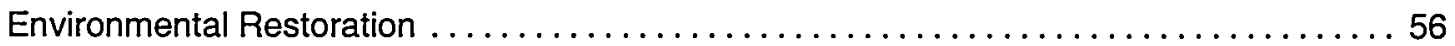

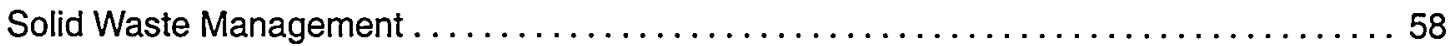

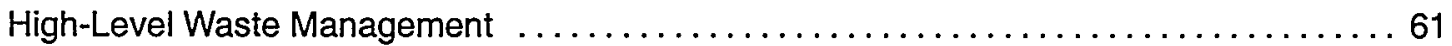

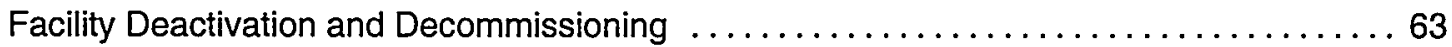

Chapter 5 Radiological Effluent Monitoring $\ldots \ldots \ldots \ldots \ldots \ldots \ldots \ldots \ldots$

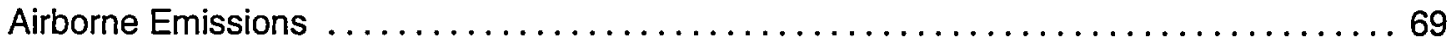

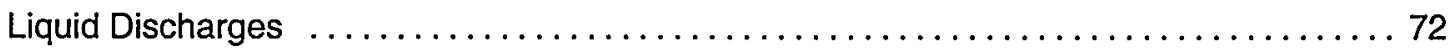

Chapter 6 Radiological Environmental Surveillance $\ldots \ldots \ldots \ldots \ldots \ldots \ldots 79$

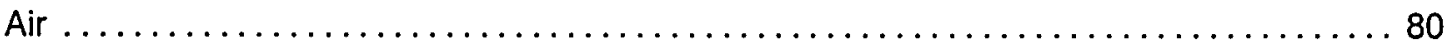

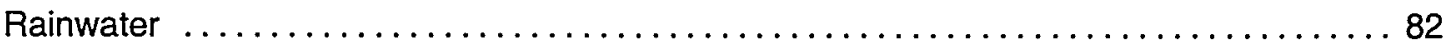

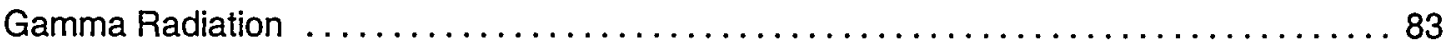

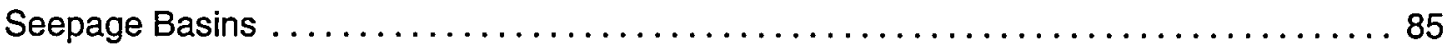

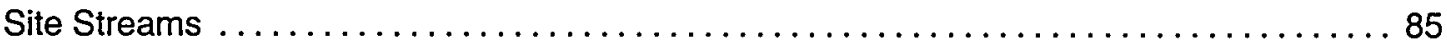

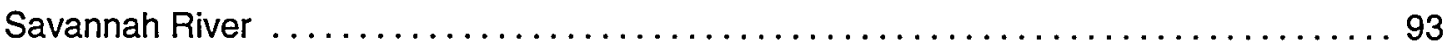

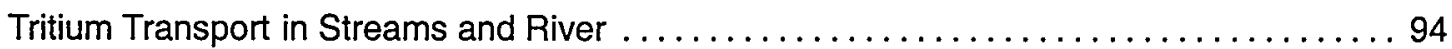

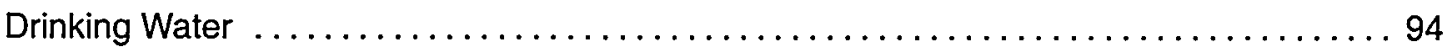

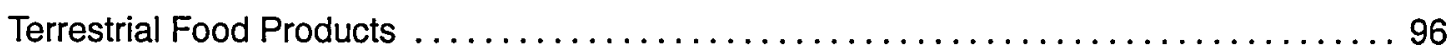

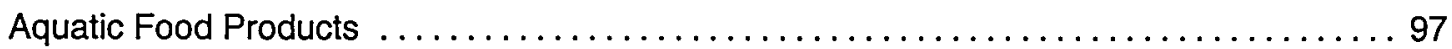

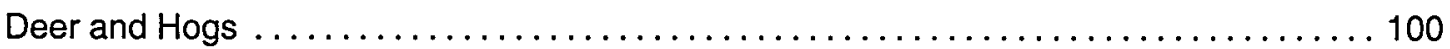

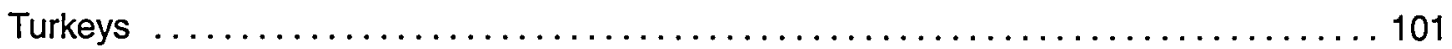

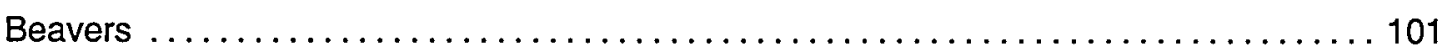

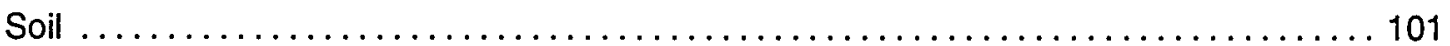




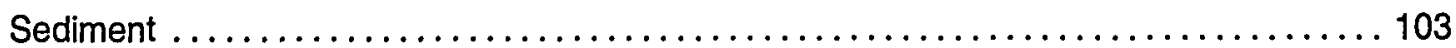

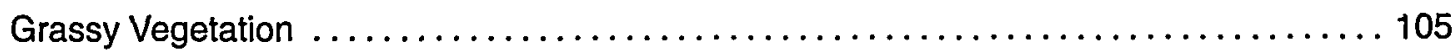

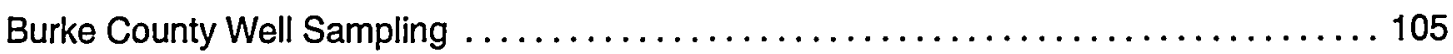

Chapter 7 Potential Radiation Doses ....................... 109

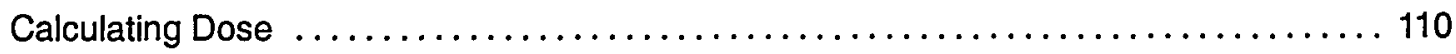

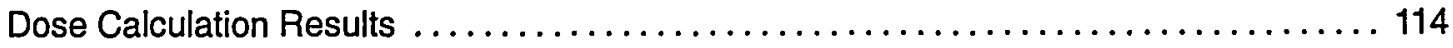

Radiological Assessment Program $\ldots \ldots \ldots \ldots \ldots \ldots \ldots \ldots \ldots \ldots \ldots \ldots \ldots \ldots \ldots \ldots \ldots \ldots$

Chapter 8 Nonradiological Effluent Monitoring $\ldots \ldots \ldots \ldots \ldots \ldots \ldots \ldots 129$

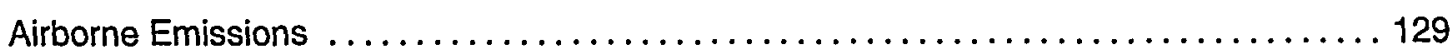

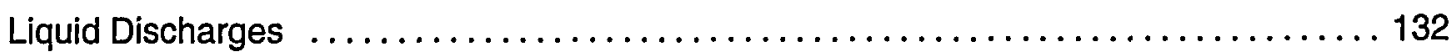

Chapter 9 Nonradiological Environmental Surveillance ........... 137

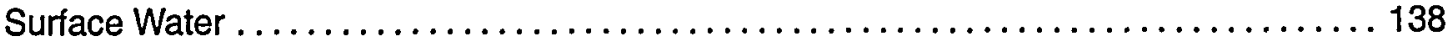

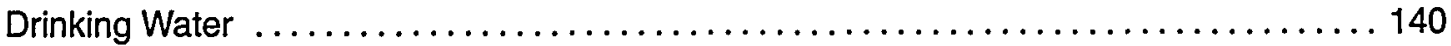

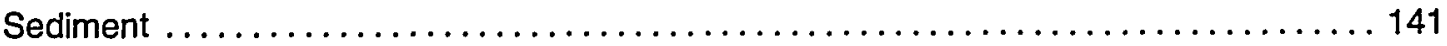

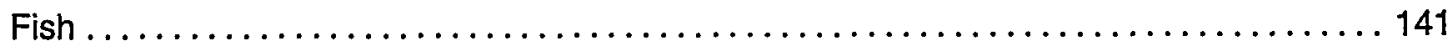

Academy of Natural Sciences of Philadelphia Surveys . . . . . . . . . . . . . . 145

Chapter 10 Groundwater .............................. 155

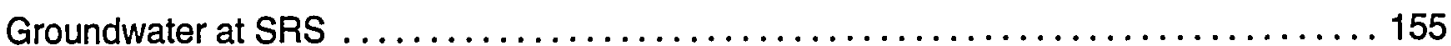

Description of the Groundwater Monitoring Program . . . . . . . . . . . . . . 159

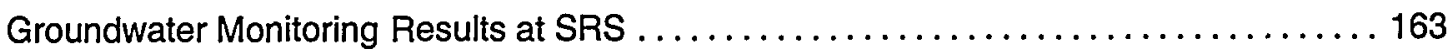

Chapter 11 Quality Assurance . . . . . . . . . . . . . . . . . . . 195

QAQC for Environmental Monitoring Section Laboratories $\ldots \ldots \ldots \ldots \ldots \ldots \ldots \ldots .196$

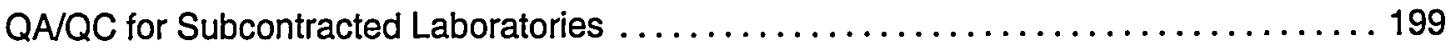

Chapter 12 Special Surveys and Projects ................... 205

Mitigation Action Plan for Pen Branch Reforestation . . . . . . . . . . . . . . 205

Academy of Natural Sciences of Philadelphia River Quality Survey .............. 208

Savannah River Swamp Survey $\ldots \ldots \ldots \ldots \ldots \ldots \ldots \ldots \ldots \ldots \ldots \ldots \ldots \ldots . \ldots \ldots . \ldots \ldots$

Appendix A Applicable Guidelines, Standards, and Regulations . . . . 211

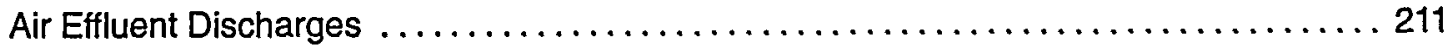

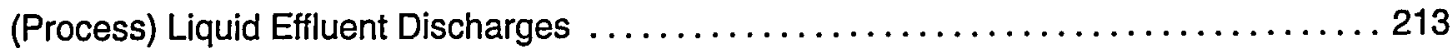




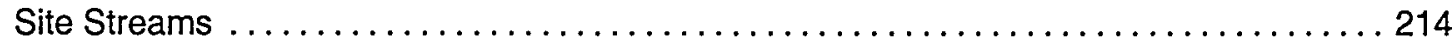

Savannah River $\ldots \ldots \ldots \ldots \ldots \ldots \ldots \ldots \ldots \ldots \ldots \ldots \ldots \ldots \ldots \ldots \ldots \ldots \ldots \ldots \ldots, 214$

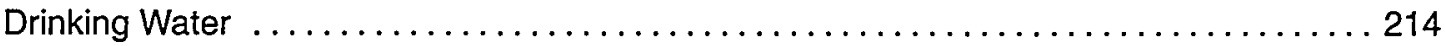

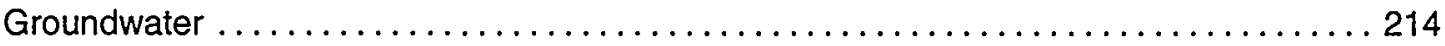

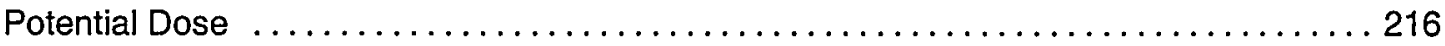

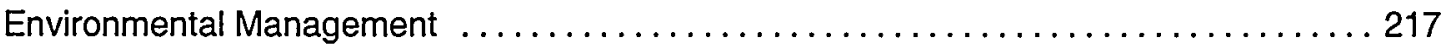

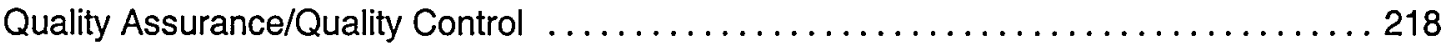

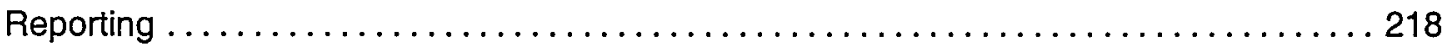

ISO 14001 Environmental Management System ........................ 219

Appendix B Drinking Water Standards for Regulated Contaminants . . . 221

Appendix C Standard No. 8 Toxic Air Pollutants ................. 225

Appendix D Radionuclide and Chemical Nomenclature $\ldots . \ldots . \ldots .233$

Appendix E Errata from 1998 Report $\ldots \ldots \ldots \ldots \ldots \ldots \ldots \ldots \ldots \ldots . \ldots \ldots$

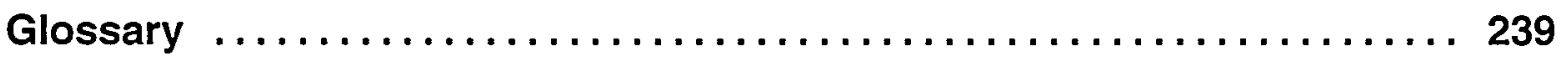

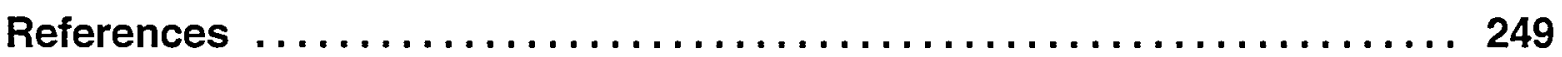

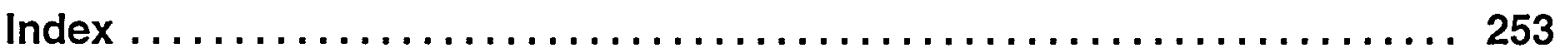




\section{List of Figures}

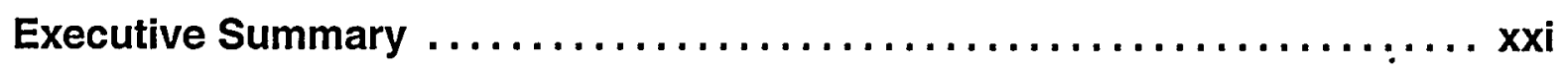

Figure 1 Ten-Year History of SRS Potential All-Pathway Doses to the

Maximally Exposed Individual (Airborne plus Liquid Pathways) .......... xxiii

Figure 2 Ten-Year History of SRS Annual Atmospheric Tritium Releases $\ldots \ldots \ldots \ldots x \mathrm{xx}$

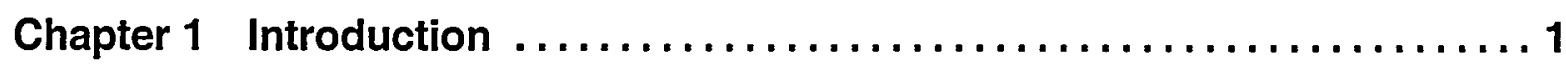

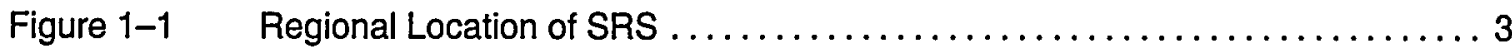

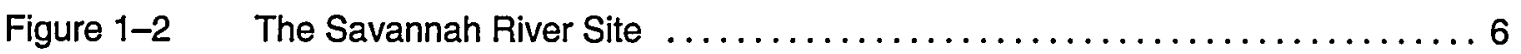

Chapter 2 Environmental Compliance ....................... 15

Figure 2-1 Total Toxic Chemical Releases at SRS, $1988-1998 \ldots \ldots \ldots \ldots \ldots \ldots \ldots 21$

Chapter 3 Environmental Program Information $\ldots \ldots \ldots \ldots \ldots \ldots \ldots \ldots 41$

Figure 3-1 Typical Liquid Effluent Monitoring and Environmental Surveillance ........44

Figure $3-2 \quad$ Some Potential Exposure Pathways ....................... 46

Chapter 4 Environmental Management $\ldots \ldots \ldots \ldots \ldots \ldots \ldots \ldots \ldots \ldots \ldots$

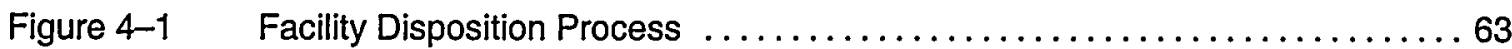

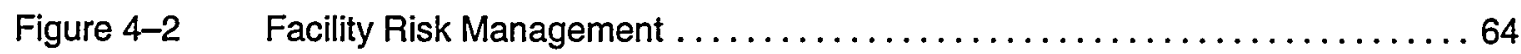

Chapter 5 Radiological Effluent Monitoring .....................69

Figure 5-1 Ten-Year History of SRS Annual Atmospheric Tritium Releases .......... 72

Figure 5-2 Direct Releases of Tritium to SRS Streams, $1990-1999 . \ldots \ldots \ldots . . . . . .74$

Chapter 6 Radiological Environmental Surveillance ................. 79

Figure $6-1 \quad$ Radiological Air Surveillance Sampling Locations $\ldots \ldots \ldots \ldots \ldots \ldots \ldots . \ldots 1$

Figure 6-2 Average Concentration of Tritium in Rainwater $\ldots \ldots \ldots \ldots \ldots \ldots \ldots \ldots$

Figure 6-3 Annual Average and Maximum Gamma Exposure Grouped

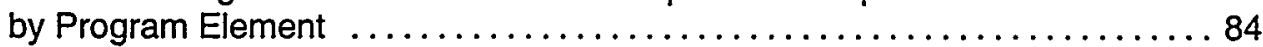

Figure $6-4 \quad$ Radiological Surface Water Sampling Locations $\ldots \ldots \ldots \ldots \ldots \ldots \ldots . \ldots 6$

Figure 6-5 Average Tritium Concentration in SRS Streams, $1990-1999 . \ldots \ldots \ldots \ldots . .88$

Figure 6-6 Radioactive-Material Trends in SRS Streams, $1995-1999$. . . . . . . . . . . . 89

Figure 6-7 Tritium Migration from Seepage Basins and SWDF to SRS Streams,

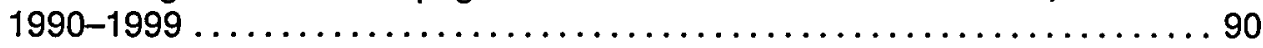

Figure 6-8 Total Tritium Releases to SRS Streams (Direct Discharges and Migration), 1990-1999, Based on Point-of-Release Concentrations and Flow Rates .... 91

Figure 6-9 Tritium Migration Releases to Upper Three Runs from the General Separations Area and SWDF, 1990-1999 ............... 92 
Figure 6-10 SRS Tritium Transport Summary, 1960-1999 ................... 95

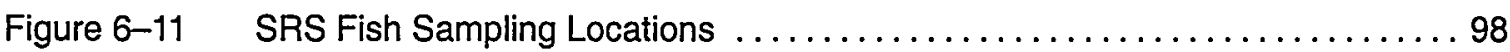

Figure $6-12$ Radiological Soil Sampling Locations ........................ 102

Figure 6-13 Radiological Sediment Sampling Locations ..................... 104

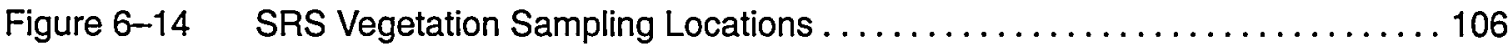

Figure $6-15 \quad$ Burke County Well Locations .......................... 107

Chapter 7 Potential Radiation Doses ............................ 109

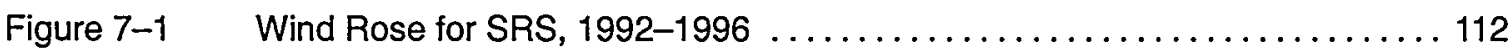

Figure 7-2 Savannah River Mile 120 Annual Average Flow Rates, 1954-1999 ....... 114

Figure 7-3 Annual Average Tritium Concentrations at River Mile 120,

Beaufort-Jasper, and Port Wentworth (1990-1999)

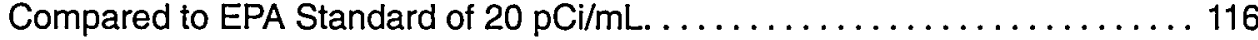

Figure 7-4 Sector-Specific Adult Maximally Exposed Individual Air Pathway Doses

(in mrem) for 1999 ........................................ 121

Figure 7-5 Ten-Year History of SRS Potential All-Pathway Doses to the Maximally Exposed Individual (Airborne plus Liquid Pathways) . . . . . . . 122

Figure 7-6 Contributions to the U.S. Average Individual Dose ................ 124

Figure 7-7 Annual Potential Radiation Doses from Consumption of Savannah River

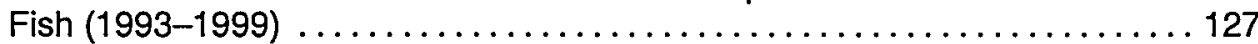

Chapter 8 Nonradiological Effluent Monitoring .................. 129

Figure $8-1 \quad$ NPDES Sampling Locations ............................ 133

Figure 8-2 History of NPDES Exceedances at SRS, and Site's Compliance Rate,

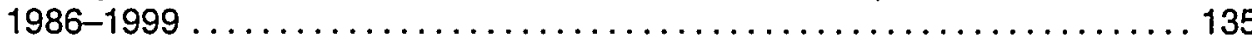

Chapter 9 Nonradiological Environmental Surveillance . ........... 137

Figure 9-1 Nonradiological Surface Water Sampling Locations ................... 139

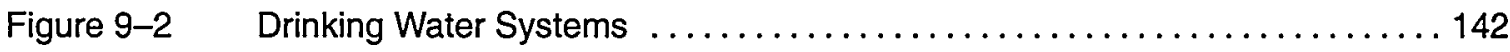

Figure 9-3 Nonradiological Sediment Sampling Locations . ..................... 143

Figure 9-4 Academy Survey Sampling Sites ........................ 146

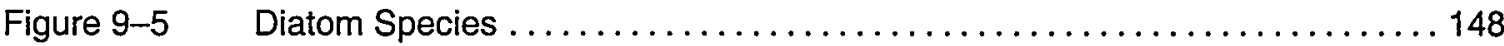

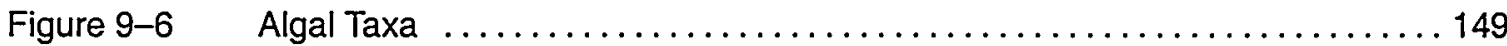

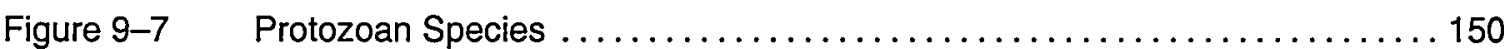

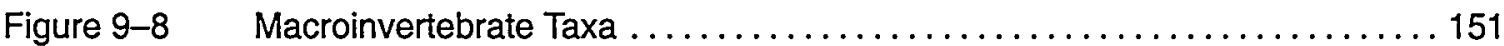

Figure 9-9 Insect Abundance (density per trap) ........................ 153

Chapter 10 Groundwater ................................ 155

Figure 10-1 Facilities Monitored by the SRS Monitoring Well Network, Including Areas Having Constituents Exceeding Drinking Water Standards in 1999 . . . . . . 156

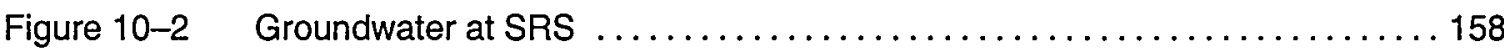


Figure 10-3 Potentiometric Surface and Horizontal Groundwater Flow Directions of the Middle Zone at SRS During the Second Quarter of 1999 ......... 160

Figure 10-4 Potentiometric Surface and Horizontal Groundwater Flow Directions of the Lower Zone at SRS During the Second Quarter of 1999

Figure 10-5 Extent of Volatile Organic Contamination of the Groundwater Beneath

A-Area and M-Area in 1999 and Location of Noteworthy Sources

of Contamination Exceeding Drinking Water Standards . . . . . . . . . 166

Figure 10-6 Trichloroethylene Concentrations in Well Cluster ASB $6 \ldots \ldots \ldots \ldots \ldots \ldots 7$

Figure 10-7 Extent of Tritium and Volatile Organic Contamination of the Groundwater Beneath C-Area in 1999 and Location of Noteworthy Sources

of Contamination Exceeding Drinking Water Standards

Figure 10-8 Extent of Volatile Organic Contamination of the Groundwater Beneath

D-Area and TNX in 1999 and Location of Noteworthy Sources

of Contamination Exceeding Drinking Water Standards

Figure 10-9 Extent of Tritium Contamination of the Groundwater Beneath the General

Separations and Waste Management Areas in 1999 and Location

of Noteworthy Sources of Contamination Exceeding

Drinking Water Standards

Figure 10-10 Gross Alpha Activities in Well Cluster FSB $95 \ldots \ldots \ldots \ldots \ldots \ldots \ldots \ldots \ldots 178$

Figure 10-11 Extent of Tritium and Volatile Organic Contamination of the Groundwater Beneath K-Area in 1999 and Location of Noteworthy Sources

of Contamination Exceeding Drinking Water Standards

Figure 10-12 Extent of Tritium and Volatile Organic Contamination of the Groundwater

Beneath L-Area and the Chemicals, Metals, and Pesticides Pits in 1999

and Location of Noteworthy Sources of Contamination Exceeding

Drinking Water Standards

Figure 10-13 Extent of Volatile Organic Contamination of the Groundwater Beneath

$\mathrm{N}$-Area in 1999 and Location of Noteworthy Sources of Contamination

Exceeding Drinking Water Standards

Figure 10-14 Extent of Tritium and Volatile Organic Contamination of the Groundwater

Beneath P-Area in 1999 and Location of Noteworthy Sources

of Contamination Exceeding Drinking Water Standards

Figure 10-15 Extent of Tritium Contamination of the Groundwater Beneath R-Area

in 1999 and Location of Noteworthy Sources of Contamination

Exceeding Drinking Water Standards . ...................... 190

Figure 10-16 Extent of Volatile Organic Contamination of the Groundwater Beneath

the Sanitary Landfill and B-Area in 1999 and Location of Noteworthy

Sources of Contamination Exceeding Drinking Water Standards

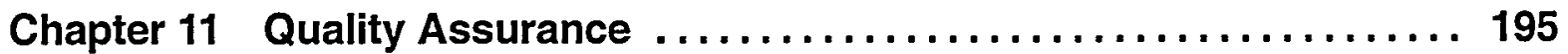

Figure $11-1 \quad$ SRS EM Program QA/QC Document Hierarchy $\ldots \ldots \ldots \ldots \ldots \ldots \ldots \ldots$

Chapter 12 Special Surveys and Projects . . . . . . . . . . . . . . 205

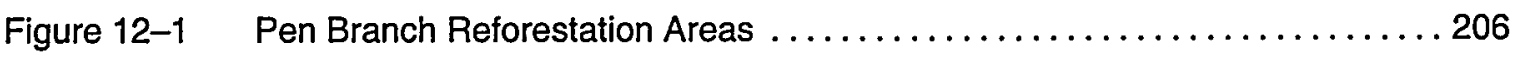

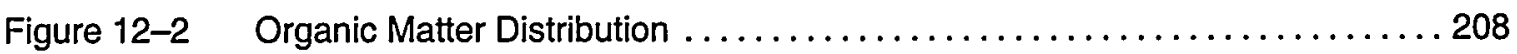





\section{List of Tables}

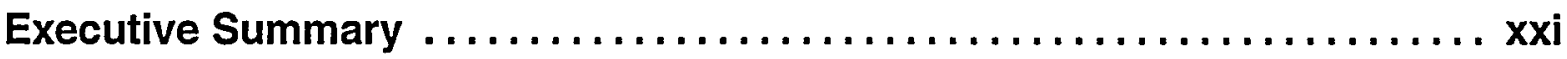

Table 1999 Potential Radiation Doses from SRS Releases Compared with Applicable Dose Standards and Estimated Doses from Naturally Occurring Radiation ............................. xxii

Chapter 2 Environmental Compliance ......................... 15

Table 2-1 Releases and Offsite Transfers of Toxic Chemicals (in Pounds) by SRS

During 1996, 1997, and 1998 Reporting Years

(Reported Under EPCRA Section 313) ...................... 22

Table 2-2 1999 SRS Reporting Compliance with Executive Order $12856 \ldots \ldots \ldots \ldots 23$

Table 2-3 Types/Quantity of NEPA Activities at SRS During $1999 \ldots \ldots \ldots \ldots \ldots . \ldots 23$

Table 2-4 SRS Project NEPA Documentation Activities During 1999 .............. 25

Table 2-5 CERCLA Releases Reported to Regulatory Agencies in 1999 . ......... 35

Table 2-6 Environmentally Related Unusual Occurrences Reported

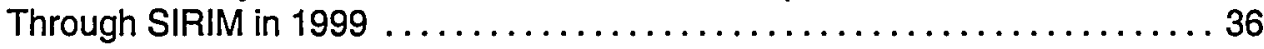

Table 2-7 SRS Construction and Operating Permits, $1995-1999 \ldots \ldots \ldots \ldots \ldots \ldots . \ldots 37$

Table 2-8 SRS 1999 Environmental Restoration Activities .................. 39

Chapter 5 Radiological Effluent Monitoring $\ldots \ldots \ldots \ldots \ldots \ldots \ldots \ldots \ldots 69$

Table 5-1 Radioactive Atmospheric Releases by Source $\ldots \ldots \ldots \ldots \ldots \ldots \ldots \ldots$

Table 5-2 Radioactive Liquid Releases by Source (Including Direct and Seepage Basin Migration Releases) $\ldots \ldots \ldots \ldots \ldots \ldots \ldots \ldots \ldots . \ldots \ldots$

\section{Chapter 6 Radiological Environmental Surveillance $\ldots \ldots \ldots \ldots \ldots \ldots \ldots 79$}

Table 6-1 Average Gross Alpha and Gross Beta Measured in Air (pCi/m3),

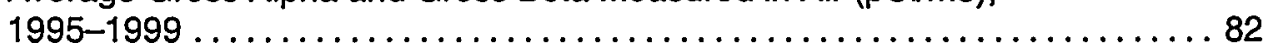

Table 6-2 TLD Surveillance Results Summary for $1999 \ldots \ldots \ldots \ldots \ldots \ldots \ldots \ldots$

Table 6-3 Average 1999 Concentration of Radioactivity in SRS and Surveillance Station Waters $(\mathrm{pCi} / \mathrm{L}) \ldots \ldots \ldots \ldots \ldots \ldots \ldots \ldots \ldots \ldots$

Table 6-4 Average 1999 Concentration of Radioactivity in the Savannah River (pCi/L) .. 93

Table 6-5 Tritium Concentrations in Burke County Wells Sampled for Tritium

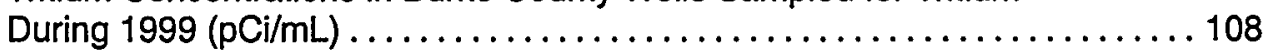

Chapter 7 Potential Radiation Doses ....................... 109

Table 7-1 1999 Radioactive Liquid Release Source Term and 12-Month Average Downriver Radionuclide Concentrations (Calculated Concentrations Are Based on Effective River Flow Rates) . . . . . . . . . . . . . . . . 115

Table 7-2 Potential Dose to the Maximally Exposed Individual from SRS Liquid Releases in $1999 \ldots \ldots \ldots \ldots \ldots \ldots \ldots \ldots \ldots \ldots \ldots$ 
Table 7-3 Ten-Year History of SRS Atmospheric Tritium and Tritium Oxide Releases and Average Measured Tritium Oxide Concentrations in Air Compared to Calculated Concentrations in Air . . . . . . . . . . . . . . . . . . . . . 119

Table 7-4 Potential Dose to the Maximally Exposed Individual from SRS Atmospheric Releases in 1999 ............................. 120

Table 7-5 1999 Maximum Potential All-Pathway and Sportsman Doses Compared to the DOE All-Pathway Dose Standard . . . . . . . . . . . . . . . . . . . . 123

Table 7-6 Potential Lifetime Risks from the Consumption of Savannah River Fish Compared to Dose Standards $(1993-1999)$..................... 126

Chapter 8 Nonradiological Effluent Monitoring .................. 129

Table 8-1 SRS Power Plant Boiler Capacities . . . . . . . . . . . . . . . . . . . . . . . . 131

Table 8-2 SRS Package Steam Boiler Capacities ........................ 131

Table 8-3 $\quad 1998$ Criteria Pollutant Air Emissions . . . . . . . . . . . . . . . . . . . . . . . 131

Table 8-4 1999 Exceedances of SCDHEC-Issued NPDES Permit

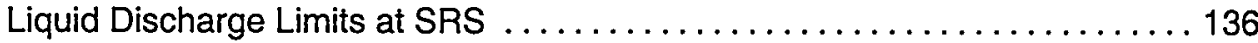

Chapter 9 Nonradiological Environmental Surveillance ............... 137

Table 9-1 Numbers of Macroinvertebrate Taxa in the Dominant Classes Collected by Hand from the Savannah River at Stations 1, 2B (1992, 1997, and 1998), 5, and 6 in August to October ..................... 152

Chapter 10 Groundwater ................................ 155

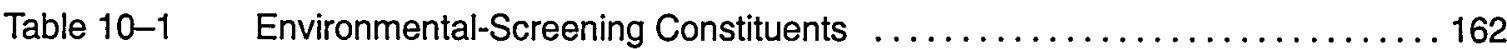

Table 10-2 Trichloroethylene Concentrations (in $\mathrm{mg} / \mathrm{L}$ ) in Selected M-Area Wells, 1995-1999 ............................................. 168

Table 10-3 Constituent Groups Above Drinking Water Standards at A-Area and M-Area, 1997-1999 .......................................... 169

Table 10-4 Constituent Groups Above Drinking Water Standards at C-Area, 1997-1999 ............................................. 170

Table 10-5 Trichloroethylene Concentrations (in $\mathrm{mg} / \mathrm{L}$ ) in Selected TNX Wells, 1995-1999 .............................................. 174

Table 10-6 Constituent Groups Above Drinking Water Standards at D-Area and TNX, 1997-1999 ........................................ 174

Table 10-7 Tritium Concentrations (in $\mu \mathrm{Ci} / \mathrm{mL}$ ) in Selected General Separations Area Wells, $1995-1999$. . . . . . . . . . . . . . . . . . . . . . . . . . . . . . . . . 179

Table 10-8 Constituent Groups Above Drinking Water Standards at the General Separations and Waste Management Areas, 1997-1999 . . . . . . 180

Table 10-9 Constituent Groups Above Drinking Water Standards at K-Area,

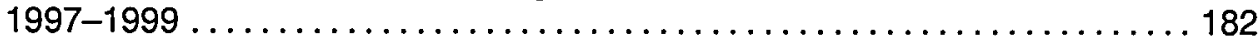

Table 10-10 Constituent Groups Above Drinking Water Standards at L-Area and the Chemicals, Metals, and Pesticides Pits, 1997-1999 185

Table 10-11 Constituent Groups Above Drinking Water Standards at N-Area,

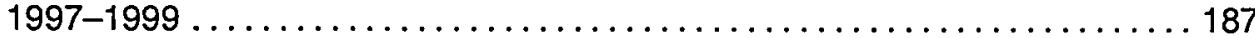

Table 10-12 Constituent Groups Above Drinking Water Standards at P-Area, 1997-1999 
Table 10-13 Constituent Groups Above Drinking Water Standards at R-Area, 1997-1999.

Table 10-14 Constituent Groups Above Drinking Water Standards at the Sanitary Landfill and B-Area, $1997-1999 \ldots \ldots \ldots \ldots \ldots \ldots \ldots \ldots . \ldots \ldots$

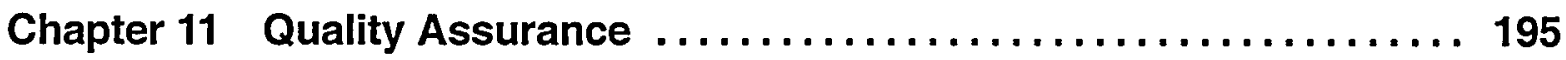

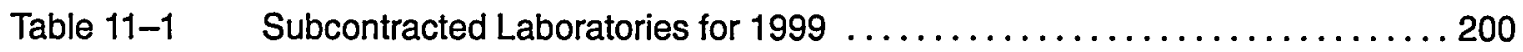

Table 11-2 Subcontract Laboratory Performance in ERA Water Pollution and Water Supply Studies . . . . . . . . . . . . . . . . . . . . . 203

Table 11-3 Subcontract Laboratory Performance on Environmental Resource Associates

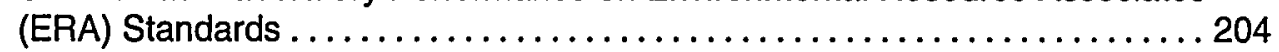

Applicable Guidelines, Standards, and Regulations $\ldots \ldots \ldots \ldots \ldots \ldots 211$

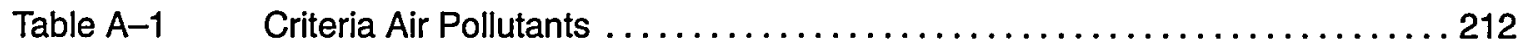

Table A-2 Airborne Emission Standards for SRS Coal-Fired Boilers . . . . . . . . . . . 212

Table A-3 Airborne Emission Standards for SRS Consolidated Incinerator Facility . . . 213

Table A-4 Airborne Emission Standards for SRS Fuel Oil-Fired Package Boilers . . ...213

Table A-5 South Carolina Water Quality Standards for Freshwaters . . . . . . . . . . . 215 



\section{Acronyms and Abbreviations}

A

ACPC - Accelerating Cleanup: Paths to Closure

AEC - U.S. Atomic Energy Commission

ALARA - As low as reasonably achievable

ANSP - Academy of Natural Sciences of

Philadelphia

APT - Accelerator for the Production of Tritium

AFS - Assets for Services

B

BTU - British Thermal Unit

C

CAA - Clean Air Act

CAAA - Clean Air Act Amendments of 1990

CAB - Citizens Advisory Board

CAS - Chemical abstract numbers

CDC - Centers for Disease Control and Prevention

CERCLA - Comprehensive Environmental Response, Compensation, and Liability Act (Superfund)

CFC - Chlorofluorocarbon

CFR - Code of Federal Regulations

CIF - Consolidated Incineration Facility

CMP - Chemicals, metals, and pesticides

COU-Catalytic oxidation unit

CSRA - Central Savannah River Area

CWA - Clean Water Act

CX-Categorical exclusion
D

DAS - Disposal Authorization Statement

D\&D - Deactivation and decommissioning

DCG - Derived concentration guide

DOE - U.S. Department of Energy

DOE/EML - U.S. Department of Energy

Environmental Measurements Laboratory

DOE-HQ - U.S. Department of Energy-Headquarters

DOE-SR - U.S. Department of Energy-Savannah

River Operations Office

DWPF - Defense Waste Processing Facility

DWS - Drinking water standards

E

EA-Environmental Assessment

ECA - Environmental Compliance Authority

EGG - Environmental Geochemistry Group

EIS - Environmental Impact Statement

EMCAP - Environmental Monitoring Computer Automation Program

EMS - Environmental Monitoring Section of the Environmental Protection Department (of

Westinghouse Savannah River Company)

EPA - U.S. Environmental Protection Agency

EPCRA - Emergency Planning and Community Right-to-Know Act

EPD - Environmental Protection Department (of Westinghouse Savannah River Company)

EPT - Ephemeroptera, Plecoptera, and Trichoptera

ERA - Environmental Resource Associates

ERD - Environmental Restoration Division

ESCO - Energy Services Company

ETF - Effluent Treatment Facility 
$\mathbf{F}$

FDD - Facilities Decommissioning Division

FFA - Federal Facility Agreement

FFCA - Federal Facility Compliance Agreement

FFCAct - Federal Facility Compliance Act

FONSI - Finding of No Significant Impact

G

GDNR - Georgia Department of Natural Resources

GPS/GIS - Global Positioning System/Geographic Information System

GOCO - Government-owned, contractor-operated

H

HBFC - Hydrobromofluorocarbon

HCFC - Hydrochlorofluorocarbon

HEAST - Health Effects Assessment Summary Tables (EPA)

HWMF - Hazardous Waste Management Facility

1

ICP - Inductively Conducted Plasma

ICRP - International Commission on Radiological

Protection

ISO - International Organization for Standardization

ITPF - In-Tank Precipitation Facility

$\mathbf{L}$

LDR - Land disposal restrictions

LETF - Liquid Effluent Treatment Facility

LLD - Lower limit of detection

LSDDP - Large-Scale Demonstration and

Deployment Project
MAP - Mitigation Action Plan

MDA - Minimum detectable activity

MDL - Minimum detectable limit

MRD - Mean relative difference

$\mathbf{N}$

NCRP - National Council on Radiation Protection and Measurements

NEPA - National Environmental Policy Act

NESHAP - National Emission Standards for Hazardous Air Pollutants

NHPA - National Historic Preservation Act

NIST - National Institute of Standards and Technology

NOV - Notice of Violation

NPDES - National Pollutant Discharge Elimination System

NSPS - New Standards of Performance for Stationary Sources

NWP - Nationwide permit

0

ODS - Ozone-depleting substances

ORWBG - Old Radioactive Waste Burial Ground

OWST - Organic Waste Storage Tank

$\mathbf{P}$

PAR Pond - Pond constructed at Savannah River Site in 1958 to provide cooling water for P-Reactor and $\mathrm{R}$-Reactor ( $\mathrm{P}$ and $\mathrm{R}$; hence, $\mathrm{PAR}$ )

PCB - Polychlorinated biphenyl

PEIS - Programmatic Environmental Impact Statement

$\mathrm{pH}-\mathrm{Measure}$ of the hydrogen ion concentration in an aqueous solution (acidic solutions, $\mathrm{pH}$ from 0-6; basic solutions, $\mathrm{pH}>7$; and neutral solutions, $\mathrm{pH}=7$

PUREX - Plutonium/uranium extraction (process) 
PVC - Polyvinyl chloride

Q

QA - Quality assurance

QAD - Quality Assurance Division (Environmental Protection Agency)

QAP - Quality Assurance Program (Department of Energy)

QAVQC - Quality assurance/quality control

QC - Quality control

$\mathbf{R}$

RBOF - Receiving Basin for Offsite Fuel

RCRA - Resource Conservation and Recovery Act

RFI/RI - RCRA Facility Investigation/Remedial Investigation

ROD - Record of Decision

$\mathbf{R Q}-$ Reportable quantity

RTF - Replacement Tritium Facility

$\mathbf{S}$

SARA - Superfund Amendments and Reauthorization Act

SCDHEC - South Carolina Department of Health and Environmental Control

SDWA - Safe Drinking Water Act

SEIS - Supplemental Environmental Impact

Statement

S\&HO - Safety and Health Operations

SIRIM - Site Item Reportability and Issues

Management

S\&M - surveillance and maintenance

SRARP - Savannah River Archaeological Research Program
SREL - Savannah River Ecology Laboratory

(University of Georgia)

SRI - Savannah River Natural Resource Management and Research Institute

SRIP - Savannah River Implementation Procedure

SRP - Savannah River Plant

SRS - Savannah River Site

SRTC - Savannah River Technology Center

STP - Site Treatment Plan

SUD - Site Utilities Division of Westinghouse

Savannah River Company

SVE - Soil vapor extraction

SWD - Solid Waste Division

SWDF - Solid Waste Disposal Facility

$\mathbf{T}$

TCLP - Toxicity Characteristic Leaching Procedure

TLD - Thermoluminescent dosimeter

TRAIN - Training Records and Information System

TRI - Toxic Release Inventory

TSCA - Toxic Substances Control Act

U

USGS - U.S. Geological Survey

V

VIA - Values Impact Assessments

VTF - Vendor Treatment Facility

W

WIPP - Waste Isolation Pilot Plant

WSI - Wackenhut Services, Inc.

WSRC - Westinghouse Savannah River Company 



\section{Sampling Location Abbreviations}

\begin{tabular}{|c|c|}
\hline Abbreviation & Location Name/Other Applicable Information \\
\hline $4 \mathrm{M}$ & Four Mile \\
\hline $4 \mathrm{MC}$ & Four Mile Creek \\
\hline $681-5 G$ & Georgia Department of Natural Resources/Environmental Monitoring Section site \\
\hline$A-14$ & Road A-14 \\
\hline AAP & Aiken Airport \\
\hline ATTA & Advanced Tactical Training Area \\
\hline AUG L\&D & Augusta Lock and Dam \\
\hline ALLEN & Allendale Gate \\
\hline BARN & Barnwell Gate \\
\hline $\mathrm{BDC}$ & Beaver Dam Creek \\
\hline$B G$ & Burial Ground \\
\hline BGN & Burial Ground North \\
\hline BGS & Burial Ground South \\
\hline CSWTF & Central Sanitary Wastewater Treatment Facility \\
\hline DARKH & Dark Horse \\
\hline E TAL & East Talatha \\
\hline FM & Four Mile \\
\hline FMC & Four Mile Creek (Fourmile Branch) \\
\hline GR PND & Green Pond \\
\hline HP & HP (sampling location designation only; not an actual abbreviation) \\
\hline HWY & Highway \\
\hline IBG & Indian Burial Ground \\
\hline IGB & Indian Grave Branch \\
\hline JACK & Jackson \\
\hline L3R & Lower Three Runs \\
\hline LSB & L-Area Seepage Basin \\
\hline LTR & Lower Three Runs \\
\hline NSB L\&D & New Savannah Bluff Lock \& Dam \\
\hline PB & Pen Branch \\
\hline PATT MR & Patterson Mill Road \\
\hline PMR & Patterson Mill Road \\
\hline PSB & P-Area Seepage Basin \\
\hline RM & River Mile \\
\hline SATA & Small Arms Training Area (pistol range) \\
\hline SAV 1 & Savannah 1 \\
\hline SAV 2 & Savannah 2 \\
\hline SC & Steel Creek \\
\hline SWDF & Solid Waste Disposal Facility \\
\hline TB & Tims Branch \\
\hline TC & Tinker Creek \\
\hline TCR & Tabernacle Church Road \\
\hline
\end{tabular}


Abbreviation Location Name/Other Applicable Information (continued)

\begin{tabular}{ll}
\hline TNX & Muitipurpose Pilot Plant Campus \\
U3R & Upper Three Runs \\
UTR & Upper Three Runs \\
WIND & Windsor Road \\
W JACK & West Jackson
\end{tabular}

Sampling Locations Known By More Than One Abbreviation

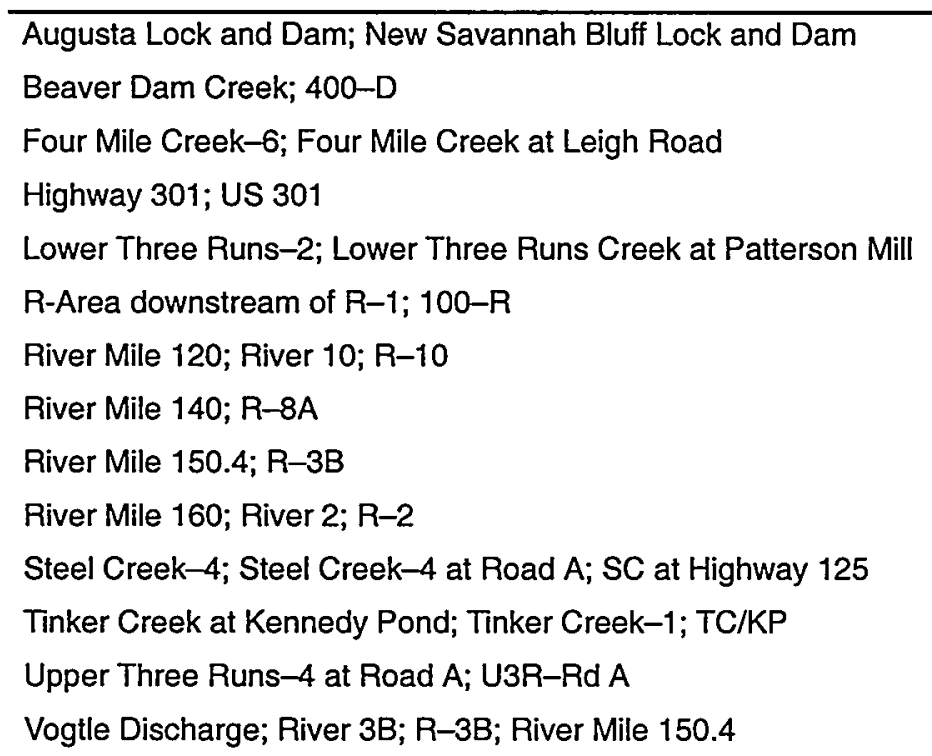




\section{Executive Summary}

$\mathrm{T}$ HE mission at the Savannah River Site (SRS) is focused primarily on support of the national defense, nonproliferation, and environmental cleanup. SRS-through its prime operating contractor, Westinghouse Savannah River Company (WSRC)-continues to maintain a comprehensive environmental monitoring program.

In 1999, effluent monitoring and environmental surveillance were conducted within a 31,000-square-mile area in and around SRS that includes neighboring cities, towns, and counties in Georgia and South Carolina and extends up to approximately 100 miles from the site. Thousands of samples of air, rainwater, surface water, drinking water, groundwater, food products, wildlife, soil, sediment, and vegetation were collected and analyzed for radioactive and/or nonradioactive contaminants.

\section{Potential Radiation Doses}

Table 1 shows the 1999 potential radiation doses from SRS releases compared with the applicable federal dose standards and with estimated doses from naturally occurring background radiation. All potential radiation doses attributed to SRS in 1999 were below applicable regulatory standards.

\section{Liquid Pathway}

For 1999, the potential dose to the maximally exposed individual from liquid releases of radioactivity to the Savannah River was estimated at $0.22 \mathrm{mrem}(0.0022 \mathrm{mSv})$. This dose is 0.22 percent of the U.S. Department of Energy (DOE) 100-mrem all-pathway dose standard for annual exposure.

The dose was about 83 percent more than the 1998 dose of 0.12 mrem $(0.0012 \mathrm{mSv})$ - primarily because a 62-percent decrease in the Savannah River flow rate resulted in less dilution of contaminants.

The 1999 collective dose from liquid releases was estimated to be 4.0 person-rem ( 0.04 person-Sv).

\section{Drinking Water Pathway}

Offsite doses were calculated for persons consuming drinking water from two water treatment plants located downriver of SRS near Beaufort, South Carolina, and Port Wentworth, Georgia. The maximum dose from each facility was $0.07 \mathrm{mrem}$ ( $0.0007 \mathrm{mSv})$. These doses are 1.75 percent of the drinking water standard of 4 mrem per year (0.04 mSv per year).

\section{Airborne Pathway}

For 1999, the potential dose to the maximally exposed individual from airborne releases of radioactive materials was $0.06 \mathrm{mrem}(0.0006 \mathrm{mSv})$. This is 14 percent less than the 1998 dose of $0.07 \mathrm{mrem}(0.0007 \mathrm{mSv})$-primarily because of decreases in the amount of tritium oxide released from SRS during 1999. The dose is 0.6 percent of the 10-mrem per year (0.1-mSv per year) limit for exposure to airborne releases from a DOE facility.

The collective dose from airborne releases was estimated to be 2.6 person-rem ( 0.026 person-Sv), which is less than 0.01 percent of the collective dose received from naturally occurring sources of radiation (about 186,000 person-rem).

\section{All Pathway}

To demonstrate compliance with the DOE Order 5400.5 all-pathway dose standard of 100 mrem per year (1.0 mSv per year), SRS conservatively combines the maximally exposed individual airborne pathway and liquid pathway dose estimates, even though the two doses are calculated for hypothetical individuals residing at different geographic locations.

For 1999, the potential maximally exposed individual all-pathway dose was $0.28 \mathrm{mrem}(0.0028 \mathrm{mSv})$ ( $0.06 \mathrm{mrem}$ from airborne pathway plus $0.22 \mathrm{mrem}$ from liquid pathway). This dose is about 47 percent more than the 1998 all-pathway dose of $0.19 \mathrm{mrem}$ $(0.0019 \mathrm{mSv})$-primarily because the 62-percent decrease in the Savannah River flow rate resulted in less dilution of contaminants. A 10-year history of SRS maximum potential all-pathway doses to the maximally exposed individual is shown in figure 1.

\section{Sportsman}

In 1999, the maximum potential dose to an actual onsite hunter was about $77 \mathrm{mrem}(0.77 \mathrm{mSv})$, which is 77 percent of DOE's 100 -mrem all-pathway dose standard. During the onsite deer hunts, this individual harvested five animals - the edible portion totaled about 121 kilograms (267 pounds) - and was assumed to have eaten all the meat.

If a hypothetical offsite hunter living near the site boundary consumed $81 \mathrm{~kg}$ (179 pounds) of meat-the annual maximum adult consumption rate for 
Table 11999 Potential Radiation Doses from SRS Releases Compared with Applicable Dose Standards and Estimated Doses from Naturally Occurring Radiation

\begin{tabular}{|c|c|c|c|c|}
\hline \multicolumn{5}{|c|}{ Maximally Exposed Individual Doses } \\
\hline $\begin{array}{l}\text { Exposure } \\
\text { Pathway }\end{array}$ & $\begin{array}{l}\text { Maximum Potential Dose } \\
\text { from } 1999 \text { Releases }\end{array}$ & $\begin{array}{l}\text { Applicable Dose } \\
\text { Standard }\end{array}$ & $\begin{array}{l}\text { Percent of } \\
\text { Standard }\end{array}$ & $\begin{array}{l}\text { Percent } \\
\text { of Natural' }\end{array}$ \\
\hline $\begin{array}{l}\text { Airborne Releases } \\
\text { Total Airborne }\end{array}$ & 0.06 mrem & $10 \mathrm{mrem}^{\mathrm{d}}$ & 0.6 & 0.02 \\
\hline \multicolumn{5}{|l|}{ Liquid Releases } \\
\hline Total Liquid & 0.22 mrem & $N A^{e}$ & $N A^{e}$ & 0.07 \\
\hline All Pathways $f$ & $0.28 \mathrm{mrem}$ & 100 mrem & 0.28 & 0.09 \\
\hline \multicolumn{5}{|c|}{ Treated Drinking Water } \\
\hline Beaufort-Jasper & 0.07 mrem & $4 \mathrm{mrem}^{\mathrm{g}}$ & 1.75 & 0.02 \\
\hline Port Wentworth & 0.07 mrem & $4 \mathrm{mrem}^{\mathrm{g}}$ & 1.75 & 0.02 \\
\hline \multicolumn{5}{|c|}{$\begin{array}{l}\text { Special-Case Exposure Scenarios } \\
\text { Sportsman Dose } \\
\text { Deer and hog consumption }\end{array}$} \\
\hline Onsite hunter & $76.5 \mathrm{mrem}$ & 100 mrem & 76.5 & 25.5 \\
\hline Offsite hunter & 9.1 mrem & 100 mrem & 9.1 & 3.0 \\
\hline $\begin{array}{l}\text { Fish consumption } \\
\text { Steel Creek bass }\end{array}$ & 0.61 mrem & 100 mrem & 0.61 & 0.2 \\
\hline Goat Milk Consumpti & tion Dose & & & \\
\hline $\begin{array}{l}\text { Max. individual } \\
\text { Irrigation Pathway Do }\end{array}$ & $0.06 \mathrm{mrem}$ & 10 mrem & 0.6 & 0.02 \\
\hline Max. individual & 0.15 mrem & 100 mrem & 0.15 & 0.05 \\
\hline
\end{tabular}

Population (Collective) Doses

$\begin{array}{lcccc}\begin{array}{l}\text { Exposure } \\ \text { Pathway }\end{array} \quad \begin{array}{c}\text { Maximum Potential Dose } \\ \text { from 1999 Releases }\end{array} & \begin{array}{c}\text { Applicable Dose } \\ \text { Standard }\end{array} & \begin{array}{c}\text { Percent of } \\ \text { Standard }\end{array} & \begin{array}{c}\text { Percent } \\ \text { of Naturalc }\end{array} \\ \begin{array}{c}\text { Airborne Releases } \\ \text { Total Airborne }\end{array} & 2.6 \text { person-rem } & N^{\mathrm{e}} & \mathrm{NA}^{\mathrm{e}} & 0.01 \\ \begin{array}{c}\text { Liquid Releases } \\ \text { Total Liquid }\end{array} & 4.0 \text { person-rem } & \mathrm{NA}^{\mathrm{e}} & \mathrm{NA}^{\mathrm{e}} & 0.01\end{array}$

a Committed effective dose equivalent.

b All the standards listed are given in DOE Order 5400.5, February 8, 1990, "Radiation Protection of the Public and the Environment."

c Estimate of average dose received from naturally occurring radiation is 300 mrem per year [NCRP, 1987]. The population (collective) dose due to naturally occurring radiation is estimated to be about 186,000 person-rem.

d The standard for airborne effluents applies to the sum of the doses from all airborne pathways: inhalation, submersion in a plume, exposure to radionuclides deposited on the ground surface, and consumption of foods contaminated as a result of the deposition of radionuclides.

e Not applicable; there is no separate standard for population dose or for all liquid pathways alone; liquid releases are included in the 100-mrem standard for all pathways.

$f$ The total airborne and liquid exposure pathways are added in order to compare maximum calculated doses from SRS releases with the DOE "all pathways" standard. This total includes the maximum airborne pathway dose of 0.06 mrem $(0.0006 \mathrm{mSv})$ and the maximum liquid pathway dose of $0.22 \mathrm{mrem}(0.0022 \mathrm{mSv})$.

g The drinking water standard applies to public drinking water systems and to drinking water supplies operated by DOE or DOE contractors. 


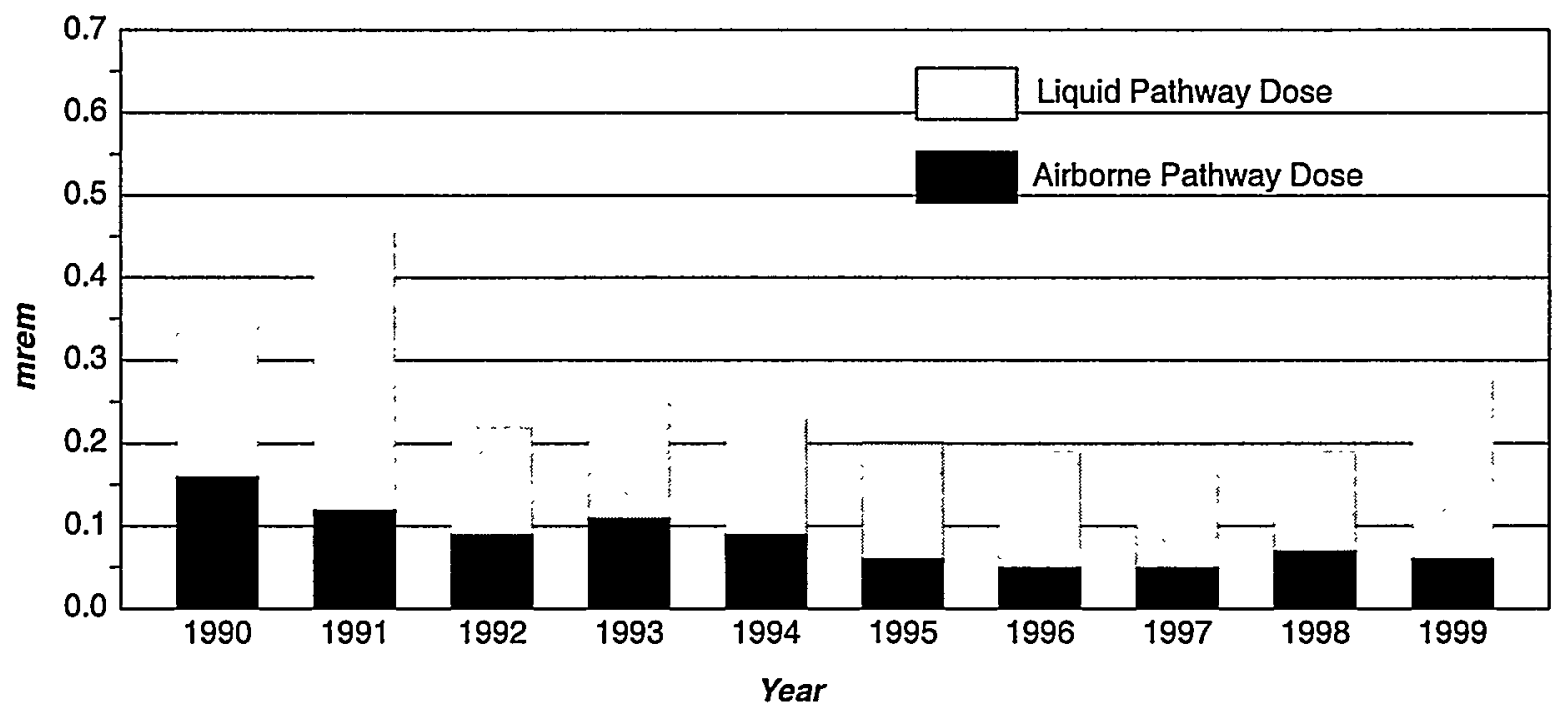

Ileaf Graphic

Figure 1 Ten-Year History of SRS Potential All-Pathway Doses to the Maximally Exposed Individual (Airborne plus Liquid Pathways)

meat-taken from deer living on site prior to being harvested, the individual's maximum dose could have been $9.1 \mathrm{mrem}(0.91 \mathrm{mSv})$. This dose was based on the average concentration of cesium- 137 measured in animals harvested at SRS during 1999.

The potential maximum dose for a recreational fisherman was based on the consumption of $19 \mathrm{~kg}$ (42 pounds)-the maximum adult consumption rate for fish - of Savannah River fish having the highest measured concentrations of radionuclides. In 1999, bass caught at the mouth of Steel Creek had the highest concentrations. Consumption of $19 \mathrm{~kg}$ of these bass could have resulted in a dose of $0.61 \mathrm{mrem}$ (0.0061 mSv).

\section{Compliance Activities}

A major goal at SRS continues to be positive environmental stewardship and full regulatory compliance, with zero violations. The site's employees maintained progress toward achievement of this goal in 1999, as a vast majority of their efforts were successful. For example, under the Clean Water Act (CWA), the site's National Pollutant Discharge Elimination System (NPDES) compliance rate was 99.8 percent (10 exceedances in 5,778 analyses), and under the Clean Air Act (CAA), the compliance rate was 100 percent.

Compliance with environmental regulations and with DOE orders related to environmental protection is an integral part of the operations at SRS. Management of the environmental programs at SRS is a significant activity, and assurance that onsite processes do not impact the environment adversely is a top priority. All site activities are overseen by one or more regulatory agencies, including the U.S.

Environmental Protection Agency (EPA) and the

South Carolina Department of Health and Environmental Control (SCDHEC).

A systematic effort is in place to identify and address all evolving regulatory responsibilities that concern SRS. As part of the process, communications are maintained with all appropriate regulatory agencies to emphasize the site's commitment to environmental compliance. SRS received three Notices of Violation (NOVs) from SCDHEC in 1999 and one from EPA.

SRS operations in 1999 continued to involve a wide variety of processes and chemicals subject to compliance with an increasing number of environmental statutes, regulations, policies, and permits. (For example, the site had 684 construction and operating permits in 1999 that specified operating levels for each permitted source.) Compliance with all requirements helps to ensure that the site, the public, and the surrounding environment are protected from adverse effects that could result from SRS operations. This section offers an overview of some of the environmental compliance issues with which the site was involved during 1999.

\section{High-Level Radioactive Waste Tank Closure}

The mission of SRS high-level waste tank closures at the F-Area and H-Area tank systems is to close out 
tanks in a way that ensures protection of human health and the environment, and in a technically and economically prudent manner. This must be done according to SCDHEC Regulation 61-82, "Proper Closeout of Wastewater Treatment Facilities," and in compliance with Resource Conservation and Recovery Act and Comprehensive Environmental Response, Compensation, and Liability Act requirements.

Tank 20F, a 1.3-million-gallon, single-shelled, carbon steel vessel, and tank $17 \mathrm{~F}$, with the same capacity, were closed in 1997. DOE determined in October 1998 that SRS should complete a tank closure environmental impact statement before conducting additional closure activities. A Record of Decision (ROD) on this action, originally scheduled for December 1999, now is expected during FY 2000.

The assessment of soils and groundwater around the waste tanks will be deferred until complete closure of a geographical grouping of tank systems and their associated support services. Currently, the tank $17 \mathrm{~F}$ and tank $20 \mathrm{~F}$ systems cannot be isolated practically from other operational systems (tanks $18 \mathrm{~F}$ and $19 \mathrm{~F}$ and the $\mathrm{IF}$ evaporator) for the purpose of assessing potential remedial actions.

The SRS Federal Facility Agreement (FFA) requires closure of tank 19F in 2003 and tank 18F in 2004.

The removal of waste from tank $19 \mathrm{~F}$ is expected to be completed by October 2000 . A tank $19 \mathrm{~F}$ closure module subsequently will be prepared and submitted to SCDHEC prior to the initiation of closure activities. The general plan for high-level waste tank system closure is scheduled to be revised and submitted during FY 2000 to DOE-HQ, EPA, and SCDHEC for approval, as required by DOE Order 435.1 ("Radioactive Waste Management").

\section{National Pollutant Discharge Elimination System}

The CWA created the NPDES program, which is regulated by SCDHEC under EPA authority. The program is designed to protect surface waters by limiting all nonradiological releases of effluents into streams, reservoirs, and other wetlands. (Radiological effluents are covered under other acts.) Discharge limits are set for each facility to ensure that SRS operations do not impact aquatic life adversely or degrade water quality.

SRS had four NPDES permits in 1999, as follows:

- One permit for industrial wastewater discharge (SC0000175) - SRS received a modification of this permit from SCDHEC January 1, 1998. The modification removed outfalls $\mathrm{P}-13, \mathrm{P}-14, \mathrm{P}-19$, and $K-08$, added outfall $X-19$, and changed the sampling requirements at several other outfalls.

- One general permit for utility water discharge (SCG250162) - Under this permit, outfall 001 discharged once during 1999.

- Two general permits for stormwater discharge (SCR000000 for industrial and SCR100000 for construction)

All results of monitoring for compliance with the industrial wastewater discharge permit and the general permit for utility water discharge were reported to SCDHEC in the monthly Discharge Monitoring Reports, as required by the permits.

\section{Air Pollution Control Program}

The CAA provides the basis for protecting and maintaining air quality. Some types of SRS air emissions, such as ozone-depleting substances (ODS), are regulated by EPA, but most are regulated by SCDHEC, which must ensure that its air pollution regulations are at least as stringent as the CAA's. This is accomplished through SCDHEC Regulation 61-62, "Air Pollution Control Regulations and Standards."

Under the CAA, and as defined in federal regulations, SRS is classified as a "major source" and, as such, is assigned one permit number (0080-0041) by SCDHEC. SRS holds operating and construction permits from SCDHEC's Bureau of Air Quality, which regulates nonradioactive toxic and criteria pollutant emissions from approximately 207 point sources. Of these point sources, 153 operated in some capacity during 1999 . The remaining 54 either were being maintained in a "cold standby" status or were under construction.

\section{NESHAP Asbestos Abatement Program}

SRS began an asbestos abatement program in 1988 and continues to manage asbestos-containing material by "best management practices." Site compliance in this area also falls under South Carolina and federal regulations, including SCDHEC Regulation 61-86.1 ("Standards of Performance for Asbestos Projects") and 40 CFR 61, Subpart M ("National Emission Standards for Asbestos").

During 1999, SRS personnel removed and disposed of approximately 1,015 linear feet and 915 square feet of regulated asbestos-containing material. In addition, contractors removed and disposed of an estimated 16,000 square feet and 780 linear feet of regulated asbestos-containing material and demolished four regulated structures. 


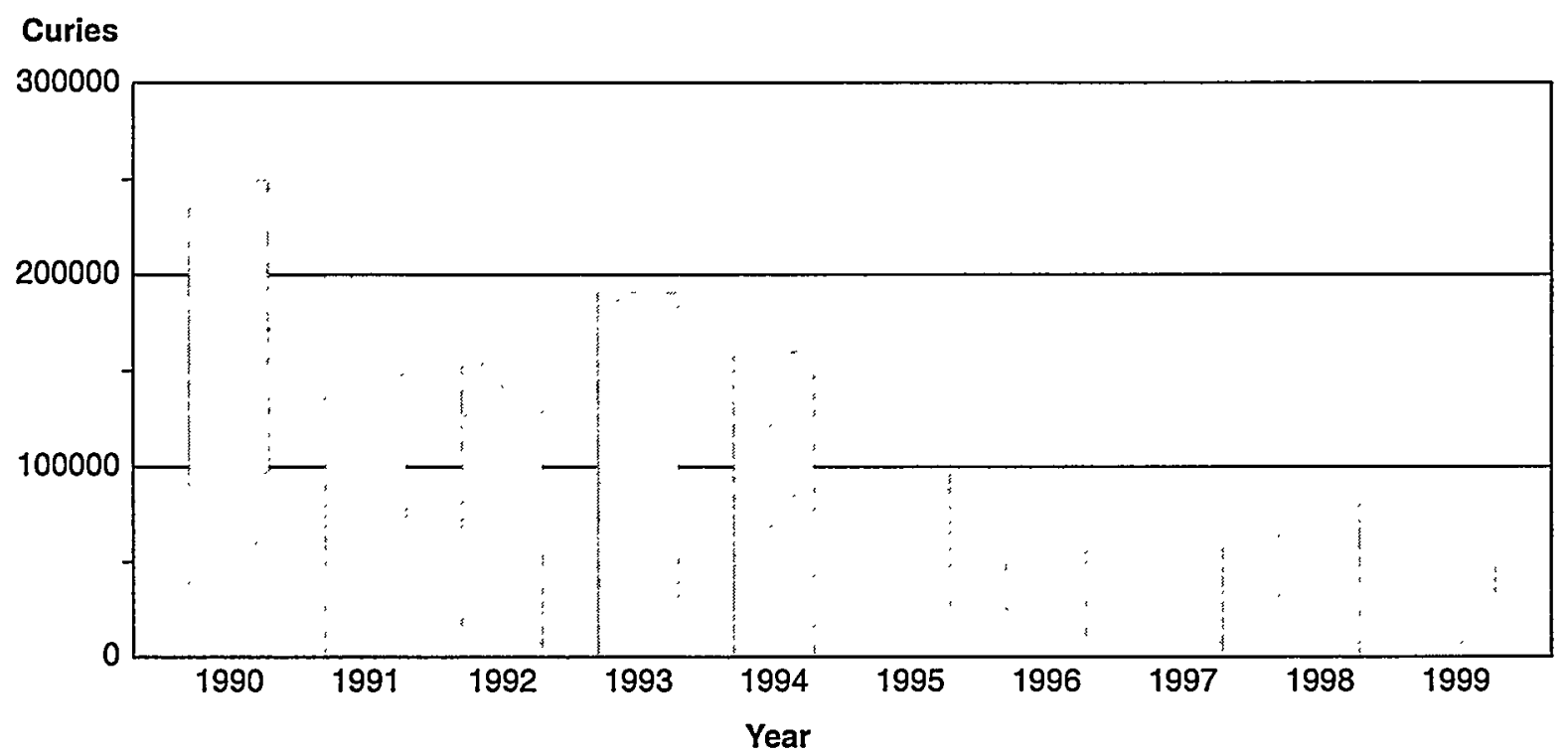

lleaf Graphic

Figure 2 Ten-Year History of SRS Annual Atmospheric Tritium Releases

\section{Radiological Effluent Monitoring}

SRS collected and analyzed about 4,200 effluent samples in 1999 to quantify radiological releases to the environment from site operations. Tritium again was the major contributor to air and liquid releases, accounting for most of the total radioactivity released.

\section{Airborne Emissions}

Krypton and tritium accounted for nearly all of the airborne radioactivity released from the site during 1999. An estimated $37,400 \mathrm{Ci}$ of krypton- 85 were released from the separations area in 1999 . However, because krypton is an inert noble gas that is not easily absorbed by the human body, it causes very little radiological dose.

Approximately $51,600 \mathrm{Ci}(1.91 \mathrm{E}+15 \mathrm{~Bq})$ of tritium (elemental plus tritium oxide) were released from the site in 1999. This was 38 percent less than the $82,700 \mathrm{Ci}(3.06 \mathrm{E}+15 \mathrm{~Bq})$ released in 1998 . The decrease was due mainly to the completion of moderator consolidation operations in P-Area during 1998. Figure 2 shows a 10-year history (1990-1999) of SRS tritium releases. Since 1995, because of changes in the site's missions and the existence of the Replacement Tritium Facility, the total amount of tritium released has been less than $100,000 \mathrm{Ci}$ per year.

\section{Liquid Discharges}

Tritium accounts for most of the radioactivity released to the Savannah River from direct process discharges and from seepage basin and Solid Waste Disposal Facility (SWDF) migration discharges. The amount of tritium released directly from SRS process areas (i.e., reactor, separations, heavy water rework) to site streams during 1999 was $1,120 \mathrm{Ci}$

$(4.14 \mathrm{E}+13 \mathrm{~Bq})$, which was 3 percent more than the 1998 total of $1,090 \mathrm{Ci}(4.04 \mathrm{E}+13 \mathrm{~Bq})$.

During 1999, the total amount of tritium released to the Savannah River from the site was about 41 percent less than the amount released during $1998-6,290 \mathrm{Ci}(2.33 \mathrm{E}+14 \mathrm{~Bq})$ in 1999 versus $10,600 \mathrm{Ci}(3.92 \mathrm{E}+14 \mathrm{~Bq})$ in 1998 . The cause of this decrease is not known but may be attributable to decreased rainfall at the site from late 1998 through 1999.

\section{Radiological Environmental Surveillance}

The radiological environmental surveillance program at SRS surveys and quantifies any effects routine and nonroutine operations may have had on the site, the surrounding area, and those populations living in or near the site. Sampled media include air, rainwater, site streams, the Savannah River, drinking water, seepage basins, food products, fish, deer, hogs, turkeys, beavers, soil, sediment, and vegetation.

Overall, 1999 activity levels generally were consistent with 1998 levels. Concentrations of some 
radionuclides-such as tritium, cesium, and strontium-were at or slightly above their nominal lower limits of detection (LLD) and were consistent with observed historical levels in sampled media. In air and surface water, some onsite activity levels were, as expected, slightly higher than observed in offsite media. Because of production slowdown, most tritium transport in site streams, which has been decreasing in recent years, was attributed to the outcropping at stream banks of contaminated groundwater from retired seepage basins and SWDF.

\section{Nonradiological Effluent Monitoring}

Nonradioactive airborne emissions released from SRS stacks-including sulfur dioxide, oxides of nitrogen, carbon monoxide, total particulate matter less than 10 microns, and various toxic air pollutants-were within applicable (SCDHEC) standards in 1999. The site continued to maintain 100-percent compliance with all permitted emission rates and special conditions.

SRS maintained its NPDES compliance rating for liquid releases above 99 percent for the 13th straight year. Results from only 10 of the 5,778 analyses performed in 1999 exceeded permit limits. This resulted in a compliance rating of 99.8 percent-again higher than the DOE-mandated rate of 98 percent.

\section{Nonradiological Environmental Surveillance}

The nonradiological environmental surveillance program at SRS involves sampling and analyzing surface waters (site streams and the Savannah River), drinking water, sediment, groundwater, and fish. In 1999 , more than 6,300 analyses for specific chemicals and metals were performed on more than 1,200 samples, not including groundwater.

The 1999 water quality data showed normal fluctuations expected for surface water. A comparison of the 1999 data with published historical data for site surface water monitoring did not indicate any abnormal deviations from past monitoring data. All results from analyses for pesticides and herbicides were below the detection limit.

All SRS drinking water systems complied with SCDHEC chemical, bacteriological, lead and copper, synthetic organic, and volatile organic water quality standards in 1999.
In Savannah River and site stream sediment samples, no pesticides or herbicides were found to be above the practical quantitation limits in 1999.

The mercury concentrations in fish analyzed from onsite waters ranged from a high of $2.90 \mu \mathrm{g} \mathrm{Hg} / \mathrm{g}$ in PAR Pond to a low of $0.11 \mu \mathrm{g} \mathrm{Hg} / \mathrm{g}$ in bream from Pond B. Mercury concentrations in offsite fish ranged from a high of $1.27 \mu \mathrm{g} \mathrm{Hg} / \mathrm{g}$ in bass from the mouth of Steel Creek to a low of $0.01 \mu \mathrm{g} \mathrm{Hg} / \mathrm{g}$ in mullet from Savannah.

\section{Academy of Natural Sciences of Philadelphia River Quality Surveys}

The Patrick Center for Environmental Research of the Academy of Natural Sciences of Philadelphia (ANSP) has been conducting biological and water quality surveys of the Savannah River since 1951. These surveys are designed to assess potential effects of SRS contaminants and warm water discharges on the general health of the river and its tributaries.

The 1998 and 1999 surveys examined algae, rooted aquatic plants (1998), protozoa (1998), macroinvertebrates, and fish yearly or twice yearly. Diatoms, a type of algae, were examined monthly.

Final results of the 1998 study are presented in this report, along with an interpretation of their place in assessing temporal trends in water quality. Progress to date for each component of the 1999 study also is reported.

Assessments of the various biological groups in the 1998 river quality survey (diatoms, other attached algae, rooted aquatic plants, insects, noninsect macroinvertebrates, and fish) were consistent with one another and demonstrated similar communities at exposed and reference stations.

Results of the 1999 river quality survey were not complete at the time of publication of this report. However, field notes and preliminary analyses of samples do not reveal any obvious differences between communities at exposed and reference stations.

\section{Groundwater}

SRS monitors groundwater for radioactive and nonradioactive constituents to identify contamination that may have occurred because of site operations. Groundwater beneath 5 to 10 percent of the site has been contaminated by industrial solvents, tritium, metals, or other constituents used or generated by SRS operations. This report describes ground water monitoring results for approximately 1,224 wells in 101 locations within designated areas at SRS. In 
1999 , approximately 26,958 radiological analyses and 134,123 nonradiological analyses were performed on groundwater samples. The numbers of analyses have decreased considerably since 1997 , primarily because of increased efficiency and reduced duplication.

Three new sites were monitored during the year, and additional wells were installed at several more sites to improve detection monitoring and plume definition and to support the Resource Conservation and Recovery Act Facility Investigation/Remedial Investigation (RFI/RI) Program. Also, four wells were abandoned, as follows:

- One was abandoned in conjunction with the closure of the 108-3C bioremediation site in C-Area.

- Another was abandoned in conjunction with the closure of the 108-3L bioremediation site in L-Area.

- The other two were abandoned and replaced in accordance with the RFI/RI characterization plan at the H-Area tank farm.

\section{Special Surveys}

In addition to routine sampling and special sampling during nonroutine environmental releases, special sampling for radiological and nonradiological surveys is conducted on and off site. Both short- and long-term radiological and nonradiological surveys are used to monitor the effects of SRS effluents on the site's environment and in its immediate vicinity.

\section{Mitigation Action Plan for Pen Branch Reforestation}

The final Environmental Impact Statement for the continued operation of K-Reactor, L-Reactor, and
P-Reactor at SRS predicted several unavoidable impacts to the site's wetlands. This resulted in the development of a Mitigation Action Plan (MAP) that documented the DOE approach to mitigating these impacts [DOE, 1990].

Natural revegetation has been occurring in the Pen Branch delta since K-Reactor last operated for an extended period of time (1988). K-Reactor thermal discharges were determined by a 1992 survey to have caused canopy loss or vegetation damage to 583 acres in the corridor, swamp, and marsh areas.

The Pen Branch corridor and delta are also being reforested by planting with indigenous wetlands species. The seeds were planted and grown at a State of Georgia nursery during 1993-1995 for use in the Pen Branch seedling planting program. These seedlings —of species appropriate to the area being reforested-subsequently were transplanted to the Pen Branch wetland areas. The reforested areas will be managed until successful reforestation has been achieved. This is the preferred method of mitigation for the Pen Branch corridor and delta because of the brief restoration time allowed by DOE.

Because of the control/restoration comparison areas, a number of research and baselining activities have been conducted to document the recovery of the faunal component of the wetland ecosystem. Many of these studies have been concluded.

While the active research phase was concluding in 1999 , monitoring of the wetland hydrology and vegetation development is required over a longer period of time to show successful restoration, and will continue periodically for the next 5 years. 


\section{Highlights}

- The Heavy Water Facility, where various contaminants were removed from the legacy heavy water, was turned over to the Facilities Decommissioning Division. All moderator water that was stored in this area has been moved to the center of the site.

- The Department of Energy designated 10,000 acres of SRS as a biological and wildlife refuge in June, creating the Crackerneck Wildlife Management Area and Ecological Reserve.

$\mathrm{T}$

HE Savannah River Site (SRS), a facility in the U.S. Department of Energy (DOE) complex, encompasses approximately

310 square miles in South Carolina and is adjacent to the Savannah River.

The site was established by the U.S. Atomic Energy Commission (AEC) in 1950 to produce plutonium and tritium for national defense and additional special nuclear materials for other government uses and for civilian purposes. Production of these materials continued for more than 40 years.

When the Cold War ended in 1991, DOE responded to changing world conditions and national policies by refocusing its mission. The site's priorities shifted toward waste management, environmental restoration, technology development and transfer, and economic development.

This chapter includes general information on the site's history; location, demographics, and environmental setting; mission; and areas, facilities, and operations.

\section{Site History}

Responding to a 1950 directive from President Harry S. Truman to the AEC, E.I. du Pont de Nemours and Company and the commission negotiated a contract whereby Du Pont would design, construct, and operate what was to become the Savannah River Plant (SRP).

On November 22 of that year, the AEC approved the present site and purchased the land for approximately $\$ 19$ million. By February 1, 1951, construction had begun. The first facility to begin operating, the heavy water plant, started up August 17, 1952, and the first of five production reactors achieved operating status
December 28, 1953. All five reactors had achieved operating status by March 1955. [Bebbington, 1990].

Until it was disbanded by the Energy Reorganization Act of 1974, the AEC oversaw and regulated site activities. In 1975, its functions were transferred to two newly established agencies-the Energy Research and Development Administration (overseeing government operations) and the Nuclear Regulatory Commission (overseeing commercial operations). By 1977, the Energy Research and Development Administration had evolved into DOE, which has overseen all site activities since that time.

Du Pont operated SRP until March 31, 1989. On April 1, 1989, Westinghouse Savannah River Company (WSRC) became the prime operating contractor, and SRP became SRS.

Beginning October 1, 1996, the site was operated under a new contract by an integrated team led by WSRC. Under this contract, WSRC is responsible for SRS's nuclear facility operations; Savannah River Technology Center (SRTC); environment, safety, health, and quality assurance; and all the site's administrative functions. Bechtel Savannah River, Inc., is responsible for environmental restoration, project management, engineering, and construction activities. Babcock \& Wilcox Savannah River Company is responsible for facility decontamination and decommissioning, and British Nuclear Fuels Savannah River Corporation is responsible for the site's solid waste program.

\section{Site Locale}

In 1950, the site was selected by applying the criteria developed to select the most suitable location in the country to carry out President Truman's directive:

- a large land area for safety and security 
- a buffer zone large enough to provide land around each operating facility for protection of human health and the environment

- land somewhat isolated yet near communities that could handle construction and operations personnel

- access to adequate transportation

- land not subject to floods and major storms

- the availability of millions of gallons of water, low in mineral content, for cooling and process use

- suitable terrain and topography

Du Pont, the AEC, and the U.S. Army Corps of Engineers considered 114 sites in 18 states before recommending the current site, which met all the established criteria.

\section{Location}

SRS covers 198,344 acres in Aiken, Allendale, and Barnwell counties of South Carolina and borders the Savannah River. The site is approximately 12 miles south of Aiken, South Carolina, and 15 miles southeast of Augusta, Georgia (figure 1-1 ). It is included within the Central Savannah River Area, which is comprised of 18 counties surrounding Augusta.

The average population density in the counties surrounding SRS is 85 people per square mile, with the largest concentration in the Augusta metropolitan area. Based on 1990 U.S. Census Bureau data, the population within a 50-mile radius of SRS is approximately 620,100 . About 70 percent of the site's

\section{Typical Climate at SRS}

- Summer

Hot and humid

Temperatures reach upper $90 \mathrm{~s}\left({ }^{\circ} \mathrm{F}\right)$

33 percent of annual rainfall

- Fall

Cool mornings, warm afternoons

Temperatures range from 50 to $76^{\circ} \mathrm{F}$ 19 percent of annual rainfall

- Winter

Mild; lasting November through March Temperatures normally above $32^{\circ} \mathrm{F}$ 21 percent of annual rainfall

- Spring

Most variable; cold snap often in March

Temperatures average $65^{\circ} \mathrm{F}$

27 percent of annual rainfall employees live in South Carolina-primarily Aiken County-and 30 percent in Georgia.

Various industrial, manufacturing, medical, and farming operations are conducted near the site. Major industrial and manufacturing facilities in the area include textile mills, polystyrene foam and paper products plants, chemical processing facilities, and a commercial nuclear power plant. Farming is diversified and includes crops such as cotton, soybeans, corn, and small grains.

\section{Climate}

SRS has a relatively mild climate, with an average frost-free season of approximately 246 days. The average annual rainfall, about 48 inches, is fairly evenly distributed throughout the year. There is no strong prevailing wind direction; however, there is a relatively high frequency of east-through-northeast winds during the summer and fall and of south-through-northwest winds during the late fall, winter, and spring [Hunter, 1990]. Except for the Savannah River, no unusual topographic features significantly influence the general climate.

\section{Geology and Hydrology}

SRS is on the upper coastal plain of South Carolina. Coastal plain deposits at SRS consist of 500 to 1,400 feet of sands, clays, and limestones of Tertiary and Cretaceous age. These sediments are underlain by sandstones of Triassic age and by older metamorphic and igneous rocks.

The sandy sediments of the coastal plain contain several productive aquifers, separated by clay-rich units, that drain into the Savannah River, its tributaries, and the Savannah River Swamp. The older, underlying rocks are nearly impermeable and are not a major water source.

\section{Water Resources}

SRS, bounded on its southwestern border by the Savannah River for about 35 river miles (as measured from the upriver boundary of the site, near Jackson, South Carolina, to the Lower Three Runs Creek corridor), is approximately 160 river miles from the Atlantic Ocean. Five major SRS streams feed into the river: Upper Three Runs Creek, Four Mile Creek (also referred to as Fourmile Branch), Pen Branch, Steel Creek, and Lower Three Runs Creek.

The two main bodies of water on site, PAR Pond and L-Lake, are manmade. PAR Pond, constructed in 1958 to provide cooling water for-and to receive heated cooling water from-P-Reactor and R-Reactor (hence the name PAR Pond), covers 2,640 acres and 




EPD/GIS Map

Figure 1-1 Regional Location of SRS

SRS is about 12 miles south of Aiken, South Carolina, and 15 miles southeast of Augusta, Georgia. The site, approximately 310 square miles in area, covers about 1 percent of the state of South Carolina. 
is approximately 60 feet deep. The 1,000-acre L-Lake was constructed in 1985 to receive heated cooling water from L-Reactor.

The Savannah River is used as a drinking water supply source for residents downriver of SRS in Port Wentworth, Georgia, and near Beaufort, South Carolina (Beaufort and Jasper counties). [Drinking water data are summarized in SRS Environmental Data for 1999 (WSRC-TR-99-00301), table 22.] The City of Savannah Industrial and Domestic Water Supply Plant intake, at Port Wentworth, is approximately 130 river miles from SRS; the Beaufort-Jasper Water Treatment Plant intake, near Beaufort, is approximately 120 river miles from SRS. The Savannah River also is used for commercial and sport fishing, boating, and other recreational activities. There is no known use of the river for irrigation by farming operations downriver of the site [Hamby, 1991]. SRS uses water from the river for some of its operations.

Approximately 200 Carolina bays exist on SRS, ranging in size from about 0.2 acre to 125 acres. Carolina bays are unique, naturally occurring wetlands found only on the southeastern coastal plain. They are elliptical in shape and oriented northwest to southeast along their long axes; their origin is unknown. Carolina bays are shallow and may dry up seasonally. At SRS, they provide important habitat and refuge for many plants and animals.

\section{Land Resources}

The SRS region is part of the Southern Bottomland Hardwood Swamp region, which extends south from Virginia to Florida and west along the Gulf of Mexico to the Mississippi River drainage basin. The main features are river swamps, rarely more than 5 miles wide.

\section{Plant and Animal Life}

In 1972, SRS was designated as the first National Environmental Research Park. These parks are used by government and university-related scientists as outdoor laboratories to study the impact of human activity on the environment. This designation has created a unique environment for preserving and studying vegetation and wildlife.

The site provides refuge for approximately 50 endangered, threatened, and sensitive species of plants and animals, such as the red-cockaded woodpecker, the southern bald eagle, the smooth purple coneflower, the Bachman's sparrow, the American alligator, the wood stork, the shortnose sturgeon, and the bog spice bush. Many site research projects are designed to protect and increase the populations of these species.

\section{Vegetation}

Most of the site's environs are rural. Approximately 40 percent of the countryside is forested with longleaf and loblolly pines and sweet gum, maple, birch, and various oak-hickory hardwood trees.

Major plant communities at SRS include cypress-gum and lowland hardwood swamps, sandhills, and old agricultural fields, as well as aquatic and semiaquatic areas. These habitats range from very sandy, dry hilltops to continually flooded swamps.

\section{Wildlife}

SRS is populated with more than 50 species of mammals, including deer, feral hogs (hogs that have reverted to the wild state from domestication), beavers, rabbits, foxes, raccoons, bobcats, river otters, and opossums. In 1952, there were fewer than three dozen white-tailed deer on site. Since then, however, the population has increased dramatically, and the site herd now is estimated at more than 3,300 deer [Fledderman, 1999]. Since 1965, managed public deer hunts have been held annually on site to reduce the number of animal-vehicle accidents and to maintain the health of the herd. The hunts are discussed in chapter 6, "Radiological Environmental Surveillance."

More than 100 species of reptiles and amphibians-including turtle, alligator, lizard, snake,

\section{Crackerneck Wildlife Management Area and Ecological Reserve}

The Department of Energy designated 10,000 acres of SRS as a biological and wildlife refuge in June, creating the Crackerneck Wildlife Management Area and Ecological Reserve. This action gives the South Carolina Department of Natural Resources overall management responsibility for the reserve and will preserve the unique plant and wildlife habitat that lies on the site's western boundary long the Savannah River, south of the town of Jackson. This area is recognized as a habitat for several wildlife species, including a variety of threatened and endangered animal species.

The agreement that formally establishes this reserve designates that a portion of the area be made available for the use and enjoyment of the surrounding community. 


\section{Savannah River Site: A Unique Outdoor Laboratory}

In 1972, the federal government designated SRS as the nation's first National Environmental Research Park. The park provides a unique outdoor laboratory to study the interaction between managed and natural systems. Research activities are conducted through site environmental organizations.

The Savannah River Swamp is 7,500 acres of natural swampland adjacent to the Savannah River. In the deep water areas of the swamp, two types of trees are dominant: the bald cypress and the water tupelo. These trees cover 50 percent of the swamp. The other 50 percent consists of islands that support bottomland hardwood forests, including oaks, red maples, and sweet gum trees. The swamp also is home to waterfowl and alligators. Studies conducted at the swamp track subtle long-term effects of land use changes on ecosystems.

SRS serves as a refuge for endangered species such as the southern bald eagle, a subspecies of the bald eagle. When fully mature, it is about 40 inches long with dark brown plumage, a white head and tail, and yellow eyes, beak, and feet. Eagles reach full maturity in 3 to 7 years. They are monogamous, mate for life, and tend to use the same nest every year.

frog, and salamander-and more than 200 species of birds also inhabit the site.

\section{Site Mission}

The changing world caused a downsizing of the site's original defense mission; SRS's current mission is to fulfill its responsibilities safely and securely in the stewardship of the nation's nuclear weapons stockpile, nuclear materials, and the environment. These stewardship areas reflect current and future missions to

- meet the needs of the enduring U.S. nuclear weapons stockpile

- store, treat, and dispose of excess nuclear materials safely and securely

- treat and dispose of legacy wastes from the Cold War and clean up environmental contamination

"Stewardship" in the context of SRS's mission is defined as "responsibility for the careful use of money, time, talents, and other resources, especially with respect to the principles and/or needs of a community."

Future mission activities include the processing of plutonium, the radioactive material that fueled one of the bombs that ended World War II and was a component of the warheads of the Cold War. SRS is the preferred site for

- a pit disassembly and conversion facility-pit disassembly and conversion involves taking apart the core of nuclear weapons and converting the plutonium inside into a powdered oxide

- a mixed oxide (MOX) fuel fabrication facility-the powdered oxide from the pit disassembly and conversion facility comes to this facility (1) to be used in the manufacture of nuclear fuel for commercial nuclear reactors or (2) to be immobilized for long-term storage

- a facility to immobilize the remaining plutonium oxide in ceramic material

The remainder of this chapter describes the site areas and some of the major facilities, operations, and activities that support these points.

\section{Site Areas (Including Major Facilities, Operations, and Activities)}

SRS was constructed to produce basic materials used in nuclear weapons, primarily tritium and plutonium-239. Five reactors-along with support facilities-were built to produce and purify these materials.

SRS is divided into several areas, based on production and other functions (figure 1-2):

- reactor materials area $(M)$

- reactor areas (C, $K, L, P$, and $R$ )

- heavy water reprocessing area (D)

- separations areas ( $\mathrm{F}$ and $\mathrm{H})$

- waste management areas (E, F, H, S, and Z)

- administration area (A)

- other areas (B, N, TNX, and G)

Since the end of the Cold War, SRS has shut down several facilities because of declining defense requirements. These included all five reactors and facilities in M-Area, D-Area, and TNX. However, 


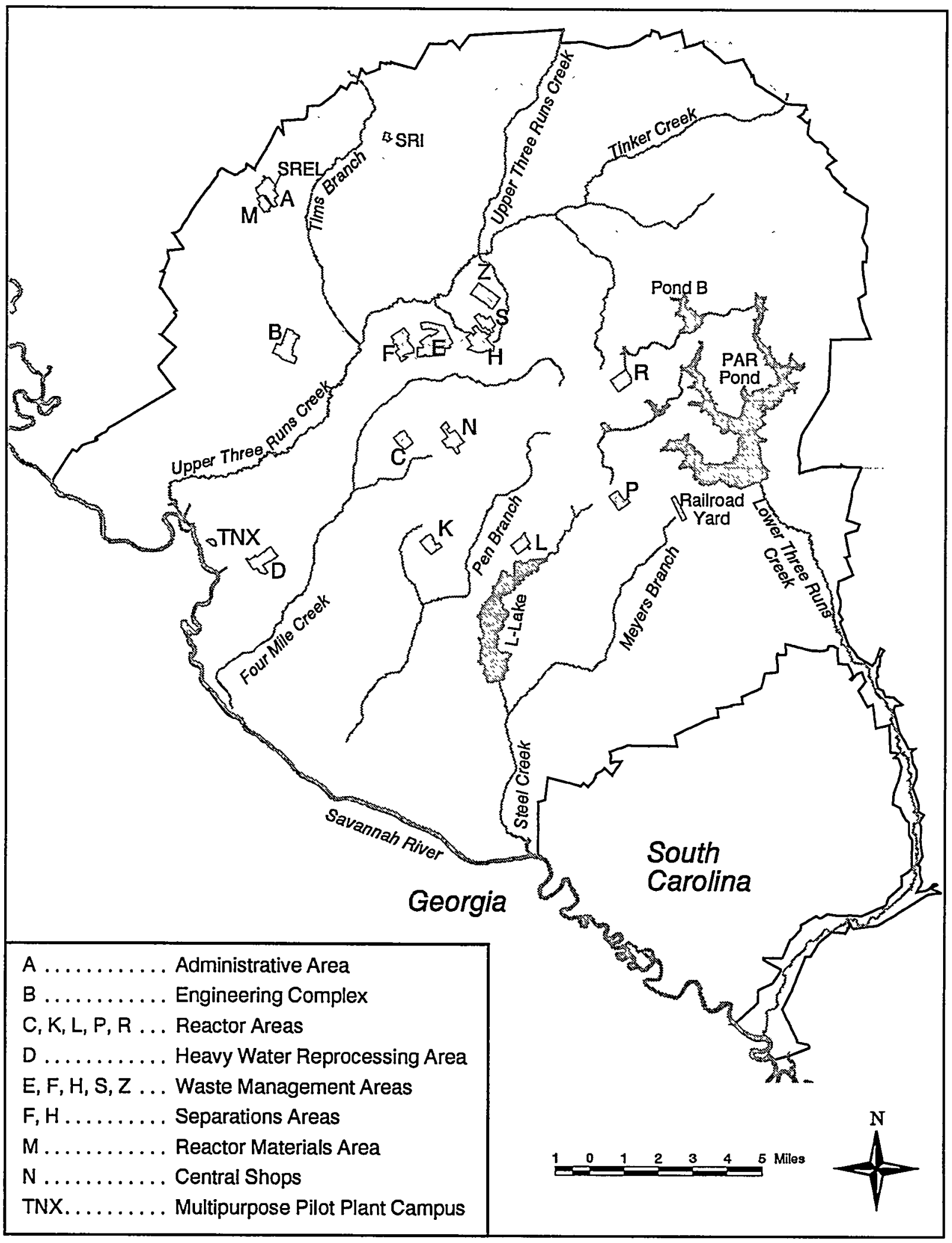

EPD/GIS Map

Figure 1-2 The Savannah River Site

SRS includes nuclear materials production areas, which are primarily in the interior of the site, and several operating areas. SREL and SRI also are located on site. 
S-Area, Z-Area, and E-Area opened to support waste management activities.

Data about emissions and discharges from the various areas and outfalls-occurring as a result of routine operations - can be found in the "Radiological Effluent" and "Nonradiological Effluent" sections of SRS Environmental Data for 1999.

\section{Reactor Materials Area (M)}

The reactor materials area (M-Area) is home to three analytical laboratories and the Vendor Treatment Facility. The Vendor Treatment Facility, which completed its operations in February, processed 670,000 gallons of mixed-waste (both radioactive and hazardous) sludge into glass beads. These beads currently are classified as Resource Conservation and Recovery Act (RCRA) waste, but they are expected to be reclassified and moved from M-Area to a low-level repository elsewhere on site.

\section{Reactor Areas (C, K, L, P, and R)}

Production reactors are in five areas: $\mathrm{C}, \mathrm{K}, \mathrm{L}, \mathrm{P}$, and $R$. Each area houses one of the site's five heavy water reactors. All five reactors, (R-Reactor, P-Reactor, L-Reactor, K-Reactor, and C-Reactor) are permanently shut down.

Facilities in C-Area, K-Area, and L-Area are being used to store heavy water. Heavy water was used as a coolant and moderator (material used to slow down neutrons from the high velocities at which they are created in the fission process) in the SRS reactors. K-Reactor and L-Reactor contain operating spent fuel storage basins. (More about spent fuel storage can be found in the Separations Areas section.)

The $\mathrm{K}$-Reactor building has been modified for usé as an interim storage location for nuclear materials from other DOE facilities.

The ground level of C-Reactor has been modified to serve as a central decontamination facility for radiologically contaminated operations and maintenance equipment.

Although some of the areas are being used, no efforts are being expended to maintain any of the reactors themselves.

\section{Heavy Water Reprocessing Area (D)}

A heavy water production plant in D-Area began operations in 1953 to produce heavy water to moderate and cool the site's reactors. The plant separated heavy water-present in small amounts in all water-from Savannah River water. The huge extraction plant discontinued operations in 1981 because of a sufficient supply of heavy water and was shut down.

The Heavy Water Facility, where various contaminants were removed from the legacy heavy water, continued operations through 1998 and has been turned over to the Facilities Decommissioning Division. All moderator water that was stored in this area has been moved to K-Area and L-Area.

\section{Separations Areas ( $F$ and $H$ )}

Activities in the separations areas (F-Area and $\mathrm{H}$-Area) include separations, receipt of offsite fuel for processing, tritium processing. and waste management. The first three are discussed here; a discussion of waste management activities, which also take place in E-Area, S-Area, and Z-Area, begins on page 10.

\section{Separations}

Two large chemical separations facilities, F-Canyon and $\mathrm{H}$-Canyon (called canyons because of their long, narrow shapes), and their associated liquid-waste treatment and storage facilities are located in F-Area and $\mathrm{H}$-Area.

These areas originally were designed to process irradiated fuel and target assemblies from site reactors. Since the end of the Cold War, the purpose has shifted to the stabilization of nuclear materials from onsite and offsite sources to ensure safe long-term storage or disposal. The materials are dissolved, and the products of interest are chemically separated and purified from waste products.

Some other facilities in the separations areas include the FB-Line and the HB-Line (located atop the canyons), the Receiving Basin for Offsite Fuel (RBOF), and the Replacement Tritium Facility (RTF). More about the RBOF and the RTF can be found on page 9 .

\section{Spent Fuel}

Beginning in the 1950s, as part of the "Atoms for Peace" program, the United States provided nuclear technology to foreign nations for peaceful applications in exchange for their promise to forego development of nuclear weapons. A major element of this program was the provision of research reactor technology and the highly enriched uranium needed to fuel the research reactors. Research reactors play a vital role in important medical, agricultural, and industrial applications. However, the uranium initially used in the fuel elements for these reactors also could be used in production of nuclear weapons. Therefore, the used fuel elements ("spent nuclear 
fuel") were transported to the United States, where they were chemically separated to extract the uranium still remaining in the fuel. In this way, the United States maintained control over disposition of the highly enriched uranium that it provided to other nations.

For years, it was routine for the foreign researchers to return this U.S.-origin spent fuel to the United States-first, under bilateral agreements, and then, (from 1964 until 1988) under the "Off-Site Fuels
Policy." The "Off-Site Fuels Policy" expired in 1988, and shipments no longer were accepted by the United States. The decision to return to the policy (of accepting spent fuel from foreign researchers) was made in 1996 [DOE, 1996], and the first shipment from foreign research reactors arrived on site in September of that year [Fact Sheet, 1996a].

Spent nuclear fuel is managed in several locations at the site. Most of the spent nuclear fuel remaining from SRS reactor operations is in water-filled

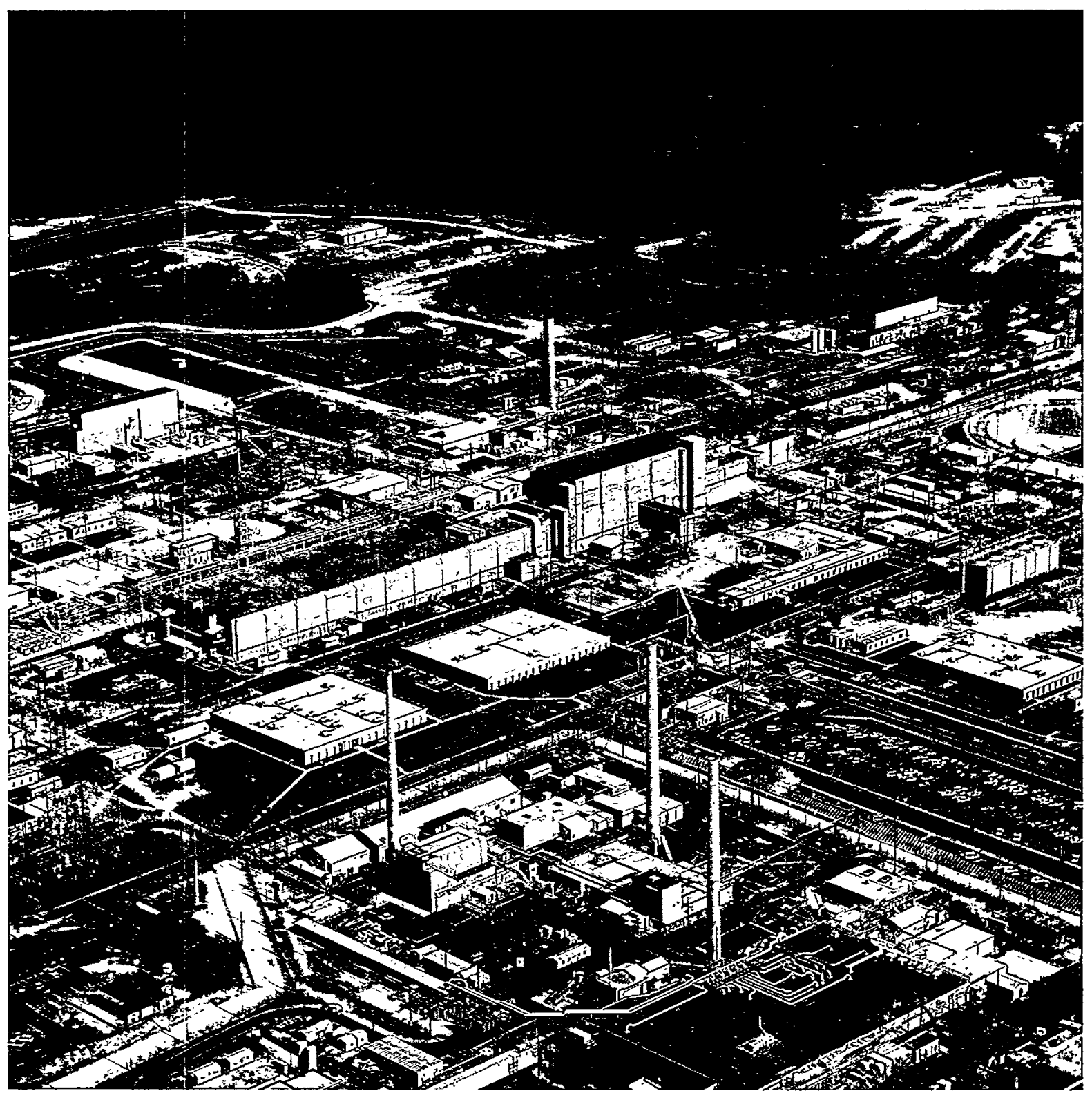

Steve Ashe Photo (WSRC-99-1119-26)

$\mathrm{H}$-Canyon, located in H-Area, is one of two large chemical separations facilities whose purpose is the stabilization of nuclear materials from onsite and offsite sources to ensure safe long-term storage or disposal. In the canyons, materials are dissolved, and the products of interest are chemically separated and purified from waste products. Some of the tritium facilities can be seen in the foreground. 


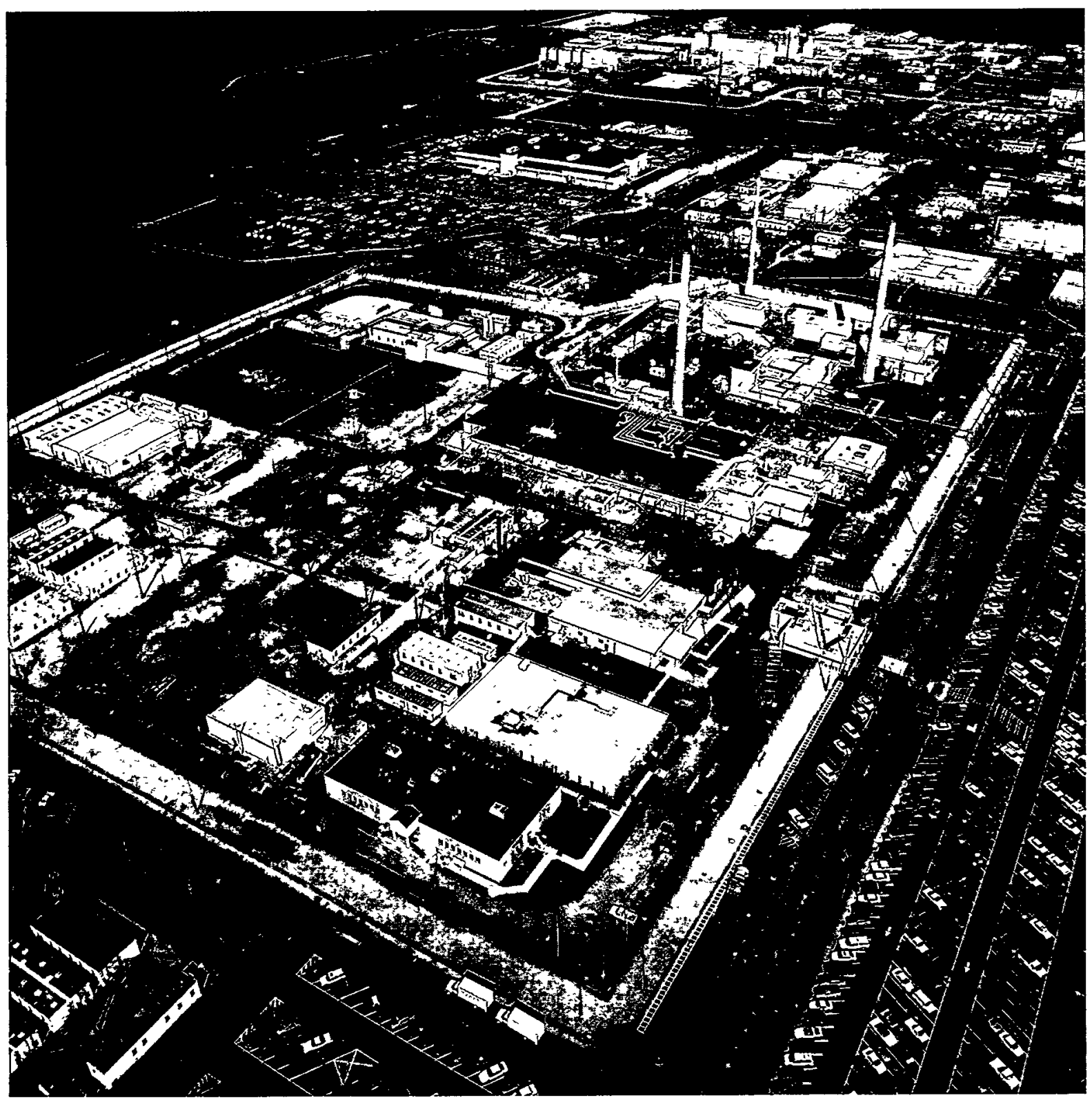

Steve Ashe Photo (WSRC-99-1440-01)

SRS's tritium facilities are located in H-Area. The main mission of the tritium facilities is to purify and maintain the declining inventories of tritium for defense purposes.

concrete storage basins, which originally were intended as interim storage facilities. Spent fuel from offsite sources (primarily domestic and foreign research reactors) is stored in the $\mathrm{RBOF}$ (located in $\mathrm{H}$-Area). The spent fuel is repackaged for extended storage and/or shipment to an onsite or offsite facility.

Storage will be a major issue for fuels that are not processed or that arrive after SRS reprocessing facilities are phased out. Many of the original storage facilities were not designed for the long interim storage period that may be required pending disposition. DOE is developing an integrated, long-term spent fuel management program that will address storage and treatment of all spent fuel until an ultimate disposition is determined.

\section{Tritium}

Tritium, one of the materials produced by the site for national defense, has,a half-life of 12.3 years and must be periodically replenished to maintain weapons in readiness for use. SRS is the nation's only facility for recycling tritium remaining after decay from nuclear weapons reservoirs returned from service. 
This recycling allows the United States to use its tritium supplies effectively and efficiently.

The SRS tritium facilities in H-Area consist of four main process buildings designed and operated to process tritium and to reclaim nuclear weapon reservoirs. The primary mission of the tritium facilities is to recover and purify tritium in order to maintain the declining inventories of tritium used for defense purposes.

With the shutdown of all SRS production reactors and no existing source of new tritium, DOE evaluated two options for tritium production-using existing or partially constructed commercial nuclear reactors and using a linear accelerator. In December 1998, DOE chose the Commercial Light Water Reactor option using the Tennessee Valley Authority's Watts Bar and Sequoyah reactors as the primary source of tritium and the Accelerator for the Production of Tritium as a backup option.

\section{Waste Management Areas (E, $F, H, S$, and $Z$ )}

Waste management activities are conducted in the following areas: $\mathrm{E}, \mathrm{F}, \mathrm{H}, \mathrm{S}$, and Z. E-Area, between F-Area and $\mathrm{H}$-Area, includes most of the site's disposal and storage facilities.

Weapons material production at SRS has generated unusable byproducts, such as highly radioactive waste. About 34 million gallons of this high-level radioactive waste is stored in tanks on site [Fact Sheet, 1996a]. In addition, other wastes at the site include low-level solid and liquid radioactive wastes; transuranic waste (which contains alpha-emitting isotopes that have decay rates and concentrations exceeding specified levels); hazardous waste (which is any toxic, corrosive, reactive, or ignitable material-as defined by the South Carolina Hazardous Waste Management Regulations-that could negatively affect human health or the environment); mixed waste (which contains both hazardous and radioactive components); and sanitary waste (which is neither radioactive nor hazardous).

An explanation of the various wastes and how the site manages them is discussed in chapter 4 ,

"Environmental Management."

Facilities in waste management areas designed to store or treat the waste generated from onsite operations include the Solid Waste Management Facility (SWMF; also referred to in this report as the Solid Waste Disposal Facility); the Effluent Treatment Facility (ETF); the high-level waste storage tanks in F-Area and H-Area ("tank farms"); the Extended Sludge Processing Facility; the Defense
Waste Processing Facility (DWPF); the Saltstone Facility; and the Consolidated Incineration Facility (CIF).

SWMF is a disposal site for low-level solid waste items such as protective clothing, tools, and equipment contaminated with radioactive material. The solid low-level waste is disposed of permanently in the engineered concrete E-Area Vaults and trenches. Wastes contaminated with small amounts of radioactive material may be disposed of in engineered trenches, while wastes that require additional isolation are disposed of in concrete vaults.

Historically, seepage basins were used to dispose of wastewater from the separations facilities in F-Area and $\mathrm{H}$-Area. The ETF, located in H-Area, treats the low-level radioactive wastewater formerly sent to the seepage basins. The ETF removes radioactive and nonradioactive contaminants, except tritium, from process effluents and discharges the water to Upper Three Runs Creek.

The F-Area and H-Area waste tank farms consist of large underground storage tanks that hold high-level liquid radioactive waste resulting primarily from the reprocessing of spent nuclear fuel. The waste is contained in 29 tanks in H-Area and 20 tanks in F-Area. Sludge and saltcake must be removed from the tanks for processing for ultimate disposal. Sludge is the viscous, brown portion of the waste that settles on the bottom of the tank. Saltcake, the thick liquid resting above the sludge, contains salts and some soluble radioactive materials.

The Extended Sludge Processing Facility washes the sludge to remove excess aluminum and salts before the sludge is ready to be fed to the DWPF. The salt fraction of high-level waste contains highly radioactive cesium. Alternatives to the in-tank precipitation process (stopped in 1998 because of formation of benzene) for separating the cesium from the salt are under evaluation. These alternatives include ion-exchange, small-tank precipitation, and solvent extraction. Technology development activities will continue in 2000 to determine the best technology for implementation at SRS.

The DWPF, located in S-Area, immobilizes the high-level waste sludge and the precipitate by "vitrifying" it into a solid glass waste form. A component of the DWPF, the Saltstone Facility, treats and disposes of the filtrate by stabilizing it in a solid, cement-based waste form [Fact Sheet, 1996b].

The CIF, located adjacent to H-Area, was designed to burn safely certain hazardous, low-level radioactive, and mixed (both hazardous and radioactive) wastes. 


\section{Administration Area (A)}

The administration area (A-Area) contains organizations that provide direct support for SRS operations. DOE's Savannah River Operations Office and most of WSRC's administrative offices are located in A-Area, as are SRTC and the Savannah River Ecology Laboratory (SREL).

\section{Other Areas (B, N, TNX, and G)}

Other onsite and offsite facilities support SRS operations. B-Area includes an engineering complex and some administrative offices; ground was broken in this area in October for the Regulatory Monitoring and Bioassay Laboratory, an environmental and worker radiation monitoring laboratory. Onsite areas also include Central Shops (N-Area) and TNX (now

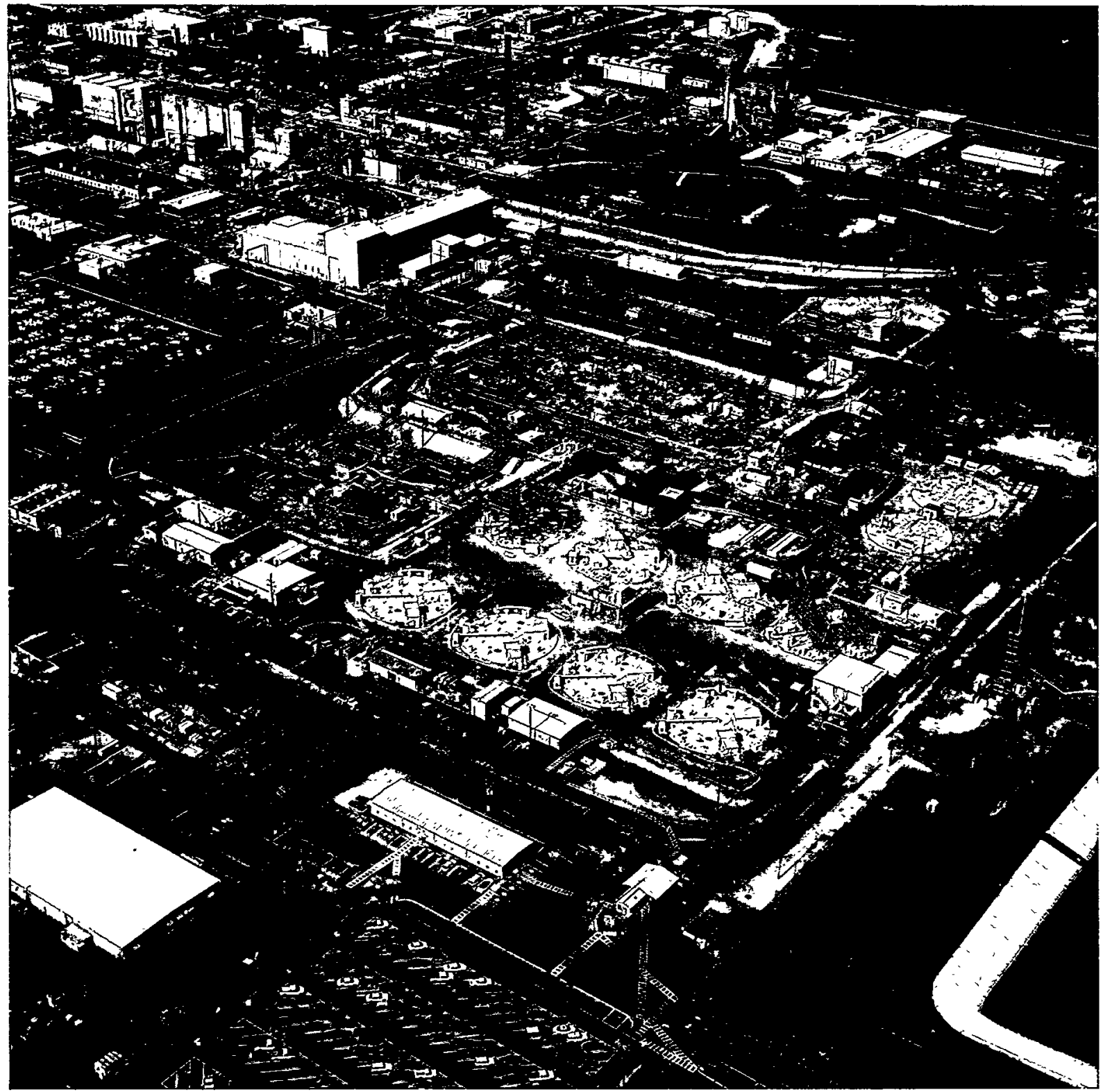

Steve Ashe Photo (WSRC-99-1120-15)

The F-Area Tank Farm contains large underground storage tanks that hold high-level liquid radioactive waste. About 34 million gallons of this waste is stored in these and in tanks in the H-Area Tank Farm. This high-level waste resulted primarily from weapons material production at SRS. 
called the Multipurpose Pilot Plant Campus), a research and development area. Locations not within areas designated for specific purposes are called G-Area, or general area. Activities conducted off site are administrative and do not involve radioactive or hazardous materials.

\section{Other Major Site Activities}

\section{Facility Disposition}

A large number of facilities at SRS do not have a continuing mission. To address this situation, separate programs have been developed

- to provide cost-effective risk management of abandoned legacy facilities

- to ensure that mission-completed facilities undergo a seamless transition from operations to a safe, shutdown condition requiring minimal cost to maintain

Excess facilities and disposition activities are discussed in chapter 4 .

\section{Environmental Restoration}

In 1981, SRS began inventorying waste sites (referred to as "units") for eventual restoration. About 515 waste units have been identified to be addressed through the site's environmental restoration program. Of these 515 units, 221 have been determined to require no further action. The remainder are in remediation or remediation design (e.g., engineering characterization, sampling studies, data compilation, designing a path forward) or have been proposed for no further action. Waste units range in size from a few square or cubic feet to tens of acres and include basins, pits, piles, burial grounds, landfills, tanks, and groundwater contamination areas.

Of the 500 acres to be addressed in the environmental restoration program, about 300 have been or are being remediated. Also, billions of gallons of groundwater have been treated to remove hundreds of thousands of pounds of solvents. Even though the site has had success in cleaning up some areas, a significant amount of environmental restoration work remains [Fact Sheet, 1996a]. More about environmental restoration can be found in chapter 4 .

\section{Environmental Monitoring}

Onsite and offsite radiological and nonradiological environmental monitoring is conducted by the Environmental Monitoring Section (EMS) of WSRC's Environmental Protection Department
(EPD). The environmental monitoring program is discussed briefly in chapter 3, "Environmental Program Information," and more thoroughly in chapters 5, ("Radiological Effluent Monitoring"), 6 ("Radiological Environmental Surveillance"), 8 ("Nonradiological Effluent Monitoring"), and 9 ("Nonradiological Environmental Surveillance").

Also, the Division of Environmental Research of the Academy of Natural Sciences of Philadelphia has performed biological and water quality surveys of the Savannah River since 1951. More about the academy's surveys can be found in chapter 9 ("Nonradiological Environmental Surveillance").

\section{Research and Development}

SRTC, the site's applied research and development laboratory, creates, tests, and puts into use solutions to SRS's technological challenges. SRTC researchers have made significant technological advances in hydrogen technology, nonproliferation, environmental characterization and cleanup, sensors and probes, use of glass for stabilizing and disposing of waste, etc.

SRTC's facilities include biotechnology laboratories, laboratories for the safe study and handling of radioactive materials, a field demonstration site for testing and evaluating environmental cleanup technologies, and laboratories for ultra-sensitive measurement and analysis of radioactive materials.

In recent years, SRTC's role has expanded and includes providing related support to DOE-Headquarters (DOE-HQ), other DOE sites, other federal agencies, and other customers. SRTC also forms strategic partnerships with private industry, academia, and other government agencies to apply the laboratory's unique expertise to challenges of mutual interest. For example, SRTC, working with a broad-based consortium, applied its extensive hydrogen expertise to the development of a hydrogen-fueled bus that became part of the Augusta public transit fleet.

The laboratory also shares its expertise by licensing private companies to manufacture and/or market technologies created at SRTC.

\section{Other Environmental Research}

In addition, environmental activities are conducted by the SREL, the Savannah River Natural Resource Management and Research Institute (SRI), and the Savannah River Archaeological Research Program (SRARP). 
Soil is one of the many media monitored by SRS as part of the environmental monitoring program. Soil plugs are collected from onsite and offsite locations. The soil program provides data for long-term trending of radioactivity deposited from the atmosphere and information on the concentrations of radioactive materials in the environment.

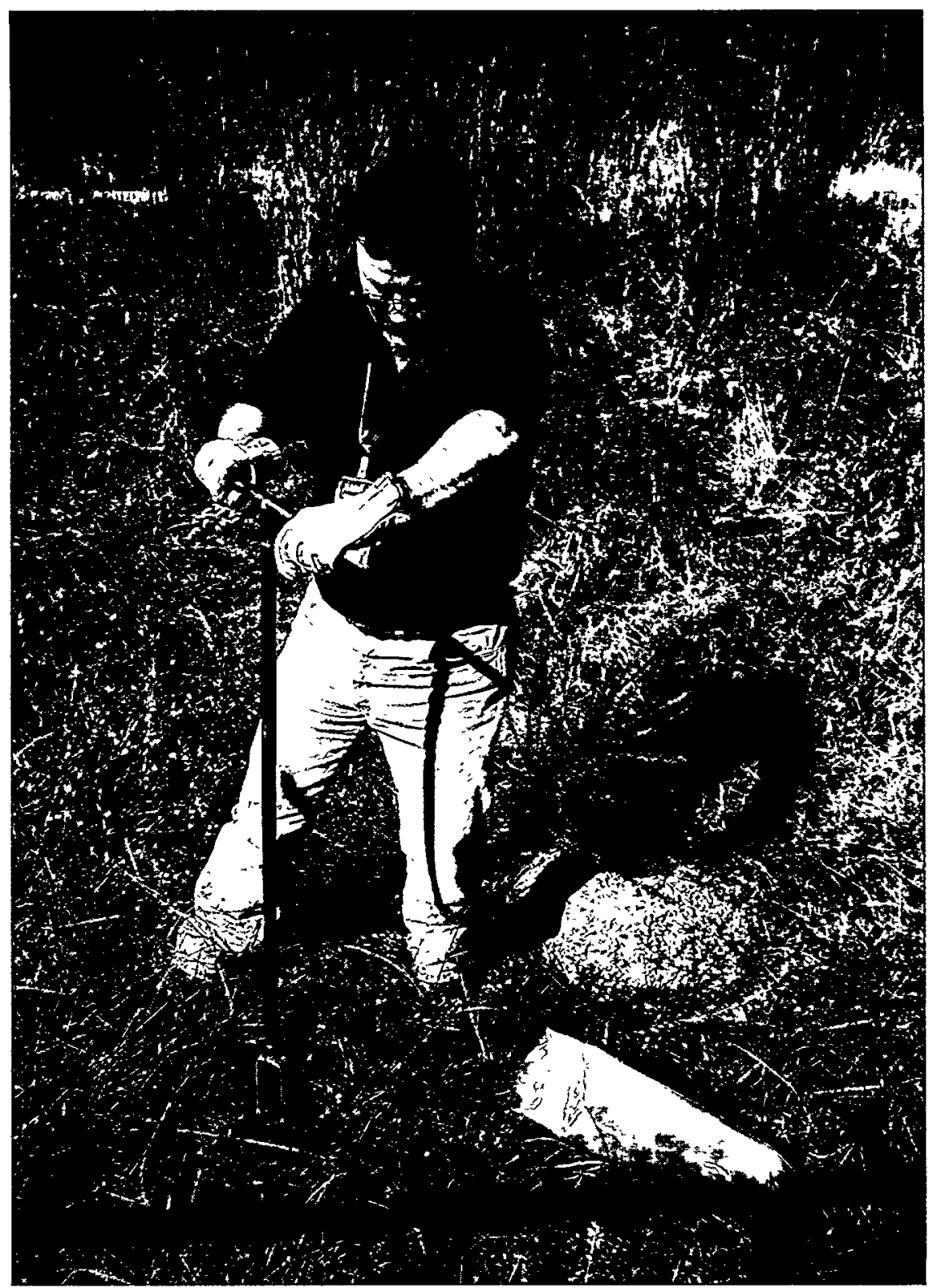

Al Mamatey Photo (99X0011.02)

\section{Savannah River Ecology Laboratory}

SREL is operated by The University of Georgia and has been funded by DOE (and its predecessors) since 1951 to conduct research related to the impact of site operations on the environment. Current research programs are organized under four groups-the Advanced Analytical Center for Environmental Sciences; Ecological Stewardship; Ecotoxicology, Remediation, and Risk Assessment; and Radioecology.

Studies in the Advanced Analytical Center for Environmental Sciences address the physical, chemical, and biological processes controlling the mobility of organic and inorganic contaminants in the environment, particularly in soils and water of SRS and other DOE sites.

One objective of the Ecological Stewardship group is to document the ecosystem health of SRS by identifying patterns of biodiversity on site and the natural and anthropogenic processes that maintain or change them. A second objective is to develop the technology necessary to restore damaged ecosystems on site.

Research in the Ecotoxicology, Remediation, and Risk Assessment group seeks to measure or predict 
bioaccumulation of contaminants in natural populations of organisms. This program also seeks to evaluate genetic and demographic markers in various species for use as possible indicators of responses to environmental contaminants.

Radioecology research assesses the distribution, fate, and ecological risk associated with radionuclides in the environment, including the genetic effects on flora and fauna at SRS and highly contaminated sites such as the Chernobyl site in the Ukraine.

Additional studies are conducted on the site's deer herd, fish, reptiles, amphibians, waterfowl, and endangered species, such as the wood stork, bald eagle, and the smooth purple coneflower. Other studies evaluate the potential of various experimental approaches for remediating contaminated soils, Carolina bays, and other habitats.

Information about SREL's education outreach program can be found in chapter 3. More information about all programs can be obtained by contacting SREL at 803-725-2473 or by viewing its website at http://www.uga.edu/srel.

\section{Savannah River Natural Resource Management and Research Institute}

SRI manages the natural resources at SRS. In 1952, the AEC and the U.S. Department of Agriculture Forest Service formed an interagency agreement to create an onsite natural resources management organization at SRS. Because the site had been farmland, an early task of the Forest Service was to plant millions of trees to help establish a buffer around the facilities being constructed. Forest Service practices since have created a unique refuge for a variety of plants and animals, including six endangered or threatened species and more than 70 sensitive species. Today, major responsibilities include the following:

- $\quad$ SRI provides administrative support for more than 60 forest research projects in cooperation with Forest Service and site organizations, universities, and research laboratories.

- Soil, water, and air personnel provide support to other groups on site involved in erosion and sediment control projects.

- Wildlife and botany personnel maintain and improve a variety of habitats that will support native plants and animals.

- SRI sells sawtimber (timber large enough to be sawed into lumber) and roundwood products (wood not big enough for lumber but useful for making paper, etc.). At the same time, it plants acres of new seedlings.

- Fire management personnel control-burn about 15,000 acres each year to protect site facilities and improve a variety of forest resources. They are responsible for suppressing any wildfires on site.

- Engineers maintain all secondary roads and exterior boundaries.

Information about SRI's education outreach program can be found in chapter 3 . Information about other programs can be obtained by contacting SRI at 803-725-0237.

\section{Savannah River Archaeological Research Program}

SRARP was formed in 1973 under a cooperative agreement with DOE and the South Carolina Institute of Archaeology and Anthropology, University of South Carolina. Its primary purpose is to make compliance recommendations to $\mathrm{DOE}$ that will facilitate the management of archaeological resources at SRS. Other functions include compliance activities involving site-use surveys, specific intensive surveys, data recovery, coordination with major land users, and reconstruction of the environmental history of the site. More information can be obtained by contacting SRARP at 803-725-3623. 


\section{Environmental Compliance}

\author{
Al Mamatey \\ Environmental Protection Department
}

Contributors' names appear on page 38.
To Read About ... $\quad$ See Page ...

Compliance Activities .............. 16

Key-Regulations Summary .......... 16

Toxic Chemical Releases .............. 22

NEPA Documentation Activities ........23

Safe Drinking Water ................24

Clean Air .......................27

CERCLA-Reportable Releases.......... 35

Facility Decommissioning ............37

Construction/Operating Permits ......... 37

Other Major Issues/Actions . .......... 38

\section{Highlights}

- All 20 of the operational petroleum storage tanks at SRS received certificates of compliance.

- Consistent with FFA milestones, six signed RODs and 22 site evaluation reports were submitted to EPA and SCDHEC for approval. Characterization was initiated at one unit to determine if hazardous constituents were present in the environment, and remedial actions were initiated at four units.

- SRS submitted its Toxic Chemical Release Inventory report for 1998 to EPA ahead of the July 1, 1999, deadline. Ten chemicals, with releases totaling 160,580 pounds were reported for 1998-compared with seven chemicals $(280,649$ pounds) reported for 1997 and seven chemicals $(31,582$ pounds) reported for 1996 . The increase from 1996 to 1997 reflects active remediation of old waste sites and the transfer of contaminated soil to an offsite facility.

- A total of 244 NEPA reviews of newly proposed actions at SRS were conducted and formally documented.

- Under the CAA, SRS achieved a compliance rate of 100 percent, with no NOVs. Under the CWA, the site achieved a compliance rate of 99.8 (above the DOE-benchmark of 98 percent) but received two NPDES-related NOVs. The site also received two NOVs under RCRA.

- SRS had one CERCLA-reportable release, compared with one such release in 1998, three in 1997, two in 1996, and four in 1995.

- Of the 592 SIRIM-reportable events in 1999, 13 were categorized as primarily environmental. Of the 13 events, none were classified as emergencies, two were classified as an unusual occurrences, and 11 were classified as off-normal occurrences.

$\mathrm{T}$

HE goal of the Savannah River Site (SRS) —and that of the U.S. Department of Energy (DOE)-is positive environmental stewardship and full regulatory compliance, with zero violations. The site's employees maintained progress toward achievement of this goal in 1999, as demonstrated by examples in this chapter.

A systematic effort is in place to identify and address all evolving regulatory responsibilities that concern SRS. As part of the process, communications are maintained with all appropriate regulatory agencies to emphasize the site's commitment to environmental compliance.

The site's compliance efforts were highly successful again in 1999. For example, no notices of violation (NOVs) were received by SRS under the Clean Air Act (CAA), which had a compliance rate for the year of 100 percent, or the Safe Drinking Water Act
(SDWA). Under the Clean Water Act (CWA), meanwhile, the site achieved a compliance rate of 99.8 percent, which was calculated by dividing the number of analyses not exceeding permit limits for the year $(5,768)$ by the total number of analyses performed $(5,778)$ to demonstrate compliance with National Pollutant Discharge Elimination System (NPDES) permits.

The site did receive two NOVs in 1999 under the CWA - one from the South Carolina Department of Health and Environmental Control (SCDHEC), the other from the U.S. Environmental Protection Agency (EPA)—and two under the Resource Conservation and Recovery Act (RCRA), as described later in this chapter.

Some key regulations with which SRS must comply - and its compliance status on each-are noted in the chart on the next page. 
Some of the Key Regulations SRS Must Follow

Legislation

RCRA

Resource Conservation and Recovery Act (1976)

FFCAct

Federal Facility Compliance Act (1992)

\section{CERCLA; SARA}

Comprehensive Environmental Response, Compensation, and Liability Act (1980); Superfund Amendments and Reauthorization Act (1986)

\section{CERCLATTITLE III (EPCRA)}

Emergency Planning and Community

Right-to-Know Act (1986)

\section{NEPA}

National Environmental Policy Act (1969)

\section{SDWA}

Safe Drinking Water Act (1974)

\section{CWA; NPDES}

Clean Water Act (1977); National Pollutant

Discharge Elimination System

\section{CAA; NESHAP}

Clean Air Act (1970); National Emission Standards for Hazardous Air Pollutants

TSCA

Toxic Substances Control Act (1976)

\section{What it Requires/SRS Compliance Status}

- The management of hazardous and nonhazardous wastes and of underground storage tanks containing hazardous substances and petroleum products-in compliance

- The development by DOE of schedules for mixed waste treatment to avoid waiver of sovereign immunity and to meet LDR requirements-in compliance

- The establishment of liability, compensation, cleanup, and emergency response for hazardous substances released to the environment-SRS placed on National Priority List in December 1989

- The reporting of hazardous substances used on site (and their releases) to EPA, state, and local planning units-in compliance

- The evaluation of the potential environmental impact of federal activities and alternatives; in 1999, WSRC conducted 244 reviews of newly proposed actions-in compliance

- The protection of public drinking water systems; enacted in 1974, amended in 1980, 1986-in compliance

- The regulation of liquid discharges at outfalls (e.g., drains or pipes) that carry effluents to streams-in compliance

s

- The establishment of air quality standards for hazardous air emissions, such as radionuclides and benzene-in compliance

- The regulation of use and disposal of PCBs-nation has inadequate disposal capacity for radioactive PCBs generated and currently stored at SRS

\section{Compliance Activities}

Compliance with environmental regulations and with DOE orders related to environmental protection is a critical part of the operations at SRS. Assurance that onsite processes do not impact the environment adversely is a top priority, and management of the environmental programs at SRS is a major activity. All site activities are overseen by one or more regulatory bodies, including EPA and SCDHEC. Significant effort and funding have been dedicated to ensuring that site facilities and operations comply with all requirements.

\section{Resource Conservation and Recovery Act}

RCRA was passed in 1976 to address the problem of solid and hazardous waste management. The law 
requires that EPA regulate the management of solid and hazardous wastes, such as spent solvents, batteries, and many other discarded substances deemed potentially harmful to human health and the environment. Amendments to RCRA regulate nonhazardous solid waste and some underground storage tanks.

Under RCRA, hazardous waste generators are responsible for managing every aspect of the generation, treatment, storage, and disposal of the waste; this is referred to as "cradle-to-grave" management. Hazardous waste generators, including SRS, must follow specific requirements for handling these wastes. For many waste management activities, RCRA requires permits for owners and operators of operating or post-closure-care hazardous waste management facilities.

EPA is responsible for all hazardous waste regulations. However, EPA can delegate this authority to a state when the state passes laws and regulations that meet or exceed the EPA hazardous waste regulations. The state plan then must be approved by EPA. The agency has approved South Carolina's plan and delegated RCRA authority to SCDHEC. Similarly, the Federal Facility Compliance Act (FFCAct) gives the state authority to enforce land disposal restrictions (LDR) for mixed wastes, which contain both hazardous and radioactive wastes. Also, SCDHEC has been authorized by the FFCAct to play the key role in the implementation of the FFCAct statute and was the lead regulatory agency for implementation of the SRS Site Treatment Plan (STP), which addresses storage and treatment of mixed waste. More information on waste management at SRS can be found in chapter 4, "Environmental Management."

\section{Land Disposal Restrictions}

The 1984 RCRA amendments established LDRs to minimize the threat of hazardous constituents migrating to groundwater sources. Hazardous wastes were banned from land disposal unless certain treatment requirements were met. LDRs do not allow storage of hazardous wastes except for the purpose of accumulating such quantities as are necessary to facilitate proper recovery, treatment, or disposal.

The same restrictions apply to mixed wastes. Because SRS did not have the capacity to treat all mixed wastes according to the applicable LDR standards, a Federal Facility Compliance Agreement (FFCA) was signed in March 1991 between DOE's Savannah River Operations Office (DOE-SR) and EPA Region IV (Alabama, Florida, Georgia, Kentucky, Mississippi, North Carolina, South Carolina, and
Tennessee). The FFCA is an independent compliance instrument initiated by SRS and is not part of the FFCAct statute. The goal of the FFCA was to address SRS mixed waste compliance with LDRs. The FFCA was terminated September 29, 1995-by mutual consent of SRS and EPA-when the STP consent order became effective.

Treatability variances are an option available to facilities for particular waste streams that either cannot be treated at the level specified in regulations-the appropriate treatment technology may not be available-or for which the treatment technology is inappropriate for the waste. SRS has identified certain mixed waste streams that are potential candidates for a treatability variance. One variance-for in-tank precipitation filters-was granted in October 1993 by EPA Region IV. The STP references three additional treatability variances for mixed wastes with special problems that prevent treatment according to LDR standards. Two of the three variances, completed and sent to EPA headquarters in September 1997, were for tritiated water with mercury and for silver saddles (silver nitrate-coated ceramic devices designed to take up iodine gas). The third variance, for plastic/lead/cadmium Raschig rings (packing material spacers used for criticality control), was submitted September 7, 1999.

\section{Federal Facility Compliance Act}

The FFCAct was signed into law in October 1992 as an amendment to the Solid Waste Disposal Act to add provisions concerning the application of certain requirements and sanctions to federal facilities. For mixed waste, the FFCAct provided a 3-year delay (until October 1995) in the imposition of fines and penalties so that DOE sites could investigate mixed waste volumes in storage, evaluate treatment capacities, and develop STPs with schedules for mixed waste treatment for approval by their state or federal regulatory agencies.

Westinghouse Savannah River Company (WSRC) submitted a mixed waste inventory report January 13, 1993, and DOE Headquarters (DOE-HQ) issued a complexwide report-U.S. Department of Energy Interim Mixed Waste Inventory Report: Waste Streams, Treatment Capacities, and

Technologies-April 21, 1993, to state governors and to regulatory agencies in states that host DOE sites. This was followed by a comment period for the regulators and states. DOE-HQ provided an update to the mixed waste inventory report in April 1994.

On March 30, 1995, DOE-SR submitted an STP that addressed the development of capacities and 
technologies for treating SRS mixed wastes in accordance with LDRs, as required by the FFCAct. This plan was approved with modifications, and the STP consent order was executed September 29, 1995.

As required by the STP consent order, SRS issued an annual update to the STP by April 30, 1999. The update identified changes in the mixed waste treatment status, including the addition of new mixed waste streams. STP updates will continue to be produced annually unless the consent order is modified.

\section{Notices of Violation (RCRA)}

SRS received two RCRA-related NOVs from SCDHEC during 1999. The first, issued to WSRC and DOE-SR March 11, stated that the site had improperly stored hazardous waste in its beta-gamma incinerator. After negotiations, SRS entered a consent order with SCDHEC that closed the NOV. Under terms of the order, the site submitted a closure plan for the tank and implemented a sitewide survey to pinpoint any other possible unidentified wastes, and WSRC paid a $\$ 39,840$ civil penalty.

SCDHEC issued the second NOV to WSRC and DOE-SR November 12, following an October 4 incident at SRTC in which SRS allegedly had combined incompatible hazardous wastes, generating a violent reaction and uncontrolled toxic fumes in sufficient quantities to threaten human health or the environment. SRS representatives presented information at a December 15 enforcement conference to support the site's position that the enforcement action should be withdrawn. SCDHEC had not closed the NOV by the end of 1999.

\section{Underground Storage Tanks}

The 20 underground storage tanks at SRS that house petroleum products-such as gasoline and diesel fuel-and hazardous substances, as defined by the Comprehensive Environmental Response, Compensation, and Liability Act (CERCLA). All the tanks are regulated under Subtitle I of RCRA.

Corrective actions to repair the connective piping of an underground storage tank belonging to Wackenhut Services, Inc., the company's security contractor, were completed in January 1999, after the the tank's piping had failed to pass tightness testing in 1998. With the completion of these repairs and of 1999 tightness testing on all underground storage tank ancillary piping across the site, SRS received compliance certificates for all 20 underground storage tanks December 6-7.

\section{High-Level Radioactive Waste Tank Closure}

The primary regulatory goal of SRS's waste tank closure process at the F-Area and H-Area high-level tank farms is to close the tank systems in a way that protects public health and the environment in accordance with South Carolina Regulation 61-82, "Proper Closeout of Wastewater Treatment Facilities." This must be accomplished in compliance with the requirements of RCRA and CERCLA, under which the high-level waste tank "farms" will be remediated. A general tank closure plan presents the environmental regulatory standards and guidelines pertinent to closure of the waste tanks and describes the process for evaluating and selecting the closure configuration (the residual source term and method of stabilizing the tanks systems' residual waste material). The plan also describes the integration of high-level waste tank system closure with existing commitments to remove waste from the tanks before closure and to ultimately remediate the entire area (including soils and groundwater) surrounding the tank farms.

Tank 20F, a 1.3-million-gallon, single-shelled, carbon steel vessel, and tank 17F, with the same capacity, were closed in 1997. Prior to the initiation of closure activities, all but approximately 1,000-2,400 gallons of waste were removed from each tank and further processed.

The assessment of soils and groundwater around the waste tanks will be deferred until complete closure of a geographical grouping of tank systems and their associated support services. Currently, the tank $17 \mathrm{~F}$ and tank $20 \mathrm{~F}$ systems cannot be isolated practically from other operational systems (tanks $18 \mathrm{~F}$ and $19 \mathrm{~F}$ and the IF evaporator) for the purpose of assessing potential remedial actions.

The SRS Federal Facility Agreement (FFA) requires closure of tank 19F in 2003 and tank 18F in 2004. The removal of waste from tank $19 \mathrm{~F}$ is expected to be completed by October 2000 . A tank 19F closure module subsequently will be prepared and submitted to SCDHEC prior to the initiation of closure activities. The general plan for high-level waste tank system closure is scheduled to be revised and submitted during FY 2000 to DOE-HQ, EPA, and SCDHEC for approval, as required by DOE Order 435.1 ("Radioactive Waste Management").

DOE determined in October 1998 that SRS should perform a tank closure Environmental Impact Statement (EIS) before conducting any further closure activities. A Record of Decision (ROD) on this action, originally scheduled for December 1999, now is expected during FY 2000. 


\section{RCRA 3004(u) Program}

The hazardous waste permit issued to SRS in September 1987 (and renewed in October 1995) requires that the site institute a program for investigating and, if necessary, performing corrective actions at solid waste management units under RCRA 3004(u). The RCRA 3004(u) requirements have been integrated with CERCLA requirements in the FFA. The integration of RCRA and CERCLA regulatory requirements is expected to provide a more cost-effective and focused investigation and remediation process. The RCRA/CERCLA program status is detailed under the CERCLA section of this chapter.

\section{Waste Minimization Program}

The SRS Waste Minimization Program is part of a broad, ongoing effort to prevent pollution and minimize waste on site. The program is designed to meet the requirements of RCRA, of DOE orders, and of applicable executive orders. More information on the site's pollution prevention activities-including specific programs such as Waste Minimization-can be found in chapter 3, "Environmental Program Information," and chapter 4.

\section{Comprehensive Environmental Response, Compensation, and Liability Act}

SRS was placed on the National Priority List in December 1989, under the legislative authority of CERCLA (Public Law 96-510), as amended by the Superfund Amendments and Reauthorization Act of 1986 (SARA, Public Law 99-499). CERCLA assigns liability and provides for compensation, cleanup, and emergency response for hazardous substances released to the environment.

In accordance with Section 120 of CERCLA, DOE, EPA Region IV, and SCDHEC entered into the FFA, which became effective August 16, 1993. Declaration of the effective date results in the FFA being an enforceable agreement. The FFA, which sets the milestones for environmental remediation at SRS, consolidates site cleanup activities into one comprehensive strategy.

The FFA also identifies about 300 site evaluation units for which investigations are required. Site evaluation reports were submitted to EPA and SCDHEC for 28 areas in 1994 and for at least 24 areas each year from 1995 to 1998 . Twenty-two site evaluation reports-encompassing many areas of potential releases-were submitted to EPA and SCDHEC in 1999.
Releases or potential releases from RCRA/CERCLA waste management units are evaluated under the FFA. Work plans detailing the proposed investigations for the RCRA/CERCLA units must be approved by both EPA and SCDHEC prior to implementation.

Remediation under CERCLA imposes requirements in addition to existing RCRA requirements. CERCLA requires remedial decisions to be based on the results of a baseline risk assessment, which examines present and future risk to human health and the environment from the waste unit, using conservative, EPA-approved exposure scenarios.

CERCLA also requires public participation in the selection of remediation alternatives. A significant step in this process is the development of a Proposed Plan, which highlights key aspects of the remedial investigation and feasibility study. The plan also provides a brief analysis of remedial alternatives that were considered, identifies the preferred alternatives, and tells the public how it can participate in the remedy selection process. After consideration of public comments and further analysis, decisions are made and documented in a ROD, which presents the selected remedy and provides the rationale for that selection. Also included in this process is the establishment of an administrative record file that documents the remediation alternatives and provides for public review of them.

SRS's 1999 environmental restoration activities included

- the submittal to EPA and SCDHEC of six signed RODs (final RODS) on (1) the Ford Building Waste Site, (2) the Miscellaneous Chemical Basin/Metals Burning Pit (interim action), (3) the Chemicals, Metals, and Pesticides (CMP) Pits (interim action), (4) the L-Area and P-Area Bingham Pump Outage Pits, (5) the SRL Seepage Basins, and (6) radiologically contaminated basins (a plug-in ROD)

- the receipt from EPA and SCDHEC of five signed RODs (issued RODs) on (1) the D-Area Oil Seepage Basin, (2) the C-Area Burning/Rubble Pit (interim action), (3) the Ford Building Waste Site, (4) the CMP Pits (interim action), and (5) radiologically contaminated basins (the plug-in ROD)

- the submittal to EPA and SCDHEC of 22 site evaluation reports

- the initiation of one characterization field start at the R-Area Acid/Caustic Basin

- the initiation of four remedial action starts at (1) the C-Area Burning/Rubble Pit (interim action), (2) the F-Area Retention Basin, (3) the D-Area 
Oil Seepage Basin, and (3) the CMP Pits (interim action)

Table 2-8 ("SRS 1999 Environmental Restoration Activities"), beginning on page 39 , includes a more complete presentation of the site environmental restoration program's environmental restoration activities. A listing of all operable units at SRS can be found in appendix C ("RCRA/CERCLA Units List") and appendix G ("Site Evaluation List") of the FFA.

\section{Emergency Planning and Community Right-to-Know Act}

Two related federal acts were enacted within a period of 4 years to help protect the public and the environment. The Emergency Planning and Community Right-to-Know Act (EPCRA) of 1986 was enacted as a freestanding provision of SARA. EPCRA requires facilities to notify state and local emergency planning entities about their hazardous chemical inventories and to report releases of hazardous chemicals. The Pollution Prevention Act of 1990 expanded the Toxic Chemical Release Inventory report to include source reduction and recycling activities.

\section{Tier II Inventory Report}

Under Section 312 of EPCRA, SRS completes an annual Tier II Inventory Report for all hazardous chemicals present at the site in excess of specified quantities during the calendar year. Hazardous chemical storage information is submitted to state and local authorities by March 1 for the previous calendar year.

\section{Toxic Chemical Release Inventory Report}

Under Section 313 of EPCRA, SRS must file an annual Toxic Chemical Release Inventory report by July 1 . SRS calculates chemical releases to the environment for each regulated chemical that exceeds its established threshold and reports the release values to EPA on Form $\mathrm{R}$ of the report. The release values include chemical releases to air, water, land, underground injection, and offsite transfers. EPA treats offsite transfers as releases to the environment for reporting purposes. The transfers actually are shipments of waste to EPA-approved facilities for further treatment, storage, disposal, or recycling.

Form R for 1998 was submitted to EPA in June 1999. Ten chemicals, with releases totaling 160,580 pounds, were reported to EPA for 1998 . This compares with seven chemicals $(280,649$ pounds of releases) reported for 1997 , and seven chemicals $(31,582$ pounds of releases) reported for 1996. For the 11-year period from 1988 through 1998, reportable releases of quantities declined by 94 percent (from 2,762,007 pounds in 1988 to 160,580 pounds in 1998).

However, the remediation of an old waste site and the resulting transfer of contaminated soil to an offsite treatment facility led to an increase in the total release value for 1997 and the early part of 1998 . Figure 2-1 shows the overall reduction in total toxic chemical releases at SRS for the period 1988-1998. Several factors have contributed to this reduction. Pollution prevention programs have supported declines in the use and release of toxic chemicals, resulting in significant decreases for chemicals such as chlorine, lead, Freon 113, and 1,1,1-trichloroethane. Two primary reasons for the dramatic decline in reported totals during the late 1980 s were as follows:

- EPA initially identified chemicals for reporting that did not meet the toxic criteria later developed for EPCRA Section 313. For example, EPA delisted nontoxic chemicals such as sodium sulfate; this resulted in a decline in reported releases for SRS.

- DOE curtailed nuclear production operations at SRS in 1989.

A breakdown of the comparison of toxic chemical releases from 1996 through 1998 is presented in table $2-1$. Changes in chemicals and amounts reported are due to (1) process modifications and shutdowns and (2) waste site cleanups.

Nitrate compounds were the largest contributor to the total reportable releases in 1998. Land disposal (saltstone closure), at 59 percent, and water (NPDES) discharges, at 12 percent, represented the two major receiving media. Wackenhut changed training ammunition in 1998 to environmentally friendly "green bullets" (lower lead content), which reduced the volume of lead discharged to land. Toluene was not reported in 1998 because the 1997 value was due largely to the transfer of 240,833 pounds of toluene-contaminated soil from an old waste site to a RCRA disposal facility. HCFC 22 is a new chemical reported for 1998 . Its release total ( 14,160 pounds) was generated primarily by the removal of a D-Area refrigeration system.

\section{3/50 Pollution Prevention Program}

In September 1992, DOE became the first federal agency to agree formally to participate in EPA's 33/50 Pollution Prevention Program. Under the agreement, DOE voluntarily adopted program goals that are expected to reduce the use and release of 17 priority chemicals. The first goal, which called for a 50 -percent reduction by the end of 1995 , applied to SRS and other contractor-operated facilities that 


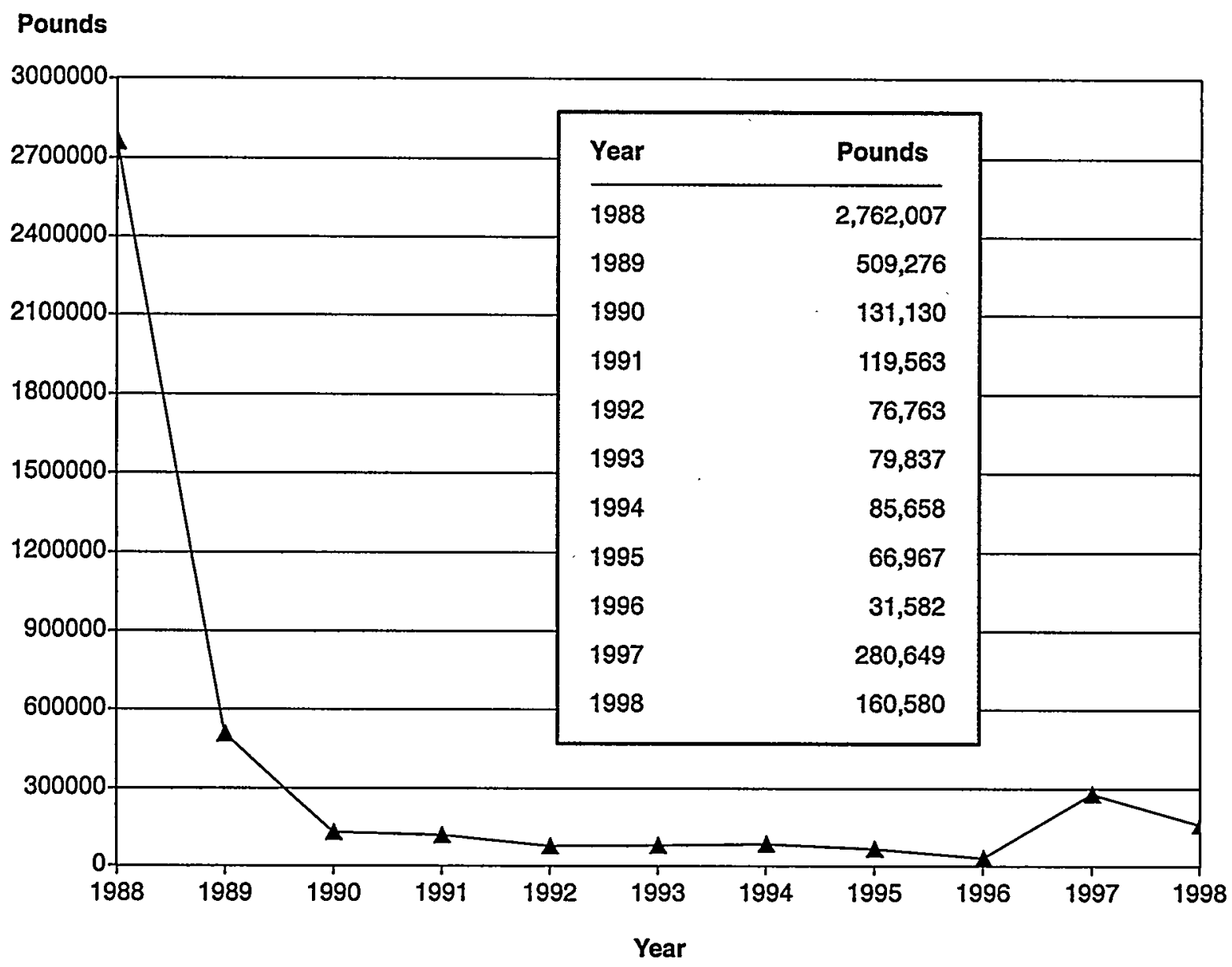

lleaf Graphic

Figure 2-1 Total Toxic Chemical Releases at SRS, 1988-1998

Through 1998, total toxic chemical releases had been reduced by about 94 percent when compared to 1988 . The sharpest drop occurred between 1988 and 1989, when EPA delisted nontoxic chemicals that did not meet toxic criteria for EPCRA Section 313. The decline between 1989 and 1990 represented curtailed nuclear production. The increase from 1996 to 1997 reflects active remediation of old waste sites by SRS and the transfer of contaminated soil to an EPA offsite treatment facility, both of which are considered "releases."

already were reporting the releases under EPCRA in 1992. The second goal, which called for a 33-percent reduction by the end of 1997, applied to the other contractor-operated facilities that met the reporting criteria in 1992 but had not previously reported the releases under EPCRA.

By 1993, the DOE complex already had met its 50-percent reduction goals. With this achievement of the 33/50 goals, the complex began to focus on reducing all toxic chemical releases, as identified in Executive Order 12856.

More about pollution prevention programs can be found in chapter 3 .

\section{Executive Order 12856}

Executive Order 12856 requires that all federal facilities comply with right-to-know laws and pollution prevention requirements. The order requires that federal facilities meet EPCRA reporting requirements and develop voluntary goals to reduce releases of toxic chemicals 50 percent on a DOE complexwide basis by the end of 1999-a goal accomplished by the complex. SRS complies with the applicable reporting requirements for EPCRA, as indicated in table 2-2, and the site incorporates the toxic chemicals on the Toxic Chemical Release Inventory report into its pollution prevention efforts. 
Table 2-1 Releases and Offsite Transfers of Toxic Chemicals (in Pounds) by SRS During 1996, 1997, and 1998 Reporting Years (Reported Under EPCRA Section 313)

1996

\begin{tabular}{lcccrr} 
Chemical & $\begin{array}{l}\text { Air } \\
\text { Emissions }\end{array}$ & $\begin{array}{l}\text { Water } \\
\text { Discharges }\end{array}$ & $\begin{array}{l}\text { Land } \\
\text { Disposal }\end{array}$ & $\begin{array}{l}\text { Offsite } \\
\text { Transfers }\end{array}$ & Total \\
\hline Formic acid & 56 & 0 & 0 & 0 & 56 \\
Lead & $9^{\mathrm{a}}$ & 83 & $7,100^{\mathrm{a}}$ & 234 & 7,426 \\
Naphthalene & 50 & 0 & 0 & 192 & 242 \\
n-Hexane & 54 & 0 & 0 & 96 & 150 \\
Nitrate compounds & 12 & 20,768 & 0 & 50 & 20,830 \\
Nitric acid & 2,840 & 0 & 4 & 0 & 2,844 \\
Sodium nitrite & 0 & 0 & 9 & 25 & 34 \\
Totals & $\mathbf{3 , 0 2 1}$ & $\mathbf{2 0 , 8 5 1}$ & $\mathbf{7 , 1 1 3}$ & $\mathbf{5 9 7}$ & $\mathbf{3 1 , 5 8 2}$
\end{tabular}

1997

\begin{tabular}{lcrrrr} 
Chemical & $\begin{array}{l}\text { Air } \\
\text { Emissions }\end{array}$ & $\begin{array}{l}\text { Water } \\
\text { Discharges }\end{array}$ & $\begin{array}{l}\text { Land } \\
\text { Disposal }\end{array}$ & $\begin{array}{l}\text { Offsite } \\
\text { Transfers }\end{array}$ & Total \\
\hline Formic acid & 60 & 0 & 0 & 0 & 60 \\
Lead & 11 & 27 & 5,700 & 2,670 & 8,408 \\
Nitrate compounds & 25 & 25,157 & 0 & 1 & 25,183 \\
Nitric acid & 2,573 & 0 & 0 & 0 & 2,573 \\
Sodium nitrite & 2 & 0 & 0 & 12 & 14 \\
Toluene & 891 & 0 & 2 & 240,833 & 241,726 \\
Xylene & 1,937 & 0 & 8 & 740 & 2,685 \\
Totals & $\mathbf{5 , 4 9 9}$ & $\mathbf{2 5 , 1 8 4}$ & $\mathbf{5 , 7 1 0}$ & $\mathbf{2 4 4 , 2 5 6}$ & $\mathbf{2 8 0 , 6 4 9}$
\end{tabular}

1998

\begin{tabular}{lrrrrr} 
Chemical & $\begin{array}{l}\text { Air } \\
\text { Emissions }\end{array}$ & $\begin{array}{l}\text { Water } \\
\text { Discharges }\end{array}$ & $\begin{array}{l}\text { Land } \\
\text { Disposal }\end{array}$ & $\begin{array}{l}\text { Offsite } \\
\text { Transfers }\end{array}$ & Total \\
\hline Chrome Compounds & 168 & 3 & 2,203 & 236 & 2,610 \\
Formic acid & 7,400 & 0 & 0 & 0 & 7,400 \\
HCFC 22 & 14,160 & 0 & 0 & 0 & 14,160 \\
Lead & 5 & 47 & 6,601 & 308 & 6,961 \\
Lithium carbonate & 16 & 0 & 0 & 0 & 16 \\
Methyl tert-butyl ether & 1 & 0 & 0 & 0 & 1 \\
Nitrate compounds & 26 & 19,721 & 95,000 & 9 & 114,756 \\
Nitric acid & 3,530 & 0 & 0 & 11 & 3,541 \\
Sodium nitrite & 2 & 0 & 8,000 & 0 & 8,002 \\
Zinc compounds & 577 & 621 & 1,933 & 2 & 3,133 \\
Totals & 25,885 & 20,392 & 113,737 & 566 & 160,580
\end{tabular}

a Revised value submitted to EPA in 1998 because additional information made available 
Table 2-2 1999 SRS Reporting Compliance with Executive Order 12856

\begin{tabular}{|c|c|c|}
\hline $\begin{array}{l}\text { EPCRA } \\
\text { Citation }\end{array}$ & $\begin{array}{l}\text { Activity } \\
\text { Regulated }\end{array}$ & $\begin{array}{l}\text { Reported per } \\
\text { Applicable } \\
\text { Requirement }\end{array}$ \\
\hline $302-303$ & Planning Notification & Not Requireda \\
\hline 304 & $\begin{array}{l}\text { Extremely Hazardous Substances } \\
\text { Release Notification }\end{array}$ & Not Required ${ }^{\mathrm{a}}$ \\
\hline $311-312$ & $\begin{array}{l}\text { Material Safety Data Sheet/ } \\
\text { Chemical Inventory }\end{array}$ & Yes \\
\hline 313 & Toxic Release Inventory Reporting & Yes \\
\hline
\end{tabular}

\section{National Environmental Policy Act}

The National Environmental Policy Act (NEPA) establishes policies and goals for the protection, maintenance, and enhancement of the human environment in the United States. NEPA's purpose is to provide the federal government with a process for implementing these goals. The act requires consideration of environmental factors during the planning process for all major federal activities that could significantly affect the quality of the environment. In practice, NEPA provides a means to evaluate the potential environmental impact of such proposed activities and to examine alternatives to those actions. Although implemented at SRS by the Energy Research and Development Administration during the 1970s, a formal maintenance and operations NEPA compliance group was not established on site until 1982. The ongoing mission of this group is to make recommendations regarding the level of NEPA review of site-proposed action and to prepare draft documentation supporting DOE-SR compliance with NEPA at SRS.

In 1999, 244 reviews of newly proposed actions were conducted at SRS and formally documented through categorical exclusions (CXs), notifications of previous NEPA coverage, environmental assessments (EAs), NEPA values impact assessments (VIAs), or EISs. WSRC also provided technical support to DOE-SR for the preparation of supplemental environmental impact statements (SEISs) and programmatic environmental impact statements (PEISs).
The types and numbers of NEPA activities conducted at SRS during 1999 are presented in table 2-3. Among the specific activities were the following:

- The final EA and finding of no significant impact (FONSI) on the SRS wetland mitigation bank were issued April 28. The EA assessed the potential impacts associated with implementing a wetland mitigation bank program at SRS. Wetland mitigation banking is a relatively new natural resource management concept that provides for advance compensation of unavoidable wetland losses attributable to development activities.

Table 2-3 Types/Quantity of NEPA Activities at SRS During 1999

\begin{tabular}{lr} 
Type of NEPA Documentation & Number \\
\hline Categorical Exclusion (CX) & 223 \\
Tiered by Previous NEPA Documentation & 10 \\
Environmental Assessment (EA) & 7 \\
Values Impact Assessment & 1 \\
Environmental Impact Statement (EIS) & 6 \\
Supplemental Environmental & 1 \\
Impact Statement (SEIS) & 1 \\
Programmatic Environmental & \\
Impact Statement (PEIS) & $249^{a}$ \\
\hline Total & \\
\hline Five of the 249 NEPA activities were carryovers from \\
\hline$\quad$ 1998, leaving 244 newly proposed actions in 1999.
\end{tabular}


- A combined ROD for the SRS's Accelerator Production of Tritium (APT) and Tritium Extraction Facility (TEF) at SRS was issued May 18. The APT EIS evaluated impacts of construction and operation of a proposed linear accelerator for the production of tritium for nuclear stockpile purposes. The TEF EIS evaluated the impacts of constructing and operating a facility to extract tritium gas from targets irradiated in a commercial light water reactor or accelerator. In the combined ROD, the secretary of energy selected the commercial light-water reactor alternative as the primary tritium production technology, with the APT as a backup. That ROD also announced DOE's decision to build and operate the TEF at SRS.

- A revised FONSI for the A-01 Outfall Constructed Wetlands Project at SRS was issued June 3. The final EA and initial FONSI had been issued October 7, 1998. WSRC revised the project scope to better define it and to concurrently reduce the cost of the proposed project. Because this scope revision was a combination of the previous proposed action and one of the alternatives, and because the impacts were comparable to those presented in the EA, $\mathrm{DOE}$ concluded that the proposed revision would not result in significant impacts to the environment-and therefore issued the revised FONSI.

- On August 26, DOE issued the third ROD related to the $\mathrm{DOE}$ waste management final PEIS. The first ROD dealt with decisions on the management of transuranic waste, while the second involved the disposal of nonradioactive hazardous waste. The third ROD dealt with decisions on the storage of high-level radioactive waste within the DOE complex. Additional RODs for the management of low-level and mixed radioactive wastes are expected to be issued in 2000 .

- The final EA and FONSI on SRS's Pond B Dam Repair Project were issued September 27. The EA assessed the potential environmental and safety impacts associated with the proposed repairs to the downstream slope and toe of the dam impounding Pond $\mathrm{B}$. Pond $\mathrm{B}$, one of the site's former reactor cooling ponds, contains low levels of radionuclide contamination within its lakebed sediments and within the waters of its impoundment. The dam is an earth embankment that was constructed in the early 1950s.

Inspections by SRS engineers and the Federal Energy Regulatory Commission have revealed seepage conditions and erosion that threaten the dam's stability. The purpose of the proposed repairs is to increase the dam's stability and reduce its risk of failure.

- The final EA and FONSI on the interim measures for the Mixed Waste Management Facility Groundwater at the Burial Ground Complex at SRS were issued December 8. The EA assessed the potential impacts associated with installation of a small dam that would impound about 1.2 acres of water around and over the Burial Ground Complex groundwater seepline. This action would be taken as part of an interim measure for the Mixed Waste Management Facility to reduce the amount of tritium seeping from the southwest groundwater plume of the Burial Ground Complex.

Table 2-4 contains a complete list of NEPA documentation activities conducted at SRS during 1999.

Ten new department NEPA coordinators completed the SRS certification program during 1999 , bringing the current total to 32 certified department NEPA coordinators within the various contractor organizations on site.

The SRS NEPA Program continues to improve the sitewide computerized NEPA database/tracking system, which was developed for reporting and analysis purposes. An SRS NEPA home page is available to offsite computer users by means of the Internet at the following address:

http://www.srs.gov/general/sci-tech/nepa/nepa.html. The home page contains (1) electronic copies of SRS EAs and EISs, (2) monthly NEPA reports, and (3) hot links to other NEPA web sites.

\section{Safe Drinking Water Act}

The federal SDWA-enacted in 1974 to protect public drinking water supplies-was amended in 1980,1986 , and 1996. SRS drinking water is supplied by 18 separate systems, all of which utilize groundwater sources. The number of drinking water systems at the site was reduced from 27 to 18 in 1997 by a project that consolidated 12 major drinking water systems into three: A-Area, D-Area, and $\mathrm{K}$-Area. These three systems are actively regulated by SCDHEC and are classified as nontransient/noncommunity systems because each serves more than 25 people. The remaining 15 site water systems, each of which serves fewer than 25 people, receive a lesser degree of regulatory oversight.

During 1999, no lead and copper compliance sampling was performed for the A-Area consolidated system. Under the SCDHEC-approved, ultrareduced 
Table 2-4 SRS Project NEPA Documentation Activities During 1999

Project Name

Level of NEPA

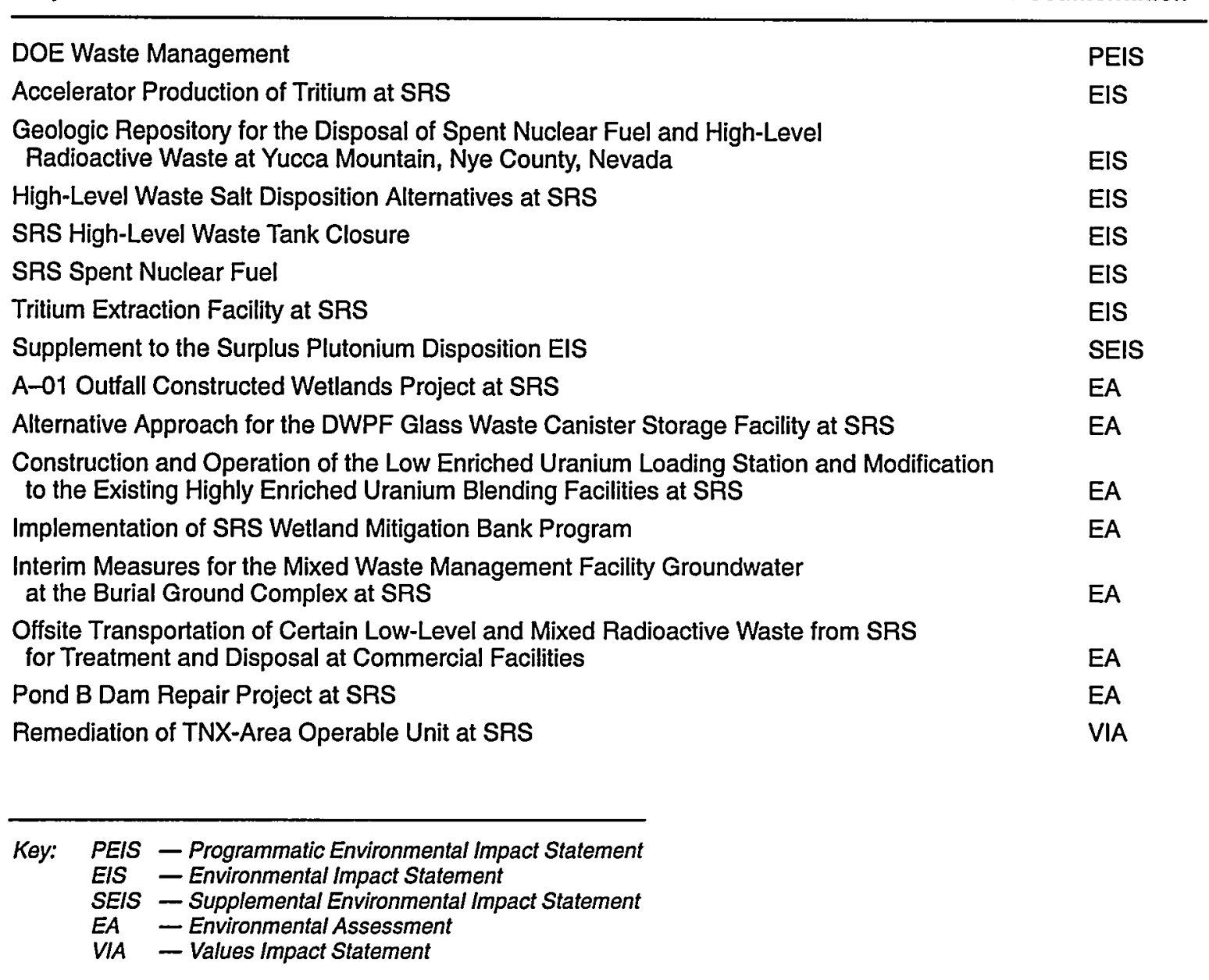

monitoring plan, lead and copper sampling will not be required for this system again until 2001 .

The D-Area and K-Area consolidated water systems qualified in 1997 for an ultrareduced monitoring plan and are not required to resample for lead and copper until the year 2000 .

The B-Area Bottled Water Facility, which was approved for operation in 1998, is listed as a public water system by SCDHEC and is required to sample quarterly for bacteriological analysis, beginning in January 2000. Unlike at the D-Area and K-Area consolidated water systems, the monitoring of lead and copper will not be required at the B-Area facility.

SCDHEC performed its biannual sanitary survey of the A-Area, D-Area, and K-Area domestic water systems in March 1999. The results of the survey indicated a "satisfactory" rating for each of the systems.

All bacteriological and chemical compliance samples for SRS domestic water systems met the primary drinking water standards in 1999.

No NOVs were issued to SRS in 1999 under the SDWA.

\section{Clean Water Act}

\section{National Pollutant Discharge Elimination System}

The CWA of 1972 created the NPDES program, which is administered by SCDHEC under EPA authority. The program is designed to protect surface waters by limiting releases of nonradiological 
effluents into streams, reservoirs, and wetlands. Radiological effluents are limited under DOE orders. Discharge limits are set for each facility to ensure that SRS operations do not adversely impact water quality.

SRS had four NPDES permits in 1999, as follows:

- One permit for industrial wastewater discharge (SC0000175) - SRS received a modification of this permit from SCDHEC January 1, 1998. The modification removed outfalls $\mathrm{P}-13, \mathrm{P}-14, \mathrm{P}-19$, and $K-08$, added outfall $X-19$, and changed the sampling requirements at several other outfalls.

- One general permit for utility water discharge (SCG250162) - Under this permit, outfall 001 discharged once during 1999.

- Two general permits for stormwater discharge (SCR000000 for industrial and SCR100000 for construction)

More information about the NPDES permits can be found in chapter 8, "Nonradiological Effluent Monitoring."

All results of monitoring for compliance with the industrial wastewater discharge permit and the general permit for utility water discharge were reported to SCDHEC in the monthly Discharge Monitoring Reports, as required by the permits.

In October 1999, SCDHEC personnel conducted a 2-week audit in which SRS wastewater facilities were inspected and the permitted NPDES outfalls were sampled. All the facilities passed the operations/maintenance part of the audit, and no significant findings were noted at the audit closeout meeting.

All monitoring for compliance with the industrial stormwater discharge permit was evaluated and recorded in the pollution prevention plan for each outfall, as required by that permit. The individual outfall pollution prevention plans were combined to form a site pollution prevention plan, which was developed and implemented in 1993 and updated in 1996 for identified stormwater outfalls. Effective in 1998 , individual outfall pollution prevention plans are kept at specific operations facilities, where they can be updated as needed. They are submitted to the Environmental Protection Department (EPD) annually. Each plan identifies facility areas where "best management practices" and/or "best available technology" should be implemented to prevent or mitigate the release of pollutants with stormwater runoff. (More about pollution prevention programs can be found in chapter 3.)
The outfalls covered by the new industrial stormwater permit (SCR000000) were reevaluated in 1998. This resulted in the development of a new sampling plan, which was implemented in 1999.

All construction activity that would result in a land disturbance of 5 or more acres must be permitted. The eight land areas associated with industrial activity from construction are permitted as required under permit SCR 100000 . Two projects in this category were closed in 1999 . The pollution prevention plan for this permit also requires a sediment reduction and erosion control plan.

Under the Code of Federal Regulations (CFR) Oil Pollution Prevention regulation (40 CFR 112), SRS must report petroleum product discharges of 1,000 gallons or more into or upon the navigable waters of the United States, or petroleum product discharges in harmful quantities that result in oil sheens. No such incidents occurred at the site during 1999.

SRS has an agreement with SCDHEC to report petroleum product discharges of 25 gallons or more to the environment. Two such incidents in this category occurred at the site during 1999 and were reported appropriately.

\section{Notices of Violation (NPDES)}

SRS's 1999 compliance rate for NPDES under the CWA was 99.8 percent. The site received one NPDES-related NOV from SCDHEC and one from EPA in 1999. The SCDHEC NOV was issued to WSRC September 30 for violation of the monitoring and reporting requirements of permit SC0000175. The agency cited a missing phenol sample and the absence of a " 1 " in the exceptions column of the Discharge Monitoring Report to reflect the sample. Because the cause of the missing sample already had been cited in the report, no reply to the NOV was required.

SRS received a notice February 16,1999 , from SCDHEC to attend a March 1 conference because of multiple 1998 exceedances for which the site had received an NOV that year and because of exceedances, missing samples, and NOVs that had occurred since early 1997. SRS and SCDHEC representatives subsequently met to discuss violations noted in these findings, and SCDHEC issued the site a draft consent order detailing corrective actions required to address the violations and eliminate the related problems.

In the $1998 \mathrm{NOV}, \mathrm{SCDHEC}$ had cited 13 violations involving flow, total suspended solids, fecal coliform, copper, and toxicity that occurred from January through July of that year. Corrective actions were 
implemented in all the cases except the one involving copper, which occurred at the $\mathrm{H}-12$ outfall. The sample type for metals at $\mathrm{H}-12$ was changed from grab to composite in December 1998, and minor sources of copper were found and eliminated during 1999. Since implementation of the change in sample type, no additional copper exceedances have occurred at $\mathrm{H}-12$.

Because no resolution could be reached on SRS's toxicity problems, however, SCDHEC turned over the enforcement action to EPA, which issued an NOV to the site August 3, 1999. The NOV, which detailed exceedances (including toxicity) and missing samples from 1996 through 1999, was discussed during an August 25 meeting (involving SRS, EPA, and SCDHEC) at which site representatives offered explanations for each point cited. EPA had not determined a course of action by the end of the year.

A toxicity problem at outfall A-11 resurfaced in October 1999, and a toxicity identification evaluation was implemented at that time. The evaluation was still under way at the end of the year. Results of 1999 toxicity tests at SRS NPDES outfalls are presented in table 54, SRS Environmental Data for 1999, and additional discussion of the site's toxicity problems appears in chapter 8.

SCDHEC issued SRS a consent order October 11 addressing compliance with the site's NPDES permit at outfall $\mathrm{A}-01$. The consent order gave SRS until October 2001 to comply with lead, copper, chlorine, and toxicity parameters at this outfall and until April 2002 to comply with the mercury parameter.

The site had 10 exceedances of permit parameters in 1999. A list of these-including outfall locations, probable causes, and corrective actions-can be found in chapter 8 (table 8-4).

\section{Dredge and Fill; Rivers and Harbors}

The CWA, Section 404, "Dredge and Fill

Permitting," as amended, and the Rivers and Harbors

Act, Sections 9 and 10, "Construction Over and

Obstruction of Navigable Waters of the United

States," protect U.S. waters from dredging and filling and construction activities by the permitting of such projects. Dredge and fill operations in U.S. waters are defined, permitted, and controlled through

implementation of federal regulations in $33 \mathrm{CFR}$

(U.S. Army Corps of Engineers) and 40 CFR (EPA).

In 1999, SRS conducted activities under four nationwide permits (each a general permit under Section 404) as part of the nationwide permits (NWP) program, but under no individual Section 404 permits. The activities were as follows:
- An upgrade of the boat ramp on Skinface Pond was completed under NWP 36, "Boat Ramps."

- The repair and maintenance of the spillway and dam at Skinface Pond were completed under NWP 3, "Maintenance."

- Replacement of the bridge on Road 8 over the north arm of PAR Pond was completed under NWP 3.

- The D-Area GeoSiphon project was conducted and completed with impacts permitted under NWP 26, "Headwaters and Isolated Waters Discharges." The impacted wetlands were restored when the project was completed.

\section{Construction in Navigable Waters}

SCDHEC Regulation 19-450, "Permit for Construction in Navigable Waters," protects the state's navigable waters through the permitting of any dredging, filling, construction, or alteration activity in, on, or over state navigable waters, in or on the beds of state navigable waters, or in or on land or waters subject to a public navigational servitude. The only state navigable waters at SRS are Upper Three Runs Creek (through the entire site) and Lower Three Runs Creek (upstream to the base of the PAR Pond Dam).

No projects were permitted or work conducted under Regulation 19-450 in 1999.

\section{Federal Insecticide, Fungicide, and Rodenticide Act}

The Federal Insecticide, Fungicide, and Rodenticide Act restricts the application of pesticides through a state-administered certification program. SRS's pesticide procedure provides guidelines for pesticide use and requires that applicators be state certified. A pesticide-use task group evaluates planned pesticide programs to ensure that they are acceptable and that appropriate pesticides are used, so that any impact on the environment is minimal. The task group also

- maintains records of pest control activities

- assists in disseminating pesticide-use information to site contractors

SRS pesticide programs typically include such activities as the maintenance of roadways, gravel areas, and fence lines through the use of herbicides.

\section{Clean Air Act}

\section{Regulation, Delegation, and Permits}

The CAA provides the basis for protecting and maintaining air quality. Some types of SRS air emissions, such as radioactive sources and 
An EMS technical analyst uses a bar code reader to record the identification of an air sample, along with air flow data, for the purpose of identifying radioactive substances and quantities.

Al Mamatey Photo (99X00118.05)

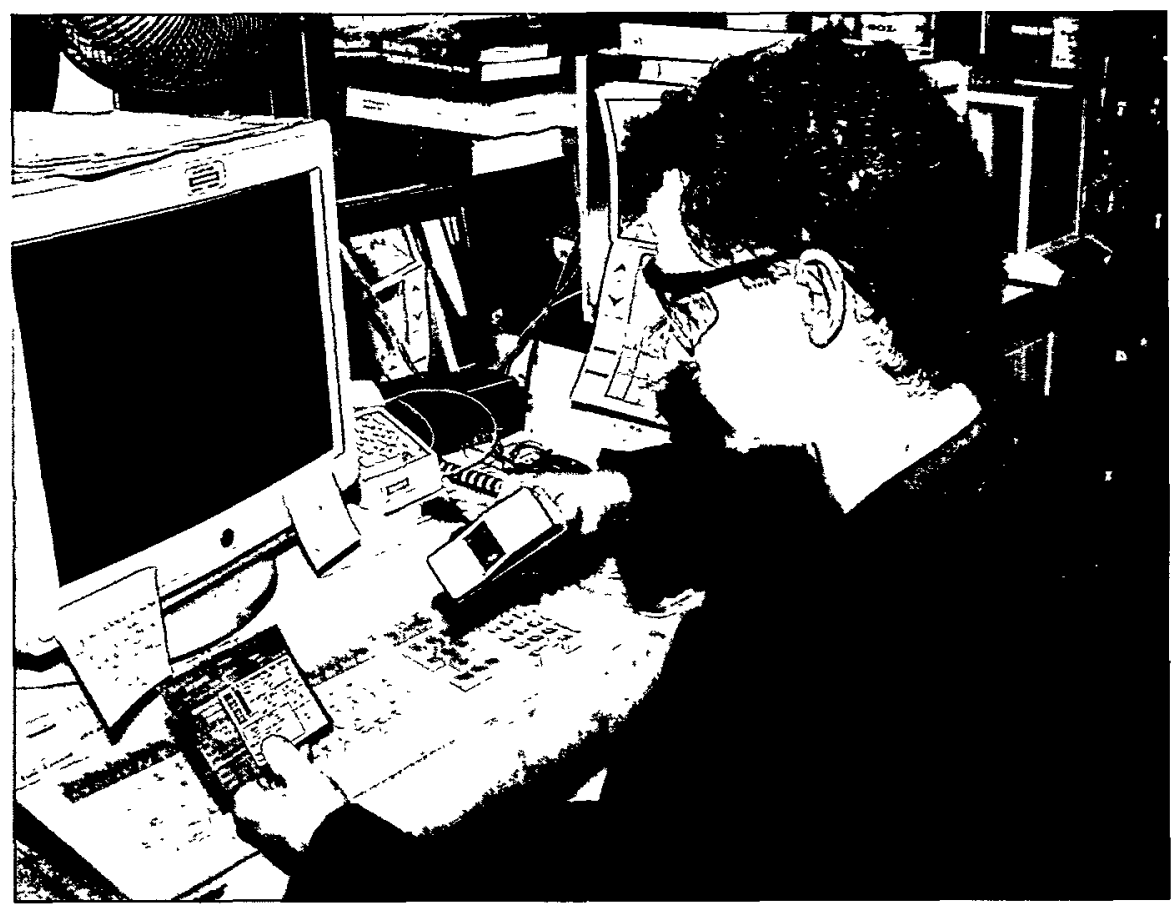

ozone-depleting substances (ODSs), are regulated by EPA, but most are regulated by SCDHEC, which must ensure that its air pollution regulations are at least as stringent as the CAA's. This is accomplished through SCDHEC Regulation 61-62, "Air Pollution Control Regulations and Standards."

Under the CAA, and as defined in federal regulations, SRS is classified as a "major source" and, as such, is assigned one permit number (0080-0041) by SCDHEC. In this permit, each emission source is identified by the area designation, by a point identification number, and by a source description. SRS holds operating and construction permits or exemptions from SCDHEC's Bureau of Air Quality, which regulates nonradioactive toxic and criteria pollutant emissions from approximately 207 point sources, several of which have specific emission limits. As of May 1994, SCDHEC had completed renewal of all SRS operating permits, which are valid for 5 years. During 1999, 10 of SRS's current operating permits were due to expire. However, because of ongoing work on the Title $\mathrm{V}$ permit, SCDHEC granted an extension of the four operating permits until the new Title $V$ permit is issued. Of the 207 point sources, 153 operated in some capacity during 1999. The remaining 54 either were under construction or were being maintained in a "cold standby" status.

During 1999, SCDHEC conducted compliance inspections of 70 permitted sources at SRS, reviewing 217 permitted parameters. The inspections included

- biennial stack tests

- initial operation inspections following completion of construction

- annual compliance inspections

As indicated earlier, the site achieved a compliance rate of 100 percent-and received no NOVs-under the CAA in 1999.

\section{National Emission Standards for Hazardous Air Pollutants}

The National Emission Standards for Hazardous Air Pollutants (NESHAP) is a CAA-implementing regulation that sets air quality standards for air emissions containing hazardous air pollutants, such as radionuclides, benzene, and asbestos. The NESHAP regulations found in $40 \mathrm{CFR} 61$ are divided into subparts based on specific hazardous pollutant categories, such as Subpart $\mathrm{H}$ for radionuclides and Subpart $M$ for asbestos. The Clean Air Act Amendments (CAAA) of 1990 revised the original list of hazardous air pollutants. The revised list of 189 air pollutants includes all radionuclides as a single item. Regulation of these pollutants has been delegated to SCDHEC; however, EPA Region IV continues to partially regulate radionuclides.

SRS, like most South Carolina industrial complexes, uses a number of chemicals identified by SCDHEC 
as toxic air pollutants and by EPA as hazardous air pollutants. These include many common consumer products-e.g., off-the-shelf bug sprays, correction fluids, paints, sealers, janitorial cleaning supplies, gasoline for vehicles-as well as a number of typical industrial chemicals, such as degreasers, solvents, metals, batteries, and diesel fuel. But SRS has at least one category, radionuclides, not found in typical industrial settings. During the course of normal operations, some radionuclides are released to the air.

NESHAP Radionuclide Program Subpart $\mathrm{H}$ of NESHAP was issued December 15, 1989, after which an evaluation of all air emission sources was performed to determine compliance status. DOE-SR and EPA Region IV signed an FFCA October 31, 1991, providing a schedule to bring SRS's emissions monitoring into compliance with regulatory requirements. An amendment to the FFCA, signed August 16, 1993, provided an extension to the original FFCA through February 10, 1995, to accomplish additional monitoring equipment upgrades. The upgrades were completed on time, and the FFCA was officially closed-and the site declared compliant-by EPA Region IV May 10, 1995. The SRS NESHAP radionuclide program continues to change to incorporate sampling, monitoring, and dose assessment practices that meet or exceed the requirements of $40 \mathrm{CFR} 61$, Subpart $\mathrm{H}$.

During 1999, the maximally exposed individual effective dose equivalent, calculated using the NESHAP-required CAP88 computer code, was estimated to be $0.05 \mathrm{mrem}(0.0005 \mathrm{mSv})$, which is 0.05 percent of the 10 -mrem-per-year (0.10-mSv-per-year) EPA standard (chapter 7, "Potential Radiation Doses").

NESHAP Nonradionuclide Program SRS uses many chemicals identified as toxic or hazardous air pollutants, but most of these chemicals are not regulated under the CAA or under federal NESHAP regulations. Except for asbestos, SRS facilities and operations do not fall into any of the "categories" listed in the subparts. Under Title III of the federal CAAA of 1990, EPA in December 1993 issued a final list of hazardous air pollutant-emitting source categories potentially subject to maximum achievable control technology standards. These standards are being developed and issued over a 10-year period that will end in the year 2000, based on a schedule arranged according to

- the effects of each pollutant

- the industry group source category

- the abatement technology available
In an attempt to regulate hazardous or toxic air pollutants in South Carolina, SCDHEC established Air Pollution Control Regulation 61-62.5, Standard No. 8, "Toxic Air Pollutants," in June 1991. To demonstrate compliance with this standard, SRS completed and submitted an air emissions inventory and air dispersion modeling data for all site sources in 1993. The submitted data demonstrated compliance by computer modeling the accumulated ambient concentration of individual toxic air pollutants at the boundary line and comparing them to the Standard No. 8 maximum allowable concentrations. To ensure continued compliance with Standard No. 8, new sources of toxic air pollutants must be permitted, which requires submittal of appropriate air permit applications and air dispersion modeling. Sources with emissions below a threshold of 1,000 pounds per month of any single toxic air pollutant may be exempted from permitting requirements. During 1999,11 sources of toxic air pollutants either were issued a construction permit or exempted from permitting requirements.

NESHAP Asbestos Abatement Program Asbestos is a naturally occurring mineral. Because of its availability, low cost, and unique properties, the U.S. construction industry used asbestos extensively from after World War II through the mid 1970s. The construction of SRS began in the early 1950s, and asbestos-containing material can be found throughout the site. The danger from exposure to airborne asbestos fibers was virtually unknown during the early years at the site. Today, however, it is well established that unprotected exposure to airborne asbestos fibers can lead to asbestosis, lung cancer, mesothelioma, and other diseases.

SRS began an asbestos abatement program in 1988 and continues to manage asbestos-containing material by "best management practices." Site compliance in asbestos abatement, as well as demolitions, falls under South Carolina and federal regulations, including SCDHEC Regulation R.61-86.1 ("Standards of Performance for Asbestos Projects") and 40 CFR 61, Subpart M ("National Emission Standards for Asbestos").

Asbestos-containing material is managed at SRS through the following control options:

- an operations and maintenance program

- enclosure

- encapsulation

- repair

- removal

Many site demolition, renovation, and maintenance projects require the removal of asbestos-containing 
material. During 1999, SRS personnel removed and disposed of an estimated 915 square feet and 1,015 linear feet of regulated asbestos-containing material. In addition, contractors removed and disposed of an estimated 16,000 square feet and 780 linear feet of regulated asbestos-containing material and demolished four regulated structures.

Radiological asbestos waste, removed by SRS personnel and contractors who are not permanent SRS employees, was disposed of at the SRS Low-Level Burial Ground. Nonradiological asbestos waste removed by SRS personnel was disposed of at the Hickory Hill Landfill, located near Ridgeland, South Carolina, and the Three Rivers Landfill, located on site. Nonradiological asbestos waste removed by contractors was disposed of at SCDHEC-approved offsite landfills.

Other CAA Requirements Only a few of the major sections of the CAA and its 1990 amendments and regulations have had-or are expected to have-a significant impact on SRS sources and facilities. These include Title V, "Permits," and Title VI, "Stratospheric Ozone Protection." The other regulations impacting SRS facilities are implemented primarily in SCDHEC Regulation 61-62 and in existing operating or construction permits.

Air Emissions Inventory SCDHEC Regulation 61-62.1, Section III ("Emissions Inventory"), requires compilation of an air emissions inventory for the purpose of locating all sources of air pollution and defining and characterizing the various types and amounts of pollutants. To demonstrate compliance, SRS personnel conducted the 1993 comprehensive air emissions inventory, compiling source information from as far back as 1985. Guidelines and procedures were written to

- ensure that all radiological and nonradiological sources had been accounted for

- ensure documentation of all vents and stacks for each building

- better characterize emission points from site processes

- calculate emissions based on design capacity, maximum potential emissions, and actual emissions for a selected period of time

- provide consistency in recording appropriate data

The inventory identified approximately 5,300 radiological and nonradiological air emission sources. Source operating data and calculated emissions from 1990 were used to establish the SRS baseline emissions and to provide data for air dispersion modeling. This modeling was required to demonstrate sitewide compliance with Regulation 61-62.5, Standard No. 2, "Ambient Air Quality Standards," and Standard No. 8.

Regulation 61-62.1, Section III, requires that inventory data be updated and recorded annually but only reported every even calendar year. Calendar year 1998 operating data for permitted and other significant sources were reported to SCDHEC in 1999. Because data collection for all SRS sources begins in January and requires up to 6 months to complete, this report provides emissions data for calendar year 1998 (table 8-3 of this document for criteria pollutants and table 52, SRS Environmental Data for 1999, WSRC-TR-99-00301, for toxic/hazardous air pollutants). Compilation of 1999 data will be completed in 2000 and reported in the SRS Environmental Report for 2000.

Title V Operating Permit Program As previously indicated, the CAAA of 1990 also include, under Title V, a major new permitting section expected to have a significant impact on the site. The primary purpose of this permitting program is to establish federally enforceable operating permits for major sources of air emissions. The implementation plan for this program was submitted to EPA in 1993 by the State of South Carolina and subsequently approved by EPA in June 1995. SRS then submitted an extensive application package for site air emission sources by the March 15, 1996, deadline set forth in the implementation plan, Regulation 62.70, "Title V Operating Permit Program."

SRS and SCDHEC have been developing the Title V (Regulation 62.70) operating air permit since 1996. In September 1998, SRS received a draft Part 70 permit from SCDHEC and subsequently submitted comments back to SCDHEC on October 1. Because of the unexpected departure of SCDHEC's permit engineer and the subsequent assignment of a replacement, however, the site-at the end of the year (1999)-still was awaiting SCDHEC's disposition of those comments and issuance of a final draft permit, which then will undergo a 30-day public comment period and a 45-day EPA comment period.

Ozone-Depleting Substances Title V of the CAAA of 1990 addresses stratospheric ozone protection. This law requires that EPA establish a number of regulations to phase out the production and consumption of ODSs. The substances commonly are used as refrigerants in air conditioning and cooling systems; as degreasers and cleaners; as spray can propellants; as fire suppressants (Halon); as laboratory extractions; and in many other common consumer products. 
Several sections of Title VI of the CAAA of 1990, along with recently established EPA regulations, apply to the site. The ODSs are regulated in three general categories, as follows:

- Class I substances - chlorofluorocarbons (CFCs), Halon, carbon tetrachloride, methyl chloroform, methyl bromide, and hydrobromofluorocarbons (HBFCs)

- Class II substances - hydrochlorofluorocarbons (HCFCs)

\section{- Substitute substances}

Class I ODSs are about 10 times more ozone-depleting than HCFCs and thus are more strictly regulated. As required by the CAAA of 1990 , most Class I Halons were phased out of production by January 1, 1994, and other Class I ODSs were phased out by January 1, 1996. This means that several very important refrigerants (CFC-11, -12 , -114 , and -502 ) used on site essentially may become unavailable for purchase. Many of the large chillers on site that use these refrigerants are being scheduled for total replacement or for retrofits that will use HCFCs or other chemical substitutes. The site also is scheduling fire suppression (Halon) system replacements. Many common degreasers are Class I ODSs and have been targeted for replacement. Most major degreasing applications already have been eliminated or replaced with non-ODSs. Smaller ODS-degreasing applications, such as those used in maintenance and electrical shops, are being targeted for phaseout. ODSs used in laboratory extraction procedures have been replaced with newly developed processes that use non-ODSs.

The SRS CAAA of 1990 Title V operating air permit application includes ODS emission sources. All large (greater than or equal to 50-pound charge) heating, ventilation, and air conditioning/chiller systems for which there are recordkeeping requirements are included as fugitive emission sources.

In 1994, the site formed a CFC steering committee of participants from all the major users of these substances to provide initial direction in the phaseout of Class I ODSs on the site. A number of technical subcommittees also were initiated at that time to address particular applications, such as refrigeration, fire suppression, degreasers, laboratory applications, and environmental compliance. The ODS

Subcommittee of the Central Environmental Committee was created in 1995 to communicate to site organizations-through field representatives-any changes in Title VI regulations that could affect established programs. The
"Savannah River Site Refrigerant Management Plan," completed and issued in September 1994, provides guidance to assist SRS and DOE in the phaseout of $\mathrm{CFC}$ refrigerants and equipment.

The site has

- purchased certified recycling equipment

- trained and certified technicians where required

- implemented required recordkeeping and leak-tracking for large cooling systems

- implemented proper labeling and other recordkeeping requirements

In 1996, SRS let a subcontract for the offsite reclamation of used refrigerants. The site also eliminated the use of CFC-114 by completing replacement of the 789-A chiller plant with a new plant that uses a non-CFC refrigerant. Plans are to sell the 55,000 pounds of CFC-114 as part of a decontamination and decommissioning contract. Additionally, Executive Order 12856 required a 50-percent reduction in CFC usage by the end of 1999 , based on 1993 data. SRS surpassed the 21,116-pound 1999 goal in 1996 by reducing CFC refrigerant usage to 12,570 pounds, but incurred a 1997 increase to 12,930 pounds-still surpassing the goal set in the executive order. In 1998, the site cut CFC usage sharply, to 6,430 pounds, then further reduced the number to 4,040 pounds in 1999 . This achievement exceeded the federal goal by 40 percent. The SRS reduction in CFC usage, based on 1993 data, was 90 percent by 1999 , compared to the federal goal of 50 percent by 1999 .

$\mathrm{CFC}$ refrigerant system replacement projects that were in various stages of implementation during 1999 included the following:

- tritium facility system replacement

- HB-Line system replacement

- 221-S system replacement

- new source recovery facility system upgrades

- a central system for F-Canyon and associated support labs

- 235-F refrigerant system upgrade

- B-Area central chiller facility upgrade

The first two phases of the tritium project were completed in 1998; a third phase, in which two chillers were replaced at $249-\mathrm{H}$, was completed in 1999. Work continued on the 235-F and F-Canyon projects, the HB-Line and 221-S replacements, and the new source recovery facility upgrades in 1999. 
The B-Area central chiller facility upgrade meanwhile, is a new project initiated during the year.

SRS is phasing out its use of Halon as a result of the January 1994 ban on Halon production. A Halon system prioritization study was completed in December 1993 for use as the basis for the managed phaseout of fixed Halon 1301 fire suppression systems. Of the 372 active Halon 1301 systems in use on site at the end of the study, 47 were determined to be essential (not to be replaced), 179 were identified as nonessential and prioritized for systematic replacement, and 146 were determined to be no longer necessary. An additional 85 systems were reactivated in F-Area in 1995, however, and based on further facility review and new guidance, the 1995 Halon Replacement Implementation Plan identified 141 systems to be removed (without replacement) and added the 47 systems originally deemed essential to the list of those to be replaced.

In 1999, three systems were replaced with non-ODS fire suppression systems and five were converted to manual operation. Of the remaining systems, approximately 15 will be replaced and four will be converted to manual operation in 2000 . The prioritization for fire suppression system phaseout was updated in 1999, and a new line item project was developed to complete the phaseout. Funding for this project is expected in FY 2001.

Portable Halon 1211 fire extinguishers are being replaced as they reach the end of their useful lives. Approximately 16,065 pounds of Halon 1211 have been shipped to a U.S. Department of Defense facility in Virginia. At the end of 1999, approximately 2,723 pounds remained in use on site, and 803 pounds were in storage.

Halon 1301 usage on site also has decreased-from 75,089 pounds in 1995 to 70,454 pounds in 1999 . However, at the end of 1999 , the site still had an inventory of 46,408 pounds of stored Halon 1301 , including 18,096 pounds received from other DOE sites.

As is the case with refrigerants, all personnel working with the site's nine Halon 1301 fire suppression systems and its Halon 1301 recycling and recharging operations have been trained in Halon emissions reduction. Training is based on vendor information for specific systems and on National Fire Protection Association-recommended practices required by Halon emissions reduction regulations.

\section{Toxic Substances Control Act}

The Toxic Substances Control Act (TSCA) gives EPA comprehensive authority to identify and control chemical substances manufactured, imported, processed, used, or distributed in commerce in the United States. Reporting and recordkeeping are mandated for new chemicals and for any chemical that may present a substantial risk of injury to human health or the environment. EPD and Industrial Hygiene personnel coordinate reporting and recordkeeping requirements under TSCA.

Polychlorinated biphenyls (PCBs) have been used in various SRS processes. The use, storage, and disposal of these organic chemicals are specifically regulated under 40 CFR 761, which is administered by EPA. SRS has a well-structured $\mathrm{PCB}$ program that complies with this TSCA regulation, with DOE orders, and with WSRC policies.

The 1998 PCB Annual Document Log was completed prior to the July 1, 1999, deadline in full compliance with $40 \mathrm{CFR} 761$. The disposal of nonradioactive PCBs routinely generated at SRS is conducted at EPA-approved facilities within the regulatory time frame. For many forms of radioactive $\mathrm{PCB}$ wastes, disposal capacity is not yet available, and the wastes must remain in long-term storage. Such wastes are held in TSCA-compliant storage facilities in accordance with 40 CFR 761. Site plans call for the disposal of incinerable radioactive PCB wastes at the TSCA incinerator in Oak Ridge, Tennessee, when the State of Tennessee approves the disposal plan.

In August 1993, PCBs were confirmed to be present as a component of dense nonaqueous phase liquids in samples from two groundwater monitoring wells around the M-Area hazardous waste management facility. Regulators were notified, and a modification to the RCRA Part B Permit Application to address the discovery of PCBs was submitted to SCDHEC in December 1993. Any waste generated was handled according to the appropriate TSCA and RCRA requirements. Savannah River Technology Center (SRTC) personnel continue to study ways to remediate the dense nonaqueous phase liquids.

In 1996 and subsequent years, site personnel discovered PCBs in certain painted surfaces and in other solid forms within several facilities constructed prior to TSCA. As such discoveries were made, SRS worked with EPA —as necessary —on related TSCA compliance issues. Current TSCA regulations prohibit the use and distribution in commerce of these forms of PCBs above specified concentrations. In December 1999, however, EPA issued a proposed 
rule to authorize the continued use of these forms of PCBs.

Also, PCBs were detected in 1997 inside the Ford Building in N-Area on some old machinery and on the floor. SRS notified EPA and formulated a detailed cleanup plan for the facility. The cleanup began in 1998 and was completed in 1999.

\section{Endangered Species Act}

The Endangered Species Act of 1973, as amended, provides for the designation and protection of wildlife, fish, and plants in danger of becoming extinct. The act also protects and conserves the ecosystems on which such species depend.

Several threatened and endangered species exist at SRS. The site conducts research on the wood stork, the red-cockaded woodpecker, the bald eagle, the shortnose sturgeon, and the smooth purple coneflower. Programs designed to enhance the habitat of such species are in place.

NEPA documentation was prepared and reviewed for several new projects at SRS in 1999 to ensure protection of threatened and endangered species. Biological assessments and evaluations were conducted to evaluate potential impacts of future activities on the

- Mixed Waste Management Facility

- A-01 outfall project

- TNX outfall delta

- TNX swamp

- Georgia old field

- red-cockaded woodpecker management plan

- Central Shops sludge lagoon

- D-Area ash basin

None of these activities was found to have had any significant potential impact on threatened and endangered species.

The biological assessment for the river water system shutdown EIS concluded in 1996 that the proposed action could affect the bald eagle, the alligator, and the wood stork. Subsequent consultations conducted by SRS in 1996-97 with U.S. Fish and Wildlife Service personnel generated a cooperative agreement in which SRS would perform studies on the bald eagle. The site completed the studies in 1999, and a report of the findings is expected during 2000.

\section{National Historic Preservation Act}

The National Historic Preservation Act (NHPA) of 1966 , Section 106, governs the protection and preservation of archaeological and historical resources. SRS ensures that it is in compliance with this act through the site-use process. All sites being considered for activities such as construction are evaluated by the University of South Carolina's Savannah River Archaeological Research Program group to ensure that archaeological or historic sites are not impacted. Reviews of timber compartment prescriptions include surveying for archaeological concerns and documenting areas of importance with regard to historic and prehistoric significance.

The archaeology group reviewed 40 site-use packages during 1999 in support of SRS project activities. Sixteen of these resulted in surveys being conducted due to potential for land alteration in 1999. Most were found to have no activities of significant impact in terms of the NHPA. However, one of the reviews in 1997 had determined that the proposed Plutonium Immobilization Plant location included a site that could be subject to such impact. The proposed location subsequently was changed, but it was determined by a 1998 review that the new location included two sites that could be subject to such impact. The Plutonium Immobilization Plant site evaluations were completed in 1999. Three sites at the Plutonium Immobilization Plant location have been nominated for the National Register of Historic Places; a determination on the nomination still must be made by the South Carolina historic preservation officer.

The archaeology group also supported forestry activities on site by surveying 515 acres in 1999; this resulted in the investigations of 17 new and existing sites for cultural resources.

\section{Floodplains and Wetlands}

Under DOE General Provisions, 10 CFR, Part 1022 ("Compliance with Floodplains/Wetlands Environmental Review Requirements"), establishes policies and procedures for implementing DOE's responsibilities in terms of compliance with Executive Orders 11988 ("Floodplain Management") and 11990 ("Protection of Wetlands"). Part 1022 includes DOE policies regarding the consideration of floodplains/wetlands factors in planning and decision making. It also includes $D O E$ procedures for identifying proposed actions involving floodplains/wetlands, providing early public reviews of such proposed actions, preparing floodplains/wetlands assessments, and issuing statements of findings for actions in floodplains. 


\section{Executive Orders 11988, "Floodplain Management," and 11990, "Protection of Wetlands"}

Executive Order 11988, "Floodplain Management," was established to avoid long- and short-term impacts associated with the occupancy and modification of floodplains. The evaluation of impacts to SRS floodplains is ensured through the NEPA Evaluation Checklist and the site-use system. Site-use applications are reviewed for potential impacts by WSRC, DOE-SR, the Savannah River Natural Resource Management and Research Institute (SRI, formerly the Savannah River Forest Station), and the Savannah River Ecology Laboratory (SREL), as well as by professionals from other organizations.

Executive Order 11990, "Protection of Wetlands," was established to mitigate adverse impacts to wetlands caused by the destruction and modification of wetlands and to avoid new construction in wetlands wherever possible. Avoidance of impact to SRS wetlands is ensured through the site-use process, various departmental procedures and checklists, and project reviews by the SRS Wetlands Task Group. Many groups and individuals, including scientists at SRTC, SREL, and EPD, review site-use applications to ensure that proposed projects do not impact wetlands.

To ensure compliance with both executive orders, floodplain/wetland assessments were conducted during the NEPA process for five projects in 1999. The Mixed Waste Management Facility interim measure project and the Pond $\mathrm{B}$ dam repair project were determined to have the potential to impact the 100-year floodplain and wetlands and will require permitting and mitigation under Section 404 of the CWA. The A-01 outfall project was determined to have had only minor impact to the floodplain, while the CMP pit project and the TNX Operable Unit project were determined to have no potential for significant impact to the floodplain or wetlands, assuming "best management practices" are followed during the project.

\section{Environmental Release Response and Reporting}

\section{Response to Unplanned Releases}

Environmental Monitoring Section (EMS) personnel respond to unplanned environmental releases-both radiological and nonradiological—upon request by area operations personnel.
A number of unplanned environmental releases occurred in 1999, but area operations personnel did not require the sampling and analysis services of EMS. If the services of EMS personnel are requested, the samples collected are given priority in preparation and, if radiological in nature, priority in the counting room. Data are validated, and a determination is made as to whether there has been an actual release. If there has been, then consequences to the public and the environment are determined.

\section{Occurrences Reported to Regulatory Agencies}

"Federally permitted" releases comply with legally enforceable licenses, permits, regulations, or orders. Under the Atomic Energy Act, for example, releases of SRS radionuclides are federally permitted as long as public dose standards in DOE orders are not exceeded.

If a nonpermitted release to the environment of a reportable quantity (RQ) or more of a hazardous substance (including radionuclides) occurs, CERCLA requires notification of the National Response Center. Also, the CWA requires that the National Response Center be notified if an oil spill causes a "sheen" on navigable waters, such as rivers, lakes, or streams. Oil spill reporting was reinforced with liability provisions in CERCLA's National Contingency Plan.

Other CERCLA provisions allow exemptions from reporting a release of an $R Q$ or more of a hazardous substance if the release is federally permitted or covered by a continuous-release notification. A continuous-release notification provides an exemption from reporting each release of a specific hazardous substance greater than an RQ. The site submitted two continuous-release notifications in 1992 - for ethylene glycol and for asbestos, each of which had a statutory RQ of 1 pound. SRS withdrew the request for continuous-release notification status for ethylene glycol in 1995, when EPA made an adjustment to that $R Q$. The asbestos continuous-release notification request was retracted during 1999 with the completion of deactivation and decommissioning activities at the D-Area Heavy Water Facility.

During 1999, SRS notified regulatory agencies of one CERCLA-reportable release, which is described in table 2-5. This performance compares with one such release reported during 1998, three during 1997, two during 1996, and four during 1995.

Nine other notifications-not required by CERCLA - were made by the site to regulatory agencies during 1999. Seven of these were made to 
Table 2-5

CERCLA Releases Reported to Regulatory Agencies in 1999

\begin{tabular}{llll}
\hline Date & $\begin{array}{l}\text { Applicable Regulation/ } \\
\text { Reason for Notification }\end{array}$ & $\begin{array}{l}\text { Agencies } \\
\text { Notified }\end{array}$ & Description \\
\hline April 1 & Exceeded RQ of 1 pound & EPAVCDHEC & $\begin{array}{l}\text { More than 1 pound of friable asbestos } \\
\text { uncovered during site preparation work. }\end{array}$ \\
\hline
\end{tabular}

inform the agencies, principally SCDHEC, of events such as permit exceedances. The other two were the result of an agreement to notify SCDHEC about sewage and petroleum product releases. The agreement requires reporting of sewage releases "equal to or greater than 100 gallons" and of petroleum product releases "equal to or greater than 25 gallons" unless the releases come in contact with "waters of the state." In these cases, releases in any amount are to be reported-whether for sewage or for petroleum products. The two agreement-based notifications were for sewage releases.

EPCRA (40 CFR 355.40) requires that reportable releases of extremely hazardous substances or CERCLA hazardous substances be reported to any local emergency planning committees and state emergency response commissions likely to be affected by the release. No EPCRA-reportable releases occurred in 1999.

It is SRS policy to notify SCDHEC and the Georgia Department of Natural Resources (GDNR) of any occurrence that may interest state regulatory agencies. Although not required by law, these "courtesy notifications" enhance environmental protection objectives. In 1997, SRS expanded the plan for the courtesy notifications in response to a request by local governments. The expanded notification plan includes such occurrences as shelter alarms and stack monitoring alarms, even though they may be false alarms.

\section{Site Item Reportability and Issues Management Program}

The Site Item Reportability and Issues Management (SIRIM) program, mandated by DOE Order 232.1A (which superceded DOE Order 232.1), "Occurrence Reporting and Processing of Operations Information," is designed to "... establish a system for reporting of operations information related to DOE-owned or operated facilities and processing of that information to provide for appropriate corrective action. ..." It is the intent of the order that DOE be "... kept fully and currently informed of all events which could: (1) affect the health and safety of the public; (2) seriously impact the intended purpose of DOE facilities; (3) have a noticeable adverse effect on the environment; or (4) endanger the health and safety of workers."

The SIRIM program at SRS is designed to meet the requirements of DOE Order 232.1A by ensuring that

- all occurrences specified are identified in a timely manner, categorized, and reported

- proper corrective actions are taken in a timely manner

- all reportable occurrences are reviewed to assess significance and root causes

- occurrence reports to DOE operations are disseminated to prevent the recurrence of similar events

All SIRIM events are classified in one of the following categories: (1) facility condition; (2) environmental; (3) personnel safety; (4) personnel radiation protection; (5) safeguards and security; (6) transportation; (7) value-based reporting; (8) facility status; (9) nuclear explosive safety (not applicable at SRS); or (10) cross-group items. The impact-or the anticipated impact-of each event is categorized as follows (based on criteria in site procedures):

- Emergency - the most serious event; requires increased alert status for onsite and, in specific cases, offsite authorities

- Unusual occurrence - a nonemergency event that has significant impact or potential for impact on safety, environment, health, security, or operations

- Off-normal occurrence - an abnormal or unplanned event or condition that deviates from established standards or specifications

In 1999, of the 592 SIRIM-reportable events, 13 were categorized as primarily environmental. Of these 13 , none were classified as emergencies, two were classified as unusual occurrences, and 11 were classified as off-normal occurrences. Table 2-6 lists the two unusual occurrences reported through SIRIM in 1999. 


\section{Assessments/Inspections}

The SRS environmental program is overseen by a number of organizations, both outside and within the DOE complex. In 1999, the WSRC environmental appraisal program consisted of self and independent assessments. The program employs total-quality management concepts that support the site's four imperatives of safety, disciplined operations, continuous improvement, and cost effectiveness. It also ensures recognition of noteworthy practices, identification of performance deficiencies, and initiation and tracking of associated corrective actions until they are satisfactorily completed. The primary objectives of the WSRC assessment program are to ensure compliance with regulatory requirements and to foster continuous improvement. The program is an integral part of the site's Integrated Safety Management System and supports the SRS Environmental Management System, which continues to be certified to the standards of International Organization for Standardization (ISO) 14001. (ISO 14000 is a family of voluntary environmental management standards and guidelines.)

WSRC conducted 16 environmental program assessments in 1999. Areas assessed included surface and domestic water quality, NEPA implementation, waste management, groundwater well operation, environmental quality assurance, asbestos management, air quality protection, community involvement in CERCLA-related activities, and environmental planning.

During 1999, personnel from DOE-SR's Environmental Quality and Management Division again performed direct oversight and evaluation of WSRC's self-assessment program to help ensure that the program continues to meet the needs and expectations of DOE Order 5482.1B, "Environment,
Safety, and Health Appraisal Program"; Savannah River Implementation Procedure (SRIP) 200, chapter 223.4, "SR Technical Assessment Program"; and SRIP 450.1, "SR Environmental Protection Program." Completed assessments have met with positive results; routine assessments have promoted improvement and helped ensure the adequacy of environmental programs and operations at SRS.

SCDHEC also inspects the SRS environmental program for regulatory compliance. Agency representatives performed four comprehensive compliance inspections in 1999, as follows:

- SCDHEC performed a sanitary survey of the site's domestic water systems March 2. Each system received a "satisfactory" rating.

- SCDHEC conducted an annual assessment of the site's air emission sources against its air construction and operating permits May 3-6. Operating records, current operating conditions and parameters, and the operability of required monitoring equipment were reviewed to verify compliance with conditions specified in the permits. For systems in operation during the inspections, opacity was evaluated according to EPA Method 9, "Visual Emissions Evaluations." Inspection reports, written for each area in July and August, indicated that SRS air emission sources were operating in compliance with all permit requirements and that no response was required.

- SCDHEC performed a comprehensive groundwater monitoring evaluation May 18, 19, and 26. No deficiencies were identified during the course of this inspection; however, two areas of concern were identified, as follows: (1) The timely placement into operation of two recovery wells installed adjacent to the Metallurgical Laboratory had not occurred, and (2) inflatable packers installed in two A-Area production wells were found not fully inflated-an operating

Table 2-6

Environmentally Related Unusual Occurrences Reported Through SIRIM in 1999

\begin{tabular}{llll}
\hline $\begin{array}{l}\text { Discovery } \\
\text { Date }\end{array}$ & Occurrence & $\begin{array}{l}\text { Report No. } \\
\text { (SR-WSRC-) }\end{array}$ & Cause/Explanation ${ }^{\text {a }}$ \\
\hline April 1 & $\begin{array}{l}\text { More than 1 pound of friable } \\
\text { asbestos uncovered during site } \\
\text { preparation work }\end{array}$ & ERF-1999-0009 & Inadequate administrative controls \\
July 17 & $\begin{array}{l}\text { More than 100 gallons of raw } \\
\text { sewage discharged to ditch from } \\
\text { plugged main line }\end{array}$ & HTANK-1999-0028 & $\begin{array}{l}\text { Stoppage caused by material } \\
\text { backing up over time within main } \\
\text { line }\end{array}$ \\
\hline a & SRS takes followup corrective actions to minimize the impact on the environment. \\
\hline
\end{tabular}


Table 2-7

SRS Construction and Operating Permits, 1995-1999

\begin{tabular}{lrrrrr} 
Type of Permit & \multicolumn{5}{c}{ Number of Permits } \\
\hline & 1995 & 1996 & 1997 & 1998 & 1999 \\
Air & 200 & 196 & 198 & 202 & 200 \\
U.S. Army Corps of Engineers 404 & 0 & 0 & 1 & 1 & 0 \\
Army Corps of Engineers Nationwide Permit & $\mathrm{a}$ & 8 & 6 & 6 & 4 \\
Domestic Water & 165 & 178 & 186 & 194 & 203 \\
Industrial Wastewater & 90 & 87 & 84 & 83 & 86 \\
NPDES-Discharge & 2 & 2 & 1 & 1 & 1 \\
NPDES-General Utility & 0 & 0 & 1 & 1 & 1 \\
NPDES-No Discharge & 1 & 1 & 1 & 1 & 1 \\
NPDES-Stormwater & 2 & 2 & 2 & 2 & 2 \\
RCRA & 1 & 1 & 1 & 1 & 1 \\
Sanitary Wastewater & 133 & 135 & 137 & 139 & 141 \\
SCDHEC 401 & 1 & 1 & 2 & 2 & 1 \\
SCDHEC Navigable Waters & $\mathrm{a}$ & 4 & 4 & 4 & 0 \\
Solid Waste & 6 & 6 & 5 & 5 & 5 \\
Underground Injection Control & 13 & 18 & 17 & 31 & 18 \\
Underground Storage Tanks & $29 \mathrm{~b}$ & 29 & 29 & 24 & 20 \\
\cline { 2 - 6 } & & & & & \\
Totals & 643 & 668 & 675 & 697 & 684
\end{tabular}

a Formal tracking of these permits was initiated in 1996.

b Additional underground storage tank permits not previously reported were identified in 1996, so numbers from 1995 have been changed accordingly.

permit condition. These two concerns were addressed immediately by the responsible organizations and were not considered programmatic issues.

- The 1999 Comprehensive Monitoring Evaluation (a RCRA inspection) of SRS was conducted May 3-12 by SCDHEC. Approximately 150 areas were visited during the evaluation, which is aimed at ensuring compliance with state solid and hazardous waste management regulations, and no deficiencies were noted.

SCDHEC also performed monthly compliance inspections during the year, with no deficiencies noted.

\section{Environmental Permits}

SRS has 684 construction and operating permits that specify operating levels for each permitted source. This compares with 697 such permits in 1998, 675 in
1997, 668 in 1996, and 643 in 1995. Table 2-7 summarizes the permits held by the site during the past 5 years. These numbers reflect only permits obtained by WSRC for itself and for other SRS contractors that requested assistance in obtaining permits.

\section{Environmental Training}

The site's environmental training program identifies training activities to teach job-specific skills that protect the employee and the environment while satisfying regulatory training requirements. Chapter 3 contains more information about the training program.

\section{Facility Decommissioning}

With the rapidly declining need for a large nuclear weapons stockpile, many SRS facilities no longer are needed to produce or process nuclear materials. They have become surplus and must be dispositioned 
safely and economically. Many of them are large and complex and contain materials that, if improperly handled or stored, could be hazardous. SRS faces a major task in the cleanup, reuse, safe storage, and demolition of these facilities. The Facilities Decommissioning Division was established in 1996 to meet this challenge. The site's 1999 deactivation and decommissioning activities are discussed in chapter 4.

\section{Other Major Environmental Issues and Actions}

DOE-SR signed a ROD December 23, 1997, on the final EIS for the SRS river water system shutdown. Based on the environmental information found in the EIS, and on economic and regulatory considerations, DOE-SR has decided to continue to operate and maintain the river water system for the immediate future. This means that the water in L-Lake-a 1,000-acre, manmade lake created in 1985 to disperse and cool water from L-Reactor-will be maintained at its current level. PAR Pond-a 2,640-acre lake created in 1958 to disperse and cool water from P-Reactor and R-Reactor-also is supplied by the river water system, but its level is adequately maintained through rainfall and groundwater seepage.

The river water system was constructed in the late 1950 s to pump cooling water from the Savannah River to the site's five nuclear material production reactors. At the reactor areas, the water passed through heat exchangers to absorb heat from the reactor cores. Though the reactors no longer are operational, the river water system continues to be used to support fire protection efforts and the sanitary waste treatment plant and to maintain L-Lake's water level.

The EIS process was initiated to study cost savings and environmental impacts associated with operation and maintenance of the river water system. The EIS evaluated three options:

- continuing operation of the system

- $\quad$ shutting down the system but maintaining it for potential restart

- shutting down and deactivating the system, with no maintenance for potential restart

Shutting down the system eventually would have lowered the level of L-Lake.

The river water system has continued to operate pending DOE-SR's completion of a characterization of L-Lake under CERCLA; the characterization work-originally expected to begin by the year 2000 - has been put on hold until 2008 because of changes in the site's FFA schedule. DOE has an agreement with EPA and SCDHEC that provides a commitment and schedule for the comprehensive remediation of contamination at SRS, including that at site streams and lakes. Sediments that contain low-level radionuclides remain under the lake-primarily in the former Steel Creek stream bed. The contaminated sediments were deposited prior to creation of the lake.

Continued operation of the river water system until the characterization efforts are completed is expected to enable DOE-SR to determine the best ultimate course of action for the system.

Editors" note: The "Environmental Compliance" chapter is unique in that its number of authors is far greater than the number for any other chapter in this report. Space/layout constraints have prevented us from listing all of them on the chapter's first page; they've appeared in the report's acknowledgments section instead. This year, however, we're listing them here. Their contributions, along with those of the report's other authors, play a critical role in helping us produce a quality document-and are very much appreciated.

Paul Carroll, EPD
Carl Cook, EPD
Keith Dyer, EPD
David Earnhart, EREC
Larry Eldridge, EPD
Ross Fanning, EPD
Tim Faugl, EPD
Chuck Hayes, EPD

Doris Hoel, EPD
Gene Laska, EPD
Bruce Lawrence, EPD
David Lester, EPD
Jeff Lintern, EPD
Nancy Lowry, EPD
Bill Maloney, EPD
Bart Marcy, EPD

Jack Mayer, EPD

Vernon Osteen, EPD

Donald Padgett, EPD

Greg Peterson, EPD

Paul Rowan, EPD

Curt Walker, EPD

Michele Wilson, EPD 


\begin{tabular}{|c|c|}
\hline Operable Unit & Activity Description \\
\hline \multicolumn{2}{|l|}{ Fourmile Branch Watershed } \\
\hline $\begin{array}{l}\text { Burial Ground Complex Groundwater (also in } \\
\text { Upper Three Runs Watershed) }\end{array}$ & $\begin{array}{l}\text { Continued characterization; submitted interim- } \\
\text { measures plan }\end{array}$ \\
\hline C-Area Burning/Rubble Pit & Issued IROD; initiated interim remedial action \\
\hline C-Area Reactor Seepage Basins & $\begin{array}{l}\text { Continued characterization; selected source unit } \\
\text { remedy (plug-in ROD) }\end{array}$ \\
\hline Central Shops Burning/Rubble Pits $(631-1 G,-3 G)$ & Revised characterization result documentation \\
\hline Central Shops Sludge Lagoon & Completed characterization \\
\hline F-Area Retention Basin (281-3F) & Initiated remedial action \\
\hline F-Area Seepage Basin Groundwater & Continued remediation system operation \\
\hline Ford Building Seepage Basin & Revised characterization results documentation \\
\hline Ford Building Waste Site & Issued ROD \\
\hline H-Area Retention Basin (281-3H) & Completed characterization result documentation \\
\hline H-Area Seepage Basin Groundwater & Continued remediation system operation \\
\hline H-Area Tank Farm Groundwater & Continued characterization \\
\hline $\begin{array}{l}\text { Heavy Equipment Wash Basin and Central } \\
\text { Shops Burning/Rubble Pit (631-5G) }\end{array}$ & Performed preworkplan characterization \\
\hline $\begin{array}{l}\text { Old Radioactive Waste Burial Ground, including } \\
\text { Solvent Tanks }\end{array}$ & Performed remedy identification and evaluation \\
\hline \multicolumn{2}{|c|}{ Lower Three Runs Watershed } \\
\hline P-Area Bingham Pump Outage Pit & Submitted signed ROD; approved by EPA/SCDHEC \\
\hline R-Area Reactor Seepage Basins & Continued characterization \\
\hline R-Area Acid/Caustic Basin & Initiated characterization \\
\hline R-Area Bingham Pump Outage Pits & Continued characterization \\
\hline \multicolumn{2}{|c|}{ Pen Branch Watershed } \\
\hline CMP Pits & Issued IROD; initiated interim remedial action \\
\hline K-Area Burning/Rubble Pit and Rubble Pile & Completed remedy evaluation \\
\hline K-Area Reactor Seepage Basin & Selected source unit remedy (plug-in ROD) \\
\hline $\begin{array}{l}\text { L-Area Burning/Rubble Pit, Rubble Pile, and Gas } \\
\text { Cylinder Disposal Facility }\end{array}$ & Completed additional characterization \\
\hline L-Area Bingham Pump Outage Pit & Submitted signed ROD; approved by EPAVSCDHEC \\
\hline \multicolumn{2}{|c|}{ Savannah River and Floodplain Swamp Watershed } \\
\hline $\begin{array}{l}\text { D-Area Expanded Operable Unit (Ash Basin, } \\
\text { Coal Pile Run-off Basin, Waste Oil Facility, } \\
\text { and Upgradient Sources) }\end{array}$ & Continued characterization \\
\hline D-Area Oil Seepage Basin & Initiated remedial action \\
\hline Road A Chemical Basin & Completed characterization planning \\
\hline Savannah River and Floodplain Swamp IOU & Continued Phase I IOU characterization planning \\
\hline
\end{tabular}


Table 2-8 SRS 1999 Environmental Restoration Activities

Page 2 of 2

\begin{tabular}{|c|c|}
\hline Operable Unit & Activity Description \\
\hline \multicolumn{2}{|c|}{ Savannah River and Floodplain Swamp Watershed (cont)) } \\
\hline TNX Operable Unit & $\begin{array}{l}\text { Continued interim-action remediation system op- } \\
\text { eration; completed characterization results docu- } \\
\text { mentation; performed remedy evaluation }\end{array}$ \\
\hline $\begin{array}{l}\text { TNX Outfall Delta, Lower Discharge Gulley, and } \\
\text { Swamp }\end{array}$ & Continued characterization \\
\hline \multicolumn{2}{|l|}{ Steel Creek Watershed } \\
\hline L-Area Hot Shop & Completed characterization planning \\
\hline L-Area Oil and Chemical Basin & Continued remedial action \\
\hline L-Area Reactor Seepage Basin & Completed preworkplan characterization \\
\hline L-Area Southern Groundwater & Completed characterization planning \\
\hline P-Area Burning/Rubble Pit & $\begin{array}{l}\text { Completed characterization and characterization } \\
\text { results documentation }\end{array}$ \\
\hline Steel Creek IOU & Completed Phase I IOU characterization planning \\
\hline \multicolumn{2}{|l|}{ Upper Three Runs Watershed } \\
\hline A-Area Burning/Rubble Pits and Rubble Pit & Completed interim-action remedy selection \\
\hline A-Area Miscellaneous Rubble Pile & Completed characterization results documentation \\
\hline M-Area HWMF - AM Groundwater & Continued remediation system operation \\
\hline M-Area HWMF - Vadose Zone & Continued remediation system operation \\
\hline Met Lab Basin/Carolina Bay & Continued remediation system operation \\
\hline $\begin{array}{l}\text { Miscellaneous Chemical Basin/Metals Burning } \\
\text { Pit }\end{array}$ & $\begin{array}{l}\text { Completed interim-action remedy selection; sub- } \\
\text { mitted signed IROD }\end{array}$ \\
\hline $\begin{array}{l}\text { Mixed Waste Management Facility (including } \\
\text { RCRA-regulated portions of LLRWDF) }\end{array}$ & Completed RCRA closure of LLRWDF \\
\hline Old F-Area Seepage Basin & Continued remedial action \\
\hline Sanitary Landfill Groundwater & $\begin{array}{l}\text { Initiated operation of interim-measure remediation } \\
\text { system }\end{array}$ \\
\hline SRL Seepage Basins & $\begin{array}{l}\text { Submitted signed ROD; approved by EPA } \\
\text { SCDHEC; initiated remedial action }\end{array}$ \\
\hline West of REL "Georgia Fields" Site & $\begin{array}{l}\text { Completed characterization results documentation; } \\
\text { selected remedy }\end{array}$ \\
\hline
\end{tabular}




\section{Environmental Program Information}

\author{
Pete Fledderman and Donald Padgett \\ Environmental Protection Department
}

Timothy Jannik

Savannah River Technology Center
To Read About ... $\quad$ Turn to Page ...

ISO $14001 \ldots \ldots \ldots \ldots . . . \ldots . . . .442$

Environmental Monitoring ........... 42

Dose Reconstruction Study ............ 47

Pollution Prevention ................. 47

Public Involvement ................. 49

Employee Training ............... 51

Information Exchange.............. 52

Public Outreach ................. 53

\section{Highlights}

- SRS maintained its ISO 14001 (Environmental Management System standard) certification. The SRS Environmental Management Systems Policy provides the basis for environmental programs and emphasizes vigilance in protecting human health and the environment.

- Solid waste generators identified more than 90 waste reduction initiatives with potential to reduce forecasted waste generation by more than 991 cubic meters over a 12-month period. The annualized radioactive and hazardous solid waste generation volumes decreased by about 77 percent, or almost 28,058 cubic meters, from 1991 to 1999. (In calendar year 1991, 27,565 cubic meters of radioactive and hazardous solid waste was generated; in fiscal year 1999, 6,217 cubic meters of radioactive and hazardous solid waste was generated.)

- In fiscal year 1999, almost 1,900 metric tons of nonradioactive, nonhazardous materials were recycled at SRS, including $\mathbf{9 0 0}$ metric tons of paper, cardboard, and aluminum cans-as well as approximately 1,000 metric tons of recyclable materials through WSRC's Salvage Operations group. SRS also recycled more than 25 metric tons of potentially hazardous materials.

- A comprehensive energy conservation program and site mission changes helped drive down facility energy consumption in British Thermal Units (BTU) per gross square foot by more than 75 percent from 1985 (baseline year) through 1999.

- The Chemical Commodity Management Center received 39,000 pounds of excess chemicals but disbursed more than 65,000 pounds of excess chemicals from its total inventory. Excess chemical disbursements resulted in the receipt of usable products by offsite institutions and the avoidance of substantial waste disposal costs by the site.

- Approximately 170,000 people participated in various SRS public outreach programs during the year. WSRC sponsors programs designed to bring science and mathematics to local teachers and students. For the 1998-1999 school year, an estimated 45,000 contacts were made with students in surrounding communities through these programs. One educational initiative was the Research Intern Program, which placed 122 students, teachers, and faculty members in research intem positions in fiscal year 1999. Another program, the School-to-Work Program, provided 98 high school and postsecondary students with work-based learning experiences at SRS in fiscal year 1999.

$\mathrm{B}$ eginning with preconstruction in the early 1950s, the Savannah River Site (SRS) has been concerned with stewardship of the environment as shown through its policies, procedures, and performance. Through the years, environmental programs have evolved to complement site missions. Policies related to these programs were formalized in recent years in the SRS Environmental Management System Policy, which emphasizes vigilance in protecting human health and the environment. The full text of this policy is provided in appendix A, "Applicable Guidelines, Standards, and Regulations."
Information in this chapter exemplifies SRS's adherence to this policy. Included are

- particulars about the International Organization for Standardization (ISO) 14000 series and SRS's ISO 14001 Environmental Management System Standard certification within the 14000 series.

- a general overview of environmental programs, including monitoring. Two goals of the environmental monitoring program are to measure concentration or quantity of 


\section{State of the Environment}

A new brochure, "State of the Savannah River Site Environment, 1999 Report, Volume 1," has been written in response to requests for information about the state of the environment at SRS. Copies are available from Jim Moore, WSRC, Building 742-A, Aiken, SC 29808 Telephone - 803-725-5663 or 800-249-8155; E-mail -jim02.moore@srs.gov

contaminants (both radiological and nonradiological) released from site operations and to provide a technical basis for any needed corrective action. The data that are generated document compliance with federal, state, and local standards, as well as U.S. Department of Energy (DOE) orders.

- an overview of the SRS Dose Reconstruction Study, which is an evaluation of historical monitoring data and other site records. An objective of this study is to provide an independent assessment of potential human health risk to populations exposed to radioactive materials and chemicals released into the surrounding environment since site operations began in the 1950s.

- a description of the site's pollution prevention program. The goal of this program is to reduce the impact of site operations on the environment by focusing on source reduction, on recycling, and on increasing employee awareness of-and participation in-waste minimization.

- an account of public involvement activities, a fundamental part of DOE's decision-making process. Included in this section is a summary of the SRS Citizens Advisory Board (CAB) stakeholder functions and its recommendations.

- descriptions of activities-i.e., employee training, information exchange, and public outreach-that offer ways to provide job-related knowledge and develop job-related skills; share information about site operations, programs, and objectives; and address public concerns.

Various site organizations have lead responsibility for the environmental programs. These groups are Westinghouse Savannah River Company's (WSRC) Environmental Protection Department (EPD), Safety and Health Operations (S\&HO), Savannah River Technology Center (SRTC), Savannah River Ecology Laboratory (SREL), Savannah River Natural Resource Management and Research Institute (SRI), and Savannah River Archaeological Research Program (SRARP). SRTC, SREL, SRI, and SRARP are discussed briefly in chapter 1, "Introduction." However, the education outreach programs of SREL, SRI, and SRARP, as well as that of WSRC, are discussed in this chapter.

\section{ISO 14001}

The ISO is composed of standards groups from 120 member countries. Founded in 1947 , ISO has set international standards for things as varied as paper sizes and automotive parts.

ISO 14000 is a family of voluntary environmental management standards and guidelines. ISO 14001 is the Environmental Management System Standard within the 14000 series. Application of the ISO 14001 environmental management principles increases cost effectiveness and environmental compliance efficiency.

ISO 14001 certification provides evidence to stakeholders that SRS is committed to an environmentally safe site, pollution prevention, environmental compliance, and continual improvement. SRS was initially registered in conformance with ISO 14001 in September 1997. The site maintained its ISO 14001 certification as the result of the annual surveillance by a third-party registrar conducted in February 1999.

\section{Environmental Monitoring}

SRS environmental monitoring, which includes both onsite and offsite activities, is the responsibility of EPD's Environmental Monitoring Section (EMS). Also, the Division of Environmental Research of the Academy of Natural Sciences of Philadelphia has performed biological and water quality surveys of the Savannah River since 1951.

The two components of environmental monitoring are effluent monitoring and environmental surveillance. Additional environmental monitoring information is provided in chapters dealing specifically with

- radiological effluent monitoring (chapter 5)

- radiological environmental surveillance (chapter 6)

- nonradiological effluent monitoring (chapter 8)

- nonradiological environmental surveillance (chapter 9)

- groundwater monitoring (chapter 10)

- special surveys and projects (chapter 12)

\section{Effluent Monitoring}

Effluent monitoring is conducted by collecting and analyzing onsite samples of liquid and airborne 


\section{Effluent Monitoring and Environmental Surveillance}

Per DOE Order 5400.5, "Radiation Protection of the Public and the Environment":

Effluent monitoring is the collection and analysis of samples or measurements of liquid and gaseous effluents for purposes of characterizing and quantifying contaminants, assessing radiation exposure to members of the public, and demonstrating compliance with applicable standards.

Environmental surveillance is the collection and analysis of samples of air, water, soil, foodstuffs, biota, and other media from DOE sites and their environs and the measurement of external radiation for purposes of demonstrating compliance with applicable standards, assessing radiation exposures to members of the public, and assessing the effects, if any, on the local environment.

Monitoring occurs at the point of discharge, such as an air stack or drainage pipe; surveillance involves looking for contaminants in the environment.

effluents taken at or very near their points of discharge to the environment. Radiological effluent monitoring meets regulatory requirements and provides source terms for calculating potential offsite radiation doses. More information about calculations can be found in chapter 7, "Potential Radiation Doses." In 1999, approximately 4,200 radiological samples were taken at 71 points of discharge.

SRS handles plutonium, tritium, and other special nuclear materials. Therefore, one focus of the environmental program is to detect possible releases of these radioactive materials from routine operations. This is done by collecting and analyzing samples of airborne and liquid effluents. Radioactive materials are monitored or sampled at their points of discharge. EMS performs most of the radiological analyses on the samples. Following validation, results of these analyses are recorded in a monthly radioactive releases report. Data from the monthly reports are summarized in an annual data publication (in 1999, SRS Environmental Data for 1999, WSRC-TR-99-00301)

The major nonradiological airborne emissions of concern from SRS stacks include-but are not limited to-sulfur dioxide, oxides of nitrogen, particulate matter, and toxic air pollutants such as trichloroethylene, perchloroethylene, benzene, and hydrochloric acid. Data generated from monitoring nonradioactive contaminants in airborne effluents at SRS provide evidence as to whether or not requirements of permits issued by the South Carolina Department of Health and Environmental Control (SCDHEC) are being met. Permits are discussed further in chapter 2, "Environmental Compliance."

As part of a network associated with the federal Clean Air Act, Georgia and South Carolina environmental agencies maintain several monitoring stations near SRS. These stations monitor ambient air

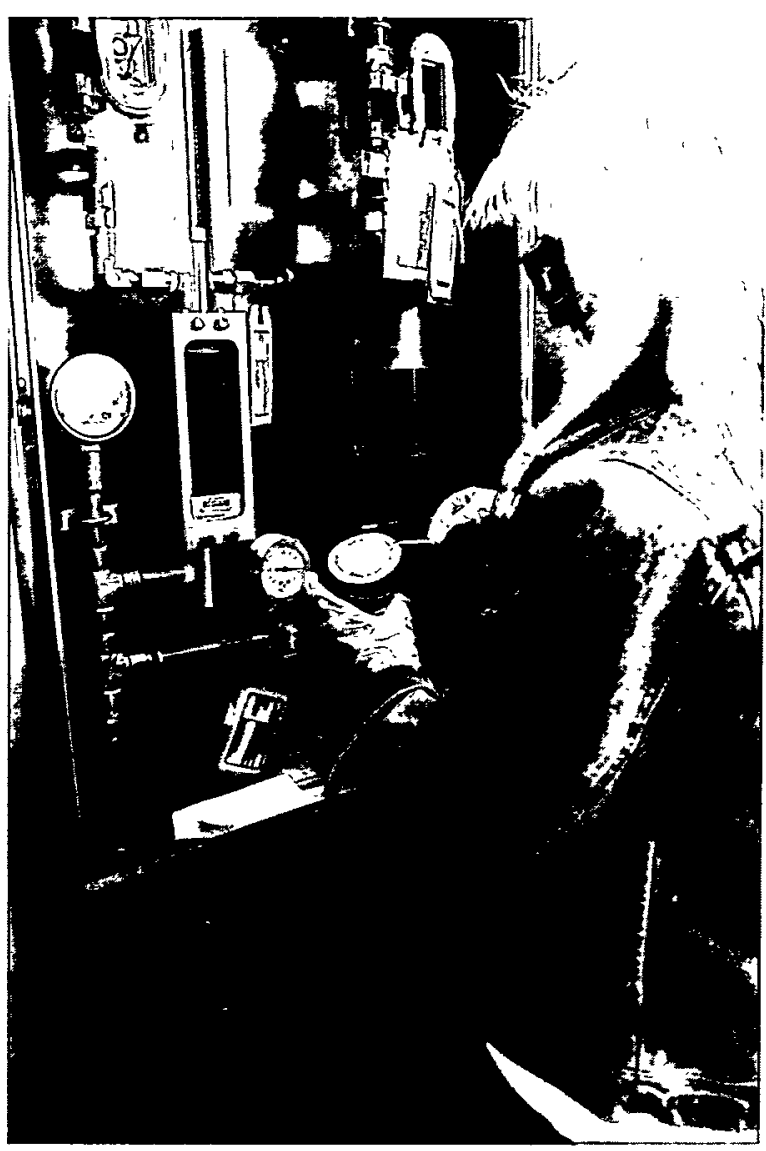

Al Mamatey Photo (00J0027201)

Radiological effluents are measured at the points of discharge and tracked through the environment. Here, as part of the airborne effluent monitoring program, an RCO technician exchanges a glass fiber filter paper on a stack sampling system. The filter paper is used to sample particulates in the exhaust.

to ensure state compliance with federal ambient air quality standards and-because of their proximity to SRS-demonstrate site compliance as well. 
Nonradioactive liquid effluents generally are sampled at National Pollutant Discharge Elimination System (NPDES) outfalls (points of discharge) and reported to SCDHEC in a monthly discharge monitoring report, as required by the Clean Water Act. Monitoring requirements for liquids may vary at each outfall, depending on the type of facility and the known characteristics of the wastewater. A typical setup for liquid effluent monitoring is shown in figure 3-1.

\section{Environmental Surveillance}

Environmental surveillance is conducted by collecting and analyzing onsite and offsite samples taken at various distances from points of discharge. In 1999 , approximately 10,000 radiological analyses were performed on approximately 5,000 samples (not including groundwater). In 1999, 26,958 radiological analyses were performed on groundwater samples collected from 1,224 monitoring wells.

Data from radiological environmental surveillance are evaluated to

- detect and characterize contaminants that could adversely affect the environment

- $\quad$ provide a way to verify dose calculations and predictions from mathematical models
Because most contaminants are released in such small amounts that they cannot be readily measured in environmental samples, SRS uses mathematical models to estimate contaminant concentrations in environmental media. The data obtained at the point of discharge (e.g., stack, pipe, or outfall)-where the concentration would be highest if a contaminant were present-is used to calculate the estimated contaminant concentration in sampled media, such as water, soil, or vegetation. More information about modeling can be found in chapter 7 .

Nonradiological environmental surveillance is conducted by collecting and analyzing samples from site streams and the Savannah River to verify the outfall sampling data and to ensure the detection and characterization of materials that could adversely affect the environment. Adverse conditions resulting from the presence of such materials are identified and evaluated to provide a basis for corrective action.

In 1999, approximately 6,300 nonradiological analyses for specific chemicals and metals were performed on about 1,200 samples, not including groundwater. In 1999, 134,123 nonradiological analyses were performed on groundwater samples collected from 1,224 monitoring wells.

\section{Objectives}

One purpose of environmental regulations is to protect human health and the environment. In support

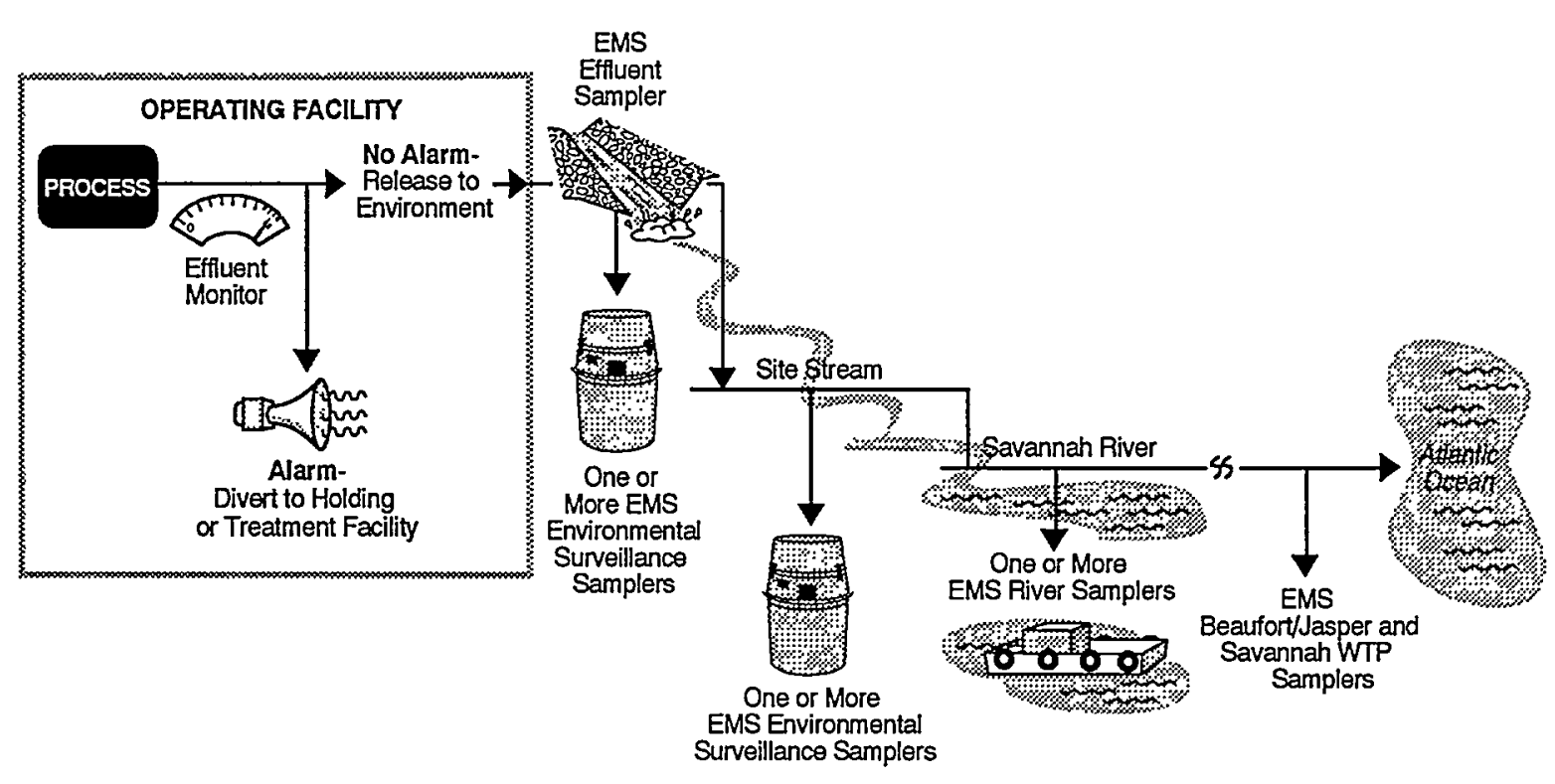

94X06608.57.AIL

Figure 3-1 Typical Liquid Effluent Monitoring and Environmental Surveillance

Effluents are monitored at points of discharge. Released materials of concern are tracked in the environment from discharge to site stream to river to water treatment plants at Beaufort/Jasper and Savannah. 
of this purpose, the SRS environmental monitoring objectives are to

- assess actual or potential exposures of radioactive and nonradioactive materials to critical groups and populations from normal site operations or from accidents

- demonstrate compliance with authorized limits and regulatory requirements or need for corrective action

- verify the adequacy of each facility in containing radioactivity and controlling effluents

- notify appropriate officials of unusual or unforeseen conditions and, if necessary, activate a special environmental monitoring program

- communicate accurate and effective EMS monitoring results to $\mathrm{DOE}$, to other government agencies, and to the general public

- maintain an accurate and continuous record of the effects of SRS operations on the environment

- determine concentrations of radioactive and nonradioactive contaminants in environmental media for the purpose of assessing the immediate and long-term consequences of normal and accidental releases

- distinguish between environmental contamination and effects from SRS operations and those from other sources

- evaluate and revise the environmental monitoring program in response to changing conditions in transport pathways and to the site's changing mission ( the site's mission is discussed in chapter 1)

- provide site-specific data for risk assessment and uncertainty analyses for human populations near SRS

- $\quad$ assess the validity and effectiveness of models used to predict the concentration of pollutants in the environment

- conduct scientific studies on the transport pathways of radioactive and nonradioactive contaminants in the environment

These objectives incorporate the recommendations of the International Commission on Radiological Protection ("Principles of Monitoring for the Radiation Protection of the Public," ICRP Publication 43), of DOE Order 5400.1 ("General Environmental Protection Program"), and of DOE/EH-0173T ("Environmental Regulatory Guide for Radiological Effluent Monitoring and Environmental Surveillance").
As a result of the environmental monitoring program, SRS seeks to

- determine any long-term buildup of-and predict environmental trends from-site-released contaminants

- establish baselines of environmental quality so that trends in the physical, chemical, and biological condition of environmental media can be characterized

- identify and quantify new or existing environmental quality problems, then assess the need for corrective actions or mitigation measures

- pinpoint exposure pathways in which contaminants are accumulated and transmitted to the public

\section{Rationale}

Many factors are considered in the determination of monitoring activities at SRS, including responsible environmental stewardship. Sampling locations, sample media, sampling frequency, and types of analysis are selected on the basis of environmental regulations, exposure pathways, public concerns, and measurement capabilities. More detailed information about the site's environmental monitoring program is documented in sections 1101-1111 (SRS EM Program) of the SRS Environmental Monitoring Section Plans and Procedures, WSRC-3Q1-2, Volume 1 . This document is reviewed annually and updated every 3 years.

\section{Environmental Regulations}

Environmental monitoring at SRS is designed to meet state and federal regulatory requirements for radiological and nonradiological programs. These requirements are stated in

- DOE orders 5400.1 and 5400.5 ("Radiation Protection of the Public and the Environment")

- the Clean Air Act-for example, National Emission Standards for Hazardous Air Pollutants (NESHAP)

- the Comprehensive Environmental Response, Compensation, and Liability Act (CERCLA-also known as the Superfund)

- the Resource Conservation and Recovery Act (RCRA)

- the Clean Water Act-for example, NPDES

SCDHEC, the U.S. Environmental Protection Agency (EPA), and DOE conduct audits to verify that the site complies with environmental regulations. Chapter 2 summarizes the site's compliance status for 1999. 


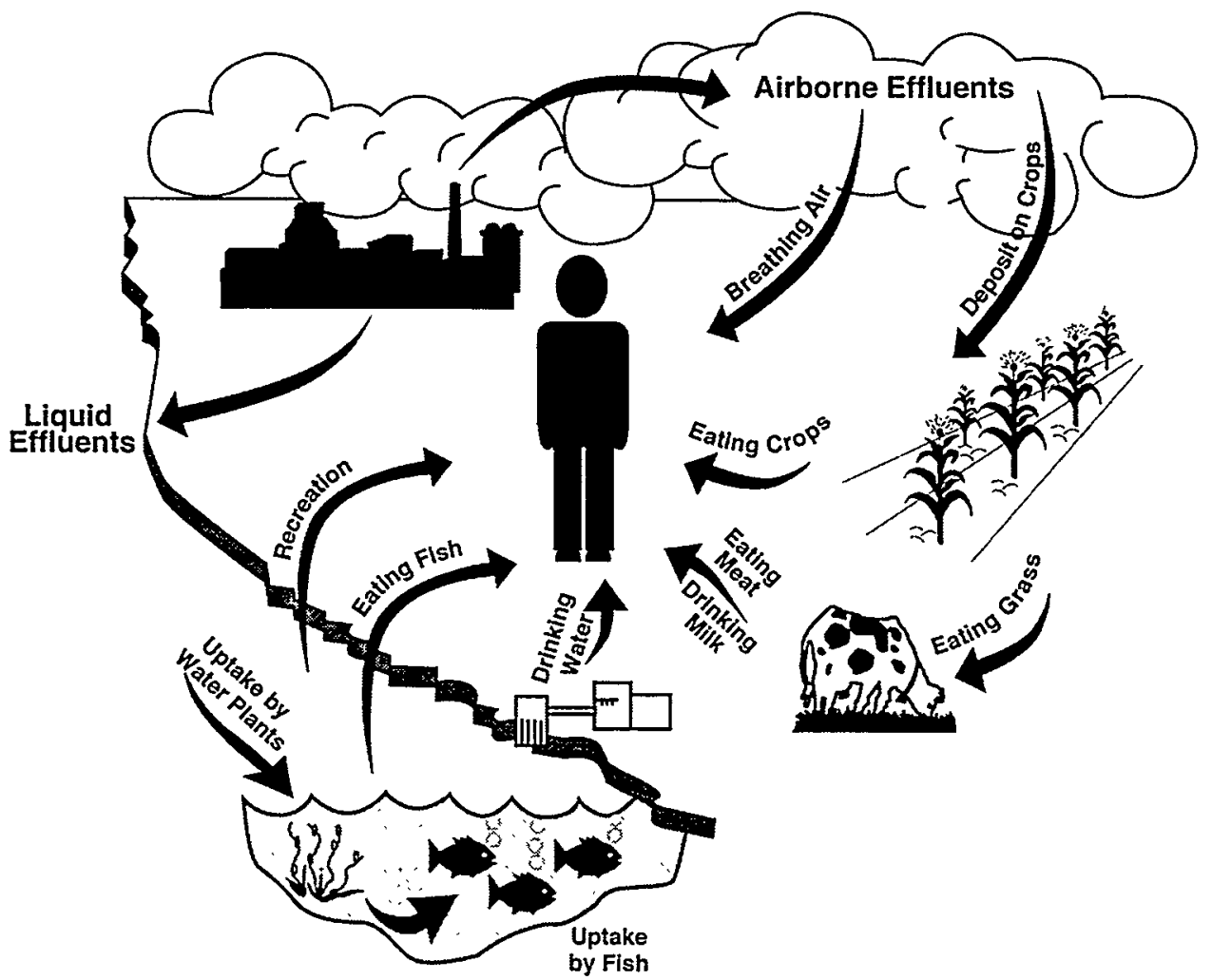

$99 \times 04844.02$ tiff

Figure 3-2 Some Potential Exposure Pathways

Airborne and liquid materials released from SRS operations can reach people in a variety of ways. These ways, or routes, are called exposure pathways.

\section{Exposure Pathways}

Materials released from SRS reach the environment and people in a variety of ways. The routes that materials follow to get from an SRS facility to the environment and then to people are called exposure pathways. Some potential exposure pathways are illustrated in figure $3-2$, which shows that materials released into the air may be taken into a human body when a person breathes air or eats food grown near the site-for example, vegetables or beef products. Similarly, materials released into site streams may be taken into the body if a person drinks Savannah River water or eats fish taken from the river. However, the released amounts of radioactive and nonradioactive materials from SRS meet-and are significantly below-all regulatory standards. Thus, the released materials present no known danger to the environment, to site workers, or to the public.

The method used to determine exposure pathways is called a critical pathways analysis. A thorough critical pathways analysis for radioactive materials released from SRS operations identified tritium and cesium-137 as the primary contributors to offsite exposures. As expected, potential exposure pathways for tritium released into air were through breathing air and eating food, whereas potential exposure pathways for tritium and cesium-137 released into site streams were through drinking river water and eating fish from the river.

Critical pathway analyses for nonradioactive materials released from SRS operations identified arsenic and benzene as the primary potential contributors to offsite exposure.

Critical pathways analysis results are used as part of the site's environmental monitoring activities to make decisions about sampling locations, sample media, and sampling frequency. Results from modeling exposure pathways can help

- verify that sampling programs perform as required

- make the best use of sampling and analysis resources 


\section{Public Concerns}

Public concerns influence the site's environmental monitoring activities. The public wants to know about releases and their potential health effects. All aspects of the environmental monitoring program are designed and implemented with public concerns in mind. Some examples include (1) offsite monitoring at air surveillance and population centers with thermoluminescent dosimeters (TLDs)—devices used to measure external gamma radiation that provide a quick, reliable method of determining the dose from gamma-emitting radionuclides in the event of an unplanned release of radioactive material; (2) public drinking water supply monitoring; and (3) fish monitoring in the Savannah River.

\section{Measurement Capabilities}

Many materials released from SRS exist in such low concentrations in the environment that they cannot be readily measured. Thus, the ability to measure low levels of concentrations becomes a significant factor in the rationale for monitoring certain materials. In these cases, modeling with nationally accepted computer programs is used to predict or estimate concentration levels. More information on modeling can be found in chapter 7 , and more on measurement capabilities can be found in tables 1-3 in SRS Environmental Data for 1999.

\section{Dose Reconstruction Study}

SRS has conducted environmental monitoring of radioactive materials and chemicals released to the environment since the beginning of site operations in the early 1950 s. Historical data from this environmental monitoring and from site operations are being evaluated independently by the federal Centers for Disease Control and Prevention (CDC) in Atlanta, Georgia, as part of the SRS Dose

Reconstruction Study, to determine the effects these materials may have had on people living near the site.

Phase I of the study - the location and review of records-was completed in 1995 and is discussed briefly in the SRS Environmental Report for 1996 (WSRC-TR-97-0171) and the SRS Environmental Report for 1997 (WSRC-TR-97-00322). Phase II of the study-the source term calculation-was completed in 1998. In Phase II, the CDC reconstructed the historical releases of radioactive materials and chemicals to calculate the total amounts and types released from the site to the environment. The draft results and reports from Phase II were released to the public by the CDC in February 1999.The report is titled DRAFT FINAL REPORT, Savannah River Site Environmental Dose
Reconstruction Project, Phase II: Source Term Calculation and Ingestion Pathway Data Retrieval, Evaluation of Materials Released from the Savannah River Site (January 28, 1999). The report is being reviewed by the $C D C$, the scientific community, and the public. A copy may be obtained by contacting the CDC (see next paragraph) or by downloading from the CDC Internet address:

http://www.cdc.gov/nceh/programs/radiation/Savannah/

Inquiries can be made about the study by writing to Centers for Disease Control and Prevention, 1600 Clifton Road NE, MS E39, Atlanta, GA 30333; by calling 888-619-6738; or by faxing 404-639-2575.

\section{Pollution Prevention}

Pollution prevention at SRS is designed to reduce the impact of site operations on the environment, reduce operational costs, and reduce employee exposure to hazardous materials. Pollution prevention at the site includes

- source reduction activities

- recycling of potential wastes and pollutants

- reduction in the use of materials, energy, water, and other resources

- protection of human health and natural resources through conservation and more efficient use

- disposal of waste in an environmentally safe manner

Pollution prevention programs are a major focus of many activities, organizations, and implementation teams. Improvements in the coordination of and communication between these program areas are ongoing, and employee awareness of-and management emphasis on-pollution prevention is increasing. Highlights of some of the 1999 SRS pollution prevention activities are discussed in the following paragraphs. Certain aspects of pollution prevention also are discussed in chapter 2 .

\section{Waste Minimization}

The SRS Waste Minimization Program continued in 1999 to reduce the generation of solid wastes that require costly treatment, storage, and disposal. The annualized radioactive and hazardous solid waste generation volumes decreased by about 77 percent, or almost 28,058 cubic meters, from 1991 to 1999 . (In calendar year 1991, 27,565 cubic meters of radioactive and hazardous solid waste was generated; in fiscal year 1999, 6,217 cubic meters of radioactive and hazardous solid waste was generated.)

The decrease is attributed largely to waste minimization efforts initiated as a site program in 
1991. In 1999, solid waste generators identified more than 90 waste reduction initiatives with potential to reduce forecasted waste generation by more than 991 cubic meters over a 12-month period. Key initiatives included incorporation of commercial radioactive waste reduction practices; emphasis on reduction in the size of radioactive contamination areas; increased use of recyclable-versus disposable-materials for radioactive jobs; and the surveying, decontaminating, and subsequent free-release of previously contaminated materials.

More about waste minimization can be found in chapter 4, "Environmental Management").

\section{Solid Waste Recycling}

In fiscal year 1999, 1,900 metric tons of nonradioactive, nonhazardous materials were recycled at SRS, including 900 metric tons of paper, cardboard, and aluminum cans-as well as approximately 1,000 metric tons of recyclable materials through WSRC's Salvage Operations group. The total number of metric tons recycled in fiscal year 1999 was about half that recycled in fiscal year 1998 (3,366 metric tons).

Also in fiscal year 1999, SRS recycled more than 25 metric tons of other potentially hazardous materials, such as lead, fluorescent light bulbs, and photographic silver fixative.

\section{Energy Conservation}

Reducing site demand for energy in turn reduces emissions and conserves resources (e.g., coal) associated with energy production. A comprehensive energy conservation program and site mission changes helped drive down facility energy consumption in British Thermal Units (BTU) per gross square foot by more than 75 percent from 1985 (baseline year) through 1999.

The Energy Savings Performance Contract, awarded in 1998, was the primary focus of the SRS Energy Management Team in 1999. Under this contracting mechanism, the Energy Services Company (ESCO) incurs the cost of implementing energy savings measures, including — but not limited to-performing energy audits and studies; designing, acquiring, and installing equipment; and training personnel. The ESCO is required by federal law to guarantee a minimum cost savings resulting directly from implementation of such measures during the term of the contract and is at risk to ensure that this minimum guarantee is achieved. In exchange for providing these services, the ESCO receives a percentage of the cost savings.
The design and construction of Task Order \#1-approved during the year and consisting of upgrades in 16 administrative area facilities-is scheduled for completion in fiscal year 2000. A total of 540,000 square feet of building space was audited, with conservation measures targeted in lighting enhancements, energy management control system installations, and heating, ventilation, and air conditioning (HVAC) improvements.

The SRS Energy Management Team also evaluated Task Order \#2, which involves potential energy conservation measures associated with the site's main administrative area steam plant and steam distribution system. Four options were considered, but none were determined to be economically feasible.

Development of Task Order \#3-the remainder of facilities within the site's main administrative area-will be initiated during fiscal year 2000 .

\section{Reduction of Chemical Releases}

Under Section 313 of the Emergency Planning and Community Right-to-Know Act (EPCRA), SRS has filed Toxic Chemical Release Inventory reports annually since 1987 . The site calculates chemical releases to the environment and reports aggregate quantities for each regulated chemical that exceeds threshold amounts. More about Toxic Chemical Release Inventory reports, including summary data results, can be found in chapter 2 .

\section{Affirmative Procurement of Recycled Products}

The SRS Affirmative Procurement Program -implemented as part of federal Executive Order 12873, "Federal Acquisition, Recycling and Waste Prevention," and RCRA

Section 6002-promotes the purchase of products made from recycled materials to help conserve natural resources. The program is based on DOE guidelines for implementing affirmative procurement requirements at federal facilities. The fiscal year 1999 program continued to expand recycled product purchasing in several areas, including paper, re-refined oil, retread tires, office supplies, and construction and building materials.

\section{Excess-Chemical Management}

The Chemical Commodity Management Center was created and staffed in 1994 to ensure environmentally sound, safe, and cost-effective acquisition, distribution, and reuse of chemicals/excess chemical products for the site. An "excess chemical product" is defined as any reusable material that can be sold, donated, or redistributed on site, that requires a 
material safety data sheet, and that is in its original form and concentration as received as a stock supply item from a supplier.

During 1999, the Chemical Commodity Management Center received 39,000 pounds of excess chemicals but disbursed more than 65,000 pounds of excess chemicals from its total inventory. The disbursements were made to offsite institutions as part of the site's excess chemical sales, recycling, and donation programs. Excess chemical disbursements resulted in the receipt of usable products by offsite institutions and the avoidance of substantial waste disposal costs by the site.

\section{Ozone-Depleting Substances}

The Clean Air Act Amendments of 1990 require that EPA publish a number of regulations to phase out the production and consumption of ozone-depleting substances. SRS has produced an internal guidance document designed to assist the site in the phaseout of these substances. The main objective of the plan is to reduce the use of chlorofluorocarbon (CFC) refrigerants by (1) replacement and retrofit of $\mathrm{CFC}$ equipment, (2) sound refrigerant containment practices (such as reducing leaks), and (3) controlling distribution of refrigerants from inventories.

More about ozone-depleting substances can be found in chapter 2.

\section{Public Involvement}

DOE considers public involvement a fundamental component in program operations, planning activities, and decision making in DOE. The public is encouraged to play a role in DOE decision making. Public involvement is a major focus in every operational division at SRS and is established annually as one of the major goals in the site's strategic plan.

Stakeholder involvement at SRS follows the legal requirements of the National Environmental Policy Act (NEPA), RCRA, and CERCLA, but also reaches beyond to provide opportunities to support the SRS $\mathrm{CAB}$ and special meetings and focus groups.

The site's public involvement program offers a comprehensive approach to citizen participation as suggested by DOE policy. The ultimate goal is that the program be dynamic and accessible to any person or organization wishing to have a voice in site activities.

\section{Environmental Restoration}

Within the environmental restoration program, the public is consulted frequently about decisions on closure of waste sites. In 1999, approximately 21 participation opportunities were provided.

Public notices and comments were provided for remedial and limited actions and for no action waste units. Public comment periods were held also for sections of the Federal Facility Agreement- and CERCLA-proposed plans for several SRS operable units. Notices of Availability for four Records of Decision, three Interim Action Proposed Plans, five Statement of Basis Proposed Plans, three Preconstruction Fact Sheets, and two Explanation of Significant Differences were provided in area newspapers, using both display and legal advertisements.

Additionally, DOE, EPA, and SCDHEC cosponsored information exchanges in Barnwell, South Carolina, and Augusta, Georgia, to better inform citizens of timely environmental issues.

\section{National Environmental Policy Act Activities}

During 1999, NEPA local and national Environmental Impact Statement (EIS) activities focused on treating and stabilizing spent nuclear materials; closing high-level waste tanks; finding an alternative to SRS's In-Tank Precipitation process; disposition of surplus plutonium; and the suitability of Yucca Mountain as a national geologic repository. Local stakeholders participated in the following EIS activities by attending scoping and draft meetings and providing individual comments to DOE, as well as by attending Citizens Advisory Board meetings to assist in recommendation development:

- Accelerator Production of Tritium EIS

- Commercial Light Water EIS

- Tritium Extraction Facility EIS

- Surplus Plutonium EIS

- SRS Spent Nuclear Fuel Management draft EIS

- High-Level Waste Tank Closures EIS

- SRS Salt Disposition Alternatives Supplemental Environmental Impact Statement (SEIS)

- Treatment and Management of Sodium Bonded Fuel draft EIS

- Yucca Mountain Repository draft EIS 


\section{Accelerated Cleanup Plan: Draft Paths to Closure}

The draft Paths to Closure document was discussed at five public meetings, and copies were distributed to those interested in reviewing and sending in comments. All comments from the public were tracked, and appropriate comments were incorporated into the draft document. The public comments resulted in a $\mathrm{CAB}$ recommendation (see Recommendations, page 50 .

Public involvement in the $\mathrm{ACPC}$ will be a continual process. The document is updated about every six months to reflect changes in DOE's strategic goals and the national budget.

\section{Citizens Advisory Board}

The $C A B$ is an independent organization officially chartered by $D O E$ to provide recommendations and stakeholder insight on site activities to DOE, EPA, and SCDHEC. It provides SRS with ongoing counsel to help guide decisions consistent with stakeholder values and opinions. Thus, it complements regulatory and program stakeholder input. The CAB is composed of 25 South Carolina and Georgia individuals who reflect the cultural diversity of the population affected by SRS. Membership applications are accepted year-round from stakeholders living in an area ranging from the Central Savannah River Area (CSRA) to Georgia and South Carolina coastal communities downriver of SRS. Applications are placed in membership categories representing labor, environmental, political, educational, and minority groups as well as public officials and the general public. Voting by ballot is held once a year at a full board meeting. Members serve a two-year term. They can serve two additional terms (six consecutive years) if elected.

\section{Recommendations}

The citizens group, nationally recognized as being one of the most productive site-specific advisory boards in the DOE complex, provided 35 recommendations to the agencies in 1999.

In the Solid Waste Program, the $\mathrm{CAB}$ acted on a national issue by asking DOE-Carlsbad and New Mexico's Environmental Department to regulate only the operation of the Waste Isolation Pilot Plant (WIPP) to ensure that transuranic mixed wastes that arrive at WIPP meet only the WIPP Waste Acceptance Criteria. The CAB felt strongly that New Mexico's Environmental Department had no regulatory authority over how generator sites prepare waste for shipment. This recommendation is significant in that the CAB's intentions are to

- assist in streamlining the process without jeopardizing health and safety and environmental protections

- initiate shipment of transuranic waste to WIPP as soon as possible

- minimize costs to the taxpayers

When the opening of WIPP was announced in September, the CAB recommended to DOE that it safely expedite shipments of transuranic waste containing plutonium-238 from SRS to WIPP as agreed to by the Governor of South Carolina and the Secretary of the Department of Energy.

DOE had asked the SRS CAB to review a draft SRS Risk Summary prepared by the DOE Center for Risk Excellence. After reviewing the summary, the $\mathrm{CAB}$ issued a recommendation that identified seven major risk-related challenges. Specific concerns focused on the 66 tons of heavy metal spent nuclear fuel, much of which is deteriorating research reactor fuel; storage of 14,000 cubic yards of transuranic waste; and the low-level and mixed low-level waste stored at SRS.

One of the recommendations concerning nuclear materials addressed a Defense Nuclear Facilities Safety Board report, "Tech-22," that discussed and questioned the safety, efficiency, and timing of the "melt and dilute" process for treating spent nuclear fuel. The $\mathrm{CAB}$ asked $\mathrm{DOE}$ to respond to the issues cited by the national oversight board.

Environmental Restoration Program Two board recommendations focused on an SRS initiative to establish "plug-in" Records of Decision to streamline the evaluation effort for remediation of similar sites under CERCLA. Under the "plug-in" approach, a Presumed Remedy is selected for a group of similar sites - with savings in time, effort, and cost compared to the normal CERCLA process.

For example, in 1999, SRS, SCDHEC, and EPA Region IV agreed to link remediation of the three C-Area Reactor seepage basins, allowing

- an in-situ remedy (in-situ stabilization using grout with soil cover)

- the groundwater remedy component of this corrective action to be combined with the overall C-Reactor Groundwater Operable Unit

This agreement allowed the "plug-in" Record of Decision to become the final Record of Decision for the Groundwater Operable Unit, eliminating the need for an additional Feasibility Study, Proposed Plan, and Record of Decision. 
The SRS CAB recommended that SRS implement a "plug-in" Record of Decision for C-Reactor, K-Reactor, L-Reactor, and P-Reactor seepage basins.

Solid Waste Program Throughout 1999, the solid waste program at SRS faced major environmental issues requiring stakeholder support. From topics such as the disposal of SRS's "orphan" waste (a category of low-level waste with no treatment path) to ensuring that the Consolidated Incineration Facility remained in compliance with the Clean Air Act of 1990 , stakeholders were provided many opportunities to participate in the public input process. In 1999, six $\mathrm{CAB}$ recommendations about solid waste issues were given to $D O E$ and the regulators.

The CAB concurred with the Solid Waste Division System Plan's recommendation to use the Solid Waste Disposal Facility trenches for disposal of low-level waste meeting the trench Waste Acceptance Criteria.

In 1996, the CAB had recommended the startup of the Consolidated Incinerator Facility (CIF) and added that the continued operation of the CIF was essential to DOE's cleanup schedule. In 1999, with the promulgation of EPA's Clean Air Act Maximum Achievable Technology Control rule, the $\mathrm{CAB}$ asked $\mathrm{DOE}$ to choose from 12 different alternatives one that will minimize cost and balance equity across the DOE complex.

Material and Facility Stabilization $\mathrm{CAB}$ members participated in the Processing Needs Assessment Study, the beginning link in the complex-wide process to integrate needs and capabilities throughout $\mathrm{DOE}$. This participation gave the $\mathrm{CAB}$ a first-hand view of the difficulties that $D O E$ faces in stabilizing thousands of tons of nuclear materials and identifying storage locations in order to close facilities. Throughout 1999, the $\mathrm{CAB}$ made five major recommendations on nuclear materials and spent nuclear fuel management.

High-Level Waste Program The $\mathrm{CAB}$ was concerned that the fiscal year 2000 budget for SRS was insufficient to meet SRS needs and provided specific recommendations to increase support of (1) In-Tank Precipitation alternative selection and (2) Defense Waste Processing Facility canister production. This resulted in an additional $\$ 10$ million allocation.

The SRS CAB also insisted on expedited schedules for the closure of high-level waste tanks; two tanks were closed, with a third planned for closure in 2002.
The process for selecting an alternative salt processing solution is being monitored by the SRS $\mathrm{CAB}$. This review should assist in minimizing public resistance to the technology ultimately selected.

Other Activities A public focus group was formed in 1999 to evaluate and recommend remediation alternatives for closure of the 76-acre Old Radioactive Waste Burial Ground (ORWBG). The ORWBG focus group recommended hiring an Independent Scientific Peer Review to study the ORWBG; the SRS CAB agreed, and the Education, Research and Development Association of Georgia Universities was selected to complete the task. The focus group will continue its work through mid-2000.

An element of the SRS CAB mission is to improve communication with communities potentially impacted by SRS and ensure that stakeholders are given an opportunity to become involved in the decisions made at SRS. The SRS CAB uses a variety of techniques including

- the "Board Beat," a semiannual newsletter about $S R S$ and $C A B$ activities

- displays at various expositions, trade shows, and conferences

- participation in local radio and cable television talk shows

- an SRS CAB video produced in 1999 to inform media and other interested groups

- holding of essay contests in conjunction with full board meetings

- establishment of a speakers' bureau to offer presentations to various groups

During 1999, the $C A B$ participated in several national stakeholder meetings in which individuals from 12 DOE site-specific advisory boards met to discuss transportation and long-term stewardship. Primarily, these workshops were educational in nature, with final reports provided to DOE Headquarters (DOE-HQ).

More information about the CAB's 1999 recommendations can be obtained by calling the SRS $\mathrm{CAB}$ administrator at 800-249-8155. Internet users may access the SRS Home Page at www.srs.gov/general/srs-home.html and click on the Citizens Advisory Board button.

\section{Employee Training}

SRS environmental training programs help achieve environmental goals at the site. SRS is committed, as a matter of policy, to maintaining its facilities and conducting its operations in full compliance with all 
applicable laws and regulations for the protection of the environment and of the health and safety of its employees and the general public. The training program identifies training activities to teach job-specific skills that protect the environment and satisfy regulatory requirements.

Environmental training at SRS addresses good environmental stewardship, which includes compliance with federal and state regulations. The focus is on required training and recommended education courses for employees (based on responsibility) involved with environmental oversight, hazardous materials, and waste management at the site.

DOE-SR and WSRC are working closely with the National Environmental Training Office to determine and/or develop "best-in-class" environmental training courses while reducing costs. These will be made available to SRS environmental professionals and others within the DOE complex.

The Training Subcommittee of the WSRC Environmental Management Council completed the "Environmental Compliance Authority (ECA) Training Program," which established the minimum training requirements necessary for WSRC professionals assigned as ECAs (formerly environmental coordinators). The new ECA is required to take a laws and regulations course and an environmental modules course, with modules ranging from site waste management practices to wetlands and endangered species concerns, and must read 30 site environmental procedures. The subcommittee redefined and upgraded the roles, responsibilities, and position description of the ECA and is developing and making available continuing education courses that will allow for development of an environmental professional career path at SRS.

Environmental training activities in 1999 included the following:

- Site environmental protection coordinators (67) were trained in responsibilities for reporting occurrences having environmental consequences. Training also was provided for DOE and environmental coordinator representatives.

- Site environmental systems operators (360) received and/or maintained water/wastewater certification.

- More than 50 persons attended environmental training through subcontracted courses.

- More than 65 site ECAs attended required ECA training courses to learn duties and responsibilities to identify, interpret, and implement environmental compliance requirements in WSRC-operated facilities.

- Site workers (595) attended Hazardous Waste Operations courses (29 CFR 1910.120), which provide health and safety training in hazardous-waste cleanup activities and in working at RCRA treatment, storage, and disposal facilities.

- Site workers $(1,159)$ attended RCRA training.

- More than 250 site workers attended other environment-related courses, such as Environmental Laws \& Regulations, Spill Control, Waste Minimization, Occurrence Reporting, Pollution Prevention, Refrigerant Recovery, and ISO 14000 \& the SRS Environmental Management System.

\section{Information Exchange}

SRS has opened several avenues of exchange with state and federal regulators, other government-owned, contractor-operated (GOCO) facilities, and scientists to improve and update its environmental monitoring and research programs.

DOE-SR representatives attend technical information exchange workshops sponsored by DOE-HQ, which provide a way to enhance the exchange of technical information among DOE sites.

Environmental awareness and information exchange tours are conducted for many special-interest groups, including environmental activists and representatives of other GOCOs, DOE-HQ, Westinghouse Electric Corporation, EPA, and SCDHEC. Tours are designed to meet the needs of a particular group. For example, EPA and SCDHEC tours might focus on regulatory issues, while tours for other GOCOs might cover activities applicable to their programs.

Initiated in 1996, the Interagency Information Exchanges are public forums that enable state and federal regulators and SRS to address environmental compliance issues. At these forums, EPA, SCDHEC, and SRS representatives discuss cleanup plans and draft RCRA permit changes while soliciting public comments. Public input is considered by the agencies and used to develop final remedial approaches.

The SRS CAB provides recommendations to DOE, $\mathrm{EPA}$, and SCDHEC on environmental remediation, waste management, and related issues. More information about the $\mathrm{CAB}$ and its 1999 recommendations can be found on page 50 .

The Environmental Advisory Committee, which is comprised of nationally recognized consultants from the fields of biology, ecology, hydrogeology, health 
physics, environmental restoration, and economics, meets quarterly to review site environmental programs and make recommendations. In 1999, this group formally reviewed the SRS Environmental Report for 1998 and SRS Environmental Data for 1998 (WSRC-TR-98-00314).

The CSRA Radiological Environmental Monitoring Program is a data exchange program involving representatives of SCDHEC, GDNR, Georgia Power Company, Chem-Nuclear Systems, DOE, and WSRC. This group has met semiannually since 1987 to share technical environmental program information and data. These meetings provide an open forum in which to review and possibly improve each organization's monitoring program.

\section{Public Outreach}

\section{Communications}

SRS public outreach activities-such as public meetings, the Visitors Program, and the Speakers Bureau-provide communication channels between the site and the public. Local newspaper, television, and radio advertisements also inform the public about environmental activities. More information can be obtained by contacting the WSRC Public Relations group at 803-725-0193.

When topics involve unusually complex issues, DOE may conduct workshops that give special-interest groups or citizens the opportunity to meet with site representatives.

\section{Environmental Justice}

Environmental justice principles set forth in Executive Order 12898, "Environmental Justice Strategy," are incorporated in the design of community-specific risk communication programs and their delivery to the targeted audience.

In carrying out these programs, DOE-HQ and EPA provided funding through SRS to continue a grant to Savannah State University in Georgia for the Savannah-based Citizens for Environmental Justice activities through fiscal year 2000 . This project provided a tool to strengthen the capacity of communities to interface with the government (DOE and EPA) in environmental decision making and environmental monitoring associated with federal facilities. The Citizens for Environmental Justice were to apply monies toward community workshops, informational literature on radiation and health effects, radio programs, newsletters, and EIS workshops on spent nuclear fuel. Savannah State University was to apply this grant toward improving academic programming in environmental studies. A final report from Savannah State was to have been submitted to DOE by December 31, 1999; the due date for this report was extended to January 31, 2000.

Additional information on SRS environmental justice activities can be obtained by calling the DOE-SR Office of Environmental Programs at 803-725-5351.

\section{Public Notice Requirements}

Various regulations require that SRS notify the public of its environmental plans and activities. RCRA, CERCLA, NEPA, and the Clean Water Act have public notice and/or meeting requirements. SRS meets these requirements by using various community involvement tools, including public meetings for certain RCRA permit application modification requests and notices to contiguous landowners, media, local and state government agencies, and any other interested stakeholders. Such notices - and the status of documentation-typically are sent in a monthly newsletter called the Environmental Bulletin and in separate mailings, as required. NEPA documentation generated by SRS and various construction and operating permits held by SRS are available to the public. Chapter 2 lists 1999 SRS project NEPA documentation activities.

\section{Education}

\section{Westinghouse Savannah River Company}

WSRC assists in conducting competitions such as the CSRA Science and Engineering Fair and the DOE Savannah River Regional Science Bowl to encourage student interest in engineering, science, and mathematics. In partnership with the Ruth Patrick Science Education Center, WSRC offers the Traveling Science Demonstration Program, which provides hands-on science kits demonstrated by working scientists and engineers to local elementary, middle, and high schools. Other education initiatives include the Research Intern Program, which placed 122 students, teachers, and faculty members in research intern positions in fiscal year 1999, and the School-to-Work Program, which provided 98 high school and postsecondary students with work-based learning experiences at SRS in fiscal year 1999. During the year, WSRC was active in the CSRA Environmental Science Education Cooperative, a partnership with private and public organizations committed to environmental education outreach in the CSRA. WSRC also was instrumental in the development and implementation of a Memorandum of Understanding with local technical colleges for the Industrial Process Technician/Technology Certificate Program, which meets core competency requirements 
for four skill areas at SRS. In partnership with Allendale County (South Carolina) Public Schools, WSRC provided support for the successful achievement of three grants. Tabulations on the 1998-1999 school year show that WSRC programs had more than 45,000 contacts with students in the surrounding communities through various programs and events in science and mathematics.

\section{Savannah River Natural Resource Management and Research Institute}

SRI made more than 45,000 contacts with people through outreach programs in 1999, including about 25,000 contacts made through community events and participation in the Visitors Program mentioned on page 53. Other outreach activities include the following:

- The Natural Resources Science, Math, and Engineering Education Program allows students in grades 3 through 12 from throughout the CSRA to have an opportunity to learn science, mathematics, and engineering principles in a hands-on setting. In 1999, the program had more than 17,000 student-visits. The program also sponsors teacher workshops, summer camps, and a graduate course for teachers.

- The Savannah River Environmental Sciences Field Station provides hands-on, field-oriented experiences for undergraduates from 25 regional historically black colleges and universities.

- SRI provides natural resource research opportunities for federal and state agencies, universities, industrial/private landowners, and conservation organizations from throughout the region.

- $\quad$ SRI provides several training classes and workshops for both onsite and offsite groups on a variety of topics, including erosion control technologies, constructed wetlands, ecosystem management, GPS/GIS (Global Positioning System/Geographic Information System), and controlled burning and wildfire suppression.

- SRI administers U.S. Department of Agriculture Natural Resource Conservation Education grants to local schools to defray the costs of curriculum development, supplies, and teacher training.

- SRI provides planning and other assistance to local rural communities to develop natural resource assets.

More information about SRI outreach can be obtained by calling $803-725-0237$.

\section{Savannah River Ecology Laboratory}

SREL's Environmental Outreach and Education Program addresses the laboratory's overall mission of acquiring and communicating environmental knowledge and DOE's focus on environmental issues. The program emphasizes (1) the importance of environmental awareness in decision making regarding ecological problems and (2) the natural history of SRS and the southeastern United States. During 1999, the program reached approximately 70,000 people while promoting environmental awareness through tours of the laboratory, lectures to students and civic and special interest groups, teacher workshops, and various exhibits. Presentation topics include animal ecology, outdoor safety, plants and wetlands, the environment, conservation, and careers in ecology and research. SREL also promotes the professional development of undergraduate and graduate students through research participation and training programs, with emphasis on conducting ecological research important to the SRS environmental stewardship mission. During 1999, 12 undergraduate students and 33 graduate students participated in SREL programs. More information can be obtained by contacting SREL at $803-725-2473$ or by visiting the SREL website at http://www.uga.edu/srel.

\section{Savannah River Archaeological Research Program}

SRARP continued its heritage education activities in 1999 with a full schedule of classroom education, public outreach, and onsite tours. In addition, in a cultural resource management effort to protect unidentified archaeological sites on SRS from future impacts, SRARP surveyed more than 2,500 acres at SRS.

Two open houses were held, with participants touring the SRARP facility and hearing presentations on archaeological compliance. Some 85 presentations, displays, and tours were provided for schools, historical societies, civic groups, and environmental and historical awareness day celebrations; an estimated 10,000 individuals took part in these outreach activities. "Discovering Archaeology" and "Classroom Dig," two outreach programs with public schools, brought methods and practices of archaeology to the classroom in a hands-on approach. More information can be obtained by contacting SRARP at 803-725-3623. 


\title{
Chapter 4
}

\section{Environmental Management}

\author{
Bruce Cadotte and Dean Campbell \\ Site Information Programs Department \\ W.T. Goldston \\ Solid Waste Division \\ Al Mamatey \\ Environmental Protection Department \\ David Yannitell \\ Facilities Decommissioning Division
}

To Read About... See Page...

Regulatory Compliance ............. 55

Environmental Restoration ...........56

Solid Waste Management ............ 58

High-Level Waste Management ........61 61

Facility Deactivation/Decommissioning ... 63

\section{Highlights}

- ERD personnel completed cleanup work on 23 more inactive waste units at SRS, bringing the total number of waste sites cleaned up through the end of the year to 221 out of 515 that have been identified.

- DOE issued an Authorization Statement for the low-level radioactive waste disposal activities being conducted at E-Area and the Saltstone Facility, allowing these activities to continue. This authorization-only the second of its kind granted to a DOE facility - was based on extensive analyses and evaluations performed by SWD and SRTC personnel.

- Construction was completed on a replacement high-level waste evaporator for the tank farms, which will help reduce the volume of anticipated quantities of high-level waste for the future. The new evaporator, approved for startup in December, will have twice the processing capacity of the two existing evaporators.

- FDD upgraded the Inactive-Facilities Risk Management Program to assess and prioritize risk reduction actions and to improve management decisions relating to excess facilities. A quantitative method was developed based on the magnitude of the potential hazard, the probability of occurrence, and the most likely consequences of the hazard.

$\mathrm{E}$ NVIRONMENTAL restoration, waste management, and facility disposition at the Savannah River Site (SRS) are part of the U.S. Department of Energy's (DOE) Environmental Management program, which was established in 1989 to address the environmental legacy of nuclear weapons production and other sources of potential pollutants, such as nuclear research. Progress continued in all three areas in terms of environmental cleanup during 1999 . This chapter provides a brief overview of the programs that guide these activities and describes some of their major 1999 milestones. These programs reflect the site's ongoing efforts to ensure the safety of its workers, the public, and the surrounding environment.

"Environmental restoration" involves the assessment and cleanup of inactive waste units and groundwater (remediation). "Cleanup" means actions taken to deal with the release or potential release of hazardous substances. This may refer to complete removal of a substance, or it may mean stabilizing, containing, or otherwise treating the substance so it will not affect human health or the environment [DOE EM, 1991].
Determining the most environmentally sound methods of cleaning up waste units is a major focus of the SRS environmental restoration program.

"Waste management" refers to the safe, effective management of various kinds of nonhazardous, hazardous, and radioactive waste generated on site. Identifying the need for appropriate waste management facilities and ensuring their availability have been major components of the SRS waste management program.

"Facility disposition" encompasses the management of SRS excess facilities-from completion of operations shutdown through final disposition-in a way that minimizes facility life cycle costs without compromising health, safety, or environmental quality.

\section{Regulatory Compliance}

Applicable environmental management guidelines can be found in appendix A, "Applicable Guidelines, Standards, and Regulations." 


\section{Environmental Restoration}

SRS began its remediation program in 1981, before many of the regulations requiring environmental restoration were written. The site's current environmental restoration program, however, was not officially established until 1990. By the end of 1999, 515 inactive waste and contaminated groundwater units had been identified.

The Environmental Restoration Division (ERD) achieved 80 enforceable agreement milestones in 1999. Accord was reached on the 1999 SRS Federal Facility Agreement, on compliance levels for the F-Area and H-Area groundwater systems, and on the approach to characterizing site waterways.

\section{Accomplishments}

ERD accomplishments in 1999 included

- stabilization of contaminated soils through in situ grouting at the old F-Area seepage basin

- completion of cleanup work on 23 inactive waste units, bringing the total number completed to 221 out of 515

- initiation of bioremediation at the Nonradioactive Waste Disposal Facility, using 1,400-foot-long horizontal wells

- deployment of three technologies at the C-Area burning/rubble pit to purge volatile organic contaminants from groundwater

- processing of an average for the year of one million gallons of water a day in major groundwater remediation systems in A-Area, M-Area, and TNX-Area to remove volatile organics

Also, 19 new technologies were deployed for environmental restoration in 1999 , resulting in savings of approximately $\$ 11$ million while fully meeting environmental goals.

\section{Upper Three Runs Projects}

A major bioremediation system was implemented at the 55-acre Nonradioactive Waste Disposal Facility during 1999. Naturally occurring bacteria in the soil are capable of breaking down chlorinated organic solvents if they are stimulated with oxygen and additional nutrients. Engineers therefore installed two horizontal wells to feed air, methane, and other nutrients to stimulate microbial activity to destroy the contaminants. These 1400 -foot-long wells have the longest screen zones in the country being used to supply nutrients for a bioremediation cleanup.
Computer modeling has shown that bioremediation will reduce groundwater cleanup time for volatile organics from 15 years to 6 when compared with conventional pump-and-treat alternatives.

Four seepage basins that received low-level radioactive wastewater from the original Savannah River Laboratory are ready for final remediation. Vegetation containing radioactivity has been packaged for onsite disposal; contaminated soils will be removed from the basins for offsite treatment and disposal in fiscal year 2000 .

The Southern Sector A/M System-part of a one-square-mile plume of groundwater contaminated with volatile organic compounds-began operation during 1999. Eleven recirculation wells, which essentially bubble air through contaminated groundwater without bringing the water to the surface, strip out the contaminants and vent them to the air. The goal is safe, economical, in-place treatment of the water for the purpose of effectively intercepting migrating contamination.

\section{D-Area Projects}

The operational testing campaign was completed in October 1999 for the Permeable Reactive Barrier/GeoSiphon ${ }^{\text {nu }}$ Cell treatment system at the $D$-Area coal pile runoff basin. Predicted groundwater treatment rates were achieved during testing. The objective of the project is to demonstrate a passive treatment system using various permeable media for the treatment of metals contaminating the groundwater. Operational testing involved a limestone-filled trench, which lowers the acidity of the water and causes metals to precipitate out of solution.

\section{Agreement on Integrator Operable Units}

DOE, the U.S. Environmental Protection Agency (EPA), and the South Carolina Department of Health and Environmental Control (SCDHEC) have previously agreed on the strategy for improving the quality of streams that drain SRS. The quality data, which have been presented annually in the $S R S$ Environmental Report, will form the basis for the initial assessment. New sampling will also take place. The first of six Integrator Operable Unit Workplans, which covers the Steel Creek watershed in the southern part of the site, was submitted to regulators in September 1999. The plan's objectives are to

- compile existing Integrator Operable Unit data

- assess the data against benchmarks

- determine if imminent or substantial endangerment to people exists and, if so, determine needed actions 


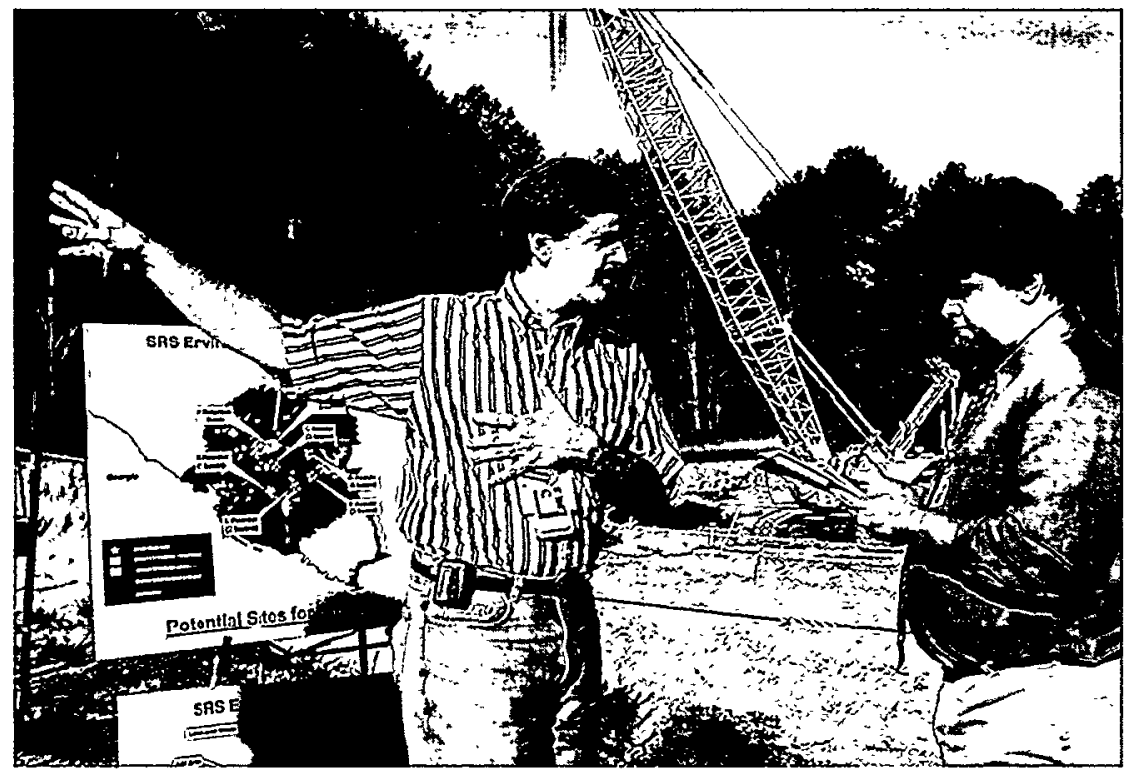

In situ soil solidification remedial action began at the old F-Area seepage basin in 1999, and a media event was held at the site in August to commemorate the milestone. Here, the project manager explains the grouting process to a newspaper reporter.

Sandy DeWald Photo (NFN)

- describe methodology and identify data gaps for early action evaluation

- develop a sampling and analysis plan

\section{General Separations Projects}

Within the General Separations Project area are the Burial Ground complex, the F-Area and H-Area groundwater treatment facilities, and the old F-Area seepage basin. The Burial Ground complex occupies approximately 194 acres in the central section of SRS between F-Area and H-Area separations facilities.

\section{Old F-Area Seepage Basin}

Project crews began the in situ soil solidification remedial action at the Old F-Area seepage basin in late August. The basin is an unlined 200- by 300 -foot seepage basin that received low-level radioactive waste water from the F-Area chemical separations facility until 1969 . The primary radioactive constituent of the liquids discharged to the basin was uranium.

In situ, or in place, solidification was accomplished in this case with a large auger that injected grout as it drilled down into the soil. A series of overlapping grouted columns resulted. Grouting protects the groundwater by preventing contaminant migration and also protects workers by minimizing personnel exposure to contaminated material. Once the grouting is completed in March 2000, a low-permeability soil cover will be built over the basin.

Similar grouting techniques will be applied to several other contaminated basins at SRS; the F-Area retention basin is next on the schedule, with work expected to get under way during early 2000 .

\section{F-Area and H-Area Groundwater Treatment Units}

During 1999, performance improvements were made to the F-Area and H-Area groundwater treatment units through reengineering and operational changes. For 30 years (until 1988), seven unlined basins covering 22 acres were used to dispose of wastewater from SRS chemical separations facilities. The basins were remediated and closed in 1991, but contaminants had reached the groundwater. The treatment units were installed to control tritium migration and to remove heavy metals, nitrates, and radionuclides. The units met required regulatory milestones in September.

\section{Reactor Area Projects}

\section{C-Area Burning/Rubble Pit}

Project crews at the C-Area burning/rubble pit began utilizing three remediation technologies in September-installation of a low-permeability soil cover, air sparging, and soil vapor extraction-to purge volatile organic contaminants from the groundwater. The low-permeability soil cover was placed over the waste unit to prevent further leaching due to rainwater. Air sparging and soil vapor extraction equipment were combined for the first time at SRS to remove solvent contamination from groundwater and soils. The sparging equipment forces air into the contaminated groundwater to evaporate the solvents; the horizontal wells-in the vadose zone-of the extraction unit are used to collect the solvents from the subsurface. The 
integrated operation provides faster and more cost-effective remediation.

\section{L-Area Oil and Chemical Basin}

Two process sewers leading to the L-Area oil and chemical basin, which had entered remediation in October 1998, were filled with grout, excavated, and sectioned; they will be stored until they are stabilized in the basin itself. Two grouting demonstrations were held in the adjacent acid/caustic basin in February and April 1999 to determine the proper grout mixture for the larger and more contaminated oil and chemical basin, which will be grouted in 2000 to solidify the soil and to trap contamination. The grouted sewer sections will be put in the basin; clean grout will be placed over them; and low-permeability soil will cover the entire basin.

\section{Other Projects}

An approach known as monitored natural attenuation is being tried at seven Chemicals, Metals, and Pesticides Pits located north of L-Area. The technique in this application is phytoremediation - the uptake and degradation of contaminants by vegetation surrounding the unit. Phytoremediation will be conducted at these pits through 2000 . Preliminary study results have been encouraging.

\section{Solid Waste Management}

SRS solid waste management facilities host a number of important waste management and environmental restoration efforts on site.

\section{Accomplishments}

The accomplishments of Solid Waste Division (SWD) personnel during 1999 included

- the treatment of $2,437,000$ pounds of radioactive waste in the Consolidated Incineration Facility (CIF) -about three times the amount processed in 1998

- the receipt by the low-level radioactive waste disposal facilities of only the second disposal authorization statement issued by DOE.

- the successful design, construction, and startup of a low-level waste Supercompactor Facility to provide for volume reduction prior to disposal

- the shipment of about 297 cubic meters of hazardous waste off site for disposal

- the retrieval, venting, and purging of more than 4,000 transuranic waste drums
- the implementation of processes to avoid creating approximately 88,000 cubic feet of radioactive and hazardous waste

The SRS solid waste program continues to support the site's transition from production to cleanup activities by managing large volumes of backlog wastes at various site facilities. Proper handling of the waste requires that the waste be categorized as sanitary, low-level, transuranic, hazardous, mixed, or high-level (high-level waste discussion begins on page 61).

\section{Sanitary Waste}

Sanitary waste includes office waste, food, garbage, refuse, and other solid wastes that can be disposed of in landfills. SRS has privatized the collection, hauling, and disposal of its sanitary waste, which consists primarily of food and office wastes.

In 1999, SRS continued shipping the compactible portion of its municipal solid waste to the City of North Augusta (South Carolina) Material Recovery Facility, which recovers recyclable materials, including white office paper, newspapers and magazines, cardboard, plastic, steel cans, aluminum cans, and glass. By using the North Augusta facility, the site was able to recycle more than 35 percent of the material from its compactible sanitary waste.

\section{Low-Level Waste}

Low-level waste is any radioactive waste not classified as high-level or transuranic waste. Examples of SRS low-level wastes include protective clothing, job control waste, equipment, tools, filters, rags, and papers. Most wastes certified as low-level are stored or disposed of in the E-Area Vaults.

More than 2 years of effort by SWD and Savannah River Technology Center (SRTC) personnel resulted in DOE's issuance in September 1999 of the E-Area and Saltstone Facility Low-Level Waste Disposal Authorization Statement (DAS). This authorization to continue low-level waste disposal activities at SRS was only the second of its kind granted to a DOE facility.

To obtain the DAS, the SWD-SRTC team produced two major technical evaluations:

- a performance assessment, which evaluates long-term (10,000 years) disposal activities against DOE-prescribed performance objectives to set radionuclide-specific limits

- a composite analysis, which incorporates potential contributions to exposure from nearby radionuclide sources to determine the total 
potential future impacts on hypothetical exposed members of the public

DOE conducted independent technical reviews of these evaluations. The SRS team responded to all review comments, which resulted in DOE's approval of the performance assessment and the composite analysis.

Issuance of the DAS also represents a direct response to a Defense Nuclear Facility Safety Board recommendation.

Programs focusing on waste minimization, waste volume reduction, waste segregation, and the release of clean waste continued in 1999. This is expected to extend the utilization period for existing disposal vaults by at least 10 years, thereby delaying or possibly eliminating the need for new vault construction.

The volume reduction program includes sorting wastes for compaction and incineration. During 1999 , SWD completed the design, construction, and startup of the waste Supercompactor Facility. Located in E-Area, the facility compacts low-level waste to reduce volume.

\section{Hazardous Waste}

Under RCRA, hazardous waste is any toxic, corrosive, reactive, or ignitable material that could damage the environment or negatively affect human health. Examples of SRS hazardous wastes include oils, solvents, acids, metals, and pesticides.

Under the site's hazardous waste program in 1999 , 261 cubic meters of legacy waste, 36 cubic meters of newly generated waste and 269 cubic meters of waste from nonhazardous waste storage were shipped off site. Overall, the inventory of waste in the Hazardous Waste Storage Facility declined more than 37 percent (from 740 cubic meters to 464 cubic meters).

\section{Mixed Waste}

Mixed waste is both radioactive and hazardous and is subject to regulations governing both waste types. During 1999, all mixed low-level waste program Site Treatment PIan (STP) commitments were met. The STP represents an agreement between SWD, DOE's Savannah River Operations (DOE-SR), and SCDHEC to properly treat SRS's mixed waste on a specific schedule. SWD accomplishments during 1999 included the following:
- The mercury-contaminated waste was treated approximately 2 years ahead of the STP schedule.

- The uranium/chromium solutions waste was treated using the M-Area vitrification system.

- A path forward for the treatment and disposal of the old solvent trailer was submitted to SCDHEC, which concurred on SWD's recommendation to treat the trailer as an empty container. This will avoid treatment as a mixed waste and thus significantly lower final disposition costs.

- A study by SWD demonstrated that it would be most economical to decontaminate the low-level lead waste using onsite facilities. Eighteen containers of low-level lead, representing 36 percent of this waste, subsequently were processed through a SRS Decontamination Facility.

- A treatability variance was submitted to EPA regarding plastic, lead, and cadmium waste. The variance requested treatment of this waste as debris, which would reduce costs while achieving environmentally sound results. No response had been received by the end of the year.

- The offsite shipment of soils from the spill remediation and dioxin soil waste outlined in the STP was completed in September.

\section{Transuranic Waste}

Transuranic waste is radioactive waste contaminated with certain isotopes that have decay rates and activity levels exceeding defined standards. It contains manmade elements that are heavier than uranium, some of which decay slowly, thus requiring thousands of years of isolation. At SRS, transuranic wastes can include contaminated equipment, protective clothing, and tools.

The site has stored 11,289 unvented transuranic waste drums-8,809 under earthen cover and 2,480 under weather cover-at the Solid Waste Management Facility since the early 1970s. It was decided in 1996 to retrieve the buried drums and to vent and purge all the drums. By the end of 1998, a total of 2,884 earth covered drums and 1,355 weather covered drums remained to be vented and purged. Both the retrieval and the vent-and-purge processes were completed in 1999.

All 11,289 drums continue to be stored in the new, safer (vented, purged, and under weather cover) configuration-and are a step closer to being shipped to the New Mexico Waste Isolation Pilot Plant for disposal. 


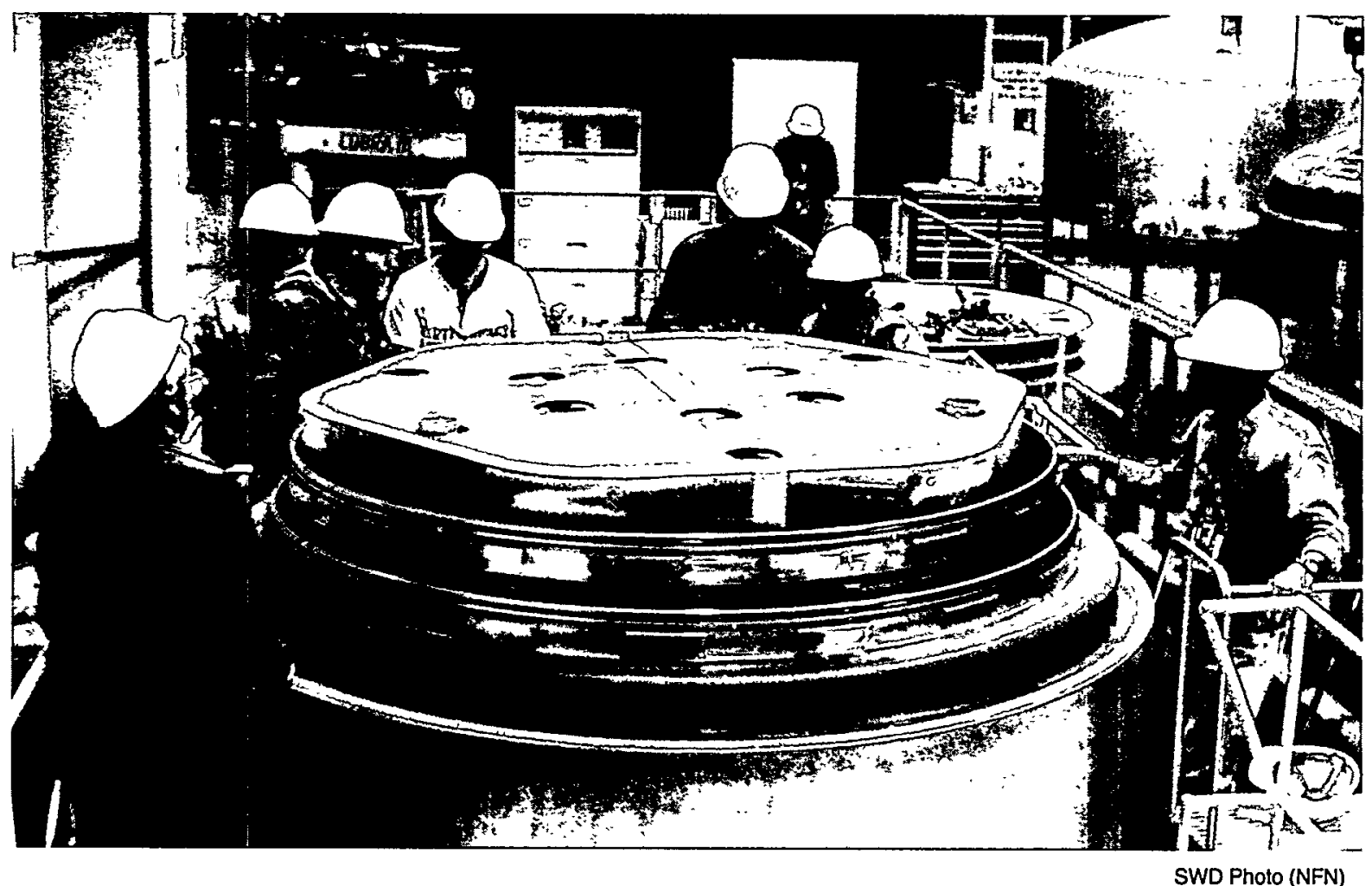

SWD operations personnel prepare to remove a drum from the specially designed container used to transport transuranic waste to a New Mexico facility for disposal. The container is 7 feet in diameter and 7 feet tall.

\section{Consolidated Incineration Facility}

The CIF met its major STP commitment in 1999 by treating more than 2,000 gallons of SRS's PUREX (plutonium/uranium extraction) backlogged mixed waste.

The CIF processed approximately $2,437,000$ pounds of solid and liquid waste in 1999-about three times the amount processed in 1998.

\section{Effluent Treatment Facility}

The Effluent Treatment Facility (ETF) collects and processes low-level radioactive and chemically contaminated wastewater from the high-level waste tank farm evaporator overheads and from reprocessing facility evaporators. The ETF process uses microfiltration, organic removal, ion exchange, and reverse osmosis to concentrate contaminants in about 5 percent of the original volume. This liquid is transferred to a storage tank for eventual disposal at the Saltstone Facility. The remaining 95 percent of the water (in 1999, more than 17 million gallons) is released to the environment through a National Pollutant Discharge Elimination System (NPDES)-permitted outfall.
In 1999, the ETF processed and released more than 17 million gallons of wastewater.

\section{Saltstone Facility}

The Saltstone Facility treats and disposes of low-level radioactive salt solutions that are the byproduct of the high-level waste treatment process at SRS.

After the salt solutions are received at the facility, they are mixed with cement, fly ash, and furnace slag to form a grout, which then is pumped into a large concrete vault (one of three at the facility) divided into sections, or cells. There, the grout cures into a stable form called "saltstone." After it is filled, the vault will be capped with clean grout to isolate it from rain and weathering. Final closure of the vault disposal area will include covering each vault with a clay cap and backfilling it with earth.

Radioactive operations began at the Saltstone Facility in June 1990; since that time, the facility has processed approximately 2.5 million gallons of salt solutions, creating more than 4 million gallons of "saltstone." The facility was placed in "standby" mode in September 1998, pending completion of a review of SRS's treatment of high-level waste precipitates. 


\section{Pollution Prevention/Waste Minimization}

During 1999, SRS waste generators implemented more than 90 projects that curbed the generation of approximately 88,000 cubic feet of radioactive and hazardous solid waste.

Contamination area rollbacks reduced low-level waste generation and employee risk while increasing productivity. Rollbacks reclaim radiologically contaminated areas for unrestricted use. In consequence, less protective clothing and other materials are contaminated in ongoing operations. Rollbacks in this way eliminated more than 12,000 cubic feet of low-level waste in 1999.

More about pollution prevention/waste minimization can be found in chapter 2 ("Environmental Compliance") and chapter 3, ("Environmental Program Information").

\section{High-Level Waste Management}

"High-level waste" is highly radioactive waste material that results primarily from the reprocessing of spent nuclear fuel. This category includes liquid waste produced directly in reprocessing, any solid waste derived from that liquid, and both transuranic waste and fission products in concentrations requiring permanent isolation from the environment.

High-level waste from the F-Area and H-Area canyons is segregated according to radionuclide and heat content. High-heat waste, generated primarily during the first extraction cycle in these canyons, contains a major portion of the radioactivity. Low-heat waste is generated primarily from the second and subsequent canyon extraction cycles.

SRS continues to manage approximately 34 million gallons of high-level liquid radioactive waste (about 498 million curies), which is stored in 49 large, shielded, and partially underground tanks grouped into two "tank farms." Twenty-nine tanks are located in the H-Area Tank Farm and 20 in the F-Area Tank Farm. All SRS tanks are built of carbon steel inside reinforced concrete containment vaults.

The major waste streams in the F-Area and H-Area tank farms include transfers from the canyons, receipts from the Receiving Basin for Offsite Fuels, and a recycle stream from the Defense Waste Processing Facility (DWPF).

\section{High-Level Waste Facilities}

Inside the storage tanks, the waste separates into three different forms. The heaviest substance, a sludge, settles to the bottom, while a salt cake forms in the middle and a liquid material on the top.

Each tank farm has one operating evaporator system used to concentrate (1) high-level waste received from the canyons and (2) dilute waste streams from other facilities. These evaporators, which reduce the waste to 10-33 percent of its original volume, reclaimed about 2 million gallons of tank space in 1999. SRS has successfully conducted this space reclamation operation in the tank farms since 1960, when the first evaporator facilities began operation. More than 100 million gallons of space have been reclaimed during this time. Without these evaporator systems, SRS would have required 85 additional waste storage tanks-at $\$ 50$ million apiece-to store waste produced over the site's lifetime.

Construction was completed in 1999 on the replacement high-level waste evaporator, which will enable the tank farms to process anticipated liquid waste volumes for the future. The new evaporator, approved for startup in December 1999, will have twice the processing capacity of the two existing evaporators.

The Extended Sludge Processing Facility, one of two DWPF pretreatment operations in the High Level Waste Division, washes sludge (unsettled insoluble waste) to reduce the concentration of sodium salts and dissolves and removes aluminum to ensure glass quality for DWPF. In 1999, the facility began processing the second of 10 sludge batches that will be required to vitrify all the high-level waste sludge. Three million gallons of sludge must be pretreated in this manner.

The washed and decanted sludge is transferred to DWPF as part of "sludge only" vitrification operations. DWPF then processes both the sludge from the original waste and the highly radioactive material from the salt cake by combining them with glass frit. The mixture is heated until it melts, then is poured into stainless steel canisters to cool. The glass-like solid that forms contains the highly radioactive material and seals it off from the environment. Another word for this process is "vitrification." The sealed canisters will be stored at SRS until a federal repository is established.

The In-Tank Precipitation Facility (ITPF), the second pretreatment operation for DWPF, was expected to process the "liquid salt" waste in tanks. The work was suspended in February 1998, however, to address safety issues arising from the excess generation of benzene during the process. In March of that year, a team began evaluating options for redirection of the ITPF design and configuration. A systems 


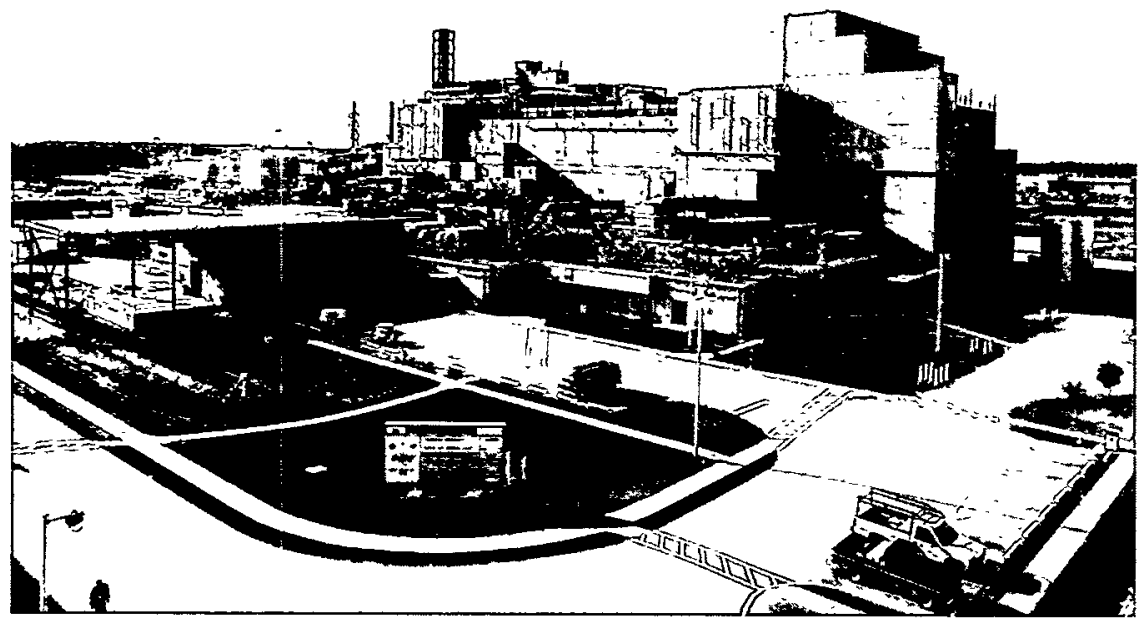

DWPF, located near the center of SRS in S-Area, continued the successful processing of radioactive sludge during 1999. More than 750 canisters of immobilized high-level waste have been produced at the facility since radioactive processing began in 1996.

Steve Ashe Photo (97-1522-1E)

engineering review of approximately 140 options has narrowed the salt processing technologies to three viable alternatives, as follows:

- small-tank precipitation

- crystalline silicotitanate ion exchange

- direct disposal in grout

Precipitation and ion exchange split the salt stream into two streams. In precipitation, the highly radioactive portion, called "precipitate," would go to DWPF for vitrification, while the remainder, called "filtrate" (about 95 percent of the salt waste), would be low-level waste to be grouted into a solid form at the Saltstone Facility.

In ion exchange, the crystalline silicotitanate incorporating the highly radioactive constituents-including cesium, strontium, and other actinides-would go to DWPF for vitrification, while the lower level waste stream would be sent for grouting at the Saltstone Facility.

In the direct disposal method, low-level waste is separated from high-level waste, then bound in grout and sent directly into a permitted facility for storage.

Science and technology work on the three options will continue in 2000 , with a decision on which new option to use expected late in the year.

\section{Accomplishments}

SRS continued to manage its high-level waste facilities in support of the integrated high-level waste removal program in 1999.

\section{Tank Farms}

The tank farm evaporators recovered more than 2.6 million gallons of tank space in 1999 through evaporation of the watery "supernate" that floats atop the sludge in the tanks. The $242-16 \mathrm{H}$ evaporator system recovered more than 2 million gallons while the $242-16 \mathrm{~F}$ evaporator system recovered more than 630,000 gallons. One of the keys to this achievement was an interarea line used to transfer waste from $\mathrm{H}$-Area to F-Area via a 2-mile underground system. Approximately 270,000 gallons of radioactive waste were transferred via the interarea line during 1999.

Modifications to the evaporator systems and tank farms continued in 1999 to enhance safe operations without affecting productivity.

\section{DWPF}

The successful processing of radioactive sludge continued during 1999. DWPF produced 219 canisters of immobilized high-level waste during the year, bringing the total to 755 canisters since radioactive processing began in March 1996.

DWPF will continue processing sludge until the "precipitate" from one of the salt processing alternatives is available. Approximately 250 canisters 
of glass are expected to be produced in fiscal year 2000.

\section{Facility Deactivation and Decommissioning}

\section{Disposition of Surplus Facilities}

With the rapidly declining need for a large nuclear weapons stockpile, many SRS facilities no longer are needed to produce or process nuclear materials. This situation poses a challenge for the site in terms of placing and maintaining the facilities in a safe, low-cost condition until they can be safely disposed.

SRS has approximately 130 facilities identified as surplus, with many others to be declared surplus within the next 10 years. These facilities range in size and complexity from large nuclear reactors to scores of small storage buildings. Many site facilities have underground structures, storage tanks and piping that require a large amount of excavation to access; some are more than 100 feet high. Many contain residual materials that could be hazardous to workers, the public, and the environment if improperly handled or stored. Others are located within the site's nuclear industrial areas-surrounded by buildings that are occupied or still being used, making their demolition extremely hazardous and difficult. SRS faces an enormous task in the surveillance, maintenance, cleanup, and ultimate disposition of these surplus facilities.

Facilities Decommissioning Division (FDD) personnel manage the disposition phase of a surplus facility's life cycle in a manner that considers life cycle costs without compromising either (1) the health or safety of workers and the public or (2) the quality of the environment. The disposition phase begins upon completion of operations shutdown and extends through placement of the facility in its end state.

The facility disposition process (figure 4-1) consists of three activities, as follows:

- Deactivation, which places a facility in a known, safe, and stable configuration by removing hazardous chemical and radioactive materials, shutting down or mothballing the equipment, and mitigating other hazardous conditions.

- Safe storage, which is a dormant period involving only surveillance and maintenance (S\&M) of the facility to ensure the continued safety of workers, the public, and the environment. (S\&M activities are performed during the entire disposition process to ensure that all structures, systems, and materials are monitored adequately and a safe configuration is maintained.)

- Decommissioning, which places the facility in its end state. This could involve decontamination,

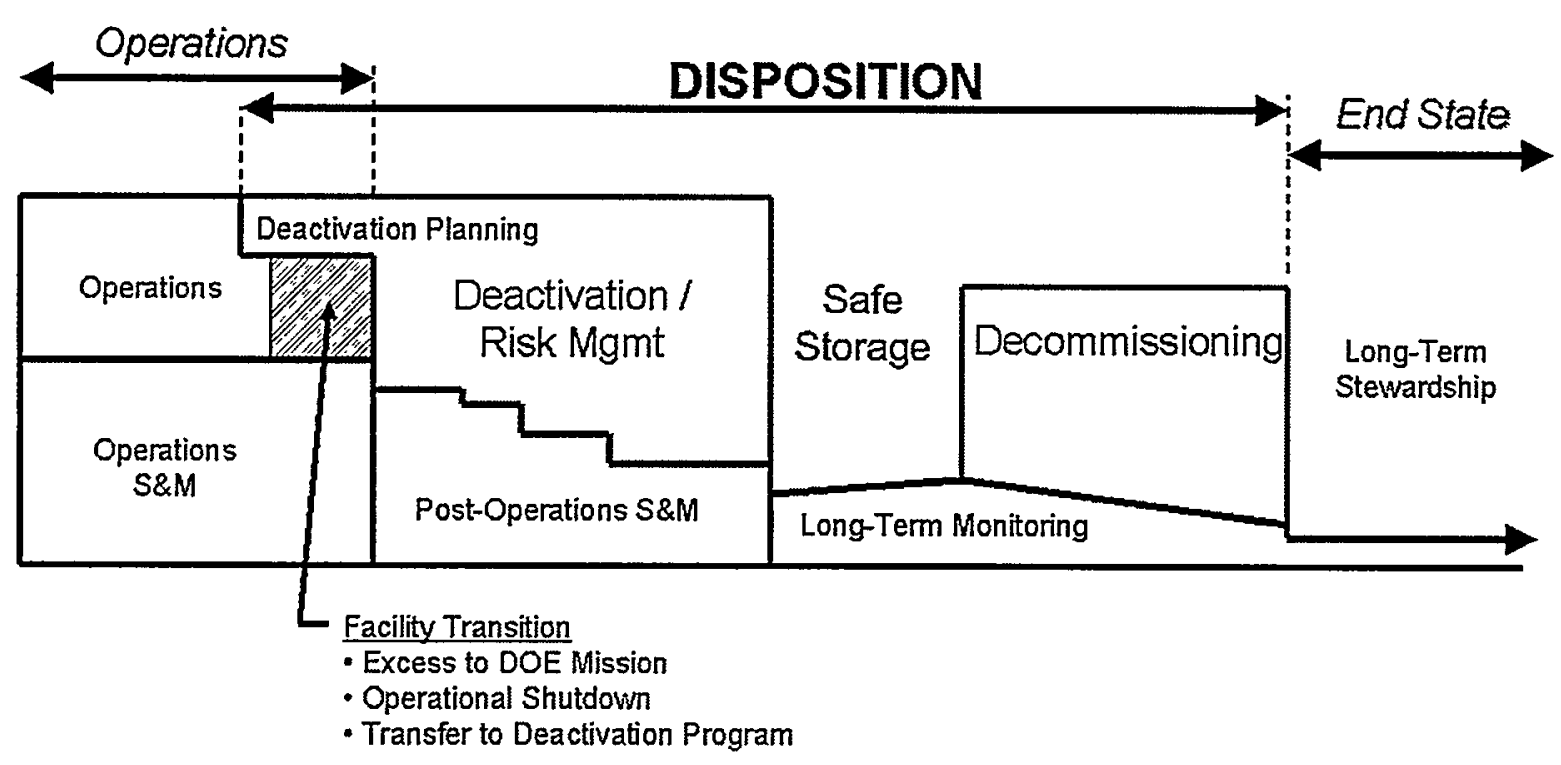

FDD Graphic (modified)

Figure 4-1 Facility Disposition Process

FDD personnel manage the disposition phase of a surplus facility's life cycle. This phase, which begins upon completion of operations shutdown and extends through placement of the facility in its end state, consists of deactivation, safe storage, and decommissioning. 
dismantlement, or some other activity to make the land available for either unrestricted use or limited applications. If not released for unrestricted use, a long-term stewardship program will provide institutional controls to ensure the safety of the public and the environment.

Despite the complexity of the facilities and the nature of the hazards, SRS has continued to safely manage the disposition of its surplus facilities through its Inactive-Facilities Risk Management Program. The immediate goal is to remove hazardous materials from surplus facilities and to place them in a safe and stable condition. The site continues to seek opportunities to reuse these facilities for mission-related activities, as well as for other industrial uses. An S\&M program will be maintained to ensure that no facility deteriorates to such a point that it becomes dangerous to workers or threatens the public and the environment with a release of hazardous materials.

\section{Accomplishments}

\section{Disposition Program Management}

The SRS Disposition Program description (the first comprehensive description of the SRS facility and asset disposition program) and the Westinghouse Savannah River Company (WSRC) Facility Disposition Procedure Manual were developed and issued in August and September 1999, respectively, by FDD. The facility disposition procedures provide for a consistent, disciplined process for facility disposition activities. The procedures are consistent with DOE's Life Cycle Asset Management System requirements and employ a graded approach to ensure cost effectiveness. FDD continues to provide management and direction to the WSRC Facility and Asset Disposition Council, which coordinates the disposition processes across the site's operating divisions.

\section{Facility Transitions}

FDD accepted custodial responsibility for an additional 34 facilities from other operating divisions in 1999. The facilities transferred were the 284-F Powerhouse, 777-10A, 717-C, and 31 facilities in D-Area.

The smooth transition of the $31 \mathrm{D}$-Area facilities from Spent Fuels to FDD represented a team effort among representatives of FDD, the Spent Fuel Storage Division, and the Project Engineering and Construction Division. The team developed a deactivation plan, implemented key deactivation activities to reduce facility hazards and surveillance and maintenance costs, and transferred custodianship to FDD at a logical point in the deactivation process. As a result of the 1999 activities, the annual S\&M cost for these D-Area Facilities has been reduced from more than $\$ 9$ million to less than $\$ 1$ million.

During the past 3 years, FDD's annual cost to provide S\&M for its facilities C-Area, M-Area, P-Area, and $\mathrm{R}$-Area has been reduced from $\$ 30$ million to $\$ 11$ million through similar activities.

\section{Inactive-Facilities Risk Management Program}

FDD had instituted an Inactive-Facilities Risk Management Program (figure 4-2) in 1997 to evaluate and mitigate risks in inactive facilities. The program was augmented in July 1999 by incorporating a quantitative method to assess and
Figure 4-2 Facility Risk Management

FDD's Inactive-Facilities Risk Management Program was updated in 1999 with the incorporation of a method of assessing and prioritizing risk reduction actions based on the magnitude of the hazard, the probability of occurrence, and the most likely consequences of the hazard.

FDD Graphic

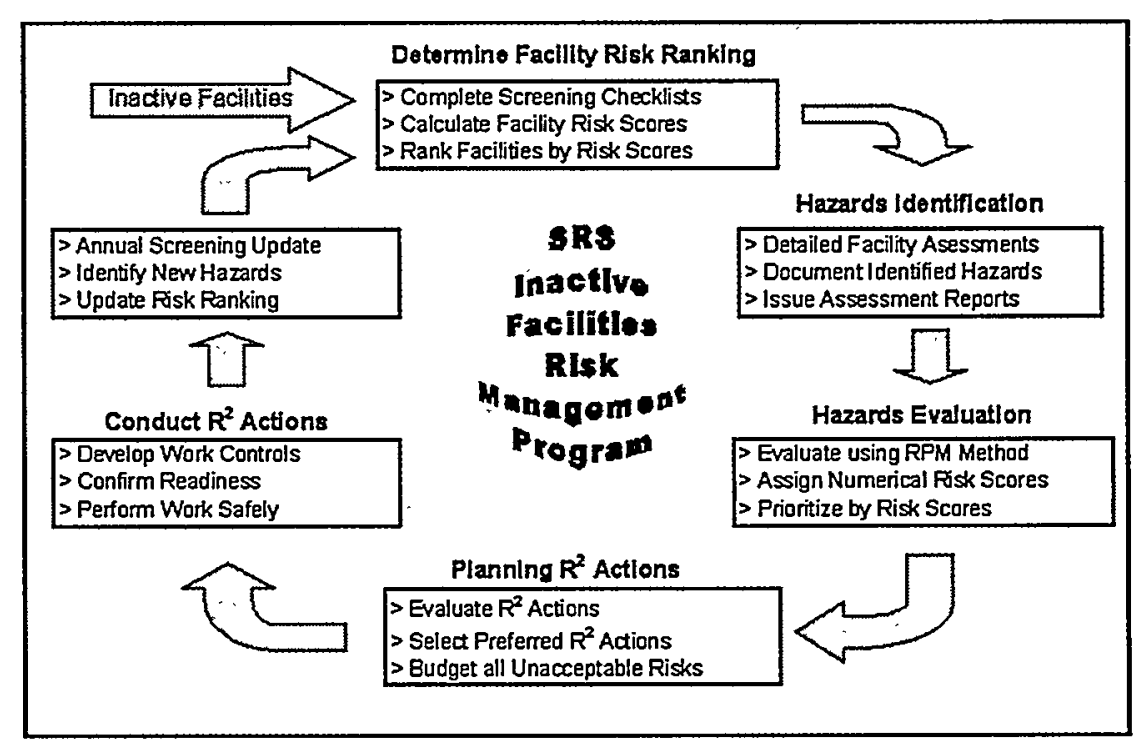




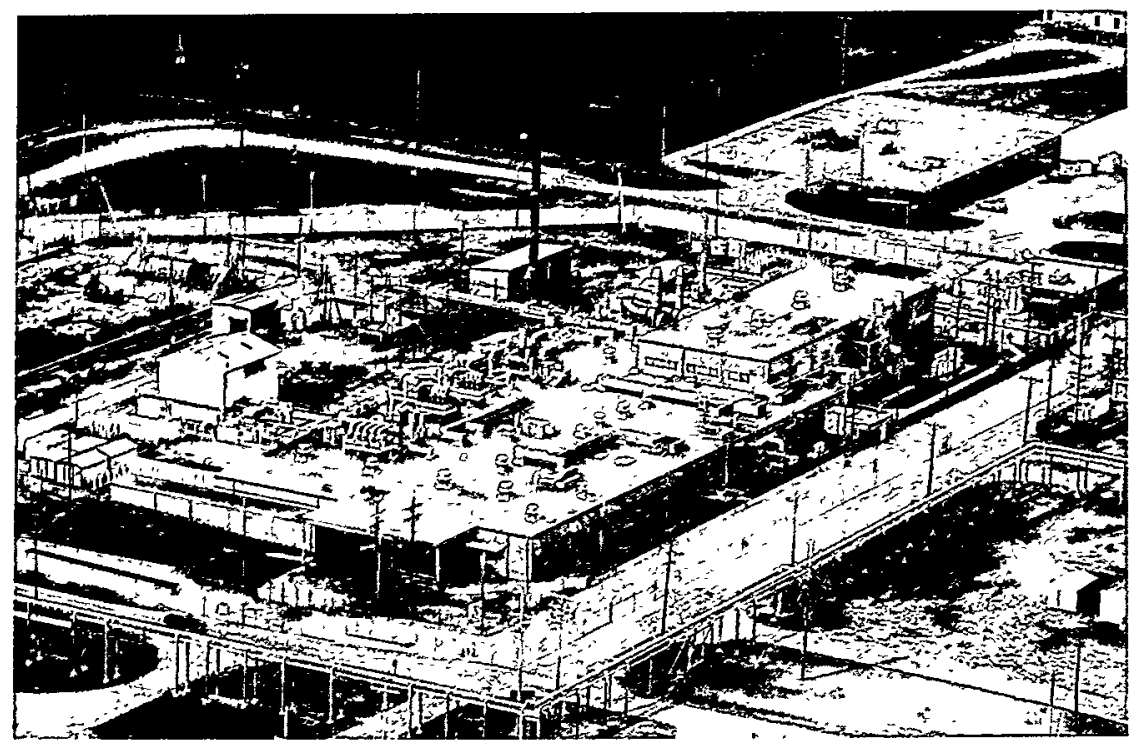

Deactivation of the Fuel Manufacturing Facility $(321-M)$ was initiated in 1999. The facility is shown in this aerial made several years ago. In conjunction with this deactivation effort, FDD completed the Large-Scale Demonstration and Deployment Project (LSDDP) in December.

Byron Williams Photo (94-1936-18E)

prioritize risk reduction actions based on the magnitude of the hazard, the probability of occurrence, and the most likely consequences of the hazard. The Inactive-Facilities Risk Management Program augments the more traditional approach - conducting complete deactivation projects-with a program that ensures that the limited funding available is used to reduce risk as much as possible, regardless of the facility in which the hazards are located.

Risk reduction actions were accomplished in 1999 for nine of the top 10 risk-ranked facilities identified in 1998. As a result of risk reduction actions, FDD has formally reduced the hazard category of eight buildings (777-10A, the Ford Building, and M-Area vitrification facilities) from "nuclear" or "radiological" to "other industrial." This reduction in the hazard category has allowed FDD to implement in these facilities a graded approach that

- provides relief from nuclear safety and regulatory requirements

- produces substantial cost savings

As part of the annual program process, FDD performed 19 detailed facility assessments during 1999 and planned 37 risk reduction actions for 2000 .

\section{Disposition of FDD Facilities}

Deactivation Projects Several disposition activities were completed or initiated at SRS in 1999. FDD personnel completed cleanup of polychlorinated biphenyls from the Ford Building, stabilized the Detoxification Treatment Facility in TNX Area, initiated stabilization of the 717-C Hot Shop, and completed deactivation of the 322-M Metallurgical Laboratory. FDD also initiated deactivation of the Liquid Effluent Treatment Facility and the Fuel Manufacturing Building (321-M), both located in M-Area.

\section{Large-Scale Demonstration and Deployment}

Project In conjunction with the ongoing 321-M Deactivation Project, FDD completed the Large-Scale Demonstration and Deployment Project (LSDDP) in December 1999. The LSDDP successfully deployed five characterization, decontamination, and dismantlement technologies. One technology in each of the three categories has been integrated into the 321-M Deactivation Project to improve safety and cost effectiveness and has been added to the SRS Decontamination Facility's available technologies to improve operations at other SRS decontamination and deactivation projects.

The LSDDP was part of a DOE effort to deploy innovative technologies at ongoing decommissioning projects and to transfer the results of the deployments to other federal facilities and to the commercial sector. By integrating the LSDDP with the 321-M Deactivation Project, FDD was able to leverage the project's budget by receiving matching funding of more than $\$ 1.3$ million from the DOE's

Environmental Management Office of Science and Technology through the National Energy Technology Laboratory, formerly the Federal Energy Technology Center.

One of the project goals was to communicate pertinent information on promising technologies to encourage deployment at other DOE facilities. WSRC has received a DOE Pollution Prevention 


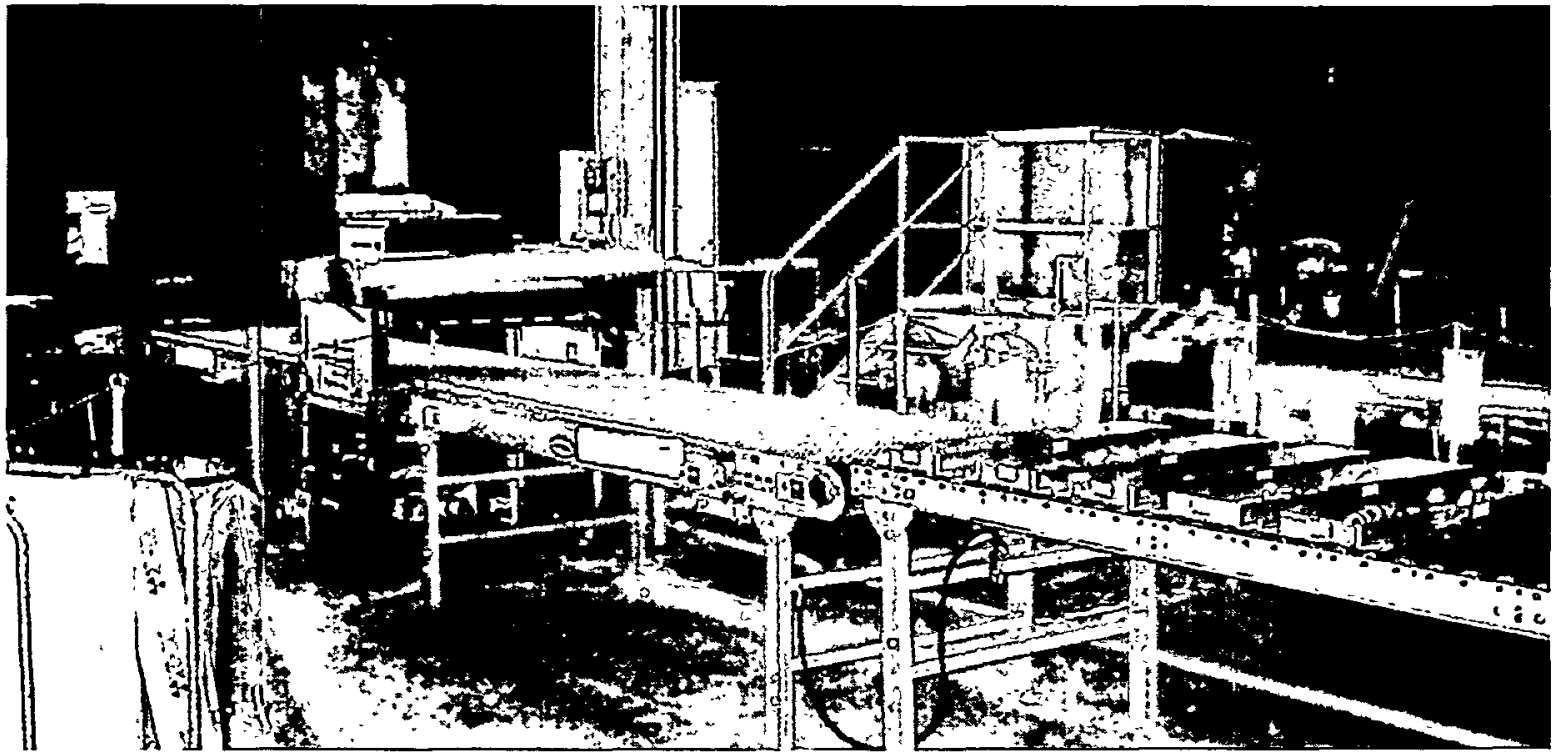

Bill Giddings Photo (00308-3)

The conveyorized monitor is a new tool developed to provide the unrestricted release of decontaminated equipment at a fraction of the cost of conventional survey methods. It should yield annual cost savings of about $\$ 100,000$.

Award for 1999 accomplishments in disseminating LSDDP information.

Removal of Legacy Facilities Using Surplus Assets FDD obtained DOE approval in September 1999 of the Assets for Services (AFS) concept as an accepted method to cost-effectively disposition surplus government property. Through this program, surplus government assets are provided to demolition subcontractors in exchange for their services to dismantle and remove surplus legacy facilities. During the past 2 years, FDD has successfully subcontracted more than $\$ 7$ million in disposition services for a cash outlay of less than $\$ 0.5$ million. This program has reduced legacy facilities by approximately 30,000 square feet.

FDD is preparing a request for proposal to dismantle and remove the 284-F Powerhouse using an AFS approach. A savings of more than $\$ 1.5$ million is projected.

\section{Vitrification of Legacy Waste}

WSRC completed vitrification of more than 670,000 gallons of a hazardous/radioactive (mixed) waste in 1999. The project was completed under a fixed unit price privatization contract with subcontractor GTS Duratek, Inc. Work under the original $\$ 13.9$ million contract, awarded in November 1993, was successfully completed at under $\$ 14$ million. The majority of the mixed waste was a plating line sludge, with depleted uranium. Other waste included slightly enriched uranium, some small volumes of enriched uranium laboratory solutions, and contaminated soils. All the wastes were blended successfully and converted into durable glass "gems," which were placed in 71-gallon square drums for eventual disposal. The process achieved an overall volume reduction of approximately 75 percent. Each batch of glass met the stringent contractual toxic characteristic leaching procedure requirements. The subcontractor also cleaned three 500,000 -gallon and six 35,000-gallon storage tanks to nonhazardous levels.

\section{Operation of Decontamination Facility}

FDD also operates the Decontamination Facility to provide cost-effective decontamination services for all WSRC divisions, as well as for FDD's own operations. These decontamination operations provide a valuable service for the SRS recycling and waste minimization programs. Approximately 30,000 cubic feet of materials were processed through the Decontamination Facility in 1999, resulting in savings of more than $\$ 1.5$ million. Also, more than 24,000 square feet of contaminated areas were covered with protective polyurethane coating to eliminate the potential for contamination spread, this resulted in a 10 -year savings of $\$ 323$ million.

As part of FDD's continuous improvement program, Decontamination Facility personnel seek opportunities to add state-of-the-art technologies that will improve the effectiveness to of the Facility's 
operations. Examples of improvement technologies implemented during 1999 include the following:

Conveyorized Monitor A collaboration over the past 3 years among FDD, SWD, SRTC, Radiological Control Operations, and Health Physics Technology personnel resulted in the development of a new tool for facilitating the unrestricted release of decontaminated equipment at a fraction of the cost of conventional survey methods. The conveyorized monitor, which was placed into initial operation in September 1999, is projected to yield an annual cost savings of approximately $\$ 100,000$ when compared to the cost of conventional surveys.

\section{Lead Encapsulation Process The}

Decontamination Facility adapted an industrial surface coating process in 1999 to encapsulate lead used for shielding. A special polyurea coating, similar to that used for spray-on truck bed liners, is applied to lead over a primer that provides an initial sealant. The process eliminates personnel exposure to lead and reduces the Occupational Safety and Health Administration lead handling training requirements and the potential for generating mixed waste.

Personal Protection Advances Decontamination Facility personnel developed eight engineering control advances in 1999 for reducing heat stress and improving personal protection from radiological and industrial hygiene hazards. 



\title{
Radiological Effluent Monitoring
}

\author{
Pete Fledderman, Phillip Miller, \\ and Donald Padgett \\ Environmental Protection Department \\ Timothy Jannik \\ Savannah River Technology Center
}

To Read About ...

See Page...

Airborne Emissions . . . . . . . . . . . . . . 69

Liquid Discharges ................. 72

\section{Highlights}

- In the 1999 radiological effluent monitoring program, approximately 4,200 samples were collected and analyzed. Data results were used as the primary basis for determining annual release totals from the site.

- Tritium in elemental and oxide forms (about 58 percent) and krypton-85 (about 42 percent) accounted for nearly all of the total radioactivity released to the atmosphere from SRS operations. About $51,600 \mathrm{Ci}(1.91 \mathrm{E}+15 \mathrm{~Bq})$ of tritium was released from SRS, compared to about $82,700 \mathrm{Ci}(3.06 \mathrm{E}+15 \mathrm{~Bq})$ in 1998 .

- Tritium also accounted for most of the radioactivity discharged in liquid effluents. In 1999, 1,120 $\mathrm{Ci}$ $(4.14 \mathrm{E}+13 \mathrm{~Bq})$ were directly released to site streams from process areas, compared to $1,090 \mathrm{Ci}(4.04 \mathrm{E}+13 \mathrm{~Bq})$ for 1998.

$\mathrm{T}$

HIS chapter describes the Savannah River Site (SRS) radiological effluent monitoring program and summarizes the 1999 effluent monitoring data results. Objectives and rationale for the SRS radiological effluent monitoring program are discussed in chapter 3, "Environmental Program Information."

Radiological effluent monitoring results are a major component in determining compliance with applicable dose standards, which can be found in chapter 7, "Potential Radiation Doses," and in appendix A, "Applicable Guidelines, Standards, and Regulations." Also, SRS management philosophy is that potential exposures to members of the public and to onsite workers be kept as far below regulatory standards as is reasonably achievable. This philosophy is known as the "as low as reasonably achievable" (ALARA) concept.

SRS airborne and liquid effluents that potentially contain radionuclides are monitored at their points of discharge by a combination of direct measurement and/or sample extraction and analysis. Each operating facility maintains ownership of and is responsible for its radiological effluents. Safety and Health Operations (S\&HO) and the Environmental Protection Department's Environmental Monitoring
Section (EMS) perform most of the radiological effluent monitoring functions. S\&HO personnel collect and screen air and liquid samples from regulated (radiologically controlled) areas and maintain monitoring equipment on stacks and at some liquid effluent discharge points. EMS personnel collect and analyze most liquid effluent samples and analyze most of the airborne effluent samples. Results of these analyses are compiled and reported in monthly radioactive releases reports.

Approximately 4,200 radiological effluent samples were collected at 71 points of discharge and analyzed during 1999.

A complete description of the EMS sampling and analytical procedures used for radiological effluent monitoring can be found in sections 1102 and 1103 of the Savannah River Site Environmental Monitoring Section Plans and Procedures, WSRC-3Q1-2, Volume 1 (SRS EM Program). A summary of data results is presented in this chapter; more detailed data can be found in SRS Environmental Data for 1999 (WSRC-TR-99-00301).

\section{Airborne Emissions}

Process area stacks that release or have the potential to release radioactive materials are monitored continuously by applicable online monitoring and/or 
sampling systems [SRS EM Program, 1999]. Filter paper samples, used to collect radioactive particles, generally are gathered daily and screened initially for radioactivity by S\&HO personnel. Charcoal canisters, used to collect radioiodines, are gathered weekly at some locations and monthly at locations with lower potential for release. S\&HO personnel routinely transfer the filter paper samples and charcoal canisters weekly to EMS sampling personnel for transport to, and analysis in, the EMS laboratories.

Depending on the processes involved, discharge stacks also may be monitored with "real-time" instrumentation by area operations and/or S\&HO personnel to determine instantaneous and cumulative atmospheric releases to the environment. Tritium is one of the radionuclides monitored with continuous real-time instrumentation.

\section{Description of Monitoring Program}

\section{Sample Collection Systems}

Sample collection systems vary from facility to facility, depending on the nature of the radionuclides being discharged. Generally, S\&HO personnel are responsible for ensuring that the sampling systems are maintained and for collecting the filter papers and charcoal filter samples.

The following effluent sampling and monitoring changes were made during 1999:

- Air effluent sampling at the 421-2D stack was discontinued in September after all emission sources had been removed with the completion of heavy water processing, drum storage, and washing activities.

- Air effluent sampling at the 772-2D stack was discontinued in August with the completion of Analytical Laboratory operations and removal of any potential sources of measurable airborne radioactivity.

- Air effluent sampling at the 420-D stack was discontinued in August with the removal of any potential sources of measurable airborne radioactivity upon completion of heavy water processing operations in Building 420-D.

- Air effluent sampling at the P-Area main stack was discontinued in January after all source material had been removed and per field request and the U.S. Environmental Protection Agency (EPA) agreement to the request.

- Air effluent sampling at the 6.1D and 6.4D dissolvers changed from a weekly schedule to sampling while dissolvers are in operation, per field request and an approved procedure to sample only during times of potential

release-during operations.

\section{Continuous Monitoring Systems}

SRS reactor and tritium facilities use real-time instrumentation to determine instantaneous and cumulative atmospheric releases of tritium and noble gas radioisotopes. All other monitored radionuclides are sampled using filter papers, charcoal filters, or other air effluent sampling media.

\section{Laboratory Analysis}

EMS provides most of the necessary radioanalytical laboratory services required to conduct the site airborne effluent monitoring program. However, tritium in airborne effluents is measured at each applicable operating facility. Also, specific low-level analyses for iodine- 129 were performed by an offsite laboratory during 1999.

\section{Effluent Flow Rates}

Stack effluent flows generally are determined with hot-wire anemometers, Pitot tubes, or fan capacity calculations. Sample line flow rates usually are determined with in-line rotameters or hot-wire anemometers. Flow rates are used to determine the total quantity of radioactive materials released.

\section{Diffuse and Fugitive Sources}

Estimates of radionuclide releases from unmonitored diffuse and fugitive sources also are included in the SRS radioactive release totals. These unmonitored sources include ponds, contaminated land areas, and structures without ventilation - or with ventilation but without well-defined release points.

Diffuse and fugitive releases are calculated using the EPA's recommended methods. The methods produce conservative estimates of release levels having a large uncertainty associated with them. However, for

\section{Diffuse and Fugitive Sources}

Emissions from DOE facilities include those from point sources (stacks or vents) and those from diffuse and fugitive sources. A diffuse source is defined as an area source. Examples of diffuse sources include resuspension of contaminants deposited on open fields and evaporation from holding ponds and basins. A fugitive source is defined as an undesigned localized source. Process leaks that discharge to the atmosphere by a path other than a stack or vent are fugitive releases. Unmonitored evaporation releases from open tanks and drums also are considered fugitive releases. 
consistency with other reported data, the estimates are reported to three significant figures.

\section{Monitoring Results}

The total amount of radioactive material released to the environment is quantified by using data obtained from continuously monitored airborne effluent releases points and estimates of diffuse and fugitive sources in conjunction with calculated release estimates of unmonitored radionuclides from the separations areas.

The unmonitored radionuclides are fission product tritium, carbon-14, and krypton-85. These radionuclides cannot be measured readily in the effluent streams; therefore, the values are calculated on an annual basis and are based on production levels in the separations areas.

Because of increased operations in F-Canyon, the amount of krypton- 85 estimated to have been released increased 120 percent. It went from $17,000 \mathrm{Ci}(6.29 \mathrm{E}+14 \mathrm{~Bq})$ in 1998 to $37,400 \mathrm{Ci}$ $(1.38 \mathrm{E}+15 \mathrm{~Bq})$ in 1999 and accounts for about 42 percent of the total radioactivity released to the atmosphere from SRS operations. However, because krypton is an inert noble gas and is not absorbed by the human body, it therefore causes only a small amount of dose, even though the released amount is relatively high (table 41 , SRS Environmental Data for 1999).

The data in table 5-1 on page 75 (and in table 4, SRS Environmental Data for 1999) are a major component in the determination of offsite dose estimations from SRS operations. The calculated individual and collective doses from atmospheric releases are presented in chapter 7 , as is a comparison of these offsite doses to EPA and the U.S. Department of Energy (DOE) dose standards.

\section{Beta- and Alpha-Emitting Radionuclides}

For 1999, releases of unspecified alpha emissions and nonvolatile beta emissions were listed separately in the source term. In previous years, these emissions were included in plutonium-239 and strontium-89,90 releases.

For dose calculations, the unspecified alpha releases were assigned the plutonium-239 dose factor, and the unspecified nonvolatile beta releases were assigned the strontium-90 dose factor.

\section{Tritium}

Tritium in elemental and oxide forms accounts for about 58 percent of the total radioactivity released to the atmosphere from SRS operations. As an isotope of hydrogen, tritium acts the same as hydrogen chemically and physically and thus is extremely difficult to remove from air effluent streams. During 1999 , about $51,600 \mathrm{Ci}(1.91 \mathrm{E}+15 \mathrm{~Bq})$ of tritium was released from SRS, compared to about $82,700 \mathrm{Ci}$ $(3.06 \mathrm{E}+15 \mathrm{~Bq})$ in 1998 . This 38 percent decrease was due mainly to completion of moderator consolidation activities at P-Area during 1998. This effort removed all the stored tritiated moderator (heavy water) from vented $P$-Area tanks and placed it in sealed drums stored in K-Area.

Because of improvements in facilities, processes, and operations and because of changes in the site's mission, the amount of tritium (and other atmospheric radionuclides) released has been reduced throughout the history of SRS. During the early years at SRS, large quantities of tritium were discharged to the atmosphere. The maximum yearly release of 2.4 million $\mathrm{Ci}(8.9 \mathrm{E}+16 \mathrm{~Bq})$ of tritium occurred during 1958. In recent years, because of the changes in the site's missions and the existence of the Replacement Tritium Facility, the total amount of tritium released has fluctuated up and down but has remained less than $100,000 \mathrm{Ci}$ per year (figure 5-1).

\section{Comparison of Average Concentrations in Airborne Emissions to DOE Derived Concentration Guides}

Average concentrations of radionuclides in airborne emissions are calculated by dividing the yearly release total of each radionuclide from each stack by the yearly stack flow quantities. These average concentrations then can be compared to the DOE derived concentration guides (DCGs) in DOE Order 5400.5, "Radiation Protection of the Public and the Environment."

DCGs are used as reference concentrations for conducting environmental protection programs at all DOE sites. Based on a 100-mrem exposure, DCGs are applicable at the point of discharge (prior to dilution or dispersion) under conditions of continuous exposure (assumed to be an average inhalation rate of 8,400 cubic meters per year). This means that the DOE DCGs are based on the highly conservative assumption that a member of the public has direct access to-and continuously breathes, or is immersed in - the undiluted air effluent 24 hours a day, 365 days a year. However, because of the distance between most SRS operating facilities and the site 
Curies

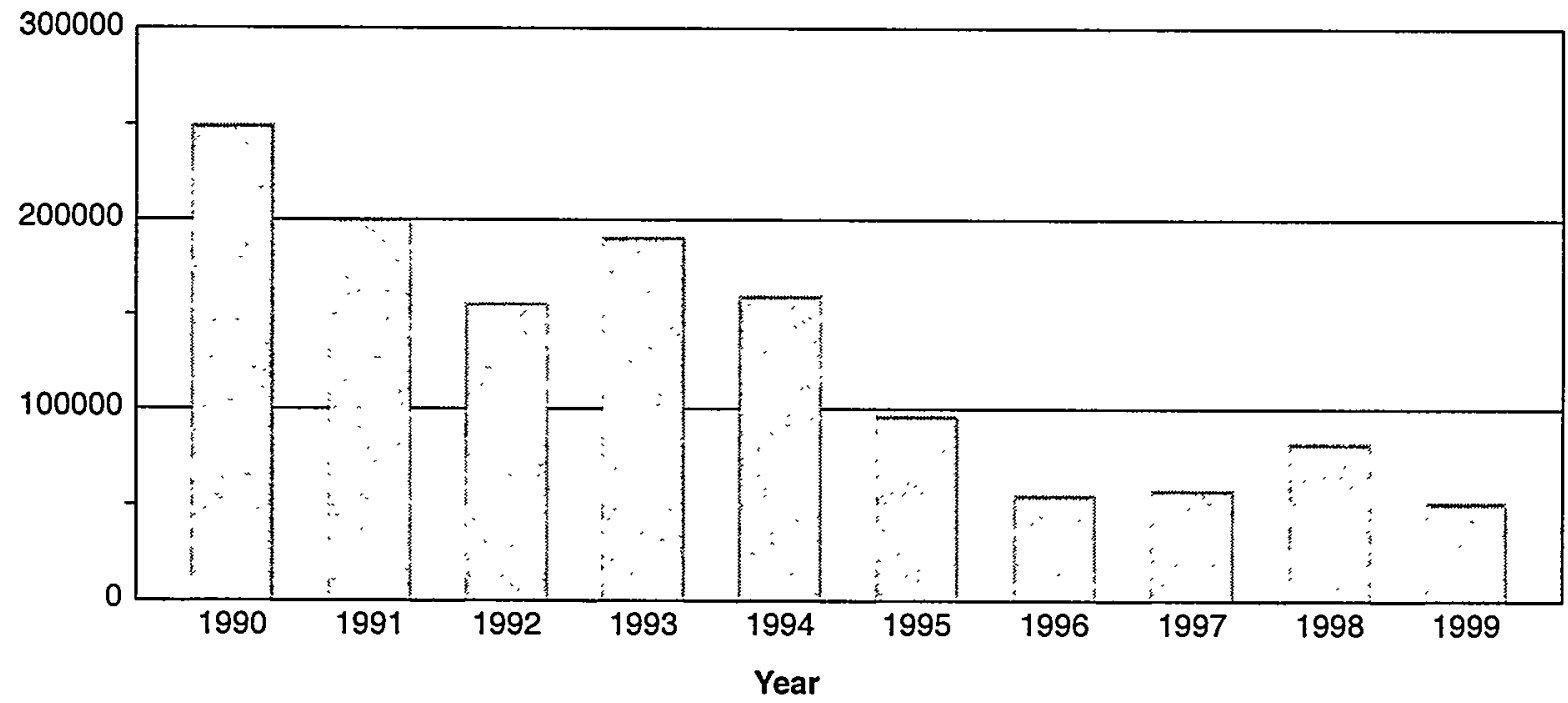

Ileaf Graphic

Figure 5-1 Ten-Year History of SRS Annual Atmospheric Tritium Releases

boundary, and because the wind rose at SRS shows no strong prevalence (chapter 7), this scenario is highly improbable.

Average annual radionuclide concentrations in SRS air effluents can be referenced to DOE DCGs as a screening method to determine if existing effluent treatment systems are proper and effective. The 1999 atmospheric effluent 12 -month average concentrations, their comparisons against the DOE DCGs, and the quantities of radionuclides released are provided, by discharge point, in table 5, SRS Environmental Data for 1999.

Most of the SRS radiological stacks/facilities release small quantities of radionuclides at concentrations below the DOE DCGs. However, certain radionuclides-tritium (in the oxide form) from the heavy water rework facilities, the reactor facilities, and the tritium facilities; americium-241, plutonium-238, and plutonium-239 in F-Area from the 6.1 and 6.4 dissolvers; plutonium-238, plutonium-239, and curium-244 in H-Area from 261-H (off gas); uranium-234 in M-Area from the 321-M machining room stack; and uranium-232, uranium-234, and uranium-238 from the M-Area Vendor Treatment Facility (VTF) - were emitted at concentration levels above the DCGs. Because of the extreme difficulty involved in removing tritium and because of current facility designs, site missions, and operational considerations, this situation is unavoidable. The offsite dose consequences from all atmospheric releases during 1999 , however, remained well below the DOE and EPA annual atmospheric pathway dose standard of $10 \mathrm{mrem}(0.1 \mathrm{mSv})$ (chapter 7).

\section{Liquid Discharges}

Each process area liquid effluent discharge point that releases or has potential to release radioactive materials is sampled routinely and analyzed for radioactivity [SRS EM Program, 1999]. The radiological liquid effluent sampling locations at SRS are shown, along with the surface water surveillance sampling locations, in chapter 6 , "Radiological Environmental Surveillance" (page 86, figure 6-4).

Site streams also are sampled upstream and downstream of seepage basins to obtain data to calculate the amount of radioactivity migrating from the basins. These results are important in calculating the total amount of radioactivity released to the Savannah River as a result of SRS operations.

\section{Description of Monitoring Program}

\section{Sample Collection Systems}

Liquid effluents are sampled continuously by automatic samplers at, or very near, their points of discharge to the receiving streams. EMS personnel normally collect the liquid effluent samples weekly and transport them to the EMS laboratory for analysis.

During 1999, F-03 was discontinued as a liquid effluent monitoring point (effective January 1) 
because it no longer receives any active facility process flows.

\section{Continuous Monitoring Systems}

Depending on the processes involved, liquid effluents also may be monitored by area operations and/or S\&HO personnel with real-time instrumentation to ensure that instantaneous releases stay within established limits. Because the instruments have limited detection sensitivity, online monitoring systems are not used to quantify liquid radioactive releases from SRS.

\section{Laboratory Analysis}

EMS provides most of the necessary radioanalytical laboratory services required to conduct the site liquid effluent monitoring program.

\section{Flow Rate Measurements}

Liquid effluent flows generally are determined by one of two methods: U.S. Geological Survey flow stations or commercial flow meters. Effluent flow rates are used to determine the total radioactivity released.

\section{Monitoring Results}

Data from continuously monitored liquid effluent discharge points are used in conjunction with site seepage basin and Solid Waste Disposal Facility migration release estimates to quantify the total radioactive material released to the Savannah River from SRS operations. SRS liquid radioactive releases for 1999 are shown by source in table 5-2, page 152, and in table 6, SRS Environmental Data for 1999).

The data in this table are a major component in the determination of offsite dose consequences from SRS operations. The calculated individual and collective doses from site liquid releases are presented in chapter 7, as is a comparison of these offsite doses to EPA and DOE dose standards.

\section{Beta- and Alpha-Emitting Radionuclides}

For 1999, releases of unspecified alpha emissions and nonvolatile beta emissions were listed separately in the source term. In previous years, these emissions were included in plutonium-239 and strontium-89,90 releases.

For dose calculations, the unspecified alpha releases were assigned the plutonium-239 dose factor, and the unspecified nonvolatile beta releases were assigned the strontium-90 dose factor.

\section{Direct Discharges of Liquid Effluents}

Direct discharges of liquid effluents are quantified at the point-of-release to the receiving stream, prior to dilution by the stream. The release totals are based on measured concentrations and flow rates.

Tritium accounts for nearly all of the radioactivity discharged in SRS liquid effluents. The total amount of tritium released directly from process areas (i.e., reactor, separations, heavy water rework) to site streams during 1999 was $1,120 \mathrm{Ci}(4.14 \mathrm{E}+13 \mathrm{~Bq})$, which was 2 percent more than the 1998 total of $1,090 \mathrm{Ci}(4.04 \mathrm{E}+13 \mathrm{~Bq})$.

Direct releases of tritium to site streams for the years 1990-1999 are shown in figure 5-2, where it can be seen that the total amount of tritium released has fluctuated up and down but has remained less than $2,000 \mathrm{Ci}$ per year in recent years.

\section{Comparison of Average Concentrations in Liquid Releases to DOE Derived Concentration Guides}

In addition to dose standards, DOE Order 5400.5 imposes other control considerations on liquid releases. These considerations are applicable to direct discharges but not to seepage basin and Solid Waste Disposal Facility migration discharges. The DOE order lists DCG values for most radionuclides. DCGs are used as reference concentrations for conducting environmental protection programs at all DOE sites. These DCG values are not release limits but screening values for "best available technology" investigations and for determining whether existing effluent treatment systems are proper and effective.

According to DOE Order 5400.5, exceedance of the DCGs at any discharge point may require an investigation of "best available technology" waste treatment for the liquid effluents. Tritium in liquid effluents is specifically excluded from "best available technology" requirements; however, it is not excluded from other ALARA considerations. DOE DCG compliance is demonstrated when the sum of the fractional DCG values for all radionuclides detectable in the effluent is less than 1.00 , based on consecutive 12 -month average concentrations.

DCGs, based on a 100-mrem exposure, are applicable at the point of discharge from the effluent conduit to the environment (prior to dilution or dispersion). They are based on the highly conservative assumption that a member of the public has continuous direct access to the actual liquid effluent and consumes 2 liters of the effluent every day, 365 days a year. However, because of security controls and the distance between most SRS 


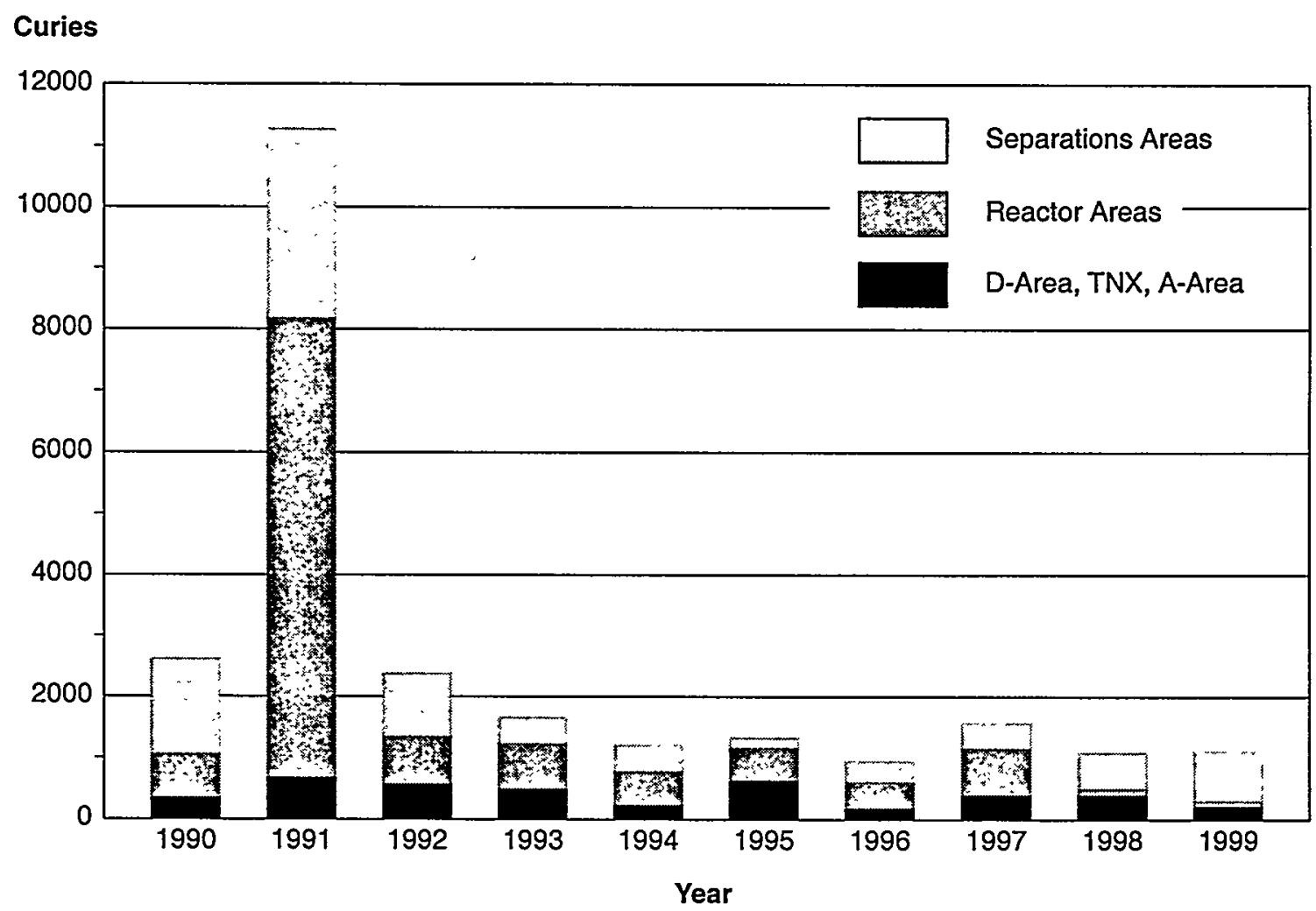

Ileaf Graphic

Figure 5-2 Direct Releases of Tritium to SRS Streams, 1990-1999

The 1991 total includes an accidental release in December of 5,700 Ci from K-Reactor.

operating facilities and the site boundary, this scenario is highly improbable.

For each site facility that releases radioactivity, EMS compares the monthly liquid effluent concentrations and 12-month average concentrations against the DOE DCGs. The 1999 liquid effluent 12-month average concentrations, their comparisons against the DOE DCGs, and the quantities of radionuclides released are provided, by discharge point, in table 7, SRS Environmental Data for 1999.

The data show that the U3R-2A ETF outfall at the Road C discharge point exceeded the DCG guide for 12-month average tritium concentrations during
1999. However, as noted previously, DOE

Order 5400.5 specifically exempts tritium from "best available technology" waste treatment investigation requirements. This is because there is no practical technology available for removing tritium from dilute liquid waste streams. In 1992, in consideration of ALARA principles for tritium discharges and while reviewing, analyzing, and modifying the process for controlling liquid releases of radioactive effluents, SRS identified several options and alternatives to continuing with these discharges at the U3R-2A ETF outfall. None of these alternatives was considered viable on a cost/benefit basis. No other discharge points exceeded the DOE DCGs during 1999. 
Table 5-1 Radioactive Atmospheric Releases by Source

Page 1 of 3

\begin{tabular}{|c|c|c|c|c|c|c|c|}
\hline \multirow[b]{2}{*}{$\begin{array}{l}\text { Radio- } \\
\text { nuclide }\end{array}$} & \multicolumn{7}{|c|}{ Curies $^{a}$} \\
\hline & Reactors & $\begin{array}{l}\text { Separa- } \\
\text { tions }\end{array}$ & $\begin{array}{l}\text { Reactor } \\
\text { Materials }\end{array}$ & $\begin{array}{l}\text { Heavy } \\
\text { Water }\end{array}$ & SRTCE & $\begin{array}{c}\text { Diffuse } \\
\text { and } \\
\text { Fugitive }^{d}\end{array}$ & Total \\
\hline \multicolumn{8}{|c|}{ Blank spaces indicate no quantifiable activity. } \\
\hline \multicolumn{3}{|c|}{ GASES AND VAPORS } & & & & & \\
\hline $\mathrm{H}-3$ (oxide) & $3.04 \mathrm{E}+03$ & $3.02 E+04$ & & $2.31 \mathrm{E}+02$ & & $4.71 E+02$ & $3.39 E+04$ \\
\hline H-3(elem.) & & 1.77E+04 & & & & & $1.77 \mathrm{E}+04$ \\
\hline $\mathrm{H}-3$ Total & $3.04 \mathrm{E}+03$ & $4.79 E+04$ & & $2.31 E+02$ & & $4.71 E+02$ & $5.16 \mathrm{E}+04$ \\
\hline $\mathrm{C}-14$ & & $2.50 \mathrm{E}-02$ & & & & $4.92 E-04$ & $2.55 \mathrm{E}-02$ \\
\hline $\mathrm{Kr}-85$ & & $3.74 \mathrm{E}+04$ & & & & & $3.74 E+04$ \\
\hline Xe-135 & & $1.94 \mathrm{E}-02$ & & & & & $1.94 \mathrm{E}-02$ \\
\hline $1-129$ & & 4.77E-03 & & & & $2.50 E-03$ & 7.27E-03 \\
\hline $\mid-131$ & & & & & $1.01 E-05$ & & $1.01 E-05$ \\
\hline $1-133$ & & & & & $1.25 E-04$ & & $1.25 \mathrm{E}-04$ \\
\hline \multicolumn{3}{|c|}{ PARTICULATES } & & & & & \\
\hline $\mathrm{Cr}-51$ & & & & & & $1.21 E-04$ & $1.21 E-04$ \\
\hline Co-57 & & 4.69E-08 & & & & $2.01 E-10$ & 4.71E-08 \\
\hline Co-58 & & & & & & 1.27E-04 & $1.27 E-04$ \\
\hline Co-60 & & $1.00 \mathrm{E}-06$ & & $1.18 \mathrm{E}-06$ & & $1.28 \mathrm{E}-04$ & $1.30 E-04$ \\
\hline $\mathrm{Ni}-59$ & & & & & & $1.02 E-09$ & $1.02 E-09$ \\
\hline $\mathrm{Ni}-63$ & & & & & & $5.89 \mathrm{E}-07$ & $5.89 E-07$ \\
\hline$Z n-65$ & & & & & & $2.23 E-05$ & $2.23 \mathrm{E}-05$ \\
\hline Sr-89,90 & & 3.11E-04 & & & & $7.02 E-04$ & $1.01 E-03$ \\
\hline Zr-95 & & & & & & $1.71 E-05$ & $1.71 E-05$ \\
\hline $\mathrm{Nb}-94$ & & & & & & $3.95 \mathrm{E}-10$ & $3.95 \mathrm{E}-10$ \\
\hline $\mathrm{Nb}-95$ & & & & & & $1.13 E-04$ & $1.13 E-04$ \\
\hline Tc-99 & & & & & & $6.22 \mathrm{E}-05$ & $6.22 E-05$ \\
\hline$R u-103$ & & & & & & $4.23 \mathrm{E}-05$ & $4.23 E-05$ \\
\hline $\mathrm{Sb}-124$ & & & & & & $2.23 E-10$ & $2.23 E-10$ \\
\hline $\mathrm{Sb}-125$ & & & & & & $5.27 E-05$ & $5.27 E-05$ \\
\hline Sn-126 & & & & & & $3.13 E-15$ & $3.13 E-15$ \\
\hline Cs-134 & & $5.72 E-08$ & & & & $1.31 E-04$ & $1.31 E-04$ \\
\hline Cs-137 & $2.32 E-05$ & $8.41 E-03$ & $3.36 \mathrm{E}-07$ & & & $6.11 E-03$ & $1.45 \mathrm{E}-02$ \\
\hline $\mathrm{Ce}-141$ & & & & & & 4.16E-05 & 4.16E-05 \\
\hline $\mathrm{Ce}-144$ & & & & & & $1.45 \mathrm{E}-04$ & $1.45 E-04$ \\
\hline
\end{tabular}

a One curie equals $3.7 \mathrm{E}+10$ Becquerels.

b Includes separations, waste management, and tritium facilities

c Savannah River Technology Center

d Estimated releases from minor unmonitored diffuse and fugitive sources 
Table 5-1 Radioactive Atmospheric Releases by Source

Page 2 of 3

\begin{tabular}{|c|c|c|c|c|c|c|c|}
\hline \multirow[b]{2}{*}{$\begin{array}{l}\text { Radio- } \\
\text { nuclide }\end{array}$} & \multicolumn{7}{|c|}{ Curies $^{a}$} \\
\hline & Reactors & $\begin{array}{l}\text { Separa- } \\
\text { tions }\end{array}$ & $\begin{array}{c}\text { Reactor } \\
\text { Materials }\end{array}$ & $\begin{array}{l}\text { Heavy } \\
\text { Water }\end{array}$ & SRTCC & $\begin{array}{c}\text { Diffuse } \\
\text { and } \\
\text { Fugitived }^{d}\end{array}$ & Total \\
\hline $\mathrm{Pr}-144$ & & & & & & $3.45 E-09$ & $3.45 \mathrm{E}-09$ \\
\hline$P m-147$ & & & & & & $3.49 E-09$ & $3.49 \mathrm{E}-09$ \\
\hline Eu-152 & & & & & & $1.21 \mathrm{E}-10$ & $1.21 \mathrm{E}-10$ \\
\hline Eu-154 & & & & & & $5.74 E-06$ & $5.74 \mathrm{E}-06$ \\
\hline Eu-155 & & & & & & $1.10 \mathrm{E}-06$ & $1.10 \mathrm{E}-06$ \\
\hline $\mathrm{Hg}-203$ & & & & & & $2.23 E-10$ & $2.23 E-10$ \\
\hline $\mathrm{Pb}-214$ & & & & & & $2.23 E-10$ & $2.23 E-10$ \\
\hline $\mathrm{Ra}-226$ & & & & & & $1.25 E-05$ & $1.25 \mathrm{E}-05$ \\
\hline $\mathrm{Ra}-228$ & & & & & & $1.87 \mathrm{E}-05$ & $1.87 E-05$ \\
\hline$A c-228$ & & & & & & $1.66 \mathrm{E}-06$ & $1.66 \mathrm{E}-06$ \\
\hline Th-228 & & & & & & $2.75 E-07$ & $2.75 E-07$ \\
\hline Th-230 & & & & & & $1.22 E-05$ & $1.22 \mathrm{E}-05$ \\
\hline Th-232 & & & & & & $1.64 \mathrm{E}-06$ & $1.64 \mathrm{E}-06$ \\
\hline Th-234 & & & & & & 4.10E-06 & $4.10 \mathrm{E}-06$ \\
\hline $\mathrm{Pa}-233$ & & & & & & 2.23E-10 & $2.23 E-10$ \\
\hline$U-232$ & & & $1.33 E-08$ & & & & 1.33E-08 \\
\hline$U-233$ & & & & & & 2.38E-06 & $2.38 \mathrm{E}-06$ \\
\hline$U-234$ & & $2.02 E-05$ & $1.41 \mathrm{E}-05$ & & & $5.29 E-05$ & $8.72 \mathrm{E}-05$ \\
\hline$U-235$ & & $1.34 \mathrm{E}-06$ & $2.68 \mathrm{E}-06$ & & & $5.89 E-06$ & $9.91 E-06$ \\
\hline$U-236$ & & & & & & $5.20 \mathrm{E}-09$ & $5.20 \mathrm{E}-09$ \\
\hline$U-238$ & & $3.61 E-05$ & $1.07 \mathrm{E}-05$ & & & $9.49 \mathrm{E}-05$ & $1.42 E-04$ \\
\hline $\mathrm{Np}-237$ & & & & & & $2.23 E-10$ & $2.23 E-10$ \\
\hline $\mathrm{Np}-239$ & & & & & & 4.51E-09 & $4.51 \mathrm{E}-09$ \\
\hline$P u-238$ & & $5.27 \mathrm{E}-04$ & $7.16 \mathrm{E}-09$ & & & $1.45 E-03$ & $1.98 \mathrm{E}-03$ \\
\hline Pu-239 & & $1.34 E-04$ & $2.39 E-08$ & & & $1.68 \mathrm{E}-05$ & $1.51 E-04$ \\
\hline Pu-240 & & & & & & $1.46 \mathrm{E}-06$ & $1.46 \mathrm{E}-06$ \\
\hline Pu-241 & & & & & & $6.47 E-05$ & $6.47 E-05$ \\
\hline Pu-242 & & & & & & $1.53 E-08$ & $1.53 E-08$ \\
\hline Am-241 & & $3.01 E-05$ & $1.46 \mathrm{E}-08$ & & & $8.44 \mathrm{E}-06$ & $3.86 \mathrm{E}-05$ \\
\hline$A m-243$ & & & & & & $4.28 \mathrm{E}-06$ & $4.28 \mathrm{E}-06$ \\
\hline
\end{tabular}

One curie equals $3.7 \mathrm{E}+10$ Becquerels.

Includes separations, waste management, and tritium facilities

Savannah River Technology Center

Estimated releases from minor unmonitored diffuse and fugitive sources 
Table 5-1 Radioactive Atmospheric Releases by Source

Page 3 of 3

\begin{tabular}{|c|c|c|c|c|c|c|c|}
\hline \multirow[b]{2}{*}{$\begin{array}{l}\text { Radio- } \\
\text { nuclide }\end{array}$} & \multicolumn{7}{|c|}{ Curies $^{a}$} \\
\hline & Reactors & $\begin{array}{c}\text { Separa- } \\
\text { tions }\end{array}$ & $\begin{array}{l}\text { Reactor } \\
\text { Materials }\end{array}$ & $\begin{array}{l}\text { Heavy } \\
\text { Water }\end{array}$ & SRTCC & $\begin{array}{c}\text { Diffuse } \\
\text { and } \\
\text { Fugitived }\end{array}$ & Total \\
\hline $\mathrm{Cm}-242$ & & & & & & $3.10 \mathrm{E}-07$ & $3.10 \mathrm{E}-07$ \\
\hline $\mathrm{Cm}-244$ & & $2.59 E-05$ & $1.69 E-08$ & & & 6.74E-06 & 3.27E-05 \\
\hline $\mathrm{Cm}-246$ & & & & & & $2.91 E-06$ & 2.91E-06 \\
\hline Alpha & $5.09 E-04$ & $4.46 E-05$ & $7.23 E-05$ & $1.05 E-05$ & $1.75 \mathrm{E}-06$ & 1.47E-03 & $2.11 \mathrm{E}-03$ \\
\hline $\begin{array}{l}\text { Nonvolatile } \\
\text { Beta }\end{array}$ & $1.19 \mathrm{E}-03$ & $3.27 \mathrm{E}-04$ & $1.84 E-03$ & $1.23 E-04$ & & $2.74 \mathrm{E}-02$ & $3.09 E-02$ \\
\hline
\end{tabular}

a One curie equals $3.7 E_{+}+10$ Becquerels.

Includes separations, waste management, and tritium facilities

Savannah River Technology Center

Estimated releases from minor unmonitored diffuse and fugitive sources 
Table 5-2 Radioactive Liquid Releases by Source

(Including Direct and Seepage Basin Migration Releases)

Page 1 of 1

\begin{tabular}{|c|c|c|c|c|c|c|}
\hline \multirow[b]{2}{*}{$\begin{array}{l}\text { Radio- } \\
\text { nuclide }\end{array}$} & \multicolumn{6}{|c|}{ Curies $^{a}$} \\
\hline & Reactors & Separations ${ }^{b}$ & $\begin{array}{c}\text { Reactor } \\
\text { Materials }\end{array}$ & $\begin{array}{c}\text { Heavy } \\
\text { Water/TNX }\end{array}$ & $\begin{array}{c}\text { Savannah } \\
\text { River } \\
\text { Technology } \\
\text { Center }\end{array}$ & Total \\
\hline Note: & \multicolumn{6}{|c|}{ Blank spaces indicate no quantifiable activity. } \\
\hline \multicolumn{7}{|l|}{ Site } \\
\hline $\mathrm{H}-3$ & $1.40 \mathrm{E}+03$ & $4.68 \mathrm{E}+03$ & & $2.13 E+02$ & $1.46 \mathrm{E}+00$ & $6.29 E+03$ \\
\hline Sr-89,90 & $1.37 E-02$ & $1.20 \mathrm{E}-01$ & & & & $1.34 E-01$ \\
\hline $\mathrm{Co}-60$ & & 4.94E-04 & & & & $4.94 E-04$ \\
\hline $1-129$ & & $7.82 E-02$ & & & & $7.82 E-02$ \\
\hline Cs-137 & $3.24 E-04$ & $1.02 E-01$ & & & & $1.02 \mathrm{E}-01^{\mathrm{c}}$ \\
\hline$U-234$ & $3.93 E-03$ & $8.60 \mathrm{E}-02$ & $1.24 \mathrm{E}-02$ & $4.88 E-06$ & $8.39 \mathrm{E}-05$ & $1.02 E-01$ \\
\hline$U-235$ & $2.50 E-04$ & $6.33 E-04$ & & & $2.99 E-06$ & $8.86 E-04$ \\
\hline$U-238$ & $3.10 E-03$ & $1.08 \mathrm{E}-02$ & 1.37E-02 & $1.00 \mathrm{E}-05$ & $7.92 \mathrm{E}-05$ & $2.77 E-02$ \\
\hline $\mathrm{Pu}-238$ & & $9.98 \mathrm{E}-05$ & & $1.14 \mathrm{E}-06$ & 7.73E-06 & $1.09 \mathrm{E}-04$ \\
\hline Pu-239 & 9.96E-05 & $1.97 \mathrm{E}-06$ & & & & $1.02 E-04$ \\
\hline Am-241 & & $1.83 E-06$ & $1.16 \mathrm{E}-05$ & & & $1.34 \mathrm{E}-05$ \\
\hline $\mathrm{Cm}-244$ & & $1.26 \mathrm{E}-06$ & & & & $1.26 \mathrm{E}-06$ \\
\hline Alpha & $6.45 \mathrm{E}-04$ & $2.05 E-02$ & $3.56 \mathrm{E}-03$ & $1.04 \mathrm{E}-03$ & $5.25 \mathrm{E}-03$ & $3.10 E-02$ \\
\hline $\begin{array}{l}\text { Nonvolatile } \\
\text { Beta }\end{array}$ & $2.40 \mathrm{E}-02$ & $2.23 E-02$ & 9.97E-04 & $3.21 \mathrm{E}-03$ & $4.63 \mathrm{E}-03$ & $5.51 E-02$ \\
\hline
\end{tabular}

a One curie equals $3.7 E+10$ Becquerels.

b Includes separations, waste management, and tritium facilities

c For conservatism, the higher release value $(2.40 \mathrm{E}-01 \mathrm{Ci})$ calculated from River Mile 120 fish concentrations was used for dose calculations. 


\section{Radiological Environmental Surveillance}

\author{
Pete Fledderman, Bill Littrell, Phillip Miller, \\ Chet Nichols, Donald Padgett, \\ and Stuart Stinson \\ Environmental Protection Department \\ Timothy Jannik \\ Savannah River Technology Center
}

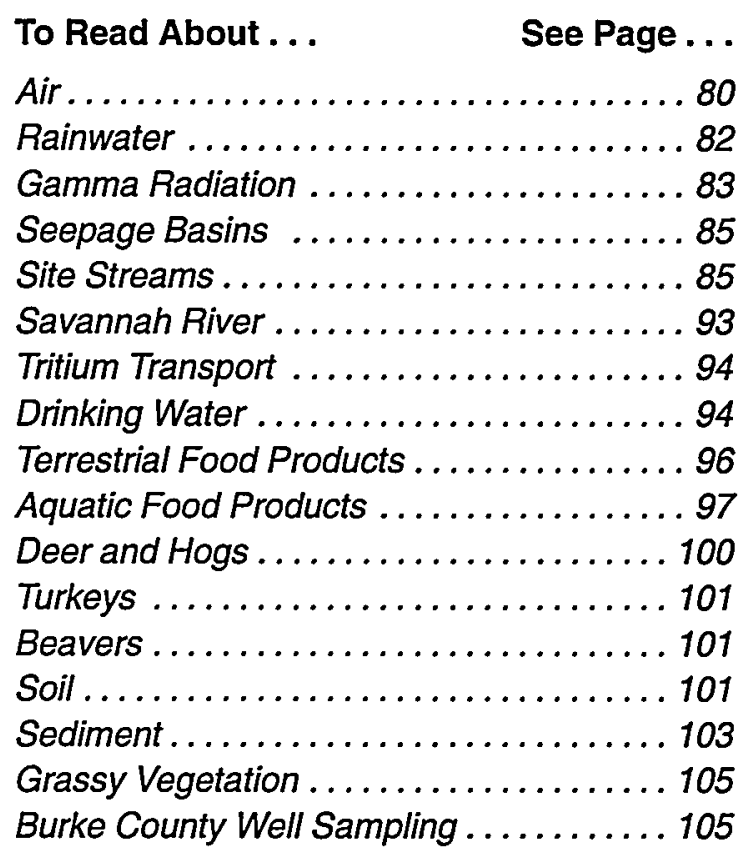

\section{Highlights}

- Results of the comprehensive radiological surveillance program conducted near the site for air, surface water, groundwater, drinking water, soil, sediments, game animals, and foodstuffs were within historical trends and did not yield any new issues of concern.

- Tritium accounted for most of the radioactivity released to the Savannah River from the site. About 6,290 Ci of tritium, compared to about $10,600 \mathrm{Ci}$ in 1998, were released to the Savannah River. Of the 1999 amount, 5,170 Ci resulted from groundwater migration, compared to 9,510 Ci in 1998.

- As in previous years, measurements of tritium in air were highest near the center of the site and at D-Area. This is consistent with the operations conducted at facilities at these locations. The tritium concentration in air rapidly decreases as a function of distance from the source and is substantially lower at the site perimeter.

- Tritium is the predominant radionuclide detected above background levels in the Savannah River. The average concentration at RM-120, located at U.S. Highway 301 below SRS, was $1,190 \mathrm{pCi} / \mathrm{L}$-less than 6 percent of the 20,000-pCi/L derived drinking water standard set by EPA for tritium in drinking water.

- No drinking water samples exceeded the 20,000-pCi/L EPA derived drinking water standard for tritium. The average tritium concentration in finished water at Beaufort-Jasper, $972 \mathrm{pCi} / \mathrm{L}$, was approximately 5 percent of the EPA derived drinking water limit, as was the average tritium concentration at Port Wentworth, $965 \mathrm{pCi} / \mathrm{L}$.

$\mathrm{T}$ HE Savannah River Site (SRS) radiological environmental surveillance program is designed to survey and quantify any effects that routine and nonroutine operations might have on the site and on the surrounding area and population. The program represented an extensive network in 1999 that covered approximately 2,000 square miles and extended up to 25 miles from the site. In conjunction with the radiological effluent monitoring program (chapter 5, "Radiological Effluent Monitoring"), the program enables SRS to monitor ambient radiological conditions and determine site contributions of radioactive materials to the environment.
Routine radiological surveillance activities are performed by the Environmental Protection Department's Environmental Monitoring Section (EMS) and by the Savannah River Technology Center (SRTC). The Savannah River also is monitored by other groups, including the South Carolina Department of Health and Environmental Control (SCDHEC) and the Georgia Department of Natural Resources (GDNR).

As part of the radiological surveillance program, routine surveillance of all radiation exposure pathways (ingestion, inhalation, immersion, and submersion) is performed on all environmental media 
that may lead to a measurable annual dose at the site boundary. This chapter summarizes surveillance results of the atmosphere (air and rainwater), surface water (seepage basins, site streams, and the Savannah River), drinking water, food products (terrestrial and aquatic), wildlife, soil, sediment, and vegetation. Also summarized are results of monitoring of ambient gamma radiation levels performed on site, at the site boundary, and in population centers (surrounding communities). A description of the surveillance program and 1999 results for groundwater can be found in chapter 10, "Groundwater."

Analytical results for 1999 appear in SRS

Environmental Data for 1999

(WSRC-TR-99-00301). Nominal lower limits of detection (LLDs) for the types of analyses being performed on the various environmental surveillance media can be found in table 2 of SRS Environmental Data for 1999. Information on the rationale for the radiological environmental surveillance program can be found in chapter 3, "Environmental Program Information." Data from earlier years can be found in previous SRS environmental reports and data publications.

A complete description of the SRS radiological environmental surveillance program can be found in section 1105 of the Savannah River Site Environmental Monitoring Section Plans and Procedures, WSRC-3Q1-2, Volume 1 (SRS EM Program).

\section{Air}

\section{Description of Surveillance Program}

EMS maintains an extensive network of 17 sampling stations in and around SRS to monitor the concentration of radioactive materials in the air. These locations are divided into four subgroups, as follows:

- onsite

- $\quad$ site perimeter

- a control location at 25 miles

- $\quad$ selected major population centers at 25 and 100 miles

Figure 6-1 shows all the sampling locations except the 25- and 100-mile stations.

The air surveillance program helps determine the impact (if any) of site operations on the environment and evaluates trends in airborne radionuclide concentrations. The program also is used to verify atmospheric transport models and to support emergency response activities in the event of an unplanned release of radioactive material to the atmosphere.

\section{Surveillance Results}

Chapter 5 details the types and quantity of radioactive material released to the environment from SRS activities in 1999. Except for tritium, specific radionuclides were not routinely detectable at the site perimeter (table 8, SRS Environmental Data for 1999). Both onsite and offsite activity concentrations were similar to levels observed in previous years.

\section{Gross Alpha and Gross Beta}

Gross alpha and gross beta activity analyses are performed on glass fiber filter papers. Although they cannot provide concentrations of specific radionuclides, these measurements are useful in providing information for trending of the total activity in an air sample or in screening samples.

A summary of the monitoring results from 1995-1999 is presented in table 6-1. As indicated in the table, sampling at the Savannah, Georgia, location (100-mile radius) was resumed in 1999. Both the average gross alpha and average gross beta results show increases relative to the results of previous years. These increases are most noticeable in gross alpha results. Similar-sized increases were not observed in gamma-emitting radionuclide analyses; therefore, a systematic analytical error is suspected. An investigation into the exact cause of the observed increases will be conducted in 2000 .

As in previous years, no significant difference was seen between the average concentrations measured on site near the operating facilities and the average concentrations observed at the site perimeter.

\section{Gamma-Emitting Radionuclides}

Glass fiber filters and activated charcoal canisters are collected weekly. Program changes implemented in 1998 eliminated the weekly analysis of activated charcoal canisters and replaced it with a single (annual) analysis. Analytical protocols for glass fiber filters were changed by eliminating composites. No manmade gamma-emitting radionuclides were observed in 1999. These results are consistent with historical results, which indicate a small number of samples with detectable activity. 


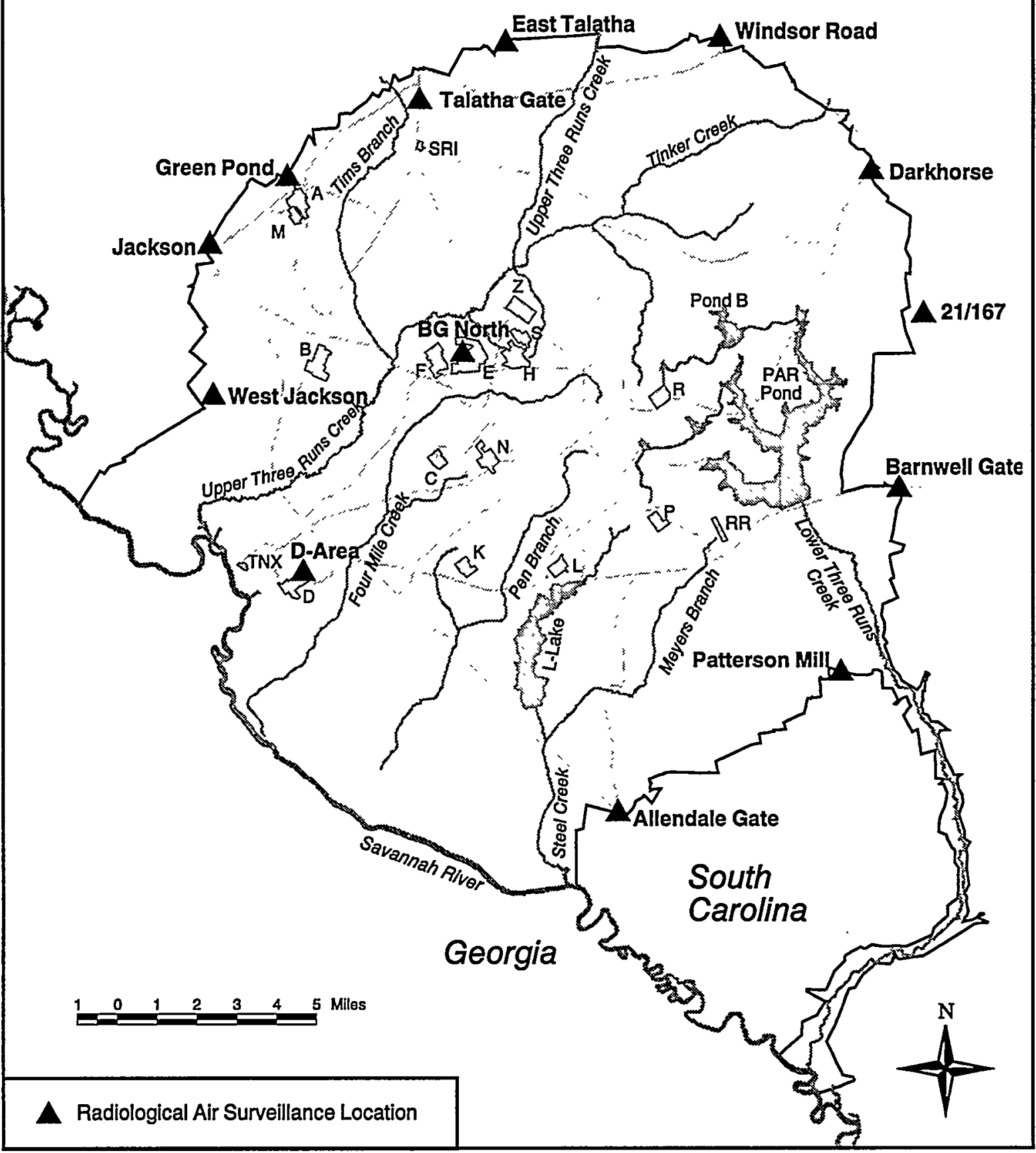

EPD/GIS Map

Figure 6-1 Radiological Air Surveillance Sampling Locations

The SRS air surveillance program consists of 13 stations located on site or along the site perimeter, as well as (not shown) three stations approximately 25 miles from the site perimeter (located near the Highway 301 Bridge over the Savannah River; the New Savannah Bluff Lock and Dam, also known as the Augusta Lock and Dam; and the Aiken airport) and one about 100 miles from the site perimeter (at Savannah, Georgia).

\section{Tritium}

Tritium-in-air analyses are conducted on biweekly silica gel samples. Tritium is released as part of routine SRS operations and becomes part of the natural environment. Monitoring ensures that there will be information available to determine whether any potential health risk to the surrounding population is created. 
Table 6-1

Average Gross Alpha and Gross Beta Measured in Air (pCi/m³), 1995-1999

\begin{tabular}{lccccc}
\hline \multicolumn{5}{c}{ Average Gross Alpha } \\
Locations & 1995 & 1996 & 1997 & 1998 & 1999 \\
On site & $1.5 \mathrm{E}-03$ & $1.1 \mathrm{E}-03$ & $1.2 \mathrm{E}-03$ & $1.1 \mathrm{E}-03$ & $2.0 \mathrm{E}-03$ \\
Site perimeter & $1.4 \mathrm{E}-03$ & $1.0 \mathrm{E}-03$ & $9.8 \mathrm{E}-04$ & $1.4 \mathrm{E}-03$ & $1.9 \mathrm{E}-03$ \\
25-mile radius & $1.4 \mathrm{E}-03$ & $1.0 \mathrm{E}-03$ & $1.0 \mathrm{E}-03$ & $1.5 \mathrm{E}-03$ & $1.9 \mathrm{E}-03$ \\
100-mile radius & $1.6 \mathrm{E}-03$ & $9.4 \mathrm{E}-04$ & $1.1 \mathrm{E}-03$ & $\mathrm{a}$ & $2.1 \mathrm{E}-03$ \\
& \multicolumn{7}{c}{ Average Gross Beta } & & \\
Locations & 1995 & 1996 & 1997 & 1998 & 1999 \\
On site & $1.8 \mathrm{E}-02$ & $1.5 \mathrm{E}-02$ & $1.7 \mathrm{E}-02$ & $1.6 \mathrm{E}-02$ & $1.9 \mathrm{E}-02$ \\
Site perimeter & $1.8 \mathrm{E}-02$ & $1.5 \mathrm{E}-02$ & $1.5 \mathrm{E}-02$ & $1.8 \mathrm{E}-02$ & $1.9 \mathrm{E}-02$ \\
25-mile radius & $1.8 \mathrm{E}-02$ & $1.6 \mathrm{E}-02$ & $1.6 \mathrm{E}-02$ & $1.9 \mathrm{E}-02$ & $1.9 \mathrm{E}-02$ \\
100-mile radius & $1.8 \mathrm{E}-02$ & $1.4 \mathrm{E}-02$ & $1.1 \mathrm{E}-02$ & $\mathrm{a}$ & $1.9 \mathrm{E}-02$
\end{tabular}

a $\quad$ Not sampled in 1998

Studies on silica gel as a sampling medium for water in air were completed in 1999; results of this research will be published in the January 2000 issue of Health Physics. The studies indicate that the analytical method used underestimates water concentrations and that corrections must be applied. The research results have been incorporated into the SRS surveillance program, and the required corrections have been applied to the analytical results for 1999.

Consequently, 1999 results appear higher than those of previous years, for which no corrections have been applied.

Consistent with the SRS source term, tritium concentrations generally decrease with increasing distance from the tritium facilities near the center of the site. In addition, the analytical results generally agree with the predictions of the SRS transport and dose assessment model, as detailed in chapter 7 , "Potential Radiation Doses."

\section{Alpha-Emitting Radionuclides}

The analysis of glass fiber filter paper was expanded in 1999 to include uranium isotopes (uranium-234, uranium-235, uranium-238), americium-241, and curium-244 - in addition to plutonium isotopes (Pu-238, Pu-239). These radionuclides are released in small quantities as part of routine site operations-primarily from the separations areas.

The observed concentrations of plutonium isotopes in 1999 were similar to historical levels; all locations were below the nominal LLDs. In general, similar concentrations of the other alpha-emitting radionuclides were observed. No readily apparent distribution pattern or difference between onsite and offsite locations was observed.

\section{Strontium}

Strontium analysis is performed on one sample per year from each monitoring site. Strontium concentrations during 1999 generally were similar to those previously observed; all samples except one had concentrations below the LLD. This concentration, however, was more than two times the corresponding gross beta result, and the lab recovery was suspect. Therefore, it is believed that the result in question was caused by analytical errors.

\section{Rainwater}

SRS maintains a network of rainwater sampling sites as part of the air surveillance program. These stations are used to measure deposition of radioactive materials.

\section{Description of Surveillance Program}

Rainwater collection pans are located at each routine air surveillance station (figure $6-1$ ). Ion-exchange resin columns are placed at seven of these locations. At each of these locations, rain passes through the column and into a collection bottle. Both the ion-exchange resin column and the collected liquid are returned to the laboratory for analysis. The 
column is analyzed weekly for gamma-emitting radionuclides, gross alpha, and gross beta and annually for plutonium-238, plutonium-239, and strontium-89,90, while the rainwater is analyzed for tritium. At all other locations, the collected rainwater is returned to the laboratory and analyzed for tritium only. Ion-exchange column sampling is performed monthly, while rainwater sampling is performed biweekly.

\section{Surveillance Results}

Detailed results of rainwater analyses can be found in tables 9 and 10 of SRS Environmental Data for 1999.

\section{Gamma-Emitting Radionuclides}

As in 1998, no detectable manmade gamma-emitting radionuclides were observed in rainwater samples during 1999.

\section{Gross Alpha and Gross Beta}

The gross alpha and gross beta results were consistent with those of 1998. Although the 1999 results generally were slightly lower than those of 1998 , no long-term increasing or decreasing trend was evident. This implies that the observed values are natural

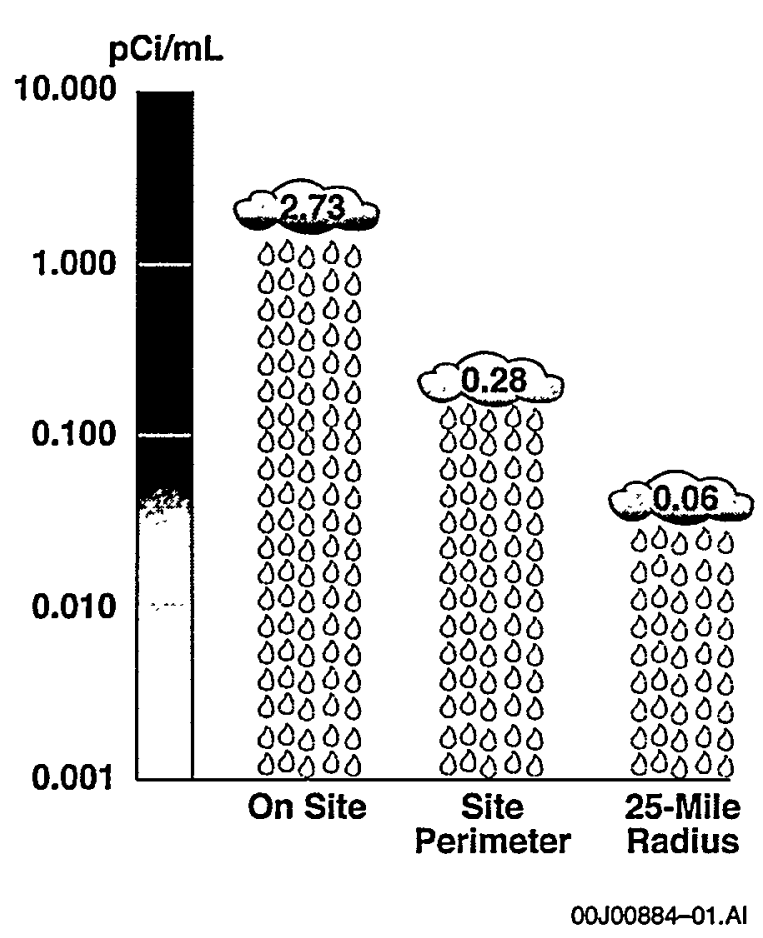

Figure 6-2 Average Concentration of Tritium in Rainwater, 1999

Tritium concentrations in rainwater (shown here in $\mathrm{pCi} / \mathrm{mL}$ ), generally decrease as the distance from the site increases. background and does not indicate any contribution directly attributable to SRS.

\section{Alpha-Emitting Radionuclides}

The analysis of rain ion columns was expanded in 1999 to include uranium isotopes (uranium-234, uranium-235, uranium-238), americium-241, and curium-244-in addition to plutonium isotopes (plutonium-238 and plutonium-239). Most isotopes were below detection levels; however, low levels of some radionuclides were observed at several locations. Generally, onsite and offsite concentrations were similar, which is consistent with historical results.

\section{Strontium}

As in 1998, no detectable levels of strontium-89,90 were observed in rainwater samples during 1999.

\section{Tritium}

As in previous years, tritium-in-rain values were highest near the center of the site. This is consistent with the H-Area effluent release points that routinely release tritium. As with tritium in air, concentrations generally decreased as distance from the effluent release point increased (figure 6-2); this observation also is consistent with the source term and with atmospheric transport.

\section{Gamma Radiation}

\section{Description of Surveillance Program}

Ambient gamma exposure rates in and around SRS are monitored by an extensive network of dosimeters. The site uses the thermoluminescent dosimeter (TLD) to quantify integrated gamma exposure on a quarterly basis. The TLD performs this function accurately, reliably, and relatively inexpensively.

SRS has been monitoring ambient environmental gamma exposure rates with TLDs since 1965. The information provided by this program is used primarily to determine the impact (if any) of site operations on the gamma exposure environment and to evaluate trends in environmental exposure levels. Other potential uses include

- support of routine and emergency response dose calculation models

- assistance in determining protective action recommendations in the event of an unplanned release of gamma-emitting radionuclides

- confirmatory accident assessment

The SRS ambient gamma radiation monitoring program is divided into four subprograms, as follows: 


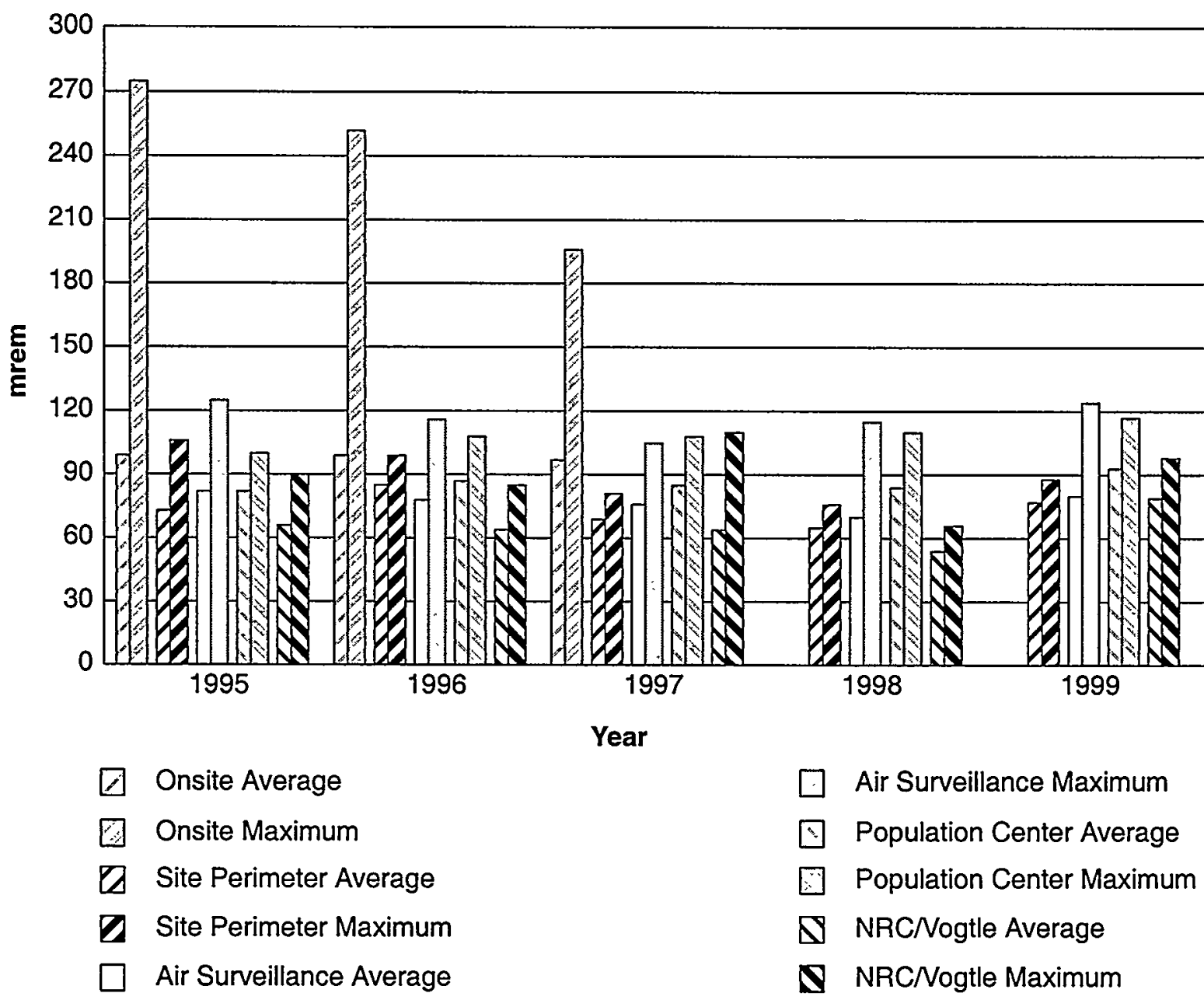

lleaf Graphic

Figure 6-3 Annual Average/Maximum Gamma Exposure Grouped by Program Element, 1995-1999 Natural background gamma exposure levels remain fairly constant with time. With the exception of a few locations, onsite gamma exposure levels at SRS are similar to regional background levels.

site perimeter stations, population centers, air surveillance stations, and Vogtle (stations that monitor potential exposures from Georgia Power's Vogtle Electric Generating Plant). All TLDs are exchanged quarterly.

Most gamma exposure monitoring is conducted on site and at the site perimeter. Monitoring continues to be conducted in population centers within approximately 9 miles $(15 \mathrm{~km})$ of the site boundary, but only limited monitoring is conducted beyond this distance and at the 25- and 100-mile air surveillance stations.

\section{Surveillance Results}

In general, the 1999 ambient gamma radiation monitoring results indicated gamma exposure rates slightly higher than those observed at the same locations in 1998. However, these results generally are consistent with previously published historical results, as indicated in figure 6-3.

Exposures at all TLD monitoring locations show some variation based on normal site-to-site and year-to-year differences in the components of natural ambient gamma exposure levels. Generally, this phenomena also is observed at both onsite and offsite locations. Table 6-2 summarizes the 1999 surveillance results, which show no significant differences in average gamma exposure rates from one monitoring network to another. Detailed analytical results from the TLD monitoring program can be found in tables $11,12,13$, and 14 of $S R S$ Environmental Data for 1999. 


\section{Seepage Basins}

During previous years of operation, SRS discharged liquid effluent to seepage basins to allow for the decay and natural removal of radioactivity in the water before it reached onsite streams. The practice of discharging water to the seepage basins was discontinued in 1988, but water accumulating in the basins from other sources continues to be monitored by EMS because of potential contamination from the basin soil.

\section{Description of Surveillance Program}

Seepage basin water is analyzed for gross alpha, gross beta, tritium, strontium, and gamma-emitting radionuclides. Analyses for specific radionuclides are determined by the makeup of previous releases to the basins.

In 1999, SRS's seepage basin sampling program was altered to reflect changes in the site's discharge practices, such as the halting of releases in 1988. Seepage basins in A-Area, C-Area, L-Area, and $P$-Area were eliminated from the program, and two basins, E-05 and E-06, were added to increase sampling coverage surrounding the burial ground.

\section{Surveillance Results}

Because of dry conditions, only one sample was obtained from both the E-06 and E-003 (EAV Basin South) locations in 1999. The remaining locations-E-001, E-002, E-004, and E-05-were sampled monthly. Because there are no active discharges to site seepage basins, the primary contributor to seepage basin water is from rainwater. As a result, there has been little variation in seepage basin results in recent years (table $15, S R S$

Environmental Data for 1999). In 1999, the highest mean tritium concentration, $(1.19 \pm 0.22) \mathrm{E}+04 \mathrm{pCi} / \mathrm{L}$, was found in SWDF Basin South (E-001). This represents only a slight increase over the highest 1998 mean concentration- $(1.08 \pm 0.66) \mathrm{E}+04 \mathrm{pCi} / \mathrm{L}$, found at $\mathrm{E}-002$-indicating that tritium levels in the seepage basins are remaining relatively constant. Mean cobalt- 60 , cesium-137, gross alpha, and gross beta concentrations all were below the nominal LLD for rainwater.

\section{Site Streams}

Continuous surveillance is used on several SRS streams (figure 6-4), including Tims Branch, Upper Three Runs Creek, Four Mile Creek (also known as Fourmile Branch), Pen Branch, Steel Creek, and Lower Three Runs Creek. Stream water sampling locations that monitor below process areas serve to detect and quantify levels of radioactivity in liquid effluents that are being transported to the Savannah River. In 1999, 21 samplers on SRS streams served as environmental surveillance points.

\section{Description of Surveillance Program}

The site's stream surveillance program monitors six streams-Tims Branch, Upper Three Runs Creek, Four Mile Creek, Pen Branch, Steel Creek, and Lower Three Runs.

- Tims Branch is a tributary of Upper Three Runs Creek, receiving effluents from $M$-Area and SRTC and stormwater runoff from A-Area and M-Area. The surveillance point on Tims Branch, TB-5, is located downstream of all release points and before entry into Upper Three Runs Creek.

- Upper Three Runs Creek receives discharges from the Effluent Treatment Facility (ETF) and Defense Waste Processing Facility (DWPF), flow from Tims Branch, and stormwater runoff from F-Area, H-Area, Z-Area, and S-Area. Tritium, the predominant radionuclide detected in Upper Three Runs Creek, is discharged primarily from the ETF.

Table 6-2

TLD Surveillance Results Summary for 1999

\begin{tabular}{lccl}
\hline $\begin{array}{l}\text { Monitoring } \\
\text { Subprogram }\end{array}$ & $\begin{array}{l}\text { Mean Exposure } \\
\text { (mrem per year) }\end{array}$ & $\begin{array}{l}\text { Maximum Exposure } \\
\text { (mrem per year) }\end{array}$ & $\begin{array}{l}\text { Maximum-Exposure } \\
\text { Location }\end{array}$ \\
\hline Site perimeter & 77 & 88 & Perimeter \#65-D \\
Air surveillance & 80 & 124 & Burial Ground North \\
Population centers & 93 & 117 & Beech Island, SC \\
NRCNogtle & 79 & 98 & GA Power \#4 High \\
& & & and NRC \#5 \\
\hline
\end{tabular}




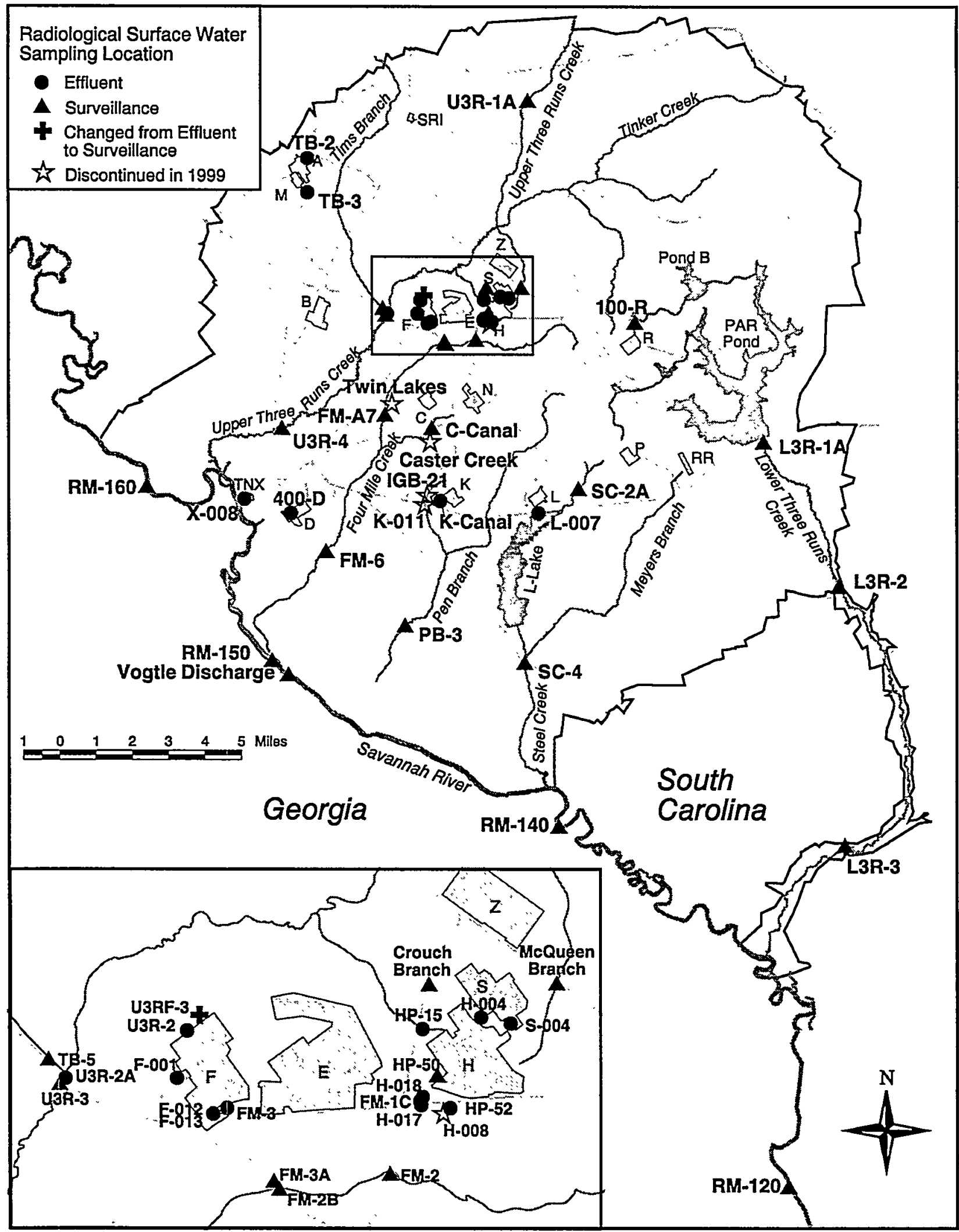

EPD/GIS Map

Figure 6-4 Radiological Surface Water Sampling Locations

Surveillance and effluent sampling points are at SRS seepage basins and streams and on the Savannah River. 
- Four Mile Creek receives effluents from F-Area and $\mathrm{H}$-Area, stormwater runoff from E-Area, C-Area, F-Area, and H-Area, and water that has migrated from seepage basins and is outcropping into the stream. Four Mile Creek transported the majority of radioactivity present in SRS streams during 1999-mostly in the form of gross beta-gamma activity and tritium.

- Pen Branch receives discharges and stormwater runoff from K-Area. Because K-Reactor has not operated since 1992, tritium detected in Pen Branch is attributed to groundwater seepage. The tritium sources are (1) the K-Area percolation field and seepage basins and (2) a migration source that enters the stream above PB-3.

- Lower Three Runs Creek receives overflow from PAR Pond, a manmade pond that receives seepage from R-Area basins and stormwater runoff from P-Area and R-Area.

- Steel Creek receives releases from L-Area effluents, tritium migration from $P$-Area seepage basins, and stormwater runoff from P-Area and L-Area.

During previous years, stream samples were collected every week and analyzed as either biweekly or monthly composites. Frequency and types of analyses performed on each sample were based on the potential quantity and type of radionuclides likely to be present in the water at the surveillance station. Generally, tritium determinations, gamma and alpha spectroscopy, and gross alpha and gross beta screenings were performed on stream water. Monthly composites also were analyzed for strontium-89,90-another likely byproduct of SRS operations.

Based on a critical contaminant/critical pathways analysis completed in 1998, a review was conducted in early 1999 of the stream sampling locations and historical data. Several changes subsequently were implemented in the stream sampling program, effective April 1. Five locations-Castor Creek, $\mathrm{H}-08$, IGB-21, K-11, and Twin Lakes-were eliminated from the program. Analyses were standardized for most locations to provide consistency. For all locations except U3R-1A, which is sampled weekly, sampling for gross alpha and gross beta, tritium, and gamma now is performed on a biweekly composite. Actinide analyses are performed annually on grab samples from all locations, while strontium-89,90 analyses are performed annually on grab samples from all except four locations on Four Mile Creek-4M-A7, 4MC-2B, 4MC-2, and $4 \mathrm{MC}-3 \mathrm{~A}$. Strontium analyses at these locations are performed on biweekly composite samples. However, more frequent actinide and/or strontium analyses were performed at several locations prior to implementation of the 1999 program changes.

\section{Surveillance Results}

The average gross alpha, gross beta, and tritium concentrations for 1999 at downstream locations near the creek mouths are presented in table 6-3. A graph showing the average tritium concentration over a 10 -year period is presented in figure $6-5$. The locations of these stations, well below all points at which radioactivity is introduced into the respective streams, ensure that adequate mixing has taken place

Table 6-3

Average 1999 Concentration of Radioactivity in SRS and Surveillance Station Waters (pCi/L)

\begin{tabular}{lccc}
\hline $\begin{array}{l}\text { Location } \\
\text { Onsite Downstream Locations }\end{array}$ & Gross Alpha & Gross Beta & Tritium \\
Tims Branch (TB-5) & $(3.13 \pm 0.29) E+00$ & $(1.80 \pm 0.16) \mathrm{E}+00$ & $(8.07 \pm 0.70) \mathrm{E}+02$ \\
Lower Three Runs (L3R-2) & $(9.15 \pm 1.01) \mathrm{E}-01$ & $(2.06 \pm 0.16) \mathrm{E}+00$ & $(2.36 \pm 0.17) \mathrm{E}+03$ \\
Steel Creek (SC-4) & $(1.49 \pm 0.23) \mathrm{E}+00$ & $(1.54 \pm 0.12) \mathrm{E}+00$ & $(6.26 \pm 0.45) \mathrm{E}+03$ \\
Pen Branch (PB-3) & $(3.47 \pm 0.77) \mathrm{E}-01$ & $(9.58 \pm 1.02) \mathrm{E}-01$ & $(1.03 \pm 0.03) \mathrm{E}+05$ \\
Four Mile Creek (FM-6) & $(4.84 \pm 1.10) \mathrm{E}+00$ & $(1.83 \pm 0.20) \mathrm{E}+01$ & $(1.91 \pm 0.03) \mathrm{E}+05$ \\
Upper Three Runs (U3R-4) & $(3.04 \pm 0.35) \mathrm{E}+00$ & $(1.68 \pm 0.19) \mathrm{E}+00$ & $(6.65 \pm 1.44) \mathrm{E}+03$
\end{tabular}

Onsite Surveillance Station (for comparison purposes) Upper Three Runs (U3R-1A) $\quad(3.67 \pm 0.17) E+00$
$(1.93 \pm 0.24) E+00$
$(3.82 \pm 0.39) \mathrm{E}+02$

a Site surveillance locations are near mouths of streams. 


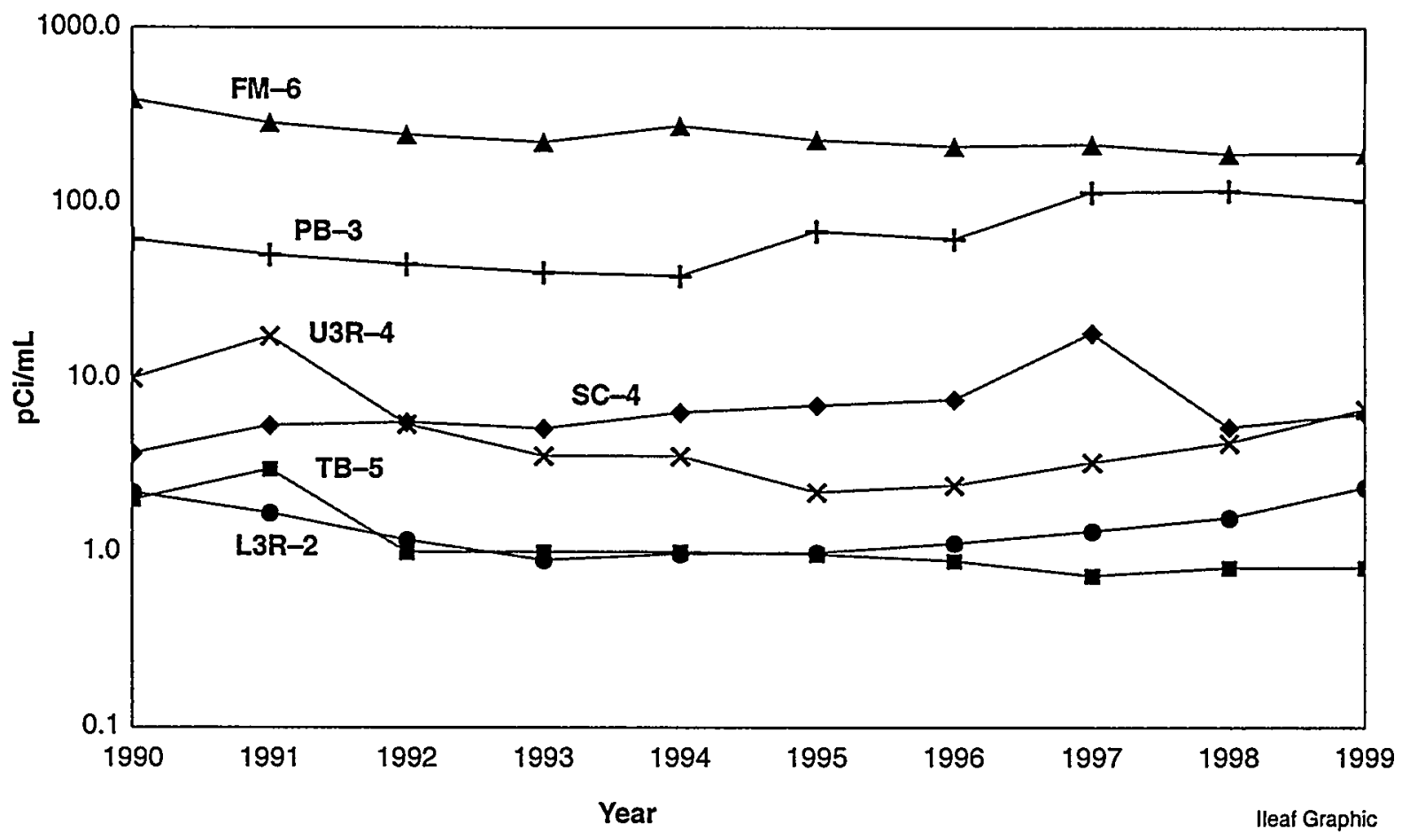

Figure 6-5 Average Tritium Concentration in SRS Streams, 1990-1999

Stream water analysis shows an increase in tritium concentration in three SRS streams.

and that a representative sample is being analyzed. Concentrations at surveillance station U3R-1A (above process effluents and runoff locations on Upper Three Runs Creek) are listed for comparison purposes in table 6-3. Detailed results of stream water analyses appear in table 16 of $S R S$ Environmental Data for 1999. Five-year trend charts showing gross alpha, gross beta, and cesium-137 concentrations for each major site stream appear in figure 6-6. The results in each chart are from the monitoring point nearest the stream's discharge to the Savannah River.

Gross alpha mean concentrations at L $3 \mathrm{R}-3, \mathrm{SC}-4$, FM-6, and U3R-4 have shown slight increases over the last 5 years. The highest mean concentration in 1999 , found at $\mathrm{FM}-6$, was $(4.84 \pm 1.10) \mathrm{E}+00 \mathrm{pCi} / \mathrm{L}$, or 32.2 percent of the $15-\mathrm{pCi} / \mathrm{L}$ EPA drinking water standard for gross alpha. Site dose calculations have noted an increase in plutonium-239 levels over the corresponding period. Much of the activity attributed to plutonium-239 was, in fact, unidentified alpha activity.

Mean gross beta concentrations were consistent with historical data except at the FM-6 location, which has shown a slight increase in mean concentration during the past 5 years. Strontium- 89,90 and cesium-137 are the primary contributors to gross beta activity.

Mean tritium concentrations at downstream locations were consistent with historical values, although the mean concentration at L3R-3 increased slightly in 1999.

\section{Seepage Basin and Solid Waste Disposal Facility Migration}

To incorporate the migration of radioactivity to site streams into total radioactive release quantities, EMS monitors and quantifies the migration of radioactivity from site seepage basins and the Solid Waste Disposal Facility (SWDF) as part of its stream surveillance program. During 1999, tritium, strontium-89,90, and cesium-137 were detected in migration releases (table 17, SRS Environmental Data for 1999). As noted in chapter 5 ('Radiological Effluent Monitoring"), measured iodine-129 results were not available from EMS and the value measured in 1996 was used for dose calculation. This value is reported in table 5-2 in chapter 5 and in tables 6 and 17, SRS Environmental Data for 1999.

Figure 6-7 is a graphical representation of releases of tritium via migration to site streams for the years 1990-1999. During 1999, the total quantity of tritium migrating from the seepage basins and SWDF was 

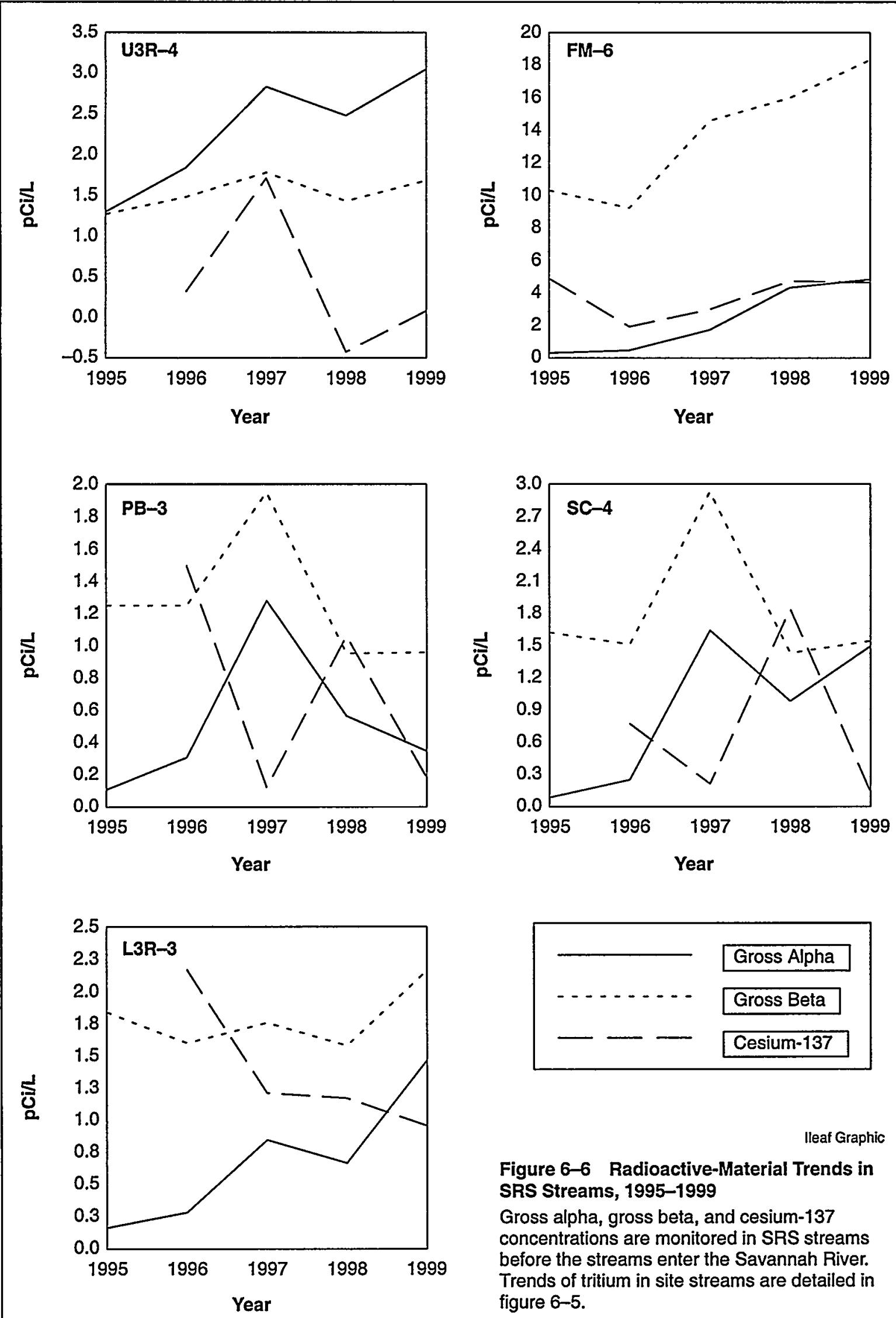

Ileaf Graphic

Figure 6-6 Radioactive-Material Trends in SRS Streams, 1995-1999

Gross alpha, gross beta, and cesium- 137 concentrations are monitored in SRS streams before the streams enter the Savannah River. Trends of tritium in site streams are detailed in figure 6-5. 


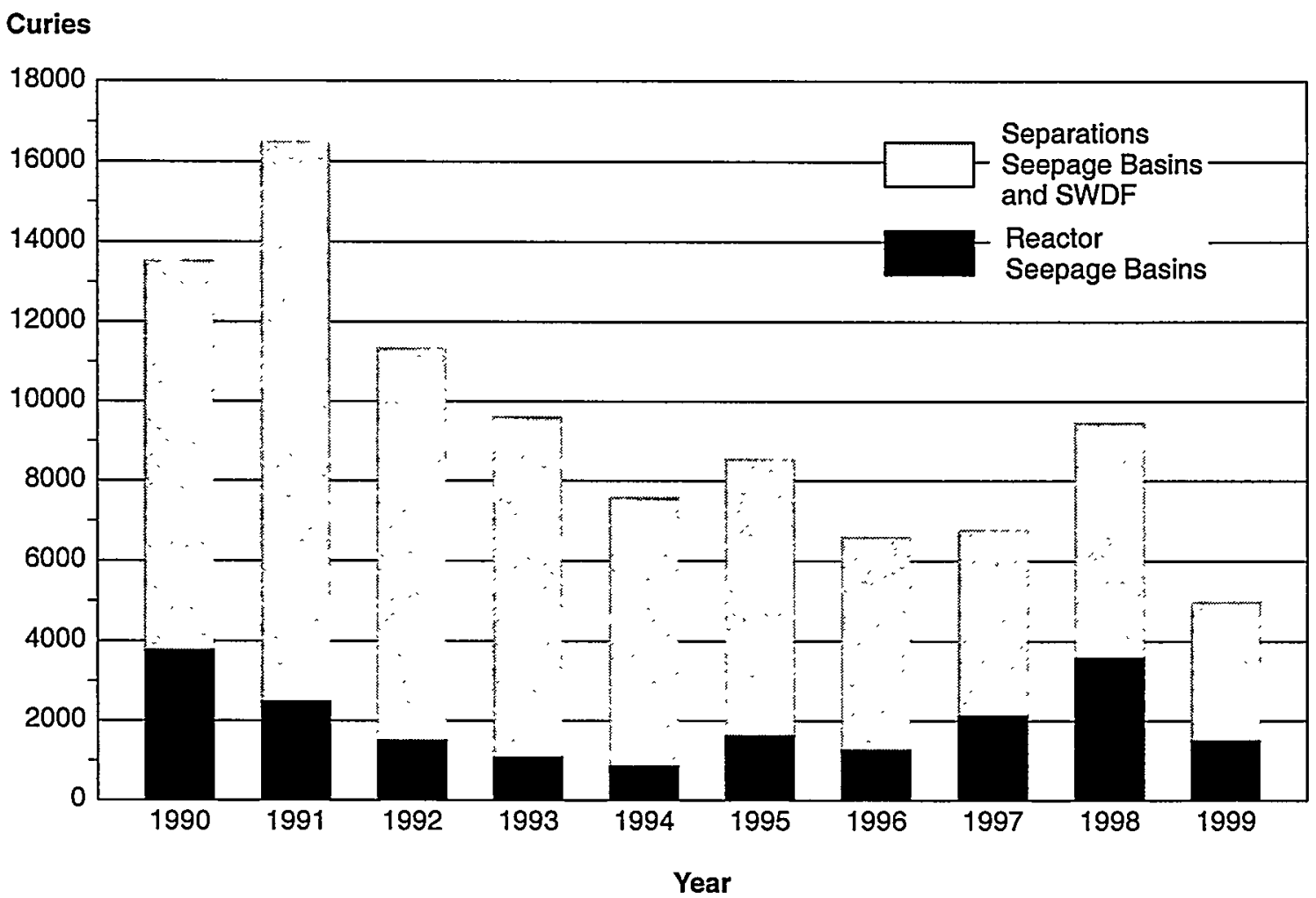

lleaf Graphic

Figure 6-7 Tritium Migration from Seepage Basins and SWDF to SRS Streams, 1990-1999

about $4,990 \mathrm{Ci}(1.84 \mathrm{E}+14 \mathrm{~Bq})$, compared to $9,460 \mathrm{Ci}$ (3.50E+14 Bq) in 1998 .

The total combined tritium releases in 1999 (direct discharges and migration from seepage basins and SWDF) were about $6,110 \mathrm{Ci}(2.26 \mathrm{E}+14 \mathrm{~Bq})$, compared to about $10,560 \mathrm{Ci}(3.91 \mathrm{E}+14 \mathrm{~Bq})$ in 1998 (table 18, SRS Environmental Data for 1999). The cause of this 42 percent decrease is not known, but decreases in tritium migration may be attributed to decreased rainfall. Figure 6-8 shows 1990-1999 total combined tritium releases.

In calculating dose (chapter 7, "Potential Radiation Doses"), the slightly higher stream transport value of $6,290 \mathrm{Ci}(2.32 \mathrm{E}+14 \mathrm{~Bq})$ was used instead of the total combined tritium release figure. SRS tritium transport data for 1960-1999 are detailed in table 21, SRS

Environmental Data for 1999, and depicted graphically in figure 6-10.

\section{F-Area and H-Area Seepage Basins and SWDF}

Radioactivity previously deposited in the F-Area and $\mathrm{H}$-Area seepage basins and SWDF continues to migrate via the groundwater and to outcrop into Four
Mile Creek (also known as Fourmile Branch) and into Upper Three Runs.

Groundwater migration from the F-Area seepage basins enters Four Mile Creek between sampling locations FM-3A, FM-2B, and FM-A7. Most of the outcropping from $\mathrm{H}$-Area seepage basins 1,2 , and 3 occurs between FM-1C and FM-2B. Outcropping from H-Area seepage basin 4 and part of SWDF occurs between FM-3 and FM-3A. Radioactivity from $\mathrm{H}$-Area seepage basin 4 and SWDF mixes during groundwater migration to Four Mile Creek. Therefore, radioactivity from the two sources cannot be distinguished at the outcrop point. Four Mile Creek sampling locations are shown in figure 6-4.

Measured migration of tritium from F-Area seepage basins was $648 \mathrm{Ci}(2.40 \mathrm{E}+13 \mathrm{~Bq})$ in 1999 . This is a 56 percent decrease from the 1998 total of $1,480 \mathrm{Ci}$ $(5.46 \mathrm{E}+13 \mathrm{~Bq})$. The measured migration from $\mathrm{H}$-Area seepage basin 4 and SWDF was 2,090 Ci $(7.73 \mathrm{E}+13 \mathrm{~Bq})$, a 40 -percent decrease from the 1998 total of $3,490 \mathrm{Ci}(1.29 \mathrm{E}+14 \mathrm{~Bq})$. The measured migration from $\mathrm{H}$-Area seepage basins 1,2 , and 3 was $258 \mathrm{Ci}(9.55 \mathrm{E}+12 \mathrm{~Bq})$, a 52-percent decrease from the 1998 total of $515 \mathrm{Ci}(1.918 \mathrm{E}+13 \mathrm{~Bq})$.

Generally, tritium migration from the F-Area and H-Area seepage basins, which were closed in 1988, 
has been declining and is projected to continue to decline [Looney, 1993]. Tritium migration from SWDF has fluctuated between 2,000 and $6,500 \mathrm{Ci}$ during the past 10 years. Based on recent assessments of the operational history of SWDF and the geology and hydrology of the site, it is anticipated that, with no corrective actions, SWDF tritium migration into Four Mile Creek will continue, but slowly decrease for the next 20 to 25 years [Flach, 1996].

In 1998, EMS began accounting for tritium migration into Upper Three Runs. This migration is quantified by subtracting direct discharges (principally from the Effluent Treatment Facility) to Upper Three Runs from the stream transport location U3R-4. In the past, these migration releases were included in the stream transport total for Upper Three Runs. The measured migration from the north side of SWDF and the General Separations Area (GSA) into Upper Three Runs in 1999 was $467 \mathrm{Ci}(1.73 \mathrm{E}+13 \mathrm{~Bq})$, a 21 -percent increase from the 1998 total of $386 \mathrm{Ci}$ $(1.43 \mathrm{E}+13 \mathrm{~Bq}$ ). (The GSA is in the central part of SRS and contains all waste disposal facilities, chemical separations facilities, associated high-level waste storage facilities, and numerous other sources of radioactive material.)
A 10-year history of tritium migration releases into Upper Three Runs is shown in figure 6-9. Except for the years 1990 and 1991, tritium migration into Upper Three Runs has remained between 150 and $500 \mathrm{Ci}$ per year. However, since 1996, the migration rate of tritium has been increasing. A recent computer-modeled groundwater migration study predicts increased tritium migration to Upper Three Runs during the next 20 years [Cook, 1997]. This analysis assumes all current and future tritium inventories will migrate relatively fast without considering past migration releases or potential corrective actions; these assumptions are considered to be very conservative. A complete and thorough assessment of tritium migration into Upper Three Runs that is based on measured groundwater concentrations and movement has not yet been performed.

As required by the Resource Conservation and Recovery Act (RCRA) Part B Permit, SRS is developing SWDF groundwater corrective action plans for South Carolina Department of Health and Environmental Control (SCDHEC) approval. Portions of SWDF also are regulated under the Comprehensive Environmental Response,

\section{Curies}

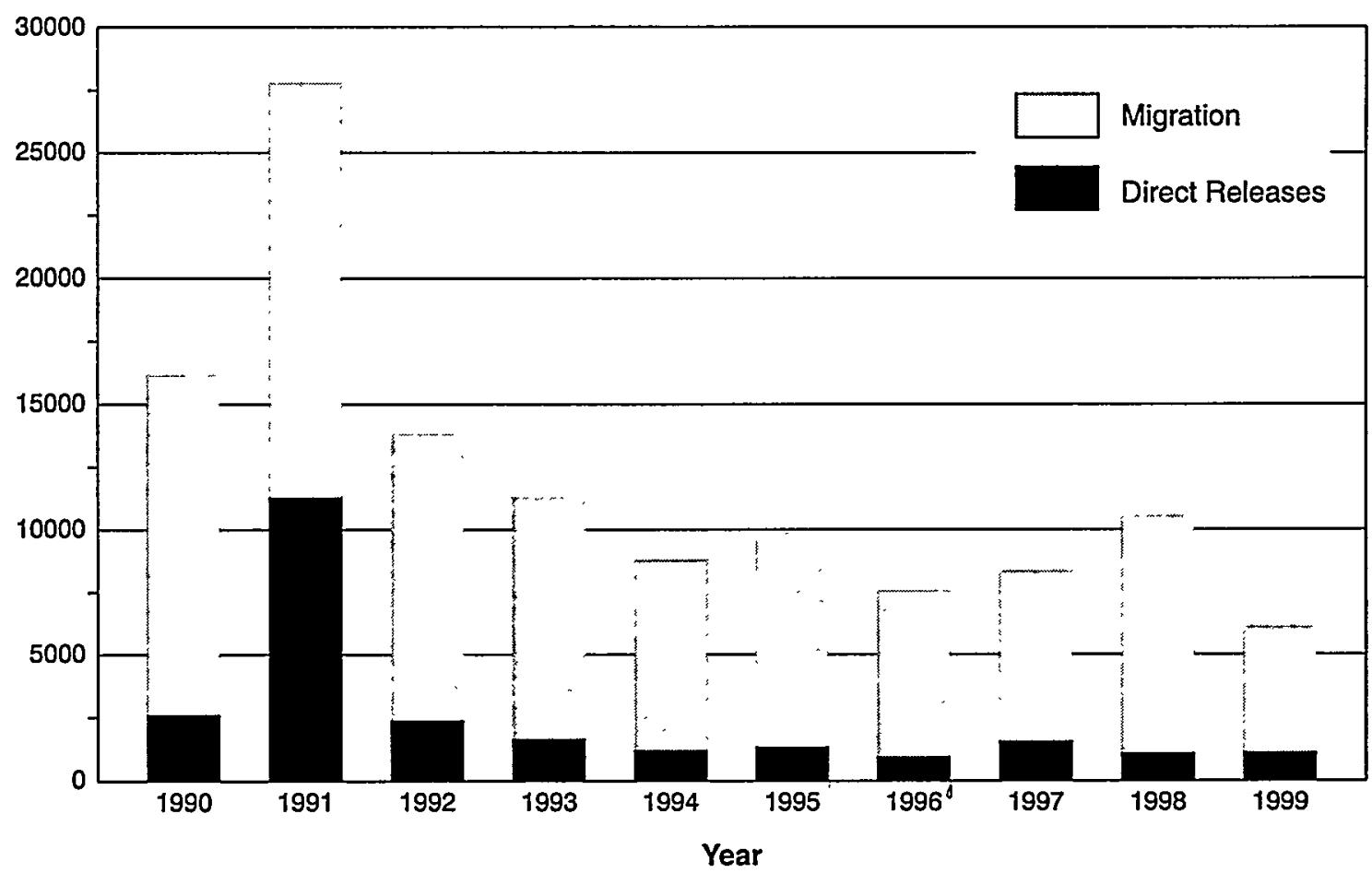

lleaf Graphic

Figure 6-8 Total Tritium Releases to SRS Streams (Direct Discharges and Migration), 1990-1999, Based on Point-of-Release Concentrations and Flow Rates 
Curies

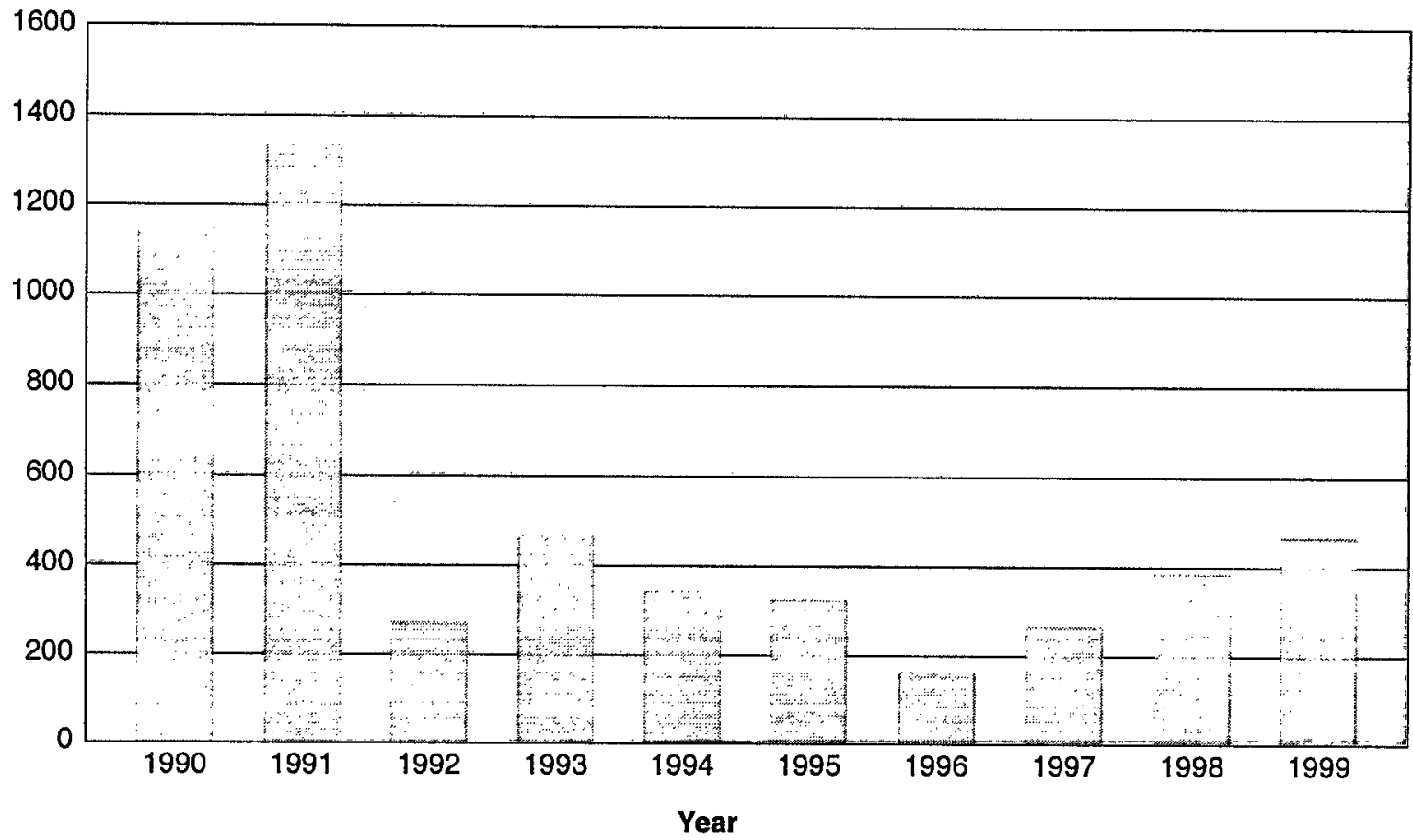

lleaf Graphic

Figure 6-9 Tritium Migration Releases to Upper Three Runs from the General Separations Area and SWDF, 1990-1999

Compensation, and Liability Act (CERCLA). CERCLA characterization and assessment continued in 1999. Reduction of tritium migration releases is one of the factors being considered during the development of these RCRA/CERCLA groundwater corrective action plans. Low-permeability caps, waste form stabilization, groundwater barriers, groundwater pump-treat-reinjection, and other technologies are under consideration, or are currently being implemented, as components of SWDF remediation. Remediation is discussed in chapter 4, "Environmental Management."

The total amount of strontium-89,90 entering Four Mile Creek from the GSA seepage basins and SWDF during 1999 was estimated to be $78 \mathrm{mCi}$ $(2.89 \mathrm{E}+09 \mathrm{~Bq})$. This was a 40-percent decrease from the 1998 level of $130 \mathrm{mCi}(4.81 \mathrm{E}+09 \mathrm{~Bq})$.

In addition, a total of $52.6 \mathrm{mCi}(1.95 \mathrm{E}+09 \mathrm{~Bq})$ of cesium-137 was estimated to have migrated from the GSA seepage basins and SWDF in 1999. As discussed previously, iodine-129 was not measured in Four Mile Creek water samples during 1999. It was assumed that $78.2 \mathrm{mCi}(2.89 \mathrm{E}+09 \mathrm{~Bq})$ migrated from the GSA seepage basins in 1999. This was the amount last measured (during 1996).

\section{K-Area Drain Field and Seepage Basin}

Liquid purges from the K-Area disassembly basin were released to the K-Area seepage basin in 1959 and 1960. Since 1960, purges from the K-Area disassembly basin have been discharged to a percolation field below the K-Area retention basin. A total tritium migration of $1,160 \mathrm{Ci}(4.29 \mathrm{E}+13 \mathrm{~Bq})$ was measured in Pen Branch during 1999. The sample location used to determine tritium migration from the K-Area seepage basin was changed in 1997 to $\mathrm{PB}-3$. This location was determined to be the best location for capturing all migration from $\mathrm{K}$-Area. The 1999 migration total represents a 62-percent decrease from the $3,090 \mathrm{Ci}(1.14 \mathrm{E}+14 \mathrm{~Bq})$ recorded in 1998.

\section{P-Area, C-Area, and L-Area Seepage Basins}

Liquid purges from the P-Area, L-Area, and C-Area disassembly basins were released periodically to their respective seepage basins from the 1950s until 1970 . Purge water was released to the seepage basins to allow a significant part of the tritium to decay before the water outcropped to surface streams and flowed into the Savannah River. The delaying action of the basins reduced the dose that users of water from downriver water treatment plants received from SRS tritium releases. Between 1970 and 1978, 
disassembly basin purge water was released directly to SRS streams. However, the earlier experience with seepage basins indicated that the extent of radioactive decay during the holdup was sufficient to recommend that the basins be used again in P-Area, L-Area, and C-Area, and the periodic release of liquid purges to the seepage basins was resumed. Because of SRS mission changes, however, these basins no longer are in service for receiving liquid purges from disassembly basins.

No radionuclide migration was attributed to the C-Area seepage basin in 1999. The failure of the Twin Lakes Dam in 1991 made the determination of migration more difficult in this area. Results from a sampler installed on Steel Creek above L-Lake indicated that $369 \mathrm{Ci}(1.37 \mathrm{E}+13 \mathrm{~Bq})$ of tritium migrated from the P-Area seepage basin during 1999 , 27 percent less than the $507 \mathrm{Ci}(1.88 \mathrm{E}+13 \mathrm{~Bq})$ of tritium in 1998. No migration of radionuclides from the L-Area seepage basin was detected in site streams.

\section{Transport of Actinides in Streams}

In 1996, a new and more sensitive analytical method for actinides was implemented for the analysis of uranium, plutonium, americium, and curium. As a result of the increased sensitivity, trace amounts of uranium and plutonium were detected at the stream transport locations FM-6, PB-3, L3R-2, and U3R-4. Consequently, these small amounts were incorporated into the source term used for the calculation of the annual dose. Results (1996 through 1999) can be found in table 19, SRS Environmental Data for 1999.

\section{Savannah River}

Continuous surveillance is performed along the Savannah River at points above and below SRS and below the point at which Plant Vogtle liquid discharges enter the river. In 1999, five locations along the river served as environmental surveillance points. River sampling locations are shown in figure 6-4.

\section{Description of Surveillance Program}

The Savannah River, which provides SRS its western boundary for a 35-mile stretch, is analyzed to determine what effects, if any, the site's effluents have on the river water. The five river locations are sampled by biweekly composites and analyzed for gross alpha, gross beta, tritium, and gamma-emitting radionuclides. An annual grab sample is obtained at each location and analyzed for strontium- 89,90 and actinides.

\section{Surveillance Results}

Detailed results of Savannah River water analyses can be found in table 20 of SRS Environmental Data for 1999.

\section{Gross Alpha, Gross Beta, and Tritium}

The average concentrations of gross alpha, gross beta, and tritium at river locations are presented in table 6-4. The order of the locations begins at RM (river mile)-160, above the site, and ends at RM-120, after all site streams enter the Savannah River. Samplers situated between RM-160 and RM-120 are located at regular intervals along the SRS boundary and where Plant Vogtle's discharges feed into the river.

Tritium is the predominant radionuclide detected above background levels in the Savannah River. The maximum concentration recorded on the river in $1999,(8.42 \pm 0.092) \mathrm{E}+03 \mathrm{pCi} / \mathrm{L}$, was found at the RM-150.4 location and represents 42 percent of the EPA drinking water standard for tritium. The maximum tritium concentration at RM-120, the farthest downstream river location, was $(2.21 \pm 0.12) \mathrm{E}+03 \mathrm{pCi} / \mathrm{L}$-approximately 11.5 percent of the EPA drinking water standard set by the EPA for tritium in drinking water. The annual mean tritium concentration at RM-120 was $(1.19 \pm 060) \mathrm{E}+03 \mathrm{pCi} / \mathrm{L}$ - less that 6 percent of the drinking water standard.

Table 6-4

Average 1999 Concentration of Radioactivity in the Savannah River (pCi/L)

\begin{tabular}{llcc}
\hline Location & Gross Alpha & Gross Beta & Tritium \\
\hline$R M-120$ & $(2.08 \pm 0.38) \mathrm{E}-01$ & $(2.12 \pm 0.08) \mathrm{E}+00$ & $(1.19 \pm 0.06) \mathrm{E}+03$ \\
$\mathrm{RM}-140$ & $(1.18 \pm 0.42) \mathrm{E}-01$ & $(2.35 \pm 0.09) \mathrm{E}+00$ & $(1.46 \pm 0.07) \mathrm{E}+03$ \\
$\mathrm{RM}-150$ & $(1.27 \pm 0.46) \mathrm{E}-01$ & $(2.12 \pm 0.09) \mathrm{E}+00$ & $(2.02 \pm 0.06) \mathrm{E}+03$ \\
$\mathrm{RM}-150.4$ (Vogtle discharge) & $(5.50 \pm 0.93) \mathrm{E}-01$ & $(2.58 \pm 0.11) \mathrm{E}+00$ & $(1.92 \pm 0.25) \mathrm{E}+03$ \\
$\mathrm{RM}-160$ & $(5.93 \pm 4.90) \mathrm{E}-02$ & $(2.22 \pm 0.07) \mathrm{E}+00$ & $(8.72 \pm 0.16) \mathrm{E}+01$ \\
\hline
\end{tabular}


The mean gross alpha concentration at each river location was below the nominal LLD in 1999, which demonstrates the absence of significant alpha-emitting radionuclides in the river. The maximum gross alpha concentration for all river locations, $(2.67 \pm 0.91) \mathrm{E}+00 \mathrm{pCi} / \mathrm{L}$, was found at the RM-150.4 site and was approximately 17.8 percent of the $15-\mathrm{pCi} / \mathrm{L}$ drinking water standard for alpha activity. The maximum concentration for 1999 at the $\mathrm{RM}-120$ location, $(9.78 \pm 4.18) \mathrm{E}-01 \mathrm{pCi} / \mathrm{L}$, was less than 7 percent of the drinking water standard for alpha activity. The maximum alpha activity level at RM-120 was nearly identical to that found at RM-160-the sampling location upstream of all SRS discharge points.

Gross beta activities at all locations were slightly above the nominal LLD for the analysis in 1999. All mean and maximum concentrations were nearly identical at all locations, indicating that there was no significant buildup of beta-emitting nuclides attributable to SRS discharges.

All mean and maximum concentrations for cesium-137 were below the nominal LLD for the analysis in 1999. The mean concentration at the upstream location (RM-160) actually was higher than at the downstream location (RM-120).

All mean concentrations for cobalt- 60 were below the nominal LLD for the analysis in 1999. At one location, RM-150.4, the maximum value for the year was slightly above the LLD but not significantly higher than the upstream $(R M-120)$ value.

\section{Strontium-89,90 and Actinides}

Activity levels for strontium-89,90-as well as for all actinides, including isotopes or uranium and plutonium - were below the representative minimum detectable concentration for radiological analysis.

\section{Tritium Transport in Streams and River}

Tritium is introduced into SRS streams and the Savannah River from production areas on site. Because of the mobility of tritium in water and the quantity of the radionuclide released during the years of SRS operations, a tritium balance has been performed annually since 1960 (table 21, SRS Environmental Data for 1999). The balance is evaluated among the following alternative methods of calculation:

- tritium releases from effluent release points and calculated seepage basin and SWDF migration (direct releases; totals appear on page 90)
- tritium transport in SRS streams and the last sampling point before entry into the Savannah River (stream transport)

- tritium transport in the Savannah River downriver of SRS after subtraction of any measured contribution above the site (river transport)

Figure 6-10 shows graphic and numeric summaries of the last 40 years of direct releases, stream transport, and river transport determined by EMS.

During 1999, the total tritium transport in SRS streams decreased by approximately 41 percent (from $10,600 \mathrm{Ci}$ in 1998 to $6,290 \mathrm{Ci}$ in 1999). The 1999 measured tritium transport in the Savannah River $(5,810 \mathrm{Ci})$ was slightly less than the stream transport total. Estimated tritium releases in SRS streams and the Savannah River can be found in table 18 of SRS Environmental Data for 1999.

General agreement between the three calculational methods of annual tritium transport-measurements at the source, stream transport, and river transport-serves to validate SRS sampling schemes and counting results. Differences between the various methods can be attributed to uncertainties arising in the collection and analytical processes, including determinations of water flows and varying transport times. For conservatism, the highest of the results obtained from the three methods is used in annual environmental dose calculations (chapter 7).

\section{Drinking Water}

EMS collects drinking water samples from locations at SRS and at water treatment facilities that use Savannah River water. Potable water is analyzed at offsite treatment facilities to ensure that SRS operations are not adversely affecting the water supply and to provide voluntary assurance that drinking water does not exceed EPA drinking water standards for radionuclides.

\section{Description of Surveillance Program}

Onsite sampling consists of quarterly grab samples at large treatment plants in A-Area, D-Area, and K-Area and annual grab samples at wells and small systems. Collected monthly off site are composite samples from

- two water treatment plants downriver of SRS that supply treated Savannah River water to Beaufort and Jasper counties in South Carolina and to Port Wentworth, Georgia

- the North Augusta (South Carolina) Water Treatment Plant 


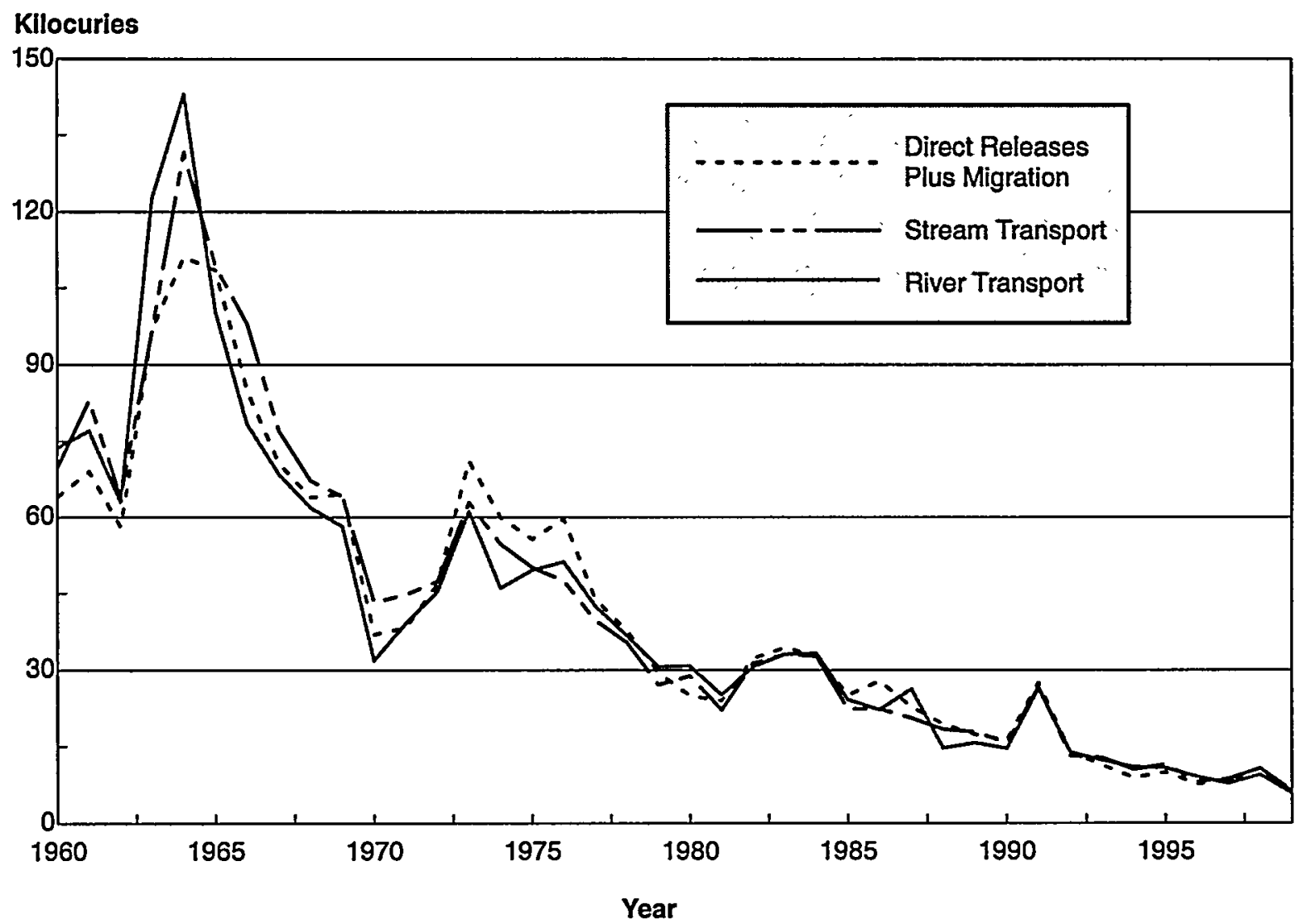

lleaf Graphic

Figure 6-10 SRS Tritium Transport Summary, 1960-1999

SRS has maintained a tritium balance of direct releases plus migration, stream transport, and river transport since 1960 in an effort to account for and trend tritium releases in liquid effluents from the site. The general downward slope over time indicates that tritium transport has decreased as production has slowed and effluent controls have been developed.

At all the offsite facilities, raw and finished water samples are collected daily and composited for analysis by EMS. All drinking water samples are screened for alpha, beta, and gamma emitters and analyzed specifically for tritium. The onsite samples also are analyzed once a year for actinides and strontium-89,90.

\section{Surveillance Results}

\section{Gross Alpha and Gross Beta}

All drinking water samples collected by EMS are screened for gross alpha and gross beta concentrations to determine if activity levels warrant further analysis (table 22, SRS Environmental Data for 1999). No samples collected in 1999 exceeded EPA's $1.50 \mathrm{E}+01-\mathrm{pCi} / \mathrm{L}$ alpha activity limit or $5.00 \mathrm{E}+01-\mathrm{pCi} / \mathrm{L}$ beta activity limit. In 1999 , the highest alpha concentration in SRS drinking water was $(1.08 \pm 2.28) \mathrm{E}+01-\mathrm{pCi} / \mathrm{L}$-at the 701-5G Aiken Barricade (Talatha Gate). Analysis of the sample for radium-226 showed a concentration of $(6.26 \pm 1.31) \mathrm{E}+00 \mathrm{pCi} / \mathrm{L}$. This analysis reflects the radionuclide content of groundwater at the supply well, but the water at Talatha Gate is used for hand-washing - not human consumption. For consumption, a separate source (bottled water) was used at the Aiken barricade location in 1999. No sample exceeded $8.00 \mathrm{E}+00 \mathrm{pCi} / \mathrm{L}$ of beta activity-the EPA limit for strontium-90, which is the most restrictive beta-emitting radionuclide.

\section{Strontium}

No drinking water samples collected and analyzed by EMS for strontium-89,90 in 1999 exceeded the $1.90 \mathrm{E}+00-\mathrm{pCi} / \mathrm{L}$ nominal LLD. This limit is approximately 25 percent of the EPA drinking water standard for strontium- 90 .

\section{Radon}

Results from radon samples collected December 9 from A-Area, B-Area, D-Area, and K-Area drinking water wells all were below a proposed regulatory 
limit of $3.00 \mathrm{E}+02 \mathrm{pCi} / \mathrm{L}$ for community water systems. The average result was

$1.40 \mathrm{E}+02 \pm 4 \mathrm{E}-02 \mathrm{pCi} / \mathrm{L}$, with a range of 0 to $2.32 \mathrm{E}+02 \mathrm{pCi} / \mathrm{L}$.

This sampling was conducted in response to a proposed EPA regulation that would establish a radon maximum contaminant limit (MCL) of 3.00E+02 $\mathrm{pCi} / \mathrm{L}$ for community water systems [EPA, 1999]. Although the regulation is not expected to apply to SRS systems, the one-time special sampling was conducted to characterize radon concentrations in SRS wells and to verify that site radon levels are below the proposed MCL.

\section{Tritium}

No onsite or offsite drinking water samples collected and analyzed by EMS in 1999 exceeded the 2.00E+04-pCi/L EPA tritium limit. The highest level observed was $(2.44 \pm 0.23) \mathrm{E}+03 \mathrm{pCi} / \mathrm{L}$-at $701-13 \mathrm{G}$ (Patrol Gate 6). Detectable levels of tritium were present in the drinking water samples collected monthly from the Beaufort-Jasper and Port Wentworth water treatment facilities. These levels reflect the introduction of tritium from SRS operations into the Savannah River. The average tritium concentration in finished water at Beaufort-Jasper in 1999, $(9.72 \pm 2.33) \mathrm{E}+02 \mathrm{pCi} / \mathrm{L}$, was 4.9 percent of the EPA drinking water limit. The average tritium concentration at Port Wentworth, $(9.65 \pm 2.16) \mathrm{E}+02 \mathrm{pCi} / \mathrm{L}$, was 4.8 percent of the EPA drinking water limit. The levels of tritium at both treatment facilities were about one percent higher than those measured in 1998.

\section{Terrestrial Food Products}

The terrestrial food products surveillance program consists of radiological analyses of food product samples typically found in the Central Savannah River Area (CSRA). Because radioactive materials can be transported to man through the consumption of milk and other food products containing radioactivity, food product samples are analyzed to determine what effects, if any, SRS operations have on them. Data from the food product surveillance program are not used to show direct compliance with any dose standard; however, the data can be used as required to verify dose models and determine environmental trends.

\section{Description of Surveillance Program}

\section{Meat, Fruit, and Greens}

The food products surveillance program divides the area that surrounds the SRS, approximately 9 miles $(15 \mathrm{~km})$ beyond its perimeter, into four quadrants: northeast, southeast, southwest, and northwest. Samples of food-including meat (beef or chicken), fruit (peaches or melons), and green vegetables (collards)-are collected from one location within each of the quadrants and from a control location within an extended (to 25 miles beyond the perimeter) southeast quadrant. All food samples are collected annually except milk.

Food samples are analyzed for the presence of gamma-emitting radionuclides, tritium, strontium-89,90, plutonium-238, and plutonium 239.

\section{Milk}

During 1999, EMS collected milk samples at five dairies within a 25-mile radius of SRS and from locally produced inventories of a major distributor. Because the dairy at Jackson, South Carolina, closed in June, only the first 5 months of samples were collected from that location.

Milk samples are collected monthly to be analyzed for the presence of tritium and gamma-emitting radionuclides, primarily cesium-137 and iodine-131. Additional samples are collected quarterly to be analyzed for the presence of strontium-89,90.

\section{Surveillance Results}

One sample of milk was not available for collection during the scheduled time frame in 1999. Detailed results of all food sample analyses can be found in tables 23 and 24 in SRS Environmental Data for 1999.

\section{Gamma-Emitting Radionuclides}

The only manmade gamma-emitting radionuclide detected in food products, excluding milk, was cesium-137. The maximum concentration, $(1.32 \pm 0.12) \mathrm{E}-01 \mathrm{pCi} / \mathrm{g}$, was measured in beef from the 0-10-mile north quadrant. Generally, concentrations of cesium-137 in indicator samples were similar to those measured at the control location. These concentrations were similar to those observed in previous years.

Cesium-137 also was the only manmade gamma-emitting radionuclide detected in milk samples during 1999. Measured average concentrations ranged from a high of 
$(7.14 \pm 1.43) \mathrm{E}+00 \mathrm{pCi} / \mathrm{L}$ at the Denmark, South Carolina, location to lows below the nominal LLD at several locations. The mean concentrations measured in 1999 were similar to those measured in 1998.

Iodine-131 was not detected in any 1999 milk samples. Because of its short physical half-life (8 days), iodine-131 generally is not detected, except

- shortly after tests of nuclear weapons

- in the wake of events such as the Chernobyl incident

- during reactor operations

- when processing fresh fuel

- when the isotope is used medically, industrially, or for research.

\section{Tritium}

Tritium in milk and other samples is attributed primarily to releases from SRS. Tritium concentrations in food products, excluding milk, ranged from a high of $(1.19 \pm 0.21) \mathrm{E}-00 \mathrm{pCi} / \mathrm{g}$, measured in fruit from the 0-25-mile southeast quadrant, to lows below the nominal LLD in several samples. The concentrations were similar to those measured in 1998.

Milk from one dairy showed detectable concentrations of tritium at some point during 1999. The maximum concentration, $(6.66 \pm 1.25) \mathrm{E}+02 \mathrm{pCi} / \mathrm{L}$, was measured at the Jackson location. The minimum concentration was below the nominal LLD at several locations. Tritium concentrations measured in milk in 1999 were slightly lower than those in 1998 and generally reflected atmospheric releases from the site.

\section{Strontium}

The highest strontium- 89,90 concentration detected in food products, excluding milk, during 1999 was $(8.84 \pm 2.15) \mathrm{E}-02 \mathrm{pCi} / \mathrm{g}$-found in greens from the southeast quadrant; the lowest was below the nominal LLD at several locations. Strontium- 89,90 levels generally were within the ranges observed during past years.

The 1999 results from the analysis of milk for strontium- 89,90 showed that only a sample from the Waynesboro, Georgia, location-at (5.52 \pm 1.65$) \mathrm{E}+00 \mathrm{pCi} / \mathrm{L}-$ had a concentration above the nominal LLD; none of the remaining samples collected showed detectable concentrations. Milk data from several quarters in 1999 were not accepted because of poor precision in duplicate measurements.

\section{Plutonium}

Plutonium-238 concentrations in food products, excluding milk, were detected during 1999 in beef from the 0-10-mile southeast quadrant, at $(2.08 \pm 1.00) \mathrm{E}-04 \mathrm{pCi} / \mathrm{g}$, and in fruit from the 0-10-mile southwest quadrant, at $(2.59 \pm 0.14) \mathrm{E}-04 \mathrm{pCi} / \mathrm{g}$. Plutonium-239 concentrations in food products, excluding milk, during 1999 were below the nominal LLD at all five sampling locations and were similar to the 1998 concentrations.

\section{Aquatic Food Products}

\section{Description of Surveillance Program}

The aquatic food product surveillance program includes both fish (freshwater and saltwater) and shellfish. To determine the potential dose and risk to the public from consumption of these fish, both are sampled.

Nine surveillance points for the collection of freshwater fish are located on the Savannah River (figure 6-11). These points are at

- the New Savannah Bluff Lock and Dam area (the control location), above the site

- five areas where site streams enter the Savannah River

- the U.S. Highway 301 bridge area, below the site

- Stokes Bluff Landing, below the site

- the U.S. Highway 17 bridge area, below the site

Nine surveillance points for freshwater fish collection also are located within the SRS boundary. These points are at PAR Pond, L-Lake, Pond B, Lower Three Runs Creek, Upper Three Runs Creek, Beaver Dam Creek, Pen Branch, Steel Creek, and Four Mile Creek. Freshwater fish are grouped into one of three categories: bass, panfish (bream), or catfish.

Saltwater fish are collected from the U.S. Highway 17 bridge area and include composites of sea trout, red drum (spottail bass), and mullet. The fish are selected for sampling because they are the most sought-after fish in the Savannah River, according to the latest creel survey conducted by the Fisheries Management Section of GDNR's Wildlife Resources Division.

For analysis purposes, five fish from each category at each collection location are combined to create a composite. Composites are divided into edible (meat and skin only) and nonedible (scales, head, fins, viscera, bone) portions; however, catfish are skinned and the skin becomes part of the nonedible 


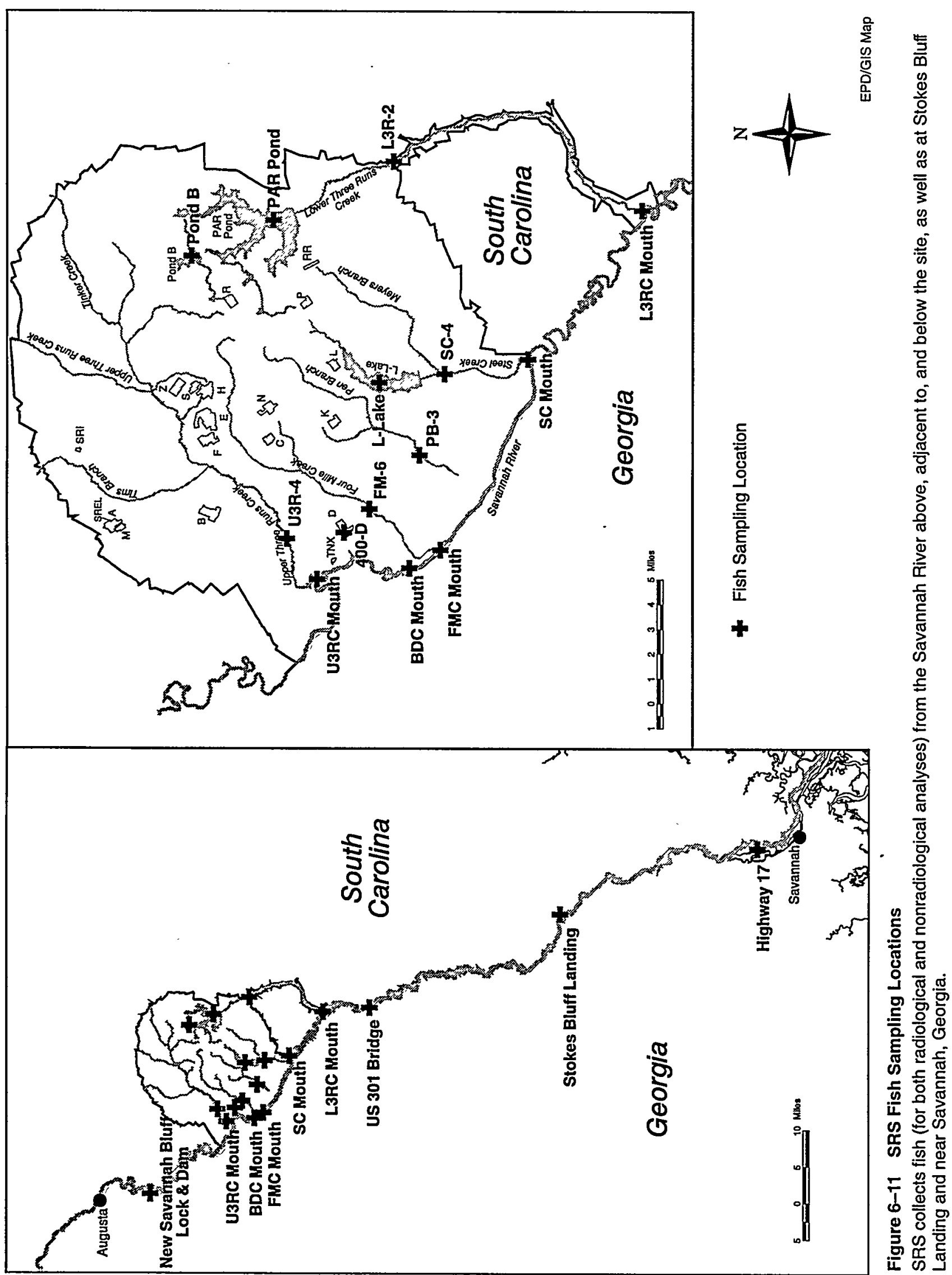


composite. Analyses are conducted for gross alpha and gross beta on edible portions for all locations and on nonedible portions for all offsite locations except those at Stokes Bluff Landing and at the U.S. Highway 17 bridge area. Freshwater fish collected from the New Savannah Bluff Lock and Dam location downstream through the U.S. Highway 301 bridge area also are analyzed for strontium-89,90; plutonium-238 and plutonium-239 and tritium (edible portions only); and gamma-emitting radionuclides. Freshwater fish (edible portions only) from river locations at Stokes Bluff Landing and the U.S. Highway 17 bridge area and from onsite streams and ponds are analyzed for gross alpha, gross beta, and gamma-emitting radionuclides.

A one-time special sample of shad, requested by DOE's Savannah River Operations Office (DOE-SR) to determine the levels of radionuclides in the fish, was conducted at four locations during the year: the U.S. Highway 301 bridge area, the mouths of Steel Creek and Four Mile Creek, and the New Savannah Bluff Lock and Dam. Fifteen fish were collected at each location and analyzed the same way as the standard fish from that location. (Data from this collection were summarized with the routine data, whose analysis results appear in the next section.)

Saltwater fish (edible portions only) also are analyzed for gross alpha, gross beta, and gamma-emitting radionuclides.

In the shellfish surveillance program, samples of oysters and crabs are collected on the coast near Savannah. The shellfish are analyzed for gross alpha, gross beta, strontium-89,90, and gamma-emitting radionuclides.

Calculations of risk from the consumption of fish from the Savannah River can be found in chapter 7 .

\section{Surveillance Results}

In the following surveillance results discussion, uncertainty values are provided because most measurements were at or near the LLDs.

\section{Freshwater Fish}

Detailed analytical results from freshwater fish composites can be found in table 25 of SRS Environmental Data for 1999.

Savannah River All categories of freshwater fish from all nine Savannah River locations were collected during 1999, including the DOE-SR special samples.
Gross alpha activity in Savannah River edible composites was below the LLD at all nine sampling locations, and gross alpha activity in river nonedible composites was below the LLD at five of seven sampling locations. Catfish, at $(1.66 \pm 1.12) \mathrm{E}+00 \mathrm{pCi} / \mathrm{g}$, was above the LLD at mouth of Four Mile Creek, and shad, at $(1.50 \pm 1.12) \mathrm{E}+00 \mathrm{pCi} / \mathrm{g}$, was above the LLD at the New Savannah Bluff Lock and Dam.

Gross beta activity in Savannah River edible composites was detectable at all nine locations and was attributed primarily to the naturally occurring radionuclide potassium- 40 . The values ranged from a high of $(4.09 \pm 0.47) \mathrm{E}+00 \mathrm{pCi} / \mathrm{g}$ in catfish from the mouth of Steel Creek to a low of $(1.09 \pm 0.33) \mathrm{E}-00 \mathrm{pCi} / \mathrm{g}$ in catfish from the mouth of Beaver Dam Creek. Gross beta activity in river nonedible composites was detectable at all seven locations, ranging from a high of $(3.65 \pm 1.06) \mathrm{E}+00$ $\mathrm{pCi} / \mathrm{g}$ in bass from the mouth of Upper Three Runs Creek to lows below the LLD in several composites.

Cesium- 137 was the only manmade, gamma-emitting radionuclide detected in 1999 fish composites. Cesium-137 activity in Savannah River edible composites was detectable at all nine sampling locations, ranging from a high of $(9.20 \pm 0.65) \mathrm{E}-01 \mathrm{pCi} / \mathrm{g}$ in bass from the mouth of Steel Creek to lows below the LLD in several composites. Cesium-137 activity in river nonedible composites was detectable at all seven sampling locations, ranging from a high of $(7.11 \pm 0.51) \mathrm{E}-01 \mathrm{pCi} / \mathrm{g}$ in bass from the mouth of Steel Creek to lows below the LLD in several composites.

Strontium-89,90 activity in Savannah River edible fish in 1999 was detectable at all seven sampling locations, ranging from a high of $(4.66 \pm 1.07) \mathrm{E}-02 \mathrm{pCi} / \mathrm{g}$ in bream from the mouth of Lower Three Runs Creek to lows below the LLD in several composites. Strontium-89,90 in river nonedible composites was detectable at all seven sampling locations, ranging from a high of $(4.51 \pm 0.56) \mathrm{E}-01 \mathrm{pCi} / \mathrm{g}$ in bream from the mouth of Beaver Dam Creek to a lows below the LLD in several composites.

Tritium activity in Savannah River edible composites in 1999 was detectable at all of the seven sampling locations and ranged from a high of $(2.38 \pm 0.01) \mathrm{E}+00 \mathrm{pCi} / \mathrm{g}$ in catfish from the mouth of Steel Creek to lows below the LLD in several composites.

Onsite Streams and Ponds Not enough fish of appropriate size could be collected from onsite 
streams and ponds in 1999 for any composite samples (five from the same category per location) from Four Mile Creek, Pen Branch, Steel Creek, Beaver Dam Creek, or Upper Three Runs Creek.

Gross alpha activity in fish composites (edible portions only) from onsite streams and ponds was below the LLD at all of the four sampled locations except for bass at Pond $B$, which had a level of $(2.54 \pm 0.65) \mathrm{E}+00 \mathrm{pCi} / \mathrm{g}$. Gross beta activity, on the other hand, was detectable at all of these locations and ranged from a high of $(6.83 \pm 0.17) \mathrm{E}+01 \mathrm{pCi} / \mathrm{g}$ in bass from Pond $B$ to a low of $(1.30 \pm 0.33) E-00$ $\mathrm{pCi} / \mathrm{g}$ in bream from L-Lake.

Cesium-137-the only manmade, gamma-emitting radionuclide found in 1999 fish composites from onsite streams and ponds-was detectable at all four sampled locations. The activity ranged from a high of $(6.73 \pm 0.34) \mathrm{E}+01 \mathrm{pCi} / \mathrm{g}$ in bass from Pond $\mathrm{B}$ to a low of $(2.48 \pm 0.42) \mathrm{E}-01 \mathrm{pCi} / \mathrm{g}$ in bream from L-Lake.

\section{Saltwater Fish}

In the saltwater fish category, red drum (spottail bass) sea trout, and mullet were collected in 1999 from the U.S. Highway 17 bridge area; the lone composite of sea trout, however, contained only three fish. All gross alpha concentrations measured in saltwater fish composites during 1999 were below the LLD. Gross beta concentrations, however, were detectable in all seven composites collected and ranged from a high of $(2.61 \pm 0.41) \mathrm{E}+00 \mathrm{pCi} / \mathrm{g}$ in spottail bass to a low of $(1.73 \pm 0.39) \mathrm{E}+00 \mathrm{pCi} / \mathrm{g}$, in mullet.

No manmade, gamma-emitting radionuclides were detected in 1999 saltwater fish composites.

Detailed analytical results from saltwater fish composites can be found in table 26 of SRS Environmental Data for 1999.

\section{Shellfish}

A sample of oysters and a sample of crabs-both from near the mouth of the Savannah River-were collected in 1999. Analytical results showed that no manmade radionuclides above the LLDs were present in these samples (table 27, SRS Environmental Data for 1999).

\section{Deer and Hogs}

\section{Description of Surveillance Program}

Annual hunts, open to members of the general public, are conducted at SRS to control the site's deer and feral hog populations and to reduce animal-vehicle accidents. Before any animal is released to a hunter, EMS uses portable sodium iodide detectors to perform field analysis for cesium-137. The dose resulting from consumption is calculated for each animal, and each hunter's cumulative total is tracked to ensure compliance with the DOE dose limit for the general public. Media samples (muscle and/or bone) are collected periodically for laboratory analysis based on a set frequency, on cesium-137 levels, and/or on exposure limit considerations.

\section{Surveillance Results}

During 1999, 1,003 deer and 45 feral hogs were taken from the site as part of the controlled hunt program. This compares with 1,293 deer and 61 feral hogs taken during the 1998 hunts. The number of hunts, which is determined each year by site safety and wildlife management concerns, remained at 12 in 1999.

\section{Gamma-Emitting Radionuclides}

In 1999, the maximum field measurement of cesium- 137 in deer muscle was approximately 20 $\mathrm{pCi} / \mathrm{g}$, while the mean cesium-137 concentration was approximately $3 \mathrm{pCi} / \mathrm{g}$. In feral hogs, the maximum field measurement of cesium- 137 in muscle was approximately $30 \mathrm{pCi} / \mathrm{g}$, while the mean concentration was approximately $5 \mathrm{pCi} / \mathrm{g}$.

Each animal is monitored prior to release, and the field measurements are supplemented by laboratory analyses. Samples are collected from approximately 10 percent of the animals processed, including every 10th animal monitored and any animal that it is estimated will result in a hunter's annual dose exceeding $25 \mathrm{mrem}$ (approximately 25 percent of the DOE limit) - either alone or in combination with previous animals killed by the hunter. In 1999, 112 samples from 104 animals were collected and analyzed for gamma-emitting radionuclides.

As observed during previous hunts, cesium- 137 was the only manmade gamma-emitting radionuclide detected during laboratory analysis. Generally, the cesium- 137 concentrations measured by the field and lab methods were comparable. Field measurements ranged from approximately $1 \mathrm{pCi} / \mathrm{g}$ to $30 \mathrm{pCi} / \mathrm{g}$, while lab measurements ranged from approximately $1 \mathrm{pCi} / \mathrm{g}$ to $48 \mathrm{pCi} / \mathrm{g}$.

\section{Strontium}

Strontium levels are determined in some of the animals analyzed for cesium-137. Typically, muscle and bone samples are collected for analysis from the same animals checked for cesium-137, and the samples are analyzed for strontium-89,90. 
In 1999, 26 muscle samples from 18 animals and eight bone samples from eight animals were collected for strontium-89,90 analysis. However, because of laboratory backlog, these samples were not analyzed.

\section{Turkeys}

\section{Description of Surveillance Program}

Wild turkeys are trapped on site by the South Carolina Wildlife and Marine Resources Department and used to repopulate game areas in South Carolina and other states. All turkeys are monitored for cesium-137 with portable sodium iodide detectors before leaving SRS. No turkey with a reading above $25 \mathrm{pCi} / \mathrm{g}$ is released off site.

\section{Surveillance Results}

EMS monitored 29 turkeys in 1999. Concentrations of cesium- 137 generally were similar to those measured in the past, with all results $4.0 \mathrm{pCi} / \mathrm{g}$ or less. This compares to maximum concentrations in 1998 of $5.0 \mathrm{pCi} / \mathrm{g}$, in 1997 of $6.0 \mathrm{pCi} / \mathrm{g}$, in 1996 of $5.0 \mathrm{pCi} / \mathrm{g}$, and in 1995 of $1.0 \mathrm{pCi} / \mathrm{g}$. All concentrations below the LLD are assigned a value of $1.0 \mathrm{pCi} / \mathrm{g}$.

\section{Beavers}

\section{Description of Surveillance Program}

The U.S. Forest Service administers a contract for the trapping of beavers in selected areas within the SRS perimeter. The purpose of this trapping is to reduce the beaver population in specific areas of the site and thereby minimize dam-building activities that can result in flood damage to timber stands, to primary and secondary roads, and to railroad beds. All beavers are monitored for cesium-137 with portable sodium iodide detectors and disposed of in the SRS sanitary landfill.

\section{Surveillance Results}

No beavers were monitored at SRS in 1999 . The cesium-137 concentration in all the beavers was less than $1.0 \mathrm{pCi} / \mathrm{g}$ in 1998 . These results compare with maximums of 12.5 in $1997,10.5 \mathrm{pCi} / \mathrm{g}$ in 1995 and 1996, and $22 \mathrm{pCi} / \mathrm{g}$ in 1994.

\section{Soil}

The SRS soil monitoring program provides

- data for long-term trending of radioactivity deposited from the atmosphere (both wet and dry deposition)

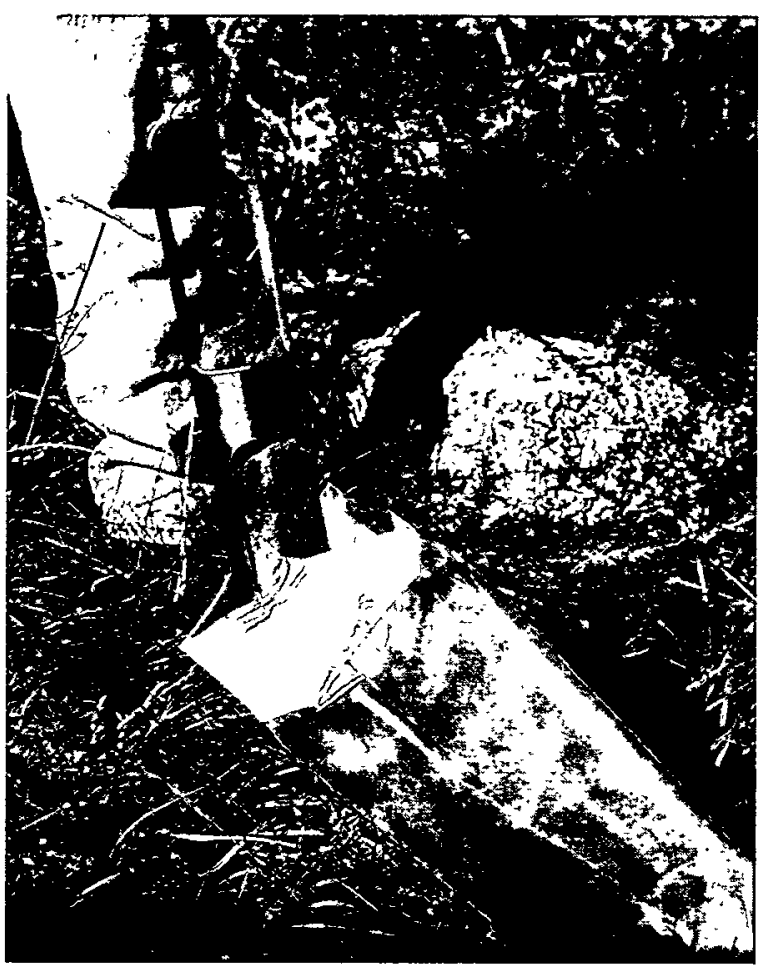

Al Mamatey Photo (99X0011.03)

Soil sampling at SRS is performed using devices such as the hand auger (pictured). Soil samples are collected annually at five locations around the site.

- information on the concentrations of radioactive materials in the environment

Routine and nonroutine SRS atmospheric releases, as well as worldwide fallout, are monitored in this program. The concentrations of radionuclides in soil vary greatly among locations because of differences in rainfall patterns and in the mechanics of retention and transport in different types of soils. Because of this program's design, a direct comparison of data from year to year is not appropriate.

\section{Description of Surveillance Program}

Soil samples were collected in 1999 from four uncultivated and undisturbed locations in E-Area (burial ground), F-Area, H-Area, and Z-Area-one sample from each area-and from one control location (off site) near the U.S. Highway 301 bridge over the Savannah River, as shown in figure 6-12. One location approximately 100 miles from SRS-at Savannah-also was sampled.

Hand augers or other similar devices are used in sample collection to a depth of 3 inches. The samples are analyzed for gamma-emitting radionuclides, strontium-89,90, plutonium-238, and plutonium-239. 


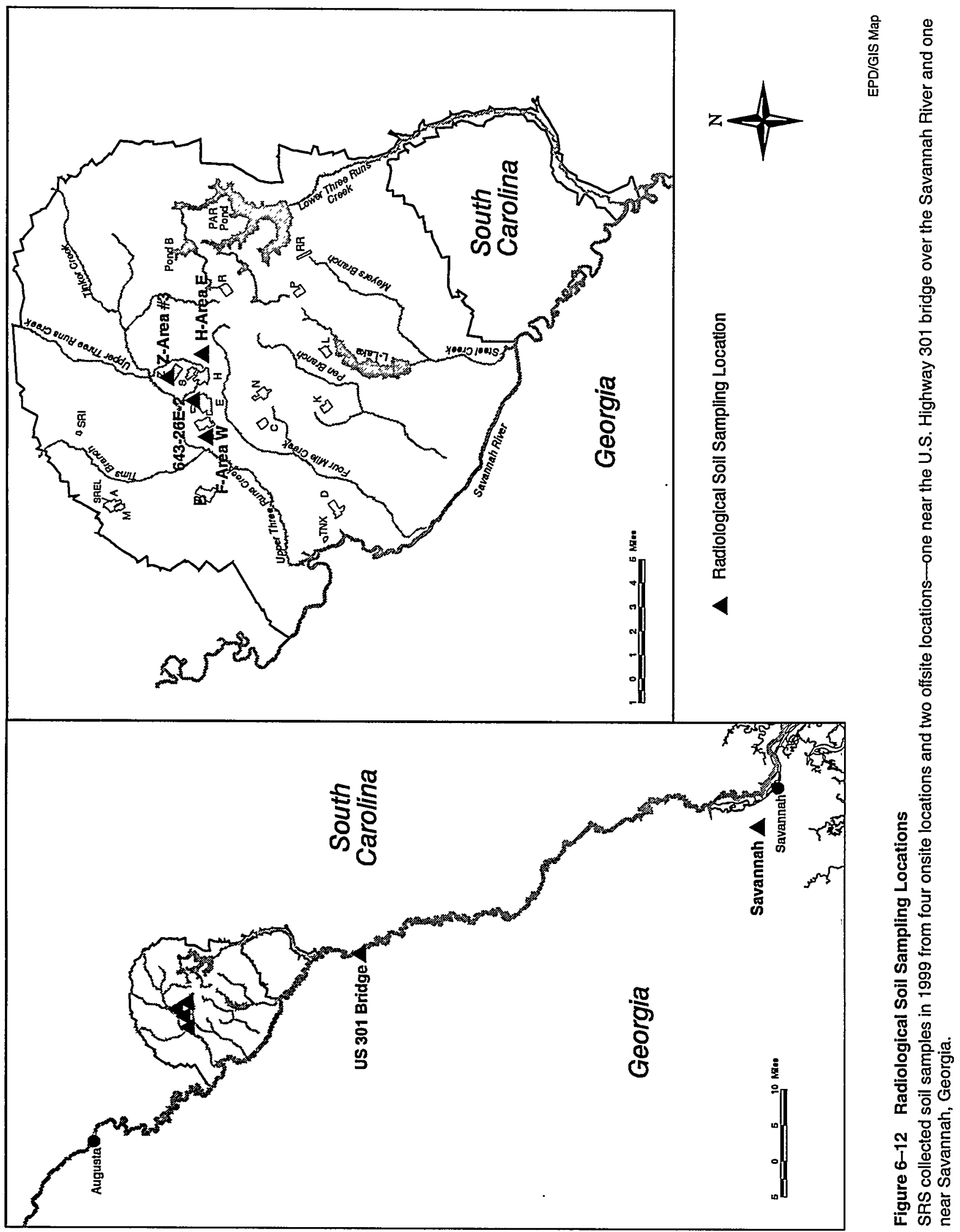


The rationale for each sampling site is explained in the SRS EM Program.

\section{Surveillance Results}

Detailed analytical results from soil samples collected during 1999 can be found in table 28, SRS

Environmental Data for 1999.

\section{Gamma-Emitting Radionuclides}

Cesium-137 was observed at levels above the nominal LLD in 1999 at both offsite locations and three of the onsite ones. The highest onsite concentration detected, $(3.30 \pm 0.37) \mathrm{E}-01 \mathrm{pCi} / \mathrm{g}$, was in a sample taken from $\mathrm{H}$-Area, and the lowest was below the nominal LLD. The highest offsite concentration was $(5.55 \pm 0.58) \mathrm{E}-01 \mathrm{pCi} / \mathrm{g}$, at the U.S. Highway 301 bridge area.

\section{Plutonium}

Two of the four onsite soil sampling locations showed concentrations of plutonium-238 above the nominal LLD. The highest was F-Area at $(3.26 \pm 0.32) \mathrm{E}-02$ $\mathrm{pCi} / \mathrm{g}$. Three of these locations had concentrations of plutonium-239 above the nominal LLD-F-Area at $(4.00 \pm 0.25) \mathrm{E}-01 \mathrm{pCi} / \mathrm{g}, \mathrm{H}$-Area at $(4.41 \pm 0.46) \mathrm{E}-02 \mathrm{pCi} / \mathrm{g}$, and Z-Area at $(6.47 \pm 0.13) \mathrm{E}-02 \mathrm{pCi} / \mathrm{g}$. One offsite location (the 100-mile-radius location at Savannah) had a concentration, $(4.20 \pm 0.99) \mathrm{E}-03$, above the nominal LLD.

\section{Strontium}

Soil samples from all locations were analyzed for strontium-89,90, and all results were below the nominal LLD.

\section{Sediment}

Sediment sample analysis measures the movement, deposition, and accumulation of long-lived radionuclides in stream beds and in the Savannah River bed. Significant year-to-year differences may be evident because of the continuous deposition and remobilization occurring in the stream and river beds-or because of slight variation in sampling locations-but the data obtained can be used to observe long-term environmental trends.

\section{Description of Surveillance Program}

Sediment samples (annual) were collected at 21 locations in 1999-eight in the Savannah River and 13 in site streams (figure 6-13). Two locations, TB-4A and TB-4B, were eliminated in 1999 because of radiological postings and entry requirements.
Location TB-5, downstream of TB-4A and TB-4B and not located in a soil contamination area, will continue to be sampled. Samples are obtained with a Ponar dredge or an Emery pipe dredge and analyzed for gamma-emitting fission and activation products, strontium-89,90, plutonium-238, and plutonium-239.

\section{Surveillance Results}

Concentrations of radionuclides in river sediment during 1999 were similar to those of past years. Detailed analytical results from all sediment samples collected during the year can be found in table 29, SRS Environmental Data for 1999.

\section{Gamma-Emitting Radionuclides}

Cesium- 137 and Cobalt- 60 were the only manmade gamma-emitting radionuclides observed in river and stream sediments during 1999.

The highest cesium-137 concentration in streams, $(4.10 \pm 0.15) \mathrm{E}+02 \mathrm{pCi} / \mathrm{g}$, was detected in sediment from R-Area Downstream of R-1; the lowest concentration, $(2.63 \pm 0.32) \mathrm{E}-01$, was found at Tims Branch 5 near Road $C$. The highest level found on the river, $(3.77 \pm 0.42) \mathrm{E}-01 \mathrm{pCi} / \mathrm{g}$, was at the mouth of Upper Three Runs Creek; the lowest level was below the nominal LLD at RM 150.2. Generally, cesium- 137 concentrations were higher in stream sediments than in river sediments. This is to be expected because the streams receive radionuclide-containing liquid effluents from the site. Most radionuclides settle out and deposit on the stream beds or at the streams' entrances to the swamp areas along the river.

Cobalt-60 was detected above the nominal LLD in sediment from the following locations:

- Four Mile Creek at Road A-7

- Four Mile A-7A

- Pen Branch Swamp Discharge

- Steel Creek 4

- R-Area Downstream of R-1

The highest Cobalt- 60 concentration, $(6.18 \pm 0.36) \mathrm{E}-01 \mathrm{pCi} / \mathrm{g}$, was measured at Four Mile A-7A; concentrations at the other 16 sediment sampling locations were below the nominal LLD.

\section{Plutonium/Uranium}

Uranium-235 was detected in sediment from one location, TB-5 near Road C, at a concentration of $(1.64 \pm 0.11) \mathrm{E}+00 \mathrm{pCi} / \mathrm{g}$. Concentrations of. plutonium-238 in sediment ranged from a high of $(1.60 \pm 0.09) \mathrm{E}+00 \mathrm{pCi} / \mathrm{g}$ at the Four Mile A-7A 


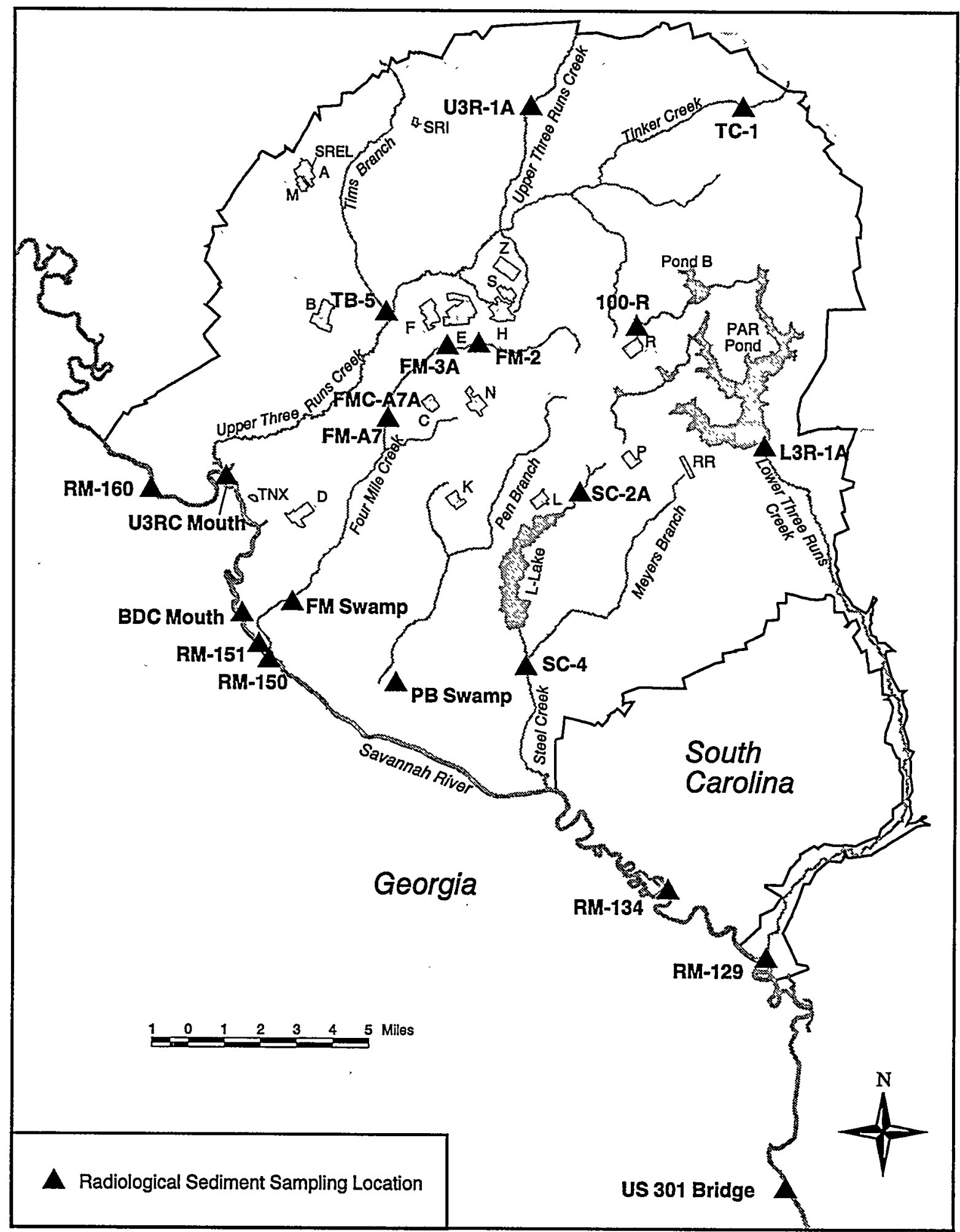

EPD/GIS Map

Figure 6-13 Radiological Sediment Sampling Locations

Sediment samples were collected in 1999 at eight Savannah River locations-upriver of, adjacent to, and downriver of the site-and 13 site stream locations. 
location to lows below the nominal LLD at several locations. Concentrations of plutonium-239 ranged from a high of (7.74 \pm 0.47$) \mathrm{E}-01$ - at the Four Mile A-7A location-to lows below the nominal LLD at several locations. As expected, concentrations of these isotopes in streams generally were higher than concentrations in the river; all concentrations in the river were below the nominal LLD. Differences observed when these data are compared to those of previous years probably are attributable to the effects of resuspension and deposition, which occur constantly in sediment media.

\section{Strontium}

Strontium-89,90 was detected above the nominal LLD in 1999 at seven of the 13 site stream sediment sampling locations. Stream concentrations ranged from a maximum of $(1.70 \pm 0.08) \mathrm{E}+00 \mathrm{pCi} / \mathrm{g}$ at the Four Mile A-7A location to lows below the nominal LLD at the other six locations. Strontium-89,90 was detected above the nominal LLD at one (Below Little Hell Landing) of the eight Savannah River locations. The concentration was $(9.91 \pm 2.88) \mathrm{E}-02 \mathrm{pCi} / \mathrm{g}$.

\section{Grassy Vegetation}

The radiological program for grassy vegetation is designed to collect and analyze samples from onsite and offsite locations to determine radionuclide concentrations. Vegetation samples are obtained to complement the soil and sediment samples in order to determine the environmental accumulation of radionuclides and help confirm the dose models used by SRS. The program also provides information that can be used to determine the effects, if any, of various radioactive material operations on the surrounding vegetation.

Typically, grasses are collected for vegetation because of their year-round availability. Bermuda grass is preferred because of its importance as a pasture grass for dairy herds.

\section{Description of Surveillance Program}

Vegetation samples are obtained from

- locations containing soil radionuclide concentrations that are expected to be higher than normal background levels

- locations receiving water that may have been contaminated

An onsite location is near the geographical center of the site, and four perimeter locations are situated near air monitoring stations that provide sampling within each 30-degree sector around the site boundary. Two offsite locations-selected as control sites-are in the vicinity of the environmental air monitoring stations at the U.S. Highway 301 bridge over the Savannah River and near the city of Savannah. All the vegetation locations, which continue to be sampled annually, are shown in figure 6-14.

Vegetation samples are analyzed for gross alpha and gross beta, gamma-emitting radionuclides, tritium, plutonium, and strontium. Vegetation can be contaminated externally by the deposition of airborne radioactive contaminants (i.e., from fallout) and internally by uptake, from soil or water, by the roots. While the vegetation surveillance program makes no attempt to differentiate between contributions of the external and internal contaminations, contributions can be approximated when radionuclide concentrations in local soils are known.

The sampling and analysis programs for grassy vegetation are documented in WSRC-3Q1-2, Volume 1, Section 1105.3.10.2. Operational details of sample collection are in procedure manual WSRC-3Q1-3, while analytical procedures are in WSRC-3Q1-4 and WSRC-3Q1-6.

\section{Surveillance Results}

All surveillance results are based on dry weight. The 1999 grassy vegetation results showed tritium, cesium, strontium, and plutonium activity near or slightly above minimum detectable concentrations at several locations. Gross beta activity was detected at all locations but was attributed primarily to the naturally occurring radionuclide potassium- 40 . Detailed analytical results from vegetation samples collected during 1999 can be found in table 30 of SRS Environmental Data for 1999.

\section{Burke County Well Sampling}

Contamination of groundwater has been detected at several locations within SRS. Concern has been raised by State of Georgia officials over the possible migration of groundwater contaminated with tritium through aquifers underlying the Savannah River into Georgia by what is sometimes referred to as trans-river flow.

\section{Previous Studies}

The US Geological Survey (USGS), in cooperation with DOE and GDNR, began a study (the Trans-River Flow Project) in 1988 to describe groundwater flow and quality near the Savannah River and to determine the potential for movement beneath the river. The study area was bounded by the 


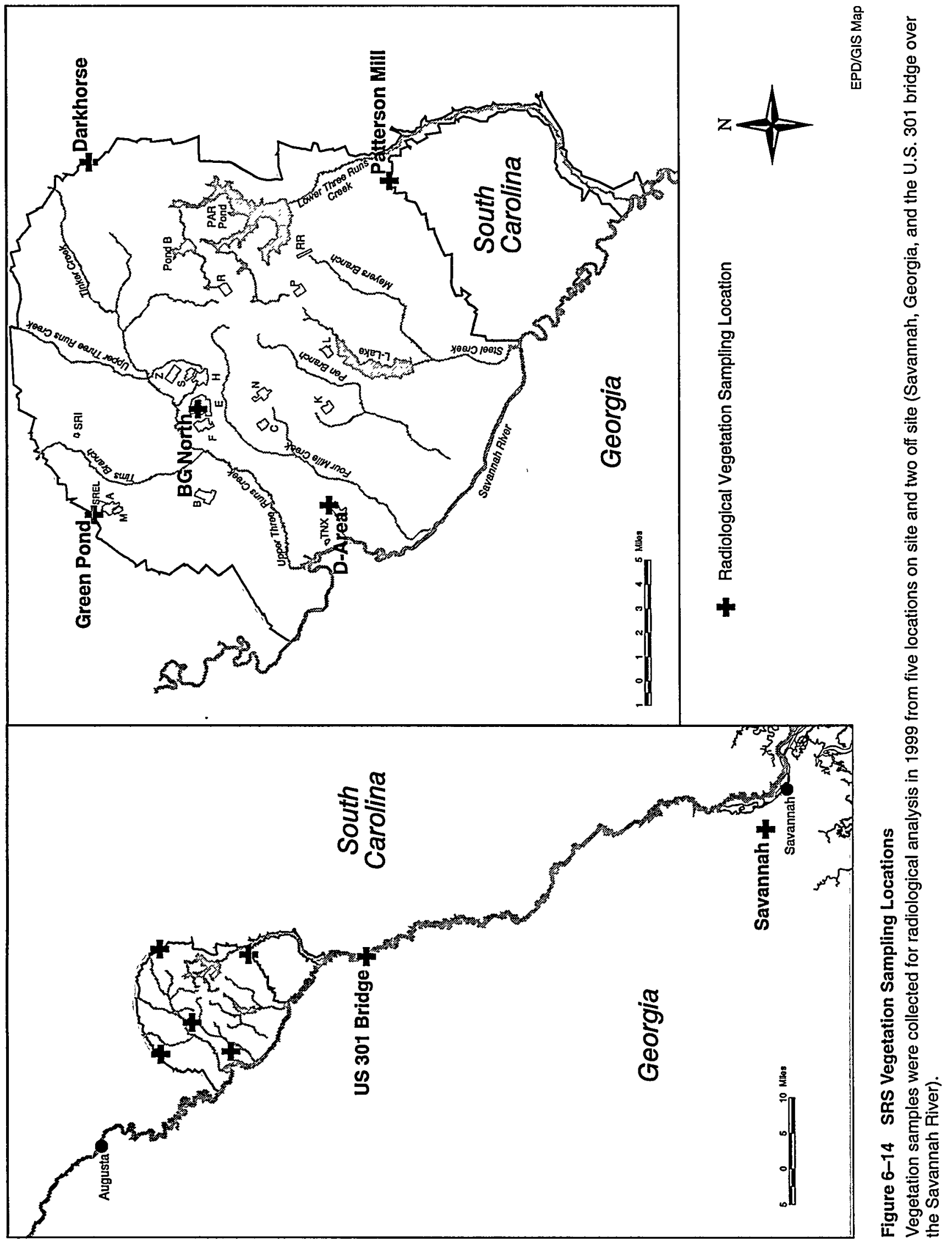


fall line, which is about 20 miles northwest of SRS, and extended to about 20 miles south of the site.

A wide expanse of swamp exists on both sides of the Savannah River as it meanders from one side of its flood plain to the other. In southern Richmond County, Georgia, and in most of Burke County, Georgia, a steep bluff with relief as much as 160 feet is present along the western bank of the river. The area on both sides of the flood plain is moderately well dissected by streams that flow into the river.

Summaries of the Trans-River Flow Project may be found in SRS environmental reports from 1992 through 1996, which concluded that there was no potential for groundwater with tritium contamination to flow under the river, and that the low levels of tritium found in Burke County came from rainfall.

The last report by the USGS was Water-Resources Investigations Report 98-4062, which describes a detailed computer model of the groundwater flow in the SRS area [Clarke, 1998]. The coastal plain sediments are divided into seven aquifers in all or

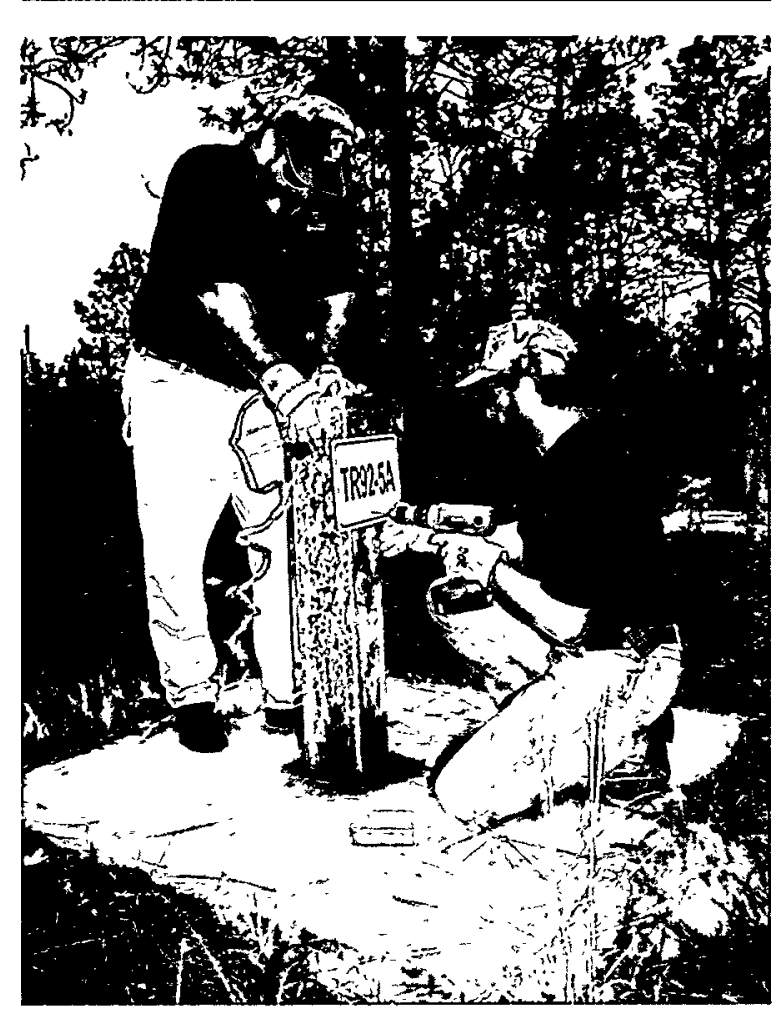

Al Mamatey Photo (00.J01150)

SRS personnel sample and affix an identification tag to a well at the Delaigle trailer park in Burke County, Georgia. The well is one of 17 that were sampled in 1999 to address the issue of potential tritium flow under the Savannah River from SRS to the Georgia side of the river.

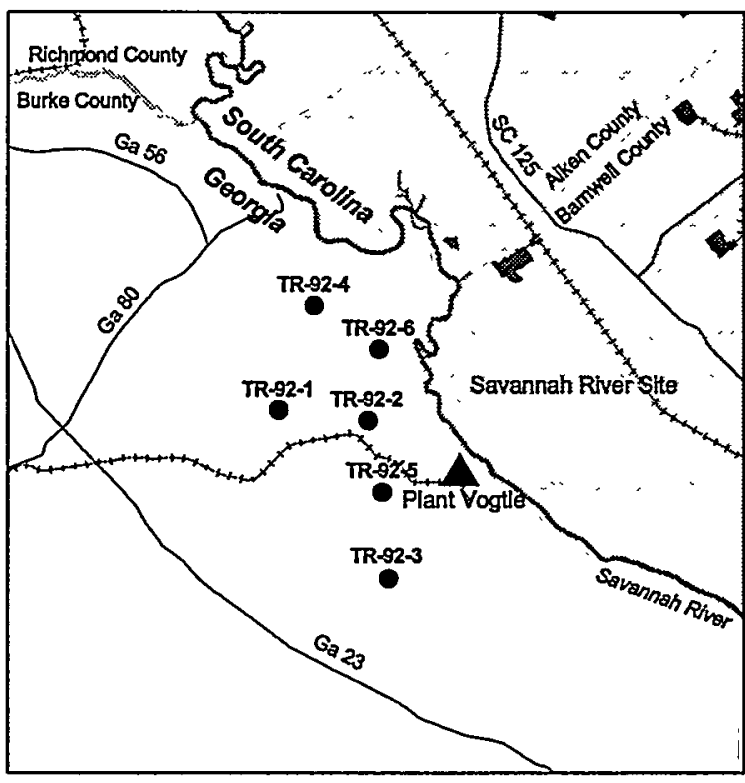

EPD/GIS Map

Figure 6-15 Burke County Well Locations

Six clusters of wells have been acquired by SRS in Burke County, Georgia.

parts of nine counties in Georgia and five counties in South Carolina. In map view, the model contains roughly 10,000 cells.

Flowpath analysis was used to track particles originating in cells along the Savannah River in an area up to 3 miles into South Carolina and Georgia. Particles of water were tracked from the center of each model cell in each of the seven aquifers. No groundwater from South Carolina was found to seep out in Georgia except into the Savannah River and its alluvial sediments. The age of this water varies from 300 to 24,000 years, depending on the flowpath of the individual particles. Because of the relatively short half-life of tritium, none of the original concentration would remain in the water after 300 years.

\section{Current Study and Results}

After a lapse in sampling for several years, SRS acquired 30 monitoring wells from GDNR in 1999 at six sites in Burke County (figure 6-15). Access was reestablished with land owners, brush and weeds were cleared around the wells, and signs were installed. EMS personnel were able to sample 17 of the wells during 1999 . The samples were analyzed for tritium; results of these analyses appear in table 6-5.

The highest value reported was $0.916 \mathrm{pCi} / \mathrm{mL}$, which is less than 5 percent of the conservative EPA drinking water standard of $20,000 \mathrm{pCi} / \mathrm{L}$. SRS plans to sample the Burke County wells for tritium again in 2000. 
Table 6-5

Tritium Concentrations in Burke County Wells Sampled for Tritium During 1999 (pCi/mL)

\begin{tabular}{cc|cc}
\hline Well Name & Tritium $(\mathrm{pCi} / \mathrm{mL})$ & Well Name & Tritium $(\mathrm{pCi} / \mathrm{mL})$ \\
\hline $92-1 \mathrm{~A}$ & $2.4 \mathrm{E}-02$ & $92-1 \mathrm{~K}$ & $2.1 \mathrm{E}-01$ \\
$92-1 \mathrm{C}$ & $1.4 \mathrm{E}-01$ & $92-1 \mathrm{~L}$ & $7.7 \mathrm{E}-02$ \\
$92-1 \mathrm{D}$ & $1.6 \mathrm{E}-02$ & $92-1 \mathrm{M}$ & $3.9 \mathrm{E}-01$ \\
$92-1 \mathrm{E}$ & $3.7 \mathrm{E}-01$ & $92-3 \mathrm{~A}$ & $5.3 \mathrm{E}-01$ \\
$92-1 \mathrm{~F}$ & $4.4 \mathrm{E}-01$ & $92-4 \mathrm{~B}$ & $5.5 \mathrm{E}-02$ \\
$92-1 \mathrm{G}$ & $7.7 \mathrm{E}-01$ & $92-5 \mathrm{~A}$ & $1.5 \mathrm{E}-01$ \\
$92-1 \mathrm{H}$ & $8.7 \mathrm{E}-01$ & $92-6 \mathrm{A2}$ & $7.8 \mathrm{E}-01$ \\
$92-11$ & $9.2 \mathrm{E}-01$ & $92-6 \mathrm{~B}$ & $8.6 \mathrm{E}-01$ \\
$92-1 \mathrm{~J}$ & $3.3 \mathrm{E}-01$ & & \\
\hline
\end{tabular}




\section{Chapter 7}

\section{Potential \\ Radiation \\ Doses}

To Read About ... $\quad$ See Page...

Calculating Dose ............... 110

Dose Calculation Results ........... 114

Potential Risk from Consumption

of SRS Creek Mouth Fish .......... 124

Radiological Assessment Program ... 127

\section{Timothy Jannik, Patricia Lee, and Ali Simpkins Savannah River Technology Center}

\section{Highlights}

- Using conservative methods, the calculated potential offsite radiation doses from site operations were below all applicable standards of radiation exposure to humans and aquatic organisms.

- The potential dose to the maximally exposed individual from liquid releases in 1999 was estimated at 0.22 mrem. This dose is 0.22 percent of DOE's $100-\mathrm{mrem}$ all-pathway dose standard for annual exposure. The dose is about 83 percent more than the 1998 dose-primarily because a 62-percent decrease in the Savannah River flow rate resulted in less dilution of contaminants.

- The estimated dose to the maximally exposed individual from airborne releases was $0.06 \mathrm{mrem}$. This dose is 0.6 percent of DOE's 10-mrem air pathway dose standard for annual exposure. The 1999 dose was 14 percent less than the 1998 dose.

- The potential maximally exposed individual all-pathway dose was 0.28 mrem-0.06 mrem from the airborne pathway plus 0.22 mrem from the liquid pathway. This dose is 47 percent more than the 1998 all-pathway dose of 0.19 mrem.

- The potential maximum dose that could have been received by an actual onsite hunter was estimated at 77 mrem, or 77 percent of DOE's 100-mrem all-pathway dose. This hunter harvested five animals, and it was assumed that he personally consumed the entire edible portion of all of them ( 267 pounds).

- The maximum dose estimated for a hypothetical recreational fisherman was based on the consumption of 19 $\mathrm{kg}$ (42 pounds) of Savannah River fish having the highest measured concentrations of radionuclides. Bass caught at the mouth of Steel Creek had the highest concentrations in 1999. Consumption of these bass could have resulted in a dose of $0.61 \mathrm{mrem}$, or 0.61 percent of DOE's $100-\mathrm{mrem}$ all-pathway dose.

$\mathrm{T}$ HIS chapter presents the potential doses to offsite individuals and the surrounding population from 1999 Savannah River Site (SRS) atmospheric and liquid radioactive releases. Additionally, potential doses from special-case exposure scenarios-such as the consumption of deer meat, creek mouth fish, goat milk, and crops irrigated with Savannah River water-are documented.

Unless otherwise noted, the generic term "dose" used in this report includes both the committed effective dose equivalent (50-year committed dose) from internal deposition of radionuclides and the effective dose equivalent attributable to sources external to the body. Use of the effective dose equivalent allows doses from different types of radiation and to different parts of the body to be expressed on the same relative basis.

Many parameters-such as radioactive release quantities, population distribution, meteorological conditions, radionuclide dose factors, human consumption rates of food and water, and environmental dispersion-are considered in the dose models used to estimate offsite doses at SRS. Descriptions of the effluent monitoring and environmental surveillance programs discussed in this chapter can be found in chapter 5 , "Radiological Effluent Monitoring," and chapter 6, "Radiological Environmental Surveillance." A complete description of how potential doses are calculated can be found in section 1108 of the Savannah River Site Environmental Monitoring Section Plans and Procedures, WSRC-3Q1-2, Volume 1 (SRS EM Program, 1999). Tables containing all potential dose calculation results are presented in $S R S$

Environmental Data for 1999

(WSRC-TR-99-00301).

Applicable dose regulations can be found in appendix A, "Applicable Guidelines, Standards, and Regulations," of this document. 


\section{Calculating Dose}

Potential offsite doses from SRS effluent releases of radioactive materials (atmospheric and liquid) are calculated for the following scenarios:

- hypothetical maximally exposed individual

- 80-kilometer (50-mile) population

Because the U.S. Department of Energy (DOE) has adopted dose factors only for adults, SRS calculates maximally exposed individual and collective doses as if the entire 80-kilometer population consisted of adults [DOE, 1988].

The International Commission on Radiological Protection (ICRP), in its Publications \#56 and \#67, has established age-specific dose factors for six age groups, ranging from 3-month-old infants to adults. However, dose factors for only a select group of radioisotopes were published, and these are applicable to only the ingestion pathway. In general, for most radioisotopes, the dose to an infant is more than to an adult. For the radioisotopes that constitute most of SRS's radioactive releases (i.e., tritium and cesium-137), the dose to infants would be approximately two to three times more than to adults. The dose to older children becomes progressively closer to the adult dose.

When the ICRP completes age-specific dose factors for all radioisotopes and develops an age-specific lung model for inhalation, and when DOE adopts these factors and models, SRS will calculate doses for the various age groups.

SRS also uses adult consumption rates for food and drinking water and adult usage parameters to estimate intakes of radionuclides (tables 35 and 37, SRS Environmental Data for 1999). These intake values and parameters were developed specifically for SRS based on an intensive regional survey [Hamby, 1991]. The survey includes data on agricultural production (table 33, SRS Environmental Data for 1999), consumption rates for food products, and use of the Savannah River for drinking water and recreational purposes.

\section{Dose Calculation Models}

To calculate annual offsite doses, SRS uses radiation transport and dose models developed for the commercial nuclear industry [NRC, 1977]. The models are implemented at SRS in the following computer programs [SRS EM Program, 1999]:

- MAXDOSE-SR: calculates maximum and average doses to offsite individuals from atmospheric releases.

- POPGASP: calculates collective doses from atmospheric releases.

- LADTAP XIC: calculates maximum and average doses to offsite individuals and the population from liquid releases.

- CAP88: calculates doses to offsite individuals from atmospheric releases to demonstrate compliance with the National Emission Standards for Hazardous Air Pollutants (NESHAP) under the Clean Air Act.

For the 1999 dose calculations, SRS began using personal computer (PC) versions of MAXIGASP (MAXDOSE-SR) and LADTAPII (LADTAP XLC) instead of the IBM Mainframe versions. A thorough comparison of MAXIGASP and MAXDOSE-SR showed less than 2 percent difference between the two codes. This difference is attributed to slight differences in precision between the Mainframe FORTRAN computer language and the PC FORTRAN.

\section{Dose to the Hypothetical Maximally Exposed Individual}

When calculating radiation doses to the public, SRS uses the concept of the maximally exposed individual; however, because of the conservative lifestyle assumptions used in the dose models, no such person is known to exist. The parameters used for the dose calculations are

For airborne releases: Someone who lives at the SRS boundary 365 days per year and consumes large amounts of milk, meat, and vegetables produced at that location

For liquid releases: Someone who lives downriver of SRS (near River Mile 120) 365 days per year, drinks 2 liters of untreated water per day from the Savannah River, consumes a large amount of Savannah River fish, and spends the majority of time on or near the river

To demonstrate compliance with the DOE Order 5400.5 all-pathway dose standard of 100 mrem per year, SRS conservatively combines the airborne pathway and liquid pathway dose estimates, even though the two doses are calculated for hypothetical individuals residing at different geographic locations. 


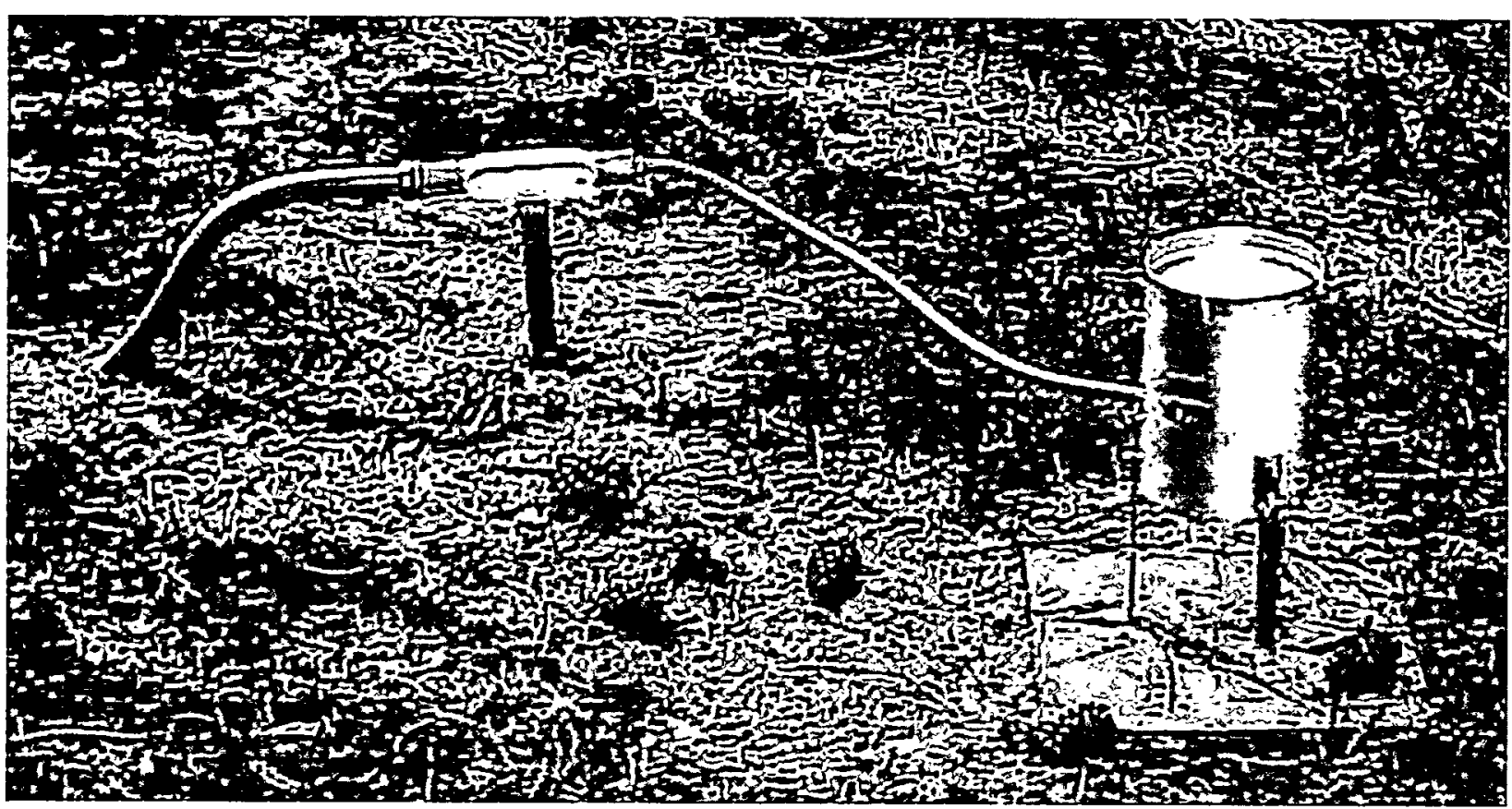

Matt Parker Photo (00.51369)

A soil moisture probe (left, buried) and adjacent rain gauge (right) are part of a new, real-time soil moisture monitoring system near SRS's P-Area meteorological tower. By using soil moisture data from a forest canopy (shown) and from an open, grassy area (not shown), personnel from the Atmospheric Technologies Group (ATG) of the Savannah River Technology Center are able to improve predictions of the height of the local atmospheric boundary layer. This critical information is used in ATG's emergency response models, which calculate the atmospheric transport and dose of unplanned releases. The data also are used to support the controlled forest burn program of the U.S. Department of Agriculture's Savannah River Natural Resource Management and Research Institute.

For the maximally exposed individual dose calculations, there is no difference between the Mainframe and PC versions of the LADTAPII computer code. However, for the population dose, LADTAP XL@ is more conservative, and the calculated dose is approximately 20 percent more than the LADTAPII-determined dose. The reason for the difference is that LADTAP XL(C) assumes that the people living downstream of SRS consume all the fish and shellfish commercially harvested from the Savannah River. LADTAPII assumes that only a small part of the harvest is consumed locally and that the rest is exported out of the area.

The CAP88 computer code is required under the Clean Air Act to calculate offsite doses from atmospheric releases from existing and proposed facilities. SRS uses the CAP88 dose estimates to show NESHAP compliance, but not for routine dose calculations. The CAP88, MAXDOSE-SR, and POPGASP codes use modeling based on U.S. Nuclear Regulatory Commission Regulatory Guide 1.109 .

\section{Meteorological Database}

Meteorological data are used as input for the atmospheric transport and dose models.

For 1999, all potential offsite doses from releases of radioactivity to the atmosphere were calculated with quality-assured meteorological data for A-Area (used for A-Area and M-Area releases), D-Area (used for $D$-Area releases), and $\mathrm{H}$-Area (used for releases from all other areas). The meteorological databases used were for the years 1992-1996, reflecting the most recent 5 -year compilation period (table $31, S R S$ Environmental Data for 1999). Five-year average databases are used instead of the actual annual data because of the difficulty of compiling, inputting, and validating all the data in time to be used for the current-year dose calculations.

The wind rose developed from the 1992-1996 $\mathrm{H}$-Area database is provided in figure 7-1. As shown, there is no prevailing wind at SRS, which is typical for the lower midlands of South Carolina. The maximum frequency that the wind blew in any one 


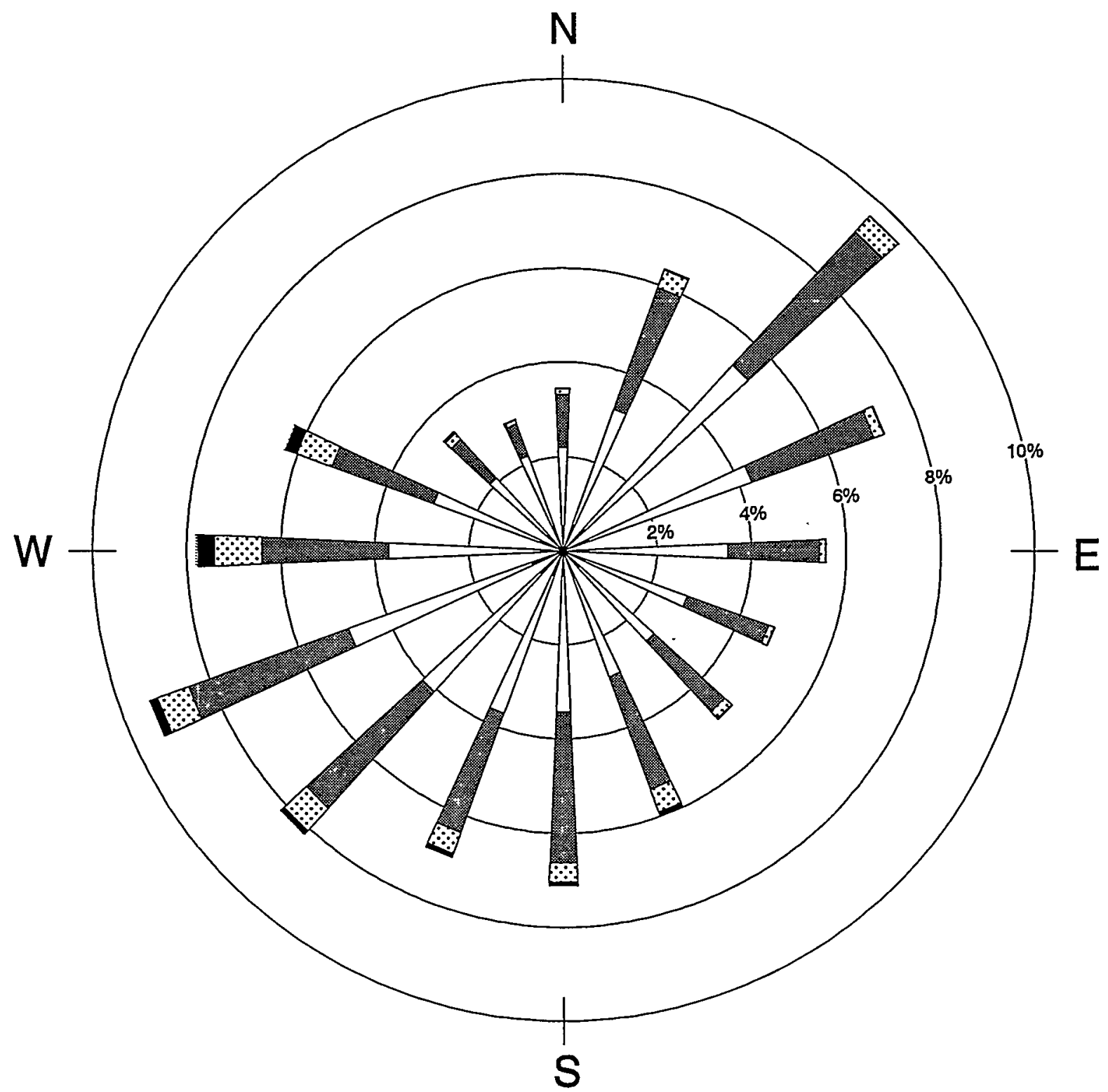

\section{$\begin{array}{llllll}0.0 & 2.0 & 4.0 & 6.0 & 8.0 & 12.0\end{array}$ \\ Wind Speed Class Boundaries \\ (Meters/Second)}

EPD/GIS Graphic

Figure 7-1 Wind Rose for SRS, 1992-1996

This wind rose graphically depicts the percent of occurrence frequencies of six wind speed categories by 16 cardinal wind direction sectors at SRS. The wind speed categories are defined on the plot; direction is defined as the sector from which the wind blows. The data used to generate the wind rose consist of hourly averages of wind speed and direction at the $\mathrm{H}$-Area meteorological tower for the 5-year period 1992-1996; measurements were taken 200 feet above the ground. 
direction was 9.7 percent of the time, which occurred toward the southwest direction.

The meteorological measurements include all dispersion conditions observed during the 5-year period, ranging from unstable (considerable turbulence, which leads to rapid dispersion) to very stable (very little turbulence, which produces a narrow, undispersed plume). The data for 1992-1996 indicate that the SRS area experiences stable conditions (atmospheric stability classes E, F, G) about 18.4 percent of the time.

\section{Population Database and Distribution}

Collective, or population, doses from atmospheric releases are calculated for the population within a 80-kilometer (50-mile) radius of SRS.

For 1999 dose calculations, the 1990 population database prepared by the University of South Carolina was used. This database distributes the population into a grid of cells one-second latitude by one-second longitude. This database is transformed by the POPGASP Code into polar coordinates of 16 compass sectors and varying radial distances out to 80 kilometers. The POPGASP Code can prepare a polar coordinate database for any release point put into the code in polar coordinates. A separate, fixed-polar-coordinate database was prepared for use with the CAP88 Code, which does not have the capability of transforming the grid into polar coordinates. The population database generated by the POPGASP Code is centered on the geographical center of SRS (table 32, SRS Environmental Data for 1999).

Within the 80-kilometer radius, the total population for 1990 was 620,100 , compared to 555,200 for 1980 , a 12-percent population growth in 10 years.

Some of the collective doses resulting from SRS liquid releases are calculated for the populations served by the City of Savannah Industrial and Domestic Water Supply Plant, near Port Wentworth, Georgia, and by the Beaufort-Jasper Water Treatment Plant, near Beaufort, South Carolina. According to the treatment plant operators, the population served by the Port Wentworth facility during 1999 remained unchanged, at approximately 10,000 persons, while the population served by the Beaufort-Jasper facility increased from approximately 60,000 to 75,000 persons because of the addition of new customers in Hilton Head, South Carolina.

\section{River Flow Rate Data}

Offsite dose from liquid effluents varies each year with the amount of radioactivity released and the amount of dilution (flow rate) in the Savannah River. Although flow rates are recorded at U.S. Geological Survey (USGS) gauging stations at the SRS boat dock and near River Mile 120 (U.S. Highway 301 bridge), these data are not used directly in dose calculations. This is because weekly river flow rates fluctuate widely (i.e., short-term dilution varies from week to week). Used instead are "effective" flow rates, which are based on measured concentrations of tritium in Savannah River water and measured concentrations in water used at the downstream water treatment plants. However, the USGS-measured flow rates are used for comparison to these calculated values.

For 1999, the River Mile 120 calculated (effective) flow rate of 5,920 cubic feet per second was used in determining doses to maximally exposed individuals, population doses from recreation and fish consumption, and potential doses from crops irrigated with river water. This flow rate was 53 percent less than the 1998 effective flow rate of 12,500 cubic feet per second. For comparison, during 1999 , the USGS-measured flow rate at River Mile 120 was 6,160 cubic feet per second, which was about 62 percent less than the 1998 measured rate of 16,300 cubic feet per second. The calculated (effective) value is more conservative because it accounts for less dilution.

The 1999 calculated (effective) flow rate for the Beaufort-Jasper facility was 7,250 cubic feet per second, which was about 56 percent less than the 1998 flow rate.

The 1999 calculated (effective) flow rate for the Port Wentworth facility was 7,300 cubic feet per second, which was about 49 percent less than the 1998 flow rate.

The 1999 calculated Savannah River estuary flow rate $(6,780$ cubic feet per second) was used only for calculation of dose from consumption of salt water invertebrates.

In figure 7-2, the annual average Savannah River flow rates, measured by the USGS at River Mile 120, are provided for the years of SRS operations (1954 to 1998). The 1999 rate of 6,160 cubic feet per second was the third lowest measured during this 46-year period. This is in contrast to the 1998 rate of 16,300 cubic feet per second, which was the second highest measured during the period.

\section{Uncertainty in Dose Calculations}

Radiation doses are calculated using the best available data. If adequate data are unavailable, then site-specific parameters are selected that would result in a conservative estimate of the maximum dose. 
Cubic feet per second

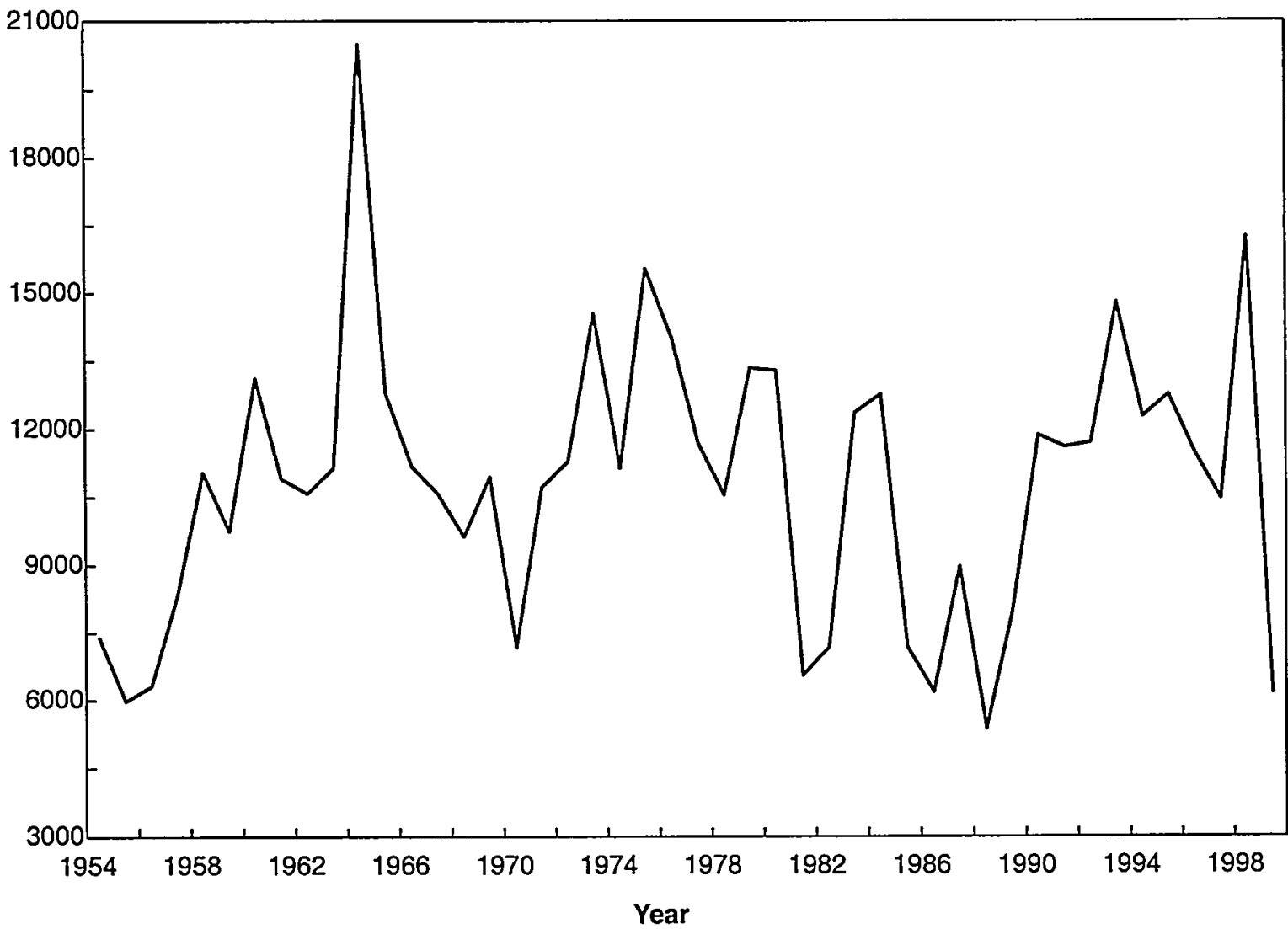

lleaf Graphic

Figure 7-2 Savannah River Mile 120 Annual Average Flow Rates, 1954-1999

The 1999 River Mile 120 flow rate of 6,160 cubic feet per second was the third lowest measured during the 46-year operating history of SRS. River Mile 120 flow rates were not measured for the years 1971-1981; mean flow rates for those years are based on rates measured near Augusta, Georgia.

All radiation data and input parameters have an uncertainty associated with them, which causes uncertainty in the dose determinations. For example, there is uncertainty in the assumed maximum meat consumption rate of $81 \mathrm{~kg}$ (179 pounds) per year for an individual. Some people will eat more than $81 \mathrm{~kg}$, but most probably will eat less. Uncertainties can be combined mathematically to create a distribution of doses rather than a single number. While the concept is simple, the calculation is quite difficult. A detailed technical discussion of the method of estimating uncertainty at SRS was published in the July 1993 issue of Health Physics [Hamby, 1993].

\section{Dose Calculation Results}

Liquid and air pathway doses are calculated for the maximally exposed individual and for the surrounding population. In addition, a sportsman dose is calculated separately for consumption of fish, deer, and feral hogs, which are nontypical exposure pathways. Finally, a dose is calculated for the aquatic biota found in SRS streams.

\section{Liquid Pathway}

This section contains information on liquid release quantities used as source terms in SRS dose calculations, including a discussion about radionuclide concentrations in Savannah River fish. The calculated dose to the maximally exposed individual, the calculated collective (population) dose, and the potential dose from agricultural irrigation are presented.

\section{Liquid Release Source Terms}

The 1999 radioactive liquid release quantities used as source terms in SRS dose calculations are presented in chapter 5 and summarized by radionuclide in table 7-1. In order to maintain conservatism, the stream transport tritium release total of $6,290 \mathrm{Ci}$ 
$(2.32 \mathrm{E}+14 \mathrm{~Bq})$, which was the highest value of the three alternative tritium release calculation methods employed at SRS (chapter 6), was used in the dose calculations.

For 1999, releases of unspecified alpha emitters and nonvolatile beta emitters were listed separately in the source term. In previous years, these alpha and beta emitters were included in plutonium-239 and strontium-89,90 releases, respectively.

For dose calculations, unspecified alpha releases were assigned the plutonium-239 dose factor, and unspecified nonvolatile beta releases were assigned the strontium- 90 factor. Accounting for the alpha and beta emitters in this way generates an overestimated dose attributed to releases from SRS because

- plutonium-239 and strontium-90 have the highest dose factors among the common alpha- and beta-emitting radionuclides

- a part of the unidentified activity probably is not from SRS operations but from naturally occurring radionuclides, such as potassium- 40 and radon progeny
For use in dose determinations and model comparisons, the concentrations of tritium in Savannah River water and cesium-137 in Savannah River fish are measured at several locations along the river. The amounts of all other radionuclides released from SRS are so small that they usually cannot be detected in the Savannah River using standard analytical techniques.

The measured concentrations of tritium in the Savannah River near River Mile 120 and at the Beaufort-Jasper and Port Wentworth water treatment facilities are shown in table 7-1, as are the LADTAP XI $\odot$-determined concentrations for the other released radionuclides.

The 12-month average tritium concentrations measured in the Savannah River near River Mile 120 $(1.19 \mathrm{pCi} / \mathrm{mL})$, and at the Beaufort-Jasper $(0.972 \mathrm{pCi} / \mathrm{mL})$ and Port Wentworth $(0.965 \mathrm{pCi} / \mathrm{mL})$ water treatment plants, remained below the U.S. Environmental Protection Agency (EPA) and DOE concentration standards of $20 \mathrm{pCi} / \mathrm{mL}$ and $80 \mathrm{pCi} / \mathrm{mL}$, respectively.

The 1999 River Mile 120 concentration was about 26 percent more than the 1998 concentration of

Table 7-1

1999 Radioactive Liquid Release Source Term and 12-Month Average Downriver Radionuclide Concentrations (Calculated Concentrations Are Based on Effective River Flow Rates)

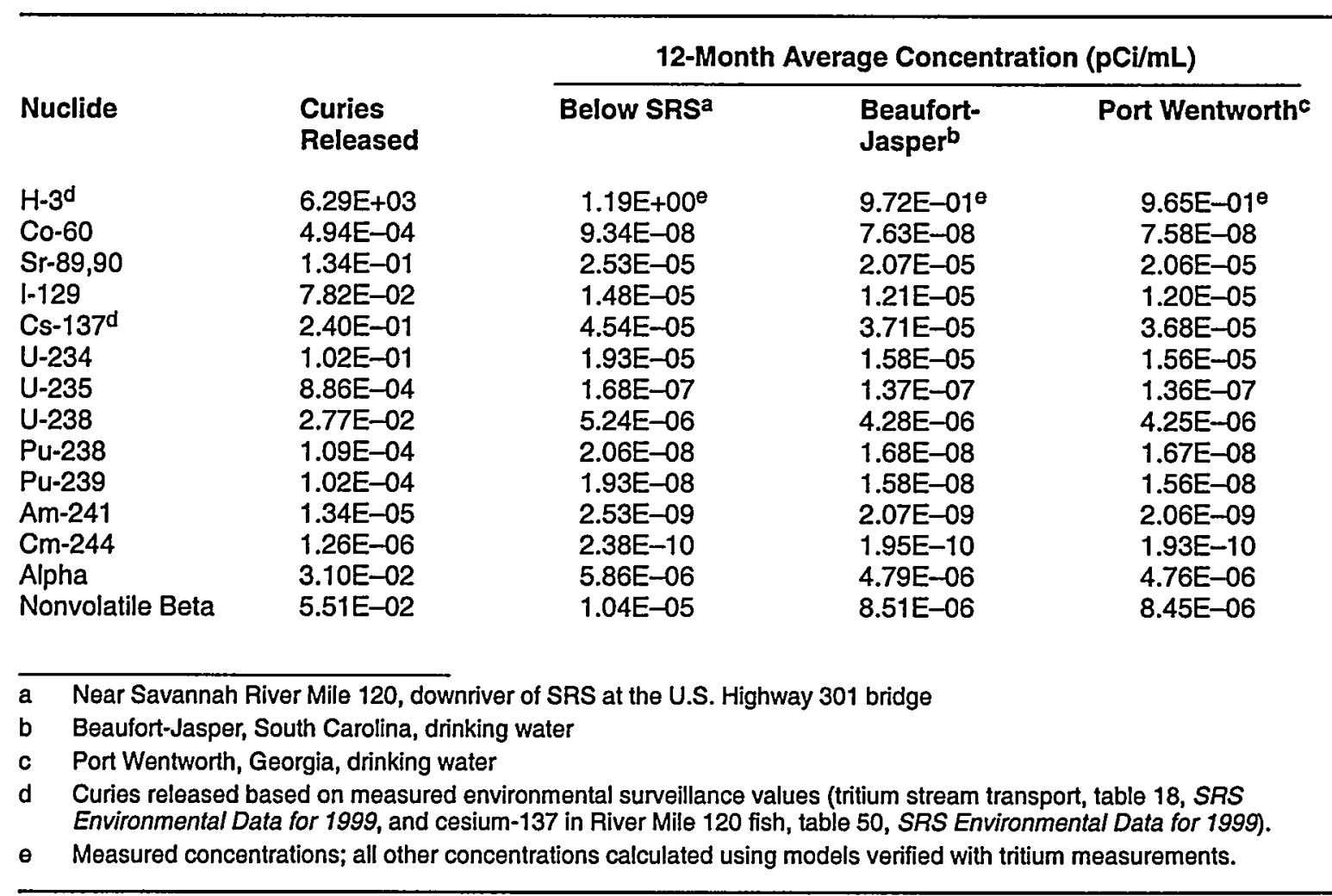


$0.948 \mathrm{pCi} / \mathrm{mL}$. This occurred-even though the amount of tritium released to the Savannah River during 1999 (6,290 curies) was 41 percent less than during 1998 (10,600 curies) - because the 1999 River Mile 120 flow rate $(6,160$ cubic feet per second) was 62 percent less than the 1998 flow rate $(16,200$ cubic feet per second), which resulted in less dilution.

Annual average tritium concentrations measured during the period 1990-1999 at River Mile 120 and at the Beaufort-Jasper and Port Wentworth facilities are compared to the EPA standard in figure 7-3. The data for Beaufort-Jasper and Port Wentworth are the tritium concentrations measured in the finished drinking water at each facility.

Radionuclide Concentrations in River Fish At SRS, an important dose pathway for the maximally exposed individual is from the consumption of fish.

Fish exhibit a high degree of bioaccumulation for certain elements. For the element cesium (including radioactive isotopes of cesium), the bioaccumulation factor for Savannah River fish is approximately 3,000 . That is, the concentration of cesium found in fish flesh is about 3,000 times more than the concentration of cesium found in the water in which the fish live.

Because of this high bioaccumulation factor, cesium-137 is more easily detected in fish flesh than in river water. Therefore, the fish pathway dose from cesium- 137 is based directly on the radioanalysis of the fish collected near Savannah River Mile 120, which is the assumed location of the hypothetical maximally exposed individual (table 50, SRS Environmental Data for 1999). The fish pathway dose from all other radionuclides is based on the calculated concentrations determined by the LADTAP XI $\odot$ code. A consumption rate of $19 \mathrm{~kg}$ (42 pounds) of fish per year is used in the maximally exposed individual dose calculation [Hamby, 1991]. Some fraction of this estimated dose is due to cesium-137 from worldwide fallout and from neighboring Vogtle Electric Generating Plant; however, that amount is difficult to determine and is not subtracted from the total.

The dose determinations are accomplished in the LADTAP XI @ code by substituting a cesium-137 release value that would result in the measured concentration in river fish, assuming the site-specific

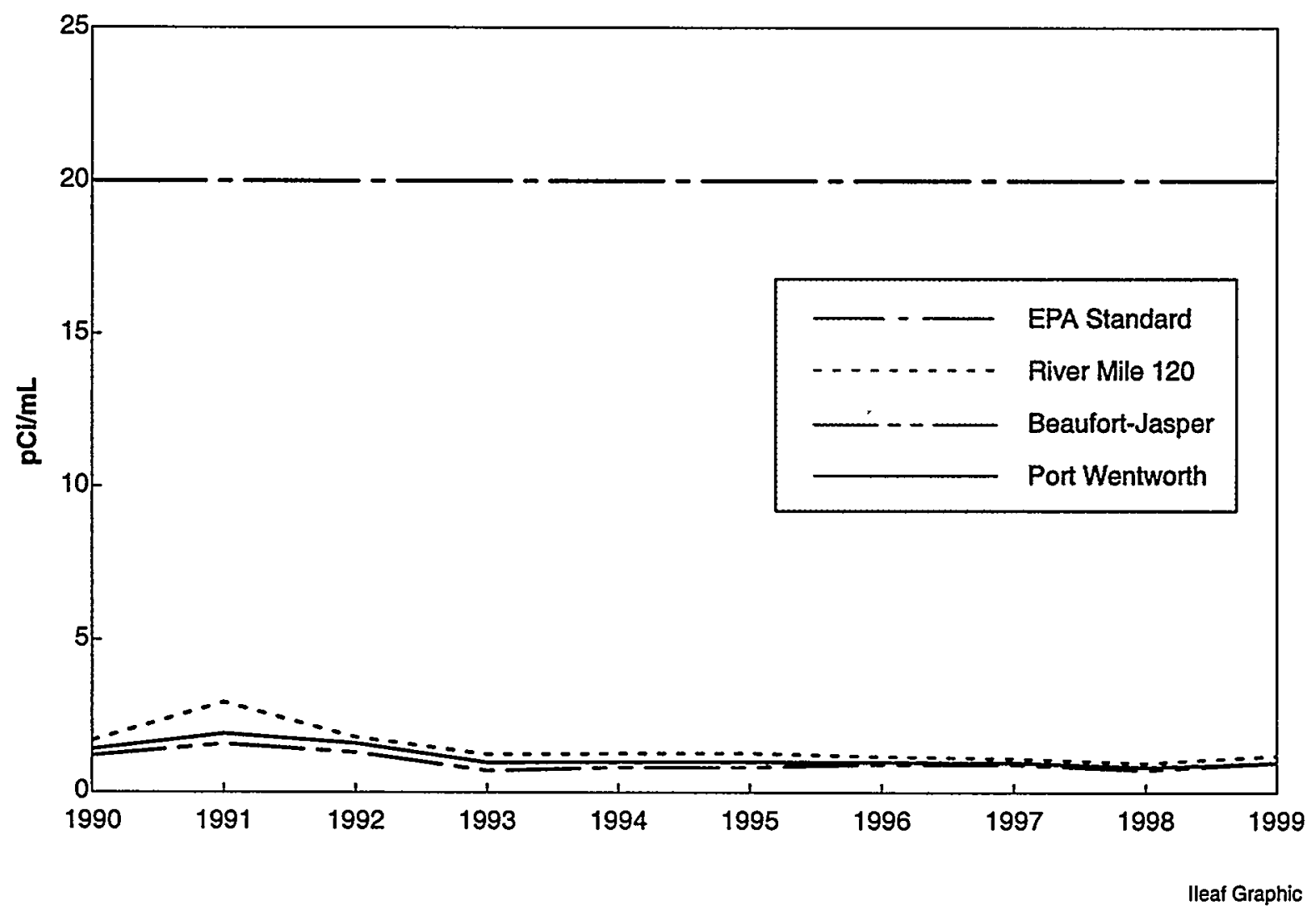

Figure 7-3 Annual Average Tritium Concentrations at River Mile 120, Beaufort-Jasper, and Port Wentworth (1990-1999) Compared to EPA Standard of $20 \mathrm{pCi} / \mathrm{mL}$. 
Table 7-2

Potential Dose to the Maximally Exposed Individual from SRS Liquid Releases in 1999

\begin{tabular}{lll} 
Committed & $\begin{array}{l}\text { Applicable } \\
\text { Standard }\end{array}$ & $\begin{array}{l}\text { Percent } \\
\text { of Standard }\end{array}$ \\
\hline
\end{tabular}

\section{Maximally Exposed Individual}

At Site Boundary

(all pathways)

At Port Wentworth

(public water supply only)

At Beaufort-Jasper

(public water supply only)
$0.22 \mathrm{mrem}$

100 mrem $^{\mathrm{a}}$

0.22

0.07 mrem

4 mrem $^{b}$

0.07 mrem

$4 \mathrm{mrem}^{\mathrm{b}}$

1.75

a All-pathway dose standard: $100 \mathrm{mrem}$ per year (DOE Order 5400.5 )

b Drinking water pathway standard: 4 mrem per year (DOE Order 5400.5 and EPA, 1975)

bioaccumulation factor of 3,000. A weighted average concentration (based on the number of fish in each composite analyzed) of cesium-137 in River Mile 120 fish was used for maximally exposed individual and population dose determinations. Using the above factors, the cesium- 137 release value used for LADTAP XL@ input was $0.24 \mathrm{Ci}(8.88 \mathrm{E}+09 \mathrm{~Bq})$, which is more conservative than the measured effluent release value of $0.10 \mathrm{Ci}(3.77 \mathrm{E}+09 \mathrm{~Bq})$ and was about 7 percent more than the 1998 value of 0.22 $\mathrm{Ci}(8.29 \mathrm{E}+09 \mathrm{~Bq})$.

\section{Dose to the Maximally Exposed Individual}

The potential liquid pathway dose to the hypothetical maximally exposed individual living downriver of SRS, near River Mile 120, was determined based on adult intake and usage parameters discussed earlier in this chapter and on other site-specific physical parameters (table 38, SRS Environmental Data for 1999).

As shown in table 7-2, the highest potential dose to the maximally exposed individual from liquid releases in 1999 was estimated at 0.22 mrem ( $0.0022 \mathrm{mSv})$. This dose is 0.22 percent of DOE's 100-mrem all-pathway dose standard for annual exposure.

The 1999 potential maximally exposed individual dose was about 83 percent more than the 1998 dose of $0.12 \mathrm{mrem}(0.0012 \mathrm{mSv})$-primarily because the 62-percent decrease in the Savannah River flow rate resulted in less dilution.

Approximately 59 percent of the dose to the maximally exposed individual resulted from the ingestion of cesium-137, mainly from the consumption of fish, and about 25 percent resulted from the ingestion (via drinking water) of tritium (table 45, SRS Environmental Data for 1999). About 9 percent of the liquid pathway maximally exposed individual dose was attributed to unspecified alpha emitters, which are conservatively assigned the dose factor for plutonium-239 in the dose calculations (chapter 5).

Drinking Water Pathway Persons downriver of SRS may receive a radiation dose by consuming drinking water that contains radioactivity as a result of liquid releases from the site. In 1999, tritium in downriver drinking water represented the majority of the dose (about 64 percent) received by persons at downriver water treatment plants.

The calculated doses to maximally exposed individuals whose entire daily intake of water is supplied by the Beaufort-Jasper and Port Wentworth water treatment facilities, located downriver of SRS, were determined for maximum ( 2 liters per day for a year) water consumption rates.

The maximum potential dose during 1999 was $0.07 \mathrm{mrem}(0.0007 \mathrm{mSv})$ at both the Beaufort-Jasper Water Treatment Plant and the City of Savannah Industrial and Domestic Water Supply Plant (Port Wentworth) (tables 46 and 47, SRS Environmental Data for 1999).

As shown in table 7-2, the maximum dose of $0.07 \mathrm{mrem}(0.0007 \mathrm{mSv})$ is 1.75 percent of the DOE and EPA standard of $4 \mathrm{mrem}$ per year for public water supplies. The 1999 maximum potential drinking water dose was 40 percent more than the 
1998 maximum dose of 0.05 mrem $(0.0005 \mathrm{mSv})$. This increase in dose is attributed to the 62-percent decrease in the Savannah River flow rate.

\section{Collective (Population) Dose}

The collective drinking water consumption dose is calculated for the discrete population groups at Beaufort-Jasper and Port Wentworth. The collective dose from other pathways is calculated for a diffuse population that makes use of the Savannah River. However, this population cannot be described as being in a specific geographical location.

Potential collective doses were calculated, by pathway and radionuclide, using the LADTAP XL ( computer code (table 48, SRS Environmental Data for 1999). In 1999, the collective dose from SRS liquid releases was estimated at 4.0 person-rem ( 0.04 person-Sv). This was 122 percent more than the 1998 collective dose of 1.8 person-rem ( 0.018 person-Sv). The reasons for the relatively large increase are as follows:

- The 62-percent decrease in the Savannah River flow rate resulted in less dilution, accounting for about 60 percent of the increase.

- The Beaufort-Jasper water treatment facility's customer base grew by approximately 15,000 , accounting for about 20 percent of the increase.

- A more conservative dose model (see the Dose Calculation Models section of this chapter, beginning on page 110) was used, accounting for about 20 percent of the increase.

\section{Potential Dose from Agricultural Irrigation}

The 1990 update of land- and water-use parameters [Hamby, 1991] revealed that there is no known use of river water downstream of SRS for agricultural irrigation purposes. However, in response to public concerns, potential doses from this pathway are calculated for information purposes only and are not included in calculations of the official maximally exposed individual or collective doses.

For 1999, a potential offsite dose of $0.15 \mathrm{mrem}$ $(0.0015 \mathrm{mSv})$ to the maximally exposed individual and a collective dose of 10 person-rem ( 0.10 person-Sv) were estimated for this exposure pathway.

As in previous years, collective doses from agricultural irrigation were calculated for 1,000 acres of land devoted to each of four major food types-vegetation, leafy vegetation, milk, and meat (table 49, SRS Environmental Data for 1999). It is assumed that all the food produced on the 1,000-acre parcels is consumed by the 80 -kilometer population of 620,100 .

\section{Air Pathway}

This section describes the atmospheric source term and concentrations used for dose determinations and presents the calculated dose to the maximally exposed individual, as well as the calculated collective (population) dose. Also included is a discussion about how SRS demonstrates NESHAP compliance.

\section{Atmospheric Source Terms}

The 1999 radioactive atmospheric release quantities used as the source term in SRS dose calculations are presented in chapter 5. For 1999, releases of unspecified alpha emitters and nonvolatile beta emitters were listed separately in the source term. In previous years, these alpha and beta emitters were included in the plutonium-239 and strontium-89,90 releases, respectively (table 4, SRS Environmental Data for 1999).

For air pathway dose calculations-as in liquid dose calculations-unspecified alpha releases were assigned the plutonium-239 dose factor, and unspecified nonvolatile beta releases were assigned the strontium-90 dose factor.

Tritium, in its elemental and oxide form, accounts for the majority of the radioactivity released to the atmosphere from SRS. It should be noted that tritium in its gaseous elemental form (HT or $\mathrm{T}^{2}$ ) is of much less concern in terms of human health than tritium in its oxide, or tritiated water, form (HTO or $\mathrm{T}^{2} \mathrm{O}$ ). This is because the physically and chemically stable elemental form of tritium is

- not readily absorbed by the human body

- much less (about 25,000 times less) radiotoxic than the oxide form [NCRP, 1979]

- not readily converted to the oxide form

- quickly dispersed in the atmosphere

Estimates of unmonitored diffuse and fugitive sources were considered, as required for demonstrating compliance with NESHAP regulations.

Airborne effluents are grouped by major release points for dose calculations. For the MAXDOSE-SR code, five release locations with specific release heights were used (table 34, SRS Environmental Data for 1999).

The CAP88 code can calculate doses from collocated release heights but cannot combine calculations for releases at different geographical locations. 
Table 7-3

Ten-Year History of SRS Atmospheric Tritium and Tritium Oxide Releases and Average Measured Tritium Oxide Concentrations in Air Compared to Calculated Concentrations in Air

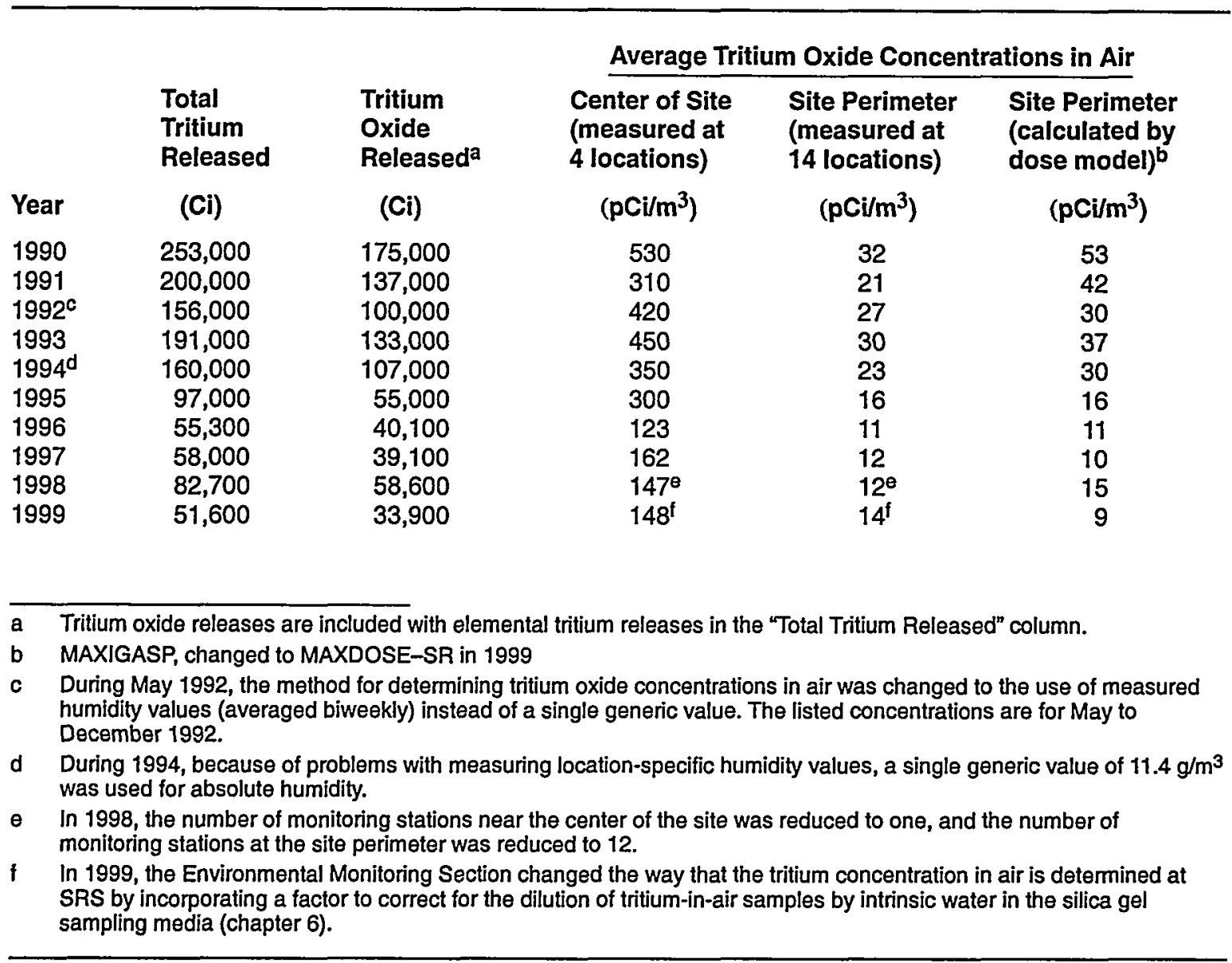

Therefore, for CAP88 calculations, airborne effluents were grouped for elevated releases (61 meters) and ground-level releases ( 0 meters), and the geographical center of the site was used as the release location for both (table 36, SRS Environmental Data for 1999).

\section{Atmospheric Concentrations}

The MAXDOSE-SR and CAP88 codes calculate average and maximum concentrations of all released radionuclides at the site perimeter. These calculated concentrations are used for dose determinations instead of measured concentrations. This is because most radionuclides released from SRS cannot be measured, using standard methods, in the air samples collected at the site perimeter and offsite locations. However, the concentrations of tritium oxide at the site perimeter locations usually can be measured and are compared with calculated concentrations as a verification of the dose models.
In table 7-3, the average 1990-1999 tritium oxide concentrations in air-measured near the center of the site and at locations along the site perimeter-are compared to the average concentrations calculated for the site perimeter, using the MAXDOSE-SR code. These data show that the calculated site-perimeter tritium oxide concentrations consistently and reasonably approximate the measured values and therefore are appropriate for use in dose determinations.

The average tritium oxide concentration in air measured at the 12 site perimeter locations during 1999 was $14 \mathrm{pCi} / \mathrm{m}^{3}\left(0.52 \mathrm{~Bq} / \mathrm{m}^{3}\right)$. The 1999 measured value is more than, but compares favorably with, the MAXDOSE-SR computer code value of $9 \mathrm{pCi} / \mathrm{m}^{3}\left(0.33 \mathrm{~Bq} / \mathrm{m}^{3}\right)$.

The maximum tritium oxide concentration measured in air at the site perimeter was $22 \mathrm{pCi} / \mathrm{m}^{3}$

$\left(0.81 \mathrm{Bg} / \mathrm{m}^{3}\right)$, which occurred at the D-Area location. This value is more than, but compares favorably with, 
the MAXDOSE-SR calculated value of $17 \mathrm{pCi} / \mathrm{m}^{3}$ $\left(0.63 \mathrm{~Bq} / \mathrm{m}^{3}\right)$.

The reasons that the average and maximum measured tritium-in-air concentrations are slightly more than the computer-predicted values are being investigated. The differences may be attributed to one or more of the following conditions:

- There is uncertainty in concentration measurements at lower release levels.

- There is uncertainty in determining the form (i.e., elemental versus oxide) of the total amount of tritium released from the site.

- Because of logistics, the D-Area sampling station (the location of the maximum measured tritium-in-air concentration), rather than being at the site perimeter, is located 2.4 kilometers (1.5 miles) closer to the center of the site.

- The MAXDOSE-SR dose model determines an average concentration at the site boundary in 16 major compass point directions, but only 12 site boundary sampling locations are included in the average measured concentration.

- A 5-year-average meteorological database is used in the dose model.

- Only five general onsite release locations are used (instead of individual stack locations).

The CAP88 code calculated a maximum site perimeter concentration of $12 \mathrm{pCi} / \mathrm{m}^{3}\left(0.44 \mathrm{~Bq} / \mathrm{m}^{3}\right)$. This value is less than the MAXDOSE-SR code value because the CAP8 8 code assumes that all releases occurred from only one point, which is located at the center of the site.

\section{Dose to the Maximally Exposed Individual}

The potential air pathway dose to a hypothetical maximally exposed individual located at the site perimeter was determined using the MAXDOSE-SR computer code. The adult consumption and usage parameters used for the calculations were discussed earlier in this chapter.

In 1999 , the estimated dose to the maximally exposed individual was $0.06 \mathrm{mrem}(0.0006 \mathrm{mSv})$, which is 0.6 percent of the DOE Order 5400.5 ("Radiation Protection of the Public and the Environment") standard of $10 \mathrm{mrem}$ per year. This dose is 14 percent less than the 1998 dose of $0.07 \mathrm{mrem}(0.0007 \mathrm{mSv})$. The decrease is attributed to the 42-percent decrease in tritium oxide releases from the site-caused by the completion of moderator consolidation operations in P-Area. Table 7-4 compares the maximally exposed individual's dose with the DOE standard.

Tritium oxide releases accounted for about 28 percent of the dose to the maximally exposed individual. In 1999 , more curies $(37,500)$ of krypton- 85 than of tritium oxide $(33,900)$ were released from the site. However, because krypton is an inert noble gas, it is biologically inactive and not easily absorbed or assimilated by the human body. Therefore, the dose consequence from krypton- 85 is relatively small, and in 1999, it accounted for only 0.1 percent of the maximally exposed individual dose.

Unspecified alpha emitters, which are conservatively assigned the dose factor for plutonium-239, accounted for about 42 percent of the maximally exposed individual dose. Nearly 70 percent of the unspecified alpha releases were estimated to be from diffuse and fugitive sources (chapter 5). During 1999, potential diffuse and fugitive releases from the D-Area coal pile runoff basin accounted for most (about 73 percent) of the estimated unspecified alpha releases from the site.

For 1999, the MAXIGASP code determined that the northwest sector of the site was the location of the highest maximally exposed individual dose.

Figure $7-4$ shows the potential dose to the maximally exposed individual residing at the site boundary for

Table 7-4

Potential Dose to the Maximally Exposed Individual from SRS Atmospheric Releases in 1999

\begin{tabular}{lll}
\hline & MAXIGASP & CAP88 (NESHAP) \\
\cline { 2 - 3 } Calculated dose & $0.06 \mathrm{mrem}$ & $0.05 \mathrm{mrem}^{-}$ \\
Applicable standard & $10 \mathrm{mrem}^{\mathrm{a}}$ & $10 \mathrm{mrem}^{\mathrm{b}}$ \\
Percent of standard & 0.6 & 0.5 \\
& & \\
\hline a DOE: DOE Order 5400.5, February 8, 1990 & & \\
b EPA: (NESHAP) 40 CFR 61 Subpart H, December 15, 1989 & \\
\hline
\end{tabular}




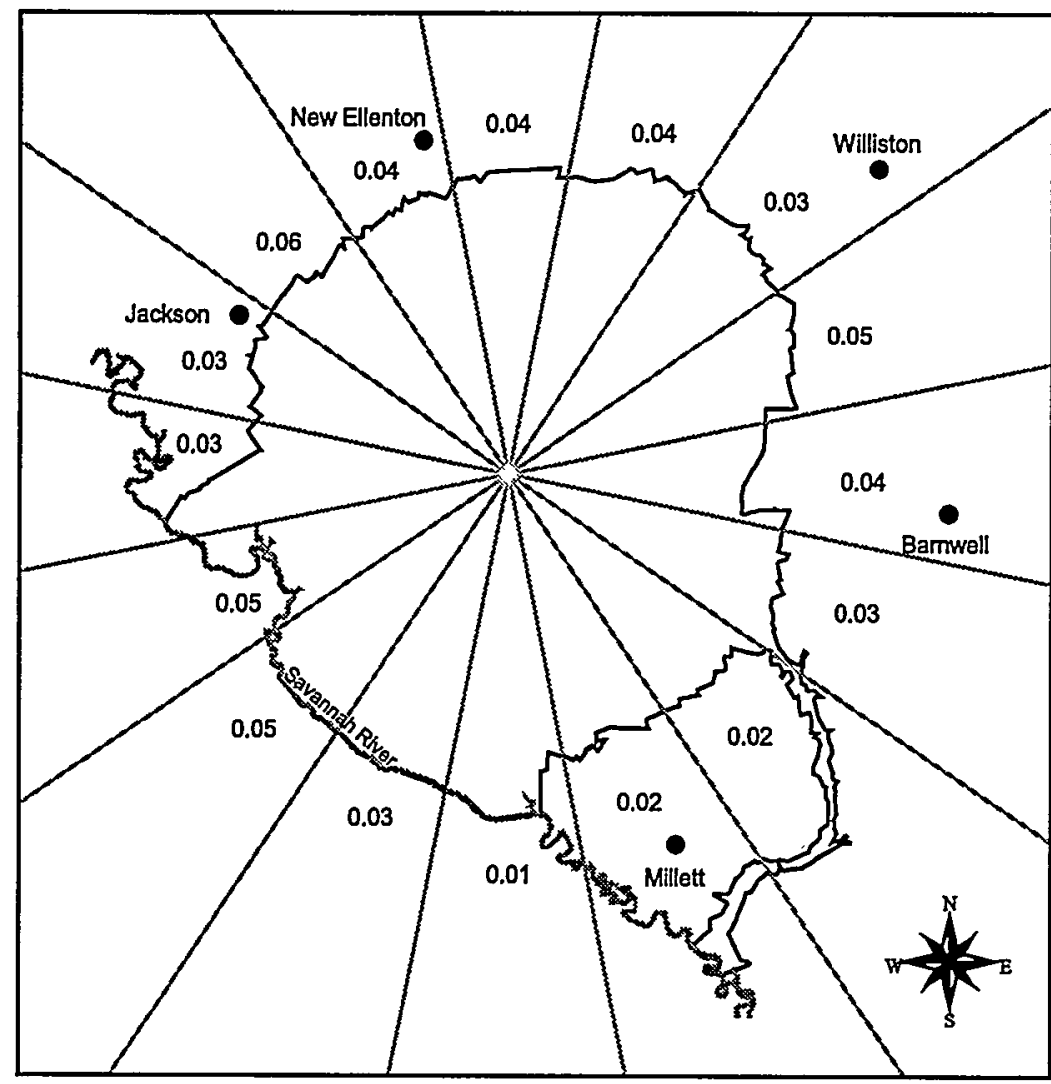

Figure 7-4 Sector-Specific Adult Maximally Exposed Individual Air Pathway Doses (in mrem) for 1999

Maximally exposed individual site boundary doses from airborne releases are shown for each of the 16 major compass point directions surrounding SRS. For 1999 , the northwest sector was the location of the highest maximally exposed individual dose (0.06 mrem).

EPD/GIS Map

each of the 16 major compass point directions around SRS.

The major pathways contributing to the dose to the maximally exposed individual from atmospheric releases were inhalation ( 48 percent) and the consumption of vegetation (44 percent), cow milk (5 percent), and meat (2 percent) (table 39, SRS Environmental Data for 1999).

Additional calculations of the dose to the maximally exposed individual were performed substituting goat milk for the customary cow milk pathway. The potential dose using the goat milk pathway was estimated at $0.06 \mathrm{mrem}(0.0006 \mathrm{mSv}$ ) (table $40, S R S$ Environmental Data for 1999).

\section{Collective (Population) Dose}

Potential doses also were calculated, by pathway and radionuclide, using the POPGASP computer code for the population $(620,100$ people) residing within 80 kilometers of the center of SRS (table 32, SRS Environmental Data for 1999).

In 1999 , the collective dose was estimated at 2.6 person-rem ( 0.026 person-Sv)-less than 0.01 percent of the collective dose received from natural sources of radiation (about 186,000 person-rem) (table 41, SRS Environmental Data for 1999).

Tritium oxide releases accounted for 60 percent of the collective dose. Primarily because of the decreased amount of tritium oxide released, the 1999 collective dose was approximately 20 percent less than the 1998 collective dose of 3.5 person-rem $(0.035$ person-Sv).

\section{NESHAP Compliance}

To demonstrate compliance with NESHAP (Clean Air Act, 40 CFR 61, Subpart $\mathrm{H}$ ) regulations, maximally exposed individual and collective doses were calculated, and a percentage of dose contribution from each radionuclide was determined using the CAP88 computer code.

The dose to the maximally exposed individual, calculated with CAP88, was estimated at 0.05 mrem $(0.0005 \mathrm{mSv})$, which is 0.5 percent of the 10-mrem-per-year EPA standard, as shown in table 7-4. Tritium oxide releases accounted for almost 87 percent of this dose (tables 42 and 43, SRS Environmental Data for 1999).

The CAP88 collective dose was estimated at 5.2 person-rem ( 0.081 person-Sv). Tritium oxide releases accounted for about 87 percent of this dose (table 44, SRS Environmental Data for 1999). 
As the data in tables 43 and 44 show, the CAP88 code estimates a higher dose for tritium oxide than do the MAXDOSE-SR and POPGASP codes.

Most of the differences occur in the tritium dose estimated from food consumption. The major cause of this difference is the CAP88 code's use of 100 -percent equilibrium between tritium in air moisture and tritium in food moisture, whereas the MAXDOSE-SR and POPGASP codes use 50-percent equilibrium values, as recommended by the Nuclear Regulatory Commission [NRC, 1977]. A recent publication indicates that the 50-percent value is correct for the atmospheric conditions at SRS [Hamby and Bauer, 1994].

Because tritium oxide dominates the doses determined using the CAP88 code, and because the CAP88 code is limited to a single, center-of-site release location, other radionuclides (such as iodine-129, plutonium-239, and ruthenium-106) are less important-on a percentage-of-dose basis-for the CAP88 doses than for the MAXDOSE-SR and POPGASP doses.

\section{All-Pathway Dose}

To demonstrate compliance with the DOE Order 5400.5 all-pathway dose standard of 100 mrem per year (1.0 mSv per year), SRS conservatively combines the maximally exposed individual airborne pathway and liquid pathway dose estimates, even though the two doses are calculated for hypothetical individuals residing at different geographic locations.
For 1999 , the potential maximally exposed individual all-pathway dose was $0.28 \mathrm{mrem}$ $(0.0028 \mathrm{mSv})-0.06 \mathrm{mrem}$ from airborne pathway plus 0.22 mrem from liquid pathway. This dose is 47 percent more than the 1998 all-pathway dose of 0.19 mrem $(0.0019 \mathrm{mSv})$, primarily because the 62-percent decrease in the Savannah River flow rate resulted in less dilution.

Figure 7-5 shows a 10-year history of SRS's all-pathway doses (airborne pathway plus liquid pathway doses to the maximally exposed individual).

As shown in table 7-5, the 1999 potential all-pathway dose of 0.28 mrem $(0.0028 \mathrm{mSv})$ is 0.28 percent of the 100-mrem-per-year DOE dose standard.

Figure 7-6 shows a comparison of the 1999 maximum potential all-pathway dose attributable to SRS operations ( 0.28 mrem) with the average annual radiation dose received by a typical Central Savannah River Area (CSRA) resident from natural and manmade sources of radiation (360 mrem).

\section{Sportsman Dose}

DOE Order 5400.5 specifies radiation dose standards for individual members of the public. The dose standard of 100 mrem per year includes doses a person receives from routine DOE operations through all exposure pathways. Nontypical exposure pathways, not included in the standard calculations of the doses to the maximally exposed individual, are considered and quantified separately. This is because they apply to low-probability scenarios, such as

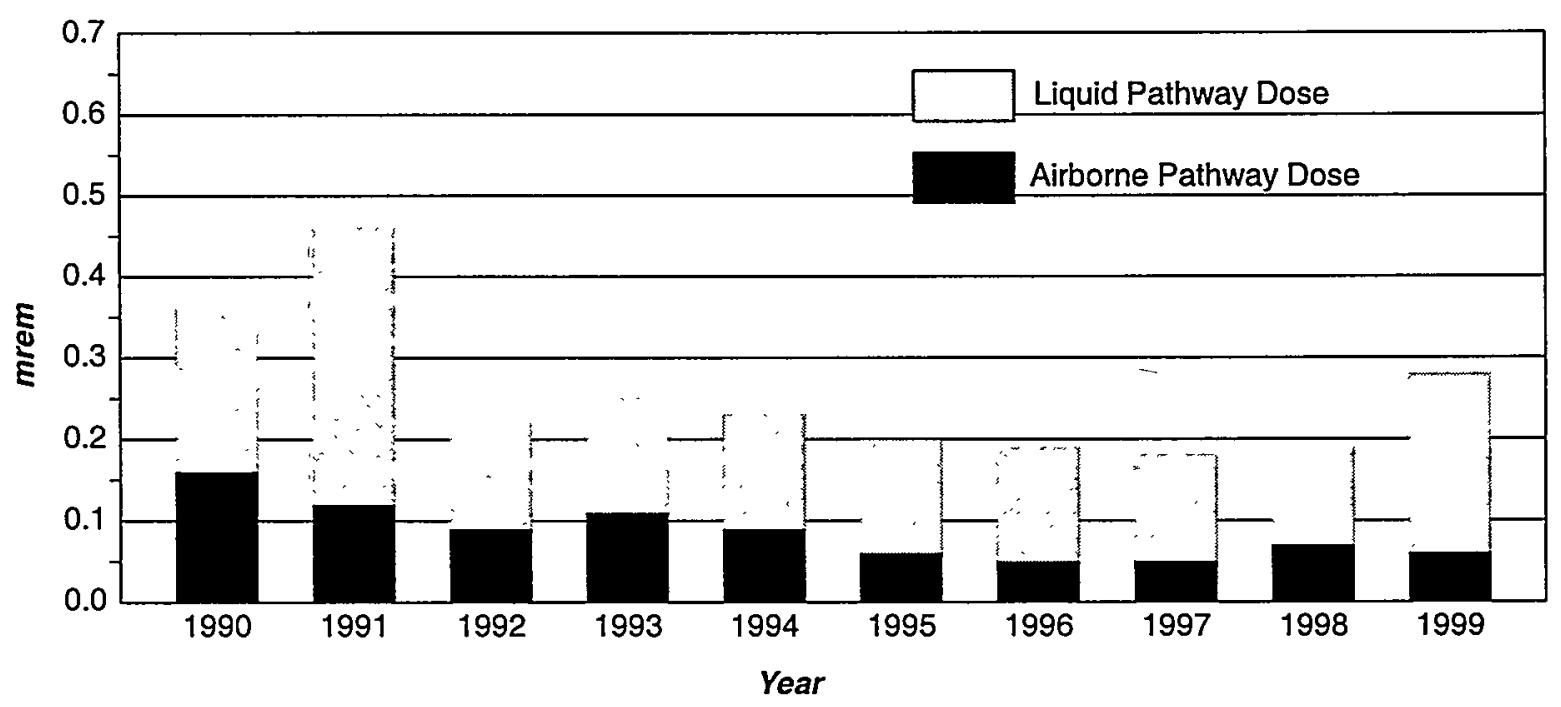

Ileaf Graphic

Figure 7-5 Ten-Year History of SRS Potential All-Pathway Doses to the Maximally Exposed Individual (Airborne plus Liquid Pathways) 
Table 7-5

1999 Maximum Potential All-Pathway and Sportsman Doses Compared to the DOE All-Pathway Dose Standard

\begin{tabular}{lccc}
\hline & $\begin{array}{l}\text { Committed } \\
\text { Dose (mrem) }\end{array}$ & $\begin{array}{l}\text { Applicable } \\
\text { Standarda (mrem) }\end{array}$ & $\begin{array}{c}\text { Percent } \\
\text { of Standard }\end{array}$ \\
\cline { 2 - 4 } Maximally Exposed Individual Dose & & 100 & 0.28 \\
$\begin{array}{l}\text { All-Pathway } \\
\text { (Liquid Plus Airborne Pathway) }\end{array}$ & 0.28 & 100 & 0.61 \\
$\begin{array}{l}\text { Sportsman Doses } \\
\text { Creek Mouth Fisherman } \\
\text { Onsite Hunter } \\
\text { Offsite Hunter }\end{array}$ & 0.61 & 100 & 77 \\
\hline a All-pathway dose standard: 100 mrem per year (DOE Order 5400.5) & 100 & 9.1 \\
\hline
\end{tabular}

consumption of fish caught exclusively from the mouths of SRS streams, or to unique scenarios, such as volunteer deer hunters.

\section{Deer and Hog Consumption Pathway}

For approximately 6 weeks each year, controlled hunts of deer and feral hogs are conducted at SRS. Hunt participants are volunteers. Before any harvested animal is released to a hunter, SRS personnel perform a field analysis for cesium-137 on the deer and hogs at the hunt site, using portable sodium iodide detectors.

The estimated dose from consumption of the harvested deer or hog meat is determined for each hunter. During 1999, the maximum potential dose that could have been received by an actual onsite hunter was estimated at $77 \mathrm{mrem}(0.77 \mathrm{mSv})$, or 77 percent of DOE's 100-mrem all-pathway dose standard (table 7-5). This dose was determined for a prolific hunter who in fact harvested five animals during the 1999 hunts. The hunter-dose calculation is based on the conservative assumption that the hunter individually consumed the entire edible portion-approximately $121 \mathrm{~kg}$ (267 pounds)—of the animals he harvested from SRS.

An additional deer meat consumption pathway considered was for a hypothetical offsite individual whose entire intake of meat during the year was deer meat. It was assumed that this individual harvested deer that had resided on SRS, but then moved off site. The estimated dose was based on the assumed maximum annual meat consumption rate for an adult of $81 \mathrm{~kg}$ per year [Hamby, 1991].
Based on these low-probability assumptions and on the gross average concentration of cesium-137 (3.24 pCi/g) in deer harvested from SRS during 1999, the potential maximum dose from this pathway was estimated at $9.1 \mathrm{mrem}(0.091 \mathrm{mSv})$. An average $80-\mathrm{km}$ background cesium-137 concentration of 1 $\mathrm{pCi} / \mathrm{g}$ is subtracted from the onsite gross average concentration before calculating the dose. The $80-\mathrm{km}$ background concentration is based on previous studies performed at SRS (table 33, SRS Environmental Data for 1994, WSRC-TR-95-077).

As shown in table 7-5, the 1999 offsite hunter potential dose is 9.1 percent of DOE's 100 -mrem all-pathway dose standard. This dose was 24 percent less than the 1998 dose of $12 \mathrm{mrem}(0.12 \mathrm{mSv})$.

\section{Fish Consumption Pathway}

For 1999, analyses were conducted of fish taken from the mouths of five SRS streams, and the subsequent estimated doses from the maximum consumption of $19 \mathrm{~kg}$ (42 pounds) per year [Hamby, 1991] of these fish were determined (table 50, SRS Environmental Data for 1999). Fish flesh was composited by species for each location and analyzed for tritium, strontium-89,90, cesium-137, plutonium-238, and plutonium-239.

As shown in table 7-5, the maximum potential dose from this pathway was estimated at $0.61 \mathrm{mrem}$ $(0.0061 \mathrm{mSv})$ from the consumption of bass collected at the mouth of Steel Creek. This hypothetical dose is based on the low-probability scenario that, during 1999 , a fisherman consumed $19 \mathrm{~kg}$ of bass caught exclusively from the mouth of Steel Creek. About 94 percent of this potential dose was from cesium-137. 


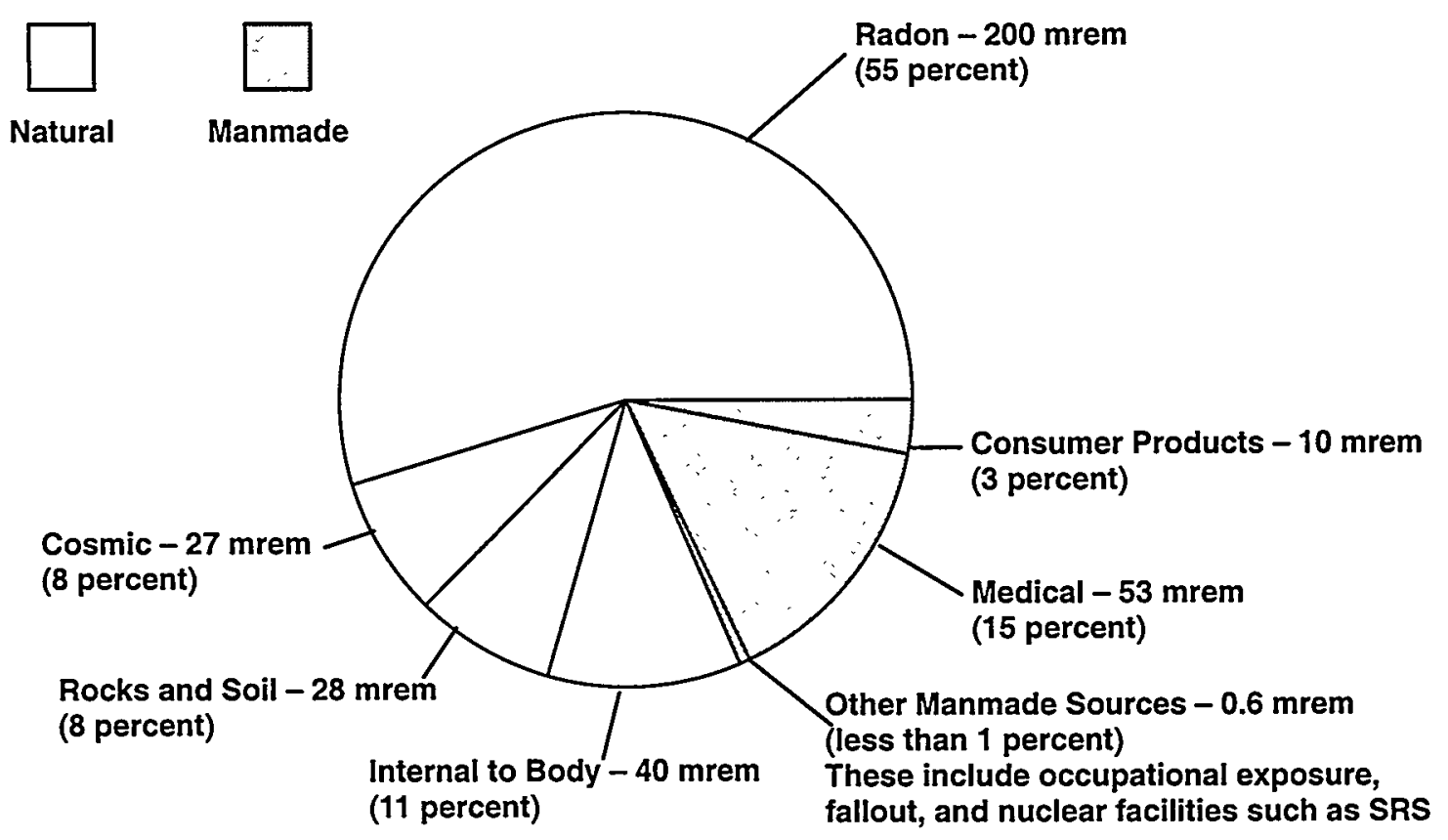

Ileaf Graphic

Figure 7-6 Contributions to the U.S. Average Individual Dose

The major contributor to the annual average individual dose in the United States, including residents of the CSRA, is naturally occurring radiation (about $300 \mathrm{mrem}$ ) [NCRP, 1987]. During 1999, SRS operations potentially contributed a maximum individual dose of $0.28 \mathrm{mrem}$, which is less than 0.08 percent of the 360-mrem total annual average dose (natural plus manmade sources of radiation).

Again, some fraction of this cesium-137 is from worldwide fallout and from neighboring Vogtle Electric Generating Plant effluent discharges; however, that amount is difficult to determine and is not subtracted from the total.

\section{Potential Risk from Consumption of SRS Creek Mouth Fish}

During 1991 and 1992, in response to a U.S. House of Representative Appropriations Committee request for a plan to evaluate risk to the public from fish collected from the Savannah River, SRS developed - in conjunction with EPA, the Georgia Department of Natural Resources (GDNR), and the South Carolina Department of Health and Environmental Control (SCDHEC)-the Westinghouse Savannah River

Company/Environmental Monitoring Section Fish Monitoring Plan [SRS EM Program, 1999]. Part of the reporting requirements of this plan are to perform an assessment of radiological risk from the consumption of Savannah River fish, and to summarize the results in the annual $S R S$ Environmental Report. The following sections discuss the potential radiological risks from the consumption of Savannah River fish, using SRS-published data from 1993 through 1999.

Potential radiological risks are determined using both the ICRP-60 [ICRP, 1990] and the EPA [EPA, 1991] methods.

Exposure Scenario In EPA's risk assessment guidance document [EPA, 1991], two fish consumption pathways are considered-the recreational fisherman scenario and the subsistence fisherman scenario. Because of SRS's relatively remote location, the recreational fisherman scenario-as opposed to the subsistence fisherman scenario-is considered the more reasonable exposure scenario and is used in this assessment.

It is assumed that a recreational fisherman fishes for a single species of fish - either panfish, such as bream; predators, such as bass; or bottom dwellers, such as catfish-from the mouth of the worst-case SRS stream. Access to upstream portions of SRS streams is prohibited by postings, fencing (where possible), and periodic patrols.

Per EPA guidance [EPA, 1991], the maximum consumption rate that should be used for determining 
risk to the recreational fisherman is 19 kilograms (42 pounds) per year. This is the same as the consumption rate used by SRS for demonstrating maximally exposed individual dose compliance [Hamby, 1991].

The EPA guidance document requires that critical subpopulations and fish species be considered in risk assessments. Currently, there are no known sensitive subpopulations (e.g., Native Americans) in the immediate SRS region who are known to regularly consume whole fish (edible and nonedible portions) as part of their typical diet. Also, there are no known species of fish, such as smelt, in the SRS region of the Savannah River that are commonly eaten whole. Therefore, it is reasonably assumed that the recreational fisherman consumes only the edible (fillet only) portion of the fish caught.

Risk Factors For the EPA method, estimates of potential risk are calculated directly by multiplying the amount of each radionuclide ingested by the appropriate risk (slope) factors provided in EPA's Health Effects Assessment Summary Tables (HEAST) [EPA, 1996]. The HEAST ingestion slope factors are best estimates of potential, age-averaged, lifetime excess cancer incidence (fatal and nonfatal) risk per unit of activity ingested.

For the ICRP -60 method, estimates of potential risk are determined first by calculating a radiation dose attributable to the amount of radionuclides ingested and then multiplying that dose by the ICRP-60 coefficient of risk of severe detriment of 7.3E-07 per mrem [ICRP, 1990]. Stated another way, if $10,000,000$ people each received a radiation dose of $1 \mathrm{mrem}$, there would theoretically be-during their collective lifetimes- 7.3 additional severe detrimental incidences (fatal/nonfatal cancer or severe hereditary effects), which is small compared to the $2,000,000$ or more expected fatal cancer incidences from other causes during their lifetimes [BELR V, 1990].

The ICRP -60 risk coefficient includes factors for

- fatal cancers (5.0E-07 per mrem)

- nonfatal cancers (1.0E-07 per mrem)

- hereditary effects (1.3E-07 per mrem)

It should be noted that all radiological risk factors are based on observed and documented health effects to actual people who have received high doses (more than 10,000 mrem) of radiation, such as the Japanese atomic bomb survivors. Radiological risks at low doses (less than 10,000 mrem) are theoretical and are estimated by extrapolating the observed health effects at high doses to the low-dose region by using a linear, no-threshold n.odel. However, cancer and other health effects have not been observed consistently at low radiation doses because the health risks either do not exist or are so low that they are undetectable by current scientific methods.

Exposure Duration According to EPA guidance, the upper bound value of 30 years can be used for exposure duration when calculating reasonable maximum residential exposures. This assessment compares the potential risks of exposure durations of 1 year, 30 years, and 50 years. The 30 -year and 50 -year exposure duration risks are simply 30 times and 50 times the 1-year exposure duration risk, respectively.

Risk Comparisons The maximum potential radiation doses and lifetime risks from the consumption of SRS creek mouth fish for 1-year, 30 -year, and 50-year exposure durations are shown in table 7-6 and are compared to the radiation risks associated with the DOE Order 5400.5 all-pathway dose standard of $100 \mathrm{mrem}(1.0 \mathrm{mSv})$ per year.

For each year, the maximum recreational fisherman dose was caused by the consumption of bass collected at the mouth of Steel Creek. More than 90 percent of the doses are attributable to cesium-137.

Figure 7-7 shows a 7-year history of the annual potential radiation doses from consumption of Savannah River fish. No apparent trends can be discerned from these data. This is because there is large variability in the annual cesium- 137 concentrations measured in fish from the same location due to differences in

- the size of the fish collected each year

- their mobility and location within the stream mouth from which they are collected

- the time of year they are collected.

Also, it should be noted that most of the cesium-137 that exists in SRS stream watersheds is legacy contamination left from relatively large liquid releases that occurred during the early years of operations at SRS (1954-1963) and is not from current direct operational releases [Carlton et al., 1994]. Therefore, there is large annual variability in the amount of cesium-137 available in the water and sediments at the site stream mouths; this is caused by annual changes in stream flow rates (turbulence) and water chemistry.

As indicated in table 7-6, the 50-year maximum potential lifetime risks from consumption of SRS creek mouth fish range between $2.2 \mathrm{E}-05$ and $6.2 \mathrm{E}-05$, which are below the 50 -year risk associated with the 100-mrem-per-year dose standard. 
Table 7-6

Potential Lifetime Risks from the Consumption of Savannah River Fish Compared to Dose Standards (1993-1999)

\begin{tabular}{|c|c|c|c|}
\hline & $\begin{array}{l}\text { Committed } \\
\text { Dose (mrem) }\end{array}$ & $\begin{array}{l}\text { ICRP-60 } \\
\text { Risk Method }\end{array}$ & $\begin{array}{l}\text { EPA/CERCLA } \\
\text { Risk Method }\end{array}$ \\
\hline \multicolumn{4}{|c|}{1999 Savannah River Fish } \\
\hline 1-Year Exposure & 0.61 & $4.5 E-07$ & $3.9 E-07$ \\
\hline 30-Year Exposure & 18 & $1.3 \mathrm{E}-05$ & $1.2 \mathrm{E}-05$ \\
\hline 50-Year Exposure & 31 & $2.2 E-05$ & $2.0 \mathrm{E}-05$ \\
\hline \multicolumn{4}{|c|}{1998 Savannah River Fish } \\
\hline 1-Year Exposure & 1.6 & $1.2 E-06$ & $1.0 \mathrm{E}-06$ \\
\hline 30-Year Exposure & 48 & $3.5 \mathrm{E}-05$ & $3.0 \mathrm{E}-05$ \\
\hline 50-Year Exposure & 80 & $5.8 \mathrm{E}-05$ & $5.0 E-05$ \\
\hline \multicolumn{4}{|c|}{1997 Savannah River Fish } \\
\hline 1-Year Exposure & 0.65 & $4.8 \mathrm{E}-07$ & $4.1 E-07$ \\
\hline 30-Year Exposure & 20 & $1.4 \mathrm{E}-05$ & $1.2 E-05$ \\
\hline 50-Year Exposure & 33 & $2.4 \mathrm{E}-05$ & $2.1 E-05$ \\
\hline \multicolumn{4}{|c|}{1996 Savannah River Fish } \\
\hline 1-Year Exposure & 1.7 & $1.2 E-06$ & $1.1 E-06$ \\
\hline 30-Year Exposure & 51 & 3.7E-05 & 3.3E-05 \\
\hline 50-Year Exposure & 85 & $6.2 E-05$ & $5.5 E-05$ \\
\hline \multicolumn{4}{|c|}{1995 Savannah River Fish } \\
\hline 1-Year Exposure & 1.2 & $8.8 \mathrm{E}-07$ & $7.4 \mathrm{E}-07$ \\
\hline 30-Year Exposure & 36 & $2.6 \mathrm{E}-05$ & $2.2 \mathrm{E}-05$ \\
\hline 50-Year Exposure & 60 & $4.4 \mathrm{E}-05$ & $3.7 E-05$ \\
\hline \multicolumn{4}{|c|}{1994 Savannah River Fish } \\
\hline 1-Year Exposure & 1.3 & $9.5 \mathrm{E}-07$ & $8.2 E-07$ \\
\hline 30-Year Exposure & 39 & $2.8 \mathrm{E}-05$ & $2.5 \mathrm{E}-05$ \\
\hline 50-Year Exposure & 65 & $4.7 \mathrm{E}-05$ & $4.1 E-05$ \\
\hline \multicolumn{4}{|c|}{1993 Savannah River Fish } \\
\hline 1-Year Exposure & 1.3 & $9.5 E-07$ & $7.9 E-07$ \\
\hline 30-Year Exposure & 39 & $2.8 E-05$ & $2.4 \mathrm{E}-05$ \\
\hline 50-Year Exposure & 65 & 4.7E-05 & $4.0 E-05$ \\
\hline \multicolumn{4}{|l|}{ Dose Standard } \\
\hline \multicolumn{4}{|c|}{ 100-mrem/year All Pathway } \\
\hline 1-Year Exposure & 100 & $7.3 E-05$ & $6.3 E-05$ \\
\hline 30-Year Exposure & 3,000 & $2.2 E-03$ & $1.9 \mathrm{E}-03$ \\
\hline 50-Year Exposure & 5,000 & $3.7 E-03$ & $3.2 E-03$ \\
\hline
\end{tabular}

According to EPA practice, if a potential risk is calculated to be less than $1.0 \mathrm{E}-06$ (i.e., one additional case of cancer over what would be expected in a group of $1,000,000$ people), then the risk is considered minimal and the corresponding contaminant concentrations are considered negligible.
If a calculated risk is more than $1.0 \mathrm{E}-04$ (one additional case of cancer in a population of 10,000 ), then some form of corrective action or remediation usually is required. However, if a calculated risk falls between $1.0 \mathrm{E}-04$ and $1.0 \mathrm{E}-06$, which is the case with the maximum potential lifetime risks from the 


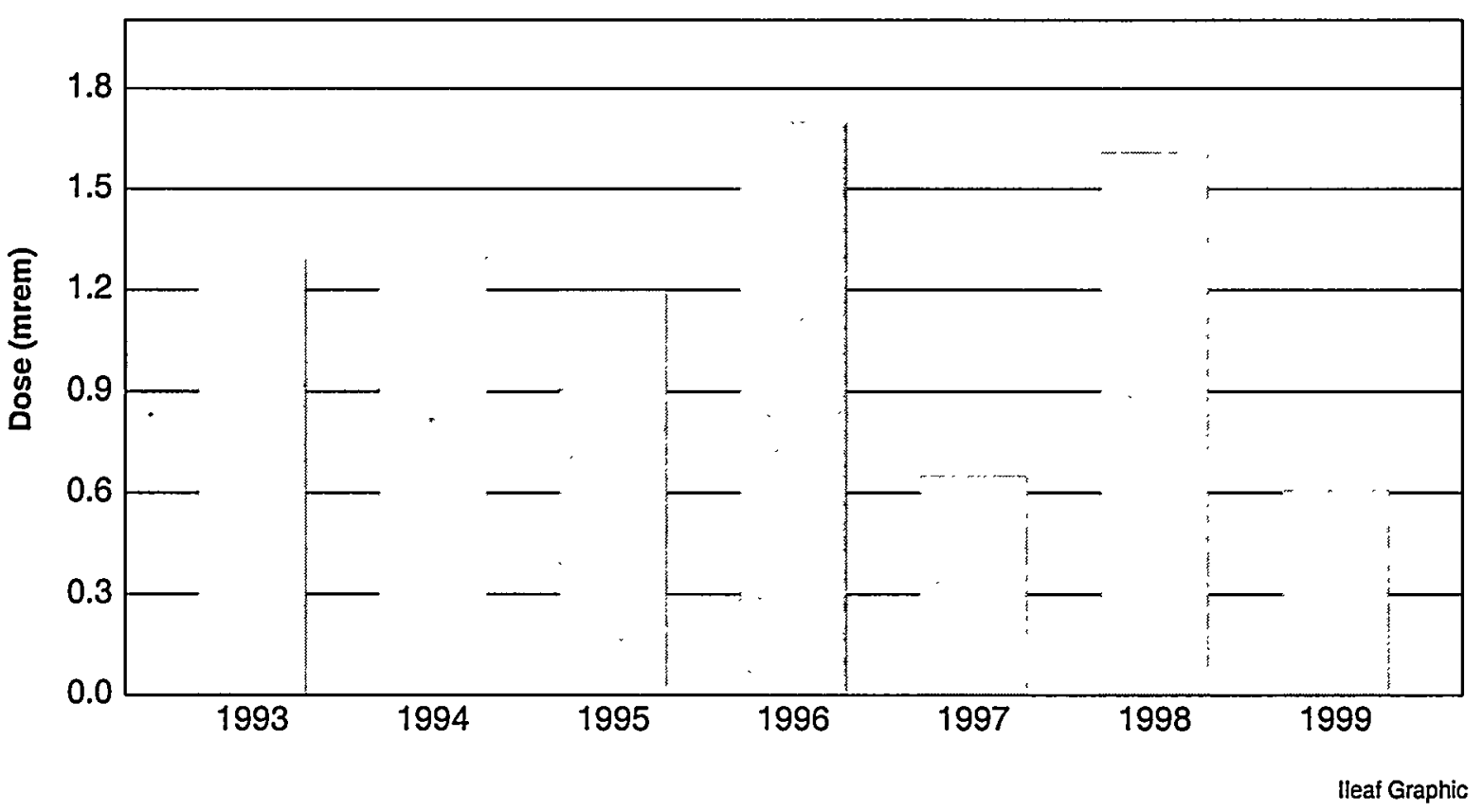

Figure 7-7 Annual Potential Radiation Doses from Consumption of Savannah River Fish, 1993-1999

consumption of Savannah River fish, then the risks are considered acceptable if they are kept as low as reasonably achievable (ALARA).

At SRS, the following programs are in place to ensure that the potential risk from site radioactive liquid effluents (and, therefore, from consumption of Savannah River fish) are kept ALARA:

- radiological liquid effluent monitoring program (chapter 5)

- radiological environmental surveillance program (chapter 6)

- environmental ALARA program [SRS EM Program, 1999]

\section{Dose to Aquatic Animal Organisms}

DOE Order 5400.5 establishes an interim dose standard for protection of native aquatic animal organisms. The absorbed dose limit to these organisms is $1 \mathrm{rad}$ per day (0.01 Gy per day) from exposure to radioactive material in liquid effluents released to natural waterways.

Hypothetical doses to various aquatic biota (fish, shellfish, algae, raccoon, and duck) in SRS streams are calculated annually to demonstrate compliance with this 1-rad-per-day dose standard. Upper-limit doses are calculated with measured radioactivity transport and minimum flow rates for each surface stream. Flow rates are chosen to maximize the biota dose. Source terms (stream transport) are provided by the site's Environmental Monitoring Section (table 51, SRS Environmental Data for 1999).

The CRITR computer code [Soldat et al., 1974], incorporated as part of the LADTAPII code, calculates internal and external doses to aquatic biota and to higher trophic levels that depend on aquatic biota for food. The CRITR Code is one of the three aquatic biota dose codes recommended by DOE [DOE, 1991].

External doses are calculated with the same external dose factors used for man [DOE, 1988]. Internal doses are based on the physical size (effective radius) of the biota and on effective energies provided for each radionuclide for each radius. Because of their size and eating habits, ducks usually are the aquatic biota that receive the largest dose.

In 1999, the maximum dose to aquatic biota was estimated at 0.039 rad per day ( 0.00039 Gy per day), which potentially occurred in ducks inhabiting Four Mile Creek. This is 3.9 percent of the 1-rad-per-day DOE dose limit.

\section{Radiological Assessment Program}

The preparation of documents describing the effects of SRS operations on the environment began in 1988. The format chosen was a separate document for each major radionuclide or group of similar radionuclides. The documents describe the operating history of the site with respect to the production, storage, and 
release of each radionuclide. The transport of the radionuclide in air, surface water, and groundwater is explained, and a calculation of the dose estimate to individuals and the population surrounding SRS is presented. As of December 31, 1999, the following documents had been published ${ }^{\mathrm{a}}$ :

- Assessment of Tritium in the Savannah River Site Environment, WSRC-TR-93-214

- Cesium in the Savannah River Site Environment, WSRC-RP-92-250

- Uranium in the Savannah River Site Environment, WSRC-RP-92-315

- Radioiodine in the Savannah River Site Environment, WSRC-RP-90-424-2

- Assessment of Radiocarbon in the Savannah River Site Environment, WSRC-TR-93-215

- Assessment of Technetium in the Savannah River Site Environment, WSRC-TR-93-217

- Assessment of Strontium in the Savannah River Site Environment, WSRC-RP-92-984
- Plutonium in the Savannah River Site Environment, WSRC-RP-92-879, Rev. 1

- Assessment of Mercury in the Savannah River Site Environment, WSRC-TR-94-0218ET

- Assessment of Noble Gases in the Savannah River Site Environment, WSRC-TR-95-0219

- Assessment of Activation Products in the Savannah River Site Environment, WSRC-TR-95-0422

- Assessment of Selected Fission Products in the SRS Environment, WSRC-TR-96-0220

- Assessment of Neptunium, Americium, and Curium in the Savannah River Site Environment, WSRC-TR-97-00266

- Assessment of Radionuclides in the Savannah River Site Environment-Summary, WSRC-TR-98-00162

No additional documents are scheduled for publication in 2000 , although some revisions may be issued.

a Copies of these documents can be obtained from the National Technical Information Service, U.S. Department of Commerce, 5285 Port Royal Road, Springfield, VA 22161. 


\title{
Nonradiological Effluent \\ Monitoring
}

To Read About ... $\quad$ See Page ...

Airborne Emissions ............... 129

Liquid Discharges ................ 132

History of NPDES Exceedances . . . . . . 135

1999 NPDES Exceedances . . . . . . . . . 136

\author{
Carl Cook, Larry Eldridge, \\ and Stuart Stinson \\ Environmental Protection Department
}

\section{Highlights}

- At SRS, there are 207 permitted/exempted nonradiological air emission sources, 153 of which were in operation to some capacity in 1999. Thirty-eight of the SRS permitted sources are permitted to release toxic air pollutants; 22 of these were operated during the year.

- SRS conducts no onsite monitoring for ambient air quality; however, the site is required to show compliance with various air quality standards. This is accomplished by using air dispersion modeling techniques. Modeling analysis for new sources permitted at SRS in 1999 showed that the site was in compliance with all applicable ambient air quality standards.

- SRS monitors nonradioactive releases to surface water through NPDES. The site discharged water into site streams and the Savannah River under four NPDES permits in 1999.

- Thirty-two of the site's 33 permitted outfalls discharged; the other was not in service. Results from 10 of the 5,778 discharge-sample analyses exceeded limits because of process upsets. This was a significant improvement over 1998 and enabled the site to achieve a 99.8-percent compliance rate. DOE has mandated a 98-percent compliance rate.

$\mathrm{N}$ ONRADIOACTIVE air emissions originating at Savannah River Site (SRS) facilities are monitored at their points of discharge by direct measurement, sample extraction and measurement, or process knowledge. Air monitoring is used to determine whether all emissions and ambient concentrations are within applicable regulatory standards.

Nonradiological liquid effluent monitoring encompasses sampling and analysis and is performed by the Environmental Protection Department's Environmental Monitoring Section (EMS) and the Savannah River Technology Center.

A complete description of EMS sampling and analytical procedures used for nonradiological monitoring can be found in sections 1101-1111 (SRS EM Program) of the Savannah River Site Environmental Monitoring Section Plans and Procedures, WSRC-3Q1-2, Volume 1. A summary of data results is presented in this chapter; more complete data can be found in SRS Environmental Data for 1999 (WSRC-TR-99-00301).

\section{Airborne Emissions}

The South Carolina Department of Health and Environmental Control (SCDHEC) regulates nonradioactive air emissions-both criteria pollutants and toxic air pollutants-from SRS sources. Each source of air emissions is permitted or exempted by SCDHEC, with specific limitations identified. The bases for the limitations are outlined in various South Carolina and federal air pollution control regulations and standards. Many of the applicable standards are source dependent, i.e., applicable to certain types of industry, processes, or equipment. However, some standards govern all sources for criteria and toxic air pollutants and ambient air quality. Air pollution control regulations and standards applicable to SRS sources are discussed briefly in appendix A, "Applicable Guidelines, Standards, and Regulations." The SCDHEC air standards for toxic air pollutants are listed in appendix C, "Standard No. 8 Toxic Air Pollutants."

At SRS, there are 207 permitted/exempted nonradiological air emission sources, 153 of which were in operation in some capacity during 1999 . The 
remaining 54 sources either were being maintained in a "cold standby" status or were under construction.

\section{Description of Monitoring Program}

Major nonradiological emissions of concern from stacks at SRS facilities include sulfur dioxide, carbon monoxide, oxides of nitrogen, particulate matter smaller than 10 microns, volatile organic compounds, and toxic air pollutants. Facilities that have such emissions include diesel engine-powered equipment, package No. 2 fuel oil steam generators, powerhouse coal-fired boilers, the Defense Waste Processing Facility, the in-tank precipitation process, groundwater air strippers, and various other process facilities. Emissions from SRS sources are determined during an annual emissions inventory from calculations using source operating parameters such as fuel oil consumption rates, total hours of operation, and the emission factors provided in the U.S. Environmental Protection Agency (EPA) "Compilation of Air Pollution Emission Factors," AP-42. The calculation for boiler sulfur dioxide emissions also uses the average sulfur content of the coal and assumes 100-percent liberation of sulfur and 100-percent conversion to sulfur dioxide. Most of the processes at SRS are unique sources requiring nonstandard, complex calculations that use process chemical or material throughputs, hours of operation, chemical properties, etc., to determine actual emissions. In addition to the annual emissions inventory, compliance with various standards is determined in several ways, as follows:

At the SRS powerhouses, stack compliance tests are performed every 2 years for each boiler by airborne emission specialists under contract to SRS. The tests include

- sampling of the boiler exhaust gases to determine particulate emission rates and carbon dioxide and oxygen concentrations

- laboratory analysis of coal for sulfur content, ash content, moisture content, and British Thermal Unit (BTU) output

Sulfur content and BTU output are used to calculate sulfur dioxide emissions. SCDHEC also conducts visible-emissions observations during the tests to verify compliance with opacity standards. The day-to-day control of particulate matter smaller than 10 microns is demonstrated by opacity meters in all SRS powerhouse stacks.

For the package steam generating boilers in $\mathrm{K}$-Area and for two portable units, compliance with sulfur dioxide standards is determined by analysis of the fuel oil purchased from the offsite vendor. The percent of sulfur in the fuel oil must be below 0.5 and is reported to SCDHEC each quarter. Compliance with particulate emission standards initially was demonstrated by mass-balance calculations rather than stack emission tests.

Compliance by SRS diesel engines and other process stacks is determined during annual compliance inspections by the local SCDHEC district air manager. The inspections include a review of operating parameters; operating hours recorded in logbooks; an examination of continuous-emission monitors, where required for process or boiler stacks; and a visible-emissions observation for opacity.

For some sources of SRS toxic air pollutants, source compliance is determined by stack testing for the permitted pollutants. SRS has several soil vapor extraction systems and two air strippers on which catalytic oxidation units were installed as pollution control devices. The construction permits for the systems required stack testing initially, with subsequent testing requirements to be specified when the operating permits were issued. However, the construction permits for most of the systems have been modified to remove the catalytic oxidation units, thus eliminating the stack testing requirement. The Consolidated Incineration Facility (CIF) also must be tested once every 3 years for both toxic and criteria air pollutants.

Compliance by all toxic air pollutant and criteria pollutant sources also is determined by using EPA-approved air dispersion models. Air dispersion modeling is extremely conservative unless refined models are used. The Industrial Source Complex Version No. 3 model was used to predict maximum ground-level concentrations occurring at or beyond the site boundary for new sources permitted in 1999.

\section{Monitoring Results}

As noted earlier, emissions are calculated each year as part of an annual emissions inventory. In 1999, operating data were compiled and emissions calculated for 1998 operations for all site air emission sources (table 52, SRS Environmental Data for 1999). Because this process, which begins in January, requires up to 6 months to complete, this report will provide a comprehensive examination of total 1998 emissions, with only limited discussion of available 1999 monitoring results. It is known from compliance inspections, however, that the site received no notices of violation in 1999 and continued to maintain 100-percent compliance with all permitted emission rates and special conditions. Actual 1999 emissions will be compiled and reported in depth in the $S R S$ Environmental Report for 2000.

Two power plants with five coal-fired boilers are operated by Westinghouse Savannah River Company 
Table 8-1

SRS Power Plant Boiler Capacities

\begin{tabular}{lcc}
\hline Location & $\begin{array}{l}\text { Number of } \\
\text { Boilers }\end{array}$ & $\begin{array}{c}\text { Capacity } \\
\text { (BTU/hr) }\end{array}$ \\
A-Area & 2 & $71.7 \mathrm{E}+06$ \\
H-Area & 3 & $71.1 \mathrm{E}+06$ \\
\hline
\end{tabular}

(WSRC) at SRS. These boilers are used to generate steam, which is used for facility heating systems and, where required, as process steam. The location, number of boilers, and capacity of each boiler for these plants are listed in table 8-1. The A-Area and $\mathrm{H}$-Area boilers are overfeed stoker fed and use coal as their only fuel. None of the A-Area and H-Area boilers were stack tested in 1999, but all are scheduled to be tested during 2000 . The No. 2 boiler in $\mathrm{H}$-Area has been placed in cold standby status and will be tested upon being restarted.

SRS also has four package steam generating boilers fired by No. 2 fuel oil. The steam from these boilers is used primarily to heat buildings during cold weather, but also for process steam. The location, number of boilers, and capacity of each boiler are shown in table 8-2. During 1999, only the 76.8- and 38.0-million BTU/hr boilers were operated. The percent of sulfur in the fuel oil burned during the year was certified by the vendor to meet the requirements of the permit.

At SRS, 131 permitted and exempted sources, both portable and stationary, are powered by internal combustion diesel engines. These sources include portable air compressors, diesel generators, emergency cooling water pumps, and fire water pumps ranging in size from 150 to 2,050 kilowatts for generators and 200 to 520 horsepower for air compressor and pump engines. Fuel oil consumption for the diesel engines operated in 1998 was 565,815 gallons. Total fuel consumption for 1999 will be included in the report for calendar year 2000.

Table 8-2

SRS Package Steam Boiler Capacities

\begin{tabular}{lcc}
\hline Location & $\begin{array}{c}\text { Number of } \\
\text { Boilers }\end{array}$ & $\begin{array}{l}\text { Capacity } \\
\text { (BTU/hr) }\end{array}$ \\
K-Area & 1 & $76.8 E+06$ \\
K-Area & 1 & $38.0 \mathrm{E}+06$ \\
Portable & 2 & $17.0 \mathrm{E}+06$
\end{tabular}

Another significant source of criteria pollutant emissions at SRS is the burning of forestry areas across the site. The Savannah River Forest Station (SRFS), a unit of the U.S. Department of Agriculture Forest Service, periodically conducts controlled burning of vegetation and undergrowth as a means of preventing uncontrolled forest fires. During 1998, SRFS personnel burned 14,690 acres across the site.

Other sources of criteria pollutants at SRS are too numerous to discuss here by type. Table $8-3$ provides the 1998 atmospheric emissions results for all SRS sources, as determined by the air emissions inventory conducted in 1999. All calculated emissions were within applicable SCDHEC standards and permit limitations during 1998.

Thirty-eight of the SRS permitted sources are permitted for toxic air pollutants; 22 of these were operated during 1999. Several of the toxic air pollutant sources-specifically, the soil vapor extraction and air strippers with catalytic oxidation units-were required to be stack tested following startup to verify initial compliance with their respective permitted emission rates. Subsequent test requirements were to be specified in their respective operating permits when the permits were issued. In 1999 , the catalytic oxidation control devices for six vapor extraction units and the two air strippers were removed, thus eliminating requirements that the stack testing be conducted. Only one vapor extraction system with a catalytic oxidation unit was placed into operation during 1999. In late 1999, an extension of the stack test requirement for this unit was granted until March 2000. As discussed in the description of the monitoring program, the CIF must be stack tested every 3 years. This facility last was tested in April 1997 and is not due for testing again until April 2000.

Table 8-3

1998 Criteria Pollutant Air Emissions

\begin{tabular}{lr} 
Pollutant Name & $\begin{array}{r}\text { Actual Emissions } \\
\text { a } \\
\text { (Tons/Year) }\end{array}$ \\
Sulfur dioxide (SOX) & $4.81 \mathrm{E}+02$ \\
Total suspended particulates & $5.45 \mathrm{E}+02$ \\
$\mathrm{PM}_{10}$ (particulate matter 10 microns) & $2.03 \mathrm{E}+02$ \\
Carbon monoxide & $3.98 \mathrm{E}+03$ \\
Ozone (volatile organic compounds) & $2.57 \mathrm{E}+02$ \\
Gaseous fluorides (as hydrogen fluoride) & $1.21 \mathrm{E}-01$ \\
Nitrogen dioxide (NOX) & $4.13 \mathrm{E}+02$ \\
Lead & $3.63 \mathrm{E}-02$ \\
& \\
\hline a From all SRS sources (permitted and nonpermitted)
\end{tabular}


Total toxic air pollutant emissions at SRS are determined annually in tons per year for each pollutant (table 52, SRS Environmental Data for 1999). It should be noted that some toxic air pollutants (e.g., benzene) regulated by SCDHEC also are, by nature, volatile organic compounds (VOCs). As such, the total for VOCs in table 8-3 includes toxic air pollutant emissions. It also should be noted that table 8-3 includes the emissions for some hazardous air pollutants that are regulated under the Clean Air Act but not by SCDHEC Standard No. 8 . These pollutants are included because they are compounds of some Standard No. 8 pollutants.

\section{Ambient Air Quality}

Under existing regulations, SRS is not required to conduct onsite monitoring for ambient air quality; however, the site is required to show compliance with various air quality standards. To accomplish this, air dispersion modeling was conducted during 1999 for new emission sources or modified sources as part of the sources' construction permitting process. The modeling analysis showed that SRS air emission sources were in compliance with applicable regulations.

South Carolina and Georgia continue to monitor ambient air quality near SRS as part of the network associated with the Clean Air Act. Resulting data are available to the public through (1) the South Carolina Bureau of Air Quality and (2) the Georgia Department of Natural Resources, Environmental Protection Division, Air Protection Branch.

\section{Liquid Discharges}

\section{Description of Monitoring Program}

SRS monitors nonradioactive releases to surface waters through the National Pollutant Discharge Elimination System (NPDES). As required by EPA and SCDHEC, SRS has NPDES permits for discharges to the waters of the United States and South Carolina. These permits require that SRS test water discharged from the site for pollutants. Also mandated are specific sites to be monitored, parameters to be tested, and monitoring frequency - as well as analytical, reporting, and collection methods. Detailed requirements for each permitted discharge point-including parameters sampled for, permit limits for each parameter, sampling frequency, and method for collecting each sample - can be found in the individual permits, which are available to the public through SCDHEC's Freedom of Information office at (803) 734-5376.
In 1999, SRS discharged water into site streams and the Savannah River under four NPDES permits: one for industrial wastewater (SC0000175), one for general utility water discharges (SCG250162), and two for stormwater runoff-SCR00000 (industrial discharge) and SCR10000 (construction discharge). A fifth permit, ND0072125, is a "no discharge" water pollution control land application permit that regulates sludge sampling at onsite sanitary wastewater treatment facilities.

Permit SC0000175 regulated 33 industrial wastewater outfalls in 1999 (figure 8-1). Permit SCG250162 requires sampling at only one utility water discharge location; that location, outfall 001, did not discharge during 1999. Permit SCR000000 regulated 46 stormwater outfalls sorted into 11 groups.

An evaluation of the stormwater sampling outfalls in late 1998 led to several changes in the stormwater program in 1999, as outfalls B-008 and GS-002 were dropped and outfalls $\mathrm{Y}-01, \mathrm{H}-06$, and $\mathrm{N}-02$ were added. Outfalls CS-006 and CS-12A were renamed $\mathrm{N}-06$ and $\mathrm{N}-12 \mathrm{~A}$, respectively. Another outfall, $\mathrm{G}-020$, was eliminated from the program because of the construction of a dike capable of holding a 50-year rain; this prevented stormwater flow.

Samples were obtained from 13 locations in 1999 to provide representative sampling of all the groups. Permit SCR100000 does not require sampling unless requested by SCDHEC to address specific discharge issues at a given construction site; SCDHEC did not request such sampling in 1999.

NPDES samples are preserved in the field according to 40 CFR 136, the federal document that lists specific sample collection, preservation, and analytical methods acceptable for the type of pollutant to be analyzed. Chain-of-custody procedures are followed after collection and during transport to the analytical laboratory. The samples then are accepted by the laboratory and analyzed according to procedures listed in 40 CFR 136 for the parameters required by the permit.

The effectiveness of the NPDES monitoring program is documented by a surveillance program involving chemical and biological evaluation of the waters to which effluents have been discharged. More monitoring information can be found in chapters 9 , "Nonradiological Environmental Surveillance," and 12, "Special Surveys and Projects."

\section{Monitoring Results}

SRS reports analytical results to SCDHEC through a monthly discharge monitoring report, which includes an explanation concerning any analytical 


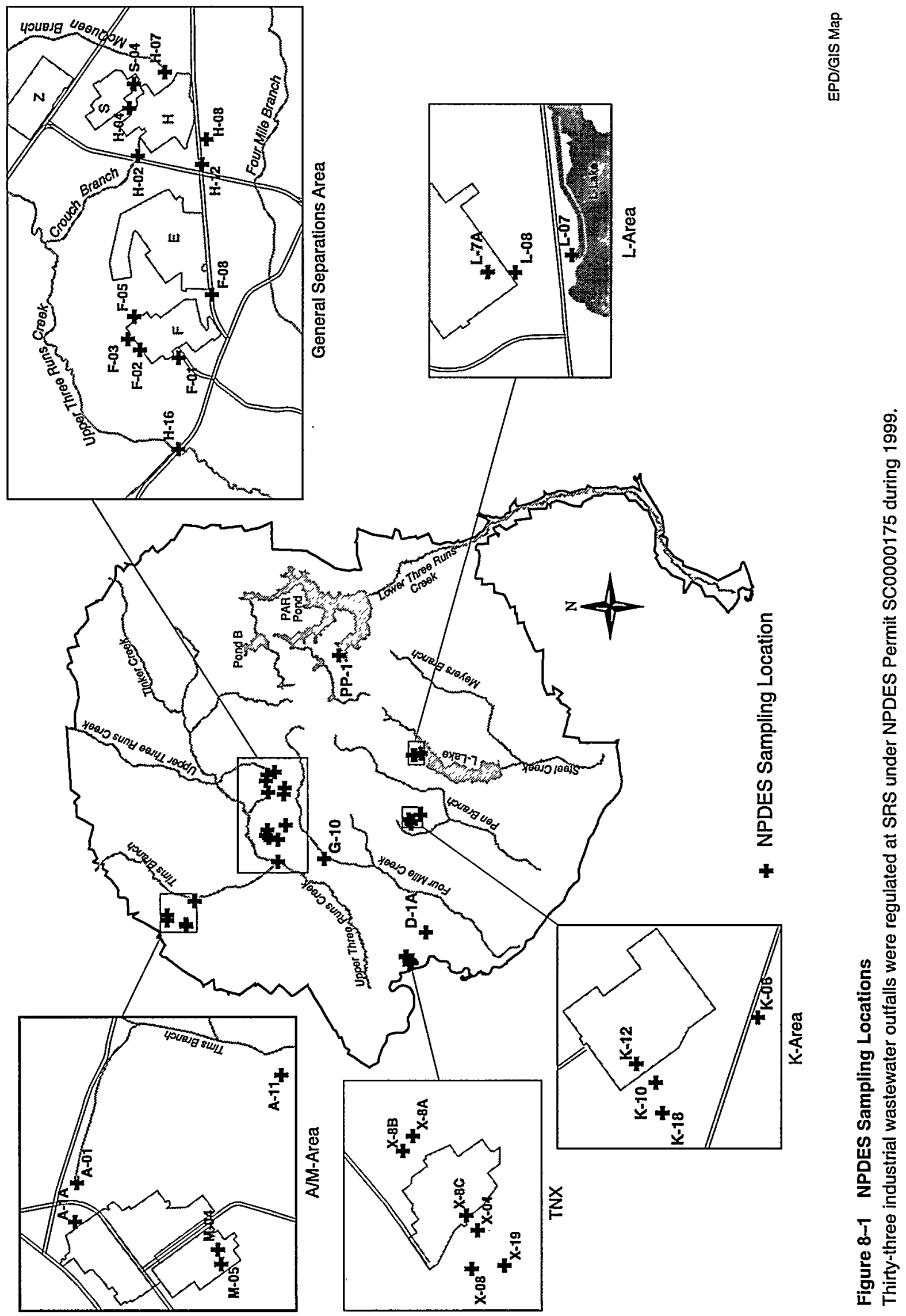




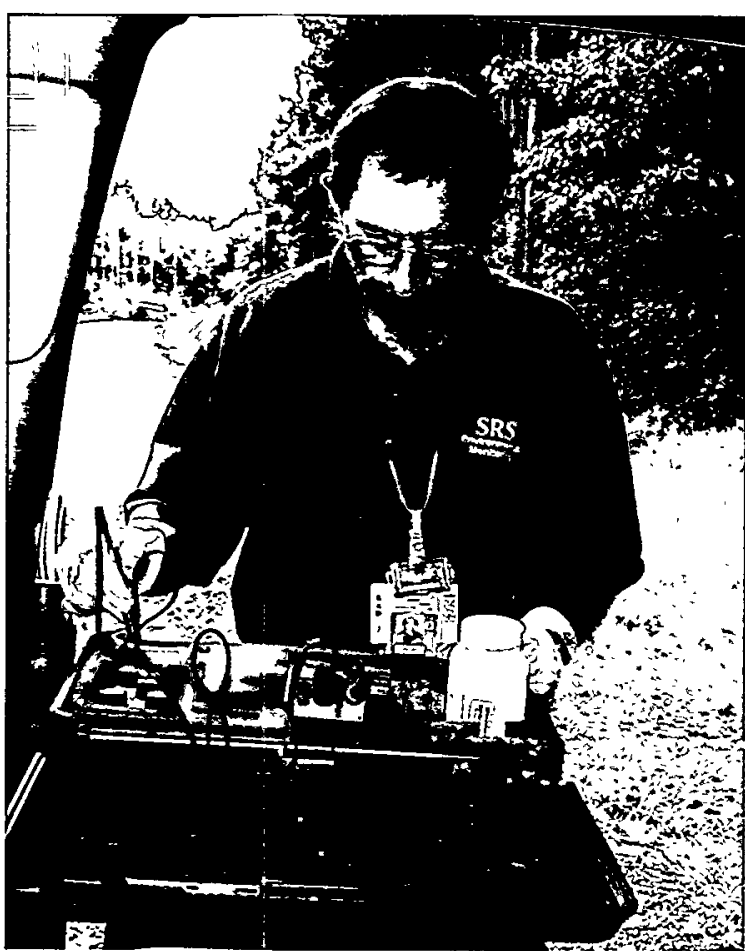

Al Mamatey Photo (00J00509.TIF)

An EMS sampling technician performs a field $\mathrm{pH}$ analysis on a water sample he has collected from one of SRS's 33 NPDES discharge locations. Field analyses must be performed-and appropriate preservatives added-within 15 minutes after the sample is collected.

measurements outside permit limits and a summary of all analyses performed at each permitted outfall. Complete results from 1999 NPDES industrial discharges (permit SC0000175) can be found in tables 53 and 54, SRS Environmental Data for 1999.

Of the 33 outfalls permitted by SC0000175 in 1999, 32 discharged and one, F-03, was not in service. Results from 10 of the 5,778 discharge sample analyses performed during the year exceeded permit limits because of process upsets, such as the $\mathrm{pH}$ exceedance at the X-04 outfall.

A list of 1999 NPDES exceedances appears in table 8-4. Figure 8-2 shows the NPDES exceedances at SRS from 1986 through 1999 , along with the site's compliance rate for each year. Complete results of 1999 industrial wastewater sample analyses can be found in table 53, SRS Environmental Data for 1999. SRS achieved a 99.8-percent compliance rate-higher than the DOE-mandated 98-percent rate.

The 1999 exceedance total of 10 represents a significant decrease from the 42 exceedances of
1998. Chronic-toxicity failures at outfall A-11 accounted for seven of the 10 exceedances. The chronic-toxicity problem, identified in 1998 and cited in a November 1998 notice of violation, has been a recurring issue. Toxicity identification evaluation analyses have been unable to determine the source of the toxicity, so SRS personnel have turned to the chronic-toxicity analysis itself for an explanation. This type of analysis tests the ability of an organism to survive and reproduce in a discharge medium. NPDES protocol requires Ceriodaphnia dubia, which has performed poorly in tests involving SRS waters. The possibility of utilizing an alternative species in the tests is being explored; this species Daphnia ambigua, is indigenous to the area and likely would produce valid test results.

A chronic toxicity problem at Outfall A-01, identified in 1998 and attributed to elevated copper levels in the effluent (caused by multiple sources throughout the A-01 drainage area), continued throughout 1999. SCDHEC issued a consent order October 11 that requires SRS to comply with permit requirements by October 2001. Because a single source of copper could not be isolated, the site is building artificial wetlands to remove copper from the waste stream. The A-01 toxicity problems also are being addressed through development of the alternative test organism. A summary of toxicity results from 1999 can be found in table 54, SRS Environmental Data for 1999.

Outfall $\mathrm{H}-12$ had three copper exceedances in 1998 - also caused by multiple sources in the area. Corrective actions were implemented in December of that year and in early 1999 . The sample type was changed from grab to composite, and several minor sources of copper were eliminated. No copper exceedances were reported at $\mathrm{H}-12$ during 1999.

A total of 534 analyses were performed during 1999 on stormwater discharge samples. SCDHEC has not mandated permit limits for stormwater outfalls. Complete results of 1999 NPDES stormwater sample analyses can be found in table 55, SRS Environmental Data for 1999.

A total of 69 analyses were performed during 1999 on sanitary sludge samples. All results were within permit specifications. Results from all the land application analyses can be found in table 56, SRS Environmental Data for 1999.

Outfall 001, permitted by SCG250162, did not flow during 1999, and no liquid samples were obtained. Complete results of 1999 utility water discharge sample analyses can be found in table 53, SRS Environmental Data for 1999. 


\section{Number \\ of Exceedances}

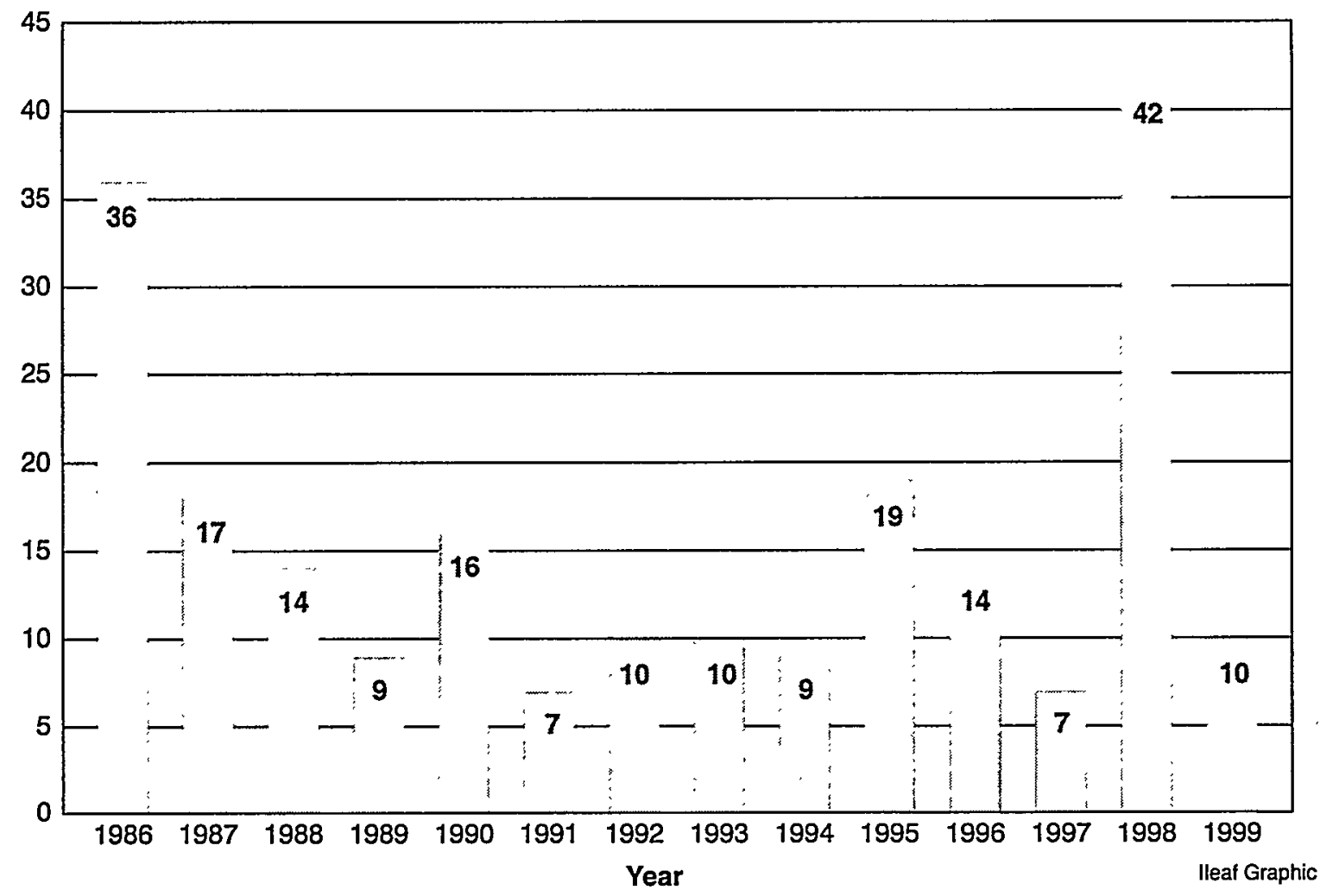

\begin{tabular}{|c|c|c|}
\hline Year & Number of Analyses & Compliance Rate \\
\hline 1986. & $\ldots \ldots 6,240$ & $99.4 \%$ \\
\hline 1987. & $\ldots 6,560$ & $99.7 \%$ \\
\hline 1988. & $\ldots 6,250 \ldots$ & . $99.8 \%$ \\
\hline 1989 . & $\ldots 6,859 \ldots$ & . $99.9 \%$ \\
\hline 1990 . & $\ldots 6,810 \ldots$ & . . $99.8 \%$ \\
\hline 1991. & $\ldots .8,329$ & $99.9 \%$ \\
\hline 1992. & $\ldots 7,729$ & $99.9 \%$ \\
\hline 1993. & $\ldots 8,000$ & . $99.9 \%$ \\
\hline 1994. & $\ldots \ldots 7,568$ & $99.9 \%$ \\
\hline 1995 . & $\ldots \ldots .7,515 \ldots$ & ... $99.8 \%$ \\
\hline 1996 . & $\ldots \ldots 5,737$. & ... $99.8 \%$ \\
\hline 1997. & $\ldots \ldots \ldots 5,758 \ldots$ & $\ldots .99 .9 \%$ \\
\hline 1998 & $\ldots .5,790$. & .. $99.3 \%$ \\
\hline 1999. & $\ldots .5,778 \ldots$ & . . $99.8 \%$ \\
\hline
\end{tabular}

Figure 8-2 History of NPDES Exceedances at SRS, and Site's Compliance Rate, 1986-1999

The chart and table provide historical information about NPDES exceedances from SRS liquid discharges to South Carolina waters, including the number of exceedances-and the site's compliance rate-for each year from 1986 to 1999.To determine the compliance rate, the number of analyses not exceeding limits for a given year is divided by the total number of analyses. For example, 5,778 analyses were performed in 1999 , with 10 exceedances. To calculate the compliance rate for that year, divide $5,768(5,778$ minus 10$)$ by 5,778 for a quotient of .9983 - or 99.8 percent. 
Table $8-4$

1999 Exceedances of SCDHEC-Issued NPDES Permit Liquid Discharge Limits at SRS

Page 1 of 1

\begin{tabular}{|c|c|c|c|c|c|c|}
\hline $\begin{array}{l}\text { Department/ } \\
\text { Division }\end{array}$ & Outfall & Date & $\begin{array}{l}\text { Parameter } \\
\text { Exceeded }\end{array}$ & Result & Possible Cause & Corrective Action \\
\hline TNX & $x-04$ & Jan. 14 & $\mathrm{pH}$ & $4.23 \mathrm{SU}$ & $\begin{array}{l}\text { Low-pH ambient } \\
\text { groundwater } \\
\text { intrusion into } \\
\text { discharge pipe }\end{array}$ & $\begin{array}{l}\text { Restart welding } \\
\text { sink flows to outfall } \\
\text { to compensate for } \\
\text { low-pH ambient } \\
\text { groundwater }\end{array}$ \\
\hline FDD & $A-11$ & Jan. 11 & C-TOX & Fail & Unknown & Under investigation \\
\hline FDD & $A-11$ & Feb. 17 & C-TOX & Fail & Unknown & Under investigation \\
\hline FDD & $A-11$ & April 14 & C-TOX & Fail & Unknown & Under investigation \\
\hline SUD & $D-1 A$ & June 16 & Flow & 0.028427 MGD & Heavy rain & None \\
\hline NMSS & $\mathrm{H}-04$ & July 27 & Foam & Present & $\begin{array}{l}\text { Washdown of } \\
\text { foam from } \\
\text { emergency } \\
\text { exercise in } \\
\text { H-Area }\end{array}$ & $\begin{array}{l}\text { Incorporate EPD/ } \\
\text { ECA input into } \\
\text { emergency } \\
\text { exercise planning } \\
\text { process }\end{array}$ \\
\hline SUD/ER & $A-11$ & Oct. 13 & C-TOX & Fail & Unknown & Under investigation \\
\hline SUD/ER & $A-11$ & Oct. 27 & C-TOX & Fail & Unknown & Under investigation \\
\hline SUD/ER & $A-11$ & Nov. 10 & C-TOX & Fail & Unknown & Under investigation \\
\hline SUD/ER & $A-11$ & Dec. 6 & C-TOX & Fail & Unknown & Under investigation \\
\hline
\end{tabular}

Key: $\quad S U-S t a n d a r d$ units

C-TOX-Chronic toxicity

MGD - Millions of gallons per day 


\title{
Nonradiological Environmental Surveillance
}

\author{
Bill Littrell and Phillip Miller \\ Environmental Protection Department
}

\author{
Robert Turner \\ Engineering Services Department
}

\section{Highlights}

- Analyses of the nonradioactive surveillance data generally indicated that SRS discharges are not significantly affecting the water quality of the streams or the river.

- All samples collected from SRS drinking water systems were in compliance with SCDHEC and EPA water quality limits.

- No pesticides or herbicides were detected in surface water samples. In addition, no pesticides or herbicides were found in sediment samples to be above the practical quantitation limits. All analyses of pesticides/herbicides were below the detection limits of EPA analytical procedures used.

- Individual fish analysis results indicated that a bass contained the highest level of mercury.

$\mathrm{N}$ ONRADIOACTIVE environmental surveillance at the Savannah River Site (SRS) involves the sampling and analysis of surface water (six onsite streams and the Savannah River), drinking water, sediment, groundwater, and fish. Surface water, drinking water, sediment, and fish surveillance programs are discussed in this chapter. However, a description of the surveillance program and 1999 results for groundwater can be found in chapter 10, "Groundwater."

The Environmental Protection Department's Environmental Monitoring Section (EMS) and the Savannah River Technology Center (SRTC) perform nonradiological surveillance activities. The Savannah River also is monitored by other groups, including the South Carolina Department of Health and Environmental Control (SCDHEC) and the Georgia Department of Natural Resources (GDNR). In addition, the Academy of Natural Sciences of Philadelphia (ANSP) conducts environmental surveys on the Savannah River through a program that began in 1951. A discussion of these surveys and latest results begins on page 145 .

A complete description of the EMS sample collection and analytical procedures used for nonradiological surveillance can be found in section 1105 of the Savannah River Site

Environmental Monitoring Section Plans and Procedures, WSRC-3Q1-2, Volume 1 (SRS EM Program). A summary of analytical results is presented in this chapter; however, more complete data can be found in SRS Environmental Data for 1999 (WSRC-TR-99-00301). Information on the rationale for the nonradiological environmental surveillance program can be found in chapter 3, "Environmental Program Information."

In 1999, approximately 6,300 nonradiological analyses for specific chemicals and metals were performed on about 1,200 samples, not including groundwater.

SRS currently does not conduct onsite surveillance for ambient air quality. However, to ensure compliance with SCDHEC air quality regulations and standards, SRTC conducted air dispersion modeling for all site sources of criteria pollutants and toxic air pollutants in 1993. This modeling indicated that all SRS sources were in compliance with air quality regulations and standards. Since that time, additional modeling conducted for new sources of criteria pollutants and toxic air pollutants has demonstrated continued compliance by the site with these regulations and standards. The states of South Carolina and Georgia continue to monitor 
ambient air quality near the site as part of a network associated with the federal Clean Air Act. (See chapter 8 for more information about criteria pollutants and toxic air pollutants.)

\section{Surface Water}

SRS streams and the Savannah River are classified as "Freshwaters" by SCDHEC. Freshwaters are defined as surface water suitable for

- primary-and secondary-contact recreation and as a drinking water source after conventional treatment in accordance with SCDHEC requirements

- fishing and survival and propagation of a balanced indigenous aquatic community of fauna and flora

- industrial and agricultural uses

Appendix A, "Applicable Guidelines, Standards, and Regulations," provides some of the specific guides used in water quality surveillance, but because some of these guides are not quantifiable, they are not tracked (i.e., amount of garbage found).

\section{Description of Surveillance Program}

SRS stream and Savannah River nonradiological surveillance is conducted for any evident degradation that could be attributed to the water discharges regulated by the site National Pollutant Discharge Elimination System (NPDES) permits and materials that may be released inadvertently from sources other than routine release points.

In addition, nonradiological surveillance is conducted to compare the SRS contribution of pollutants with background levels of chemicals from natural sources and from contaminants produced by municipal sewage plants, medical facilities, and other upriver industrial facilities.

Each SRS stream receives varying amounts of treated wastewater and rainwater runoff from site facilities. Stream locations are sampled for water quality at monthly and quarterly frequencies by the conventional grab-collection technique. Each grab sample shows the water quality at the time of sampling only.

River sampling sites are located upriver of, adjacent to, and downriver of the site. In the surveillance program, site streams and the Savannah River are sampled monthly for various physical and chemical properties. Surface water sampling locations are shown in figure 9-1.

To monitor the quality of water coming onto and leaving the site, field measurements for conductivity, dissolved oxygen, $\mathrm{pH}$, and temperature are taken monthly and laboratory analyses are conducted for other water quality parameters, such as metals, pesticides/herbicides (quarterly), and other physical properties. Comparison of the results from upstream and downstream locations (locations that are below process areas or at points where the water leaves the site) indicates any impact the site may have had on the water.

The natural chemical and physical parameters measured monthly on each stream and in the river vary to some extent throughout the year. This natural variation can be trended on a month-to-month basis. When results diverge greatly from the historical norm, an abnormal discharge event or occurrence in the environment may be indicated. An investigation is held to determine if a release has occurred.

\section{Surveillance Results}

Results can be found in table 57, SRS Environmental Data for 1999.

Comparison of the upstream and downstream locations where available (Upper Three Runs Creek) and month-to-month trends for each of these stations indicated normal trends for a southern pine forest stream. The upstream $\mathrm{pH}$ varied within a range of 4.0 to 7.2 , while the conductivity ranged from a low of $14 \mu \mathrm{hmos} / \mathrm{cm}$ at the Upper Three Runs Creek-1A location to a high of $34 \mu \mathrm{hmos} / \mathrm{cm}$ at Tinker Creek-1. The downstream station at Upper Three Runs Creek -4 had a pH range of 5.5 to 6.8 and a conductivity range of 21 to $27 \mu \mathrm{hmos} / \mathrm{cm}$.

Nitrate levels for the river and most stream locations usually ranged below $0.50 \mathrm{mg} / \mathrm{L}$. Four Mile Creek-6 had the highest nitrate concentration of all the streams (between 0.32 and $2.11 \mathrm{mg} / \mathrm{L}$ ). This was due to discharges into Four Mile Creek from the waste treatment facility above the sampling location.

Phosphate levels were typically higher in the Savannah River than on site. Levels ranged from below detection to a high of $1.64 \mathrm{mg} / \mathrm{L}$ at River Mile-150.4 (formerly called the Vogtle Discharge sampling location). The August phosphate level at Beaver Dam Creek $(0.686 \mathrm{mg} / \mathrm{L})$ was the highest level in a site stream. Levels ranged to "not detected" at all locations. 


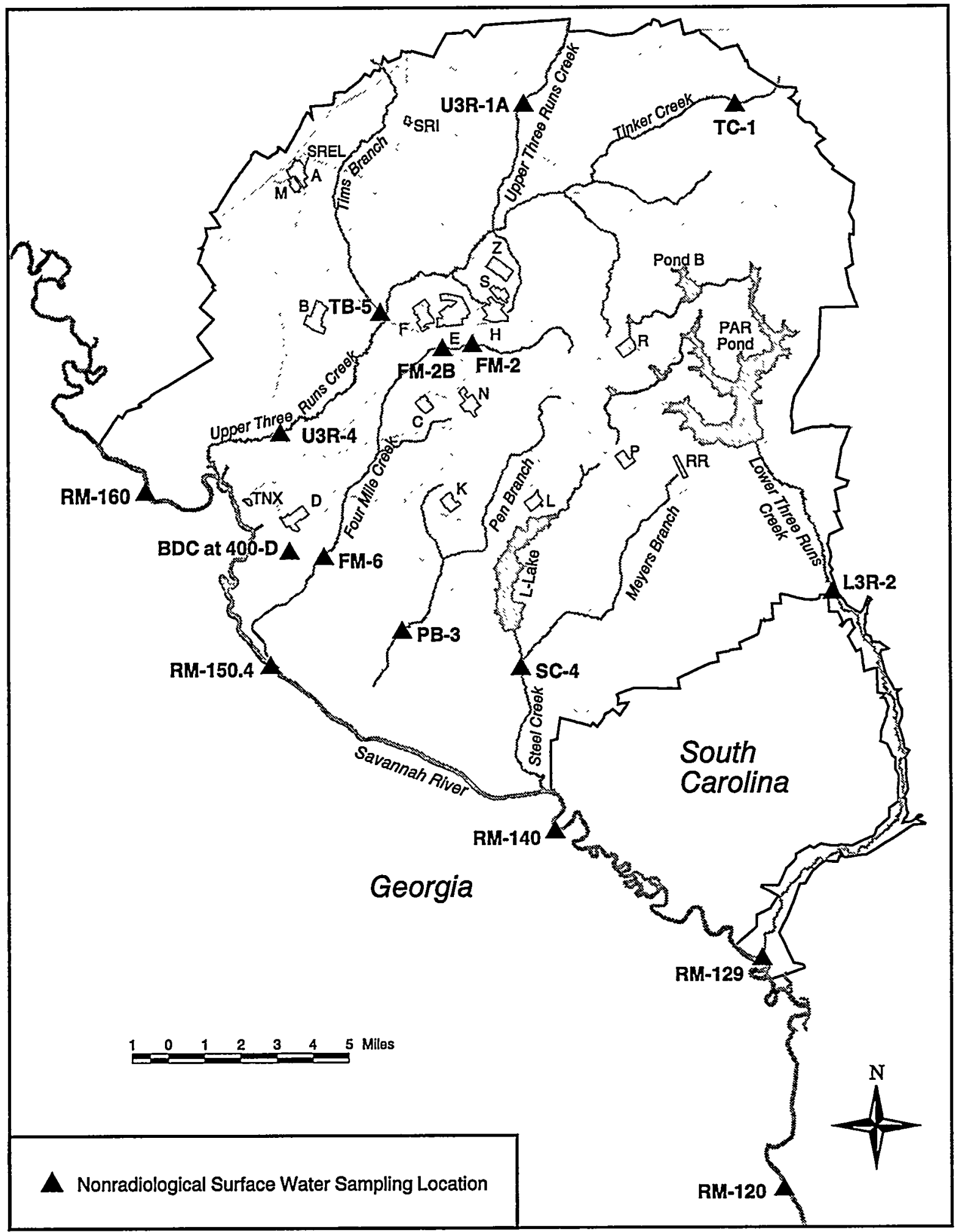

EPD/GIS Map

Figure 9-1 Nonradiological Surface Water Sampling Locations

Surface water samples are collected from five Savannah River and eleven SRS stream locations and are analyzed for various chemical and physical properties. 


\section{Mill Creek Background Water Quality Study}

The Mill Creek Background Water Quality Study was undertaken to quantify background water quality and hydrology in Mill Creek, an undisturbed blackwater forest stream on SRS. Blackwater forest streams are fairly common throughout the southeastern coastal plain of the United States, and a significant number of these blackwater drainages are being converted to urban and agricultural land uses due to increased economic and population growth. Future missions at SRS could require the conversion of such site forestland to industrial landscapes. Benchmarking water chemistry and hydrology in Mill Creek will provide a baseline for evaluating the water quality impacts of proposed land use changes in undeveloped forested watersheds. Data generated by this study also will assist in defining criteria necessary for developing pollutant reduction goals and watershed management plans and for performing National Environmental Policy Act (NEPA) onsite assessments.

Mill Creek discharges to Tinker Creek, a major tributary within the Upper Three Runs Creek drainage system of the Savannah River basin. It possesses a shifting, sandy bottom and a well developed floodplain canopy. Mill Creek's watershed encompasses approximately $23.57 \mathrm{~km}^{2}$ of mixed pine-hardwood forestland. There are no pollutant discharges into the creek. Most of the stream, its tributaries, and associated floodplain are protected from SRS activities by ecological buffer areas. Soils in the watershed are predominately sandy and possess a high infiltration rate and low runoff potential, even on the steeper slopes. Depth to the water table in the watershed ranges from 0 meters ( 0 feet) in the creek's floodplain to 37 meters ( 120 feet) in upland areas near the watershed divide. The area possesses a humid, semitropical climate with an average annual rainfall of $1237 \mathrm{~mm}$ (48.7 in). The greatest mean seasonal precipitation is normally recorded in the summer-followed by the winter, spring, and fall periods.

Water quality samples were collected from Mill Creek at a location approximately $3.2 \mathrm{~km}$ upstream of the stream's confluence with Tinker Creek. The drainage area upstream of the sampling location encompasses approximately $17.18 \mathrm{~km}^{2}$, or about 73 percent of the creek's total drainage area. Composite samples were collected during varying temporal (base and storm flow) and seasonal conditions over a 21-month period (January 1995 through September 1996).

The water quality parameters sampled included total Kjeldahl nitrogen (TKN), total phosphorus (TP), total organic carbon (TOC), ammonia- $\mathrm{N}\left(\mathrm{NH}_{4}-\mathrm{N}\right)$, nitrate- $\mathrm{N}\left(\mathrm{NO}_{3}-\mathrm{N}\right)$, chemical oxygen demand (COD), turbidity, total dissolved solids (TDS), total suspended solids (TSS), volatile solids (VS), fixed residues (FR), total solids (TS), turbidity, chloride (Cl), and sulfate $\left(\mathrm{SO}_{4}\right)$. Sample analyses were performed by three state-certified environmental laboratories.

Analysis of the data indicates that during the period of observation there were no significant differences between mean base and storm flow concentrations for $\mathrm{NO}_{3}-\mathrm{N}, \mathrm{NH}_{4}-\mathrm{N}, \mathrm{TKN}$, and TP. However, mean concentrations of TOC, TSS, and VS were significantly greater during storm flow than during base flow. This was probably attributable to a close relationship between these latter constituents and particulate matter, which is transported during storm flow conditions. Highest seasonal concentrations of TKN, TP, TOC, TSS, and VS occurred during the late fall period, possibly due to the mineralization or leaching of fresh leaf litter. Greatest seasonal concentrations for $\mathrm{NO}_{3}-\mathrm{N}$ and $\mathrm{NH}_{4}-\mathrm{N}$ occurred during the summer and winter periods, respectively. The summer $\mathrm{NO}_{3}-\mathrm{N}$ high may have been due to increased instream mineralization of organic nitrogen in excess of biotic demands and/or the concentrating effect of evapotranspiration on surface soil and groundwater $\mathrm{NO}_{3}-\mathrm{N}$ levels.

A comprehensive assessment of all hydrologic and hydrochemical data collected during the 21-month period of observation is ongoing. More information about this study can be obtained by calling 803-725-5197.

Aluminum, iron, manganese, and zinc were seen in surface waters at all river and stream locations.

April data indicated low levels of mercury and lead at several locations. Copper was noted four times at Tinker Creek-1 (coming on to the site), twice at Upper Three Runs-1A (also coming on to the site), and five times at Tims Branch-5.

No pesticides or herbicides were detected during 1999.
Analyses of the data generally indicated that SRS discharges are not significantly affecting the water quality of the streams or the river.

\section{Drinking Water}

Most of the drinking water at SRS is supplied by three systems that have treatment plants in A-Area, $\mathrm{D}$-Area, and $\mathrm{K}$-Area. The site also has 15 small drinking water facilities at remote security barricades, field laboratories, and field offices that 
serve populations of fewer than 25 persons (figure 9-2).

Well water from the McBean, Congaree, Black Creek, and Middendorf aquifers is utilized for the 18 drinking water systems. Many of these well water supplies require treatment to ensure that SCDHEC and U.S. Environmental Protection Agency (EPA) drinking water quality standards are maintained. Treatment processes include aeration to remove dissolved gases; filtration to remove iron; and addition of potable water treatment chemicals to adjust $\mathrm{pH}$, prevent piping corrosion, and prevent bacterial growth.

\section{Description of Surveillance Program}

SRS drinking water supplies are tested routinely by site personnel and by SCDHEC to ensure compliance with SCDHEC and EPA drinking water standards (the drinking water standards can be found in appendix B) and monitoring requirements. This testing includes

- daily testing to monitor concentration of any potable water treatment chemicals added

- monthly or quarterly testing to confirm that bacteria are not present

- periodic testing for metals, organic and inorganic chemicals, and radionuclides

\section{Surveillance Results}

All samples collected from SRS drinking water systems during 1999 were in compliance with SCDHEC and EPA water quality limits (maximum contaminant levels).

\section{Sediment}

EMS's nonradiological sediment surveillance program provides a method of determining the deposition, movement, and accumulation of nonradiological contaminants in stream systems.

\section{Description of Surveillance Program}

The nonradiological sediment program consists of the collection of sediment samples at eight onsite stream locations and three Savannah River locations (figure 9-3). Collection is made by either a Ponar sediment sampler or an Emery pipe dredge sampler. The samples are analyzed for various inorganic contaminants (metals) and pesticides/herbicides by the Toxicity Characteristic Leaching Procedure (TCLP) method. This method analyzes for the soluble constituents in sediment. The program is designed to check for the existence and possible buildup of the inorganic contaminants as well as for pesticides/herbicides.

\section{Surveillance Results}

Sediment results can be found in table 58, $S R S$ Environmental Data for 1999.

As in the previous three years, no pesticides or herbicides were found in sediment samples to be above the practical quantitation limits in 1999. All pesticide/herbicide results were below the detection limits of EPA analytical procedures used.

Aluminum, barium, magnesium, manganese, and zinc were seen in sediment at all river and stream locations. Levels for these metals were consistent with those seen in soil samples. From year to year, most metals vary from nondetectable levels to very low levels.

In 1999, copper was found at all onsite locations and consistently was between 0.01 and $0.024 \mathrm{mg} / \mathrm{L}$. For the previous four years, it had ranged as high as $0.103 \mathrm{mg} / \mathrm{L}$ at Tinker Creek-1 (control location) to below the lower limit of detection (LLD) at several locations as well as Tinker Creek-1.

In 1999, Upper Three Runs-4 showed $0.0001 \mathrm{mg} / \mathrm{L}$ of mercury, which is at the detection level. No other sites showed mercury in 1999. The 1998 level at Tinker Creek-1 was slightly above detection. No mercury was detected at any site in 1996 and 1997.

Lead was detected at six locations-Upper Three Runs Creek-1A, Upper Three Runs Creek-4, Beaver Dam Creek (400-D), Four Mile Creek, Tinker Creek-1, and River Mile 120. The levels ranged from below detection to $0.199 \mathrm{mg} / \mathrm{L}$. In 1998 , lead was found at three locations-Upper Three Runs Creek-1A, Upper Three Runs Creek-4, and Beaver Dam Creek (400-D). In 1997, lead was found at the Steel Creek-4 location only. No significant trends were observed for the metals in the Savannah River or on site.

\section{Fish}

\section{Description of Surveillance Program}

EMS analyzes the flesh of fish caught from onsite streams and ponds and from the Savannah River to determine concentrations of mercury in the fish [SRS EM Program, 1999]. The freshwater fish analyzed (bass, bream, and catfish) represent the most common edible species of fish in the Central Savannah River Area (CSRA), an 18-county area in Georgia and South Carolina that surrounds Augusta, Georgia, and includes SRS. Saltwater fish analyzed 


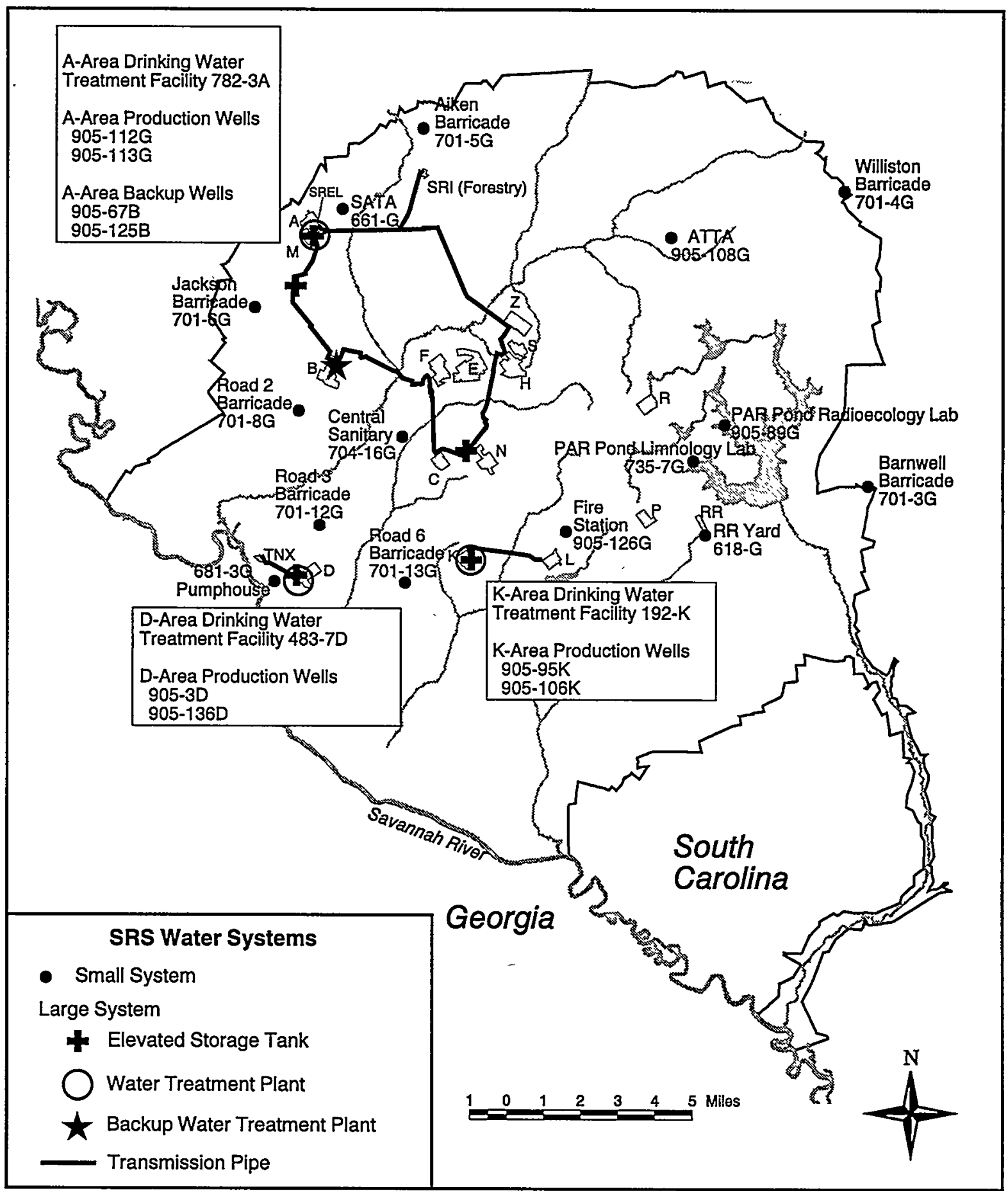

EPD/GIS Map

Figure 9-2 Drinking Water Systems

Most of the drinking water at SRS is supplied by three systems. The site also has 15 small drinking water facilities that serve populations of fewer than 25 persons. The three larger systems are depicted by transmission pipes, elevated storage tanks, water treatment plants, and a backup water treatment plant. 


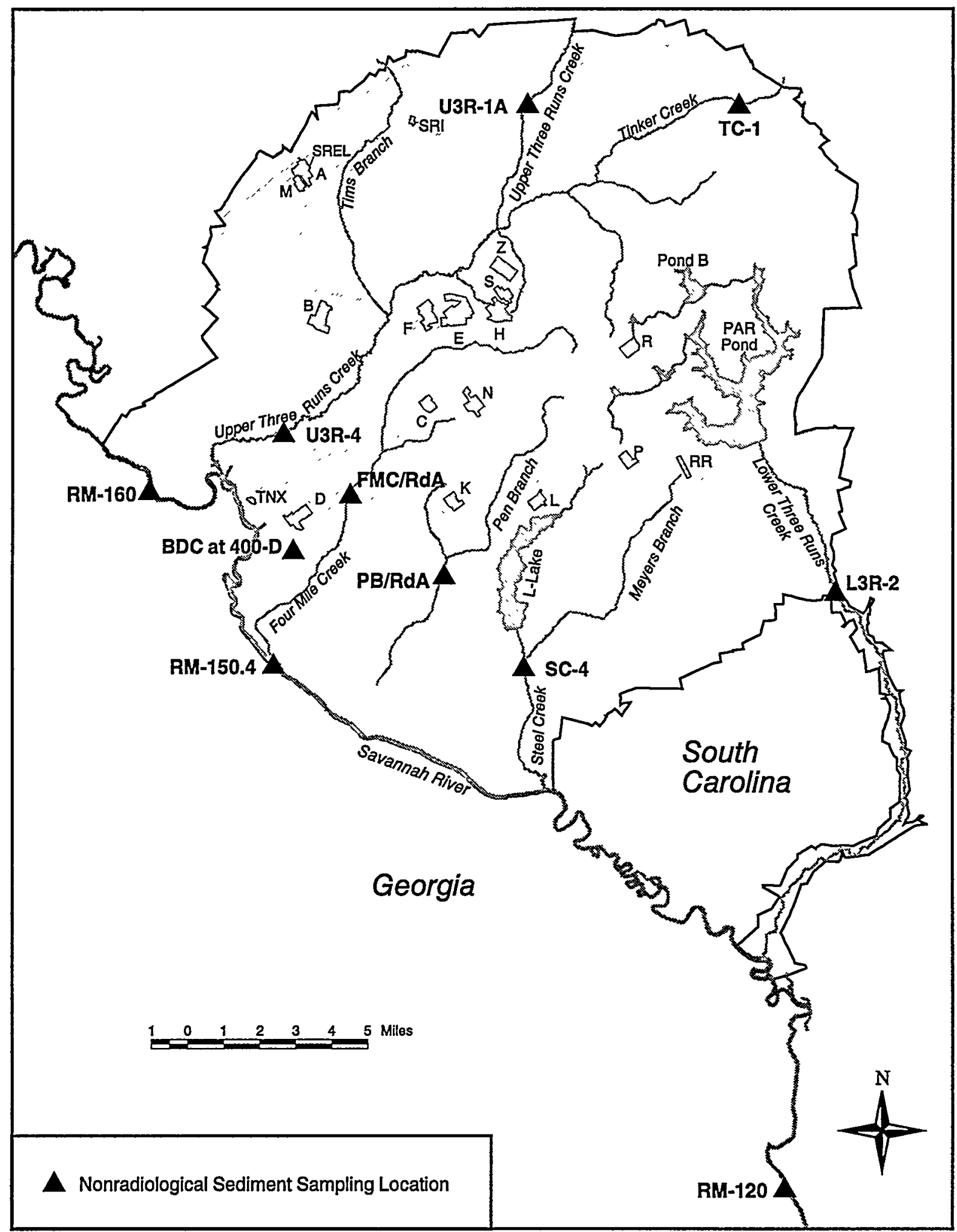

EPD/GIS Map

Figure 9-3 Nonradiological Sediment Sampling Locations

Sediment samples are collected at eight onsite stream locations and three Savannah River locations. The samples are analyzed for various inorganic contaminants (metals) and pesticides/herbicides. 
in 1999 included mullet, redfish, and sea trout. (Sampling locations for fish are depicted in a map on page 98 in chapter 6 , "Radiological

Environmental Surveillance.”)

\section{Surveillance Results}

In 1999, 213 fish from SRS streams and ponds and the Savannah River were caught and analyzed for mercury (table 59, SRS Environmental Data for 1999). Because of low water, no fish were caught from the Pen Branch-3, Four Mile Creek-6, Steel Creek -4 , and Upper Three Runs -4 locations.

The mercury concentrations in fish analyzed from onsite waters ranged from a high of $2.90 \mu \mathrm{g} / \mathrm{g}$ in a bass from PAR Pond to a low of 0.11 in a bream in Pond B. Mercury concentrations in offsite fish ranged from a high of $1.27 \mu \mathrm{g} / \mathrm{g}$ in a bass from the Steel Creek Mouth to values of 0.01 in mullet upstream of the Highway 17 Bridge area. Because of more sensitive instruments, the practical quantitation limit for mercury in fish flesh dropped to $0.008 \mu \mathrm{g} / \mathrm{g}$ in 1999 (from 0.33 in 1998).

In addition to the routine samples of bass, bream, and catfish, four special samples of shad were collected in the Savannah River at the request of the Department of Energy (DOE). The four samples were taken at the Four Mile Creek Mouth, Steel Creek Mouth, New Savannah Lock and Dam, and Highway 301 Bridge locations.

Overall individual results of all samples indicated that bass contained the highest levels of mercury. After bass, the order of fish with the next highest levels of mercury was mixed, depending on location.

Table 3-57 in the EPA publication mentioned in the sidebar on page 145 indicates that the recommended monthly consumption limit for fish collected at the highest offsite location for 1999 (Steel Creek Mouth) would be between one and two 8-ounce servings per month.

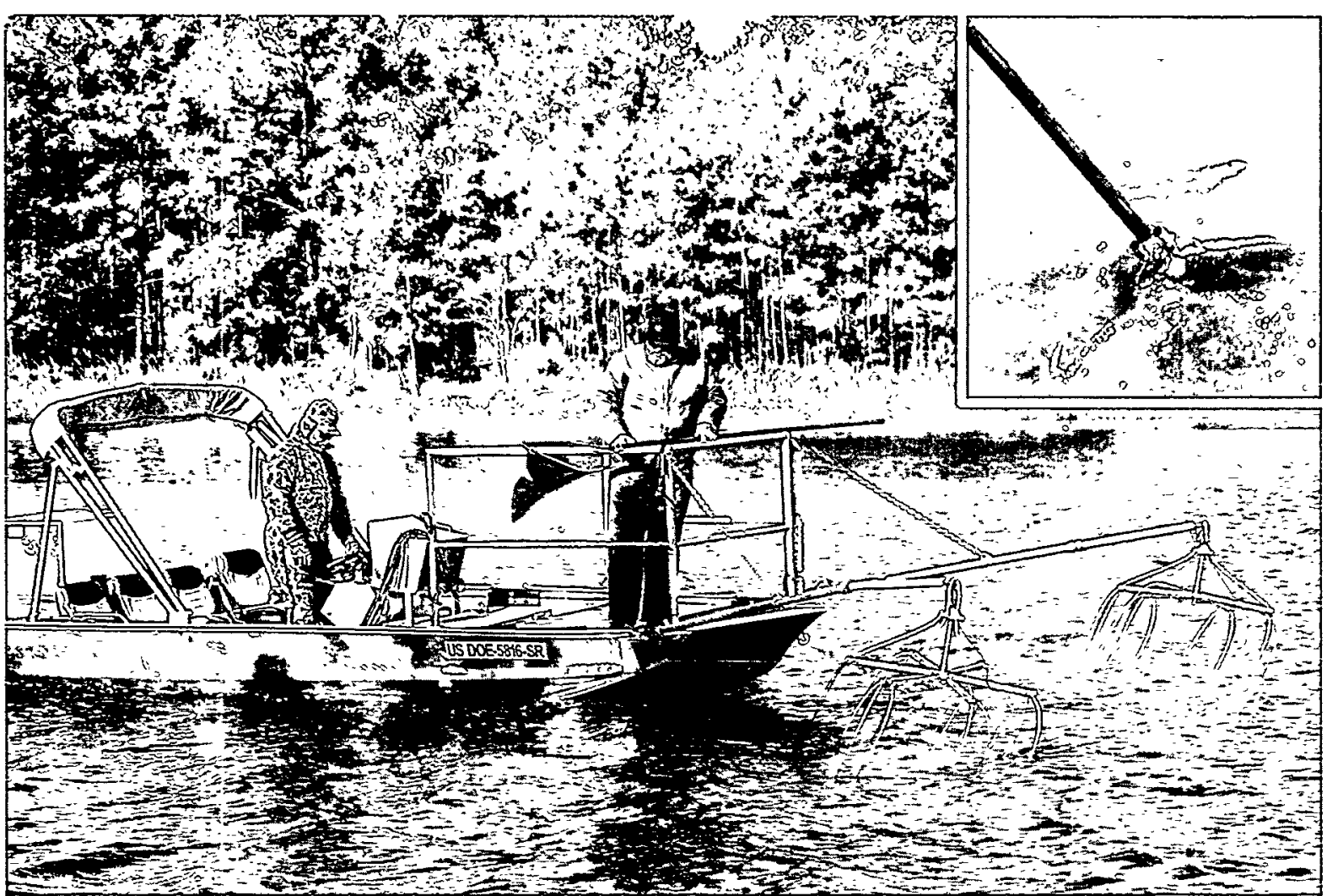

Bill Littrell Photos (WSRC-00J0083701)

For several years, EMS technicians have used an electro-fishing boat to collect most of the fish needed for analysis in the surveillance program. After the shocking apparatus is lowered into the water, the stunned fish are collected by hand with a nonconductive net basket and transported to the laboratory. 


\section{Perspective on Mercury}

Mercury in the environment can come from natural sources, such as volcanoes and venting of the earth's crust, and from manmade sources and processes, such as fungicides and fossil fuel combustion byproducts and the manufacture of chlorine, sodium hydroxide, plastics, and electrical apparatus.

An important source in the SRS region may be in releases upriver of the site. Much of the mercury detected in SRS fish has been attributed to offsite sources, such as Savannah River water [Davis et al., 1989]. Savannah River water is pumped onto the site to support fire protection efforts and the sanitary waste treatment plant and to maintain L-Lake's water level. The water subsequently is released into site streams and lakes.

The naturally occurring metal cycles between land, water, and air. As mercury enters streams and rivers through rainfall, runoff, and discharges, it is converted to the chemical compound methylmercury by bacterial and other processes. As part of the natural cycling, some methylmercury is absorbed by plants and animals into their tissues. Fish absorb methylmercury from food they ingest and from water as it passes over their gills; the methylmercury then is bound in their tissues. Consumption by people of fish containing methylmercury then completes the mercury pathway to humans. The amount of fish that can be eaten safely varies with (1) the concentration of methylmercury, (2) the amount consumed, and (3) the frequency of consumption. These factors are the basis of calculations performed during "risk analysis," a method to determine how much fish can be consumed safely.

State and federal regulatory agencies calculate the health risk associated with the consumption of fish, then recommend consumption guidelines based on that risk. Adherence to these guidelines can effectively control one's exposure to methylmercury. A list of fish advisories and/or recommended consumption limits can be obtained from state environmental agencies. EPA criteria taken from "Guidance For Assessing Chemical Contaminant Data For Use In Fish Advisories, Volume II Risk Assessment And Fish Consumption Limits" (EPA 823-B-94-004, June 1994), gives the monthly consumption limits for chronic systemic health endpoint for the general population.

\section{Academy of Natural Sciences of Philadelphia River Quality Surveys}

\section{Description of Surveys}

ANSP has been conducting biological and water quality surveys of the Savannah River since 1951. These surveys are designed to assess potential effects of SRS contaminants and warm water discharges on the general health of the river and its tributaries. This is accomplished by seeking patterns of biological disturbance that are geographically associated with the site patterns of change over seasons or years that indicate improving or deteriorating conditions.

Multiple levels of the aquatic food web are studied in the surveys because no single group or organisms is the best indicator of all aspects of ecosystem health and because there is a broad consensus that maintaining the integrity of the entire system is important. Studies are timed to coincide with periods of the year that are most stressful to aquatic biota (e.g., low flows, elevated temperatures) and when pollution-sensitive taxa are most abundant. A limited amount of more frequent monitoring over the course of the year to detect perturbations that may occur outside the once or twice yearly studies is conducted.

The 1998 and 1999 surveys examined algae, rooted aquatic plants (1998), protozoa (1998), macroinvertebrates, and fish yearly or twice yearly. Diatoms, a type of algae, were examined monthly using artificial substrates.

The study design employed in the ANSP Savannah River surveys during 1998 and 1999 included five sampling stations (figure 9-4): four exposed to SRS influence (stations $2 \mathrm{~A}, 2 \mathrm{~B}, 5$, and 6-station $2 \mathrm{~A}$ is monitored for diatoms only) and an unexposed reference station upriver (station 1). Multiple exposed stations are employed because of the complex pattern of SRS inputs along the river. Potential impacts are assessed by determining whether differences exist between the exposed and reference stations that are either greater or of a different character than would be expected if they were due merely to chance or natural differences among sampling sites.

The character of differences among stations is judged in part by comparing the individual species collected. Evidence of impact exists if a station shows elevated abundances of species known to tolerate pollution and depressed abundances of species known to be sensitive to pollution. If this pattern is detected at the exposed stations, but not at 


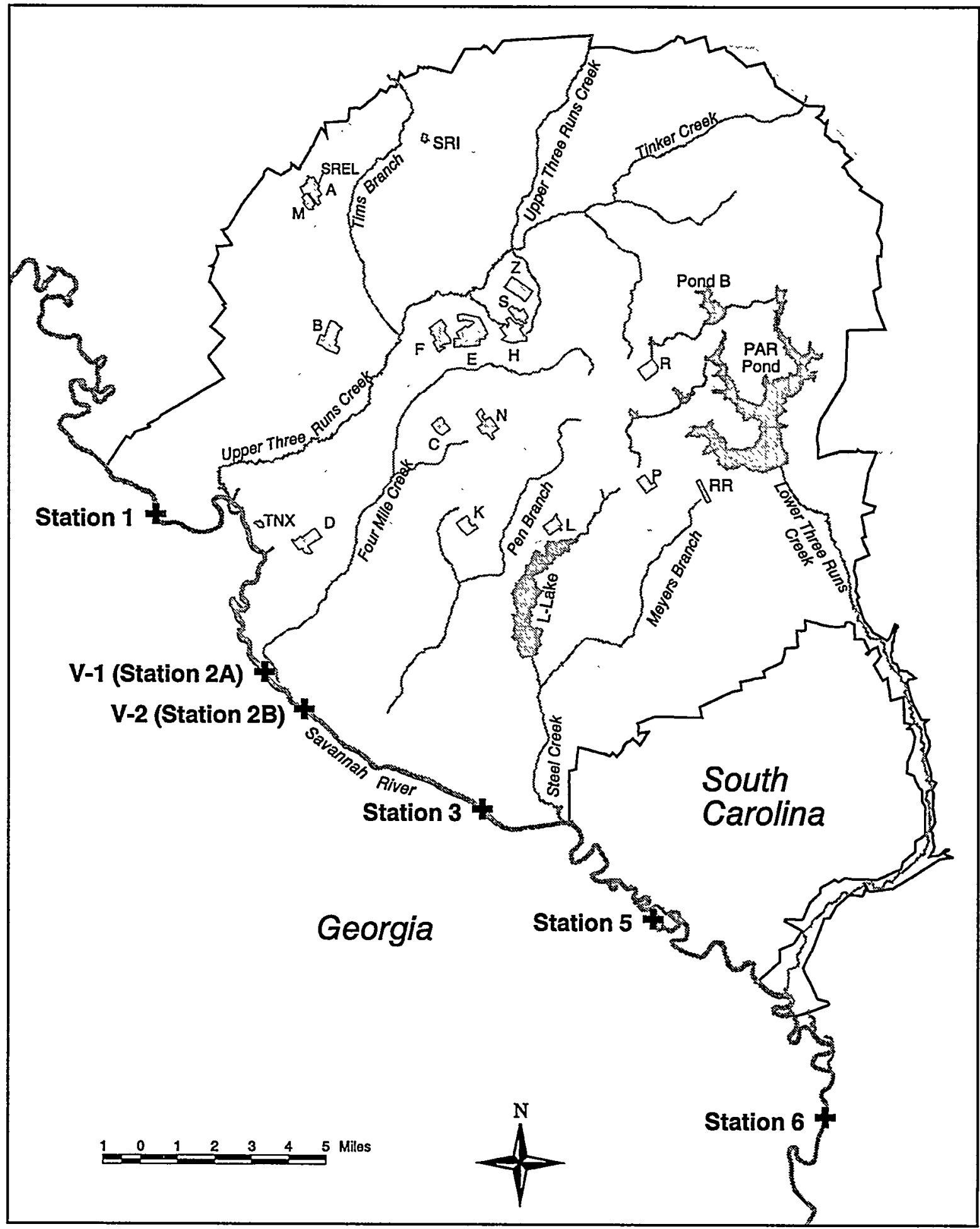

EPD/GIS Map

Figure 9-4 Academy Survey Sampling Sites

The Academy of Natural Sciences of Philadelphia has established specific sampling locations for surveys of the Savannah River-five exposed to SRS and other influences (stations 2A to 6) and one unexposed reference station (station 1). 


\section{ANSP Glossary}

areal

of, relating to, or involving an area

assemblage

a group of organisms sharing a common habitat

nutrient loading

the amounts of nitrogen and phosphorus added to an aquatic system over time

perturbations

disturbances or variations (of water quality) from what is usual or expected

species abundance the number of individuals of one kind in an area under consideration

species density the number of individuals of one kind per unit area

species diversity

a combined measure of the number of different kinds of individuals and the similarity of their abundances in an area under consideration

species richness

the number of different kinds of individuals in an area under consideration

the reference station, SRS is implicated. If, however, the pattern is seen at the reference station, the impact must be due to sources upstream from the study area.

Other types of evidence for impact at a station include

- decreased numbers of species

- increased dominance by a few species

- decreased population sizes or densities of common species

- increases or decreases in the abundances of insect functional feeding groups known to be associated with certain forms of pollution

These patterns arise because pollution tends to reduce populations of a majority of species, while a few are able to thrive and dominate under such conditions.

Determining whether exposed and reference stations differ is complicated by the fact that considerable variation exists even among samples collected at the same time from the same location. Apparent differences may therefore be misleading if each station is characterized by only a single sample. For this reason, the ANSP surveys typically collect multiple samples from each station, making it possible to quantify both of the important components of variation-within and among stations. Compelling evidence for station differences exists if variation among samples from different stations is significantly greater than average variation among samples from the same station, as judged by appropriate statistical techniques. Otherwise, apparent station differences can be explained simply by chance or natural variability.

The ANSP surveys also address variation over time (temporal variation). Important components of temporal variation include seasonal trends, multiyear trends, and trendless variability. All these components can be assessed using the unique data set generated by ANSP's long-term monitoring program in the Savannah River. Regular sampling with standardized collection techniques has continued largely unmodified since the early 1950 s, making this one of the most comprehensive ecological data sets available for any of the world's rivers.

Such long-term records of biological change are valuable for several reasons. Because they allow the normal degree of year-to-year variability at a site to be quantified, one can observe changes from one survey to the next and determine whether they fall within the normal range, much as one would use a control chart. (Figure 9-5, for example, gives the number of diatom species at one location over a period of several years.) On average, two-thirds of the data should fall between the standard deviation lines. Changes well outside this range provide evidence of altered conditions at the study site.

These data sets also are useful in distinguishing between potential impacts of SRS and variation caused by other factors. In particular, part of the biological variation observed over time is caused by documented changes in river flow, wastewater treatment methods, dredging activities, and so on. Correlations between the known history of such changes on the one hand, and components of variation in long-term data sets on the other, provide evidence that these components were not caused by SRS activities.

Finally, long-term data sets can provide compelling evidence for multiyear trends of improvement or deterioration in ecosystem health. For example, analyses of some of ANSP's long-term data suggest a relatively steady increase in the number of different kinds of aquatic insects living in the river 
during the past 35 years. Because aquatic insect diversity is believed to be a sensitive measure of environmental quality, this pattern may indicate a long-term trend of improving water quality in the river.

\section{Survey Results}

All components of the 1998 study are complete, and analyses of samples from the 1999 study are currently under way. Final results of the 1998 study are presented here, along with an interpretation of their place in assessing temporal trends in water quality. Progress to date for each component of the 1999 study is also reported.

\section{Diatometer Monitoring}

Periphyton are an assemblage of simple plants (e.g., algae) that grow attached to rocks and other submerged surfaces in the river. Diatoms, a type of microscopic algae, are particularly useful as indicators of water quality. In the diatometer monitoring program, diatoms are collected using a device called the Catherwood Diatometer, which floats glass slides near the surface of the water for two-week periods. Diatoms attach and grow on these slides and can then be scraped off and examined in the laboratory to assess potential effects of SRS operations.

In 1998 and 1999, diatometers were deployed on a monthly basis from locations above SRS (reference station 1), above and below the discharge of Vogtle Electric Generating Plant (stations 2A and 2B), below Steel Creek (station 5) and below Lower Three Runs Creek (station 6). Samples were analyzed to determine the number and types of diatom species at all stations except station $2 \mathrm{~A}$ (samples from station 2A were archived for future reference). More detailed analyses were performed on slides from one exposure period in both April and October. (Analyses of the August through December 1999 samples are incomplete at this time.) Water quality was assessed by comparing the diatom assemblages from the different sampling periods and locations - based on diatom assemblage parameters of species richness (number of species) and evenness (the degree of similarity among species

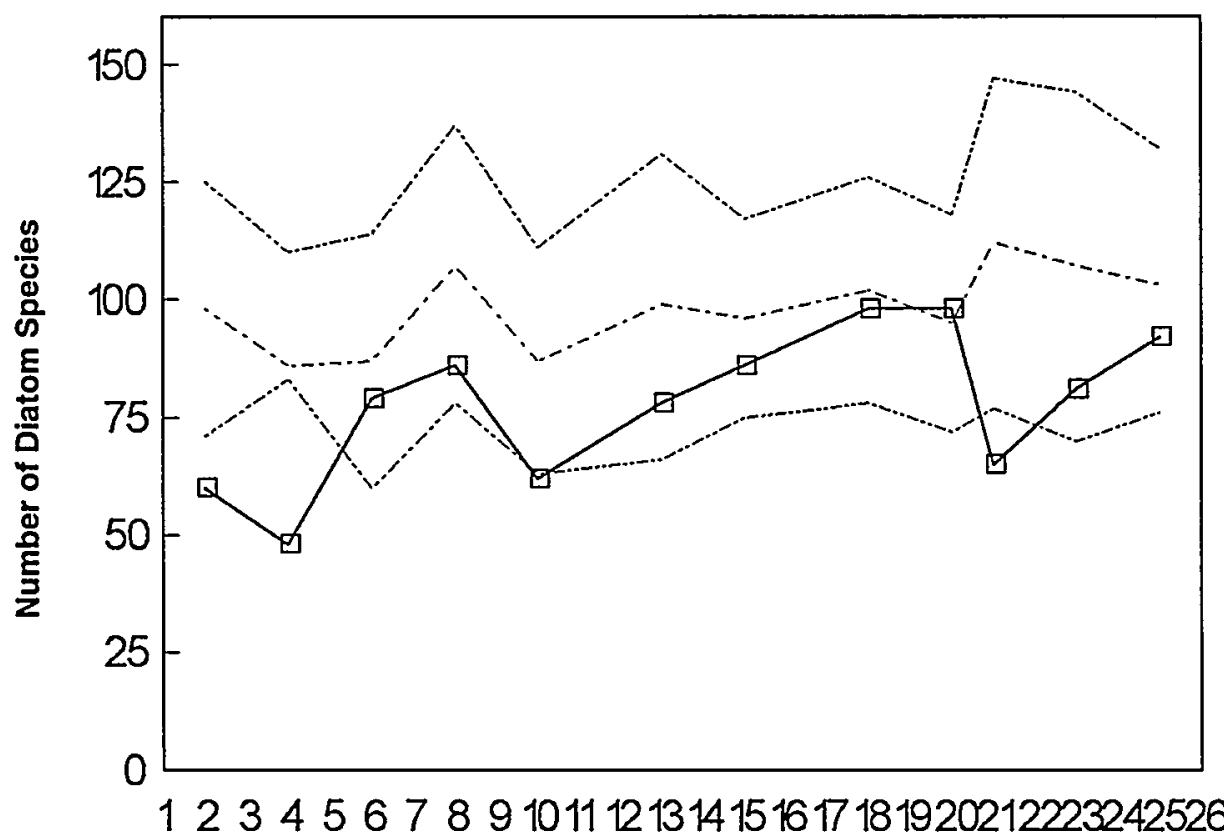

Exposure Period (Station 5), 1982-1998

ANSP Graphic (modified)

Figure 9-5 Diatom Species

The graph depicts the number of diatom species in diatometers at station 5 , showing the 1998 values (solid line) superimposed on the mean plus or minus 1 standard deviation (dotted lines) for the period 1978-1998. Exposure periods represent 26 two-week intervals during which diatometers were deployed in the Savannah River. Note that only 20 exposure periods were analyzed in 1996 and only 12 in 1997 and 1998. 


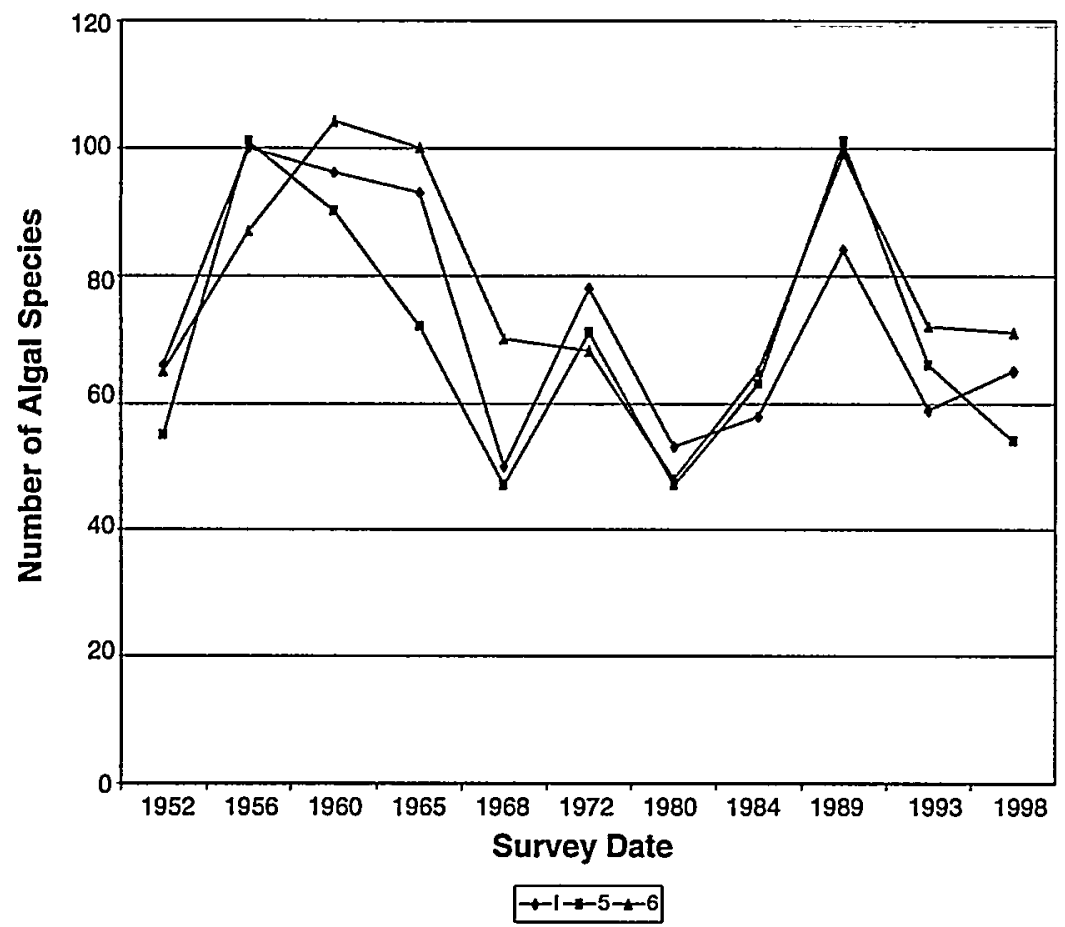

Figure 9-6 Algal Taxa

The graph depicts the number of algal taxa at stations 1,5 , and 6 during spring surveys conducted on the Savannah River from 1952-1998.

ANSP Graphic (modified)

abundances) - as well as the relative abundances and ecological tolerances of the common species.

1998 Results No statistically significant among-station variation was detected for either species richness or evenness. Species richness tended to be lower than the long-term average for previous studies, especially for the first six months of the 1998 study. Conversely, percent dominance values were higher than the established average, especially from June through September. A trend of lower species richness and higher percent dominance at the SRS stations compared to the reference station was noted for the exposure periods from October through December. Ecological tolerances of the dominant diatom species were similar at all stations, with most dominants being characteristic of alkaline waters with moderate to high nutrient concentrations. Results of the 1998 diatometer study do not indicate a negative SRS impact.

1999 Survey Preliminary results of 1999 analyses (January through July) indicate average to above-average diatom assemblage diversity. Compared with trends established in prior years (1978 through 1998), the number of species was above average (none less than the established average), especially in the earlier months of the year (five of the six values for number of diatom species exceeded the established average by at least one standard deviation in the January and February studies). Compared with results from 1998 (when values were lower than average), the increase in number of species is noteworthy.

\section{Algae and Aquatic Macrophyte Studies}

The 1998 and 1999 comprehensive algal and aquatic macrophyte studies were carried out on the Savannah River at four stations, one upstream (station 1) and three downstream (stations 2B, 5, and 6) from possible influence from SRS. Station and year comparisons were based on

- the number of species in major taxonomic groups

- known pollution tolerances of individual species

- their relative abundances

Figure 9-6 gives the number of algal taxa at three stations during surveys conducted on the Savannah River from 1952 through 1998.

1998 Results The algal flora was similar at all four stations in 1998. The diatom flora showed evidence of nutrient enrichment at all stations, apparently from an upstream source. As has been true since 1990 (inclusive), no significant beds of submerged aquatic vegetation were observed. Species richness and composition of both algae and macrophytes 


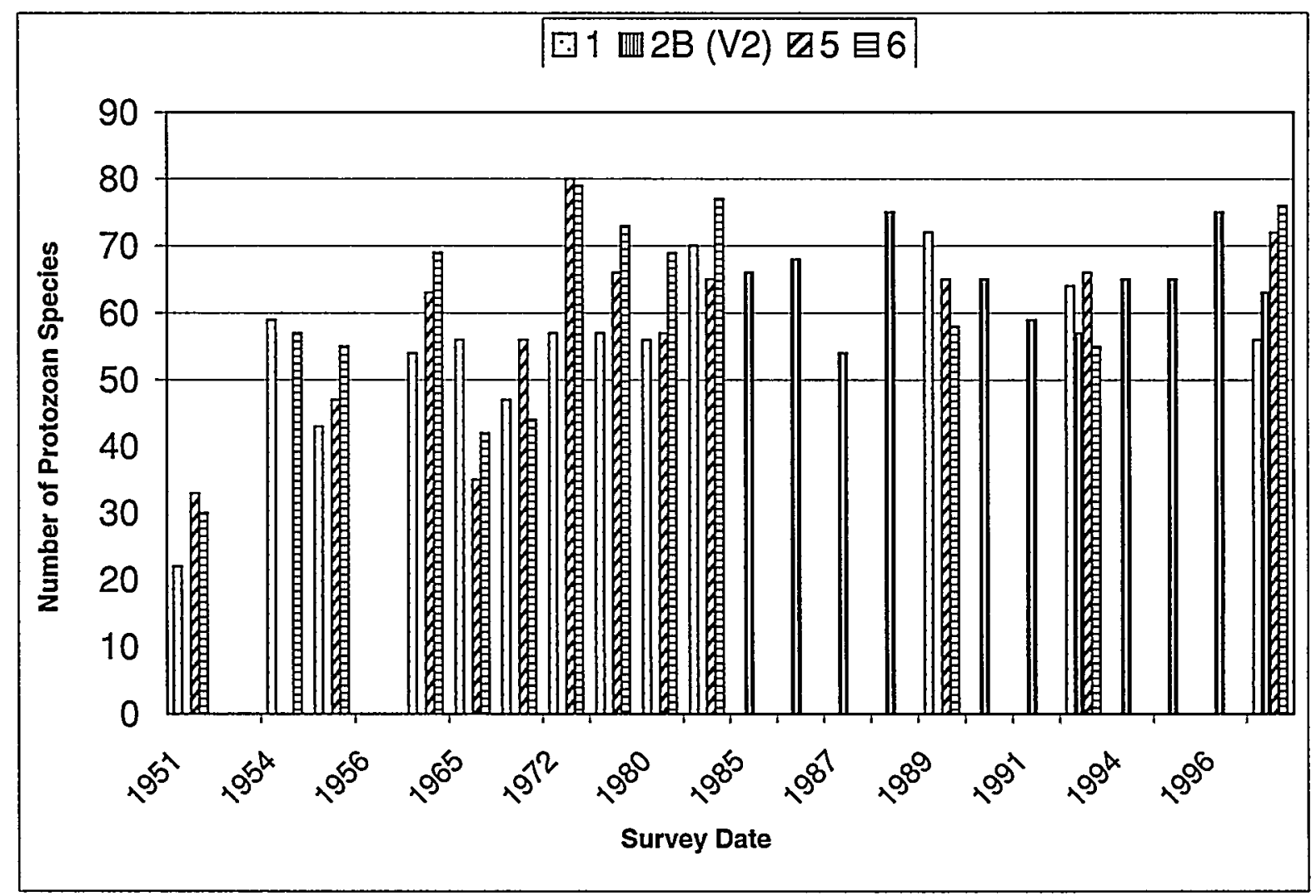

ANSP Graphic (modified)

Figure 9-7 Protozoan Species

The graph depicts the number of protozoan species collected at stations 1, 2B, 5, and 6 on the Savannah River during summer and fall surveys from 1951 through 1998.

were similar to those of previous studies and showed no evidence of an SRS impact.

1999 Survey Although sample analysis is incomplete at this time, field observations did not indicate any obvious changes since 1998.

\section{Protozoan Studies}

Protozoa in 1998 were sampled at stations 1, 2B, 5, and 6. All specimens were identified to species. Station and year comparisons were based primarily on the number of species in major protozoan taxonomic subgroups, taking into account the availability of suitable habitat.

1998 Results The protozoan assemblage was found to be predominantly heterotrophic (i.e., not utilizing light energy via photosynthesis) and was basically similar at all stations. It was also comparable to assemblages in previous years. These results do not indicate an SRS impact (figure 9-7).
1999 Survey No protozoan studies were undertaken in 1999.

\section{Noninsect Macroinvertebrate Studies}

Qualitative samples of noninsect macroinvertebrates were collected at stations 1, 2B, 5, and 6 during 1998 and 1999. All specimens were identified to the lowest practical taxonomic level.

1998 Results The results of the 1998 survey indicate that the noninsect macroinvertebrate fauna of the Savannah River in the vicinity of SRS is broadly similar to those in recent surveys (1976 to 1997 periods), with four major groups dominating. Of the 47 species collected in 1998 at stations 1, 2B, 5 , and 6 , the four principal groups were the bivalves [21 species-mussels (14) and clams (7)], snails (7 species), crustaceans ( 7 species) and leeches (4 species). These same four groups dominated the noninsect macroinvertebrate fauna of the previous six studies $(1997,1993,1989,1984,1980$, and 1976). It is in these larger groups that major changes in fauna among years can be observed. The 
remaining smaller groups are either widely collected, spotty in distribution, rarely collected, or represent taxa whose collection and/or taxonomic effort have been beyond the scope of the study. Higher numbers of species were collected in 1972 and were correlated with the dense stands of submerged aquatic plants. With the exception of the mussels, most members of the remaining five groups are typically abundant in areas associated with these dense stands, and their species richness and/or abundance reflects the areal extent of these growths. Since 1990, the weed beds have been lacking from the study areas, and population densities of many species have declined (e.g., snails and sphaeriid clams). However, despite recent changes in vegetation (1993,1997, and 1998), small numbers of most of these taxa can be found in other habitats if a sufficient effort is expended. The differences between the 1989-to-1976 and 1972 surveys reflect variation in density of vegetation. Groups of strongest differences since the 1972 survey can be found in a comparison of the leech, snail, and mite species richness. The decline in numbers may be a reflection of the areal extent of the vegetation (figure 9-8).

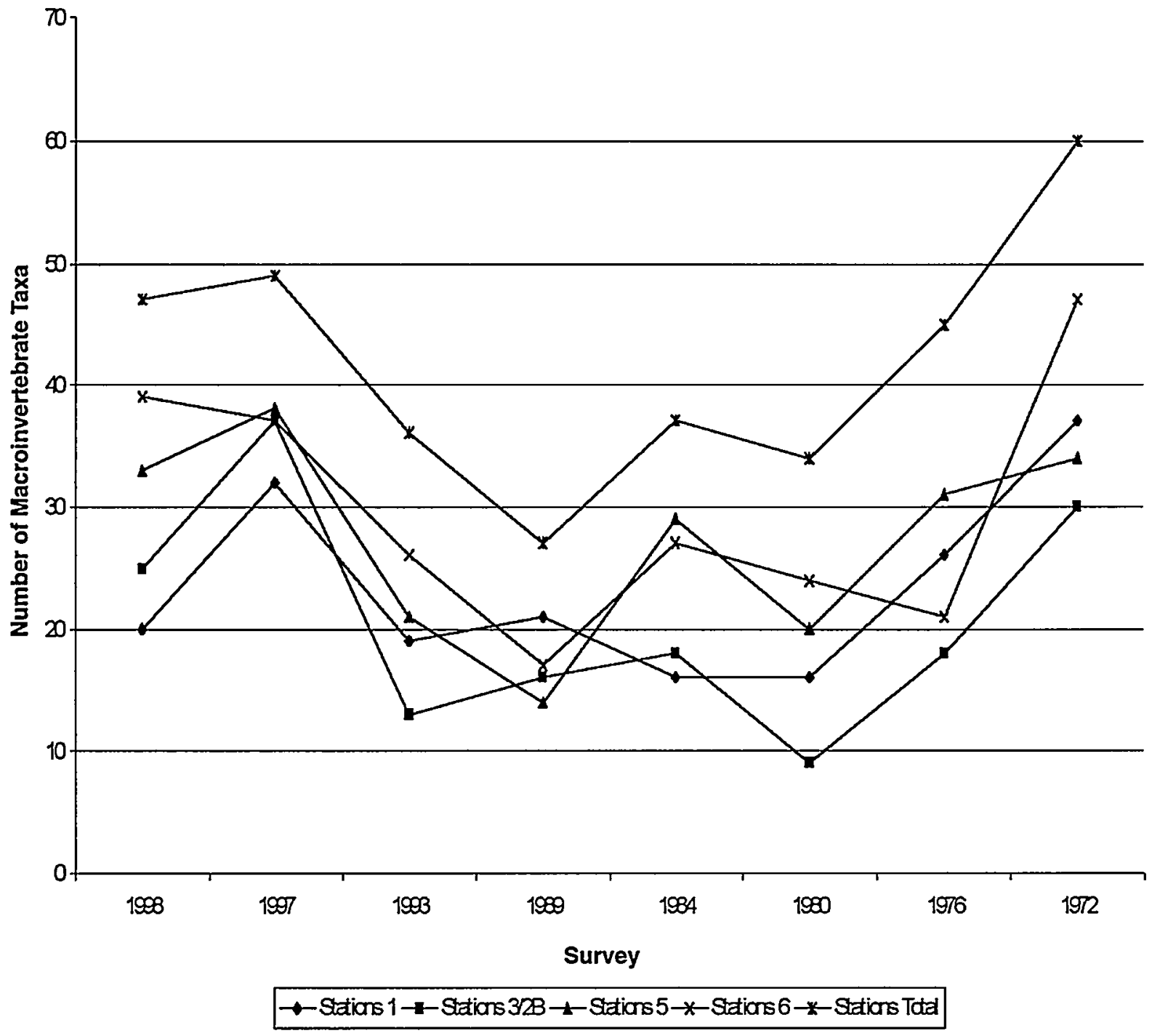

ANSP Graphic (modified)

Figure 9-8 Macroinvertebrate Taxa

The graph depicts the numbers of macroinvertebrate taxa collected by hand from the Savannah River at stations 1, 2B (1993, 1997, and 1998), 3 (1989-1972), 5, and 6 in August to October 1972, 1976, 1980, 1984, 1989, 1993, 1997, and 1998. Numbers for 1998 and 1997 include the mussel studies. 
Table 9-1 Numbers of Macroinvertebrate Taxa in the Dominant Classes Collected by Hand from the Savannah River at Stations 1, 2B (1992, 1997, and 1998), 5, and 6 in August to October.

\begin{tabular}{lccccc}
\hline Year & Leeches & Snails & $\begin{array}{c}\text { Clams/Mussels } \\
\text { Bivalves }\end{array}$ & Crustaceans & Mites \\
\hline 1998 & 4 & 7 & $7 / 14$ & 7 & 1 \\
1997 & 6 & 10 & $6 / 14$ & 5 & 2 \\
1993 & 4 & 8 & $5 / 13$ & 6 & 1 \\
1989 & $2(1)$ & 7 & $3(1) / 10$ & 5 & 1 \\
1984 & $2(1)$ & $6(1)$ & $5 / 10$ & 5 & 2 \\
1980 & 2 & 7 & $4 / 14$ & $4(1)$ & 5 \\
1976 & 6 & 8 & $5 / 15$ & 5 & \\
1972 & 10 & 11 & \multicolumn{5}{l}{} \\
\multicolumn{5}{l}{ Note: Species totals for 1993-1998 include mussel surveys. [Numbers in parentheses (1989 to 1972) } \\
represent additional species from Station 3 (e.g., 6(1) = 7 species at Stations 1, 3, 5, and 6 to permit four \\
station comparisons 1998 to 1972).]
\end{tabular}

A comparison of the species numbers of noninsect macroinvertebrates collected during the 1998 surveys ( 47 species) reveals a higher average number of species collected at stations 5 (33 in 1998,37 in 1997, and 21 in 1993) and $6(39,37$, and 26 , respectively) than at stations $1(20,32$, and 19 , respectively) and $2 \mathrm{~B}(25,37$, and 13 , respectively). The long-term database for the August to October period indicates that in a given survey more species are typically collected at stations 5 and 6 than at stations 1 or 2B (differences in 1989 are due to high water levels at stations 5 and 6 ). The downriver stations 5 and 6 are in a lower gradient portion of the river in an area of former meandering bends that have been cut off by river modifications and are further removed from the Fall Line zone than stations 1 and 2B (table 9-1).

The most endangered group of invertebrates in North America is the freshwater mussels. The nature of the mussel fauna in the Savannah River in the area of SRS has changed since the early 1951-to-1968 studies when the yellow lamp mussel, eastern elliptio, Carolina slabshell, Atlantic spike, variable spike, and rayed pink fatmucket were all listed as the most abundant species. Only the Carolina slabshell, variable spike, and Atlantic spike were among the dominant taxa in hand collections in 1993, 1997, and 1998. The Eastern elliptio and rayed pink fatmucket were moderately common and the yellow lamp mussel uncommon in the recent surveys. The Savannah lilliput is known from only six populations-four in North Carolina, one in South Carolina, and one the Savannah River population in the area of SRS between South Carolina and Georgia. To date, the Savannah lilliput in the Savannah River has been found to be common only from River Mile 138.1 (\#54 Pilings, upriver from Jack of Clubs Point, between stations 3 and 5) downriver to River Mile 118.9 (upriver from the U.S. Highway 301 bridge).

The total numbers of species in September and October 1998 versus September 1997 and September and October 1993 show a decided increase in numbers of taxa in 1997 and 1998. Recent (1998) and long-term trends (26 years-1972 to 1998) reveal no impact on the noninsect macroinvertebrate biota of the Savannah River by SRS.

1999 Survey An examination of field notes from the September 1999 Savannah River study of the noninsect macroinvertebrate fauna indicates (1) a species diversity that probably will be similar among the four study stations and (2) mussel populations similar to previous years. Analyses of these samples will be undertaken in 2000 .

\section{Insect Studies}

Quantitative and qualitative samples of aquatic insects were collected at stations $1,2 \mathrm{~B}, 5$, and 6 during 1998 and 1999. The quantitative samples were collected using standardized artificial substrates, which permit replicate samples at each station and rigorous statistical comparisons. All specimens were identified to the lowest practical taxonomic level (figure 9-9).

Station and season comparisons were based primarily on quantitative per-sample estimates of several types of indices. These indices include

- densities of selected taxa 
- total species richness

- richness of selected groups of

pollution-sensitive taxa (Ephemeroptera,

Plecoptera, Trichoptera) and pollution-tolerant taxa (Chironomidae)

- Shannon-Wiener diversity

- dominance indices (percent Chironomidae, percent Dominance-1, percent Dominance-5)

- indices of the overall degree of pollution tolerance exhibited by the insect assemblage (Hilsenhoff Biotic Index, North Carolina Biotic Index)

1998 Results Results of the 1998 study showed that all four stations supported insect assemblages with numerous species, including abundant pollution-sensitive taxa. A few differences among stations were observed, but aquatic insect composition and abundance at the downstream stations were quite similar to that at the upstream reference station. Thus, exposure to effluent and runoff from SRS did not appear to have a measurable effect on the aquatic insect assemblage.

1999 Survey Aquatic insect samples were collected in 1999 during May and September. Laboratory analysis of these samples has begun but is incomplete.

\section{Fish Studies}

Fish were sampled at stations 1, 2B, 5, and 6 in 1998 and 1999. The main collecting techniques were seining, boat electroshocking in the main channel, and walk-along electroshocking in backwaters. Specimens were identified to species. Species richness (number of species), species diversity (Shannon-Wiener index), and densities of individual species were estimated for each quantitative seine sample.

1998 Results In the 1998 study, no statistically significant differences among stations were found for species richness or species diversity. A few weak differences in the densities of individual species

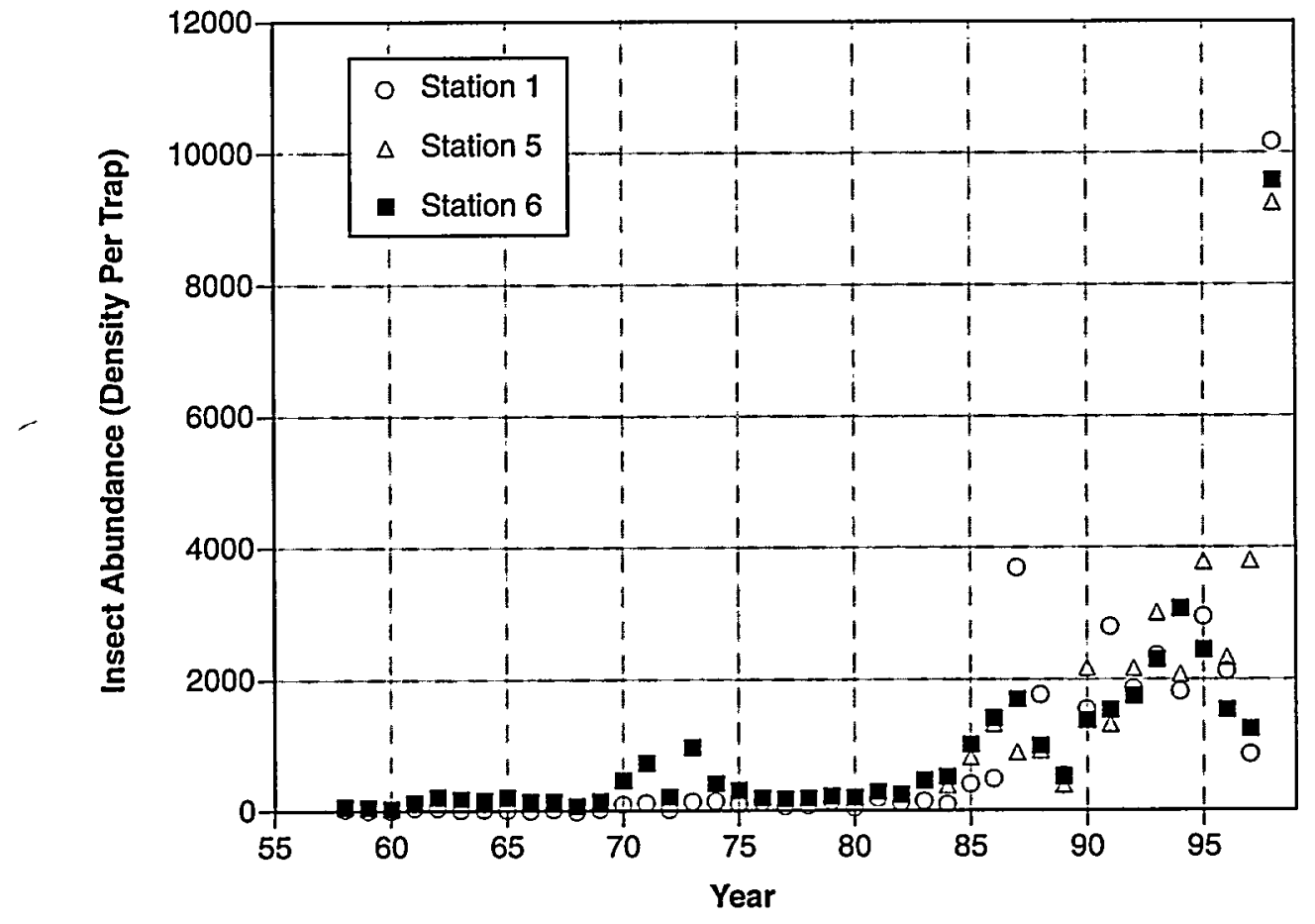

ANSP Graphic (modified)

Figure 9-9 Insect Abundance (density per trap)

The graph depicts the total insect abundance (annual mean number of individuals per trap) at Savannah River stations 1,5, and 6. Annual means summarize four sampling seasons for 1958-1995 and two sampling seasons for 1996-1998. Samples from 1998 were washed through a $0.5-\mathrm{mm}$ mesh sieve (a modern standard) rather than the 1.8 $\times 1.4-\mathrm{mm}$ mesh screen that was used earlier. This change presumably contributed to the high densities observed in 1998. The impact of this methodological change on the historical data set is currently being explored. 
were detected, but these were not consistent with an SRS impact.

Taking the 1998 results into account, several temporal patterns in the abundance of individual fish species are evident over the 1985-1998 survey period:

- The Eastern silvery minnow was rare or absent in most of the 1980s and early 1990s. It appears to have increased in the mid-1990s. In 1998, it was the most abundant species for all three main collecting techniques.

- Several species frequently caught in previous surveys were not collected in 1998 , notably the longnose and Florida gars, yellow and brown bullheads, and silver redhorse. The absence of these species probably reflects the recent switch in collection techniques (from netting and trapping to electrofishing) rather than shifts in species abundances.

- The coastal shiner remains at relatively low levels following relatively high abundances from 1987-1995. The tessellated darter has shown the opposite pattern.

- An apparent decrease in the abundance of the spotted sunfish continues. This species generally has been less abundant in more recent surveys (1991-1998) than in earlier surveys (1985-1990). It was collected in one backwater sample in 1998, where it was relatively common and was only moderately common in 1997.
These temporal changes in fish abundance may be a reflection of environmental alterations occurring in the river (e.g., variations in flow patterns, changes in macrophyte abundance, and changes in nutrient loading). Consistent differences in the fish communities at the survey stations attributable to SRS operations have not been detected in the surveys.

1999 Survey Analyses of the 1999 fish studies are not yet complete, and no conclusions can be ascertained at this time.

\section{Conclusions}

Assessments of the various biological groups in the 1998 river quality survey (diatoms, other attached algae, rooted aquatic plants, insects, noninsect macroinvertebrates, and fish) were consistent with one another and demonstrated similar communities at exposed and reference stations. Several species showed station differences that were related to differences in habitat availability rather than SRS influence. Statistical comparisons of community attributes at the various sampling stations detected few significant differences, and there were no patterns that would indicate a negative impact of SRS. Thus, results of the 1998 study do not provide evidence of an SRS impact on biological communities in the Savannah River.

Results of the 1999 river quality survey are not complete at this time. However, field notes and preliminary analyses of samples do not reveal any obvious differences between communities at exposed and reference stations. 


\section{Highlights}

- Most analytical results from groundwater monitoring were similar to those of recent years. In A-Area and M-Area, trichloroethylene continued as the most widespread contaminant and appears to be moving to the southwest. However, ongoing remediation efforts are slowing the spread of contamination (primarily organics and metals) and reducing the impact of past operations in those areas on the groundwater.

- In the reactor areas (C-Area, K-Area, L-Area, P-Area, and R-Area), tritium continues as the most widespread contaminant. Volatile organics were detected in groundwater near the seepage and disassembly basins in K-Area, the seepage basin in L-Area, the retention basin in P-Area, and the Bingham pump outage pits in R-Area. Volatile organics also were found near the burning/rubble pits in these areas and near the chemicals, metals, and pesticides pits just north of L-Area. Metals were detected near the reactor seepage basins in P-Area and R-Area; near the chemicals, metals, and pesticides pits; and in some locations in K-Area and L-Area.

- D-Area shows continued contamination associated with activities at the coal-fired power plant and related facilities and with volatile organics and metals near the oil disposal basin. The contaminant plume in the TNX area comprises volatile organics (especially trichloroethylene), metals, radionuclides, and other constituents near disposal sites.

- In the general separations and waste management areas (E-Area, F-Area, and H-Area), the groundwater contamination plumes include tritium as the primary contaminant, volatile organics (especially trichloroethylene and tetrachloroethylene), radionuclides, metals, and other constituents. Sampling from previous years shows that volatile organics, metals, and radionuclides are present in N-Area. Stabilization and closure programs are ongoing in these areas. In Z-Area, radionuclides were detected in one well and tritium in another. S-Area shows evidence of groundwater contamination comprised primarily of tritium in the vicinity of the vitrification building.

- Volatile organics (especially trichloroethylene and vinyl chloride), are the most widespread contaminants in the groundwater near the sanitary landfill. Metals, tritium, and other radionuclides also are present.

$\mathrm{T}$ his chapter summarizes the groundwater monitoring results for 1,224 wells in 101 locations (figure 10-1) within designated areas at the Savannah River Site (SRS), with emphasis on results exceeding the Safe Drinking Water Act primary drinking water standards (DWS). Most constituents are compared to the final federal primary DWS. In some cases, comparison is to the proposed primary DWS or to the interim final primary DWS. (See appendix A, "Applicable Guidelines, Standards, and Regulations," for additional information about applicable monitoring standards, and appendix B, "Drinking Water Standards," for the DWS.) Other constituents of interest also are discussed in the text of this chapter.

Detailed groundwater monitoring results are presented in the following public documents: The Savannah River Site's Groundwater Monitoring Program, First Quarter 1999 (ESH-EMS-99-0520); The Savannah River Site's Groundwater Monitoring Program, Second Quarter 1999
(ESH-EMS-99-0521); The Savannah River Site's Groundwater Monitoring Program, Third Quarter 1999 (ESH-EMS-99-0522); and The Savannah River Site's Groundwater Monitoring Program, Fourth Quarter 1999 (ESH-EMS-99-0523, to be published in 2000). Full results for each well sampled during a quarter are presented alphabetically in the quarterly reports.

Another public document, the Environmental Protection Department's Well Inventory (ESH-EMS-99-0536), contains detailed maps of the wells at each monitored location.

\section{Groundwater at SRS}

When rain falls, part of the rainwater runs off of the surface of the earth into streams, and part of it soaks into the soil. The water that runs off is called direct runoff, and the water that soaks in and infiltrates the soil is called groundwater. Groundwater moves through the soil and eventually reappears at the surface in springs, swamps, or rivers. Potentially 


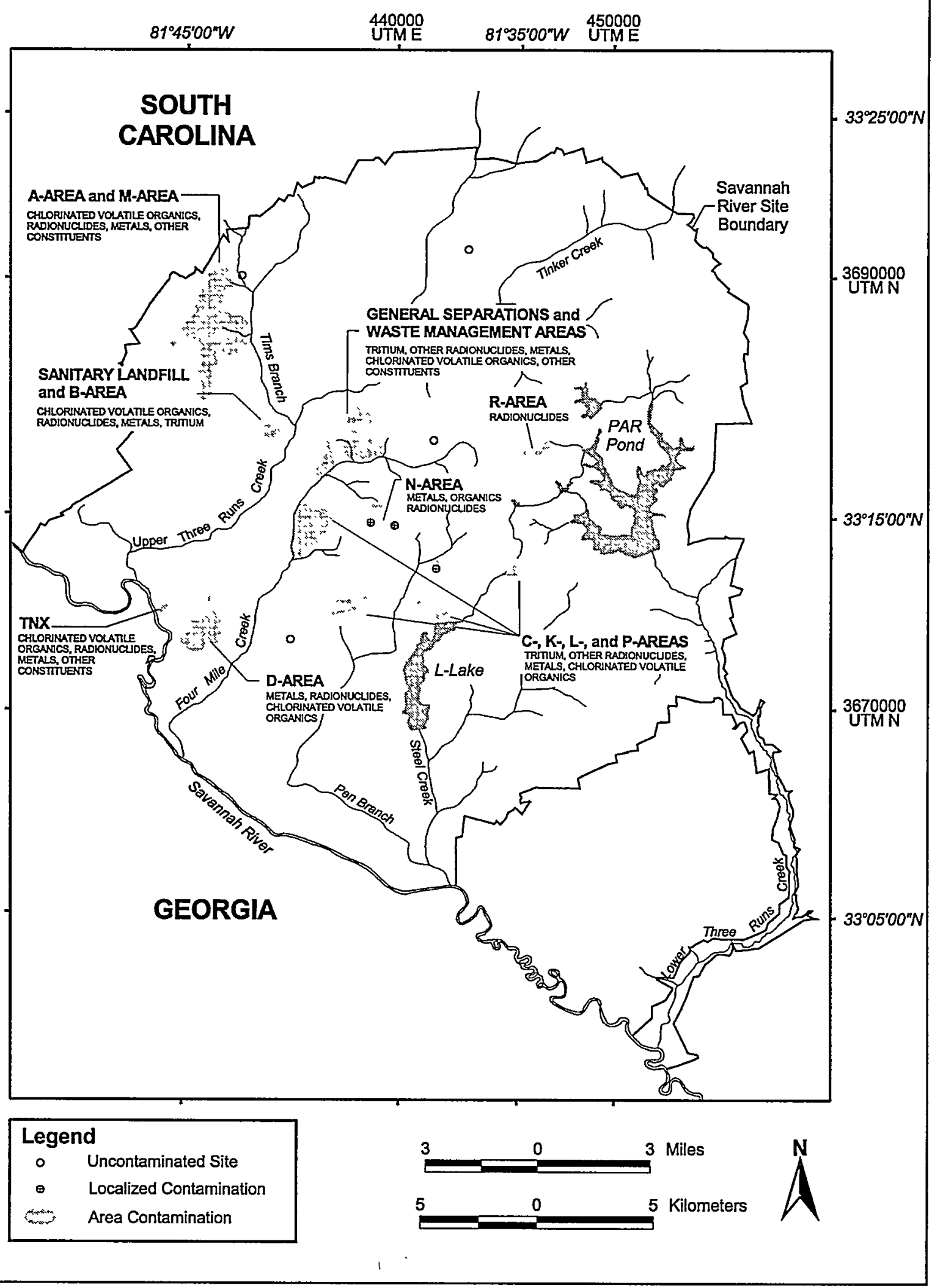

E\&GIS/ER

Figure 10-1 Facilities Monitored by the SRS Monitoring Well Network, Including Areas Having Constituents Exceeding Drinking Water Standards in 1999 


\section{A-Area and M-Area}

- A-Area and M-Area Recovery Well Network

- A-Area Background Well Near Firing Range

- A-Area Burning/Rubble Pits and A-Area Ash Pile

- A-Area Coal Pile Runoff Containment Basin

- A-Area Metals Burning Pit

- M-Area Hazardous Waste Management Facility and M-Area Plume Definition

- Metallurgical Laboratory Seepage Basin

- Miscellaneous Chemical Basin

- Motor Shop Oil Basin

- Savannah River Laboratory Seepage Basins

- Silverton Road Waste Site

General Separations and Waste Management Areas (E-Area, F-Area, H-Area, S-Area, and Z-Area)

- Burial Grounds Perimeter

- Burma Road Rubble Pit

- E-Area Vaults near the Burial Grounds

- F-Area Ash Basin

- F-Area Burning/Rubble Pits

- F-Area Canyon Building and A-Line Uranium Recovery Facility

- F-Area Coal Pile Runoff Containment Basin

- F-Area Effluent Treatment Cooling Water Basin

- F-Area Retention Basins

- F-Area Sanitary Sludge Land Application Site

- F-Area Seepage Basins and Inactive Process Sewer Line

- F-Area Seepage Basins Remediation Extraction Wells and Tank

- F-Area Seepage Basins Remediation Injection Tank

- F-Area Tank Farm

- H-Area Auxiliary Pump Pit

- H-Area Canyon Building

- H-Area Coal Pile Runoff Containment Basin

- H-Area Effluent Treatment Cooling Water Basin

- H-Area Retention Basins

- H-Area Seepage Basins and Inactive Process Sewer Line

- H-Area Seepage Basins Remediation Extraction Wells and Tank

- H-Area Seepage Basins Remediation Injection Tank

- H-Area Tank Farm and Tank Farm Groundwater Operable Unit

- Hazardous Waste/Mixed Waste Disposal Facility

- HP-52 Outfall and Warner's Pond Area

- Old Burial Ground

- Old F-Area Seepage Basin

- Old H-Area Retention Basin

- S-Area Defense Waste Processing Facility

- S-Area Low-Point Pump Pit

- S-Area Vitrification Building

- Waste Solidification and Disposal Facility

- Wells Between the F-Area Canyon Building and the Naval Fuel Material Facility

- Z-Area Low-Point Drain Tank

- Z-Area Saltstone Facility Background Wells

C-Area

- C-Area Burning/Rubble Pit

- C-Area Coal Pile Runoff Containment Basin

- C-Area Disassembly Basin

- C-Area Reactor Seepage Basins

\section{K-Area}

- K-Area Ash Basin

- K-Area Bingham Pump Outage Pit

- K-Area Burning/Rubble Pit

- K-Area Coal Pile Runoff Containment Basin

- K-Area Disassembly Basin

- K-Area Reactor Seepage Basin

- K-Area Retention Basin

- K-Area Tritium Sump

L-Area

- L-Area Acid/Caustic Basin and L-Area Oi and Chemical Basin

- L-Area Bingham Pump Outage Pits

- L-Area Burning/Rubble Pit

- L-Area Disassembly Basin

- L-Area Reactor Seepage Basin

- L-Area Research Wells

\section{P.Area}

- P-Area Bingham Pump Outage Pit

- P-Area Burning/Rubble Pit

- P-Area Coal Pile Runoff Containment Basin

- P-Area Disassembly Basin

- P-Area Reactor Seepage Basins

\section{R-Area}

- R-Area Acid/Caustic Basin

- R-Area Bingham Pump Outage Pit

- R-Area Burning/Rubble Pits

- R-Area Coal Pile

- R-Area Disassembly Basin

- R-Area Reactor Seepage Basins

\section{Sanitary Landfill and B-Area}

- B-Area Microbiology Wells

- Sanitary Landfill and Interim Sanitary Landfill

\section{Central Shops (N-Area)}

- Ford Building Seepage Basin

- Hazardous Waste Storage Facility

- Hydrofluoric Acid Spill

- N-Area Diesel Spill

- $\quad$ N-Area Burning/Rubble Pits

- N-Area (Central Shops) Sludge Lagoon

- $\quad \mathrm{N}$-Area Fire Department Training Facility

\section{D-Area and TNX}

- D-Area Burning/Rubble Pits

- D-Area Oil Seepage Basin

- D-Area Coal Pile, Coal Pile Runoff Containment Basin, and Ash Basins

- New and Old TNX Seepage Basins

- Road A Chemical Basin (Baxley Road)

- TNX-Area Assessment Wells

- TNX-Area Background Wells

- TNX-Area Points along Seepline

- TNX-Area Operable Unit Wells

- TNX-Area Floodplain Wells

- TNX-Area Recovery Wells

- TNX Burying Ground

- TNX Intrinsic Remediation Piezometers

\section{Other Sites}

- Accelerator for Production of Tritium Area

- Chemicals, Metals, and Pesticides Pits

- $\quad$ SREL Flowing Springs Site 


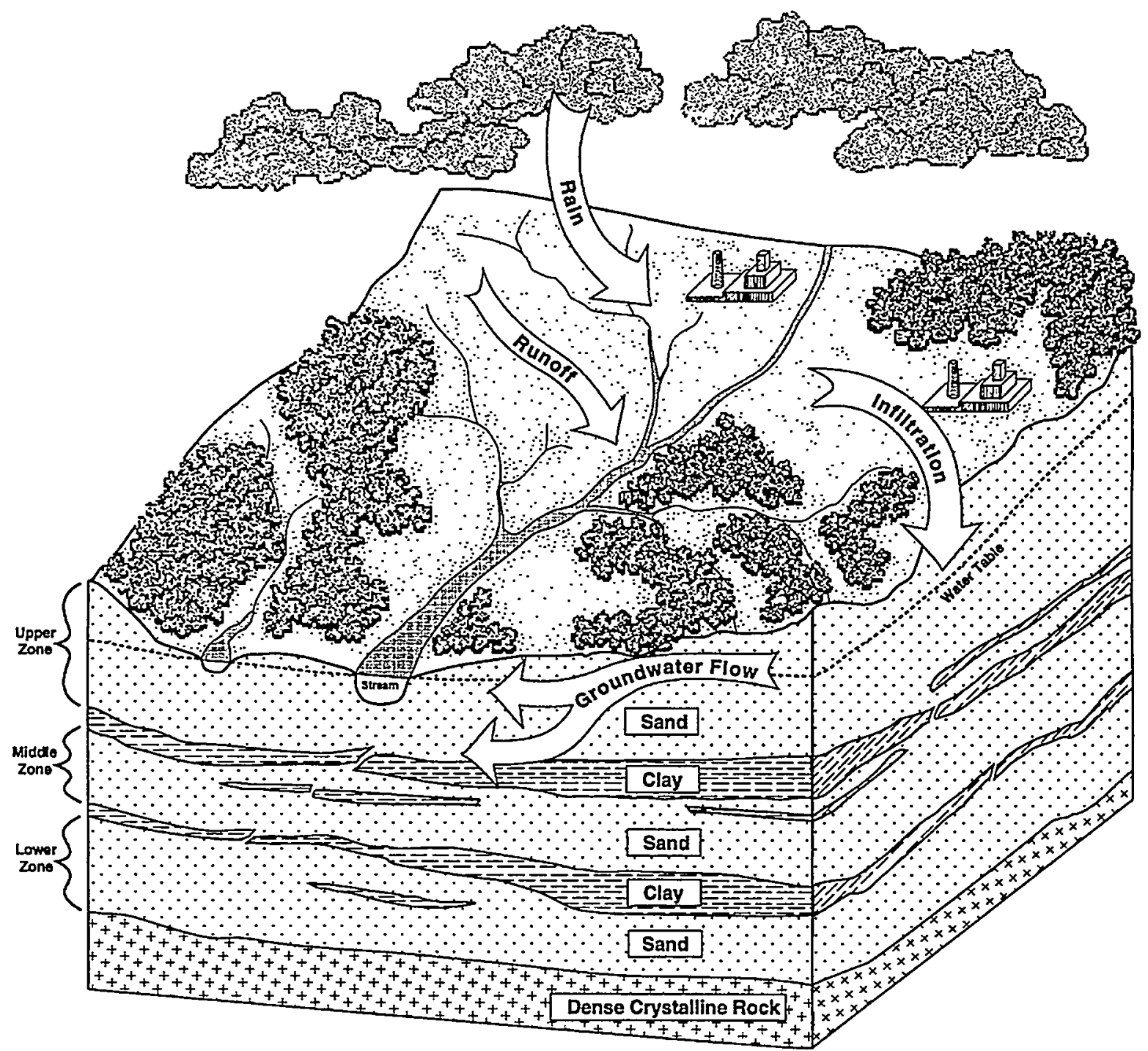

Exploration Resources, Inc.

Figure 10-2 Groundwater at SRS

hazardous substances in the soil may dissolve as the groundwater infiltrates and moves down through the soil to the water table. In this way, contaminants in the soil can move with the groundwater and may become a health risk.

Figure 10-2 provides a conceptual image of the groundwater processes at SRS but is not intended to represent any specific location. Because the actual conditions vary from place to place within the site, the assignment of aquifer names to the upper, middle, or lower zones is not appropriate. In addition, some areas of the site contain more than three zones.

SRS is built on a 700- to 1,200-foot sequence of sediments composed of sand, clayey sand, and clay, with a small amount of limestone. Dense crystalline rock lies under the sediments. The groundwater in the vicinity moves through the sediments, mostly in the sand layers. The clay layers allow very little groundwater to flow through them; therefore, their presence between sand layers helps direct the flow of groundwater and contaminants.

At SRS, groundwater moves in several sandy zones that are separated by less permeable clay layers. The upper zone comprises the rainwater that moves down from the surface. Water in this zone moves either laterally to discharge or downward into lower zones. Beneath the upper zone is a clay layer that retards the water moving downward into the lower zones. In some areas of SRS, this clay layer is thick and 
undisturbed and is effective in preventing the upper zone of groundwater from moving downward. In other areas, this clay layer is thin, broken, or missing, and the groundwater from the upper zone can move readily into lower zones.

Below the upper zone is another zone of sand where the water moves relatively freely. Water in this middle zone is used for domestic water supplies. Below the middle zone is another clay layer and then a lower zone of groundwater. The lowest zone is the most important aquifer in the region and supplies water to domestic and industrial users.

Groundwater beneath SRS flows slowly-at rates ranging from inches (in the clay zones) to several hundred feet (in the sand zones) per year - toward streams and swamps on site and into the Savannah River. Figures $10-3$ and $10-4$ illustrate the potentiometric contours and horizontal-flow directions of the middle and lower zones beneath SRS. Similar to contour lines on a weather map that connect points of equal barometric pressure, the figures' potentiometric surface contour lines connect below-ground regions of equal hydraulic head (elevation of the water in a well or piezometer). Horizontal-flow directions of groundwater within these zones are indicated on figures 10-3 and 10-4 by bold arrows perpendicular to the contour lines. In both zones, the direction of flow beneath monitored waste sites generally is toward the Savannah River, the Savannah River Swamp, Upper Three Runs Creek, or Lower Three Runs Creek. Surface water in the swamp and creeks eventually flows into the Savannah River.

Groundwater beneath an estimated five to 10 percent of SRS has been contaminated by industrial solvents, tritium, metals, or other constituents used or generated by operations at SRS. The upper zone is the most affected in general by activity at SRS. The middle zone is known to be contaminated in several areas. Contamination in the lowest zone has been identified primarily in A-Area and M-Area. Additional information about the contamination in A-Area and M-Area appears on page 165.

Monitoring wells are used extensively at SRS to assess the effect of site activities on groundwater quality. Most of the wells monitor the upper groundwater zone, although wells in lower zones are present at the sites with the larger groundwater contamination plumes. Groundwater in areas indicated on figure 10-1 contains one or more constituents at or above the levels of the DWS of the U.S. Environmental Protection Agency (EPA).

\section{Description of the Groundwater Monitoring Program}

The groundwater monitoring program at SRS gathers information to determine the effect of site operations on groundwater quality. The program is designed to

- assist SRS in complying with environmental regulations and U.S. Department of Energy (DOE) directives

- provide data to identify and monitor constituents in the groundwater

- permit characterization of new facility locations to ensure that they are suitable for the intended facilities

- $\quad$ support basic and applied research projects

The groundwater monitoring program at SRS is conducted by the Environmental Geochemistry Group (EGG) of the Environmental Protection Department/Environmental Monitoring Section (EPD/EMS) of Westinghouse Savannah River Company (WSRC). To assist other departments in meeting their responsibilities, EGG provides the services for installing monitoring wells, collecting and analyzing samples, and reporting results.

The WSRC Environmental Compliance Manual (WSRC-3Q1) provides details about the following aspects of the groundwater monitoring program:

- well siting, construction, maintenance, and abandonment

- sample planning

- sample collection and field measurements

- analysis

- data management

- related publications, files, and databases

The next four sections of this chapter present overviews of several of these topics, along with information specific to 1999.

\section{Sample Scheduling and Collection}

EMS schedules groundwater sampling either in response to specific requests from SRS personnel or as part of its ongoing groundwater monitoring program. These groundwater samples provide data for reports required by federal and state regulations and for internal reports and research projects. The groundwater monitoring program schedules wells to be sampled at intervals ranging from quarterly to triennially. 


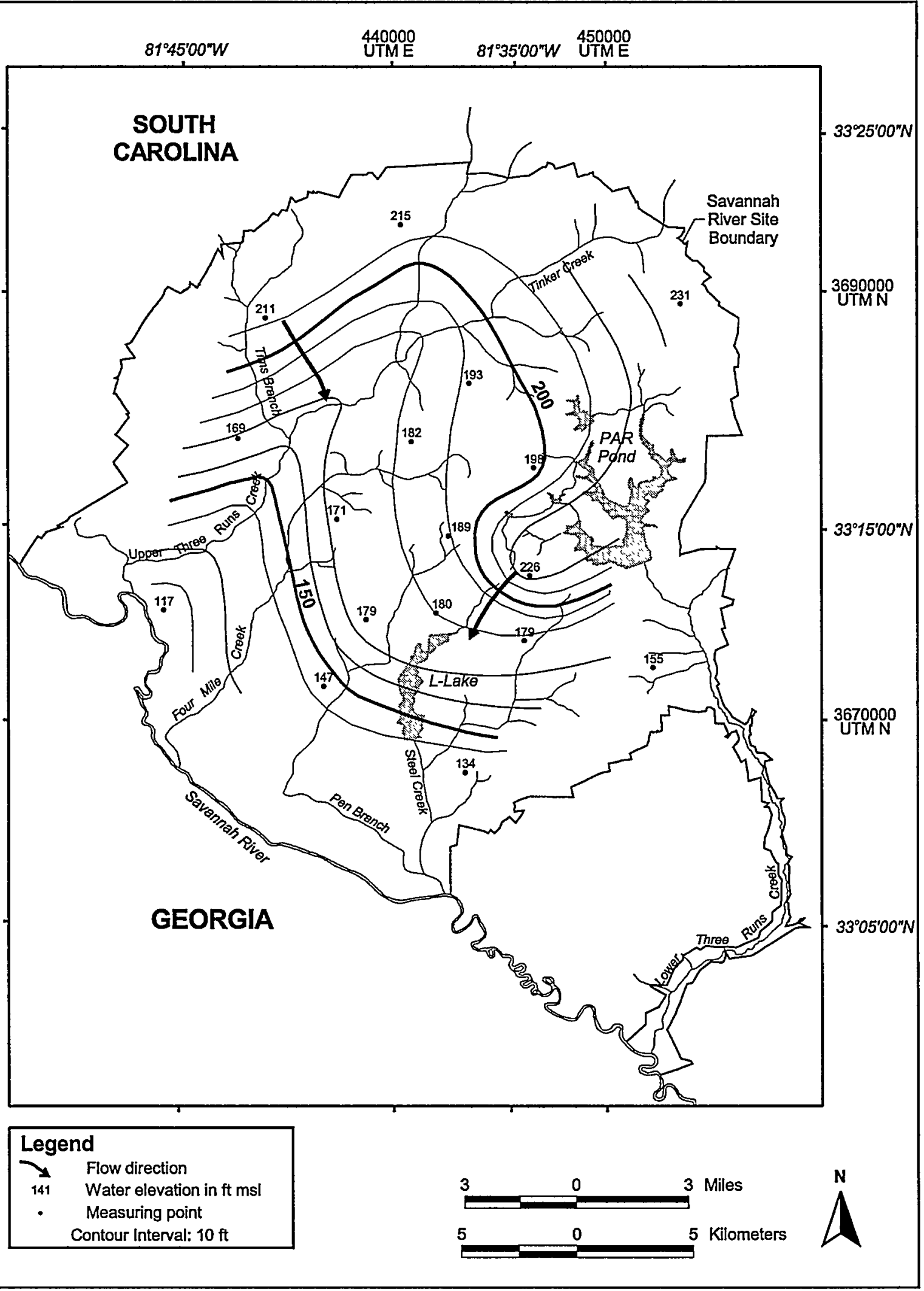

Exploration Resources, Inc.

Figure 10-3 Potentiometric Surface and Horizontal Groundwater Flow Directions of the Middle Zone at SRS During the Second Quarter of 1999 


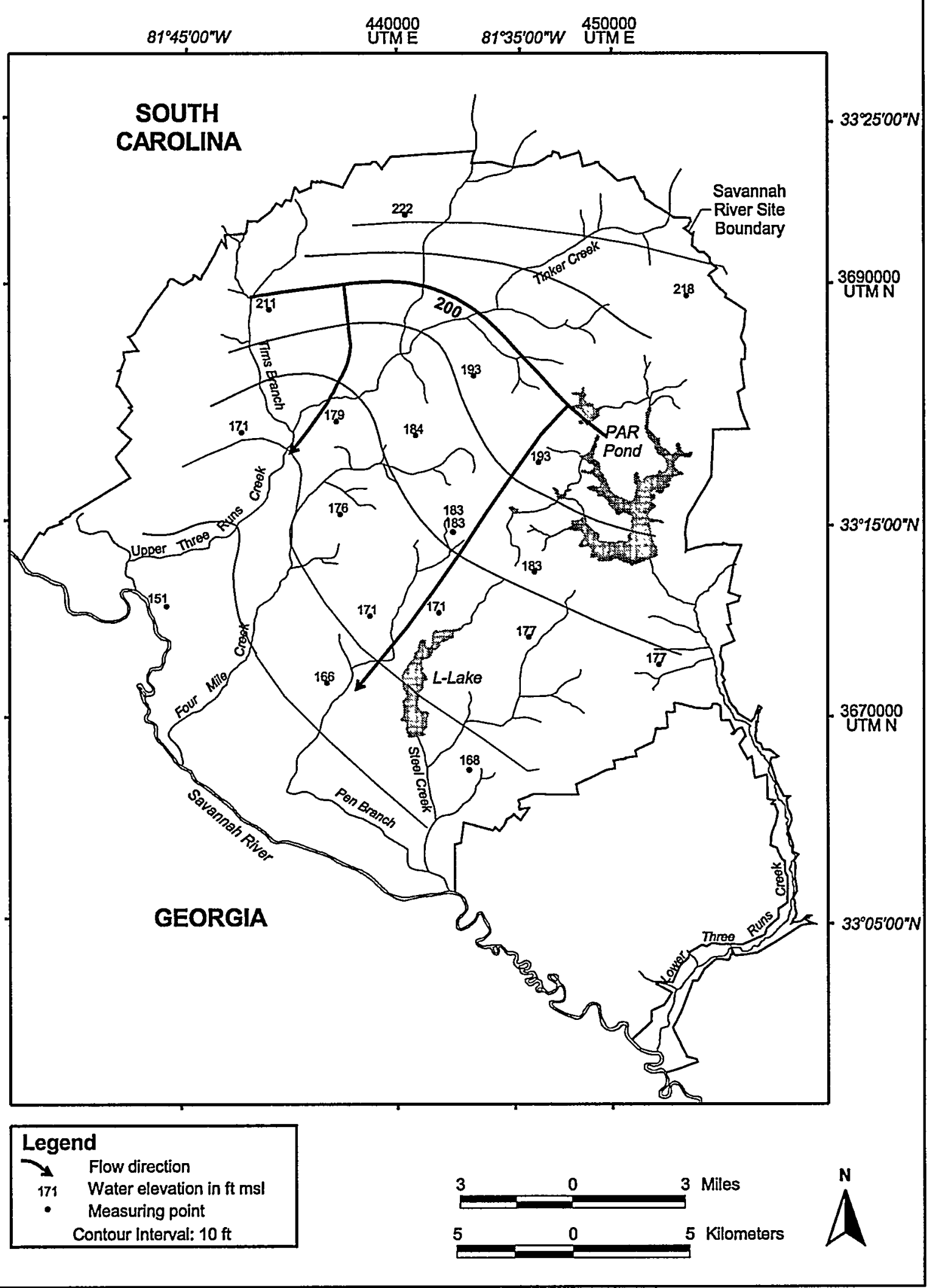

Exploration Resources, Inc.

Figure 10-4 Potentiometric Surface and Horizontal Groundwater Flow Directions of the Lower Zone at SRS During the Second Quarter of 1999 
Table 10-1 Environmental-Screening

Constituents

Aluminum
Arsenic
Barium
Boron
Cadmium
Calcium
Chloride
Chromium
Fluoride
Gross alpha
Iron
Lead
Lithium
Magnesium
Manganese
Mercury
Nitrate-nitrite as nitrogen
Nonvolatile beta
Potassium
Selenium
Silica
Silver
Sodium
Sulfate
Total dissolved solids
Total organic carbon
Total organic halogens
Total phosphates (as P)
Tritium

Tritium

- Groundwater from new wells added to the program is analyzed for environmental-screening constituents (table 10-1) for 4 consecutive quarters for only the wells identified in the Savannah River Site Screening Program Wells (ESH-EMS-99-0539).

- Environmental-screening analyses are conducted once every 3 years for only the wells identified in the Savannah River Site Screening Program Wells (ESH-EMS-99-0539).

- If their environmental-screening constituent concentrations are above certain limits, wells identified in the Savannah River Site Screening Program Wells (ESH-EMS-99-0539) are sampled annually.

Personnel outside EMS may request sample collection as often as weekly. In addition to environmental-screening constituents, constituents that may be analyzed by request include suites of herbicides, pesticides, additional metals, volatile organics, and others. Radioactive constituents that may be analyzed by request include gamma emitters, iodine-129, strontium-90, radium-228, uranium isotopes, and other alpha and beta emitters.

Groundwater samples are collected from monitoring wells, generally with either pumps or bailers dedicated to the well to prevent cross-contamination among wells. Occasionally, portable sampling equipment is used; this equipment is decontaminated between wells.

Sampling and shipping equipment and procedures are consistent with EPA, South Carolina Department of Health and Environmental Control (SCDHEC), and U.S. Department of Transportation guidelines. EPA-recommended preservatives and sample-handling techniques are used during sample storage and transportation to both onsite and offsite analytical laboratories. Potentially radioactive samples are screened for total activity (alpha and beta emitters) prior to shipment to determine appropriate packaging and labeling requirements.

Deviations (caused by dry wells, inoperative pumps, etc.) from scheduled sampling and analysis for 1999 are enumerated in the SRS quarterly groundwater monitoring reports cited previously in this chapter.

In 1999, 26,958 radiological analyses and 134,123 nonradiological analyses were performed on groundwater samples collected from 1,224 monitoring wells.

\section{Analytical Procedures}

In 1999, General Engineering Laboratories of Charleston, South Carolina; Recra LabNet Philadelphia of Lionville, Pennsylvania; and EMAX Laboratories, Inc., of Torrance, California, performed most of the groundwater analyses. In addition, the General Engineering Mobile Laboratory performed onsite analyses of volatile organics and semivolatile organics and metals. The contracted laboratories are certified by SCDHEC to perform specified analyses.

The EMS laboratory at SRS screened potentially radioactive samples for total activity prior to shipment. General Engineering Laboratories performed radiological analyses, and Thermo NUtech of Oak Ridge, Tennessee, subcontracted radiological analyses from Recra LabNet Philadelphia.

Full lists of constituents analyzed, analytical methods used, and the laboratories' estimated quantitation limits are given in the SRS quarterly groundwater reports referenced earlier.

\section{Evaluation of Groundwater Data}

EMS receives analytical results and field measurements as reports and as ASCII files that are 
loaded into databases at SRS. Logbooks track receipt and transfer of data to the Geochemical Information Management System (GIMS) database, and computer programs present the data in a format that can be validated.

Quality control practices include the following:

- verification of well names and sample dates for field and analytical data

- verification that all analyses requested on the chain-of-custody forms were completed by each laboratory

- identification of data entry problems (e.g., duplicate records, incorrect units)

- comparison of analytical data to historical data and review of the data for transcription, instrument, or calculation errors

- comparison of blind replicates and laboratory in-house duplicates for inconsistencies

- identification of laboratory blanks and blind blanks with elevated concentrations

Possible transcription errors and suspect results are documented and submitted to the appropriate laboratory for verification or correction. No changes are made to the database until the laboratory documents the problem and solution. Changes to the database are recorded in a logbook.

The quarterly groundwater monitoring reports identify queried results verified by the laboratory and list groundwater samples associated with blanks having elevated results. These reports also present the results of intralaboratory and interlaboratory quality assurance comparisons (chapter 11, "Quality Assurance").

\section{Changes to the Groundwater Monitoring Program during 1999}

\section{Well Abandonments and Additions; Changes to the Sampling Schedule}

During 1999, four wells were abandoned-one in conjunction with the $108-3 \mathrm{C}$ bioremediation site closure and another in conjunction with the 108-3L bioremediation site closure. Two wells were abandoned and replaced in conjunction with the Resource Conservation and Recovery Act (RCRA) Facility Investigation/Remedial Investigation (RFI/RD) characterization plan at the H-Area Tank Farm.

The following 122 wells were monitored for the first time in 1999:
- Six new wells installed in the C-Area reactor seepage basins to support the RFI/RI investigation.

- Thirty-eight new wells installed in support of the implementation of the RFI/RI workplan for the 488-D ash basin and D-Area coal pile runoff basin operable unit.

- Forty new wells and two replacement wells installed in the H-Area tank farm in support of RFI/RI characterization.

- Five new wells installed in the northern sector of M-Area in conjunction with an RFI/RI project.

- Seven new wells installed in the N-Area (Central Shops) sludge lagoon in conjunction with the RFI/RI project.

- Twelve new wells installed in compliance with the TNX-Area Effectiveness Monitoring Strategy Addendum.

- Twelve flood plain wells installed in the TNX-Area groundwater operable unit.

\section{Groundwater Monitoring Results at SRS}

This section summarizes groundwater monitoring results during 1999 for each of the following areas at SRS:

- A-Area and M-Area

- C-Area

- D-Area and TNX

- General separations and waste management areas (E-Area, F-Area, H-Area, S-Area, and Z-Area)

- K-Area

- L-Area and chemicals, metals, and pesticides (CMP) pits

- N-Area

- P-Area

- R-Area

- Sanitary Landfill and B-Area

Groundwater monitoring results for each area in the above list are (1) illustrated with a figure showing the extent of contamination for selected contaminants, (2) described in the text, and (3) summarized with a table.

A figure (from each area) shows facilities of interest at or near the site and illustrates areas of notable contamination above DWS. The figures do not specify every contaminant identified through groundwater monitoring, but they illustrate contamination above DWS. 
Each figure is accompanied by a brief description of the sites and facilities of interest in the area, an explanation of groundwater flow, and the nature of contamination in the area. Note that the figures display the estimated extent of contamination determined from previous as well as current years' monitoring well results, and from additional data.

The description of contamination at each area concludes with a table that summarizes the following information:

- major groups of constituents
- percent of wells sampled (for 1997 through 1999) that contained constituents above drinking water standards

- number of wells sampled (for 1997 through 1999) for each constituent group

- sources of contamination

Substantial areas of contamination identified in the tables are illustrated in more detail, in some cases, in the accompanying figures. For example, a table may identify volatile organics contamination, and the figure may show that most of that contamination is trichloroethylene. 


\section{Groundwater Contamination at A-Area and M-Area}

\section{Location and Facilities}

The administration and manufacturing areas, A-Area and M-Area, are located in the northwest portion of SRS. A-Area houses administrative and research facilities, including the Savannah River Technology Center (SRTC). M-Area was used for production of nuclear fuels, targets, and other reactor components.

A-Area and M-Area include the following facilities and sites associated with the groundwater monitoring program:

- A-Area ash pile

- A-Area burning/rubble pits

- A-Area coal pile runoff containment basin

- A-Area metals burning pit

- M-Area Hazardous Waste Management Facility (HWMF)

- M-Area settling basin

- Metallurgical Laboratory seepage basin

- Miscellaneous chemical basin

- Motor Shop oil basin

- Savannah River Laboratory (SRL) seepage basins

- Silverton Road waste site

\section{Nature of Contamination}

Surface drainage in A-Area and M-Area is toward Tims Branch, approximately to the east, and toward valleys to the northwest and southwest that lead to the Savannah River. The water table in this vicinity slopes to the southeast, south, and southwest toward Tims Branch and other discharge points. Most of the water of the upper saturated zone migrates downward into lower water-bearing zones.

Figure 10-5 shows the extent of contamination and the location of contaminants of primary concern at A-Area and M-Area. There is a large groundwater contamination plume under and downgradient of A-Area and M-Area. Volatile organic constituents-the primary contaminants-are found throughout the area and account for the largest percentage of contaminated wells. Trichloroethylene, tetrachloroethylene, and other volatile organic compounds were used as degreasers during manufacturing and research. After use, organic wastes, metals, and other contaminants were placed into unlined basins, from which they slowly seeped into the groundwater. Contaminants also entered the groundwater as the result of spills or leaking pipes.

The highest concentrations of volatile organics and metals generally are found beneath seepage and settling basins in central and southern portions of the area. The entire contaminant plume covers approximately 5.5 square miles and is approximately one-third mile from the SRS boundary.

Because of the chemical nature of trichloroethylene and tetrachloroethylene and the groundwater conditions in the upper aquifer zone, the contaminant movement generally is downward into deeper aquifers. Once in the deeper aquifers, these contaminants may be moved horizontally by faster groundwater flow rates.

The ASB 6 well cluster monitors the contaminant plume just west of the Savannah River Laboratory seepage basins. Figure 10-6 illustrates the concentration of trichloroethylene in these wells since January 1993 and demonstrates the trend for that contaminant to move to lower aquifer zones. Wells ASB 6A and ASB 6C, which monitor the uppermost aquifer zones, exhibit trichloroethylene levels near the detection limit. The trichloroethylene concentration is highest in well ASB 6AA, which is screened in the next lower zone. Trichloroethylene concentrations also are notable in well ASB 6TA, which monitors the deepest aquifer zone monitored in A-Area and M-Area.

Trending data for trichloroethylene and tetrachloroethylene contamination in A-Area and M-Area indicate that all wells on the southern extent of the central portion of the areas show an upward trend for concentrations. Table 10-2 illustrates this movement of trichloroethylene toward the southeast in selected M-Area wells. All the wells included on this table are located west and south of central M-Area facilities, in the vicinity of the M-Area settling basin and generally north of Lost Lake. Wells MSB 11C, 12B, 14A, 15A, 16A, 23B, and 25A, which are the most northern and eastern wells on the table, show decreasing or relatively unchanging levels of trichloroethylene between 1995 and 1999. Wells MSB 1B, 2B, 2C, 3C, 4C, 17B, and 38C, which are further south and west, display increasing trichloroethylene levels during the same 5-year period. Most other wells show downward trends or no overall trends.

Table 10-3 summarizes 1997-1999 groundwater monitoring results for A-Area and M-Area. 


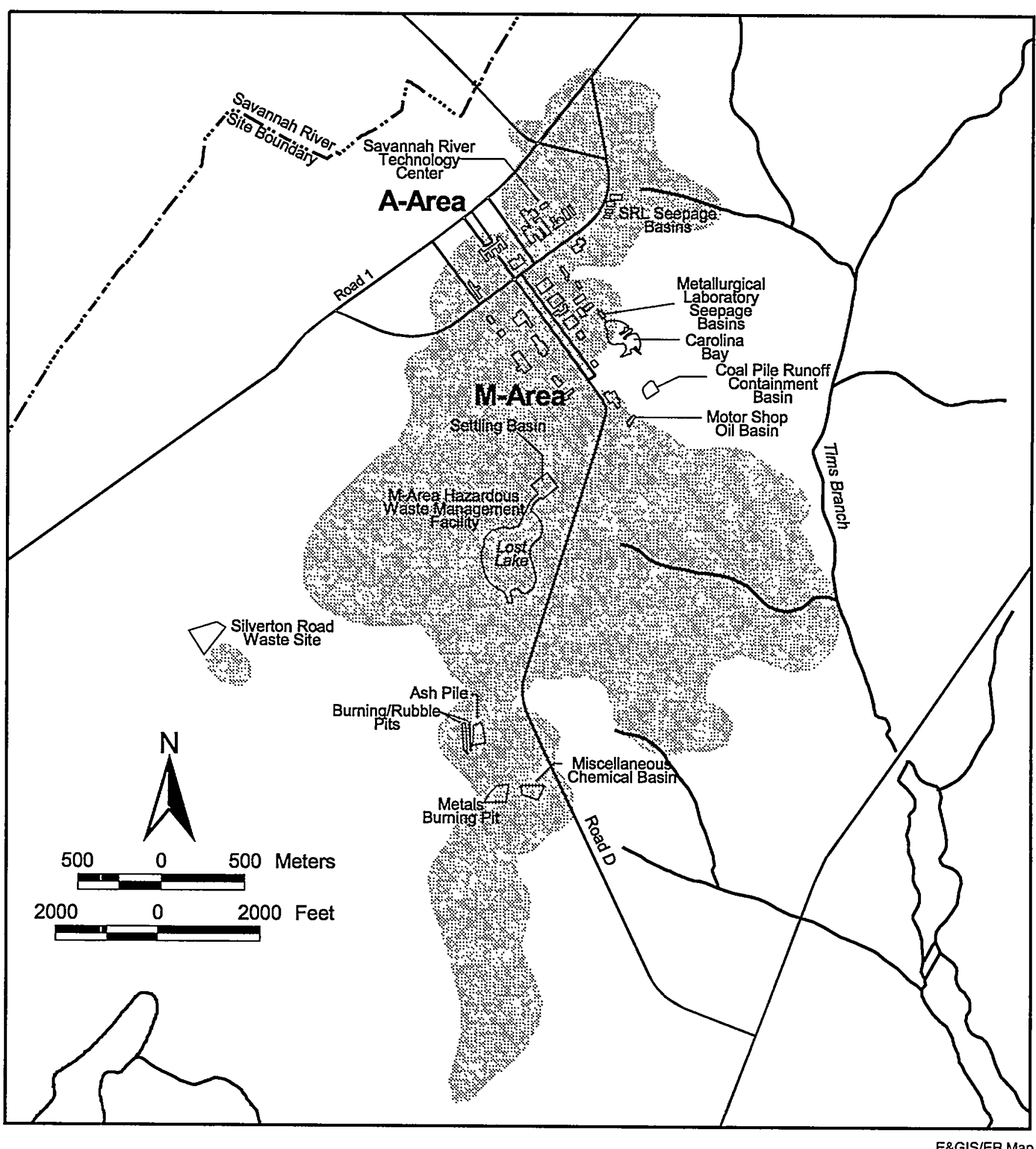

Figure 10-5 Extent of Volatile Organic Contamination of the Groundwater Beneath A-Area and M-Area in 1999 and Location of Noteworthy Sources of Contamination Exceeding Drinking Water Standards 


\section{Trichloroethylene Concentrations}

Well Cluster ASB 6

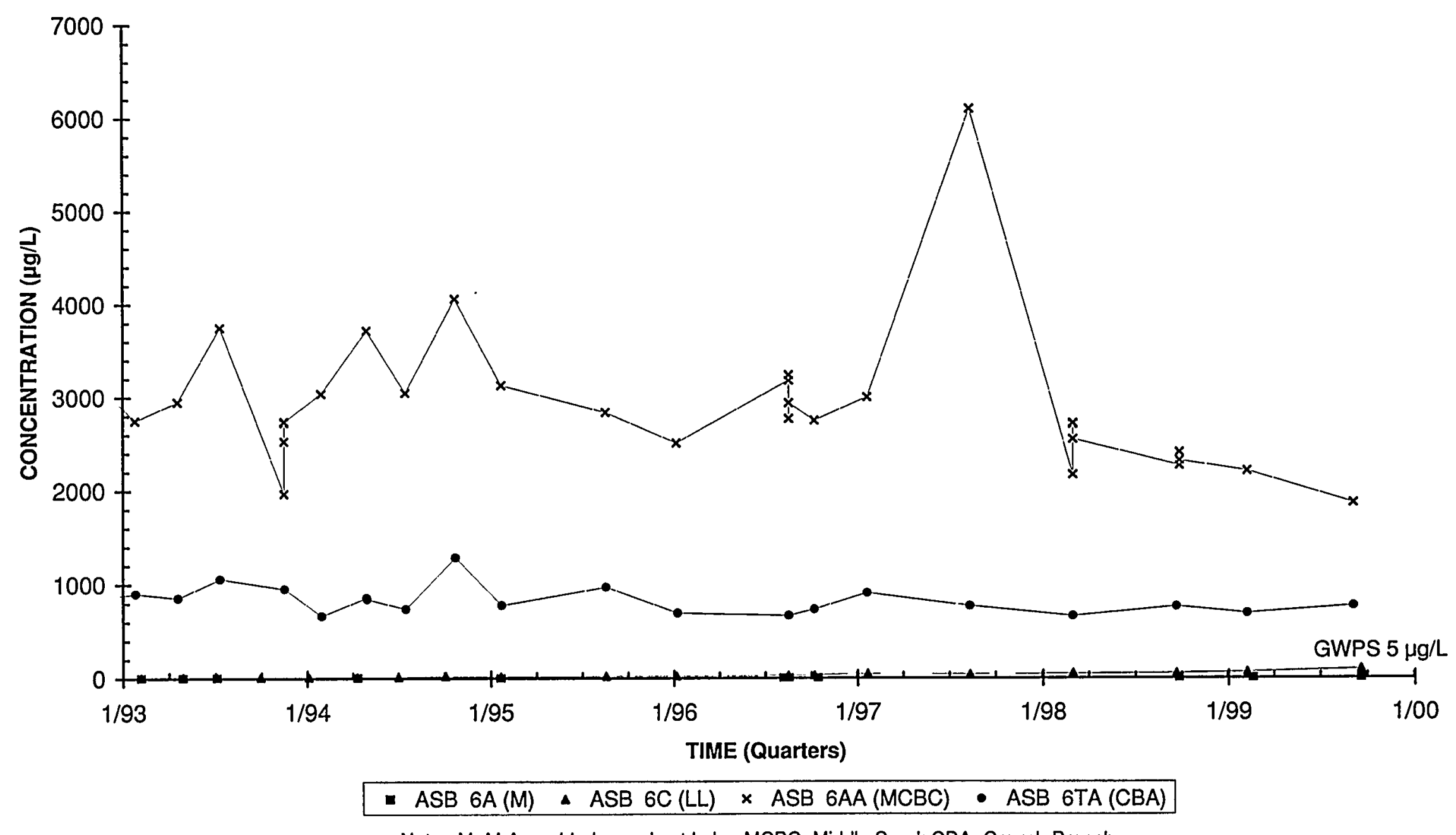

Note: $M=M$ Area; $L L=L$ ower Lost Lake; $M C B C=$ Middle Sand; $C B A=C r o u c h$ Branch 


\section{Remediation}

Ongoing remediation efforts have substantially altered the groundwater and contaminant flow patterns in the upper, middle, and lower aquifer zones beneath A-Area and M-Area. These efforts include capping the basins and extracting and processing volatile organics from the groundwater. Remediation efforts also include pumping contaminated air to six soil vacuum-extraction units, where the volatile organic compounds are destroyed. While ongoing remediation never will clean up contaminated groundwater zones completely, it can slow the spread of contamination and minimize the impact to the environment.

Table 10-2 Trichloroethylene Concentrations (in $\mu \mathrm{g} / \mathrm{L}$ ) in Selected M-Area Wells, 1995-1999

\begin{tabular}{llllll}
\hline Well & 1995 & 1996 & 1997 & 1998 & 1999 \\
\hline MSB 1B & 640 & 459 & 970 & 1,240 & 1,700 \\
MSB 2B & 5,320 & 4,880 & 6,900 & 8,970 & 10,900 \\
MSB 2C & 9,950 & 22,200 & 41,000 & 25,500 & 44,500 \\
MSB 3C & 8,950 & 10,300 & 11,000 & 18,700 & 23,400 \\
MSB 4C & 2,150 & 8,930 & 19,000 & 10,600 & 11,300 \\
MSB 11C & 72,500 & 105,000 & 73,000 & 44,700 & 42,900 \\
MSB 12B & NA & 16,500 & 19,000 & 23,800 & 15,600 \\
MSB 14A & 4,030 & 3,240 & 2,700 & 4,240 & 8,530 \\
MSB 15A & 5,850 & 7,080 & 8,000 & 8,310 & 7,990 \\
MSB 16A & 12,400 & 13,100 & 13,000 & 9,890 & 10,600 \\
MSB 17B & 6,490 & 5,140 & 7,100 & 7,140 & 11,200 \\
MSB 23B & 43,300 & 21,400 & 27,000 & 30,100 & 23,600 \\
MSB 25A & 1,400 & 1,350 & 1,200 & 1,140 & 1,290 \\
MSB 38C & 3,910 & 3,620 & 4,000 & 6,880 & 18,700 \\
\hline
\end{tabular}

Notes: NA = not analyzed. Well MSB 12B was not sampled during 1995.

All data are from third quarter of the respective years, with the following exceptions: during 1995, data for well MSB 15A are from first quarter; during 1997, data for wells MSB $2 C$ and $11 \mathrm{C}$ are from first quarter; and during 1999 , data from wells MSB $3 C, 11 \mathrm{C}, 12 \mathrm{~B}$, and $38 \mathrm{C}$ are from first quarter.

The federal primary DWS for trichloroethylene is $5 \mu \mathrm{g} / \mathrm{L}$. 
Table 10-3 Constituent Groups Above Drinking Water Standards at A-Area and M-Area, 1997-1999

\begin{tabular}{|c|c|c|c|c|c|c|c|}
\hline \multirow[t]{2}{*}{ Constituent Groups } & \multicolumn{3}{|c|}{$\begin{array}{l}\text { Percent of Wells } \\
\text { With Results } \\
\text { Above Standards }\end{array}$} & \multicolumn{3}{|c|}{$\begin{array}{l}\text { Number of } \\
\text { Wells Sampled }\end{array}$} & \multirow[t]{2}{*}{ Sources of Contamination } \\
\hline & 1997 & 1998 & 1999 & 1997 & 1998 & 1999 & \\
\hline Dioxins/furans & $0 \%$ & $0 \%$ & $0 \%$ & 13 & 14 & 13 & None (no contamination) \\
\hline Metals & $2 \%$ & $5 \%$ & $4 \%$ & 288 & 271 & 290 & $\begin{array}{l}\text { HWMF, Motor Shop oil basin, settling } \\
\text { basin, Silverton Road waste site }\end{array}$ \\
\hline Organics & $54 \%$ & $58 \%$ & $55 \%$ & 288 & 273 & 292 & $\begin{array}{l}\text { Burning/rubble pits, HWMF, metals burn- } \\
\text { ing pit, Met Lab seepage basin, SRL } \\
\text { seepage basins }\end{array}$ \\
\hline Pesticides/PCBs & $5 \%$ & $0 \%$ & $0 \%$ & 43 & 49 & 49 & None (no contamination) \\
\hline Tritium & $0 \%$ & $0 \%$ & $0 \%$ & 41 & 1 & 20 & None (no contamination) \\
\hline Other radionuclides & $24 \%$ & $10 \%$ & $5 \%$ & 271 & 261 & 267 & HWMF, SRL seepage basins \\
\hline Other constituents & $7 \%$ & $5 \%$ & $5 \%$ & 276 & 267 & 289 & HWMF \\
\hline
\end{tabular}

Note: Drinking Water Standards refer to federal final primary DWS, proposed primary DWS, and interim final primary DWS. 


\section{Groundwater Contamination at C-Area}

\section{Location and Facilities}

C-Area, which is in the west-central part of SRS, contains the C-Area reactor. The C-Area reactor achieved criticality in March 1955 and was shut down in 1985 for maintenance. It was placed on cold standby in 1987 , followed by cold shutdown.

C-Area includes the following facilities associated with the groundwater monitoring program:

- C-Area burning/rubble pit

- C-Area coal pile runoff containment basin

- C-Area disassembly basin

- C-Area reactor

- C-Area reactor seepage basins

- C-Area retention basin

\section{Nature of Contamination}

Groundwater flow beneath C-Area tends to be toward incised creeks near the area. Horizontal flow generally is west toward Four Mile Creek (also known as Fourmile Branch), and surface drainage is predominantly west toward a tributary of Four Mile Creek.

During routine reactor operations, the radioactivity level from tritium built up in the disassembly basins that held activated target rods. Periodically, the water from these basins was purged to limit worker exposure. During different time periods, the water was discharged to the reactor seepage basins or to surface streams. Tritium also escaped from the disassembly basins.

The C-Area burning/rubble pit and basins also received materials that could cause groundwater contamination.

Figure 10-7 shows the extent of contamination and the location of contaminants of primary concern at $\mathrm{C}$-Area. Consistent with results from previous years, trichloroethylene and tritium are the most widespread contaminants of concern. Other radionuclides and lead are also elevated in several wells in the vicinity of the seepage basins and the reactor disassembly basin.

Table 10-4 summarizes 1997-99 groundwater monitoring results for C-Area.

Table 10-4 Constituent Groups Above Drinking Water Standards at C-Area, 1997-1999

\begin{tabular}{|c|c|c|c|c|c|c|c|}
\hline \multirow[t]{2}{*}{ Constituent Groups } & \multicolumn{3}{|c|}{$\begin{array}{l}\text { Percent of Wells } \\
\text { With Results } \\
\text { Above Standards }\end{array}$} & \multicolumn{3}{|c|}{$\begin{array}{l}\text { Number of } \\
\text { Wells Sampled }\end{array}$} & \multirow[t]{2}{*}{ Sources of Contamination } \\
\hline & 1997 & 1998 & 1999 & 1997 & 1998 & 1999 & \\
\hline Dioxins/furans & - & - & - & - & - & - & \\
\hline Metals & $60 \%$ & $0 \%$ & $21 \%$ & 15 & 5 & 19 & $\begin{array}{l}\text { Disassembly basin, reactor seepage } \\
\text { basins }\end{array}$ \\
\hline Organics & $67 \%$ & $33 \%$ & $42 \%$ & 18 & 6 & 19 & $\begin{array}{l}\text { Burning/rubble pit, reactor seepage } \\
\text { basins }\end{array}$ \\
\hline Pesticides/PCBs & $0 \%$ & $0 \%$ & $0 \%$ & 6 & 4 & 6 & None (no contamination) \\
\hline Tritium & $58 \%$ & $22 \%$ & $56 \%$ & 12 & 9 & 18 & $\begin{array}{l}\text { Disassembly basin, reactor seepage ba- } \\
\text { sins, burning/rubble pit }\end{array}$ \\
\hline Other radionuclides & $36 \%$ & $60 \%$ & $0 \%$ & 11 & 5 & 9 & None (no contamination) \\
\hline Other constituents & $0 \%$ & $0 \%$ & $0 \%$ & 17 & 5 & 11 & None (no contamination) \\
\hline
\end{tabular}

Notes: Drinking Water Standards refer to federal final primary DWS, proposed primary DWS, and interim final primary DWS.

Dioxins/furans were not sampled at C-Area during 1997, 1998, and 1999. 


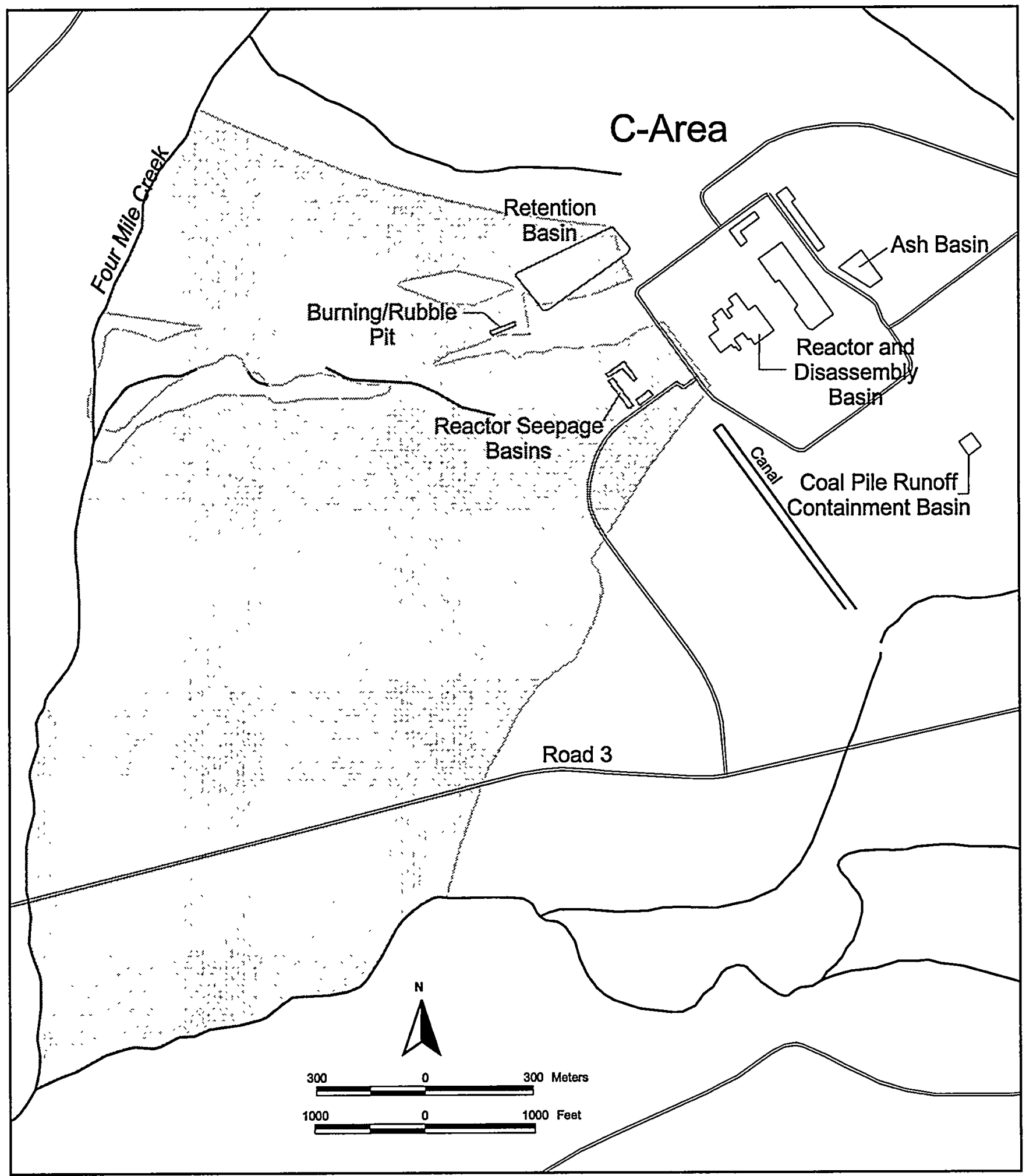

E\&GIS/ER Map

Figure 10-7 Extent of Tritium and Volatile Organic Contamination of the Groundwater Beneath C-Area in 1999 and Location of Noteworthy Sources of Contamination Exceeding Drinking Water Standards 


\section{Groundwater Contamination at D-Area and TNX}

\section{Location and Facilities}

D-Area, located in the southwest part of SRS, includes a large coal-fired power plant and the inactive heavy-water facilities.

D-Area includes the following facilities associated with the groundwater monitoring program:

- D-Area burning/rubble pits

- D-Area coal pile, coal pile runoff containment basin, and ash basins

- D-Area oil disposal basin

- Road A chemical basin (Baxley Road)

TNX, also located in the southwest part of SRS-and operated by SRTC - tests equipment prior to installation and develops new designs. The nearest SRS boundary is the Savannah River, approximately one-quarter mile to the west.

Facilities in TNX include the following:

- New TNX seepage basin

- $\quad$ Old TNX seepage basin

- TNX burying ground

\section{Nature of Contamination}

The water table aquifer in D-Area discharges to the Savannah River and to a nearby swamp along Beaver Dam Creek. The water table aquifer surface in the vicinity of the coal pile runoff containment basin in $\mathrm{D}$-Area is very close to the ground surface and drains to Beaver Dam Creek, which flows into the Savannah River Swamp.
Figure 10-8 shows the extent of contamination and the location of contaminants of primary concern at D-Area and TNX. In D-Area, there is substantial contamination of the groundwater near the coal pile,coal pile runoff containment basin, and ash basins. The most widespread contaminants are trichloroethylene and tritium. The water also is characterized by high conductivity and low $\mathrm{pH}$. solids. Elevated levels of metals and alpha-emitting radionuclides are found as well. The contamination is consistent with the leaching of coal and coal ash.

A separate, smaller plume of contaminated groundwater is present near the D-Area oil disposal basin. Volatile organics (especially trichloroethylene) and lead have been detected above DWS.

The water table aquifer in TNX discharges to the Savannah River and the nearby Savannah River Swamp.

There is a plume of contaminated groundwater underneath much of TNX and downgradient into the Savannah River Swamp. Volatile organic compounds (especially trichloroethylene) and nitrate are the most widely distributed contaminants. Metals also are present near the known disposal sites. The highest levels of trichloroethylene are found northwest and southeast of the TNX burying ground, although a plume appears to be moving to the southwest of the TNX outfall delta toward the Savannah River. Table 10-5 summarizes trichloroethylene concentrations in selected TNX wells between 1995 and 1999. These wells are located in and around the TNX burying ground and the old TNX seepage basin. In general, although trichloroethylene levels in wells exceed standards, they appear to demonstrate stable contamination levels over time.

Table 10-6 summarizes 1997-1999 groundwater monitoring results for D-Area and TNX. 


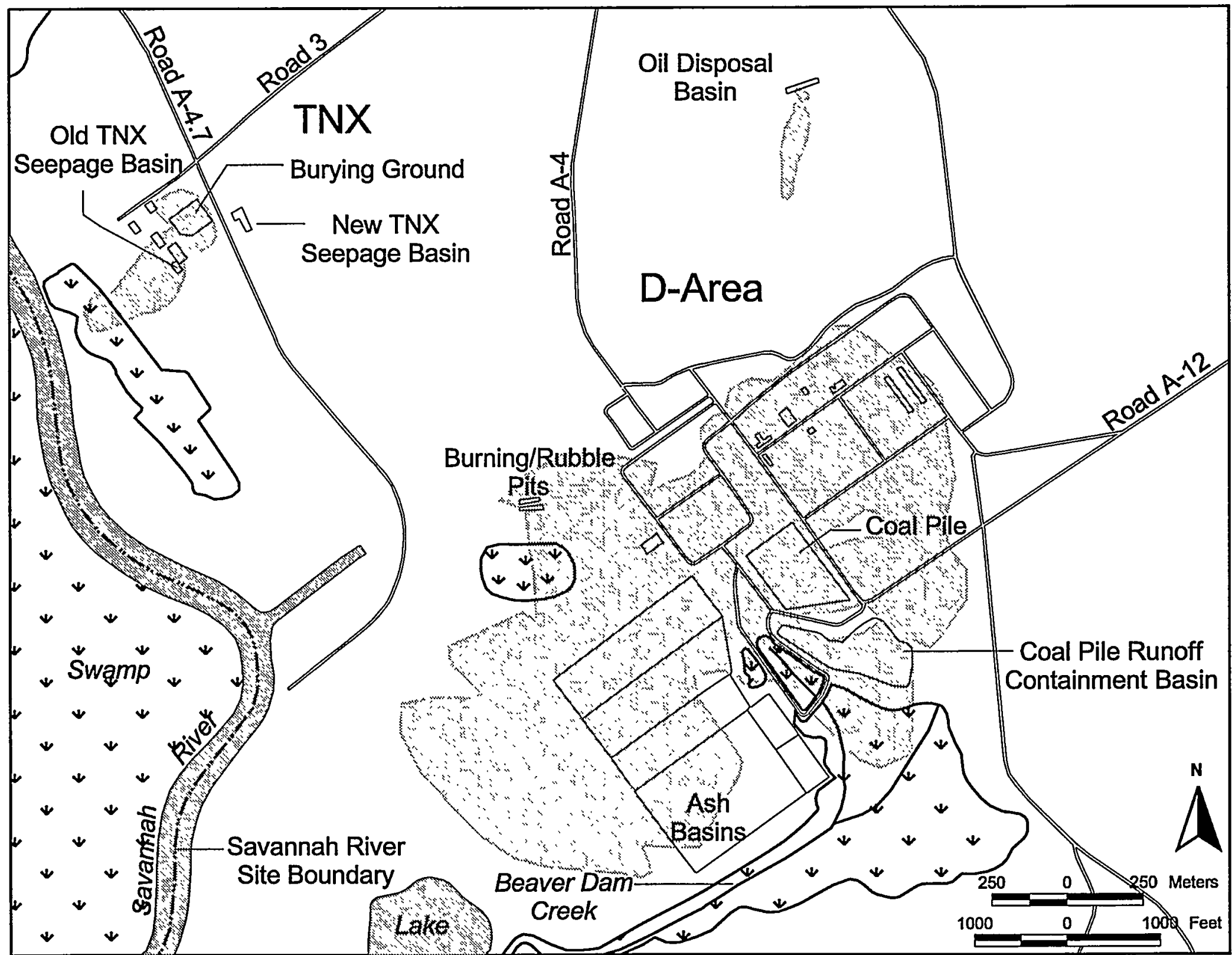

E\&GIS/ER MaP

Figure 10-8 Extent of Volatile Organic Contamination of the Groundwater Beneath D-Area and TNX in 1999 and Location of Noteworthy Sources of Contamination Exceeding Drinking Water Standards 
Table 10-5 Trichloroethylene Concentrations (in $\mu \mathrm{g} / \mathrm{L}$ ) in Selected TNX Wells, 1995-1999

\begin{tabular}{llllll}
\hline Well & 1995 & 1996 & 1997 & 1998 & 1999 \\
\hline TBG 1 & 7.0 & 10.3 & 12.6 & 8.16 & 61.0 \\
TBG 3 & 473 & 360 & 217 & 875 & 310 \\
TBG 4 & 617 & 561 & 263 & 687 & 500 \\
TBG 5 & 644 & 1,400 & 1,410 & 1,710 & 1,600 \\
TBG 6 & 735 & 1,780 & 62.3 & 465 & 3.000 \\
XSB 1D & 84 & 289 & 9.23 & 282 & 260 \\
XSB 2D & 98 & 106 & 74.0 & 15.2 & 18.0 \\
XSB 3A & NA & 388 & 34.9 & 12.3 & 33.0 \\
XSB 4D & 14 & 21.8 & 3.18 & 288 & 45.0 \\
XSB 5A & $<2.0$ & 12.6 & 48.9 & 34.5 & 18.0 \\
\hline
\end{tabular}

Notes: NA = not analyzed. Well XSB 3A was not sampled during 1995.

All data are from fourth quarter for 1995, 1996, and 1997; from third quarter for 1998, except for wells TBG 5 and XSB 5A (first quarter) and wells XSB 1D and 4D (second quarter); and from second quarter for 1999, eXcept for wells XSB 1D, 3A, and 5A (third quarter) and well TBG 1 (fourth quarter).

The federal primary DWS for trichloroethylene is $5 \mu \mathrm{g} / \mathrm{L}$.

Table 10-6 Constituent Groups Above Drinking Water Standards at D-Area and TNX, 1997-1999

\begin{tabular}{|c|c|c|c|c|c|c|c|}
\hline \multirow[t]{2}{*}{ Constituent Groups } & \multicolumn{3}{|c|}{$\begin{array}{l}\text { Percent of Wells } \\
\text { With Results } \\
\text { Above Standards }\end{array}$} & \multicolumn{3}{|c|}{$\begin{array}{l}\text { Number of } \\
\text { Wells Sampled }\end{array}$} & \multirow[t]{2}{*}{ Sources of Contamination } \\
\hline & 1997 & 1998 & 1999 & 1997 & 1998 & 1999 & \\
\hline Dioxins/furans & $0 \%$ & $0 \%$ & $0 \%$ & 31 & 30 & 1 & None (no contamination) \\
\hline Metals & $36 \%$ & $16 \%$ & $5 \%$ & 107 & 43 & 75 & $\begin{array}{l}\text { Coal facilities, oil disposal basin, old } \\
\text { TNX seepage basin, TNX burying } \\
\text { ground }\end{array}$ \\
\hline Organics & $41 \%$ & $52 \%$ & $47 \%$ & 108 & 44 & 95 & $\begin{array}{l}\text { Coal facilities, oil disposal basin, old } \\
\text { TNX seepage basin, TNX burying } \\
\text { ground, burning/rubble pit }\end{array}$ \\
\hline Pesticides/PCBs & $0 \%$ & $0 \%$ & $0 \%$ & 80 & 30 & 6 & None (no contamination) \\
\hline Tritium & $2 \%$ & $0 \%$ & $13 \%$ & 99 & 7 & 32 & $\begin{array}{l}\text { Coal facilities, north of TNX seepage ba- } \\
\text { sin, TNX burying ground }\end{array}$ \\
\hline Other radionuclides & $29 \%$ & $18 \%$ & $12 \%$ & 99 & 37 & 59 & Coal facilities, TNX burying ground \\
\hline Other constituents & $16 \%$ & $23 \%$ & $15 \%$ & 104 & 37 & 73 & $\begin{array}{l}\text { Old TNX seepage basin, TNX burying } \\
\text { ground }\end{array}$ \\
\hline
\end{tabular}

Notes: Drinking Water Standards refer to federal final primary DWS, proposed primary DWS, and interim final primary DWS. 


\section{Groundwater Contamination at the General Separations and Waste Management Areas}

\section{Location and Facilities}

The separations and waste management areas, which include E-Area, F-Area, H-Area, S-Area, and Z-Area, are located in the central part of SRS.

Reactor-produced materials are processed in the chemical separations plants in F-Area and H-Area, where uranium, plutonium-238, and plutonium-239 are separated from each other and from fission products. These areas also have facilities for purification and packaging of tritium and for storage of fission wastes.

The separations and waste management areas include the following facilities associated with the groundwater monitoring program:

\section{E-Area}

- Burial Grounds perimeter

- E-Area Vaults near the Burial Ground

- Hazardous Waste/Mixed Waste Disposal Facility

- Old Burial Ground

- Radioactive Waste Burial Ground (also known as Solid Waste Disposal Facility)

\section{F-Area}

- F-Area acid/caustic basin

- F-Area Burma Road rubble pit

- F-Area burning/rubble pits

- F-Area canyon building and A-Line Uranium Recovery Facility

- F-Area coal pile runoff containment basin and ash basins

- F-Area effluent treatment cooling water basin

- F-Area sanitary sludge land application site

- F-Area seepage basins and inactive process sewer line

- F-Area tank farm

- New F-Area retention basin

- Old F-Area retention basin

- Old F-Area seepage basin

H-Area

- H-Area acid/caustic basin

- H-Area auxiliary pump pit
- H-Area canyon building

- H-Area coal pile runoff containment basin and ash basin

- H-Area effluent treatment cooling water basin

- H-Area sanitary sludge land application site

- H-Area retention basin

- H-Area seepage basins and inactive process sewer line

- H-Area tank farm

- New H-Area retention basin

- Old H-Area retention basin

S-Area

- $\quad$ S-Area auxiliary pump pit

- S-Area Defense Waste Processing Facility

- S-Area low-point pump pit

- S-Area Vitrification Building

Z-Area

- Waste Solidification and Disposal Facility

- Z-Area low-point drain tank

- Z-Area Saltstone Disposal Facility

Nature of Contamination

Surface drainage in these areas of SRS is to Four Mile Creek to the south and Upper Three Runs Creek and its tributaries to the north and west.

E-Area, F-Area, and H-Area are located on the groundwater divide between Four Mile Creek and Upper Three Runs Creek. Near-surface groundwater in the southern portions of these areas discharges to Four Mile Creek and its tributaries. Near-surface groundwater in the northern portions of these areas discharges to Upper Three Runs Creek and its tributaries to the north.

S-Area and Z-Area are located on the groundwater divide between Upper Three Runs Creek and its tributaries to the west.

Figure 10-9 shows the extent of contamination and the locations of contaminants of primary concern at the general separations areas. The facilities at E-Area, F-Area, and H-Area have been sources of substantial groundwater pollution. In the past, the seepage and retention basins in F-Area and H-Area have been used to dispose of liquids containing radionuclides, metals, organics, and nitrates. Radioactive liquids have leaked into the groundwater below the tank farms. Tritium and metals have leached from materials buried in E-Area. Several stabilization and 
closure programs have been implemented to reduce the impact of the sources of groundwater contamination. In Z-Area during 1999, radionuclides were detected in one well, and tritium was found in another. Contamination was found in the vicinity of the vitrification building in S-Area.

Many groundwater contamination plumes overlap in the area. Plumes from the Old Burial Ground and the F-Area and $\mathrm{H}$-Area seepage basins discharge tritium, radionuclides, metals, and nitrates into Four Mile Creek. Table 10-7 summarizes tritium concentrations in wells to the west and south of the Old Burial Ground and demonstrates stable concentrations of the contaminant over time. The highest tritium concentrations generally are found in wells to the south of the central portion of the Old Burial Ground, near the intersection of Roads $E$ and $E-0.2$, screened in the Water Table and next lower (Barnwell/McBean) aquifers.
An extensive tritium plume is migrating north from the Solid Waste Disposal Facility. Other plumes are under the buildings, tank farms, and other waste disposal areas.

The F-Area Hazardous Waste Management Facility well network monitors three distinct hydrostratigraphic units in the uppermost aquifer beneath the facility. Figure 10-10 illustrates the concentration of gross alpha in well cluster FSB 95 since June 1993. The gross alpha concentration is higher in well FSB 95DR but is also notable in FSB 95CR. Groundwater flows in Water Table and Barnwell/McBean aquifer zones generally are south or southwest toward Four Mile Creek.

Table 10-8 summarizes 1997-1999 groundwater monitoring results for the general separations and waste management areas. 


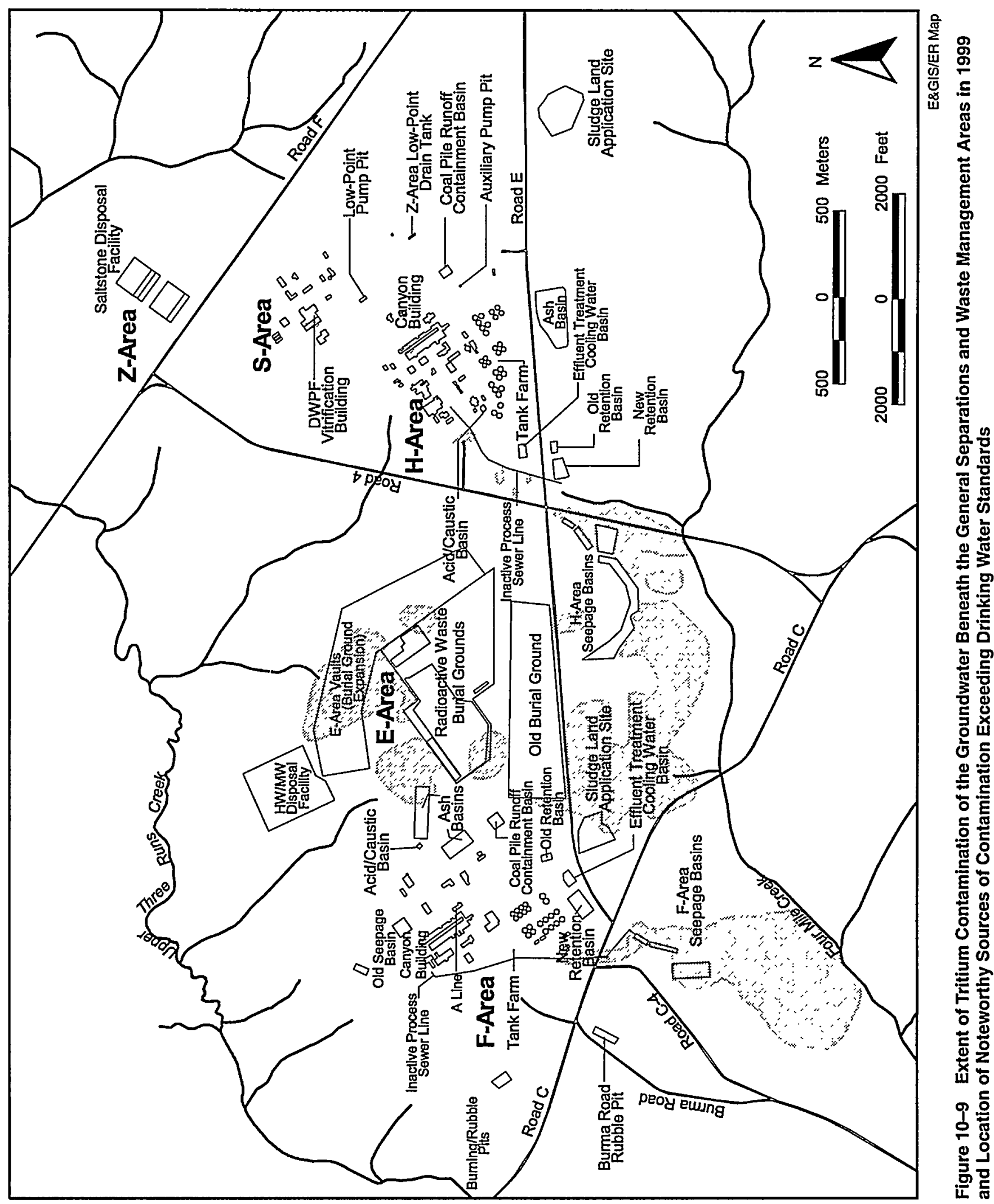




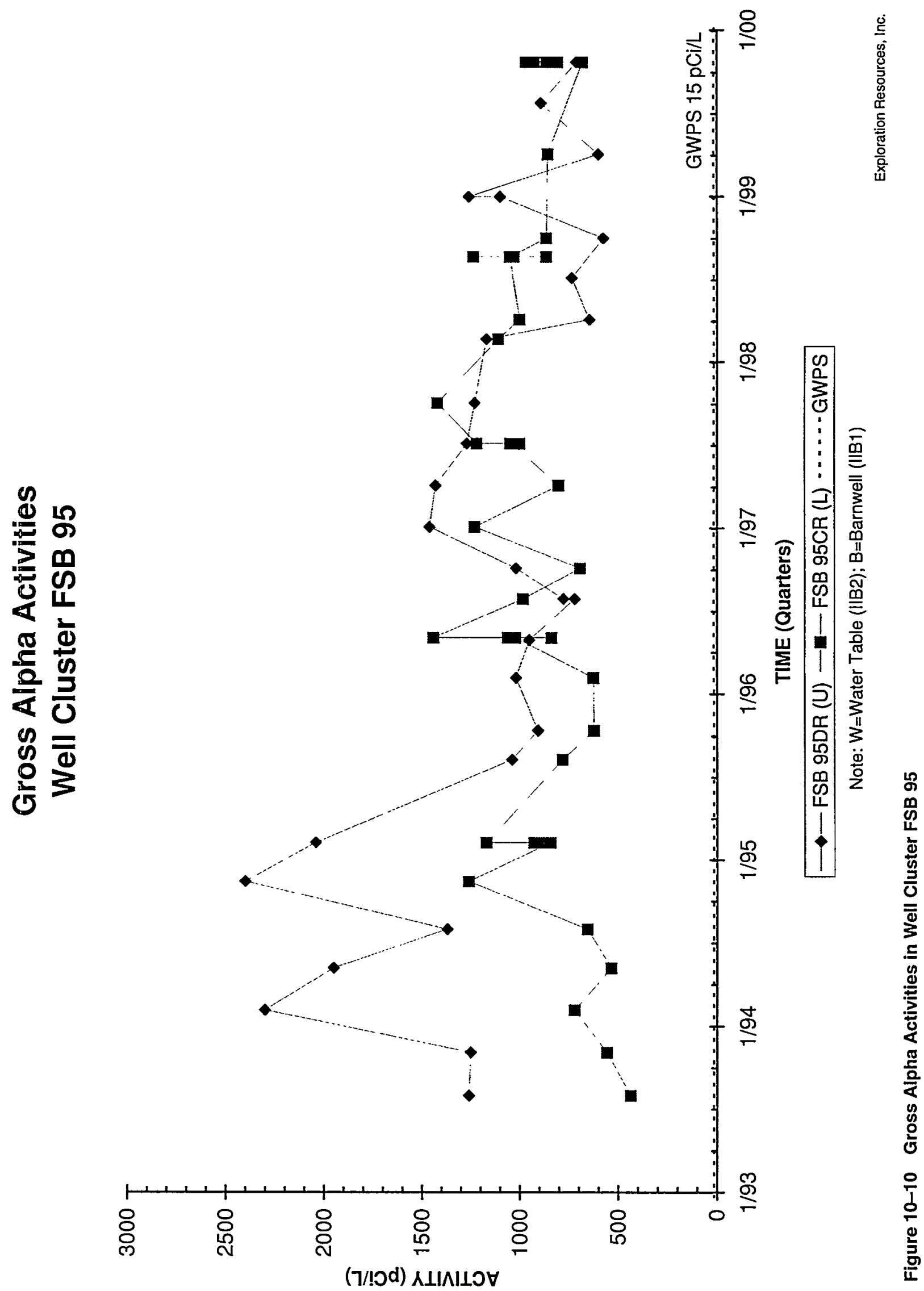


Table 10-7 Tritium Concentrations (in $\mu \mathrm{Ci} / \mathrm{mL}$ ) in Selected General Separations Area Wells, 1995-1999

\begin{tabular}{|c|c|c|c|c|c|}
\hline Well & 1995 & 1996 & 1997 & 1998 & 1999 \\
\hline BGO 29D & $7.9 \mathrm{E}-06$ & $8.16 E-06$ & $8.40 E-06$ & $N A$ & NA \\
\hline BGO 30C & $1.2 E-03$ & 1.37E-03 & $8.58 E-04$ & NA & NA \\
\hline BGO 30D & $3.4 \mathrm{E}-03$ & $4.05 E-03$ & $1.94 E-02$ & $N A$ & $1.45 \mathrm{E}-02$ \\
\hline BGO $31 \mathrm{C}$ & $3.1 E-03$ & $3.59 E-03$ & 4.34E-03 & $N A$ & $6.68 \mathrm{E}-03$ \\
\hline BGO 31D & $1.75 E-05$ & $1.38 E-05$ & $3.65 E-05$ & $N A$ & $5.25 \mathrm{E}-05$ \\
\hline BGO 32D & $3.4 \mathrm{E}-04$ & $5.97 E-06$ & NA & NA & 7.23E-04 \\
\hline BGO 33C & $1.2 E-02$ & $1.14 \mathrm{E}-02$ & $1.21 E-02$ & $1.29 E-02$ & $1.45 \mathrm{E}-02$ \\
\hline BGO 33D & $2.3 E-05$ & $2.10 \mathrm{E}-05$ & $2.42 E-05$ & 2.11E-05 & $2.33 E-05$ \\
\hline BGO 34D & 1.7E-05 & $1.29 \mathrm{E}-05$ & $1.55 E-05$ & $3.69 \mathrm{E}-05$ & 2.71E-05 \\
\hline BGO 35C & $5.5 E-05$ & $5.62 \mathrm{E}-05$ & $5.12 E-05$ & $2.10 \mathrm{E}-04$ & $4.80 E-04$ \\
\hline BGO 35D & $4.5 E-05$ & $2.09 E-05$ & $6.72 E-05$ & $3.10 E-05$ & $6.93 E-05$ \\
\hline BGO 36D & 2.7E-05 & 2.34E-05 & $2.32 E-05$ & $2.31 E-05$ & $2.19 \mathrm{E}-05$ \\
\hline BGO 37C & NA & $1.60 E-01$ & 2.10E-01 & $2.66 \mathrm{E}-01$ & $1.70 E-01$ \\
\hline BGO 37D & $2.9 \mathrm{E}-05$ & 2.67E-05 & $2.71 E-05$ & $2.88 \mathrm{E}-05$ & $2.65 \mathrm{E}-05$ \\
\hline BGO 46C & 4.6E-04 & $9.17 \mathrm{E}-04$ & $1.33 E-03$ & NA & $4.30 \mathrm{E}-03$ \\
\hline BGO 46D & $2.0 E-02$ & $9.78 \mathrm{E}-03$ & $3.88 \mathrm{E}-02$ & NA & NA \\
\hline BGO 47C & $3.8 E-04$ & $3.61 E-04$ & $3.65 E-04$ & NA & $3.80 E-04$ \\
\hline BGO 47D & $1.1 E-03$ & 7.35E-04 & $5.20 E-04$ & NA & $2.50 E-04$ \\
\hline BGO 48C & $6.6 E-03$ & 4.31E-03 & $2.78 E-03$ & NA & $3.86 \mathrm{E}-03$ \\
\hline BGO 48D & $2.5 E-02$ & $3.70 E-02$ & $3.78 E-02$ & NA & NA \\
\hline BGO 50C & $1.5 E-04$ & $1.49 E-04$ & $1.77 E-04$ & NA & $6.98 E-04$ \\
\hline BGO 50D & $3.5 E-04$ & $1.66 \mathrm{E}-03$ & $6.88 E-04$ & $N A$ & $9.71 E-04$ \\
\hline
\end{tabular}

Notes: NA $=$ not analyzed. Well BGO 37C was not analyzed in 1995. Well BGO 32D was not analyzed in 1997. Wells BGO 29D, 30C, 30D, 31C, 31D, 32D, 46C, 46D, 47C, 47D, 48C, 48D, 50C, and 50D were not analyzed in 1998. Wells BGO 29D, 30C, 46D, and 48D were not analyzed in 1999.

All data for 1995, 1996, and 1997 are from fourth quarter. Data for 1998 are from third quarter except for well BGO 33C (second quarter). Data for 1999 are from fourth quarter except for wells BGO 33D, 35C, 35D, 36D, and 37D (first quarter) and wells BGO $33 \mathrm{C}$ and $34 \mathrm{D}$ (third quarter).

The federal final primary DWS for tritium is $2.0 \mathrm{E}-05 \mu \mathrm{Ci} / \mathrm{mL}$. 
Table 10-8 Constituent Groups Above Drinking Water Standards at the General Separations and Waste Management Areas, 1997-1999

\begin{tabular}{lccc|ccccl}
\hline & \multicolumn{3}{l}{$\begin{array}{l}\text { Percent of Wells } \\
\text { With Results }\end{array}$} & \multicolumn{2}{l}{$\begin{array}{l}\text { Number of } \\
\text { Wells Sampled }\end{array}$} & Sources of Contamination \\
\hline Constituent Groups & Above Standards & 1997 & 1998 & 1999 & 1997 & 1998 & 1999 & \\
\hline Dioxins/furans & $0 \%$ & $0 \%$ & $0 \%$ & 14 & 14 & 16 & None (no contamination) \\
Metals & $16 \%$ & $21 \%$ & $18 \%$ & 520 & 334 & 365 & $\begin{array}{l}\text { Canyon buildings, tank farms, seepage } \\
\text { basins, Burial Grounds }\end{array}$ \\
Organics & $8 \%$ & $10 \%$ & $10 \%$ & 384 & 371 & 471 & $\begin{array}{l}\text { Burial Grounds, burning/rubble pit, can- } \\
\text { yon buildings, F-Area seepage basins }\end{array}$ \\
Pesticides/PCBs & $0 \%$ & $0 \%$ & $0 \%$ & 38 & 21 & 14 & $\begin{array}{l}\text { None (no contamination) } \\
\text { Tritium }\end{array}$ \\
\hline & $48 \%$ & $51 \%$ & $53 \%$ & 432 & 426 & 483 & $\begin{array}{l}\text { Burial Grounds, canyon buildings, tank } \\
\text { farms, seepage basins }\end{array}$ \\
Other radionuclides & $37 \%$ & $43 \%$ & $40 \%$ & 421 & 412 & 372 & $\begin{array}{l}\text { Burial Grounds, seepage basins, tank } \\
\text { farms, saltstone disposal facility }\end{array}$ \\
Other constituents & $25 \%$ & $28 \%$ & $31 \%$ & 365 & 322 & 307 & Seepage basins, burning/rubble pit \\
\hline
\end{tabular}

Notes: Drinking Water Standards refer to federal final primary DWS, proposed primary DWS, and interim final primary DWS. 


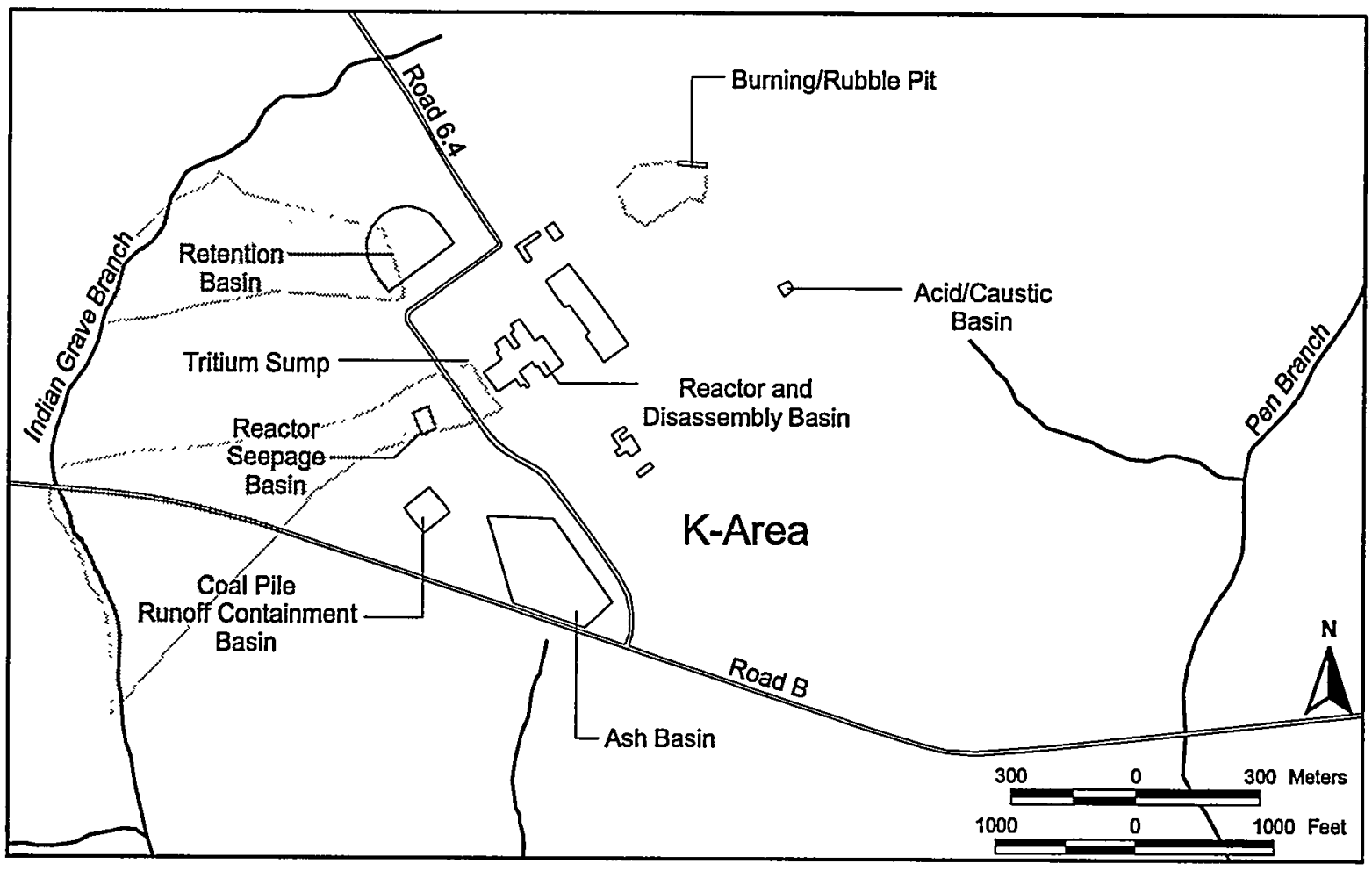

E\&GIS/ER Map

Figure 10-11 Extent of Tritium and Volatile Organic Contamination of the Groundwater Beneath K-Area in 1999 and Location of Noteworthy Sources of Contamination Exceeding Drinking Water Standards

\section{Groundwater Contamination at K-Area}

\section{Location and Facilities}

$\mathrm{K}$-Area is in the south-central part of SRS and contains the K-Area reactor, which achieved criticality in 1954 and was shut down in 1988 for maintenance. The reactor was placed in cold shutdown in February 1996.

$\mathrm{K}$-Area includes the following facilities associated with the groundwater monitoring program:

- K-Area ash basin

- K-Area Bingham pump outage pit

- K-Area burning/rubble pit

- K-Area coal pile runoff containment basin

- K-Area diesel tank spill

- K-Area disassembly basin

- K-Area reactor

- K-Area reactor seepage basin

- K-Area retention basin

- K-Area tritium sump

\section{Nature of Contamination}

The bisection of Pen Branch and Indian Grave Branch isolates the near-surface groundwater in K-Area. Deeper groundwater flows toward the Savannah River.

Figure 10-11 shows the extent of contamination and the location of contaminants of primary concern in $\mathrm{K}$-Area. Two major plumes of contaminated groundwater exist at K-Area. The large plume consists of tritium-contaminated water around the disassembly, reactor seepage, and retention basins. As described in the C-Area discussion, these sites are known sources of tritium. Low levels of volatile organics, especially trichloroethylene and tetrachloroethylene, are detected in some wells that monitor this plume. A second plume of volatile organics, primarily tetrachloroethylene, appears to be located in the vicinity of the burning/rubble pit.

Some groundwater under and near the ash basin and the coal pile runoff containment basin has gross-alpha contamination. This is a typical contaminant leached from coal and coal ash.

Table 10-9 summarizes 1997-1999 groundwater monitoring results for $\mathrm{K}$-Area. 
Table 10-9 Constituent Groups Above Drinking Water Standards at K-Area, 1997-1999

\begin{tabular}{|c|c|c|c|c|c|c|c|}
\hline \multirow[t]{2}{*}{ Constituent Groups } & \multicolumn{3}{|c|}{$\begin{array}{l}\text { Percent of Wells } \\
\text { With Results } \\
\text { Above Standards }\end{array}$} & \multicolumn{3}{|c|}{$\begin{array}{l}\text { Number of } \\
\text { Wells Sampled }\end{array}$} & \multirow[t]{2}{*}{ Sources of Contamination } \\
\hline & 1997 & 1998 & 1999 & 1997 & 1998 & 1999 & \\
\hline Dioxins/furans & - & - & - & - & - & - & \\
\hline Metals & $0 \%$ & $0 \%$ & $11 \%$ & 15 & 13 & 19 & $\begin{array}{l}\text { Coal pile runoff containment basin, dis- } \\
\text { assembly basin }\end{array}$ \\
\hline Organics & $57 \%$ & $38 \%$ & $25 \%$ & 7 & 8 & 12 & $\begin{array}{l}\text { Burning/rubble pit, disassembly basin, } \\
\text { reactor seepage basin }\end{array}$ \\
\hline Pesticides/PCBs & - & $0 \%$ & 一 & - & 6 & 一 & \\
\hline Tritium & $87 \%$ & $60 \%$ & $63 \%$ & 15 & 10 & 16 & $\begin{array}{l}\text { Disassembly basin, reactor seepage ba- } \\
\text { sin, retention basin }\end{array}$ \\
\hline Other radionuclides & $18 \%$ & $17 \%$ & $29 \%$ & 17 & 12 & 14 & $\begin{array}{l}\text { Ash basin, coal pile runoff containment } \\
\text { basin }\end{array}$ \\
\hline Other constituents & $0 \%$ & $0 \%$ & $0 \%$ & 11 & 8 & 6 & None (no contamination) \\
\hline
\end{tabular}

Notes: Drinking Water Standards refer to federal final primary DWS, proposed primary DWS, and interim final primary DWS.

Dioxins/furans were not sampled at K-Area during 1997, 1998, and 1999. Pesticides/PCBs were not sampled at K-Area during 1997 and 1999. 


\section{Groundwater Contamination at L-Area and the Chemicals, Metals, and Pesticides Pits}

\section{Location and Facilities}

L-Area is in the south-central part of SRS and contains the L-Area reactor, which achieved criticality in 1954 and continued production until 1968 , when it was placed in warm standby. It subsequently operated from 1985 until 1988, when it was shut down for maintenance. It was placed in warm standby in December 1991 to be put into operation as a backup to K-Reactor, if necessary, but since has been placed in cold shutdown.

L-Area includes the following facilities associated with the groundwater monitoring program:

- L-Area acid/caustic basin

- L-Area Bingham pump outage pits

- L-Area burning/rubble pits

- L-Area disassembly basin

- L-Area oil and chemical basin

- L-Area reactor

- L-Area reactor seepage basin

The CMP pits are near the head of Pen Branch. The pits were used from 1971 to 1979 to dispose of waste consisting of drummed oil, organic solvents, and small amounts of pesticides and metals. In 1984, the pits were excavated to form two trenches, backfilled, and capped. During excavation, most of the contaminated material was removed to the Hazardous Waste Storage Facility.

\section{Nature of Contamination}

Figure 10-12 shows the extent of contamination and the location of contaminants of primary concern at L-Area and the CMP pits. There is a plume of contaminated groundwater downgradient between the L-Area reactor buildings and L-Lake. Tritium is the most extensive contaminant, and results from current and previous years show that lead, nitrate, and tetrachloroethylene are present in low concentrations. Tritium activity in a monitoring well about 1,000 feet southwest of the reactor building has increased substantially since 1994 . Tetrachloroethylene and nitrate are present near the disassembly basin and the oil and chemical basin.

Several small tributaries of Steel Creek receive surface drainage from L-Area. The near-surface groundwater discharges to Steel Creek and Pen Branch.

A plume of groundwater beneath the CMP pits is contaminated with volatile organics, most notably carbon tetrachloride, and metals.

Surface drainage at the CMP pits is to the north toward Pen Branch and to the south toward a tributary of Pen Branch. Groundwater flows downward and horizontally away from the pits.

Table 10-10 summarizes 1997-1999 groundwater monitoring results for L-Area and the CMP pits. 


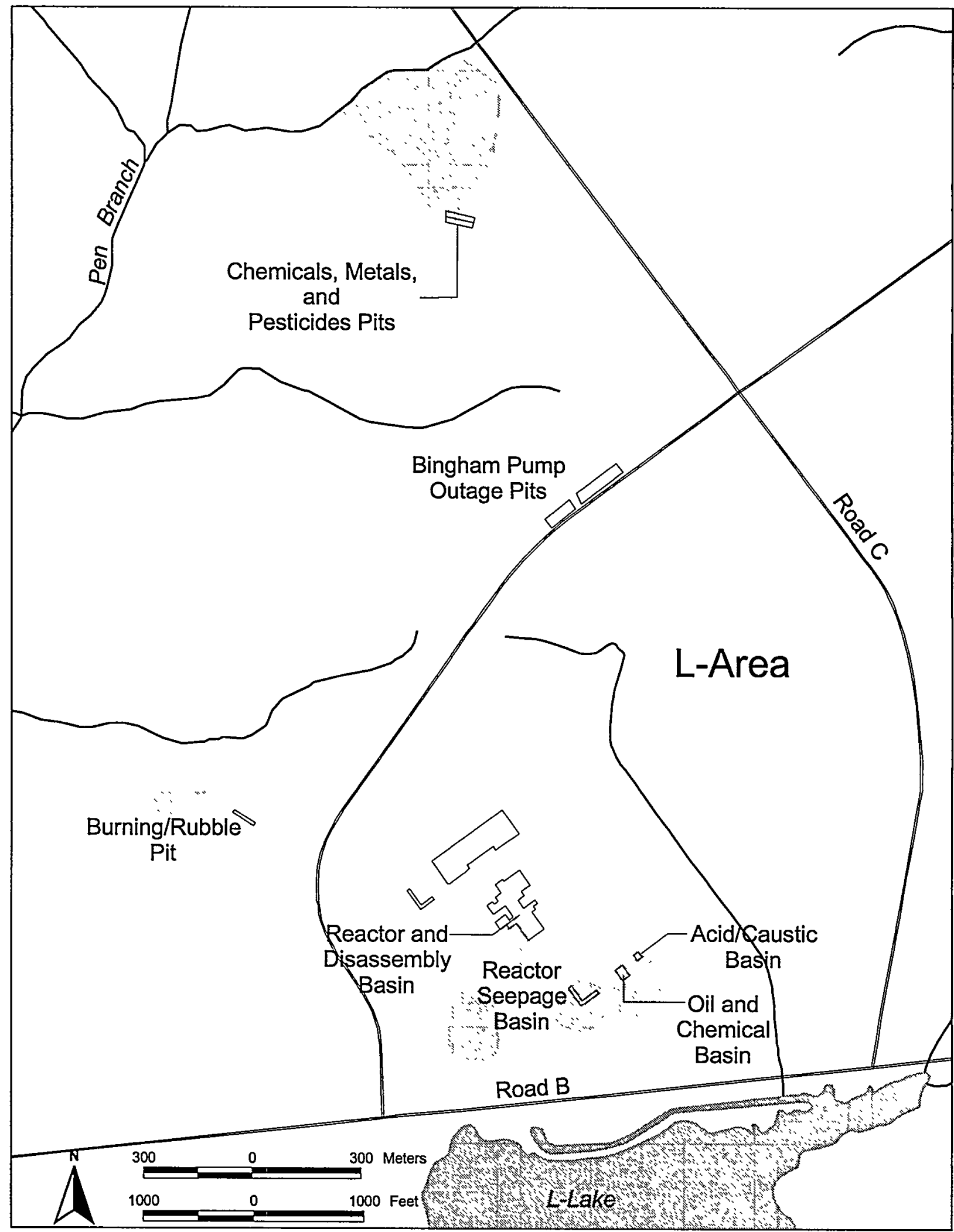

E\&GIS/ER Map

Figure 10-12 Extent of Tritium and Volatile Organic Contamination of the Groundwater Beneath L-Area and the Chemicals, Metals, and Pesticides Pits in 1999 and Location of Noteworthy Sources of Contamination Exceeding Drinking Water Standards 
Table 10-10 Constituent Groups Above Drinking Water Standards at L-Area and the Chemicals, Metals, and Pesticides Pits, 1997-1999

\begin{tabular}{lccc|ccccc}
\hline & \multicolumn{3}{l}{$\begin{array}{l}\text { Percent of Wells } \\
\text { With Results }\end{array}$} & \multicolumn{2}{l}{$\begin{array}{l}\text { Number of } \\
\text { Constituent Groups }\end{array}$} & Above Standards & Wells Sampled & Sources of Contamination \\
\hline & 1997 & 1998 & 1999 & 1997 & 1998 & 1999 & \\
\hline Dioxins/furans & - & - & - & - & - & - & \\
Metals & $9 \%$ & $23 \%$ & $9 \%$ & 22 & 13 & 11 & CMP pits, burning/rubble pit \\
Organics & $27 \%$ & $8 \%$ & $0 \%$ & 159 & 12 & 14 & None (no contamination) \\
$\begin{array}{l}\text { Pesticides/PCBs } \\
\text { Tritium }\end{array}$ & $0 \%$ & $0 \%$ & - & 7 & 6 & - & \\
& $30 \%$ & $36 \%$ & $50 \%$ & 20 & 14 & 10 & $\begin{array}{l}\text { Disassembly basin, oil and chemical ba- } \\
\text { sin, reactor seepage basin }\end{array}$ \\
Other radionuclides & $5 \%$ & $0 \%$ & $0 \%$ & 19 & 9 & 8 & None (no contamination) \\
Other constituents & $6 \%$ & $0 \%$ & $0 \%$ & 18 & 10 & 8 & None (no contamination) \\
\hline
\end{tabular}

Notes: Drinking Water Standards refer to federal final primary DWS, proposed primary DWS, and interim final primary DWS.

Dioxins/furans were not sampled at L-Area or the CMP pits during 1997, 1998, and 1999. Pesticides/PCBs were not sampled at L-Area or the CMP pits during 1999. 


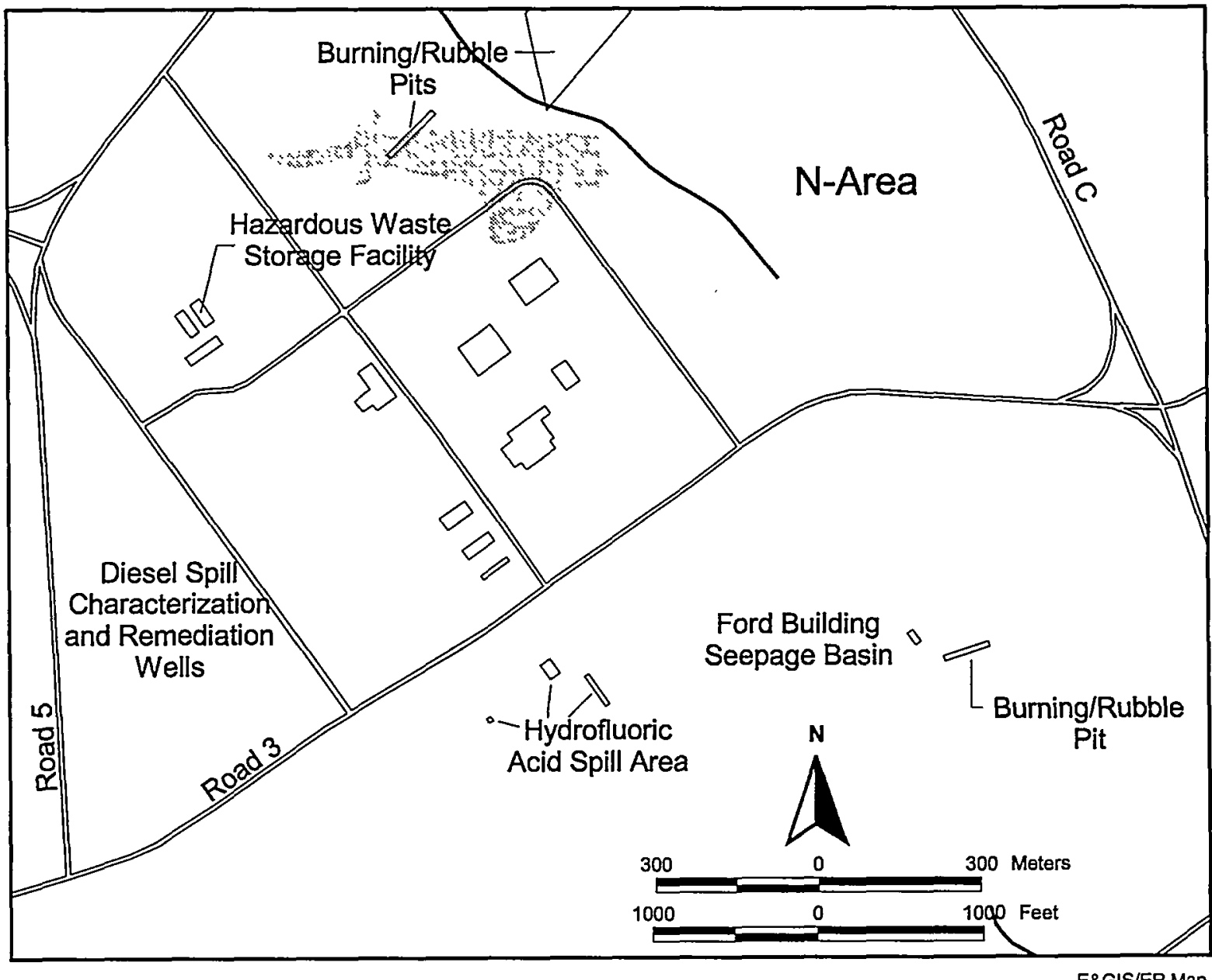

Figure 10-13 Extent of Volatile Organic Contamination of the Groundwater Beneath N-Area in 1999 and Location of Noteworthy Sources of Contamination Exceeding Drinking Water Standards

\section{Groundwater Contamination at N-Area}

\section{Location and Facilities}

$\mathrm{N}$-Area, also called the Central Shops area, is located in the central part of SRS and provides supply, maintenance, and other support services for the site.

$\mathrm{N}$-Area includes the following facilities associated with the groundwater monitoring program:

- Ford Building seepage basin

- Hazardous Waste Storage Facility

- Hydrofluoric acid spill

- $\quad \mathrm{N}$-Area burning/rubble pits

- N-Area (Central Shops) sludge lagoon

- N-Area diesel spill
- N-Area Fire Department Training Facility

Figure 10-13 shows the extent of contamination and the location of contaminants of primary concern in $\mathrm{N}$-Area. Surface drainage in $\mathrm{N}$-Area is to tributaries of Four Mile Creek to the north, west, and south and to tributaries of Pen Branch to the east. Four Mile Creek, Upper Three Runs Creek, and several other incised creeks are located between $\mathrm{N}$-Area and the SRS boundary and are areas of groundwater discharge. Figure 10-1 shows the locations of these streams.

Table 10-11 summarizes 1997-1999 groundwater monitoring results for N-Area. Monitoring well sampling in 1999 was performed outside the volatile organic plume identified in the vicinity of the burning/rubble pits from previous years' sampling; for this reason, there are no sources of contamination identified on table 10-11 for 1999. 
Table 10-11 Constituent Groups Above Drinking Water Standards at N-Area, 1997-1999

\begin{tabular}{lccc|ccccc}
\hline & $\begin{array}{l}\text { Percent of Wells } \\
\text { With Results }\end{array}$ & $\begin{array}{l}\text { Number of } \\
\text { Wells Sampled }\end{array}$ & Sources of Contamination \\
\hline & 1997 & 1998 & 1999 & 1997 & 1998 & 1999 & \\
\hline Above Standards & - & $0 \%$ & - & - & 3 & - & \\
Metals & $0 \%$ & $11 \%$ & $0 \%$ & 11 & 10 & 9 & None (no contamination) \\
Organics & $33 \%$ & $11 \%$ & $0 \%$ & 3 & 10 & 11 & None (no contamination) \\
Pesticides/PCBs & $0 \%$ & $0 \%$ & - & 1 & 10 & - & \\
Tritium & $0 \%$ & $0 \%$ & $0 \%$ & 6 & 8 & 7 & None (no contamination) \\
Other radionuclides & $0 \%$ & $14 \%$ & $0 \%$ & 3 & 8 & 7 & None (no contamination) \\
Other constituents & $0 \%$ & $0 \%$ & $0 \%$ & 3 & 10 & 10 & None (no contamination) \\
\hline
\end{tabular}

Notes: Drinking Water Standards refer to federal final primary DWS, proposed primary DWS, and interim final primary DWS.

Dioxins/furans were not sampled at N-Area during 1997 and 1999. Pesticides/PCBs were not sampled at N-Area during 1999. 


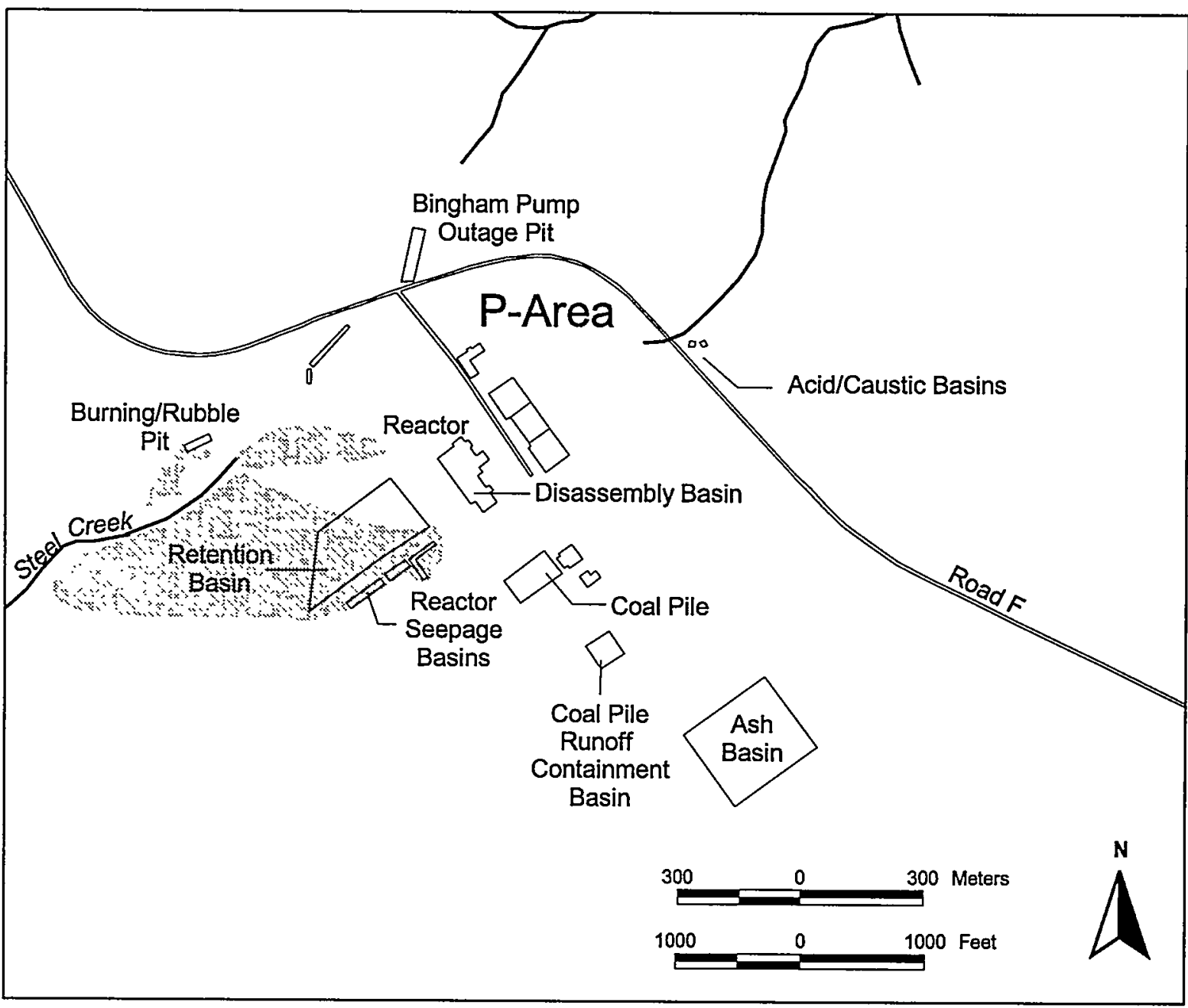

E\&GIS/ER Map

Figure 10-14 Extent of Tritium and Volatile Organic Contamination of the Groundwater Beneath P-Area in 1999 and Location of Noteworthy Sources of Contamination Exceeding Drinking Water Standards

\section{Groundwater Contamination at P-Area}

\section{Location and Facilities}

P-Area, located in the south-central part of SRS, houses the P-Area reactor, which achieved criticality in 1954, was shut down for maintenance in 1987, and has since been placed in cold shutdown.

P-Area includes the following facilities associated with the groundwater monitoring program:

- P-Area acid/caustic basins

- P-Area ash basin

- P-Area Bingham pump outage pit

- P-Area burning/rubble pit
- P-Area coal pile and coal pile runoff containment basin

- P-Area disassembly basin

- P-Area reactor

- P-Area reactor seepage basins

- P-Area retention basin

\section{Nature of Contamination}

Lower Three Runs Creek to the east, Steel Creek to the southwest, and Meyers Branch to the south and east isolate the near-surface groundwater in P-Area. Figure 10-1 shows the locations of these streams. The horizontal hydraulic gradients vary across P-Area and increase near a tributary to PAR Pond. The horizontal gradients also increase near a tributary to Steel Creek to the southeast. 
Figure 10-14 shows the extent of contamination and the location of contaminants of primary concern at P-Area. The largest plume of contaminated groundwater in P-Area historically has consisted of tritium contamination near the disassembly basin and the reactor seepage basins. Sampling also shows that lead is elevated in a few wells near the seepage basins. The available results are consistent with those of past years and are expected, based on the tritium disposal at these sites.

Sampling from this and previous years detected low levels of volatile organics, primarily trichloroethylene and/or tetrachloroethylene, in the groundwater northwest of the reactor, in the retention basin, and near the burning/rubble pits.

Table 10-12 summarizes 1997-1999 groundwater monitoring results for $\mathrm{P}$-Area.

Table 10-12 Constituent Groups Above Drinking Water Standards at P-Area, 1997-1999

\begin{tabular}{llll|lllll}
\hline & \multicolumn{3}{l}{$\begin{array}{l}\text { Percent of Wells } \\
\text { With Results }\end{array}$} & \multicolumn{2}{l}{$\begin{array}{l}\text { Number of } \\
\text { Wells Sampled }\end{array}$} & Sources of Contamination \\
\hline & 1997 & 1998 & 1999 & 1997 & 1998 & 1999 & \\
\hline Dioxins/furans & - & - & - & - & - & - & \\
Metals & $23 \%$ & $14 \%$ & $6 \%$ & 22 & 7 & 17 & $\begin{array}{l}\text { Burning/rubble pit, coal pile runoff con- } \\
\text { tainment basin, reactor seepage basins }\end{array}$ \\
Organics & $13 \%$ & $25 \%$ & $6 \%$ & 15 & 4 & 18 & Burning/rubble pit \\
Pesticides/PCBs & $0 \%$ & $0 \%$ & - & 13 & 4 & - & \\
Tritium & $67 \%$ & $0 \%$ & $64 \%$ & 15 & 7 & 14 & Reactor seepage basins \\
Other radionuclides & $10 \%$ & $7 \%$ & $25 \%$ & 20 & 14 & 12 & Reactor seepage basins \\
Other constituents & $0 \%$ & $0 \%$ & $14 \%$ & 19 & 7 & 7 & Coal pile runoff containment basin \\
\hline
\end{tabular}

Notes: Drinking Water Standards refer to federal final primary DWS, proposed primary DWS, and interim final primary DWS.

Dioxins/furans were not sampled at P-Area during 1997, 1998, and 1999. Pesticides/PCBs were not sampled at $P$-Area during 1999. Tritium was not sampled in all the P-Area wells during 1998. 


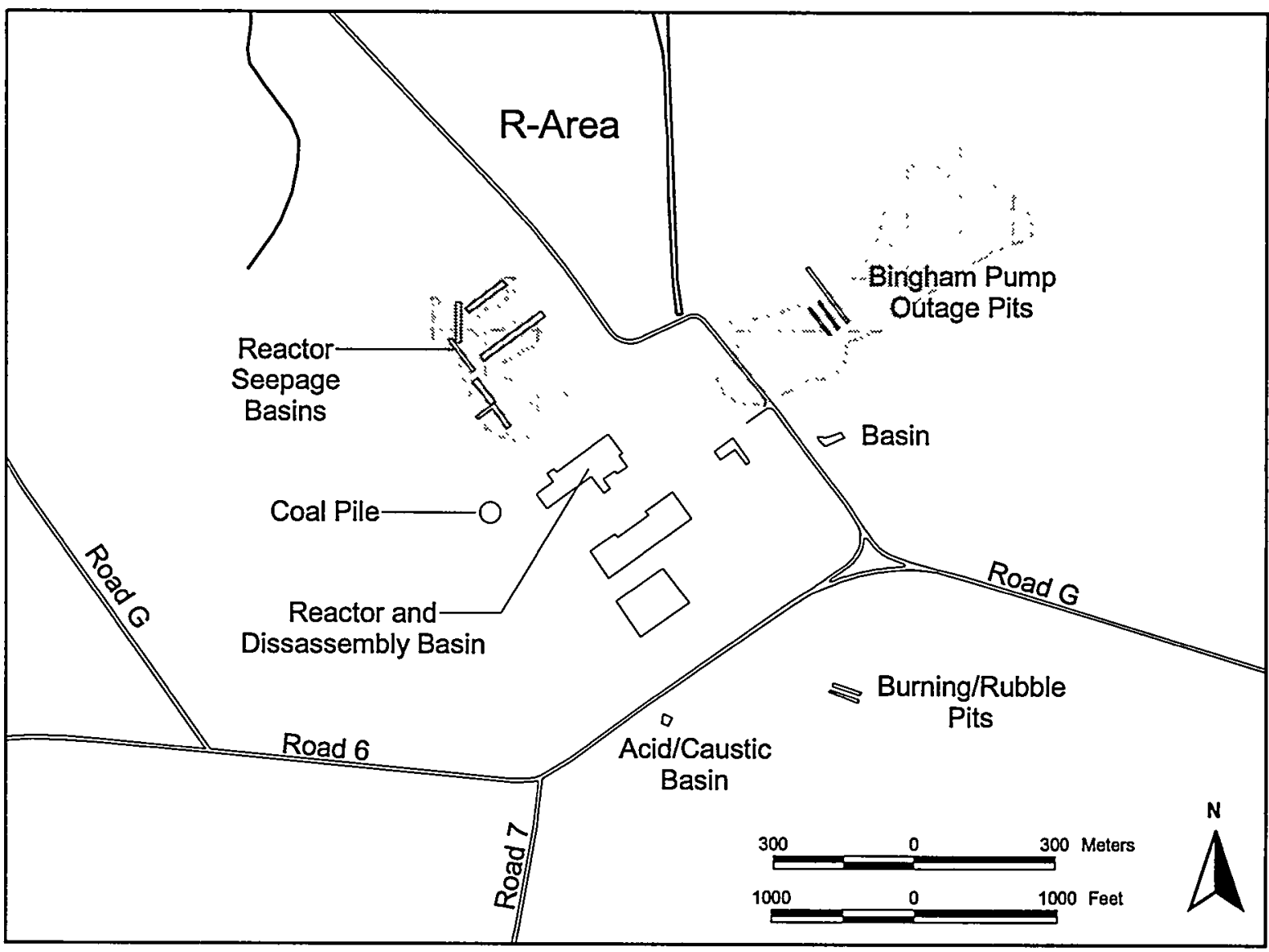

E\&GIS/ER Map

Figure 10-15 Extent of Tritium Contamination of the Groundwater Beneath R-Area in 1999 and Location of Noteworthy Sources of Contamination Exceeding Drinking Water Standards

\section{Groundwater Contamination at R-Area}

\section{Location and Facilities}

R-Area, located in the east-central part of SRS, houses the R-Reactor, which achieved criticality in 1953 and was shut down permanently in 1964.

$\mathrm{R}$-Area includes the following facilities associated with the groundwater monitoring program:

- R-Area acid/caustic basin

- R-Area Bingham pump outage pit

- R-Area burning/rubble pits

- R-Area coal pile

- R-Area disassembly basin

- R-Area reactor

- R-Area reactor seepage basins

\section{Nature of Contamination}

Surface drainage in R-Area is to the northwest and northeast toward Mill Creek and Pond A and to the southeast and southwest toward tributaries of Pond 2 and Pond 4. Figure 10-1 shows the locations of these streams.

Incised tributaries and streams and PAR Pond separate near-surface groundwater at R-Area from the site boundary to the east. R-Area is near a groundwater divide between Mill Creek and PAR Pond. The groundwater just north of R-Area naturally discharges to Mill Creek to the northwest and to the R-Area Canal of Pond A to the northeast. The groundwater from the southern part of R-Area naturally discharges to a tributary of Pond 4 south of R-Area.

Figure 10-15 shows the extent of contamination and the location of contaminants of primary concern at $\mathrm{R}$-Area. Analyses indicate that there is a plume of volatile organics in the vicinity of the Bingham pump outage pits. Sampling also shows that elevated levels 
of metals are present in a substantial percentage of the wells sampled in the area around the reactor seepage basins.

On November 8, 1957, an experimental fuel element failed during a calorimeter test in the emergency section of the R-Area disassembly basin. Following this incident, the original seepage basin received approximately $2,700 \mathrm{Ci}$ of gross beta activity, including strontium- 90 and cesium-137, each of which has a half-life of about 30 years. Much of the released radioactivity was contained in that basin, which was backfilled in December 1957. Five more basins were placed in operation in 1957 and 1958 to assist in containing the radioactivity.

Table 10-13 summarizes 1997-1999 groundwater monitoring results for $\mathrm{R}$-Area.

Table 10-13 Constituent Groups Above Drinking Water Standards at R-Area, 1997-1999

\begin{tabular}{lccc|cccl}
\hline & \multicolumn{3}{l}{$\begin{array}{l}\text { Percent of Wells } \\
\text { With Results }\end{array}$} & \multicolumn{2}{l}{$\begin{array}{l}\text { Number of } \\
\text { Wells Sampled }\end{array}$} & Sources of Contamination \\
\hline & 1997 & 1998 & 1999 & 1997 & 1998 & 1999 & \\
\hline Above Standards & - & - & - & - & - & - & \\
Metals & $30 \%$ & $0 \%$ & $31 \%$ & 27 & 7 & 13 & Reactor seepage basins \\
Organics & $0 \%$ & $0 \%$ & $6 \%$ & 3 & 7 & 16 & Bingham pump outage pits \\
Pesticides/PCBs & $0 \%$ & $0 \%$ & - & 3 & 4 & - & \\
Tritium & $0 \%$ & $0 \%$ & $0 \%$ & 12 & 8 & 7 & None (no contamination) \\
Other radionuclides & $25 \%$ & $14 \%$ & $0 \%$ & 24 & 35 & 13 & None (no contamination) \\
Other constituents & $0 \%$ & $0 \%$ & $0 \%$ & 18 & 7 & 10 & None (no contamination) \\
\hline
\end{tabular}

Notes: Drinking Water Standards refer to federal final primary DWS, proposed primary DWS, and interim final primary DWS.

Dioxins/furans were not sampled at R-Area during 1996, 1997, and 1998. 


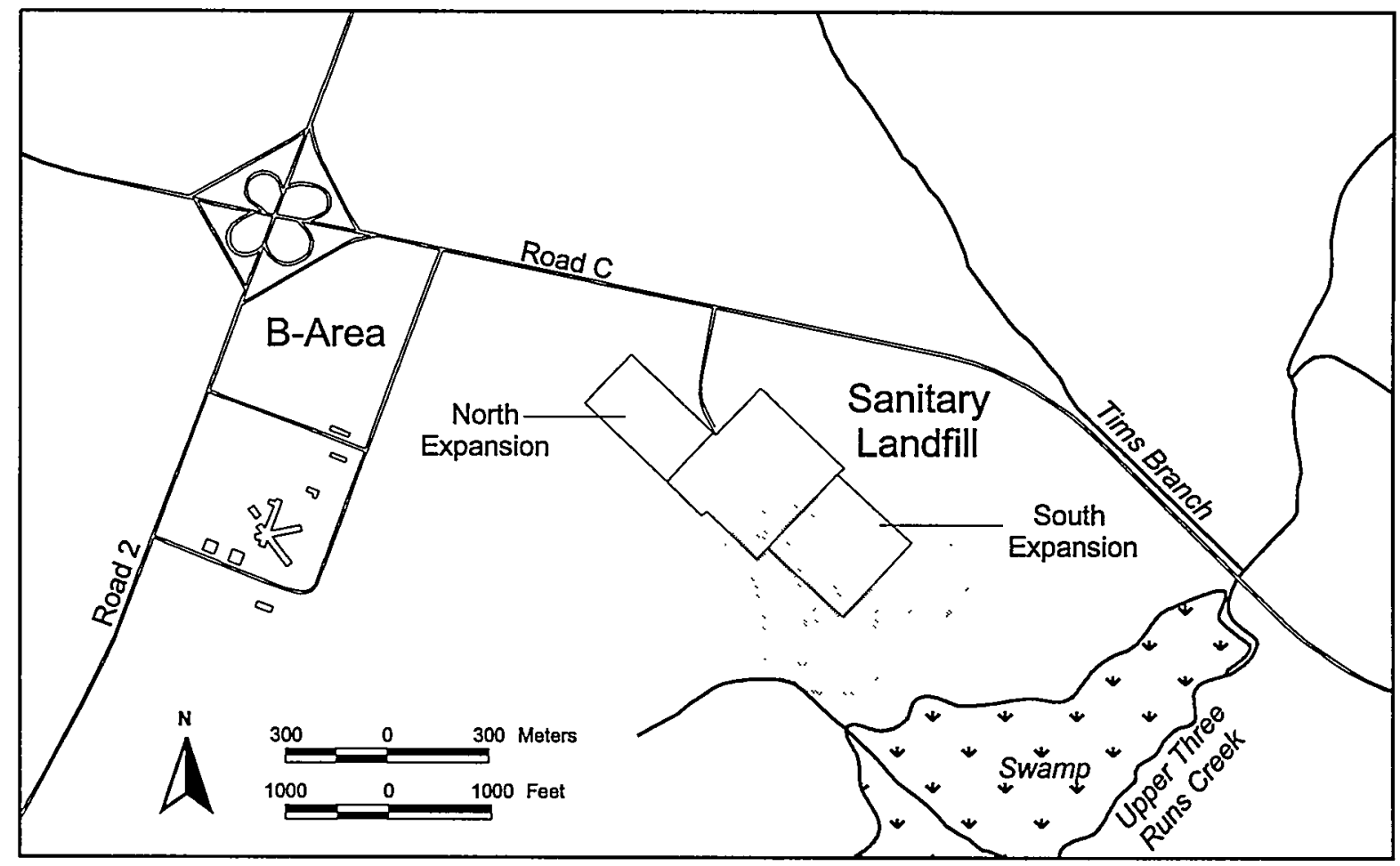

E\&GIS/ER Map

Figure 10-16 Extent of Volatile Organic Contamination of the Groundwater Beneath the Sanitary Landfill and B-Area in 1999 and Location of Noteworthy Sources of Contamination Exceeding Drinking Water Standards

\section{Groundwater Contamination at the Sanitary Landfill and B-Area}

\section{Location and Facilities}

The Sanitary Landfill is south of Road C, about midway down the slope from the Aiken Plateau to Upper Three Runs Creek. The landfill began receiving waste from office, cafeteria, and industrial activities during 1974. Materials such as paper, plastics, rubber, wood, cardboard, rags, metal debris, pesticide bags, empty cans, carcasses, asbestos in bags, and sludge from SRS's wastewater treatment plant were placed in unlined trenches and covered daily with soil or a fabric substitute. The original section of the landfill and its southern expansion, with a total area of approximately 54 acres, have been filled. The portion of approximately 16 acres known as the northern expansion, or the interim sanitary landfill, ceased operations in November 1994.

\section{Nature of Contamination}

Surface drainage at the Sanitary Landfill is to the south-southeast, toward Upper Three Runs Creek. Horizontal groundwater flow is to the southeast, toward Upper Three Runs Creek.
Sanitary landfills are intended to receive only nonradioactive, nonhazardous waste. However, until October 1992, some hazardous wastes (specifically, solvent-laden rags and wipes used for cleaning, decontamination, and instrument calibration) were buried in portions of the original 32-acre landfill and its southern expansion.

Figure 10-16 shows the extent of contamination and the location of contaminants of primary concern at the Sanitary Landfill and near B-Area. There is a substantial plume of contaminated groundwater under and downgradient of the Sanitary Landfill. Volatile organic compounds (primarily trichloroethylene and vinyl chloride) are the most widespread contaminants, but metals, tritium, and other radionuclides also are present.

Tritium was detected in three wells above DWS near the Sanitary Landfill in 1999. Gross alpha, a screening level analysis, was not found in excess of DWS during the first two quarters; however, levels slightly above DWS were detected in three wells near the landfill during third quarter. Fourth-quarter analyses detected similar levels for two of the wells.

Table 10-14 summarizes 1997-1999 groundwater monitoring results for the landfill and B-Area. 
Table 10-14 Constituent Groups Above Drinking Water Standards at the Sanitary Landfill and B-Area, 1997-1999

\begin{tabular}{|c|c|c|c|c|c|c|c|}
\hline \multirow[t]{2}{*}{ Constituent Groups } & \multicolumn{3}{|c|}{$\begin{array}{l}\text { Percent of Wells } \\
\text { With Results } \\
\text { Above Standards }\end{array}$} & \multicolumn{3}{|c|}{$\begin{array}{l}\text { Number of } \\
\text { Wells Sampled }\end{array}$} & \multirow[t]{2}{*}{ Sources of Contamination } \\
\hline & 1997 & 1998 & 1999 & 1997 & 1998 & 1999 & \\
\hline Dioxins/furans & - & - & 一 & - & - & - & \\
\hline Metals & $13 \%$ & $6 \%$ & $4 \%$ & 48 & 50 & 50 & Sanitary Landfill \\
\hline Organics & $37 \%$ & $30 \%$ & $35 \%$ & 51 & 50 & 49 & Sanitary Landfill \\
\hline Pesticides/PCBs & $0 \%$ & $0 \%$ & $0 \%$ & 8 & 15 & 9 & None (no contamination) \\
\hline Tritium & $4 \%$ & $4 \%$ & $8 \%$ & 49 & 50 & 49 & Sanitary Landfill \\
\hline Other radionuclides & $2 \%$ & $3 \%$ & $8 \%$ & 42 & 38 & 38 & Sanitary Landfill \\
\hline Other constituents & $0 \%$ & $0 \%$ & $0 \%$ & 4 & 8 & 10 & None (no contamination) \\
\hline
\end{tabular}

Notes: Drinking Water Standards refer to federal final primary DWS, proposed primary DWS, and interim final primary DWS.

Dioxins/furans were not sampled in the Sanitary Landfill or B-Area during 1997, 1998, and 1999. 


\section{Chapter 11 \\ Quality Assurance}

\author{
Bob Henderson, Moheb Khalil, \\ Walt Kubilius, and Stuart Stinson \\ Environmental Protection Department
}

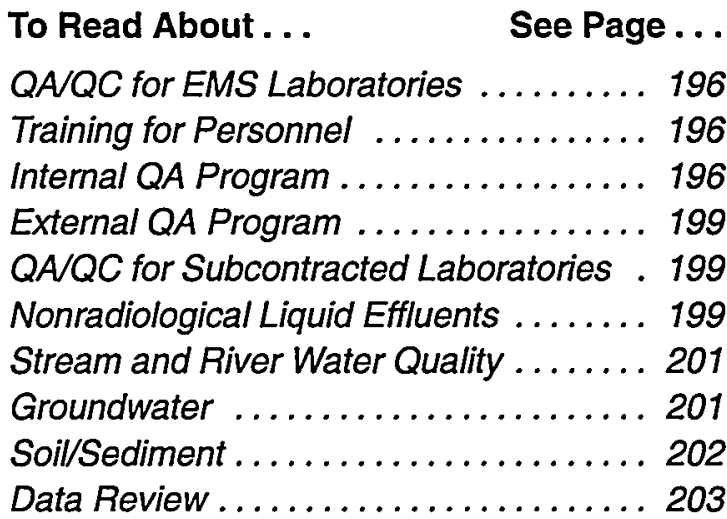

\section{Highlights}

- When DOE Order 414.1, "Quality Assurance," superseded DOE Order 5700.6C, WSRC issued its Quality Assurance Management Plan (WSRC-RP-92-225, Revision 8, August 1999) to comply with DOE requirements.

- In the blind sample program routinely conducted by EMS to assess the quality and reliability of $\mathrm{pH}$ field data, $\mathrm{pH}$ measurements were taken on 24 samples. All field pH measurements were well within EPA's suggested acceptable control limit.

- Twelve blind samples were analyzed for tritium by the EMS laboratory. EMS performance demonstrated a high level of accuracy. All tritium data were within the control limits and were within 15 percent of the true value. The results of these blind samples were used to validate analytical work in the chemistry and counting laboratory.

- EMS received its first-ever onsite certification for 26 metal analytes under the CWA program and 27 metal analytes under the RCRA program.

- The EMS laboratory achieved an acceptability ratio of 97 percent during the first DOE QAP intercomparison study of the year. Of the 39 isotopes analyzed by EMS, the results of 38 were within the acceptable range. The laboratory achieved an acceptability ratio of 98 percent during the second DOE QAP intercomparison study of the year. Of the 40 isotopes analyzed by EMS, the results of 39 were within the acceptable range. The results of the two studies reflects the accuracy and precision of the data produced by EMS. All laboratories that provide environmental measurements for DOE sites are required to participate in the QAP studies twice a year.

$\mathrm{T}$ HE Environmental Monitoring Section (EMS) of the Savannah River Site's (SRS) Environmental Protection Department (EPD) maintains a quality assurance (QA) program to continuously verify the integrity of data generated by its own environmental monitoring program and by its subcontracted laboratories.

Various definitions have been suggested for QA and quality control (QC). Frequently, the terms are used interchangeably. In the EMS program, QA consists of the system whereby the laboratory can assure clients and other outside entities, such as government agencies and accrediting bodies, that the laboratory is generating data of proven and known quality. QC refers to those operations undertaken in the laboratory to ensure that the data produced are generated within known probability limits of accuracy and precision.

Although QC represents the core activity in a QA program, the latter encompasses much more than the technical operations of controlling quality. Another QA component is quality assessment, which refers to the evaluation activities that provide assurance that the $\mathrm{QC}$ job is being done effectively.

Each aspect of the environmental monitoring program, from sample collection to data reporting, must address QC and quality assessment standards defined in the Savannah River Site Environmental Monitoring Program Quality Assurance Plan (WSRC-3Q1-2, Volume 3, Section 8000).

This chapter summarizes the QA program. Tables containing the 1999 QA/QC data can be found in $S R S$ Environmental Data for 1999 ,

WSRC-TR-99-00301. A more complete description of the EMS QA program can be found in section 1110 of the Savannah River Site Environmental Monitoring Section Plans and Procedures, WSRC-3Q1-2, Volume 1 (SRS EM Program).

Guidelines and applicable standards for the QA environmental monitoring program are referenced in 
appendix A, "Applicable Guidelines, Standards, and Regulations," of this document. Detailed information about federal, state, and local QA regulations and standards can be found in the SRS EM Program. Figure 11-1 illustrates the hierarchy of relevant guidance documents that support the EMS QA/QC program.

\section{QA/QC for Environmental Monitoring Section Laboratories}

General objectives of the QA/QC program include validity, traceability, and reproducibility of reported results; comparability of results within databases; representativeness of each sample to the population or condition being measured; and accuracy and precision.

\section{Training for Personnel}

EMS personnel are responsible for understanding and complying with all requirements applicable to the activities with which they are involved.

Consequently, appropriate training courses are provided to assist them in fulfilling their responsibilities. Courses include training on applicable QA procedures, Occupational Safety and Health Administration-mandated training, and General Employee Training. Regulations and procedures that govern the environmental monitoring program are emphasized.

EMS analysts begin with specific training determined by job assignment. The section's technical work is based on procedures in the WSRC-3Q1 series of manuals:

- "Environmental Sampling Procedures," WSRC-3Q1-3

- "Environmental Radiochemistry Procedures," WSRC-3Q1-4

- "Environmental Water Quality Procedures," WSRC-3Q1-5

- "Environmental Counting Room Procedures," WSRC $-3 Q 1-6$

- "Environmental Data Management and Computer Support Procedures," WSRC-3Q1-10

\section{Program Changes}

The U.S. Environmental Protection Agency (EPA) discontinued the voluntary external radiological quality assurance program that had been administered by the Quality Assurance Division (QAD) of Environmental Monitoring System Laboratory. A description of the external quality assurance program in which EMS did participate begins on page 199.

The water pollution (WP) and water supply (WS) studies formerly administered by EPA were conducted in 1999 by Environmental Resource Associates (ERA) of Arvada, Colorado. A discussion of these studies begins on page 202.

\section{Internal Quality Assurance Program}

Specific QA checks and accepted practices are conducted by each EMS group, as described in the following paragraphs.

\section{Field Sampling Group}

Blind Sample Program EMS routinely conducts a blind sample program for field measurements of $\mathrm{pH}$ to assess the quality and reliability of field data measurements. Measurements of $\mathrm{pH}$ are taken in the field using the same equipment as is used for routine measurements.

During 1999, blind $\mathrm{pH}$ field measurements were taken for 24 samples (table 60, SRS Environmental Data for 1999). All field $\mathrm{pH}$ measurements were within the U.S. Environmental Protection Agency's (EPA) suggested acceptable control limit of $\pm 0.4 \mathrm{pH}$ units of the true (known) value.

Instrumentation Calibration EMS personnel also measure chlorine, dissolved oxygen, and temperature in water samples; but because of the difficulties in providing field standards, these measurements are not suitable for a blind sample program. Therefore, quality control of these analyses relies instead on instrumentation calibration, per the WSRC-3Q1 procedure series.

\section{Chemistry and Counting Laboratories}

Laboratory performance is evaluated through instrument checks, control charts, and data analyses. In the Environmental Chemistry and Analysis group, graphical control checks and numerical trending is conducted on technician and method performance, with reports generated for sample results that exceed warning limits. The counting laboratory runs source checks and instrument backgrounds and performs calibrations regularly to monitor and characterize instrumentation.

Routine samples prepared and counted in EMS laboratories are subject to a variety of $\mathrm{QC}$ checks to assess and ensure validity. These checks make up 30 percent of the analytical workload. The Environmental Chemistry and Analysis group prepares spikes, blanks, duplicates, and blind samples to check the performance of routine analyses. Spikes 


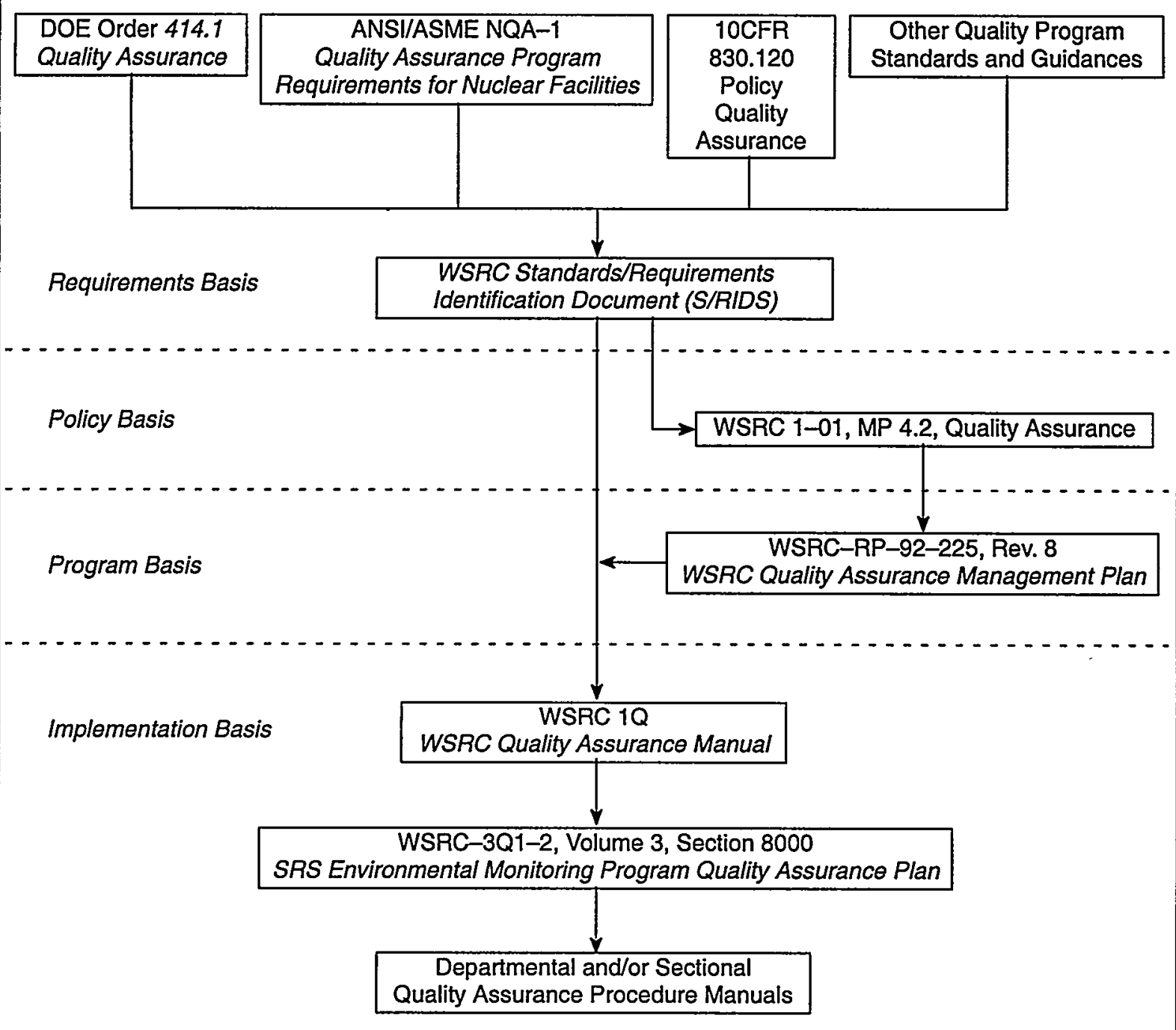

\section{Other Quality Program Standards and Guidances}

- International Organization for Standardization (ISO) 9000 Series of Standards, including ISO 14001, Environmental Management System

- Specifications and Guidelines for Environmental Data Collection and Environmental Technology Programs (ANSI/ASQC E-4)

- General Requirements for the Competence of Calibration and Testing Laboratories (ISO/IEC Guide 25-1990)

\section{Figure 11-1 SRS EM Program QAVQC Document Hierarchy}

This diagram depicts the hierarchy of relevant guidance and supporting documents for the QAQC program. 


\section{Statistical Terms}

coefficient of variation measure of precision calculated as the standard deviation divided by the average of a set of values; usually multiplied by 100 to be expressed as a percentage

mean measurement of central tendency, commonly called the average

mean relative difference measure of reproducibility of identical chemical analyses

median middle value of a set of data when the data are ranked in increasing or decreasing order percent difference measure of accuracy used to compare "known" values with laboratory measurements; represents the absolute difference between the known and measured value divided by the known value; usually multiplied by 100 to be expressed as a percentage

standard deviation indication of the dispersion of a set of results around the average of samples collected and blanks are used to calculate a recovery efficiency of an analytical method, to adjust for background radiation, and to evaluate counting equipment performance.

Blind Tritium Samples Blind tritium samples provide a continuous assessment of laboratory sample preparation and counting. The tritium activity is unknown to the technicians preparing the samples or the counting laboratory personnel. The blind samples are prepared from National Institute of Standards and Technology (NIST)-traceable material or standardized against NIST material. The results are added to control charts to identify trends. During 1999, 12 blind samples were analyzed for tritium (table 61, SRS Environmental Data for 1999). All tritium data were within the control limits. The results of these blind samples were used to validate analytical work in the chemistry and counting laboratories.
Laboratory Certification The EMS laboratory is certified by the South Carolina Department of Health and Environmental Control (SCDHEC) for the following analytes:

- under the Clean Water Act (CWA), alkalinity, chemical oxygen demand, total suspended solids, specific conductance, nitrate-nitrogen, orthophosphate phosphorus, chloride, sulfate, total dissolved solids, and field $\mathrm{pH}$

- under the Resource Conservation and Recovery Act (RCRA), 50 volatile organic compounds (VOCs)

During 1999, EMS received its first-ever onsite certification for 26 metal analytes under the CWA program and 27 metal analytes under the RCRA program.

\section{Data Verification and Validation}

Results received from the counting laboratory are electronically evaluated by the Environmental

\section{QA Terminology in the Laboratory}

accuracy degree of agreement between a measurement and an accepted reference or true value

bias systematic (constant) underestimation or overestimation of the true value

spiked sample sample to which a known amount of a substance has been added

precision measure of mutual agreement among individual measurements of the same property

duplicate sample repeated but independent determinations on the same sample split sample portions taken from the same sample and analyzed by different technicians or laboratories

blind sample (blind duplicate or blind blank) mock sample of known constituent(s) or concentration(s); used as a control

blanks clean samples analyzed to establish a baseline or background value used to adjust or correct results

control chart graphical chart of some measured parameter for a series of samples 
Monitoring Computer Automation Program (EMCAP). Sample parameters--such as air flows, counting aliquots, and decay times-are flagged if values exceed preset limits or vary significantly from previous entries. An acceptance range for each analysis, based on historical results, is calculated for all routine environmental samples. Sample results outside the acceptance range are submitted for individual review, which may result in repeating the analyses, recounting, recalculating, or resampling for verification.

Before data are reported, they must be reviewed and validated by qualified personnel. Electronic verification is performed on 100 percent of the data stored in EMS databases. Through this verification, data anomalies are removed or data are rejected if there is disagreement with EMS QA/QC policies. The validation methods and criteria are documented in section 21-1 of WSRC-1Q and in "Environmental Geology Procedures," WSRC-3Q1-7. Quality control requirements for managing, evaluating, and publishing environmental monitoring data are defined in WSRC-3Q1-2, section 8250.

\section{External Quality Assurance Program}

In 1999, the EMS laboratory participated in the DOE Quality Assurance Program (QAP), an interlaboratory comparison program that tracks performance accuracy and tests the quality of environmental data reported to DOE by its contractors.

Under this program, the DOE/EML (Environmental Measurements Laboratory) sends samples to participating laboratories twice a year and compares the laboratories' results to program values. These comparisons verify the accuracy of EMS radiochemical analytical results. The $\mathrm{QC}$ chemist maintains control charts to monitor trends and bias for each matrix (e.g., water, air filter, vegetation, soil) and analysis for various nuclides.

Reference samples for the QAP program-including soil/sediment, water, vegetation, and air filter samples-are prepared by DOE/EML and sent to the participating laboratories. Analytical results are reported to DOE/EML and are compared with the test results of other laboratories. DOE/EML evaluates the results and distributes a report to the participating laboratories. Results are rated as acceptable (A), acceptable with warning $(W)$, and not acceptable (N). Control charts are maintained according to DOE/EML control limits. The following EMS analytical methods and instruments are tested in these studies:
- gamma emitters by gamma spectroscopy

- actinides by alpha spectroscopy

- strontium and gross alpha/beta by gas-flow proportional counters

- tritium by liquid scintillation

Work was completed in June on the 50th set of QAP samples from a DOE/EML radiological

intercomparison study. EMS analyzed 11 isotopes in air, 10 in soil, seven in vegetation, and 11 in water for a total of 39 results. Thirty-three of the results were rated " $A$," five were rated " $W$," and one was rated "N." A performance rating of 97 percent acceptable was achieved for this study.

In QAP set 51, which was completed in December, EMS analyzed 13 isotopes in air, 10 in soil, seven in vegetation, and 112 in water for a total of 41 results. Thirty-six of the results were rated " $A$," four were rated "W," and one was rated "N." A performance rating of 98 percent acceptable was achieved for this study. (EMS QA personnel consider 80 percent to be a minimum acceptance rate in this program.)

The QAP results for the two sets can be found in table 62, SRS Environmental Data for 1999. The table includes the DOE/EML control limits for nonacceptable results.

\section{QA/QC for Subcontracted Laboratories}

Subcontracted laboratories providing analytical services must have a documented QA/QC program and meet the quality requirements defined in WSRC-1Q. The subcontracted laboratories used during 1999 and the types of analyses performed are listed in table 11-1.

EMS personnel perform an annual evaluation of each subcontracted laboratory to ensure that the laboratories maintain technical competence and follow the required QA programs. Each evaluation includes an examination of laboratory performance with regard to sample receipt, instrument calibration, analytical procedures, data verification, data reports, records management, nonconformance and corrective actions, and preventive maintenance. EMS provides reports of the findings and recommendations to each laboratory and conducts followup evaluations as necessary.

\section{Nonradiological Liquid Effluents}

Nonradiological liquid effluent samples are collected at each permitted SRS outfall according to requirements in the National Pollutant Discharge 
Table 11-1

Subcontracted Laboratories for 1999

General Engineering Laboratories (Charleston, S.C.)

groundwater nonradiological analyses soil/sediment

waste characterization

Recra LabNet Philadelphia (Philadelphia, Pa.)

groundwater nonradiological analyses soil/sediment

waste characterization

ThermoNUtech

(Oak Ridge, Tenn.)

groundwater radiological analyses

soil/sediment radiological analyses

waste characterization radiological analyses

EMAX Laboratories, Inc.

(Torrence, Calif.)

groundwater nonradiological analyses

\author{
Microseeps \\ (Pittsburgh, Pa.) \\ soil gas \\ site evaluation
}

\section{Shealy Environmental Services}

(Cayce, S.C.)

NPDES analyses

metals analyses for SRS streams

and the Savannah River

domestic water analysis

Elimination System (NPDES) permit issued by SCDHEC (discussed in appendix A, page 213). Effluent samples are analyzed by three laboratories - two onsite laboratories and one subcontract laboratory. Laboratories must be certified by SCDHEC for all analyses. The EMS laboratory performs analyses for temperature, $\mathrm{pH}$, dissolved oxygen, most total suspended solids, and total residual chlorine. The WSRC Site Utilities Division (SUD) Wastewater Laboratory performs analyses for $\mathrm{pH}$, dissolved oxygen, biological oxygen demand, and total suspended solids on sanitary facility wastewater samples. Shealy Environmental Services was the primary subcontractor for the NPDES program throughout 1999.

\section{Interlaboratory Comparison Program}

Interlaboratory comparison studies are used to compare the quality of results between laboratories performing the same analyses. All subcontracted laboratories analyzing NPDES samples must participate in the EPA Discharge Monitoring Report Laboratory Performance Evaluation program. Under this program, EPA sends to participating laboratories performance samples containing constituents normally found in industrial and municipal wastewaters.

These water samples have known chemical parameters, such as chemical oxygen demand, and contain known concentrations of constituents, such as total suspended solids, oil and grease, and certain trace metals. EPA provides a final comprehensive report to the program participants. The report contains a statistical analysis of all data, as well as documentation of the known sample value, with stated acceptance limits and warning limits. Accepted variations from the known sample value depend on a variety of factors, including the precision of the analysis and the extent to which the results can be reproduced.

In 1999, the EPA canceled the chemistry portion of the annual two-part Discharge Monitoring Report Quality Assurance (DMRQA) Study 19. The cancellation was due to EPA delays in providing a list of accredited chemistry standard providers to participating laboratories. Shealy Environmental Services completed the toxicity portion of Study 19, with all parameters falling within acceptable limits.

NPDES Discharge Monitoring Report protocols require SRS to assign a "0" value to all nondetect values for reporting purposes. To facilitate data evaluation and provide consistency, SRS assigns a value of "0" to all QAJQC nondetect analysis results.

The EMS laboratory, as part of a QA/QC program begun in 1998, sent two sets of blind standards to Shealy in 1999. (The QA/QC control standards and acceptance limits were provided by ERA.) The first set of blind standard data was invalidated because of problems with labeling and preservation of the standards. When the second set of standards was sent, a duplicate set of standards was also sent to General Engineering Laboratories (GEL) for comparative purposes. Shealy correctly reported results for 18 of 22 parameters, and GEL correctly reported results for 21 of 22 parameters (table 63, SRS Environmental Data for 1999). Shealy was outside limits for ammonia, nitrate plus nitrite, chemical oxygen demand, and mercury. GEL was outside limits for mercury. In response to the parameters found outside 
limits, Shealy performed additional blind standard analyses for all four parameters. All rerun results were within acceptable limits. Literature from the standards provider states that "preservative treatment is rendered ineffective once the concentrates are opened and diluted." Since the standards were prepared in the EMS laboratory and sent to Shealy as normal samples, it is suspected that the lag time between receipt of the samples and analysis at the subcontract laboratory is responsible for the out-of-limits parameters. Subsequent blind samples, prepared at the subcontract laboratory and analyzed immediately, did not experience any problems. This problem was experienced with 1998 blind samples as well.

\section{Intralaboratory Comparison Program}

The intralaboratory program compares performance within a laboratory by analyzing duplicate and blind samples throughout the year. Shealy and the EMS laboratory analyzed 148 duplicate samples during 1999 (table 64, SRS Environmental Data for 1999). Shealy analyzed 116 duplicate samples from various parameters, and the EMS laboratory analyzed 32 duplicate samples for total suspended solids. Percent difference calculations showed that four of the 116 samples analyzed by Shealy were outside the EMS internal QA/QC requirement of 20 percent. Two of the exceptions were at or near the analytical detection limit, which produces large percent variations for small differences in actual data. For these analyses, the actual difference in results between duplicates was small and not significant. Two exceedances-for aluminum and zinc-appeared to be related to analytical error at the subcontract laboratory, sample contamination, or improper sampling techniques. The EMS laboratory was within the 20-percent acceptance range on 27 of 32 samples. All five exceptions were near the detection limit of the analysis, and the actual differences were small and not significant.

Seventy-one blind samples were submitted to the Shealy and EMS laboratories, with 122 analyses performed -91 by Shealy and 31 by EMS (table 65 , SRS Environmental Data for 1999). Percent difference calculations showed that seven total suspended solids analyses, all performed by the EMS laboratory, were outside the acceptance range of 20 percent. All seven of the total suspended solids analyses were very close to the detection limits for the analysis, and the differences between results were not significant. Of the 91 analyses that Shealy conducted, 82 were within the 20-percent acceptance range. Of the nine analyses outside the acceptance range, eight were the result of data at or near the analytical detection limit. The remaining exception-for ammonia - appeared to be related to analytical error at the subcontract laboratory, sample contamination, or improper sampling technique.

Results for the duplicate and blind sampling programs were considered to be excellent, with no indications of consistent problems in the laboratories.

\section{Stream and River Water Quality}

The water quality program requires quality checks of 10 percent of the samples to verify the analytical results. Analyses are required to be performed by a certified laboratory. Duplicate grab samples from SRS streams and the Savannah River were submitted to Shealy Environmental Services and analyzed for metals, total organic carbon, phosphorus, herbicides, and pesticides. A total of 508 analyses were performed. (table 66, SRS Environmental Data for 1999).

A percent relative difference calculation was performed on each data pair and compared to the acceptance limit of 20 percent. Fifty-one samples were outside the acceptance limit. For all of these results, the actual differences were small and the parameter concentrations low. Forty-three of the 51 analyses were at or near the detection limit, where small variations in results can yield large variations in percent difference calculations. The remaining eight analyses-five for iron, one for zinc and two for phosphorus-were above the detection limit but still low. The errors are attributed to two primary factors:

- The analytical method introduces fluctuations at low levels.

- The grab sample method of obtaining samples does not provide a reliably homogenous sample for comparative studies.

Shealy, in response to concerns about phosphorus analyses, agreed to run an ERA standard with each batch of samples and perform an investigation to identify potential problems with the analysis. No problems were identified with the analyses, and the ERA standards were consistently within acceptance limits. If problems had been identified, the samples would have been rerun. The errors in 1999 were consistent with those found in 1998 (discussed in the SRS Environmental Report for 1998,

WSRC-TR-98-00312), which have been attributed to the same causes.

\section{Groundwater}

Groundwater analyses at SRS are performed by subcontracted laboratories. During 1999, EMAX Laboratories, Inc., General Engineering Laboratories, 
and Recra LabNet Philadelphia were the primary subcontractors for nonradiological analyses. Environmental Physics, Inc., and Thermo NUtech were the primary subcontractors for radiological analyses. In addition, the General Engineering Mobile Laboratory performed onsite analyses of volatile and semivolatile organics and metals.

\section{Internal QA}

During 1999, approximately 5 percent of the samples collected (radiological and nonradiological) for the Resource Conservation and Recovery Act (RCRA) and the Comprehensive Environmental Response, Compensation, and Liability Act (CERCLA) programs were submitted to the primary laboratory for analysis as blind duplicates and to a different laboratory as a QA check. The laboratories' results were evaluated on the basis of the percentage within an acceptable concentration range.

A statistical measure, the mean relative difference (MRD), is calculated to assess result reproducibility and laboratory performance. The laboratories also analyze approximately 10 percent of samples as intralaboratory QA checks. Interlaboratory comparisons were conducted between the following:

- EMAX/Recra LabNet

- Environmental Physics/Thermo NUtech

- General Engineering/Recra LabNet

- EMAX/General Engineering Mobile Laboratory

Analytes outside or near acceptance limits do not appear to be systematic or to exhibit any identifiable trends. Full results for all QA/QC evaluations, including MRD calculations where appropriate, may be found in the following groundwater reports:

- The Savannah River Site's Groundwater Monitoring Program, First Quarter 1999 (ESH-EMS-99-0520)

- The Savannah River Site's Groundwater Monitoring Program, Second Quarter 1999 (ESH-EMS-99-0521)

- The Savannah River Site's Groundwater Monitoring Program, Third Quarter 1999 (ESH-EMS-99-0522)

- The Savannah River Site's Groundwater Monitoring Program, Fourth Quarter 1999 (ESH-EMS-99-0523)

\section{External QA (Environmental Resource Associates Standards)}

Water Pollution and Water Supply Studies EMS subcontract laboratories participate in the InterlaB
WatR ${ }^{\text {TM }}$ Supply Water Pollution (WP) and Water Supply (WS) Performance Evaluation Programs administered by ERA. ERA's format for the WP statistical summary is based on EPA's National Standards for Water Proficiency Testing Studies Criteria Document, December 1998. Its format for the WS statistical summary is based on the Safe Drinking Water Act regulated acceptance limits. The statistical summaries are designed to show subcontract laboratories' performance against the national WP and WS studies formerly run by EPA.

During 1999, EMAX, Recra, and General Engineering laboratories participated in various WP and WS studies. Performance results by the laboratories can be found in table 11-2. The proficiency rating is calculated as follows: acceptable parameters divided by total parameters analyzed, multiplied by 100 .

EPA uses WP and WS results to certify laboratories for specific analyses. As part of the recertification process, EPA requires that subcontract laboratories investigate the outside-acceptance-limit results and implement corrective actions as appropriate.

Quarterly Assessments During 1999, EPD/EMS conducted quality assessments of the primary analytical laboratories to review their performance on certain analyses. Each laboratory received a set of certified environmental quality control standards from ERA and its results were compared with the ERA-certified values and performance acceptance limits. The performance acceptance limits are listed as guidelines for acceptable analytical results, given the limitations of the EPA methods used to determine these parameters. The performance acceptance limits closely approximate the 95 percent confidence interval. Results from the laboratories (EMAX, General Engineering, Recra, and General Engineering's Mobile Laboratory) are summarized in table 11-3.

\section{Soil/Sediment}

Environmental investigations of soils and sediments, primarily for RCRA/CERCLA units, are performed by subcontracted laboratories (General Engineering Laboratories, Recra LabNet Philadelphia, Environmental Physics, Inc., ThermoNUtech and Microseeps-table 11-1, page 200).

EMS personnel validated and managed approximately 200,000 analytical records during 1999. Data are validated according to EPA standards for analytical data quality unless specified otherwise by site customers. Forty-nine projects were begun in 1999. Most projects, when completed, include a project summary report, which contains 
- a project QAVQC summary

- a discussion of validation findings

- tables of validated and qualified data

Validation activities resulted in rejection of 2,025 analytical records analyzed in 1999 , or about one percent of the reported data. Typical reasons included spectral interference and low tracer recovery.

The EMS validation program is based on an EPA guidance document, Data Quality Objectives Process for Superfund (EPA-540-R-93-071). This document identifies QA issues to be addressed, but it does not formulate a procedure for how to evaluate these inputs, nor does it propose pass/fail criteria to apply to data and documents. Hence, the EMS validation program necessarily contains elements from-and is influenced by - several other EPA sources, including

- $\quad Q A / Q C$ Guidance for Removal Activities, interim final guidance, EPA-540-G-90-004

- National Functional Guidelines for Organic Data Review, Multi-Media, Multi-Concentration (OLM 01.0), and Low Concentration Water (OLC 01.0), draft, June 1991

- Test Methods for Evaluating Solid Waste, EPA, November 1986, SW-846, Third Edition
- Data Validation Procedures for Radiochemical Analysis, WHC-SD-EN-SPP-001

Data management personnel in the soil/sediment program perform additional functions to ensure the quality of the data released by EMS. Two people enter the data for each entry to help eliminate errors, and all field, shipping, invoice, and analytical data are 100 percent verified.

Relative percent difference for the soil/sediment program is calculated for field duplicates and laboratory duplicates. A summary of this information is presented in each project report prepared by the Environmental Geochemistry Group of EMS. A detailed description of the activities performed during validation of soil/sediment data can be found in the Environmental Geochemistry Group Operating Handbook, WSRC-IM-99-00013.

\section{Data Review}

Several detailed data validation activities have been added to the QA program for groundwater and soil/sediment analyses procured from offsite commercial laboratories:

- laboratory data record reviews (since 1993)

- radiological data reviews (since 1996)

Table 11-2 Subcontract Laboratory Performance in ERA Water Pollution and Water Supply Studies

\begin{tabular}{lllll}
\hline Laboratory & \multicolumn{2}{c}{$\begin{array}{c}\text { Water Pollution Studies } \\
\text { (Percent Acceptable) }\end{array}$} & \multicolumn{2}{c}{$\begin{array}{c}\text { Water Supply Studies } \\
\text { (Percent Acceptable) }\end{array}$} \\
\hline EMAX & WP 51 $\left(92 \%^{\mathrm{a}}\right)$ & & WS $32(96 \% \mathrm{~b})$ \\
Recra & WP $48\left(93 \%^{\mathrm{c}}\right)$ & WP $54\left(96 \%^{\mathrm{d}}\right)$ & WS $30\left(94 \%^{\mathrm{e}}\right)$ & WS $35\left(90 \%^{\mathrm{f}}\right)$ \\
General Engr. & WP $53\left(90 \%^{\mathrm{g}}\right)$ & WP $56(100 \%)$ & WS $35\left(95 \%^{\mathrm{h}}\right)$ &
\end{tabular}

a Results for total suspended solids, calcium, magnesium, calcium hardness as $\mathrm{CaCO} 3$, total hardness as $\mathrm{CaCO}$, and fluoride were not acceptable.

b Results for alkalinity, fluoride, total dissolved solids, and vinyl chloride were not acceptable.

c Results for total cyanide, conductivity, and total organic carbon were not acceptable. Results for total residual chlorine, chemical biological oxygen demand, and chemical oxygen demand were acceptable but near the acceptance limits.

d Results for chloride and total suspended solids were not acceptable. Results for conductivity, sodium, and biological oxygen demand were acceptable but near the acceptance limits.

e Results for hardness as $\mathrm{CaCO}$, bis(2-ethylhexyl)adipate, 2,4-D, dinoseb, pentachlorophenol, and dichlorodifluoromethane were not acceptable.

f Results for aluminum, chloride, fluoride, 1,2-dichlorobenzene, 1,1-dichloroethylene, 1,1,2,2-tetrachloroethane, chloroform, toxaphene, and pentachlorophenol were not acceptable.

g Results for total phosphorous as $\mathrm{P}$, calcium, magnesium, calcium hardness as $\mathrm{CaCO}$, and total hardness as $\mathrm{CaCO} 3$ were not acceptable. Results for $\mathrm{pH}$, conductivity, iron, total phenolics, and aldrin were acceptable but near the acceptance limits.

h Results for orthophosphate as P, boron, iron, silver, dichlorodifluoromethane, and 2,4-D were not acceptable. 
Table 11-3 Subcontract Laboratory Performance on Environmental Resource Associates (ERA) Standards

\begin{tabular}{lccccc}
\hline & & \multicolumn{2}{c}{ Percent Within Limits } & \\
Laboratory & 1st Quarter 1999 & 2nd Quarter 1999 & 3d Quarter 1999 & 4th Quarter 1999 \\
\hline EMAX & $95^{\mathrm{a}}$ & $94^{\mathrm{b}}$ & $93^{\mathrm{c}}$ & $91^{\mathrm{d}}$ \\
General Engineering & $99^{\mathrm{e}}$ & $98^{\mathrm{f}}$ & $99^{\mathrm{g}}$ & 100 \\
Recra & $87^{\mathrm{h}}$ & $87^{\mathrm{i}}$ & $93^{\mathrm{j}}$ & $95^{\mathrm{k}}$ \\
$\begin{array}{l}\text { General Engineering's } \\
\text { Mobile Laboratory }\end{array}$ & & & & $96^{1, \mathrm{~m}}$
\end{tabular}

a Results for ammonia as nitrogen, diethyiphthalate, dimethylphthalate, fluoride, and potassium were not acceptable.

b Results for butylbenzyl phthalate, 2-sec-butyl-4,6-dinitrophenol, di-n-butyl phthalate, grease and oil, sodium, and total petroleum hydrocarbons were not acceptable.

c Results for bromodichloromethane, di-n-butyl phthalate, 1,4-dichlorobenzene, 1,2-dichloroethane, endrin, mercury, potassium, and sodium were not acceptable.

d Results for boron, 2-sec-butyl-4, 6-dinitrophenol, calcium, 2-chlorophenol, o-cresol (2-methylphenol), 2,4-dichlorophenol, magnesium, phenol, sodium, and 2,4,5-trichlorophenol were not acceptable.

e Results for dimethylphthalate were not acceptable.

f Results for acetone and phenol were not acceptable.

g Results for methoxychlor were not acceptable.

h Results for aluminum, bromoform, chlorobenzene, dibromochloromethane, 1,3-dichlorobenzene, 1,4-dichlorobenzene, 1,2-dichloroethane, ethylbenzene, specific conductance, 1,1,2,2-tetrachloroethane, toluene, 1,1,2-trichloroethane, and $\mathrm{m} / \mathrm{p}$-xylene were not acceptable. There was not enough information to determine if result for total petroleum hydrocarbons was not acceptable.

i Results for aldrin, alpha-benzene hexachloride, beta-benzene hexachloride, alpha-chlordane, 4,4'-DDD, 4,4'-DDT, dieldrin, endrin, heptachlor, heptachlor epoxide, fluoride, PCB 1248, pentachlorophenol, and potassium were not acceptable. There was not enough information to determine if result for toxaphene was not acceptable.

j Results for endrin and tetrachloroethylene were not acceptable. There was not enough information to determine if results for beta-benzene hexachloride, bis(2-ethylhexyl) phthalate, gamma-chlordane, $\mathrm{m} / \mathrm{p}$-cresol, pyrene, and 2,4,6-trichlorophenol were not acceptable.

k Results for cyanide, fluoride, hexachloroethane, nitrate-nitrite as nitrogen, and total petroleum hydrocarbons were not acceptable.

1 Results for chlorobenzene and tetrachloroethylene were not acceptable.

$\mathrm{m}$ Fourth quarter results only were received from the mobile laboratory.

- metals interference reviews (since 1997)

The detailed data review is described in section 1110 of the SRS EM Program.

In $1999, \mathrm{QA}$ issues that were discovered and corrected in connection with these programs included

- false negatives in metals due to inadequate interference corrections

- poor tracer recovery in actinide chemical separation
- false positives of americium-241 and plutonium-238 due to contamination by natural thorium

- false positives of carbon-14 due to tritium contamination

- poor peak definition for radium-226

These findings illustrate that, although laboratory procedures are well defined, analytical data quality does benefit from technical scrutiny. 


\section{Special Surveys and Projects}

To Read About ... See Page...

Pen Branch Reforestation MAP ....... 205

ANSP River Quality Surveys .......... 208

Savannah River Swamp Surveys ...... 209

Pete Fledderman

Environmental Protection Department

Eric Nelson

Environmental Sciences Section

\section{Highlights}

- Reforestation of the Pen Branch corridor and delta by natural succession and planting continued. Several studies to assess the hydrogeochemical aspects normally present in wetland ecosystems were concluded in 1999. Monitoring of the wetland hydrology and vegetation development will continue periodically for the next 5 years.

- The section that covers the ANSP river quality surveys each year is being moved to chapter 9 , "Nonradiological Environmental Surveillance."

I $\mathrm{N}$ addition to routine sampling and special sampling during nonroutine environmental releases, special sampling for radiological and nonradiological surveys is conducted on and off site by personnel from the Savannah River Site (SRS) Environmental Protection Department's Environmental Monitoring Section (EMS) and from other groups, such as the Savannah River Technology Center (SRTC).

Both short- and long-term radiological and nonradiological surveys are used to monitor the effects of SRS effluents on the site's environment and in its immediate vicinity.

All conclusions discussed in this chapter are based on samples and analyses that have been completed. Because of sampling and/or analytical difficulties, some sample analyses may be missing. These analyses typically are small in number and represent only a very small fraction of the total number of samples exclusion does not affect the results drawn from the data set.

\section{Mitigation Action Plan for Pen Branch Reforestation}

The final Environmental Impact Statement for the continued operation of K-Reactor, L-Reactor, and P-Reactor at SRS predicted several unavoidable impacts to the site's wetlands. This resulted in the development of a Mitigation Action Plan (MAP) that documented the U.S. Department of Energy (DOE) approach to mitigating these impacts [DOE, 1990].
Permanent closure of these reactors mandated reevaluation of the mitigation strategies identified in the $1991 \mathrm{MAP}$ and its 1992 update. The section on "Mitigation for Wetlands Adversely Impacted by Operations" in the original MAP is the only remaining active program element. All parties involved with the reporting process have agreed that the SRS Environmental Report will be used as the document to report annual progress on the reforestation portion of the commitment.

A complete history of the regulatory commitment for the reforestation can be found in the MAP 1992 update [DOE, 1992]. Since that time, the change in mission relating to K-Reactor and the increased technical information on the extent of damage and natural recovery in the Pen Branch corridor and delta have altered details of the reforestation effort. The following paragraphs describe 1999 reforestation mitigation actions.

\section{Reforestation of the Pen Branch Corridor and Delta by Natural Succession}

Natural revegetation has been occurring in the Pen Branch delta since K-Reactor last operated for an extended period of time (1988). K-Reactor thermal discharges were determined by a 1992 survey to have caused canopy loss or vegetation damage to 583 acres in the corridor and swamp areas. The survey, which used aerial photography and aircraft-acquired multispectral data, showed less damage than anticipated [Blohm, 1995]. The final Environmental 
Impact Statement had estimated that 670 acres would be impacted [DOE, 1990].

During 1995, an extensive survey of natural regeneration of forest species was conducted around the outer perimeter of the delta region of Pen Branch. Results of that survey indicated that approximately 100 acres of the exterior delta had sufficient bald cypress seedlings and saplings to consider the area reforested. Stocking tallies taken in 1997 quantified these high densities and the vigor of this natural regeneration. Naturally regenerating areas closer to the terrace areas were heavily stocked with maple, sweetgum, water tupelo, green ash, and bald cypress - and averaged more than 319 seedlings per acre. Areas of natural regeneration in the deeper swamp, stocked primarily with water tupelo and bald cypress, averaged more than 1,087 seedlings per acre. These areas are included in a Geographic Information System layer for mapping of the Pen Branch area. All areas of the Pen Branch corridor above Risher Pond Road (A-13.2) also are considered to have been reforested by natural regeneration to a bottomland hardwood forest type.

\section{Reforestation of the Pen Branch Corridor and Delta by Planting}

The Pen Branch corridor and delta are being reforested by planting with indigenous wetlands species. Seeds were collected from individual trees at SRS and in the Upper Coastal Plain during 1992-1993 to ensure appropriate genetic material for use in the project. The seeds were planted and grown at a State of Georgia nursery during 1993-1995 for use in the Pen Branch seedling planting program. These seedlings —of species appropriate to the area being reforested-subsequently were transplanted to the Pen Branch wetland areas. The reforested areas will be managed until successful reforestation has been achieved. This is the preferred method of mitigation for the Pen Branch corridor and delta because of the brief restoration time allowed by DOE.

The initial and secondary seedling plantings of the entire corridor and delta areas (figure 12-1), in those locations in which it was determined intervention would be required for successful mitigation, have been completed. This intervention consisted of planting approximately 31 acres of the lower corridor with a mixture of flood-tolerant hardwood species and cypress seedlings in 1993. Forty-seven acres of the upper corridor was replanted with a mixture of bottomland hardwood seedlings in 1994. Species planted have included water and pignut hickory, sycamore, green ash, swamp and water tupelo, black gum, persimmon, cherrybark and water oak, bald

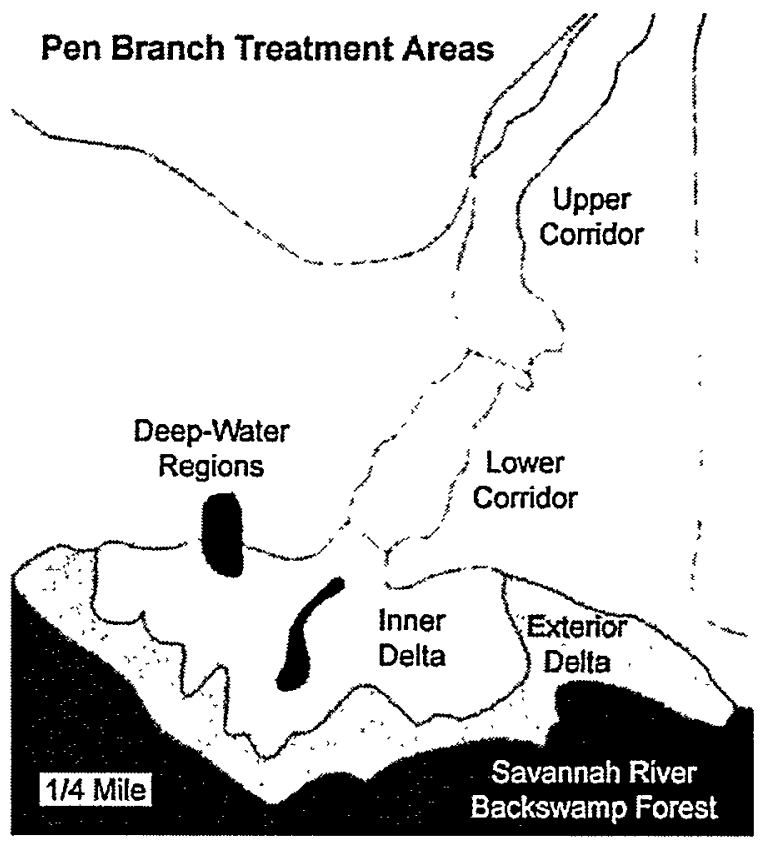

SRI/SRTC Graphic (modified)

Figure 12-1 Pen Branch Reforestation Areas Each of five areas in the Pen Branch corridor and delta requires a specific regeneration strategy to ensure successful reforestation.

cypress, and swamp chestnut oak. In 1995, the upper corridor section was replanted with seedlings because of the mortality that resulted from feral hog predation on the original planted seedlings. Also in 1995, the inner delta area was planted for the first time with bald cypress, water tupelo, and-on drier ridges-green ash seedlings; approximately 90 acres were planted at densities of 425 seedlings per acre. Approximately 85,000 seedlings were planted during the 3 years of planting (1993-1995) in the corridor and delta areas. An establishment report detailing all activities associated with the reforestation was issued in 1996 and serves as the operational guidebook describing the silvicultural activities that have been used to accomplish the mitigation to this point [Dulohery et al., 1996].

A regeneration survey was conducted in 1997 to establish the current stocking levels of desirable species in the different areas of the Pen Branch corridor and delta regions. Results of the survey indicated that appropriate species were present at densities of 160 trees per acre in the corridor and 200 trees per acre in the inner delta. Some mortality will continue to occur over time, but the number of seedlings available in planted areas is considerably above what would be present in a normal unimpacted bottomland hardwood or swamp forest. It is anticipated, therefore, that these stocking levels will 
provide sufficient numbers of trees to ensure reforestation success.

Within each area that has been planted are sections that will serve as untreated and unplanted controls to assess the effectiveness of the reforestation effort. Twenty-eight acres in the delta and 20 in the corridor were left in these control sections. This inclusion of control sections is allowing research to compare the treated and untreated areas for the purpose of measuring differences in ecological responses to the treatments. This control acreage is part of that committed to in the MAP. It will be assessed to determine if it will reforest naturally because of its proximity to the mitigated acreage; if it will not, it may receive plantings at a later date.

Because of the control/restoration comparison areas, a number of research and baselining activities have been conducted to document the recovery of the faunal component of the wetland ecosystem. Many of these studies have been concluded. Some of their results are reported briefly here; others, as noted below, have been reported at professional meetings, in peer-reviewed publications, and in graduate theses.

Several studies to assess the hydrogeochemical aspects normally present in wetland ecosystems were begun in the restoration area from fall 1997 through 1998 and completed in 1999. These studies examined

- the native seed bank of the corridor and delta

- organic matter production and cycling

- carbon and nutrient fluxes and transportation into and out of the water column

- leaf litter decomposition dynamics

The studies have compared data collected in the Pen Branch restoration with data from Fourmile Branch and Meyers Branch, which have a similar hydrologic regime. Fourmile Branch is a naturally recovering, thermally impacted stream that was returned to normal hydrology about 5 years earlier than Pen Branch, and that has not been actively restored. Meyers Branch is an unimpacted ecosystem typical of a mature bottomland hardwood area at SRS. The results of these studies are being drafted into theses, dissertations, and peer-reviewed articles by the researchers.

A characterization of the reestablishment of the seed bank in impacted floodplain ecosystems showed that the abundance and richness of the seed bank was highest in these ecosystems-due largely to early successional species of annuals and biennials that rapidly establish after a disturbance. The mature unimpacted reference ecosystem (Meyers Branch) had greater representation by perennial and woody species than the impacted ecosystems (Pen Branch and Fourmile Branch). Corridor ecosystems generally had greater numbers of species and individuals than swamp and delta ecosystems.

A study of organic matter and carbon accumulation in the impacted ecosystems indicated that organic matter buildup was rapid, but that total carbon content was less than in the unimpacted bottomland hardwood ecosystem (Meyers Branch). Forest floor organic matter increased rapidly due to high herbaceous input into the impacted ecosystems (figure 12-2). The mature ecosystem (Meyers Branch) had very low herbaceous input, but had higher carbon levels due to the predominately woody input. This woody component has a higher resident time in the soil and litter layer than the rapidly decomposed herbaceous input. As the impacted ecosystems mature and have higher input due to woody shrubs and trees, they should become more similar to mature (unimpacted) ecosystems.

The study of litter input and decomposition into and out of all three ecosystems showed very similar patterns. The impacted ecosystems had higher total biomass productivity than the unimpacted reference ecosystem-and similar species richness. The litter input was primarily herbaceous, and therefore rapidly moved out of the soil carbon fraction. Soil carbon in the unimpacted ecosystem was approximately three times greater than in the impacted ecosystems. Again, as the woody shrub and tree components begin to form a closed canopy on the landscape, they are expected to provide a greater proportion of the litter input into the two impacted ecosystems.

Monitoring of the hydrology and water budgets for all three ecosystems have confirmed slight differences in these parameters. Canopy manipulation in Pen Branch modified throughfall and evapotranspiration components of the water budget. The unimpacted ecosystem (Meyers Branch) had the highest evapotranspiration component because of its large, closed forest canopy. Projections of the impacted ecosystems indicate that they will more closely resemble Meyers Branch as canopy closure begins.

Studies throughout the project have been conducted by cooperators at Clemson University, the University of South Carolina, the University of Georgia, the Savannah River Ecology Laboratory, Auburn University, Virginia Polytechnic Institute and State University, and the University of South Carolina at Aiken. While the active research phase was concluding in 1999, monitoring of the wetland hydrology and vegetation development is required over a longer period of time to show successful 


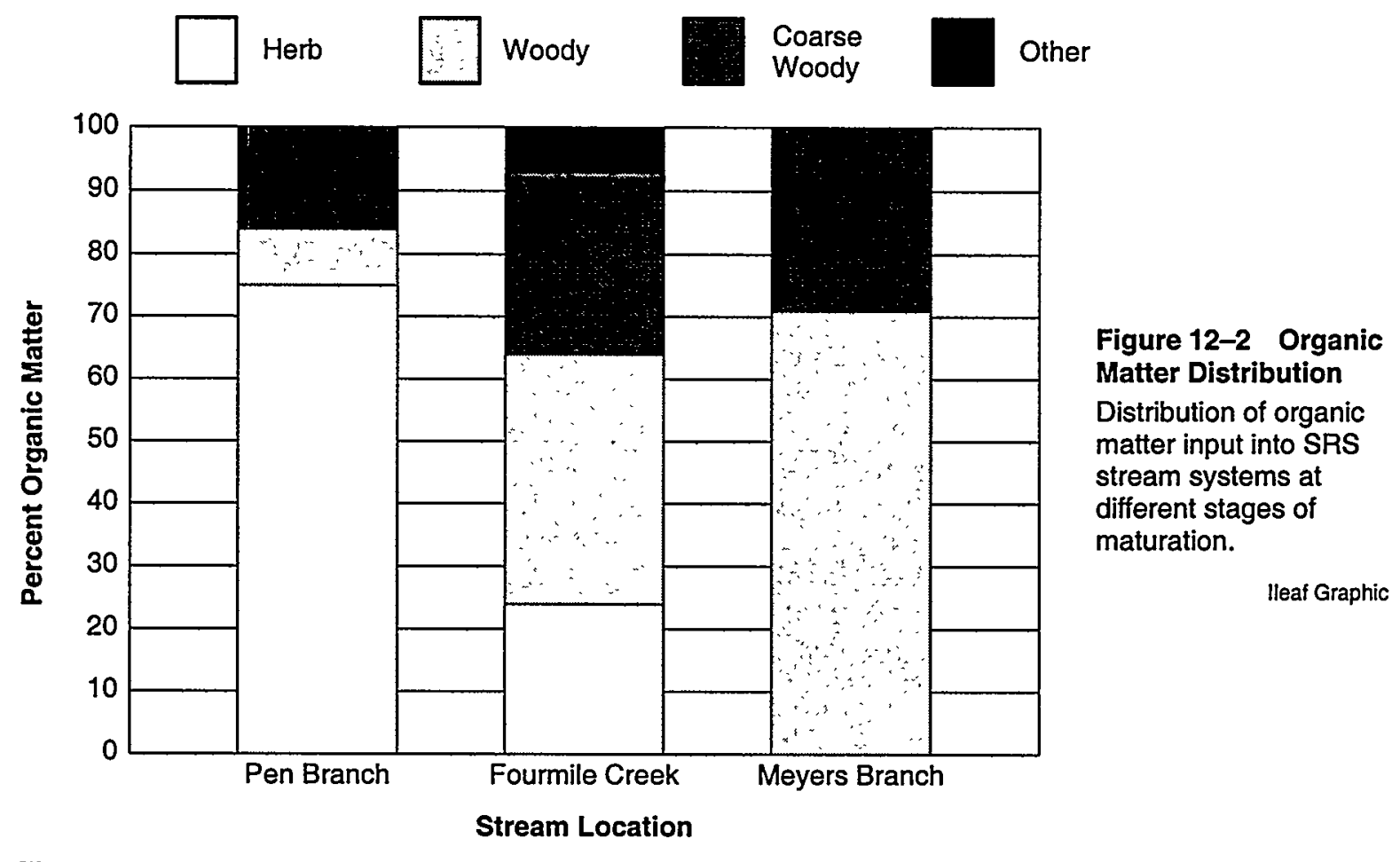

restoration, and will continue periodically for the next 5 years.

Several presentations to professional meetings (Society of Wetland Scientists and Soil Science Society of America) were made during 1999 to highlight the interdisciplinary assessment methodology being developed at SRS. Also, the proceedings of a symposium held in 1996 continued to be a regularly cited document relating to the broad effort that has taken place in the Pen Branch ecosystem [Nelson, 1996]. The symposium-organized by the Environmental Sciences Section of SRTC - provided all parties involved in the restoration, monitoring, and research efforts the opportunity to share their preliminary findings. As an action item from that meeting, it was proposed that the group reconvene at a future date to present complete papers of the research programs.

Group members subsequently held a workshop, "Restoration of a Severely Impacted Southeastern Riparian Wetland Systems - The Pen Branch Project," in April 1999 at Clemson University. The workshop's purpose was to convene into a single forum all efforts that had taken place in support of the restoration that might be helpful in defining an assessment methodology to measure success. Papers were presented on a variety of disciplines, and included silvicultural establishment, vegetation characterization, hydrology, faunal recolonization, hydrogeochemistry and carbon cycling, and assessment indices.

Twenty papers were presented during the workshop, and a peer-reviewed, special volume of Ecological Engineering (an environmental professional journal) will be published in 2000 that contains 15 of the papers that were presented at the workshop or that were part of the research effort. The journal also will contain a summary paper of the major points (from discussions at the workshop) that relate to success criteria for wetland restoration.

\section{Compensatory Mitigation}

The option exists to compensate-by enhancing degraded wetlands or creating new wetlands-for an inability to restore Pen Branch. The option will be considered following evaluation of the success of reforesting the Pen Branch corridor and delta in the year 2000. However, it is the least desired option and will be implemented only should the existing efforts in Pen Branch prove unsuccessful.

\section{Academy of Natural Sciences of Philadelphia River Quality Surveys}

The Patrick Center for Environmental Research of ANSP has been conducting biological and water quality studies of the Savannah River since 1951. The ANSP water quality studies are designed to assess 
potential effects of SRS contaminants and warm-water discharges on the general health of the Savannah River and its tributaries. They therefore look for spatial patterns of biological disturbance that are geographically associated with the site, and for temporal patterns of change that indicate improving or deteriorating conditions.

It was determined in 1999 that the ANSP studies-as a long-term, ongoing project-are more closely aligned with surveillance activities than special surveys. Because of this, the section that covers the studies each year is being moved to chapter 9, "Nonradiological Environmental Surveillance."

\section{Savannah River Swamp Surveys}

In the 1960s, an area of the Savannah River Swamp between Steel Creek Landing and Little Hell Landing was contaminated with about $25 \mathrm{Ci}$ of cesium- 137 and $1 \mathrm{Ci}$ of cobalt-60. This contaminated area, which extends beyond the SRS boundary into private property known as Creek Plantation, is uninhabited and not easily accessible.
The contamination originated mainly from failed reactor fuel elements that leaked radioactivity into the P-Area containment basin, which was always filled with water to cool the fuel elements. Periodically, the containment basin water was purged to Steel Creek. When these purges occurred during high river flow, Steel Creek flowed into the lowlands comprising the Savannah River Swamp and deposited the entrained contamination in the swamp.

In 1974, 10 sampling trails and 54 sampling locations were established so that specific locations could be monitored to determine changes in the amount and distribution of radioactivity in the swamp.

Comprehensive and cursory surveys of the swamp have been conducted periodically (water levels permitting) since 1974. The next comprehensive survey, scheduled for 2000 , will provide sampling and radioanalysis at all 54 locations. Results of the survey will be published in the SRS Environmental Report for 2000. 



\section{Applicable Guidelines, Standards, and Regulations}

$\mathrm{T}$ HE Savannah River Site (SRS)

environmental monitoring program is designed to meet state and federal regulatory requirements for radiological and nonradiological programs. These requirements are stated in U.S. Department of Energy (DOE) Order 5400.1, "General Environmental Protection Program," and DOE Order 5400.5, "Radiation Protection of the Public and the Environment"; in the Clean Air Act [Standards of Performance for New Stationary Sources, also referred to as New Source Performance Standards (NSPS), and the National Emission Standards for Hazardous Air Pollutants (NESHAP)]; in the Comprehensive Environmental Response, Compensation, and Liability Act (CERCLA - also known as the Superfund); in the Resource Conservation and Recovery Act (RCRA); in the Clean Water Act (i.e., National Pollutant Discharge Elimination System-NPDES); and in the National Environmental Policy Act (NEPA). Compliance with environmental requirements is assessed by DOE-Savannah River (DOE-SR), the South Carolina Department of Health and
Environmental Control (SCDHEC), and the U.S. Environmental Protection Agency (EPA).

The SRS environmental monitoring program's objectives incorporate recommendations of the International Commission on Radiological Protection ("Principles of Monitoring for the Radiation Protection of the Public," ICRP Publication 43), of DOE orders 5400.1 and 5400.5, and of DOE/EH-0173T, "Environmental Regulatory Guide for Radiological Effluent Monitoring and Environmental Surveillance." In addition, SRS has implemented and adheres to the SRS Environmental Management System Policy. As a result, the site has obtained International Organization for Standardization (ISO) 14001 certification. The full text of the policy is included in this appendix and begins on page 219 .

Drinking water standards and maximum allowable concentrations of toxic air pollutants can be found in appendix B, "Drinking Water Standards for Regulated Contaminants," and appendix C, "Standard No. 8 Toxic Air Pollutants." More information about certain media is presented in this appendix.

\section{Air Effluent Discharges}

DOE Order 5400.5 establishes Derived Concentration Guides (DCGs) for radionuclides in air. DCGs, calculated by the Department of Energy (DOE) using methodologies consistent with recommendations found in International Commission on Radiological Protection (ICRP) publications 26 and 30 , are used as reference concentrations for conducting environmental protection programs at DOE sites. DCGs are not considered release limits. DCGs for radionuclides in air are discussed in more detail on page 216.

Radiological airborne releases also are subject to EPA regulations cited in 40 CFR 61, Subpart $\mathrm{H}$, NESHAP.

Regulation of radioactive and nonradioactive air emissions - both criteria pollutants and toxic air pollutants-has been delegated to SCDHEC. SCDHEC, therefore, must ensure that its air pollution regulations are at least as stringent as federal regulations required by the Clean Air Act. This is accomplished by SCDHEC

Regulation 61-62, "Air Pollution Control Regulations and Standards." As with many regulations found in the Code of Federal Regulations (CFR), many of SCDHEC's regulations and standards are source specific. Each source of air pollution at SRS is permitted or exempted by SCDHEC, with specific emission rate limitations or special conditions identified. The bases for the limitations and conditions are the applicable South Carolina air pollution control regulations and standards. In some cases, specific applicable CFRs are also cited in the permits issued by SCDHEC.

Two SCDHEC standards, which govern criteria and toxic air pollutants and ambient air quality, are applicable to all SRS sources. Regulation 61-62.5, Standard No. 2, "Ambient Air Quality Standards," 
identifies eight criteria air pollutants commonly used as indices of air quality (e.g., sulfur dioxide, nitrogen dioxide, and lead) and provides allowable site boundary concentrations for each pollutant as well as the measuring intervals. Compliance with the various pollutant standards is determined by conducting air dispersion modeling for all sources of each pollutant using EPA-approved dispersion models and then comparing the results to the standard. The pollutants, measuring intervals, and allowable concentrations are given in table $\mathrm{A}-1$. The standards are in micrograms per cubic meter unless noted otherwise.

Two-hundred fifty-six toxic air pollutants and their respective allowable site boundary concentrations are identified in Regulation 61-62.5, Standard No. 8, "Toxic Air Pollutants." As with Standard No. 2, compliance is determined by air dispersion modeling. The pollutants, chemical abstract

Table A-1

Criteria Air Pollutants

\begin{tabular}{|c|c|c|}
\hline Pollutant & Interval & $\mu \mathrm{g} / \mathrm{m}^{\mathrm{a}, \mathrm{b}}$ \\
\hline Sulfur Dioxide & $\begin{array}{l}3 \text { hours } \\
24 \text { hours } \\
\text { annual }\end{array}$ & $\begin{array}{l}1300^{c} \\
365^{c} \\
80\end{array}$ \\
\hline $\begin{array}{l}\text { Total Suspended } \\
\text { Particulates }\end{array}$ & $\begin{array}{l}\text { Annual Geometric } \\
\text { Mean }\end{array}$ & 75 \\
\hline PM10 & $\begin{array}{l}24 \text { hours } \\
\text { annual }\end{array}$ & $\begin{array}{l}150^{d} \\
50^{d}\end{array}$ \\
\hline Carbon Monoxide & $\begin{array}{l}1 \text { hour } \\
8 \text { hours }\end{array}$ & $\begin{array}{l}40 \mathrm{mg} / \mathrm{m} 3 \\
10 \mathrm{mg} / \mathrm{m} 3\end{array}$ \\
\hline Ozone & 1 hour & $0.12 \mathrm{ppm}^{\mathrm{o}}$ \\
\hline $\begin{array}{l}\text { Gaseous } \\
\text { Fluorides } \\
\text { (as HF) }\end{array}$ & $\begin{array}{l}\text { 12-hour avg. } \\
24 \text {-hour avg. } \\
\text { 1-week avg. }\end{array}$ & $\begin{array}{l}3.7 \\
2.9 \\
1.6\end{array}$ \\
\hline Nitrogen Dioxide & annual & 100 \\
\hline Lead & $\begin{array}{l}\text { Calendar Quarterly } \\
\text { Mean }\end{array}$ & 1.5 \\
\hline
\end{tabular}

a Arithmetic average except in case of total suspended particulate matter (TSP)

b At $25^{\circ} \mathrm{C}$ and $760 \mathrm{~mm} \mathrm{Hg}$

c Not to be exceeded more than once a year

d Attainment determinations will be made based on the criteria contained in appendices $\mathrm{H}$ and $\mathrm{K}, 40$ CFR 50 , July $1,1987$.
Table A-2

\section{Airborne Emission Standards for SRS Coal-Fired Boilers}

\begin{tabular}{ll}
\hline Sulfur Dioxide & $3.6 \mathrm{lb} / 10^{6}$ BTUa \\
Total Suspended Particulates & $0.6 \mathrm{~b} / 10^{6}$ BTU \\
Opacity & $40 \%$ \\
\hline a $\quad$ British Thermal Unit & \\
\hline
\end{tabular}

numbers (CAS), and maximum allowable concentrations are shown in appendix $\mathrm{C}$.

SCDHEC airborne emission standards for each SRS permitted source may differ, based on size and type of facility, type and amount of expected emissions, and the year the facility was placed into operation. For example, SRS powerhouse coal-fired boilers are regulated by Regulation 61-62.5, Standard No. 1, "Emissions From Fuel Burning Operations." This standard specifies that for powerhouse stacks built before February 11, 1971, the opacity standard is 40 percent. For new sources constructed after this date, the opacity standard typically is 20 percent. The standards for particulate and sulfur dioxide emissions are shown in table A-2.

Regulation 61-62.5, Standard No. 3, "Waste Combustion and Reduction," is applicable to several sources at SRS. Under this standard, the Consolidated Incinerator Facility (CIF) in H-Area is considered a hazardous waste incinerator. Several of the standards for the CIF, given in table A-3, are adjusted for British Thermal Unit (BTU) content of the waste being burned.

Likewise, under the regulation cited in the previous paragraph, catalytic oxidation units (COUs) - used as pollution control devices for some SRS soil vapor extraction (SVE) systems-are classified as industrial. As such, the COUs have an opacity limit of 20 percent. During 1999, the COUs for several SRS soil vapor extraction and groundwater air stripper systems in A-Area and M-Area were removed because they were no longer necessary to meet other overall standards. At this time, only one SVE system has a COU and is regulated by this standard.

Regulation 61-62.5, Standard No. 4, "Emissions from Process Industries," is applicable to all SRS sources except those regulated by a different source specific standard. For some SRS sources, particulate matter emission limits are dependent on the weight of the material being processed and are determined 
Table A-3

Airborne Emission Standards for SRS Consolidated Incinerator Facility

\begin{tabular}{ll}
\hline Opacity & $10 \%$ \\
Hydrochloric acid (HCl) & $4 \mathrm{lb} / \mathrm{hr}$ \\
Particulate Matter & $0.08 \mathrm{gr} / \mathrm{DSCF}$ \\
Nickel & $0.11 \mathrm{lb} / \mathrm{hr}^{\mathrm{b}}$ \\
Cadmium & $0.0018 \mathrm{lb} / \mathrm{hr}^{\mathrm{b}}$ \\
Chromium & $0.0090 \mathrm{lb} / \mathrm{hr}^{\mathrm{b}}$ \\
Arsenic & $0.0046 \mathrm{lb} / \mathrm{hr}^{\mathrm{b}}$ \\
Lead & $0.090 \mathrm{lb} / \mathrm{hr}^{\mathrm{b}}$ \\
Organic Compounds & Various \\
Dioxin & $99.9999 \%$ DRE \\
\hline \multicolumn{2}{l}{ Corrected to $7 \%$ oxygen } \\
b Adjusted for BTU content of waste \\
c Must be destroyed with an efficiency of at least \\
\hline \multicolumn{2}{l}{$99.99 \%$} \\
\hline
\end{tabular}

from a table in the regulation. For process and diesel engine stacks in existence on or before December 31, 1985, emissions shall not exhibit an opacity greater than 40 percent. For new sources, where construction was started after December 31,1985 , the opacity standard is 20 percent.

As previously mentioned, some SRS sources have both SCDHEC and CFRs applicable and identified in their permits. For the package steam generating boilers in $\mathrm{K}$-Area and two portable package boilers, both SCDHEC and federal regulations are applicable. The standard for sulfur dioxide emissions is specified in 40 CFR 60, Subpart Dc,
Table A-4

Airborne Emission Standards for SRS Fuel Oil-Fired Package Boilers

$\begin{array}{ll}\text { Sulfur Dioxide } & 0.5 \mathrm{lb} / 10^{6} \text { BTU } \\ \begin{array}{l}\text { Total Suspended } \\ \text { Particulates }\end{array} & 0.6 \mathrm{~b} / 10^{6} \text { BTU } \\ \text { Opacity } & 20 \%\end{array}$

"Standards of Performance for Small Industrial-Commercial-Institutional Steam Generating Units," while the standard for particulate matter is found in Regulation 61-62.5, Standard No. 1, "Emissions From Fuel Burning Operations." Because these units were constructed after applicability dates found in both regulations, the opacity limit for these units is the same in both regulations. The emissions standards for these boilers are presented in table $A-4$.

Another federal regulation, 40 CFR 60 , Subpart Kb, "Standards of Performance for Volatile Organic Liquid Storage Vessels (Including Petroleum Liquid Storage Vessels) for which Construction, Reconstruction, or Modification Commenced after July 23, 1984," specifies types of emission controls that must be incorporated into the construction of a source. In this regulation, the type of control device required is dependent on the size of the tank and the vapor pressures of the material being stored. This regulation is applicable to several sources at SRS, such as the two 30,000-gallon No. 2 fuel oil storage tanks in K-Area or the four mixed solvent storage tanks in H-Area. However, because of the size of these tanks and vapor pressures of the materials being stored, these tanks are not required to have control devices installed. The only requirements applicable to SRS storage tanks are those for record keeping.

\section{(Process) Liquid Effluent Discharges}

DOE Order 5400.5 establishes DCGs for radionuclides in process effluents. (DCGs for radionuclides in water are discussed in more detail on page 217.) DCGs were calculated by DOE using methodologies consistent with recommendations found in ICRP Publications 26 and 30 and are used

- as reference concentrations for conducting environmental protection programs at DOE sites
- as screening values for considering best available technology for treatment of liquid effluents

DOE Order 5400.5 exempts aqueous tritium releases from best available technology requirements but not from ALARA (as low as reasonably achievable) considerations.

SRS discharges water into site streams and the Savannah River under four NPDES permits: one 
industrial wastewater permit (SC0000175), one general utility water discharge permit (SCG250162), and two stormwater runoff permits (SCR000000 for industrial discharges and SCR 100000 for construction discharges).

A fifth permit (ND0072125) is a no-discharge water pollution control land application permit that regulates sludge generated at onsite sanitary waste treatment plants.

Detailed requirements for each permitted discharge point-including parameters sampled for, permit limits for each parameter, sampling frequency, and method for collecting each sample-can be found in the individual permits, which are available to the public through SCDHEC's Freedom of Information Office at (803) 734-5376.

\section{Site Streams}

SRS streams are classified as "Freshwaters" by the South Carolina Pollution Control Act. Freshwaters are defined as surface water suitable for

- primary-and secondary-contact recreation and as a drinking water source after conventional treatment in accordance with SCDHEC requirements
- $\quad$ fishing and survival and propagation of a balanced indigenous aquatic community of fauna and flora

- industrial and agricultural uses

Table A-5 provides some of the specific guides used in water quality surveillance, but because some of these guides are not quantifiable, they are not tracked in response form (i.e., amount of garbage found).

\section{Savannah River}

Because the Savannah River is defined under the South Carolina Pollution Control Act as a
Freshwater system, the river is regulated in the same manner as are site streams (table A-5).

\section{Drinking Water}

The federal Safe Drinking Water Act (SDWA) - enacted in 1974 to protect public drinking water supplies-was amended in 1980 , 1986, and 1996.

SRS drinking water systems are tested routinely by SRS and SCDHEC to ensure compliance with SCDHEC State Primary Drinking Water Regulations, R61-58, and EPA National Primary Drinking Water Regulations, 40 CFR 141.

SRS drinking water is supplied by 18 separate systems, all of which utilize groundwater sources. The three larger consolidated systems (A-Area, $\mathrm{D}$-Area, and $\mathrm{K}$-Area) are actively regulated by SCDHEC and are classified as nontransient/noncommunity systems because each serves more than 25 people. The remaining 15 site water systems, each of which serves fewer than 25 people, receive a lesser degree of regulatory oversight.
Under the SCDHEC-approved, ultra-reduced monitoring plan, lead and copper sampling will not be required again for the A-Area consolidated system until 2001. The D-Area and K-Area consolidated water systems qualified in 1997 for an ultra-reduced monitoring plan, and lead and copper sampling will not be required until the year 2000 .

The B-Area Bottled Water Facility, which was approved for operation in 1998, is listed as a public water system by SCDHEC and is required to be sampled for bacteriological analysis on a quarterly basis beginning in January 2000 . Unlike the D-Area and $\mathrm{K}$-Area consolidated water systems, lead and copper monitoring will not be required.

Drinking water standards for specific radionuclides and contaminants are provided in appendix B, "Drinking Water Standards for Regulated Contaminants," of this document.

\section{Groundwater}

The analytical results of samples taken from SRS monitoring wells that exceed various standards are discussed in this report. Constituents discussed are compared to final federal primary drinking water standards (DWS), or other standards if DWS do not exist, because groundwater aquifers are defined as potential drinking water sources by the South Carolina Pollution Control Act. [SCDHEC, 1985]. The DWS can be found in appendix B, "Drinking Water Standards." DWS are not always the 
Table A-5

South Carolina Water Quality Standards for Freshwaters

Note: This is a partial list only of water quality standards for freshwaters.

\section{Parameters Standards}

a. Fecal coliform Not to exceed a geometric mean of $200 / 100 \mathrm{~mL}$, based on five consecutive samples during any 30 -day period; nor shall more than 10 percent of the total samples during any 30 -day period exceed $400 / 100 \mathrm{~mL}$.

b. pH Range between 6.0 and 8.5 .

c. Temperature

d. Dissolved oxygen

e. Garbage, cinders, ashes, sludge, or other refuse

f. Treated wastes, toxic wastes, deleterious substances, colored or other wastes, except those in (e) above.

g. Ammonia, chlorine, and toxic pollutants listed in the federal Clean Water Act (307) and for which EPA has developed national criteria (to protect aquatic life).
Generally, shall not be increased more than $5^{\circ} \mathrm{F}\left(2.8^{\circ} \mathrm{C}\right)$ above natural temperature conditions or be permitted to exceed a maximum of $90^{\circ} \mathrm{F}\left(32.2^{\circ} \mathrm{C}\right)$ as a result of the discharge of heated liquids. For exceptions, see E-9.A, Regulation 61-68, "Water Classifications and Standards" (June 26, 1998).

Daily average not less than $5.0 \mathrm{mg} / \mathrm{L}$, with a low of $4.0 \mathrm{mg} / \mathrm{L}$.

None allowed.

None alone or in combination with other substances or wastes in sufficient amounts to make the waters unsafe or unsuitable for primary-contact recreation or to impair the waters for any other best usage as determined for the specific waters assigned to this class.

See $E-10$ (list of water quality standards based on organoleptic data) and $E-12$ (water quality criteria for protection of human health), Regulation 61-68, "Water Classifications and Standards" (June 26, 1998).

SOURCE: [SCDHEC, 1998]

standards applied by regulatory agencies to the SRS waste units under their jurisdiction. For instance, standards under RCRA are DWS, groundwater protection standards, background levels, and alternate concentration limits.

Two constituents having DWS-dichloromethane and bis(2-ethylhexyl) phthalate-are not discussed in this report. Both are common laboratory contaminants and are reported in groundwater samples with little or no reproducibility. Both are reported, with appropriate flags and qualifiers, in the data tables of the quarterly reports cited in chapter 10, "Groundwater."

The standard used for lead, $50 \mu \mathrm{g} / \mathrm{L}$, is the SCDHEC DWS. The federal standard of $15 \mu \mathrm{g} / \mathrm{L}$ is a treatment standard for drinking water at the consumer's tap; thus, it is inappropriate for use as a groundwater standard.

Of the radionuclides discussed, only gross alpha, strontium-90, and tritium are compared to true primary DWS. The regulatory standards for radionuclide discharges from industrial and governmental facilities are set under the Clean Water Act, RCRA, and Nuclear Regulatory Commission and DOE regulations. The proposed drinking water maximum contaminant levels discussed in this report are only an adjunct to these release restrictions and are not used to regulate SRS groundwater.

The standard used for gross beta is a screening standard; when public drinking water exceeds this standard, the supplier is expected to analyze for individual beta and gamma emitters. A gross beta 
result above the standard is an indication that one or more radioisotopes are present in quantities that would exceed the EPA annual dose equivalent for persons consuming 2 liters daily. Thus, for the individual beta and gamma radioisotopes (other than strontium-90 and tritium), the standard discussed in this report is the activity per liter that would, if only that isotope were present, exceed the dose equivalent. Similarly, the standards for alpha emitters discussed in this report are calculated to present the same risk at the same rate of ingestion.

Although radium has a DWS of $5 \mathrm{pCi} / \mathrm{L}$ for the sum of radium-226 and radium-228, the standards discussed in this report are the proposed standards of $20 \mathrm{pCi} / \mathrm{L}$ for each isotope separately. Radium-226, an alpha emitter, and radium-228, a beta emitter, cannot be analyzed by a single method. Analyses for total alpha-emitting radium, which consists of radium-223, radium-224, and radium-226, are compared to the standard for radium-226.

Four other constituents without DWS are discussed in this report when their values exceed specified levels. These constituents are specific conductance at values equal to or greater than $100 \mu \mathrm{S} / \mathrm{cm}$, alkalinity (as $\mathrm{CaCO}_{3}$ ) at values equal to or greater than $100 \mathrm{mg} / \mathrm{L}$, total dissolved solids (TDS) at values equal to or greater than $200 \mathrm{mg} / \mathrm{L}$, and $\mathrm{pH}$ at values equal to or less than 4.0 or equal to or greater than 8.5. The selection of these values as standards for comparison is somewhat arbitrary; however, these values exceed levels usually found in background wells at SRS. The occurrence of elevated alkalinity (as $\mathrm{CaCO}_{3}$ ), specific conductance, $\mathrm{pH}$, and TDS within a single well may indicate leaching of the grouting material used in well construction, rather than degradation of the groundwater.

\section{Potential Dose}

The radiation protection standards followed by SRS are outlined in DOE Order 5400.5 and include EPA regulations on the potential doses from airborne releases and treated drinking water.

The following radiation dose standards for protection of the public in the SRS vicinity are specified in DOE Order 5400.5.

Drinking Water Pathway ... 4 mrem per year Airborne Pathway ...... 10 mrem per year All Pathways ........ 100 mrem per year

The EPA annual dose standard of 10 mrem $(0.1 \mathrm{mSv})$ for the atmospheric pathway, which is contained in "National Emission Standards for Hazardous Air Pollutants-Radionuclides (NESHAP)," 40 CFR Part 61, Subpart H, is adopted in DOE Order 5400.5.

These dose standards are based on recommendations of the ICRP and the National Council on Radiation Protection and Measurements (NCRP).

The DOE dose standard enforced at SRS for drinking water consumed from site drinking water systems, community drinking water systems, and downriver water treatment plants is consistent with the criteria contained in "National Interim Primary Drinking Water Regulations, 40 CFR Part 141." Under these regulations, persons consuming drinking water shall not receive an annual whole body dose-DOE Order 5400.5 interprets this dose as committed effective dose equivalent -of more than 4 mrem (0.04 mSv). Both dose standards are based on a consumption rate of 2 liters of water per day. However, some radionuclide dose conversion factors (including tritium) differ between EPA and DOE.

Because SRS must use DOE-provided, ICRP-based dose conversion factors, a direct comparison of the estimated drinking water doses in chapter 7, "Potential Radiation Doses," to the EPA drinking water dose standard cannot be made. However, radionuclide concentrations found in drinking water are directly compared to the EPA drinking water concentration standards in chapter 6, "Radiological Environmental Surveillance."

\section{Comparison of Average Concentrations in Airborne Emissions to DOE Derived Concentration Guides}

Average concentrations of radionuclides in airborne emissions are calculated by dividing the yearly release total of each radionuclide from each stack by the yearly stack flow quantities. These average concentrations then can be compared to the DOE
DCGs, which are found in DOE Order 5400.5 for each radionuclide.

DCGs are used as reference concentrations for conducting environmental protection programs at all 
DOE sites. DCGs, which are based on a 100-mrem exposure, are applicable at the point of discharge (prior to dilution or dispersion) under conditions of continuous exposure (assumed to be an average inhalation rate of 8,400 cubic meters per year). This means that the DOE DCGs are based on the highly conservative assumption that a member of the public has direct access to and continuously breathes (or is immersed in) the actual air effluent 24 hours a day,
365 days a year. However, because of the large distance between most SRS operating facilities and the site boundary, and because the wind rose at SRS shows no strong prevalence (chapter 7, "Potential Radiation Doses"), this scenario is improbable.

Average annual radionuclide concentrations in SRS air effluent can be referenced to DOE DCGs as a screening method to determine if existing effluent treatment systems are proper and effective.

\section{Comparison of Average Concentrations in Liquid Releases} to DOE Derived Concentration Guides

In addition to dose standards, DOE Order 5400.5 imposes other control considerations on liquid releases. These considerations are applicable to direct discharges but not to seepage basin and Solid Waste Disposal Facility (SWDF) migration discharges. The DOE order lists DCG values for most radionuclides. DCGs are used as reference concentrations for conducting environmental protection programs at all DOE sites. These DCG values are not release limits but screening values for best available technology investigations and for determining whether existing effluent treatment systems are proper and effective.

Per DOE Order 5400.5, exceedance of the DCGs at any discharge point may require an investigation of best available technology waste treatment for the liquid effluents. Tritium in liquid effluents is specifically excluded from best available technology requirements; however, it is not excluded from other ALARA considerations. DOE DCG compliance is demonstrated when the sum of the fractional DCG values for all radionuclides detectable in the effluent is less than 1.00 , based on consecutive 12 -month average concentrations.

DCGs, based on a 100-mrem exposure, are applicable at the point of discharge from the effluent conduit to the environment (prior to dilution or dispersion). They are based on the highly conservative assumption that a member of the public has continuous direct access to the actual liquid effluents and consumes 2 liters of the effluents every day, 365 days a year. However, because of security controls and the large distance between most SRS operating facilities and the site boundary, this scenario is highly improbable, if not impossible.

For each site facility that releases radioactivity, the site's Environmental Monitoring Section (EMS) compares the monthly liquid effluent concentrations and 12-month average concentrations against the DOE DCGs.

\section{Environmental Management}

SRS began its cleanup program in 1981. Two major federal statutes provide guidance for the site's environmental restoration and waste management activities-RCRA and CERCLA. RCRA addresses the management of hazardous waste and requires that permits be obtained for facilities that treat, store, or dispose of hazardous or mixed waste. It also requires that $\mathrm{DOE}$ facilities perform appropriate corrective action to address contaminants in the environment. CERCLA (also known as Superfund) addresses the uncontrolled release of hazardous substances and the cleanup of inactive waste sites. This act establishes a National Priority List of sites targeted for assessment and, if necessary, corrective/remedial action. SRS was placed on this list December 21, 1989 [Fact Sheet, 1995]. In August 1993, SRS entered into the Federal Facility Agreement (FFA) with EPA Region IV and SCDHEC. This agreement governs the corrective/remedial action process from site investigation through site remediation. It also describes procedures for setting annual work priorities, including schedules and deadlines, for that process [FFA under section 120 of CERCLA and sections $3008(\mathrm{~h})$ and 6001 of RCRA].

Additionally, DOE is complying with Federal Facility Compliance Act requirements for mixed waste management-including high-level waste, most transuranic waste, and low-level waste with hazardous constituents. This act requires that DOE develop and submit site treatment plans to the EPA or state regulators for approval.

A Facilities Decommissioning Division was established on site in 1996 to manage SRS excess facilities-from completion of operations shutdown through final disposition. Today, facility disposition activities at the site are conducted according to 
directives established in DOE Order 430.1A, "Life Cycle Asset Management," and DOE guidance. This order addresses requirements associated with the planning, acquisition, operation, maintenance, leasing, and disposition of physical assets. As such, it replaces 14 previous orders for the management of physical assets-from acquisition through disposition.

\section{Quality Assurance/Quality Control}

DOE Order 414.1, "Quality Assurance," which superseded DOE Order $5700.6 \mathrm{C}$, sets requirements and guidelines for departmental quality assurance (QA) practices. To ensure compliance with regulations and to provide overall quality requirements for site programs, Westinghouse Savannah River Company (WSRC) developed its Quality Assurance Management Plan, Rev. 8 (WSRC-RP-92-225). The requirements of WSRC-RP-92-225 are implemented by the Westinghouse Savannah River Company Quality Assurance Manual (WSRC 1Q).

The Environmental Monitoring Section Quality Assurance Plan, (WSRC-3Q1-2, Volume 3, Section 8000), part of the EMS WSRC-3Q1 procedure series, was written to apply the $\mathrm{QA}$ requirements of WSRC $1 Q$ to the environmental monitoring and surveillance program. The EMS WSRC-3Q1 procedure series includes procedures on sampling, radiochemistry, and water quality that emphasize the quality control requirements for EMS.

NESHAP defines specific $Q A$ requirements for monitoring radiological air emissions [EPA, 1989]. For radiological air emissions at SRS, the responsibilities and lines of communication are detailed in National Emission Standards for Hazardous Air Pollutants Quality Assurance Project Plan (U) (WSRC-IM-91-60).

To ensure valid and defensible monitoring data, the records and data generated by the monitoring program are maintained according to the

\section{Reporting}

DOE Order 231.1, "Environment, Safety and Health Reporting," requires that SRS submit an annual environmental report.

This report, the Savannah River Site Environmental requirements of DOE Guide $1324.5 \mathrm{~B}$, "Implementation Guide for Use with $36 \mathrm{CFR}$ Chapter XII - Subchapter B Records Management," and of WSRC 1Q. QA records include sampling and analytical procedure manuals, logbooks, chain-of-custody forms, calibration and training records, analytical notebooks, control charts, validated laboratory data, and environmental reports. These records are maintained and stored per the requirements of WSRC-1M-93-0060, WSRC Sitewide Records Inventory and Disposition Schedule.

EMS assessments are implemented according to the following documents:

- WSRC-12Q

- WSRC-1Q

- DOE Order 414.1, "Quality Assurance"

- DOE/EM-0159P, “Analytical Laboratory Quality Assurance Guidance"

- DOE/EM-0157P, "Laboratory Assessment Plates"

- DOE/EH-0173T, "Program Guidance"

The Environmental Protection Department (EPD) FY 2000 Self Assessment Unit Assessment Plan (ESH-ENV-99-0073) defines the requirements for self assessment and provides for verification of the compliance and effectiveness of the EMS QA/QC program. The plan's purpose is to assist management in evaluating the performance of EMS activities and the effectiveness of management controls and procedures.

Report for 1999, is an overview of effluent monitoring and environmental surveillance activities conducted on and in the vicinity of SRS from January 1 through December 31, 1999. 


\section{ISO 14001 Environmental Management System}

International Organization for Standardization (ISO) 14001 is the Environmental Management System Standard within the ISO 14000 series of standards, a family of voluntary environmental management standards and guidelines. SRS achieved ISO 14001 certification in 1997 by demonstrating adherence to and programmatic implementation of the SRS Environmental Management System Policy. The full text of the policy (without the names of the signatories) follows.

\section{Savannah River Site (SRS) Environmental Management System Policy November 1, 1999}

\section{OBJECTIVE:}

The objective of this policy is to ensure every employee of the DOE Savannah River Operations Office (SR), all contractors, subcontractors, and other entities performing work at the Savannah River Site (SRS) do so in accordance with the requirements of ISO 14001, DOE Order 5400.1 and the mission, the vision, the core values, and the environmental goals and objectives of the Savannah River Site Strategic Plan.

\section{DIRECTIVE:}

Recognizing that all aspects of operations carried out at the SRS may impact the environment, the DOE-SR policy is that all employees, contractors, subcontractors, and other entities performing work at the SRS shall abide by the directives in this document. Westinghouse Savannah River Company (WSRC), Wackenhut Services, Inc. - Savannah River Site (WSI), Savannah River Ecology Laboratory (SREL), General Services Administration - Savannah River Site (GSA), and the Savannah River Natural Resources Management and Research Institute (SRI) shall, by virtue of their signature, endorse the principles stated in this policy.

- This document describes the SRS Environmental Management System Policy. It shall serve as the primary documentation for the environmental goals and objectives of the SRS and shall be available to the public. It shall be centrally maintained and updated as necessary to reflect the changing needs, missions, and goals of the SRS.

- The Environmental Management System shall pursue and measure continual improvement in performance by establishing and maintaining documented environmental objectives and targets that correspond to SRS's mission, vision, and core values. The environmental objectives and targets shall be established for each relevant function and level within DOE-SR and all contractors, subcontractors, and other entities performing work at the SRS for all activities having actual or potentially significant environmental impacts.

- DOE-SR and all contractors, subcontractors, and other entities performing work at SRS shall:

1 Manage the SRS environment, natural resources, products, waste, and contaminated materials so as to eliminate or mitigate any threat to human health or the environment at the earliest opportunity and implement process improvements as appropriate to ensure continued improvement of performance in environmental management.

2 Implement a pollution prevention program to reduce waste generation, releases of pollutants, future waste management/pollution control costs; and to minimize environmental impacts as well as promote increased energy efficiency.

3 Conduct operations in compliance with the letter and spirit of all applicable federal, state, and local laws, regulations, statutes, executive orders, DOE directives and standards/requirements identification documents.

4 Work cooperatively and openly with appropriate local, state, federal agencies, public stakeholders, and site employees to prevent pollution, achieve environmental compliance, conduct cleanup/restoration activities, enhance environmental quality, and ensure the protection of workers and the public health.

5 Design, develop, construct, operate, maintain, decommission and deactivate facilities and operations in a manner that shall be resource efficient and will protect and improve the quality of the 
environment for future generations and continue to maintain the SRS as a unique national environmental asset.

6 Recognize that the responsibility for quality communications rests with each individual employee and that it shall be the responsibility of all employees to identify and communicate ideas for improving environmental protection activities and programs at the site.

Adherence to and programmatic implementation of this policy shall be monitored by the DOE-SR Assistant Manager for Environmental Programs in coordination with the contractors, subcontractors, and other entities performing work on the SRS. An annual evaluation of the Environmental Management System, with recommendations for improvement, shall be provided to the undersigned managers. [Editors' note: The names of the signatories that appeared at the end of the full text of the policy have not been included here.] 


\section{Appendix $B$ \\ Drinking Water Standards for Regulated Contaminants}

\begin{tabular}{|c|c|c|c|c|c|}
\hline \multicolumn{2}{|c|}{ Analyte } & $\begin{array}{c}\text { Maximum } \\
\text { Contaminant Levela }\end{array}$ & Units & Status & Reference ${ }^{b}$ \\
\hline Note: & \multicolumn{5}{|c|}{$\begin{array}{l}\text { The Environmental Protection Agency is revising the national primary drinking water standards for } \\
\text { radionuclides, which have been in effect since } 1977 \text {. Revisions are expected by November } 2000 .\end{array}$} \\
\hline \multicolumn{2}{|c|}{ Alachlor } & 0.002 & $\mathrm{mg} / \mathrm{L}$ & final & CFR \\
\hline \multicolumn{2}{|c|}{ Aldicarb } & 0.003 & $\mathrm{mg} / \mathrm{L}$ & final & CFR \\
\hline \multicolumn{2}{|c|}{ Aldicarb sulfone } & 0.002 & $\mathrm{mg} / \mathrm{L}$ & final & CFR \\
\hline \multicolumn{2}{|c|}{ Aldicarb sulfoxide } & 0.004 & $\mathrm{mg} / \mathrm{L}$ & final & CFR \\
\hline \multicolumn{2}{|c|}{ Antimony } & 0.006 & $\mathrm{mg} / \mathrm{L}$ & final & CFR \\
\hline \multicolumn{2}{|c|}{ Arsenic } & 0.05 & $\mathrm{mg} / \mathrm{L}$ & final & CFR \\
\hline \multicolumn{2}{|c|}{ Asbestos } & $7,000,000$ & fibers $/ L^{c}$ & final & CFR \\
\hline \multicolumn{2}{|c|}{ Atrazine } & 0.003 & $\mathrm{mg} / \mathrm{L}$ & final & CFR \\
\hline \multicolumn{2}{|c|}{ Barium } & 2.0 & $\mathrm{mg} / \mathrm{L}$ & final & CFR \\
\hline \multicolumn{2}{|c|}{ Benzene } & 0.005 & $\mathrm{mg} / \mathrm{L}$ & final & CFR \\
\hline \multicolumn{2}{|c|}{ Benzo[a]pyrene } & 0.0002 & $\mathrm{mg} / \mathrm{L}$ & final & CFR \\
\hline \multicolumn{2}{|c|}{ Beryllium } & 0.004 & $\mathrm{mg} / \mathrm{L}$ & final & CFR \\
\hline \multicolumn{2}{|c|}{$\begin{array}{l}\text { 2-sec-Butyl-4, 6-dinitrophenol } \\
\text { (Dinoseb) }\end{array}$} & 0.007 & $\mathrm{mg} / \mathrm{L}$ & final & CFR \\
\hline \multicolumn{2}{|c|}{ Cadmium } & 0.005 & $\mathrm{mg} / \mathrm{L}$ & final & CFR \\
\hline \multicolumn{2}{|c|}{ Carbofuran } & 0.04 & $\mathrm{mg} / \mathrm{L}$ & final & CFR \\
\hline \multicolumn{2}{|c|}{ Carbon tetrachloride } & 0.005 & $\mathrm{mg} / \mathrm{L}$ & final & CFR \\
\hline \multicolumn{2}{|c|}{ Chlordane } & 0.002 & $\mathrm{mg} / \mathrm{L}$ & final & CFR \\
\hline \multicolumn{2}{|c|}{$\begin{array}{l}\text { Chlorobenzene } \\
\text { (Monochlorobenzene) }\end{array}$} & 0.1 & $\mathrm{mg} / \mathrm{L}$ & final & CFR \\
\hline \multicolumn{2}{|c|}{$\begin{array}{l}\text { Chloroethene } \\
\text { (Vinyl chloride) }\end{array}$} & 0.002 & $\mathrm{mg} / \mathrm{L}$ & final & CFR \\
\hline \multicolumn{2}{|c|}{ Chloroform } & 0.1 & $\mathrm{mg} / \mathrm{L}$ & final & CFR \\
\hline \multicolumn{2}{|c|}{ Chromium } & 0.1 & $\mathrm{mg} / \mathrm{L}$ & final & CFR \\
\hline \multicolumn{2}{|c|}{ Copper } & $1^{e}$ & $\mathrm{mg} / \mathrm{L}$ & final & SCDHEC \\
\hline \multicolumn{2}{|c|}{ Cyanide } & 0.2 & $\mathrm{mg} / \mathrm{L}$ & final & CFR \\
\hline \multicolumn{2}{|c|}{ Dalapon } & 0.2 & $\mathrm{mg} / \mathrm{L}$ & final & CFR \\
\hline \multicolumn{2}{|c|}{ 1,2-Dibromo-3-chloropropane } & 0.0002 & $\mathrm{mg} / \mathrm{L}$ & final & CFR \\
\hline \multicolumn{2}{|c|}{$\begin{array}{l}\text { 1,2-Dichlorobenzene } \\
\text { (o-Dichlorobenzene) }\end{array}$} & 0.6 & $\mathrm{mg} / \mathrm{L}$ & final & CFR \\
\hline
\end{tabular}

a Standards for beta- and gamma-emitting radionuclides are based on the 4-mrem/yr whole-body dose [CFR].

b Bibliographical information concerning the references is included at the end of this table, page 223.

c Longer than $10 \mu \mathrm{m}$

d The level for total trihalomethanes is set at $0.1 \mathrm{mg} / \mathrm{L}$. Because bromated methanes are rarely detected in SRS groundwater, the Environmental Protection Department presumes that most of the trihalomethanes present in site groundwater are chloroform.

e This is a South Carolina state drinking water "action level" used by the SRS groundwater monitoring program. 


\begin{tabular}{|c|c|c|c|c|}
\hline Analyte & $\begin{array}{c}\text { Maximum } \\
\text { Contaminant Levela }\end{array}$ & Units & Status & Reference $^{b}$ \\
\hline $\begin{array}{l}\text { 1,4-Dichlorobenzene } \\
\text { (p-Dichlorobenzene) }\end{array}$ & 0.075 & $\mathrm{mg} / \mathrm{L}$ & final & CFR \\
\hline 1,2-Dichloroethane & 0.005 & $\mathrm{mg} / \mathrm{L}$ & final & CFR \\
\hline 1,1-Dichloroethylene & 0.007 & $\mathrm{mg} / \mathrm{L}$ & final & CFR \\
\hline cis-1,2-Dichloroethylene & 0.07 & $\mathrm{mg} / \mathrm{L}$ & final & CFR \\
\hline trans-1,2-Dichloroethylene & 0.1 & $\mathrm{mg} / \mathrm{L}$ & final & CFR \\
\hline $\begin{array}{l}\text { Dichloromethane } \\
\text { (Methylene chloride) }\end{array}$ & 0.005 & $\mathrm{mg} / \mathrm{L}$ & final & CFR \\
\hline $\begin{array}{l}\text { 2,4-Dichlorophenoxyacetic acid } \\
(2,4-D)\end{array}$ & 0.07 & $\mathrm{mg} / \mathrm{L}$ & final & CFR \\
\hline 1,2-Dichloropropane & 0.005 & $\mathrm{mg} / \mathrm{L}$ & final & CFR \\
\hline Di(2-ethylhexyl) adipate (Deha) & 0.4 & $\mathrm{mg} / \mathrm{L}$ & final & CFR \\
\hline $\begin{array}{l}\text { Di(2-ethylhexyl) phthalate } \\
\text { [Bis(2-ethylhexyl) phthalate] }\end{array}$ & 0.006 & $\mathrm{mg} / \mathrm{L}$ & final & CFR \\
\hline $\begin{array}{l}\text { Dioxin }(2,3,7,8-T C D D) \\
(2,3,7,8-T C D D)\end{array}$ & $3.00 E-08$ & $\mathrm{mg} / \mathrm{L}$ & final & CFR \\
\hline $\begin{array}{l}\text { Diquat } \\
\text { (Diquat dibromide) }\end{array}$ & 0.02 & $\mathrm{mg} / \mathrm{L}$ & final & CFR \\
\hline Endothall & 0.1 & $\mathrm{mg} / \mathrm{L}$ & final & CFR \\
\hline Endrin & 0.002 & $\mathrm{mg} / \mathrm{L}$ & final & CFR \\
\hline Ethylbenzene & 0.7 & $\mathrm{mg} / \mathrm{L}$ & final & CFR \\
\hline $\begin{array}{l}\text { Ethylene dibromide } \\
\text { (1,2-Dibromoethane) }\end{array}$ & 0.00005 & $\mathrm{mg} / \mathrm{L}$ & final & CFR \\
\hline Fluoride & 4 & $\mathrm{mg} / \mathrm{L}$ & final & CFR \\
\hline Glyphosate & 0.7 & $\mathrm{mg} / \mathrm{L}$ & final & CFR \\
\hline Gross alpha & 15 & $\mathrm{pCi} / \mathrm{L}$ & final & CFR \\
\hline Heptachlor & 0.0004 & $\mathrm{mg} / \mathrm{L}$ & final & CFR \\
\hline Heptachlor epoxide & 0.0002 & $\mathrm{mg} / \mathrm{L}$ & final & CFR \\
\hline Hexachlorobenzene & 0.001 & $\mathrm{mg} / \mathrm{L}$ & final & CFR \\
\hline Hexachlorocyclopentadiene & 0.05 & $\mathrm{mg} / \mathrm{L}$ & final & CFR \\
\hline Lead & $0.05^{c}$ & $\mathrm{mg} / \mathrm{L}$ & final & SCDHEC \\
\hline Lindane & 0.0002 & $\mathrm{mg} / \mathrm{L}$ & final & CFR \\
\hline Mercury & 0.002 & $\mathrm{mg} / \mathrm{L}$ & final & CFR \\
\hline Methoxychlor & 0.04 & $\mathrm{mg} / \mathrm{L}$ & final & CFR \\
\hline Nickel & 0.1 & $\mathrm{mg} / \mathrm{L}$ & final & CFR \\
\hline Nitrate + Nitrite (As N) & 10 & $\mathrm{mg} / \mathrm{L}$ & final & CFR \\
\hline Nitrate (as N) & 10 & $\mathrm{mg} / \mathrm{L}$ & final & CFR \\
\hline Nitrite (as N) & 1 & $\mathrm{mg} / \mathrm{L}$ & final & CFR \\
\hline Nonvolatile beta & 4 & mrem/yr & final & CFR \\
\hline Oxamyl (Vydate) & 0.2 & $\mathrm{mg} / \mathrm{L}$ & final & CFR \\
\hline
\end{tabular}




\begin{tabular}{|c|c|c|c|c|}
\hline Analyte & $\begin{array}{c}\text { Maximum } \\
\text { Contaminant Level }\end{array}$ & Units & Status & Reference $^{b}$ \\
\hline $\begin{array}{l}\text { Polychlorinated Biphenyls } \\
\text { (PCBs) }\end{array}$ & 0.0005 & $\mathrm{mg} / \mathrm{L}$ & final & CFR \\
\hline Pentachlorophenol & 0.001 & $\mathrm{mg} / \mathrm{L}$ & final & CFR \\
\hline Picloram & 0.5 & $\mathrm{mg} / \mathrm{L}$ & final & CFR \\
\hline $\begin{array}{l}\text { Total Radium (Radium-226 and } \\
\text { Radium-228) }\end{array}$ & 5 & $\mathrm{pCi} / \mathrm{L}$ & final & CFR \\
\hline Selenium & 0.05 & $\mathrm{mg} / \mathrm{L}$ & final & CFR \\
\hline Simazine & 0.004 & $\mathrm{mg} / \mathrm{L}$ & final & CFR \\
\hline Strontium-89/90 & $8 \mathrm{E}+00^{c}$ & $\mathrm{pCi} / \mathrm{L}$ & final & CFR \\
\hline Strontium-90 & $8 \mathrm{E}+00$ & $\mathrm{pCi} / \mathrm{L}$ & final & CFR \\
\hline Styrene & 0.1 & $\mathrm{mg} / \mathrm{L}$ & final & CFR \\
\hline Tetrachloroethylene & 0.005 & $\mathrm{mg} / \mathrm{L}$ & final & CFR \\
\hline Thallium & 0.002 & $\mathrm{mg} / \mathrm{L}$ & final & CFR \\
\hline Toluene & 1.0 & $\mathrm{mg} / \mathrm{L}$ & final & CFA \\
\hline $\begin{array}{l}\text { Total Trihalomethanes } \\
\text { (includes bromodichloro- } \\
\text { methane, bromoform, } \\
\text { chloroform, and } \\
\text { dibromochloromethane) }\end{array}$ & 0.1 & $\mathrm{mg} / \mathrm{L}$ & final & CFR \\
\hline Toxaphene & 0.003 & $\mathrm{mg} / \mathrm{L}$ & final & CFR \\
\hline 2,4,5-TP (Silvex) & 0.05 & $\mathrm{mg} / \mathrm{L}$ & final & CFR \\
\hline 1,2,4-Trichlorobenzene & 0.07 & $\mathrm{mg} / \mathrm{L}$ & final & CFR \\
\hline $1,1,1$-Trichloroethane & 0.2 & $\mathrm{mg} / \mathrm{L}$ & final & CFR \\
\hline 1,1,2-Trichloroethane & 0.005 & $\mathrm{mg} / \mathrm{L}$ & final & CFR \\
\hline Trichloroethylene & 0.005 & $\mathrm{mg} / \mathrm{L}$ & final & CFR \\
\hline Tritium & $2 E+01$ & $\mathrm{pCi} / \mathrm{mL}$ & final & CFR \\
\hline Xylenes & 10 & $\mathrm{mg} / \mathrm{L}$ & final & CFR \\
\hline
\end{tabular}

\section{References:}

CFR (Code of Federal Regulations), 1998. "National Primary Drinking Water Regulations," 40 CFR, Part 141, Washington, D.C.

SCDHEC (South Carolina Department of Health and Environmental Control), 1981. "State Primary Drinking Water Regulations," R.61-58.5, Columbia, S.C.

a Standards for beta- and gamma-emitting radionuclides are based on the 4-mrem/yr whole-body dose [CFR].

b Bibliographical information conceming the references is included at the end of this table below.

c For double radionuclide analyses where each separate radionuclide has its own standard, the more stringent standard is used.

d EMS does not test for total trihalomethanes, but each of these analytes is tested separately. 


\section{Appendix C}

\section{Standard No. 8 Toxic Air Pollutants}

\begin{tabular}{lccc}
\hline Chemical Name & $\begin{array}{c}\text { Chemical Abstract } \\
\text { Number (CAS) }\end{array}$ & $\begin{array}{c}\text { Toxicity } \\
\text { Category }\end{array}$ & $\begin{array}{c}\text { Maximum Allowable } \\
\text { Concentration }\left(\mu \mathrm{g} / \mathrm{m}^{3}\right)^{\mathrm{b}}\end{array}$ \\
\hline
\end{tabular}

Note: For all listings that contain the word "compounds" and for glycol ethers, the following applies: Unless otherwise specified, these listings are defined as including any unique chemical substance that contains the named chemical (i.e., antimony, arsenic, etc.) as part of that chemical infrastructure.

\begin{tabular}{|c|c|c|c|}
\hline Acetaldehyde & $75-07-0$ & 2 & 1800.00 \\
\hline Acetamide & $60-35-5$ & 3 & c \\
\hline Acetic Anhydride & $108-24-7$ & 1 & 500.00 \\
\hline Acetonitrile & $75-05-8$ & 1 & 1750.00 \\
\hline Acetophenone & $98-86-2$ & 3 & c \\
\hline 2-Acetylaminofluorne & $53-96-3$ & 3 & c \\
\hline Acrolein & $107-02-8$ & 3 & 1.25 \\
\hline Acrylamide & $79-06-1$ & 2 & 0.30 \\
\hline Acrylic Acid & $79-10-7$ & 3 & 147.50 \\
\hline Acrylonitrile & $107-13-1$ & 3 & 22.50 \\
\hline Aldicarb & $116-06-3$ & 2 & 6.00 \\
\hline Allyl Chloride & $107-05-1$ & 2 & 30.00 \\
\hline p-Aminodiphenyl (4-Aminobiphenyl) & $92-67-1$ & 3 & 0.00 \\
\hline Ammonium Chloride & $12125-02-9$ & 1 & 250.00 \\
\hline Aniline & $62-53-3$ & 3 & 50.00 \\
\hline o-Anisidine & $90-04-0$ & 3 & 2.50 \\
\hline p-Anisidine & $104-94-9$ & 3 & 2.50 \\
\hline Antimony Compounds & d & 1 & 2.50 \\
\hline Arsenic Pentoxide & $1303-28-2$ & 3 & 1.00 \\
\hline Arsenic & $7440-38-2$ & 3 & 1.00 \\
\hline Benzene & $71-43-2$ & 3 & 150.00 \\
\hline Benzidine & $92-87-5$ & 3 & 0.00 \\
\hline Benzotrichloride & $98-07-7$ & 3 & 300.00 \\
\hline Benzyl Chloride & $100-44-7$ & 3 & 25.00 \\
\hline Beryllium Oxide & $1304-56-9$ & 3 & 0.01 \\
\hline Beryllium Sulfate & $13510-49-1$ & 3 & 0.01 \\
\hline Beryllium & $7440-41-7$ & 3 & 0.01 \\
\hline Biphenyl & $92-52-4$ & 3 & 6.00 \\
\hline Bis(Chloromethyl) Ether & $542-88-1$ & 3 & 0.03 \\
\hline Bis(2-ethylhexyl)phthalate (DEHP) & $117-81-7$ & 3 & 25.00 \\
\hline
\end{tabular}

a Category $1=$ low toxicity; category $2=$ moderate toxicity; and category $3=$ high toxicity.

b For the purpose of this standard, these values shall be rounded to the nearest hundredth of a $\mu \mathrm{g} / \mathrm{m}^{3}$. For example, a test or modeled value of 0.005 through 0.01 would be rounded to 0.01 , but values less than 0.005 would be rounded to 0.00 .

c To be determined

d No CAS number 


\begin{tabular}{|c|c|c|c|}
\hline Chemical Name & $\begin{array}{l}\text { Chemical Abstract } \\
\text { Number (CAS) }\end{array}$ & $\begin{array}{c}\text { Toxicity } \\
\text { Category }\end{array}$ & $\begin{array}{c}\text { Maximum Allowable } \\
\text { Concentration }\left(\mu \mathrm{g} / \mathrm{m}^{3}\right)^{\mathrm{b}}\end{array}$ \\
\hline Bromoform & $75-25-2$ & 3 & 25.85 \\
\hline 1,3-Butadiene & $106-99-0$ & 3 & 110.50 \\
\hline 1-Butanethiol (n-Butyl Mercaptan) & $109-79-5$ & 2 & 15.00 \\
\hline n-Butylamine & $109-73-9$ & 3 & 75.00 \\
\hline Cadmium Oxide & $1306-19-0$ & 3 & 0.25 \\
\hline Cadmium Sulfate & $10124-36-4$ & 3 & 0.20 \\
\hline Cadmium & $7440-43-9$ & 3 & 0.25 \\
\hline Calcium Cyanamide & $156-62-7$ & 3 & 2.50 \\
\hline Caprolactam, vapor & $105-60-2$ & 1 & 500.00 \\
\hline Caprolactam, dust & $105-60-2$ & 1 & 25.00 \\
\hline Captan & $133-06-2$ & 3 & 25.00 \\
\hline Carbaryl & $63-25-2$ & 3 & 25.00 \\
\hline Carbon Disulfide & $75-15-0$ & 3 & 150.00 \\
\hline Carbon Tetrachloride & $56-23-5$ & 3 & 150.00 \\
\hline Carbonyl Sulfide & $463-58-1$ & 3 & 12250.00 \\
\hline Catechol & $120-80-9$ & 3 & 297.00 \\
\hline Chloramben & $133-90-4$ & 3 & c \\
\hline Chlordane & $57-74-9$ & 3 & 2.50 \\
\hline Chlorine & $7782-50-5$ & 1 & 75.00 \\
\hline Chloroacetic Acid & $79-11-8$ & 3 & 900.00 \\
\hline 2-Chloroacetophenone & $532-27-4$ & 1 & 7.50 \\
\hline Chlorobenzene & $108-90-7$ & 3 & 1725.00 \\
\hline Chlorobenzilate & $510-15-6$ & 3 & c \\
\hline Chloroform & $67-66-3$ & 3 & 250.00 \\
\hline Chloromethyl Methyl Ether & $107-30-2$ & 3 & c \\
\hline $\mathrm{p}$-Chloronitrobenzene & $100-00-5$ & 3 & 5.00 \\
\hline Chloroprene & $126-99-8$ & 3 & 175.00 \\
\hline Chromium(+6) Compounds & $d$ & 3 & 2.50 \\
\hline Cobalt Compounds & d & 3 & 0.25 \\
\hline Coke Oven Emissions & $d$ & 3 & c \\
\hline Cresols/cresylic acid and mixture & $1319-77-3$ & 3 & 220.00 \\
\hline m-Cresol & $108-39-4$ & 3 & 110.50 \\
\hline o-Cresol & $95-48-7$ & 3 & 110.50 \\
\hline p-Cresol & $106-44-5$ & 3 & 110.50 \\
\hline Cumene & $98-82-8$ & 2 & $9.00^{e}$ \\
\hline Cyanamide & $420-04-2$ & 1 & 50.00 \\
\hline
\end{tabular}

a Category 1 = low toxicity; category 2 = moderate toxicity; and category $3=$ high toxicity.

b For the purpose of this standard, these values shall be rounded to the nearest hundredth of a $\mu \mathrm{g} / \mathrm{m}^{3}$. For example, a test or modeled value of 0.005 through 0.01 would be rounded to 0.01 , but values less than 0.005 would be rounded to 0.00 .

c To be determined

d No CAS number

$e \quad$ Verified reference concentration (RfC) established by the U.S. Environmental Protection Agency 


\begin{tabular}{|c|c|c|c|}
\hline Chemical Name & $\begin{array}{c}\text { Chemical Abstract } \\
\text { Number (CAS) }\end{array}$ & $\begin{array}{c}\text { Toxicity } \\
\text { Categorya }\end{array}$ & $\begin{array}{l}\text { Mbaximum Allowable } \\
\text { Concentration }\left(\mu \mathrm{g} / \mathrm{m}^{3}\right)^{b}\end{array}$ \\
\hline Cyanic Acid & $420-05-3$ & 1 & 500.00 \\
\hline Cyanide & $57-12-5$ & 1 & 125.00 \\
\hline Cyanide compounds ${ }^{c}$ & d & 1 & e \\
\hline Cyanoacetamide & $107-91-5$ & 1 & 125.00 \\
\hline Cyanogen & $460-19-5$ & 1 & 500.00 \\
\hline $2,4-D$, salts and esters & $94-75-7$ & 3 & 50.00 \\
\hline DDE & $3547-04-4$ & 3 & e \\
\hline Diazomethane & $334-88-3$ & 3 & 2.00 \\
\hline Dibenzofuran & $132-64-9$ & 3 & e \\
\hline 1,2-Dibromo-3-chloropropane & $96-12-8$ & 3 & 0.05 \\
\hline Dibutylphthalate & $84-74-2$ & 3 & 25.00 \\
\hline p-Dichlorobenzene & $106-46-7$ & 2 & 4500.00 \\
\hline 3,3-Dichlorobenzidine & $91-94-1$ & 3 & 0.15 \\
\hline 1,3-Dichloropropene & $542-75-6$ & 3 & $20.00^{f}$ \\
\hline Dichlorvos & $62-73-7$ & 3 & 4.52 \\
\hline Diethanolamine & $111-42-2$ & 2 & 129.00 \\
\hline $\mathrm{n}, \mathrm{n}$-Diethylaniline(n,n-Dimethylaniline) & $121-69-7$ & 2 & 250.00 \\
\hline Diethyl Phthalate & $84-66-2$ & 3 & 25.00 \\
\hline Diethyl Sulfate & $64-67-5$ & 3 & e \\
\hline Diisodecyl Phthalate & $2671-40-0$ & 2 & 50.00 \\
\hline 3,3-Dimethoxybenzidine & $119-90-4$ & 3 & 0.30 \\
\hline 3,3'-Dimethyl Benzidine & $119-93-7$ & 3 & e \\
\hline Dimethyl Carbamoyl Chloride & $79-44-7$ & 3 & e \\
\hline Dimethyl Formamide & $68-12-2$ & 2 & 300.00 \\
\hline 1,1-Dimethyl Hydrazine & $57-14-7$ & 3 & 5.00 \\
\hline 1,2-Dimethyl Hydrazine & $540-73-8$ & 3 & 5.00 \\
\hline Dimethyl Phthalate & $131-11-3$ & 3 & 25.00 \\
\hline Dimethyl Sulfate & $77-78-1$ & 3 & 2.50 \\
\hline 4-Dimethylaminoazobenzene & $60-11-7$ & 3 & 125.00 \\
\hline m-Dinitrobenzene & $99-65-0$ & 2 & 10.00 \\
\hline 4,6-Dinitro-o-cresol and salts & $534-52-1$ & 2 & 2.00 \\
\hline 2,4-Dinitrophenol & $51-28-5$ & 3 & e \\
\hline 2,4-Dinitrotoluene & $121-14-2$ & 3 & 1.50 \\
\hline Dioctyl Phthalate & $117-84-0$ & 2 & 50.00 \\
\hline 1,4-Dioxane & $123-91-1$ & 3 & 450.00 \\
\hline
\end{tabular}

\footnotetext{
a Category 1 = low toxicity; category 2 = moderate toxicity; and category 3 = high toxicity.

b For the purpose of this standard, these values shall be rounded to the nearest hundredth of a $\mu \mathrm{g} / \mathrm{m}^{3}$. For example, a test or modeled value of 0.005 through 0.01 would be rounded to 0.01 , but values less than 0.005 would be rounded to 0.00 .

c $\mathrm{XCN}$ where $\mathrm{X}=\mathrm{H}+$ or any other group where a formal dissociation may occur. For example, $\mathrm{KCN}$ or $\mathrm{Ca}(\mathrm{CN})_{2}$.

d No CAS number

a To be determined

$f$ Verified reference concentration (RfC) established by the U.S. Environmental Protection Agency
} 


\begin{tabular}{|c|c|c|c|}
\hline Chemical Name & $\begin{array}{l}\text { Chemical Abstract } \\
\text { Number (CAS) }\end{array}$ & $\begin{array}{c}\text { Toxicity } \\
\text { Categorya }\end{array}$ & $\begin{array}{c}\text { Maximum Allowable } \\
\text { Concentration }\left(\mu \mathrm{g} / \mathrm{m}^{3}\right)^{\mathrm{b}}\end{array}$ \\
\hline 1,2-Diphenylhydrazine & $122-66-7$ & 3 & $c$ \\
\hline Epichlorohydrin & $106-89-8$ & 3 & 50.00 \\
\hline 1,2-Epoxybutane & $106-88-7$ & 3 & c \\
\hline Ethanethiol & $75-08-1$ & 2 & 10.00 \\
\hline Ethanolamine & $141-43-5$ & 1 & 200.00 \\
\hline Ethyl Acrylate & $140-88-5$ & 3 & 102.50 \\
\hline Ethyl Benzene & $100-41-4$ & 2 & 4350.00 \\
\hline Ethyl Chloride & $75-00-3$ & 2 & 26400.00 \\
\hline Ethylene Dibromide & $106-93-4$ & 2 & 770.00 \\
\hline Ethylene Dichloride & $107-06-2$ & 3 & 200.00 \\
\hline Ethylene Glycol & $107-21-1$ & 3 & 650.00 \\
\hline Ethylene Oxide & $75-21-8$ & 3 & 10.00 \\
\hline Ethylene Thiourea & $96-45-7$ & 3 & c \\
\hline Ethylene Imine & $151-56-4$ & 3 & 5.00 \\
\hline Ethylidene Dichloride & $75-34-3$ & 3 & 2025.00 \\
\hline Formaldehyde & $50-00-0$ & 2 & 15.00 \\
\hline Formamide & $75-12-7$ & 1 & 750.00 \\
\hline Formic Acid & $64-18-6$ & 1 & 225.00 \\
\hline Furfural & $98-01-1$ & 1 & 200.00 \\
\hline Furfuryl Alcohol & $98-00-0$ & 2 & 400.00 \\
\hline Glycidaldehyde & $765-34-4$ & 3 & 75.00 \\
\hline $\begin{array}{l}\text { Glycol Ethers }{ }^{d} \\
\text { (mono- and di-ethers of diethylene glycol } \\
\text { or triethylene glycol) }\end{array}$ & e & 1 & $c$ \\
\hline $\begin{array}{l}\text { Glycol Ethers } \\
\text { (mono- and di-ethers of ethylene glycol) }\end{array}$ & $\mathrm{e}$ & 3 & $c$ \\
\hline Heptachlor & $76-44-8$ & 3 & 2.50 \\
\hline Hexachlorobenzene & $118-74-1$ & 3 & c \\
\hline Hexachlorobutadiene & $87-68-3$ & 3 & 1.20 \\
\hline Hexachlorocyclohexane (multiple isomers) & $608-73-1$ & 2 & 5.00 \\
\hline Hexachlorocylopentadiene & $77-47-4$ & 3 & 0.50 \\
\hline Hexachloroethane & $67-72-1$ & 3 & 48.50 \\
\hline Hexachloronapthalene & $1335-87-1$ & 3 & 1.00 \\
\hline Hexamethylene-1, 6-diisocyanate & $822-06-0$ & 2 & 0.34 \\
\hline Hexamethylphosphoramide & $680-31-9$ & 3 & 14.50 \\
\hline
\end{tabular}

a Category $1=$ low toxicity; category 2 moderate toxicity; and category $3=$ high toxicity.

b For the purpose of this standard, these values shall be rounded to the nearest hundredth of a $\mu \mathrm{g} / \mathrm{m}^{3}$. For example, a test or modeled value of 0.005 through 0.01 would be rounded to 0.01 , but values less than 0.005 would be rounded to 0.00 .

c To be determined

d Includes mono- and di-ethers of ethylene glycol, diethylene glycol, and triethylene glycol R- $\left(\mathrm{OCH}_{2} \mathrm{CH}_{2}\right) \mathrm{n}-\mathrm{OR}^{\prime}$, where $n=1,2$, or 3; $R=$ alkyl or aryl groups; and $R^{\prime}=R, H$, or groups which, when removed, yield glycol ethers with the structure: $\mathrm{R}-\left(\mathrm{OCH}_{2} \mathrm{CH}\right) \mathrm{n}-\mathrm{OH}$. Polymers are excluded from the glycol category.

e No CAS number 


\begin{tabular}{|c|c|c|c|}
\hline Chemical Name & $\begin{array}{l}\text { Chemical Abstract } \\
\text { Number (CAS) }\end{array}$ & $\begin{array}{c}\text { Toxicity } \\
\text { Categorya }\end{array}$ & $\begin{array}{c}\text { Maximum Allowable } \\
\text { Concentration }\left(\mu \mathrm{g} / \mathrm{m}^{3}\right)^{b}\end{array}$ \\
\hline Hexane & $110-54-3$ & 3 & 900.00 \\
\hline Hydrazine & $302-01-2$ & 3 & 0.50 \\
\hline Hydrochloric Acid & $7647-01-0$ & 1 & 175.00 \\
\hline Hydrogen Cyanide & $74-90-8$ & 1 & 250.00 \\
\hline Hydrogen Sulfide & $7783-06-4$ & 2 & 140.00 \\
\hline Hydroquinone & $123-31-9$ & 2 & 20.00 \\
\hline Isophorone & $78-59-1$ & 2 & 250.00 \\
\hline Isopropylamine & $75-31-0$ & 1 & 300.00 \\
\hline Kepone (Chlordecone) & $143-50-0$ & 3 & 0.00 \\
\hline Ketene & $463-51-4$ & 3 & 4.50 \\
\hline Lead Arsenate & $7645-25-2$ & 3 & 0.75 \\
\hline Lead(+2) Arsenate & $7784-40-9$ & 3 & 0.75 \\
\hline Lindane & $58-89-9$ & 3 & 2.50 \\
\hline Malathion & $121-75-5$ & 2 & 100.00 \\
\hline Maleic Anhydride & $108-31-6$ & 2 & 10.00 \\
\hline Manganese Compounds & c & 3 & 25.00 \\
\hline Mercury & $7439-97-6$ & 3 & 0.25 \\
\hline Methanol & $67-56-1$ & 3 & 1310.00 \\
\hline Methoxychlor & $72-43-5$ & 3 & 50.00 \\
\hline Methyl Bromide & $74-83-9$ & 3 & 100.00 \\
\hline Methyl Chloride & $74-87-3$ & 3 & 515.00 \\
\hline Methyl Chloroform (1,1,1- Trichloroethane) & $71-55-6$ & 3 & 9550.00 . \\
\hline Methylene Biphenyl Isocyanate & $101-68-8$ & 2 & 2.00 \\
\hline 4,4-Methylene Bis (2-chloroaniline) & $101-14-4$ & 3 & 1.10 \\
\hline 4,4-Methylenedianiline & $101-77-9$ & 3 & 4.00 \\
\hline Methyl Ethyl Ketone (2-Butone) & $78-93-3$ & 1 & 14750.00 \\
\hline Methyl Hydrazine & $60-34-4$ & 3 & 1.75 \\
\hline Methyl lodide & $74-88-4$ & 3 & 58.00 \\
\hline Methyl Isobutyl Ketone & $108-10-1$ & 2 & 2050.00 \\
\hline Methyl Isocyanate & $624-83-9$ & 3 & 0.23 \\
\hline Methyl Mercaptan & $74-93-1$ & 2 & 10.00 \\
\hline Methyl Methacrylate & $80-62-6$ & 1 & 10250.00 \\
\hline Methylamine & $74-89-5$ & 1 & 300.00 \\
\hline Methylene Chloride & $75-09-2$ & 1 & 8750.00 \\
\hline Methyl-t-Butyl Ether & $1634-04-4$ & 1 & $d$ \\
\hline
\end{tabular}

a Category 1 = low toxicity; category 2 = moderate toxicity; and category 3 = high toxicity.

b For the purpose of this standard, these values shall be rounded to the nearest hundredth of a $\mu \mathrm{g} / \mathrm{m}^{3}$. For example, a test or modeled value of 0.005 through 0.01 would be rounded to 0.01 , but values less than 0.005 would be rounded to 0.00 .

c No CAS number

d To be determined 


\begin{tabular}{|c|c|c|c|}
\hline Chemical Name & $\begin{array}{c}\text { Chemical Abstract } \\
\text { Number (CAS) }\end{array}$ & $\begin{array}{c}\text { Toxicity } \\
\text { Category }\end{array}$ & $\begin{array}{c}\text { Maximum Allowable } \\
\text { Concentration }\left(\mu \mathrm{g} / \mathrm{m}^{3}\right)^{\mathrm{b}}\end{array}$ \\
\hline Mineral Fibers, Fine ${ }^{c}$ & $\bar{d}$ & 3 & $\bar{e}$ \\
\hline Mineral Oil Mist (Paraffin Oil) & $8012-95-1$ & 3 & 25.00 \\
\hline Mirex & $2385-85-5$ & 3 & 4500.00 \\
\hline Naphthalene & $91-20-3$ & 1 & 1250.00 \\
\hline a-Naphthylamine & $134-32-7$ & 3 & 0.00 \\
\hline b-Naphthylamine & $91-59-8$ & 3 & 0.00 \\
\hline Nickel Carbonyl & $13463-39-3$ & 3 & 1.75 \\
\hline Nickel Oxide & $1313-99-1$ & 3 & 5.00 \\
\hline Nickel Sulfate & $7786-81-4$ & 3 & 5.00 \\
\hline Nickel & $7440-02-0$ & 3 & 0.50 \\
\hline Nitric Acid & $7697-37-2$ & 1 & 125.00 \\
\hline p-Nitroaniline & $100-01-6$ & 3 & 15.00 \\
\hline Nitrobenzene & $98-95-3$ & 3 & 25.00 \\
\hline 4-Nitrobiphenyl & $92-93-3$ & 3 & 0.00 \\
\hline Nitrogen Mustard & $51-75-2$ & 3 & 0.00 \\
\hline Nitroglycerin & $55-63-0$ & 2 & 5.00 \\
\hline p-Nitrophenol & $100-02-7$ & 3 & 0.00 \\
\hline 1-Nitropropane & $108-03-2$ & 1 & 2250.00 \\
\hline 2-Nitropropane & $79-46-9$ & 3 & 182.00 \\
\hline p-Nitrosophenol & $104-91-6$ & 3 & 0.00 \\
\hline n-Nitroso-n-methylurea & $684-93-5$ & 3 & e \\
\hline n-Nitrosodimethylamine & $62-75-9$ & 3 & 0.00 \\
\hline n-Nitrosomorpholine & $59-89-2$ & 3 & 5000.00 \\
\hline p-Nitrotoluene & $99-99-0$ & 3 & 5.50 \\
\hline Octachloronaphthalene & $2234-13-1$ & 3 & 0.50 \\
\hline Oxalic Acid & $144-62-7$ & 2 & 10.00 \\
\hline Paraquat & $1910-42-5$ & 3 & 0.50 \\
\hline Parathion & $56-38-2$ & 3 & 0.50 \\
\hline Pentachloronitrobenzene (Quintobenzene) & $82-68-8$ & 3 & e \\
\hline Pentachlorophenol & $87-86-5$ & 2 & 5.00 \\
\hline Phenol & $108-95-2$ & 2 & 190.00 \\
\hline p-Phenylenediamine & $106-50-3$ & 2 & 1.00 \\
\hline Phenylhydrazine & $100-63-0$ & 2 & 200.00 \\
\hline Phosgene (Carbonyl Chloride) & $75-44-5$ & 2 & 4.00 \\
\hline Phosphine & $7803-51-2$ & 3 & 2.09 \\
\hline
\end{tabular}

a Category $1=$ low toxicity; category $2=$ moderate toxicity; and category $3=$ high toxicity.

b For the purpose of this standard, these values shall be rounded to the nearest hundredth of a $\mu \mathrm{g} / \mathrm{m}^{3}$. For example, a test or modeled value of 0.005 through 0.01 would be rounded to 0.01 , but values less than 0.005 would be rounded to 0.00 .

c Includes mineral fiber emissions from facilities manufacturing or processing glass, rock, and slag fibers (or other mineral-derived fibers) of average diameter 1 micrometer or less

d No CAS number

e To be determined 


\begin{tabular}{|c|c|c|c|}
\hline Chemical Name & $\begin{array}{l}\text { Chemical Abstract } \\
\text { Number (CAS) }\end{array}$ & $\begin{array}{c}\text { Toxicity } \\
\text { Categorya }\end{array}$ & $\begin{array}{c}\text { Maximum Allowable } \\
\text { Concentration }\left(\mu \mathrm{g} / \mathrm{m}^{3}\right)^{\mathrm{b}}\end{array}$ \\
\hline Phosphoric Acid & $7664-38-2$ & 1 & 25.00 \\
\hline Phosphorus & $7723-14-0$ & 2 & 0.50 \\
\hline Phthalic Anhydride & $85-44-9$ & 3 & 30.30 \\
\hline Picric Acid & $88-89-1$ & 2 & 1.00 \\
\hline $\begin{array}{l}\text { Polychlorinated Biphenyls (PCB) } \\
\text { (multiple compounds) }\end{array}$ & c & 3 & 2.50 \\
\hline Polycyclic Organic Matter & c & 3 & 160.00 \\
\hline 1,3-Propane Sultone & $1120-71-4$ & 3 & e \\
\hline b-Propiolactone & $57-57-8$ & 3 & 7.50 \\
\hline Proprionaldehyde & $123-38-6$ & 1 & e \\
\hline Propoxur & $114-26-1$ & 3 & 2.50 \\
\hline Propylene Dichloride & $78-87-5$ & 3 & 1750.00 \\
\hline Propylene Oxide & $75-56-9$ & 3 & 250.00 \\
\hline 1,2-Propylenimine & $75-55-8$ & 3 & 23.35 \\
\hline Pyrethrin I & $121-21-1$ & 3 & 25.00 \\
\hline Pyrethrin II & $121-29-9$ & 3 & 25.00 \\
\hline Pyrethrum & $8003-34-7$ & 2 & 50.00 \\
\hline Quinoline & $91-22-5$ & 3 & e \\
\hline Quinone & $106-51-4$ & 3 & 2.00 \\
\hline Rotenone & $83-79-4$ & 2 & 50.00 \\
\hline Selenium Compounds & c & 3 & 1.00 \\
\hline Sodium Hydroxide ${ }^{f}$ & $1310-73-2$ & 1 & 50.00 \\
\hline Styrene & $100-42-5$ & 1 & 5325.00 \\
\hline Styrene Oxide & $96-09-3$ & 3 & e \\
\hline Sulfuric Acid & $7664-93-9$ & 2 & 10.00 \\
\hline Tetrachlorinate Dibenzo-p-dioxins & $1746-01-6$ & 3 & 0.00 \\
\hline $\begin{array}{l}\text { 1,1,2,2-Tetrachloroethane } \\
\text { (Acetylene Tetrachloride) }\end{array}$ & $79-34-5$ & 3 & 35.00 \\
\hline Tetrachloroethylene (Perchloroethylene) & $127-18-4$ & 2 & 3350.00 \\
\hline Titanium Tetrachloride & $7550-45-0$ & 1 & 2500.00 \\
\hline Toluene & $108-88-3$ & 3 & 2000.00 \\
\hline 2,4-Toluenediamine & $95-80-7$ & 3 & e \\
\hline Toluene Diisocyanate & $26471-62-5$ & 2 & 0.40 \\
\hline Toluene-2,4-disocyanate & $584-84-9$ & 2 & 0.40 \\
\hline o-Toluidine & $95-53-4$ & 3 & 43.85 \\
\hline
\end{tabular}

a Category $1=$ low toxicity; category 2 = moderate toxicity; and category $3=$ high toxicity.

$b$ For the purpose of this standard, these values shall be rounded to the nearest hundredth of a $\mu \mathrm{g} / \mathrm{m}^{3}$. For example, a test or modeled value of 0.005 through 0.01 would be rounded to 0.01 , but values less than 0.005 would be rounded to 0.00 .

c No CAS number

d Includes organic compounds with more than one benzene ring and that have a boiling point greater than or equal to $100^{\circ} \mathrm{C}$

e To be determined

$f$ The use of sodium hydroxide in a scrubber for air pollution control purposes is exempt from this standard. 


\begin{tabular}{lccc}
\hline Chemical Name & $\begin{array}{c}\text { Chemical Abstract } \\
\text { Number (CAS) }\end{array}$ & $\begin{array}{c}\text { Toxicity } \\
\text { Category }\end{array}$ & $\begin{array}{c}\text { Maximum Allowable } \\
\text { Concentration }\left(\mu \mathrm{g}^{3} \mathbf{m}^{\mathbf{b}}\right)^{\mathrm{b}}\end{array}$ \\
\hline Toxaphene & $8001-35-2$ & 3 & 2.50 \\
$1,2,4-$ Trichlorobenzene & $120-82-1$ & 2 & 400.00 \\
$1,1,2-$ Trichloroethane & $79-00-5$ & 3 & 273.00 \\
Trichloroethylene & $79-01-6$ & 1 & 6750.00 \\
$2,4,5-$ Trichlorophenol & $95-95-4$ & 3 & $\mathrm{c}$ \\
2,4,6-Trichlorophenol & $88-06-2$ & 3 & $\mathrm{c}$ \\
Triethylamine & $121-44-8$ & 3 & 207.00 \\
Trifluralin & $1582-09-8$ & 3 & $\mathrm{c}$ \\
$2,2,4-$ Trimethylpentane & $540-84-1$ & 1 & 8750.00 \\
Urethane (Carbamic Acid Ethyl Ester) & $51-79-6$ & 2 & 5000.00 \\
Vinyl Acetate & $108-05-4$ & 3 & 176.00 \\
Vinyl Bromide & $593-60-2$ & 3 & 100.00 \\
Vinyl Chloride & $75-01-4$ & 3 & 50.00 \\
Vinyl Fluoride & $75-02-5$ & 2 & 19.00 \\
Vinylidene chloride & $75-35-4$ & 3 & 99.00 \\
Xylene & $1330-20-7$ & 2 & 4350.00 \\
m-Xylene & $108-38-3$ & 2 & 4350.00 \\
O-Xylene & $95-47-6$ & 2 & 4350.00 \\
p-Xylene & $106-42-3$ & 2 & 4350.00 \\
Xylidine & $1300-73-8$ & 3 & 50.00
\end{tabular}

a Category 1 = low toxicity; category 2 = moderate toxicity; and category $3=$ high toxicity.

$\mathrm{b}$ For the purpose of this standard, these values shall be rounded to the nearest hundredth of a $\mu \mathrm{g} / \mathrm{m}^{3}$. For example, a test or modeled value of 0.005 through 0.01 would be rounded to 0.01 , but values less than 0.005 would be rounded to 0.00 .

c To be determined 


\section{Appendix D \\ Radionuclide and Chemical \\ Nomenclature}

\begin{tabular}{|c|c|c|c|c|c|}
\hline \multicolumn{6}{|c|}{ Nomenclature and Half-Life for Radionuclides } \\
\hline Radionuclide & Symbol & Half-life ${ }^{a, b}$ & Radionuclide & Symbol & Half-life ${ }^{a, b}$ \\
\hline Actinium-228 & Ac-228 & $6.15 \mathrm{~h}$ & Niobium-94 & $\mathrm{Nb}-94$ & $2.0 \mathrm{E} 4 \mathrm{y}$ \\
\hline Americium-241 & Am-241 & $432.7 y$ & Niobium-95 & $\mathrm{Nb}-95$ & $34.97 d$ \\
\hline Americium-243 & Am-243 & $7370 y$ & Plutonium-238 & $\mathrm{Pu}-238$ & 87.7 y \\
\hline Antimony-124 & $\mathrm{Sb}-124$ & $60.2 \mathrm{~d}$ & Plutonium-239 & Pu-239 & $2.41 E 4$ y \\
\hline Antimony-125 & $\mathrm{Sb}-125$ & $2.758 y$ & Plutonium-240 & Pu-240 & $6560 y$ \\
\hline Beryllium-7 & $\mathrm{Be}-7$ & $53.28 \mathrm{~d}$ & Plutonium-241 & Pu-241 & $14.4 \mathrm{y}$ \\
\hline Bismuth-212 & $\mathrm{Bi}-212$ & $2.14 \mathrm{~m}$ & Plutonium-242 & Pu-242 & $3.75 E 5 y$ \\
\hline Bismuth-214 & $B i-214$ & $19.9 \mathrm{~m}$ & Potassium-40 & $K-40$ & $1.27 E 9 y$ \\
\hline Carbon-14 & C-14 & $5714 y$ & Praseodymium-144 & Pr-144 & $17.28 \mathrm{~m}$ \\
\hline Cerium-141 & $\mathrm{Ce}-141$ & $32.5 \mathrm{~d}$ & Promethium-147 & $\mathrm{Pm}-147$ & $2.6234 \mathrm{y}$ \\
\hline Cerium-144 & Ce-144 & $284.6 \mathrm{~d}$ & Protactinium-231 & Pa-231 & $3.28 E 4 y$ \\
\hline Cesium-134 & Cs-134 & 2.065 y & Protactinium-233 & Pa-233 & $27.0 \mathrm{~d}$ \\
\hline Cesium-137 & Cs-137 & $30.07 y$ & Radium-226 & $\mathrm{Ra}-226$ & $1599 y$ \\
\hline Chromium-51 & Cr-51 & $27.702 \mathrm{~d}$ & Radium-228 & Ra-228 & $5.76 y$ \\
\hline Cobalt-57 & $\mathrm{Co}-57$ & $271.8 \mathrm{~d}$ & Radon-222 & $R n-222$ & $3.8235 d$ \\
\hline Cobalt-58 & $\mathrm{Co}-58$ & $70.88 \mathrm{~d}$ & Ruthenium-103 & Ru-103 & $39.27 \mathrm{~d}$ \\
\hline Cobalt-60 & $\begin{array}{l}\text { Co-60 } \\
\text { Cm-242 }\end{array}$ & $\begin{array}{l}5.271 \mathrm{y} \\
162.8 \mathrm{~d}\end{array}$ & Ruthenium-106 & Ru-106 & $1.020 y$ \\
\hline Curium-244 & $\mathrm{Cm}-244$ & $18.1 \mathrm{y}$ & Selenium-75 & Se-75 & $119.78 \mathrm{~d}$ \\
\hline Curium-246 & $\mathrm{Cm}-246$ & $4.76 E 3 y$ & Selenium-79 & Se-79 & $6.5 \mathrm{E} 5 \mathrm{y}$ \\
\hline Europium-152 & Eu-152 & $13.54 \mathrm{y}$ & Sodium-22 & $\mathrm{Na}-22$ & $2.604 \mathrm{y}$ \\
\hline Europium-154 & Eu-154 & $8.593 y$ & Strontium-89 & Sr-89 & $50.52 \mathrm{~d}$ \\
\hline Europium-155 & Eu-155 & $4.75 y$ & Strontium-90 & Sr-90 & $28.78 y$ \\
\hline lodine-129 & $1-129$ & 1.57E7 y & Technetium-99 & TC-99 & $2.13 E 5 y$ \\
\hline lodine-131 & $\mid-131$ & $8.0207 d$ & Thallium-208 & TI-208 & $3.053 \mathrm{~m}$ \\
\hline Krypton-85 & $\mathrm{Kr}-85$ & $10.76 y$ & Thorium-228 & Th-228 & $1.913 y$ \\
\hline Lead-212 & $\mathrm{Pb}-212$ & $10.64 \mathrm{~h}$ & Thorium-230 & Th-230 & 7.54E4 y \\
\hline Lead-214 & $\mathrm{Pb}-214$ & $27 \mathrm{~m}$ & Thorium-232 & Th-232 & $1.40 \mathrm{E} 10 \mathrm{y}$ \\
\hline Manganese-54 & $M n-54$ & $312.1 \mathrm{~d}$ & Thorium-234 & Th-234 & $24.10 \mathrm{~d}$ \\
\hline Mercury-203 & $\mathrm{Hg}-203$ & $46.61 d$ & Tin-126 & Sn-126 & 2.5E5 y \\
\hline Neptunium-237 & $\mathrm{Np}-237$ & 2.14E6 y & Tritium (Hydrogen-3) & $\mathrm{H}-3$ & $12.32 y$ \\
\hline Neptunium-239 & Np-239 & $2.355 \mathrm{~d}$ & Uranium-232 & $\mathrm{U}-232$ & $69.8 \mathrm{y}$ \\
\hline Nickel-59 & $\mathrm{Ni}-59$ & $7.6 E 4 y$ & Uranium-233 & $\mathrm{U}-233$ & $1.592 E 5 y$ \\
\hline Nickel-63 & $\mathrm{Ni}-63$ & $100 y$ & Uranium-234 & U-234 & $2.46 \mathrm{E} 5 \mathrm{y}$ \\
\hline
\end{tabular}

a $m=$ minute; $h=$ hour; $d=$ day; $y=$ year

b Reference: Chart of the Nuclides, 15th edition, revised 1996, General Electric Company 


\begin{tabular}{llrllr}
\hline \multirow{2}{*}{ Radionuclide } & \multicolumn{4}{c}{ Nomenclature and Half-Life for Radionuclides, Continued } & \\
& Symbol & Half-life $^{\text {a,b }}$ & Radionuclide & Symbol & Half-life \\
\hline Uranium-235 & U-235 & $7.04 E 8$ y & Yttrium-90 & Y-90 & $2.67 \mathrm{~d}$ \\
Uranium-236 & $\mathrm{U}-236$ & $2.342 E 7 \mathrm{y}$ & Zinc-65 & Zn-65 & $243.8 \mathrm{~d}$ \\
Uranium-238 & $\mathrm{U}-238$ & $4.47 \mathrm{E} 9 \mathrm{y}$ & Zirconium-95 & Zr-95 & $64.02 \mathrm{~d}$ \\
Xenon-135 & Xe-135 & $9.10 \mathrm{~h}$ & & &
\end{tabular}


Constituent

Nomenclature for Elements and Chemical Constituent Analyses Symbol Constituent Symbol

Note: Some of the symbols listed in this table came from various databases used to format the data tables in this book and are included here to assist the reader in understanding the tables.

\begin{tabular}{|c|c|c|c|}
\hline Aluminum & $A l$ (or $A L)$ & Oil and Grease & O\&G \\
\hline Ammonia & $\mathrm{NH}_{3}$ & $\mathrm{pH}$ & $\mathrm{pH}($ or $\mathrm{PH})$ \\
\hline Ammonia as Nitrogen & $\mathrm{NH}_{3}-\mathrm{N}$ (or AN) & Phenol & PHE \\
\hline Antimony & $\mathrm{Sb}$ (or SB) & Phosphorus & $P$ \\
\hline Arsenic & As (or AS) & \multirow[t]{2}{*}{ Phosphate } & \multirow{2}{*}{$\begin{array}{l}\mathrm{PO}_{4} \text { (or PO4-P or } \\
\mathrm{PO}_{4}-\mathrm{P} \text { ) }\end{array}$} \\
\hline Barium & $\mathrm{Ba}$ (or $\mathrm{BA})$ & & \\
\hline Biological Oxygen Demand & $B O D$ & Polychlorinated Biphenyl & $\mathrm{PCB}$ \\
\hline Benzene & BEN & Potassium & K \\
\hline Beryllium & $\mathrm{Be}$ & Radium & $\mathrm{Ra}$ \\
\hline Boron & $\mathrm{B}$ & Selenium & Se (or SE) \\
\hline Cadmium & $\mathrm{Cd}($ or $C D)$ & Silver & $\mathrm{Ag}$ (or $\mathrm{AG}$ ) \\
\hline Calcium & $\mathrm{Ca}$ & Sodium & $\mathrm{Na}$ \\
\hline $\begin{array}{l}\text { Carbon } \\
\text { Chemical Oxygen Demand }\end{array}$ & $\begin{array}{l}C \\
\text { COD }\end{array}$ & Sulfate & $\mathrm{SO}_{4}$ (or SO4) \\
\hline $\begin{array}{l}\text { Chemical Oxygen Demand } \\
\text { Chlorine }\end{array}$ & $\mathrm{Cl}$ (or $\mathrm{CHL}$ ) & Temperature & TMP (or T or \\
\hline Chromium & $\mathrm{Cr}$ (or $\mathrm{CR})$ & & \multirow{2}{*}{ PERCL } \\
\hline cis-1,2-dichloroethene & $1,2-D C E$ & $\begin{array}{l}\text { Tetrachloroethylene } \\
\text { (Perchloroethylene) }\end{array}$ & \\
\hline Cobalt & Co & Trichloroethylene & TRICL \\
\hline Copper & $\mathrm{Cu}$ (or $\mathrm{CU})$ & 1,1,1-Trichloroethane & TCE \\
\hline Cyanide & $\mathrm{CN}$ & Tin & SN \\
\hline Dissolved Oxygen & $\begin{array}{l}\text { DO } \\
\text { FEC }\end{array}$ & Total Dissolved Solids & TDS \\
\hline $\begin{array}{l}\text { Fecal Coliform } \\
\text { Fixed Residues }\end{array}$ & $\begin{array}{l}\text { FEC } \\
\text { FR }\end{array}$ & Total Kjeldahl Nitrogen & TKN \\
\hline Flow & FLO & Total Organic Carbon & TOC \\
\hline Iron & $\mathrm{Fe}$ (or FE) & Total Organic Halogens & $\mathrm{TOH}$ \\
\hline Lead & $\mathrm{Pb}$ (or $\mathrm{PB})$ & Total Phosphates & \multirow{2}{*}{$\begin{array}{l}\mathrm{TPO}_{4} \text { (or Total } \\
\text { Phos) }\end{array}$} \\
\hline Lithium & $\mathrm{Li}$ & & \\
\hline Magnesium & $M g($ or $M G)$ & Total Phosphorus & TP \\
\hline Manganese & $\mathrm{Mn}($ or $\mathrm{MN})$ & Total Suspended Solids & TSS \\
\hline Mercury & $\mathrm{Hg}$ (or HG) & Total Volatile Solids & TVS \\
\hline Nickel & $\mathrm{Ni}$ (or NI) & Uranium & $\mathrm{U}$ \\
\hline Nitrate as Nitrogen & $\mathrm{NO}_{3}-\mathrm{N}$ & Vinyl Chloride & VC \\
\hline Nitrite as Nitrogen & $\mathrm{NO}_{2}-\mathrm{N}$ & Volatile Organic Compound & Voc \\
\hline \multirow[t]{2}{*}{ Nitrite, Nitrate } & \multirow{2}{*}{$\begin{array}{l}\mathrm{NO} 2, \mathrm{NO}_{3} \text { (or } \\
\mathrm{NO}_{2}, \mathrm{NO}_{3} \text { or } \\
\left.\mathrm{NO}_{2} / \mathrm{NO} 3\right) \text { ) }\end{array}$} & Volatile Solids & vs \\
\hline & & Zinc & $\mathrm{Zn}$ (or ZN) \\
\hline
\end{tabular}




\section{Appendix E \\ Errata from 1998 Report}

The following information was reported incorrectly in the Savannah River Site Environmental Report for 1998 (WSRC-TR-98-00312):

Page 32, left column, second paragraph, next-to-last sentence: The reference to number of sites should have read as follows: ". . . the new location still included two sites that could be subject to such impact."

Page 133, left column, second full paragraph, second sentence: The reference to fire water pumps ranging in size from 15 to 205 kilowatts for generators and 20 to 52 horsepower for air compressor and pump engines should have read as follows: “. . . ranging in size from 150 to 2,050 kilowatts for generators and 200 to 520 horsepower for air compressor and pump engines."

Page 144, left column, second full paragraph, first sentence: "B-Area" should have been "D-Area." 



\section{Glossary}

A

accuracy - Closeness of the result of a measurement to the true value of the quantity.

activity - See radioactivity.

air flow - Rate of flow, measured by mass or volume per unit of time.

air stripping - Process used to decontaminate groundwater by pumping the water to the surface, "stripping" or evaporating the chemicals in a specially-designed tower, and pumping the cleansed water back to the environment.

alkalinity - Alkalinity is a measure of the buffering capacity of water, and since $\mathrm{pH}$ has a direct effect on organisms as well as an indirect effect on the toxicity of certain other pollutants in the water, the buffering capacity is important to water quality.

alpha particle - Positively charged particle emitted from the nucleus of an atom having the same charge and mass as that of a helium nucleus (two protons and two neutrons).

ambient air - Surrounding atmosphere as it exists around people, plants, and structures.

analyte - Constituent or parameter that is being analyzed.

analytical detection limit - Lowest reasonably accurate concentration of an analyte that can be detected; this value varies depending on the method, instrument, and dilution used.

aquifer - Saturated, permeable geologic unit that can transmit significant quantities of water under ordinary hydraulic gradients.
Atomic Energy Commission - Federal agency created in 1946 to manage the development, use, and control of nuclear energy for military and civilian application. It was abolished by the Energy Reorganization Act of 1974 and succeeded by the Energy Research and Development Administration (now part of the U.S. Department of Energy and the U.S. Nuclear Regulatory Commission).

bailer - Container lowered into a well to remove water. The bailer is allowed to fill with water and then is removed from the well.

best available technology - Technology that is the best available at the time to treat waste. See best available demonstrated technology.

best management practices - Sound engineering practices that are not, however, required by regulation or by law.

beta particle - Negatively charged particle emitted from the nucleus of an atom. It has a mass and charge equal to those of an electron.

blank - Control sample that is identical, in principle, to the sample of interest, except that the substance being analyzed is absent. In such cases, the measured value or signal for the substance being analyzed is believed to be due to artifacts. Under certain circumstances, that value may be subtracted from the measured value to give a net result reflecting the amount of the substance in the sample. The Environmental Protection Agency does not permit the subtraction of blank results in Environmental Protection Agency-regulated analyses.

blind blank - Sample container of deionized water sent to a laboratory under an alias name as a quality control check.

blind replicate - In the Environmental Monitoring Section groundwater monitoring program, a second sample taken from the same well at the same time as the primary sample, assigned an alias well name, and sent to a laboratory for analysis (as an unknown to the analyst). 
blind sample - Control sample of known concentration in which the expected values of the constituent are unknown to the analyst.

calibration - Determination of variance from a standard of accuracy of a measuring instrument to ascertain necessary correction factors.

Carolina bay - Type of shallow depression commonly found on the coastal Carolina plains. Carolina bays are typically circular or oval. Some are wet or marshy, while others are dry.

\section{Central Savannah River Area (CSRA) -}

Eighteen-county area in Georgia and South Carolina surrounding Augusta, Georgia. The Savannah River Site is included in the Central Savannah River Area. Counties are Richmond, Columbia, McDuffie, Burke, Emanuel, Glascock, Jenkins, Jefferson, Lincoln, Screven, Taliaferro, Warren, and Wilkes in Georgia and Aiken, Edgefield, Allendale, Barnwell, and McCormick in South Carolina.

chemical oxygen demand - Indicates the quantity of oxidizable materials present in a water and varies with water composition, concentrations of reagent, temperature, period of contact, and other factors.

chlorocarbons - Compounds of carbon and chlorine, or carbon, hydrogen, and chlorine, such as carbon tetrachloride, chloroform, tetrachloroethylene, etc. They are among the most significant and widespread environmental contaminants. Classified as hazardous wastes, chlorocarbons may have a tendency to cause detrimental effects, such as birth defects.

cleanup - Actions taken to deal with release or potential release of hazardous substances. This may mean complete removal of the substance; it also may mean stabilizing, containing, or otherwise treating the substance so that it does not affect human health or the environment.

closure - Control of a hazardous waste management facility under Resource Conservation and Recovery Act requirements.

compliance - Fulfillment of applicable requirements of a plan or schedule ordered or approved by government authority.

composite - Blending of more than one portion to make a sample for analysis.
Comprehensive Environmental Response, Compensation, and Liability Act (CERCLA) - This act addresses the cleanup of hazardous substances and establishes a National Priorities List of sites targeted for assessment and, if necessary, restoration (commonly known as "Superfund").

\section{Comprehensive Environmental Response, Compensation, and Liability Act (CERCLA)-reportable release-Release to the environment that exceeds reportable quantities as defined by the Comprehensive Environmental Response, Compensation, and Liability Act.}

concentration - Amount of a substance contained in a unit volume or mass of a sample.

conductivity - Measure of water's capacity to convey an electric current. This property is related to the total concentration of the ionized substances in a water and the temperature at which the measurement is made.

contamination - Deposition of unwanted material on the surfaces of structures, areas, objects, or personnel.

cosmic radiation - Ionizing radiation with very high energies, originating outside the earth's atmosphere. Cosmic radiation is one source contributing to natural background radiation.

count - Signal that announces an ionization event within a counter; a measure of the radiation from an object or device.

criteria pollutant - any of the pollutants commonly used as indices for air quality that can have a serious effect on human health and the environment, including sulfur dioxide, nitrogen dioxide, total suspended particulates, $\mathrm{PM}_{10}$, carbon monoxide, ozone, gaseous fluorides, and lead.

curie - Unit of radioactivity. One curie is defined as $3.7 \times 10^{10}$ (37 billion) disintegrations per second.

Several fractions and multiples of the curie are commonly used:

kilocurie $(\mathrm{kCi})-10^{3} \mathrm{Ci}$, one thousand curies; $3.7 \mathrm{x}$ $10^{13}$ disintegrations per second.

millicurie $(\mathrm{mCi})-10^{-3} \mathrm{Ci}$, one-thousandth of a curie; $3.7 \times 10^{7}$ disintegrations per second.

microcurie $(\mu \mathrm{Ci})-10^{-6} \mathrm{Ci}$, one-millionth of a curie; $3.7 \times 10^{4}$ disintegrations per second.

picocurie $(\mathrm{pCi})-10^{-12} \mathrm{Ci}$, one-trillionth of a curie; 0.037 disintegrations per second. 
D

decay (radioactive) - Spontaneous transformation of one radionuclide into a different radioactive or nonradioactive nuclide, or into a different energy state of the same radionuclide.

decay time - Time taken by a quantity to decay to a stated fraction of its initial value.

deactivation - The process of placing a facility in a stable and known condition, including the removal of hazardous and radioactive materials to ensure adequate protection of the worker, public health and safety, and the environment-thereby limiting the long-term cost of surveillance and maintenance.

decommissioning - Process that takes place after deactivation and includes surveillance and maintenance, decontamination, and/or dismantlement.

decontamination - The removal or reduction of residual radioactive and hazardous materials by mechanical, chemical, or other techniques to achieve a stated objective or end condition.

deactivation and decommissioning - Program that reduces the environmental and safety risks of surplus facilities at SRS.

derived concentration guide - Concentration of a radionuclide in air or water that, under conditions of continuous exposure for one year by one exposure mode (i.e., ingestion of water, submersion in air or inhalation), would result in either an effective dose equivalent of $0.1 \mathrm{rem}(1 \mathrm{mSv})$ or a dose equivalent of $5 \mathrm{rem}(50 \mathrm{mSv})$ to any tissue, including skin and lens of the eye. The guides for radionuclides in air and water are given in Department of Energy Order 5400.5 .

detection limit - See analytical detection limit, lower limit of detection, minimum detectable concentration.

detector - Material or device (instrument) that is sensitive to radiation and can produce a signal suitable for measurement or analysis.

diatometer - Diatom collection equipment consisting of a series of microscope slides in a holder that is used to determine the amount of algae in a water system. diatoms - Unicellular or colonial algae of the class Bacillariophyceae, having siliceous cell walls with two overlapping, symmetrical parts. Diatoms represent the predominant periphyton (attached algae) in most water bodies and have been shown to be reliable indicators of water quality.

disposal - Permanent or temporary transfer of $\mathrm{DOE}$ control and custody of real property to a third party, which thereby acquires rights to control, use, or relinquish the property.

disposition - Those activities that follow completion of program mission-including, but not limited to, surveillance and maintenance, deactivation, and decommissioning.

dissolved oxygen - Desirable indicator of satisfactory water quality in terms of low residuals of biologically available organic materials. Dissolved oxygen prevents the chemical reduction and subsequent leaching of iron and manganese from sediments.

dose-Energy imparted to matter by ionizing radiation. The unit of absorbed dose is the rad, equal to 0.01 joules per kilogram in any medium.

absorbed dose - Quantity of radiation energy absorbed by an organ, divided by the organ's mass. Absorbed dose is expressed in units of rad (or gray) (1 $\mathrm{rad}=0.01 \mathrm{~Gy}$ ).

dose equivalent - Product of the absorbed dose (rad) in tissue and a quality factor. Dose equivalent is expressed in units of rem (or sievert) ( 1 rem $=0.01$ sievert).

committed dose equivalent - Calculated total dose equivalent to a tissue or organ over a 50-year period after known intake of a radionuclide into the body. Contributions from external dose are not included. Committed dose equivalent is expressed in units of rem (or sievert).

committed effective dose equivalent - Sum of the committed dose equivalents to various tissues in the body, each multiplied by the appropriate weighting factor. Committed effective dose equivalent is expressed in units of rem (or sievert).

effective dose equivalent - Sum of the dose equivalents received by all organs or tissues of the body after each one has been multiplied by an appropriate weighting factor. The effective dose equivalent includes the committed effective dose equivalent from internal deposition of radionuclides and the effective dose equivalent attributable to sources external to the body. 
collective dose equivalent/collective effective dose equivalent - Sums of the dose equivalents or effective dose equivalents of all individuals in an exposed population within a 50 -mile $(80-\mathrm{km})$ radius, and expressed in units of person-rem (or personsievert). When the collective dose equivalent of interest is for a specific organ, the units would be organ-rem (or organ-sievert). The 50-mile distance is measured from a point located centrally with respect to major facilities or DOE program activities.

dosimeter - Portable detection device for measuring the total accumulated exposure to ionizing radiation.

downgradient - In the direction of decreasing hydrostatic head.

drinking water standards - Federal primary drinking water standards, both proposed and final, as set forth by EPA.

duplicate result - Result derived by taking a portion of a primary sample and performing the identical analysis on that portion as is performed on the primary sample.

E

effluent - Any treated or untreated air emission or liquid discharge to the environment.

effluent monitoring - Collection and analysis of samples or measurements of liquid and gaseous effluents for purposes of characterizing and quantifying the release of contaminants, assessing radiation exposures of members of the public, and demonstrating compliance with applicable standards.

environmental compliance - Actions taken in accordance with government laws, tegulations, orders, etc., that apply to site operations' effects on onsite and offsite natural resources and on human health; used interchangeably in this document with regulatory compliance.

environmental monitoring - Program at Savannah River Site that includes effluent monitoring and environmental surveillance with dual purpose of (1) showing compliance with federal, state, and local regulations, as well as with U.S. Department of Energy orders, and (2) monitoring any effects of site operations on onsite and offsite natural resources and on human health. environmental restoration - Department of Energy program that directs the assessment and cleanup of inactive waste units and groundwater (remediation) contaminated as a result of nuclear-related activities.

environmental surveillance - Collection and analysis of samples of air, water, soil, foodstuffs, biota, and other media from Department of Energy sites and their environs and the measurement of external radiation for purposes of demonstrating compliance with applicable standards, assessing radiation exposures to members of the public, and assessing effects, if any, on the local environment.

exceedance - Term used by the Environmental Protection Agency and the South Carolina Department of Health and Environmental Control that denotes a report value is more than the upper guide limit. This term is found on the Discharge Monitoring Report forms that are submitted to the Environmental Protection Agency or the South Carolina Department of Health and Environmental Control.

exposure (radiation) - Incidence of radiation on living or inanimate material by accident or intent. Background exposure is the exposure to natural background ionizing radiation. Occupational exposure is that exposure to ionizing radiation which takes place during a person's working hours. Population exposure is the exposure to the total number of persons who inhabit an area.

exposure pathway - Route that materials follow to get to the environment and then to people.

fallout - See worldwide fallout.

Federal Facility Agreement (FFA) - Agreement negotiated among the Department of Energy, the Environmental Protection Agency, and the South Carolina Department of Health and Environmental Control, specifying how the Savannah River Site will address contamination or potential contamination to meet regulatory requirements at the Savannah River Site waste units identified for evaluation and, if necessary, cleanup.

feral hog - Hog that has reverted to the wild state from domestication. 
$\mathbf{G}$

gamma ray - High-energy, short wavelength electromagnetic radiation emitted from the nucleus of an excited atom. Gamma rays are identical to $\mathrm{X}$-rays except for the source of the emission.

gamma-emitting radionuclide - Radionuclide that emits gamma rays.

gamma spectrometry - System consisting of a detector, associated electronics, and a multichannel analyzer that is used to analyze samples for gamma-emitting radionuclides.

grab sample - Sample collected instantaneously with a glass or plastic bottle placed below the water surface to collect surface water samples (also called dip samples).

H

half-life (radiological) - Time required for half of a given number of atoms of a specific radionuclide to decay. Each nuclide has a unique half-life.

heavy water - Water in which the molecules contain oxygen and deuterium, an isotope of hydrogen that is heavier than ordinary hydrogen.

hydraulic gradient - Difference in hydraulic head over a specified distance.

hydraulic head - Elevation of the water in a well or piezometer.

hydrology - Science that treats the occurrence, circulation, distribution, and properties of the waters of the earth, and their reaction with the environment.

in situ - In its original place. Field measurements taken without removing the sample from its origin; remediation performed while groundwater remains below the surface.

inorganic - Involving matter other than plant or animal. ion exchange - Process in which a solution containing soluble ions is passed over a solid ion exchange column that removes the soluble ions by exchanging them with labile ions from the surface of the column. The process is reversible so that the trapped ions are removed (eluted) from the column and the column is regenerated.

irradiate-Expose to radiation.

irradiation - Exposure to radiation.

isotopes - Forms of an element having the same number of protons in their nuclei but differing in the number of neutrons.

long-lived isotope - Radionuclide that decays at such a slow rate that a quantity of it will exist for an extended period (half-life is greater than three years).

short-lived isotope - Radionuclide that decays so rapidly that a given quantity is transformed almost completely into decay products within a short period (half-life is two days or less).

$\mathbf{L}$

laboratory blank - Deionized water sample generated by the laboratory; a laboratory blank is analyzed with each batch of samples as an in-house check of analytical procedures. Also called an internal blank.

legacy - Anything handed down from the past; inheritance, as of nuclear waste.

lower limit of detection - Smallest concentration/amount of analyte that can be reliably detected in a sample at a 95 percent confidence level.

M

macroinvertebrates - Size-based classification used for a variety of insects and other small invertebrates; as defined by the Environmental Protection Agency, those organisms that are retained by a No. 30 (590 micron) U.S. Standard Sieve.

macrophyte - A plant that can be observed with the naked eye.

manmade radiation - Radiation sources such as consumer products, medical procedures, and nuclear industry. 
maximally exposed individual - Hypothetical individual who remains in an uncontrolled area and would, when all potential routes of exposure from a facility's operations are considered, receive the greatest possible dose equivalent.

mean relative difference - Percentage error based on statistical analysis.

mercury - Silver-white, liquid metal solidifying at $-38.9^{\circ} \mathrm{C}$ to form a tin-white, ductile, malleable mass. It is widely distributed in the environment and biologically is a nonessential or nonbeneficial element. Human poisoning due to this highly toxic element has been clinically recognized.

migration - Transfer or movement of a material through the air, soil, or groundwater.

minimum detectable concentration - Smallest amount or concentration of a radionuclide that can be distinguished in a sample by a given measurement system at a preselected counting time and at a given confidence level.

moderate - To reduce the excessiveness of; to act as a moderator.

moderator - Material, such as heavy water, used in a nuclear reactor to moderate or slow down neutrons from the high velocities at which they are created in the fission process.

monitoring - Process whereby the quantity and quality of factors that can affect the environment and/or human health are measured periodically in order to regulate and control potential impacts.

nonpoint source - any source that does not meet the definition for point source (National Emission Standards for Hazardous Air Pollutants radionuclide program).

nonroutine radioactive release - Unplanned or nonscheduled release of radioactivity to the environment.

nuclide - Atom specified by its atomic weight, atomic number, and energy state. A radionuclide is a radioactive nuclide. organic - Of, relating to, or derived from living organisms (plant or animal).

outcrop - Place where groundwater is discharged to the surface. Springs, swamps, and beds of streams and rivers are the outcrops of the water table.

outfall - Point of discharge (e.g., drain or pipe) of wastewater or other effluents into a ditch, pond, or river.

parameter - Analytical constituent; chemical compound(s) or property for which an analytical request may be submitted.

permeability - Physical property that describes the ease with which water may move through the pore spaces and cracks in a solid.

person-rem - Collective dose to a population group. For example, a dose of one rem to 10 individuals results in a collective dose of 10 person-rem.

$\mathrm{pH}-$ Measure of the hydrogen ion concentration in an aqueous solution. Acidic solutions have a $\mathrm{pH}$ from $0-6$, basic solutions have a $\mathrm{pH}>7$, and neutral solutions have a $\mathrm{pH}=7$.

piezometer - Instrument used to measure the potentiometric surface of the groundwater. Also, a well designed for this purpose.

plume - Volume of contaminated air or water originating at a point-source emission (e.g., a smokestack) or a waste source (e.g., a hazardous waste disposal site).

point source - stack or vent (National Emission Standards for Hazardous Air Pollutants radionuclide program).

population dose - See collective dose equivalent under dose.

process sewer - Pipe or drain, generally located underground, used to carry off process water and/or waste matter.

purge - To remove water prior to sampling, generally by pumping or bailing. 
Q

quality assurance (QA) - In the Environmental Monitoring System program, QA consists of the system whereby the laboratory can assure clients and other outside entities, such as government agencies and accrediting bodies, that the laboratory is generating data of proven and known quality.

quality control (QC) - In the Environmental Monitoring System program, QC refers to those operations undertaken in the laboratory to ensure that the data produced are generated within known probability limits of accuracy and precision.

$\mathbf{R}$

rad - Unit of absorbed dose deposited in a volume of material.

radioactivity - Spontaneous emission of radiation, generally alpha or beta particles, or gamma rays, from the nucleus of an unstable isotope.

radioisotopes - Radioactive isotopes.

radionuclide - Unstable nuclide capable of spontaneous transformation into other nuclides by changing its nuclear configuration or energy level. This transformation is accompanied by the emission of photons or particles.

real-time instrumentation - Operation in which programmed responses to an event are essentially simultaneous with the event itself.

reforestation - Process of planting new trees on land once forested.

regulatory compliance - Actions taken in accordance with government laws, regulations, orders, etc., that apply to site operations' effects on onsite and offsite natural resources and on human health; used interchangeably in this document with environmental compliance.

release - Any discharge to the environment.

Environment is broadly defined as any water, land, or ambient air. rem - Unit of dose equivalent (absorbed dose in rads $x$ the radiation quality factor). Dose equivalent is frequently reported in units of millirem (mrem) which is one-thousandth of a rem.

remediation - Assessment and cleanup of Department of Energy sites contaminated with waste as a result of past activities. See environmental restoration.

remediation design - Planning aspects of remediation, such as engineering characterization, sampling studies, data compilation, and determining a path forward for a waste site.

replicate - In the Environmental Monitoring Section groundwater monitoring program, a second sample from the same well taken at the same time as the primary sample and sent to the same laboratory for analysis.

Resource Conservation and Recovery Act (RCRA) - Federal legislation that regulates the transport, treatment, and disposal of solid and hazardous wastes. This act also requires corrective action for releases of hazardous waste at inactive waste units.

Resource Conservation and Recovery Act (RCRA) site - Solid waste management unit under Resource Conservation and Recovery Act regulation. See Resource Conservation and Recovery Act.

retention basin - Unlined basin used for emergency, temporary storage of potentially contaminated cooling water from chemical separations activities.

RFI Program - RCRA Facility Investigation Program; Environmental Protection Agency-regulated investigation of a solid waste management unit with regard to its potential impact on the environment.

RFI/RI Program - RCRA Facility Investigation/Remedial Investigation Program. At the Savannah River Site, the expansion of the RFI Program to include Comprehensive Environmental Response, Compensation, and Liability Act and hazardous substance regulations.

routine radioactive release - Planned or scheduled release of radioactivity to the environment.

S seep - Area, generally small, where water moves slowly to the land surface. 
seepage basin - Excavation that receives wastewater. Insoluble materials settle out on the floor of the basin and soluble materials seep with the water through the soil column where they are removed partially by ion exchange with the soil. Construction may include dikes to prevent overflow or surface runoff.

sensitivity - Capability of methodology or instruments to discriminate between samples with differing concentrations or containing varying amounts of analyte.

settling basin - Temporary holding basin (excavation) that receives wastewater which is subsequently discharged.

site stream - Any natural stream on the Savannah River Site. Surface drainage of the site is via these streams to the Savannah River.

source - Point or object from which radiation or contamination emanates.

source check - Radioactive source with a known amount of radioactivity used to check the performance of the radiation detector instrument.

source term - Quantity of radioactivity released in a set period of time that is traceable to the starting point of an effluent stream or migration pathway.

spent nuclear fuel - Used fuel elements from reactors.

spike - Addition of a known amount of reference material containing the analyte of interest to a blank sample.

split sample - Two samples taken at the same time and sent to two different laboratories for analysis.

stable - Not radioactive or not easily decomposed or otherwise modified chemically.

stack - Vertical pipe or flue designed to exhaust airborne gases and suspended particulate matter.

standard deviation - Indication of the dispersion of a set of results around their average.

stormwater runoff - Surface streams that appear after precipitation.

Superfund - see Comprehensive Environmental Response, Compensation, and Liability Act (CERCLA). supernate - Portion of a liquid above settled materials in a tank or other vessel.

surface water - All water on the surface of the earth, as distinguished from groundwater.

$T$

tank farm - Installation of interconnected underground tanks for storage of high-level radioactive liquid wastes.

temperature - Thermal state of a body considered with its ability to communicate heat to other bodies.

thermoluminescent dosimeter (TLD) - Device used to measure external gamma radiation.

total dissolved solids - Dissolved solids and total dissolved solids are terms generally associated with freshwater systems and consist of inorganic salts, small amounts of organic matter and dissolved materials.

total phosphorus - When concentrations exceed $25 \mathrm{mg} / \mathrm{L}$ at the time of the spring turnover on a volume-weighted basis in lakes or reservoirs, it may occasionally stimulate excessive or nuisance growths of algae and other aquatic plants.

total suspended particulates - Refers to the concentration of particulates in suspension in the air irrespective of the nature, source, or size of the particulates.

transport pathway - pathway by which a released contaminant physically is transported from its point of discharge to a point of potential exposure to humans. Typical transport pathways include the atmosphere, surface water, and groundwater.

transuranic waste - Solid radioactive waste containing primarily alpha-emitting elements heavier than uranium.

turbidity - Measure of the concentration of sediment or suspended particles in solution.

V

vitrify - Change into glass.

vitrification - Process of changing into glass.

volatile organic compounds - Broad range of organic compounds, commonly halogenated, that vaporize at ambient, or relatively low, temperatures (e.g., acetone, benzene, chloroform, and methyl alcohol). 
waste management - The Department of Energy uses this term to refer to the safe, effective management of various kinds of nonhazardous, hazardous, and radioactive waste generated on site.

waste unit - Inactive area that is known to have received contamination or had a release to the environment.

water table - Planar, underground surface beneath which earth materials, as soil or rock, are saturated with water. weighting factor - Value used to calculate dose equivalents. It is tissue specific and represents the fraction of the total health risk resulting from uniform, whole-body irradiation that could be contributed to that particular tissue. The weighting factors used in this report are recommended by the International Commission on Radiological Protection (Publication 26).

wetlands - Lowland area, such as a marsh or swamp, inundated or saturated by surface or groundwater sufficiently to support hydrophytic vegetation typically adapted for life in saturated soils.

wind rose - Diagram in which statistical information concerning direction and speed of the wind at a location is summarized.

worldwide fallout - Radioactive debris from atmospheric weapons tests that has been deposited on the earth's surface after being airborne and cycling around the earth. 



\section{References}

Arnett and Mamatey, 1997 Arnett, M.W., and A.R. Mamatey, eds., 1997, Savannah River Site Environmental Report for 1996, WSRC-TR-97-0171, Savannah River Site, Aiken, S.C.

Arnett and Mamatey, 1998 Arnett, M.W., and A.R. Mamatey, eds., 1998, Savannah River Site Environmental Report for 1997, WSRC-TR-97-00322, Savannah River Site, Aiken, S.C.

Arnett and Mamatey, 1999 Arnett, M.W., and A.R. Mamatey, eds., 1999, Savannah River Site Environmental Report for 1998, WSRC-TR-98-00312, Savannah River Site, Aiken, S.C.

Bebbington, 1990 Bebbington, W.P., 1990, History of Du Pont at the Savannah River Site, E.I. du Pont de Nemours and Company, Wilmington, Del.

BEIR V, 1990 National Research Council, 1990, Health Effects of Exposure to Low Levels of Ionizing Radiation, BEIR V Report, Washington, D.C., 1982.

Blohm, 1995 Blohm, J.D., 1995, Pen Branch Stream Corridor and Delta Wetlands Change Assessment, Savannah River Site, EGG-11265-1013, Savannah River Site, Aiken, S.C. (available to the public from the National Technical Information Service, U.S. Department of Commerce, 5285 Port Royal, Springfield, Va. 22161)

Carlton et al., 1994 Carlton, W.H., C.E. Murphy, Jr., and A.G. Evans, 1994, "Radiocesium in the Savannah River Site Environment," Health Physics, Volume 67, Number 3, Williams \& Wilkins, Baltimore, Md.

CDC, 1999 Centers for Disease Control and Prevention, 1999, “DRAFT FINAL REPORT, Savannah River Site Environmental Dose Reconstruction Project, Phase II: Source Term Calculation and Ingestion Pathway Data Retrieval, Evaluation of Materials Released from the Savannah River Site (January 28, 1999), Atlanta, $\mathrm{Ga}$.

Clarke, 1998 Cook, J.S., and West, T.W., 1998, "Simulation of Ground-Water Flow and Stream-Aquifer Relations in the Vicinity of the Savannah River Site, Georgia and South Carolina, Predevelopment Through 1992," Water-Resources Investigations Report 98-4062, p. 134, U.S. Geological Survey, Atlanta, Ga.

Cook, 1997 Cook, et al., 1997, "Composite Analysis - E-Area Vaults and Saltstone Disposal Facilities," WSRC-RP-97-311, Rev. 0, Savannah River Site, Aiken, S.C.

Davis et al., 1989 Davis, H.A., D.K. Martin, and J.L. Todd, 1989, Savannah River Site Environmental Report for 1988, WSRC-RP-89-59-1, Savannah River Site, Aiken, S.C.

DOE, 1988 U.S. Department of Energy, 1988, External and Internal Dose Conversion Factors for Calculation of Dose to the Public, DOE/EH-0070\&71, U.S. Department of Energy, Washington, D.C.

DOE, 1990 U.S. Department of Energy, 1990, Final Environmental Impact Statement, Continued Operation of $K-, L-$, and P-Reactors, Savannah River Site, Aiken, South Carolina, DOE/EIS-0147.

DOE, 1991 U.S. Department of Energy, 1991, Environmental Regulatory Guide for Radiological Effluent Monitoring and Environmental Surveillance, DOE/EH-0173T, National Technical Information Service, Springfield, Va.

DOE, 1992 U.S. Department of Energy, 1992, Mitigation Action Plan, 1992 Annual Update, Continued Operation of $K-, L-$, and P-Reactors, Environmental Impact Statement, DOE/EIS-0147.

DOE, 1996 U.S. Department of Energy, 1996, Nuclear Weapons Nonproliferation Policy Concerning Foreign Research Reactor Spent Nuclear Fuel, Record of Decision, Washington, D.C.

DOE EM, 1991 U.S. Department of Energy Office of Environmental Restoration and Waste Management, 1991, Environmental Restoration and Waste Management (EM) Program An Introduction, DOE/EM-0013P, U.S. Department of Energy, Washington, D.C. 
Dulohery, 1996 Dulohery, N.J., C.S. Bunton, C.C. Trettin, and W.H. McKee, Jr., 1996, Reforestation of the Pen Branch Corridor and Delta, WSRC-TR-96-0005, U.S. Department of Agriculture Forest Service, Establishment Report, Center for Forested Wetlands Research, Charleston, S.C.

EPA, 1989 U.S. Environmental Protection Agency, 1989, "National Emission Standards for Hazardous Air Pollutants; Radionuclides," Title 40 Code of Federal Regulations, Part 61, Volume 54, No. 240, Washington, D.C.

EPA, 1991 U.S. Environmental Protection Agency, 1991, Risk Assessment Guidance for Superfund, Volume I: Human Health Evaluation Manual Supplemental Guidance "Standard Default Exposure Factors," OSWER Directive: 9285.6-03, Washington, D.C.

EPA, 1995 U.S. Environmental Protection Agency, 1995, Health Effects Assessment Summary Tables FY 1995, 11/95 Supplement, Publication 9200.6-303 (95-1), Washington, D.C.

EPA, 1999 U.S. Environmental Protection Agency, 1999, "National Primary Drinking Water Regulations; Radon-222," Proposed Rule, Federal Register, Volume 64, No. 211 (59295-59344), November 2, 1999, Washington, D.C.

EPD, 1999 Environmental Protection Department/Environmental Monitoring Section, 1999, Environmental Protection Department's Well Inventory, ESH-EMS-99-0536, Savannah River Site, Aiken, S.C.

Fact Sheet, 1995 Westinghouse Savannah River Company, 1995, "Environmental Restoration," Fact Sheet, WSRC-MS-96-0623, Savannah River Site, Aiken, S.C.

Fact Sheet, 1996a Westinghouse Savannah River Company, 1996, "Savannah River Site," Fact Sheet, WSRC-MS-96-0620, Rev 1, Savannah River Site, Aiken, S.C.

Fact Sheet, 1996b Westinghouse Savannah River Company, 1996, "High-Level Waste Processing Facilities," Fact Sheet, WSRC-MS-96-0619, Rev 1, Savannah River Site, Aiken, S.C.

Flach, 1996 Flach, G.P., et al, 1996, "Groundwater Flow and Tritium Migration from the SRS Old Burial Ground to Fourmile Branch (U)," Savannah River Site, Aiken, S.C.

Fledderman, 1999 Fledderman, P.D., December 3, 1999, telephone conversation with James M. Novak, Savannah River Ecology Laboratory, Savannah River Site, Aiken, S.C.

Hamby, 1991 Hamby, D.M., 1991, Land and Water Use Characteristics in the Vicinity of the Savannah River Site (U), WSRC-RP-91-17, Savannah River Site, Aiken, S.C.

Hamby, 1993 Hamby, D.M., 1993, “A Probabilistic Estimation of Atmospheric Tritium Dose," Health Physics, Volume 65, Number 1, Williams \& Wilkins, Baltimore, Md.

Hamby and Bauer, 1994 Hamby, D.M., and L.R. Bauer, 1994, "The Vegetation-to-air Concentration Ratio in a Specific Activity Atmospheric Tritium Model," Health Physics, Volume 66, Number 3, Williams \& Wilkins, Baltimore, Md.

Hunter, 1990 Hunter, C.H., 1990, A Climatological Description of the Savannah River Site, WSRC-RP-89-313, Savannah River Site, Aiken, S.C.

ICRP, 1990 International Commission on Radiation Protection, 1990, Recommendations of the ICRP, Publication 60, Elmsford, N.Y.

Looney, 1993 Looney, B.B., et al, 1993, Projected Tritium Releases from $F$ \& H Area Seepage Basins and the Solid Waste Disposal Facilities to Fourmile Branch (U), WSRC-RP-93-459, Savannah River Site, Aiken, S.C.

NCRP, 1979 National Council on Radiation Protection and Measurements, 1979, Tritium in the Environment, NCRP Report No. 62, Bethesda, Md.

NCRP, 1987 National Council on Radiation Protection and Measurements, 1987, Ionizing Radiation Exposure of the Population of the United States, NCRP Report No. 93, Bethesda, Md.

NRC, 1977 U.S. Nuclear Regulatory Commission, 1977, Regulatory Guide 1.109, Calculation of Annual Doses to Man from Routine Releases of Reactor Effluents for the Purpose of Evaluating Compliance with 10 CFR 50, Appendix I, Revision 1, Washington, D.C. 
SCDHEC, 1985 South Carolina Department of Health and Environmental Control, 1985, Savannah River Plant, Aiken, Allendale, and Barnwell Counties, NPDES Permit 0000175, Columbia, S.C.

SCDHEC, 1998 South Carolina Department of Health and Environmental Control, 1998, South Carolina Code of Regulations, R.61-68, "Water Classifications and Standards," Columbia, S.C.

Soldat et al., 1974 Soldat, J.K., N.M. Robinson, and D.A. Baker, 1974, Models and Computer Codes for Evaluating Environmental Radiation Doses, BNWL-1754, Battelle Pacific Northwest Laboratories.

SRS Data, 1995 Environmental Protection Department Environmental Monitoring Section, 1995, Savannah River Site Environmental Data for 1994, WSRC-TR-95-077, Savannah River Site, Aiken, S.C.

SRS Data, 1999 Environmental Protection Department Environmental Monitoring Section, 1999, Savannah River Site Environmental Data for 1998, WSRC-TR-98-00314, Savannah River Site, Aiken, S.C.

SRS Data, 2000 Environmental Protection Department Environmental Monitoring Section, 2000, Savannah River Site Environmental Data for 1999, WSRC-TR-99-00301, Savannah River Site, Aiken, S.C.

SRS Screening, 1999 Savannah River Site Screening Program Wells, ESH-EMS-99-0539, Savannah River Site, Aiken, S.C.

SRS EM Program, 1996 Savannah River Site Environmental Monitoring Program Quality Assurance Plan, 1996, WSRC-3Q1-2, Volume 3, Section 8000, Savannah River Site, Aiken, S.C.

SRS EM Program, 1999 Savannah River Site Environmental Monitoring Section Plans and Procedures, 1999, WSRC-3Q1-2, Volume 1, Section 1100, Savannah River Site, Aiken, S.C.

SRS Groundwater, 1999a The Savannah River Site's Groundwater Monitoring Program, First Quarter 1999, ESH-EMS-99-0520, Savannah River Site, Aiken, S.C.

SRS Groundwater, 1999b The Savannah River Site's Groundwater Monitoring Program, Second Quarter 1999, ESH-EMS-99-0521, Savannah River Site, Aiken, S.C.

SRS Groundwater, 1999c The Savannah River Site's Groundwater Monitoring Program, Third Quarter 1999, ESH-EMS-99-0522, Savannah River Site, Aiken, S.C.

WSRC, 1992 Westinghouse Savannah River Company, 1999, Quality Assurance Management Plan (WSRC-RP-92-225), Rev. 8, Savannah River Site, Aiken, S.C.

WSRC, 1999 Westinghouse Savannah River Company, 1999, Environmental Geochemistry Group Operating Handbook, Volumes I and II, WSRC-IM-99-00013, Savannah River Site, Aiken, S.C.

WSRC, 2000 Westinghouse Savannah River Company, 2000, WSRC Environmental Compliance Manual, WSRC--3Q, Savannah River Site, Aiken, S.C. 


\section{Index}

\section{A}

A-Area, 11

A-Area and M-Area, groundwater monitoring results, 165

Academy of Natural Sciences of Philadelphia river quality surveys, 145

results of

algae and aquatic macrophyte studies, 149

diatometer monitoring, 148

fish studies, 153

insect studies, 152

noninsect macroinvertebrate studies, 150

protozoan studies, 150

sampling sites for, 146

accelerated cleanup plan, 50

Accelerator for Production of Tritium, as backup option, 10

actinide transport, 93

administration area, 11

Advanced Analytical Center for Environmental Sciences (Savannah River Ecology

Laboratory), 13

Affirmative Procurement Program, 48

air, radiological surveillance of, 80

sampling stations for, 81

air dispersion modeling, 132, 137

air emissions inventory, 30, 130

airborne emissions

nonradiological monitoring of, 129

radiological monitoring of, 69

comparison of average concentrations to

Derived Concentration Guides, 71

diffuse and fugitive sources, 70

results of, 71

ambient air monitoring, 43

ambient air quality, 132, 137

appraisals and surveillances of environmental program, 36

aquatic food products, radiological surveillance of, 97

archaeology at SRS and public outreach, 54 areas of Savannah River Site

A-Area, 11

administration, 11

B-Area, 11

D-Area, 7

F-Area, 7

G-Area, 12

H-Area, 7

Heavy Water Reprocessing Area, 7

M-Area, 7

Multipurpose Pilot Plant Campus, 12

N-Area, 11

reactor $(\mathrm{C}, \mathrm{K}, \mathrm{L}, \mathrm{P}$, and $\mathrm{R}), 7$

reactor materials, 7

separations, 7

TNX, 11

waste management (E, F, H, S, and $\mathrm{Z}), 10$

as low as reasonably achievable concept, 69

asbestos removal program, 29

Atomic Energy Commission, 1, 14

Atoms for Peace program, 7

\section{B}

B-Area, 11

groundwater monitoring results, 192

Babcock \& Wilcox Savannah River Company, as Savannah River Site contractor, 1

bald eagle, 33

Beaufort-Jasper Water Treatment Plant, 4, 113 doses at, 117

beavers, radiological surveillance of, 101

Bechtel Savannah River, Inc., as Savannah River Site contractor, 1

beef, radiological surveillance of, 96

bioremediation, 56

Board Beat, 51

British Nuclear Fuels Savannah River Corporation, as Savannah River Site contractor, 1

Burial Ground complex, 57

Burke County well sampling, 105 


\section{C}

C-Area

groundwater monitoring results, 170

remediation of burning/rubble pit, 57

canyons, 7,61

CAP88, 110

Carolina bays, 4

Central Savannah River Area Environmental Science Education Cooperative, 53

Central Savannah River Area Radiological Environmental Monitoring Program, 53

Central Savannah River Area Science and Engineering Fair, 53

Chemical Commodity Management Center, 48

chemicals, management of excess, 48

chemicals, metals, and pesticides pits, groundwater monitoring results, 183

chicken, radiological surveillance of, 96

Citizens Advisory Board 1999 recommendations, 50

and information exchange, 52

and public involvement, 50

Citizens for Environmental Justice, 53

City of Savannah Industrial and Domestic Water Supply Plant, 4, 113

doses at, 117

Clean Air Act, 27

air emissions inventory, 30

asbestos removal program, 29

National Emission Standards for Hazardous Air Pollutants, 28, 121

ozone-depleting substances, 30

Title V Operating Program, 30

Clean Water Act, 25

construction in navigable waters, 27

dredge and fill permitting, 27

National Pollutant Discharge Elimination

System program, 25

notices of violation, 26

reportable occurrences, 34

Rivers and Harbors Act, 27

climate of Savannah River Site, 2

coal-fired boilers, capacities of, 131

collards, radiological surveillance of, 96

compensatory mitigation, for Pen Branch, 208
Comprehensive Environmental Response, Compensation, and Liability Act, 19

reportable occurrences, 34, 35

Superfund Amendments and Reauthorization Act, 19

conservation of energy, 48

Consolidated Incineration Facility, 10, 51, 58, 60

Effluent Treatment Facility, 60

construction in navigable waters, 27

continuous monitoring, 70, 73

courtesy notifications to regulators, 35

Crackerneck Wildlife Management Area and

Ecological Reserve, 4

Creek Plantation, 209

criteria pollutant air emissions (1998), 131

critical pathways analysis, 46

CRITR, 127

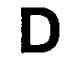

D-Area, 7

environmental restoration projects, 56

groundwater monitoring results, 172

data review (for groundwater quality assurance), 203

data verification and validation, 198

decommissioning of facilities, 37

Decontamination Facility, 65, 66

deer

dose from consumption of, 123

radiological surveillance of, 100

deer herd at Savannah River Site, size of, 4

Defense Waste Processing Facility, 10, 61, 62

Derived Concentration Guides, 71, 73

diffuse and fugitive sources, radioactive releases from, 70

disposition of facilities, 12

disposition program, 64

dose

calculating for children, 110

calculating, by Savannah River Site, 110

calculation models, 110

contributions to average individual, 124

definition of in this report, 109

to maximally exposed individual, 110, 117

10-year history, 122 
uncertainty in calculation of, 113

dose calculation results

air pathway, 118

atmospheric concentrations, 119

atmospheric source terms, 118

collective dose (population dose), 121

maximally exposed individual, 120

National Emission Standards for Hazardous

Air Pollutants compliance, 121

all-pathway, 122

aquatic animal organisms, 127

comparison of, to standard, 123

deer and hog consumption pathway, 123

drinking water pathway, 117

fish consumption pathway, 123

liquid pathway, 114

collective effective dose equivalent (population dose), 118

irrigation, 118

liquid release source terms, 114

maximally exposed individual, 117

maximally exposed individual, (sector-specific), 121

sportsman dose, 122

deer and hog consumption pathway, 123

fish consumption pathway, 123

Dose Reconstruction Study, 47

dredge and fill permitting, 27

drinking water

nonradiological surveillance of, 140

radiological surveillance of, 94

site drinking water systems map, 142

Du Pont, 1

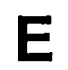

E.I. du Pont de Nemours and Company, 1

E-Area

groundwater monitoring results, 175

Vaults, 10

E-Area and Saltstone Facility Low-Level Waste

Disposal Authorization Statement, 58

Ecological Stewardship (Savannah River Ecology Laboratory), 13

Ecotoxicology, Remediation, and Risk Assessment (Savannah River Ecology Laboratory), 13

Education, Research and Development Association of Georgia Universities, 51

effluent monitoring

See also individual medium definition of, 43

responsibilities for nonradiological, 129

responsibilities for radiological, 69

Effluent Treatment Facility, 10

EMAX Laboratories, Inc., 162, 201

EMCAP (Environmental Monitoring Computer

Automation Program), 199

Emergency Planning and Community

Right-to-Know Act, 20

33/50 Pollution Prevention Program, 20

reportable occurrences, 35

Tier II Inventory Report, 20

Toxic Chemical Release Inventory, 20

endangered and threatened species, 4

Endangered Species Act, 33

energy conservation, 48

Energy Reorganization Act of 1974, 1

Energy Research and Development

Administration, 1

Environmental Advisory Committee, 52

Environmental Bulletin, 53

environmental compliance

and courtesy notifications to regulators, 35

key regulations for, 16

Environmental Compliance Authority Training Program, 52

environmental justice (Executive Order 12898), 53

Environmental Management Council, 52

Environmental Management System, 41

environmental monitoring program, 42

and radioactive contaminants, 43

environmental regulations for, 45

measurement capabilities as factors in, 47

objectives of, 44

public concerns about releases, 47

rationale for, 45

Environmental Physics, Inc., 202

environmental restoration

1999 accomplishments, 56

1999 activities, 19, 39-40

and public involvement activities, 49

description of program, 56

environmental surveillance

See also individual medium

definition of, 43

responsibilities for nonradiological, 137

responsibilities for radiological, 79 
Executive Order

11988,34

11990,34

12856, 21

12873,48

12898,53

12989,53

exposure pathways, and environmental monitoring program, 46

Extended Sludge Processing Facility, 10, 61

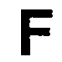

F-Area, 7

groundwater monitoring results, 175

F-Area and $\mathrm{H}$-Area groundwater treatment units, remediation of, 57

F-Canyon operations, 7

Facilities Decommissioning Division, 1999 accomplishments, 64

facility deactivation and decommissioning, 63

facility decommissioning, 37

facility disposition, 12, 63, 65

facility transitions, 64

Federal Facility Agreement, 18, 19, 56

Federal Facility Compliance Act, 17

Federal Facility Compliance Agreement, 17

Federal Insecticide, Fungicide, and Rodenticide Act, 27

fish

dose from consumption of, 123

nonradiological surveillance of, 141

radiological surveillance of, 97

risk from consumption of, 126

sampling locations for, 98

fish monitoring in the Savannah River, and public concern, 47

fish monitoring plan, 124

floodplain management (Executive Order 11988), 34

flow rate measurements, $70,73,113$

food products, radiological surveillance of, 96

freshwater fish, radiological surveillance of, 99

Freshwaters, classification of, 138

fruit, radiological surveillance of, 96

\section{G}

G-Area, 12

gamma radiation, radiological surveillance of, 83

General Engineering Laboratories, 162, 201

General Engineering Mobile Laboratory, 162, 202

general separations areas, 7 environmental restoration projects, 57 groundwater monitoring results, 175

geology of Savannah River Site, 2

grassy vegetation, radiological surveillance of, 105

greens, radiological surveillance of, 96

groundwater

and quality assurance, 201

changes in 1999 monitoring program for, 163

description of monitoring program for, $159-163$

evaluation of data, 162

monitoring well network (map), 156

movement of, 155-159

quality control for, 163

groundwater monitoring results, 163-193

A-Area and M-Area, 165

B-Area, 192

C-Area, 170

chemicals, metals, and pesticides pits, 183

D-Area, 172

E-Area, 175

F-Area, 175

H-Area, 175

K-Area, 181

L-Area, 183

N-Area, 186

P-Area, 188

R-Area, 190

S-Area, 175

Sanitary Landfill, 192

TNX, 172

Z-Area, 175

\section{H}

H-Area, 7

groundwater monitoring results, 175

H-Canyon operations, 7

hazardous waste, 59

Hazardous Waste Storage Facility, 59

Heavy Water Reprocessing Area, 7

high-level waste management, 61 1999 accomplishments of, 62 
hogs

dose from consumption of, 123

radiological surveillance of, 100

hydrology of Savannah River Site, 2

In-Tank Precipitation Facility, 61

Inactive-Facilities Risk Management Program, 64

Industrial Process Technician/Technology

Certificate Program, 53

information exchange, 52

Integrator Operable Units, 56

Interagency Information Exchanges, 52

interlaboratory comparison

for National Pollutant Discharge Elimination System, 200

Quality Assurance Program (Department of Energy), 199

intralaboratory comparison, for National Pollutant

Discharge Elimination System, 201

ISO 14001,42

\section{K}

K-Area, groundwater monitoring results, 181

key regulations for environmental compliance, 16

L-Area

groundwater monitoring results, 183

remediation of oil and chemical basin, 58

L-Lake

and maintenance at current level, 38

characterization of under Comprehensive Environmental Response, Compensation, and Liability Act, 38

construction of, 2

LADTAP XL, 110

LADTAPII, 110

land disposal restrictions, 17

land resources of Savannah River Site, 4

Large-Scale Demonstration and Deployment

Project, 65 liquid discharges

direct, 73

nonradiological monitoring of, 132

monthly discharge monitoring report, 132

radiological monitoring of, 72

comparison of average concentrations to

Derived Concentration Guides, 73

results of, 73

seepage basins and Solid Waste Disposal

Migration, 88

low-level waste, 58

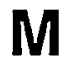

M-Area, 7

MAXIDOSE-SR, 110

MAXIGASP, 110

meat, radiological surveillance of, 96

melons, radiological surveillance of, 96

melt and dilute process, 50

mercury

in fish, 141

perspective on, 145

meteorological data as input for dose calculations, 111

Microseeps, 202

milk, radiological surveillance of, 96

Mill Creek background water quality study, 140

mission of Savannah River Site, 5

mitigation, compensatory, for Pen Branch, 208

Mitigation Action Plan for Pen Branch

Reforestation, 205

mixed waste, 59

monthly discharge monitoring report, 132

Multipurpose Pilot Plant Campus, 12

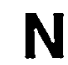

N-Area, 11

groundwater monitoring results, 186

National Emission Standards for Hazardous Air

Pollutants, compliance with for dose

calculation, 121

National Emissions Standards for Hazardous Air Pollutants, 28 
National Environmental Policy Act, 23

documentation activities, 25

public involvement activities, 49

National Environmental Research Park, designation of Savannah River Site as, 4, 5

National Environmental Training Office, 52

National Historic Preservation Act, 33

National Pollutant Discharge Elimination System, 25

1999 exceedances, 136

and quality assurance, 199

Environmental Protection Agency Discharge

Monitoring Report Laboratory Performance

Evaluation program, 200

history of exceedances, 135

notices of violation, 26

program results, 132

National Priority List, 19

Natural Resource Conservation Education grants, 54

Natural Resources Science, Math, and

Engineering Education Program, 54

Nonradioactive Waste Disposal Facility, 56

nonradiological effluent monitoring

See also individual medium

responsibilities for, 129

nonradiological environmental surveillance

See also individual medium

responsibilities for, 137

notices of violation

National Pollutant Discharge Elimination

System, 26

Resource Conservation and Recovery Act, 18

Nuclear Regulatory Commission, 1

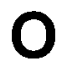

Off-Site Fuels Policy, 8

Oil Pollution Prevention regulation, 26

Old F-Area seepage basin, remediation at, 57

Old Radioactive Waste Burial Ground, 51

orphan waste, 51

outreach

communications, 53

education, 53

environmental justice, 53

public notice requirements, 53 ozone-depleting substances, $28,30,49$

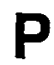

P-Area, groundwater monitoring results, 188

PAR Pond, construction of, 2

pathways

examples of exposure, 46

surveillance of radiation exposure, 79

Patrick Center for Environmental Research, 208

peaches, radiological surveillance of, 96

Pen Branch reforestation

by natural succession, 205

by planting, 206

Mitigation Action Plan for, 205

Permeable Reactive Barrier/GeoSiphon treatment system, 56

permits

and environmental compliance, 37

summary list of construction and operating, 37

phytoremediation, 58

plant and animal life at Savannah River Site, 4

plug-in Records of Decision, 50

pollution prevention, 47,61

33/50 Pollution Prevention Program, 20

Pollution Prevention Act of 1990, 20

POPGASP, 110

population database and distribution as input for dose calculations, 113

Process Needs Assessment Study, 51

products from recycled materials (Executive Order 12873), 48

public

concerns about releases, 47

notification to, about environmental plans and activities, 53

outreach, 53

public drinking water supply monitoring, and public concern, 47

public involvement, 49

accelerated cleanup plan, 50

Citizens Advisory Board, 50

environmental restoration, 49,50

material and facility stabilization, 51

National Environmental Policy Act , 49

purple coneflower, 33 
Q

quality assurance

1999 program changes, 196

definition of terms, 198

external program, 199

for Environmental Monitoring Section

laboratories, 196

for groundwater analyses, 201

for National Pollutant Discharge Elimination

System analyses, 199

for soil and sediment analyses, 202

for stream and river water analyses, 201

for subcontracted laboratories, 199

internal program, 196

relevant guidance documents for, 197

Quality Assurance Program (Department of Energy), 199

quality control practices for groundwater, 163

\section{$\mathbf{R}$}

R-Area, groundwater monitoring results, 190

Radiation Assessment Program, 127

Radioecology (Savannah River Ecology

Laboratory), 14

radiological effluent monitoring

See also individual medium

responsibilities for, 69

radiological environmental surveillance

See also individual medium

responsibilities for, 79

rainwater, radiological surveillance of, 82

reactor areas, 7

environmental restoration projects, 57

reactor materials area, 7

reactors, history of, 7

real-time instrumentation, 70

Receiving Basin for Offsite Fuel, 9, 61

Recra LabNet Philadelphia, 162, 202

recycled products, affirmative procurement of, 48

recycling, of solid waste, 48

red-cockaded woodpecker, 33

reportable occurrences for environmental compliance

Clean Water Act, 34
Comprehensive Emergency Response, Compensation, and Liability Act, 35

Emergency Planning and Community Right-to-Know Act, 35

Site Item Reportability and Issues Management program, 35

reporting

courtesy notifications to regulators, 35

of environmental releases, 34

research and development at Savannah River Site, 12

Research Intern Program, 53

Resource Conservation and Recovery Act, 16 3004(u) Program, 19

Federal Facility Compliance Act, 17

land disposal restrictions, 17

notices of violation, 18

underground storage tanks, 18

Waste Minimization Program, 19

waste tank closure, 18

risk from consumption of fish, 124

compared to dose standards, 126

river flow rate data as input for dose calculations, 113

river water system, decision not to shut down, 38

Rivers and Harbors Act, 27

Ruth Patrick Science Education Center, 53

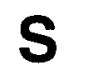

S-Area, groundwater monitoring results, 175

Safe Drinking Water Act, 24

Saltstone Facility, 10, 60

saltwater fish, radiological surveillance of, 100

sampling locations

nonradiological

fish, 98

sediment, 143

surface water, 139

radiological

air, 81

fish, 98

sediment, 104, 107

seepage basins, streams, Savannah River, 86

soil, 102

vegetation, 106

Sanitary Landfill, groundwater monitoring results, 192

sanitary waste, 58 
Savannah River

See also surface water, nonradiological surveillance of

radiological surveillance of, 93

sampling locations for, 86

tritium transport, 94

Savannah River Archaeological Research

Program, 14

and public outreach, 54

Savannah River Ecology Laboratory, 13

and public outreach, 54

Savannah River Natural Resource Management and Research Institute, 14

and public outreach, 54

Savannah River Regional Science Bowl, 53

Savannah River Site

areas, 6

as National Environmental Research Park, 4, 5

climate of, 2

criteria for locale for, 1

geology of, 2

history, 1

hydrology of, 2

land resources of, 4

location of, 2,3

map of areas, 6

mission of, 5

plant and animal life at, 4

research and development at, 12

tours of, 52

water resources of, 2

wildlife at, 4

Savannah River Swamp surveys, 209

Savannah River Technology Center, 12

Savannah State University, and environmental justice, 53

School-to-Work Program, 53

sediment

nonradiological surveillance of, 141

sampling locations for, 143

radiological surveillance of, 103

sampling locations for, 104, 107

seepage basins

history of, in F-Area and H-Area, 10

migration results, 88

radiological surveillance of, 85

sampling locations for, 86

Sequoyah Reactor, 10

Shealy Environmental Services, 200 shellfish, radiological surveillance of, 100

shortnose sturgeon, 33

Site Item Reportability and Issues Management program, 35

reportable occurrences, 35

Site Treatment Plan, 17

Site Utilities Division Wastewater Laboratory, 200

soil, radiological surveillance of, 101

sampling locations for, 102

solid waste

management, 58

recycling, 48

Solid Waste Disposal Facility, 10

migration results, 88

Solid Waste Management Facility, 10, 59

source terms

air pathway, 118

liquid pathway, 114

South Carolina Institute of Archaeology and Anthropology, 14

Speakers Bureau, 53

spent fuel activities at Savannah River Site, 7

steam boilers, capacities of, 131

stratospheric ozone protection, 30

streams

See also surface water, nonradiological surveillance of

radiological surveillance of, 85

sampling locations for, 86

tritium transport, 94

subcontracted laboratories, 200

Supercompactor Facility, 59

Superfund Amendments and Reauthorization Act, 19

surface water

See also seepage basins, streams, Savannah

River (radiological surveillance of)

nonradiological surveillance of, 138

sampling locations for, 139

tank farms, 10

evaporator facilities, 61,62

Tech-22 (Defense Nuclear Facilities Safety Board report), 50 
Tennessee Valley Authority's Watts Bar and Sequoyah reactors, 10

terrestrial food products, radiological surveillance of, 96

Thermo NUtech, 162, 202

thermoluminescent dosimeter program and public concern, 47

and radiological surveillance, 83

Tier II Inventory Report, 20

Title V Operating Program, 30

TNX, 11

groundwater monitoring results, 172

tours of Savannah River Site, 52

Toxic Chemical Release Inventory, 20, 48

toxic chemical releases, 21,22

Toxic Substances Control Act, 32

training

employee environmental, 51

for environmental compliance, 37

for quality assurance, 196

Trans-River Flow Project, 105

transition of site facilities, 37

transuranic waste, 59

Traveling Science Demonstration Program, 53

tritium facilities, 10

tritium transport in streams and Savannah River, 94

turkeys, radiological surveillance of, 101

\section{U}

U.S. Department of Agriculture Forest Service, 14

underground storage tanks, and environmental compliance, 18

Upper Three Runs environmental restoration project, 56

\section{V}

vegetation, radiological surveillance of, 105

sampling locations for, 106

Vendor Treatment Facility, 7

Visitors Program, 53

vitrification, 61

\section{W}

Waste Isolation Pilot Plant, 50, 59

waste management

areas, 10

groundwater monitoring results, 175

high-level, 61

solid, 58

waste minimization, 61

Waste Minimization Program, 19, 47

waste tanks

closure of and environmental compliance, 18

description of, 10

water quality and quality assurance, 201

water resources of Savannah River Site, 2

water supply studies for quality assurance, 202

Watts Bar Reactor, 10

Westinghouse Savannah River Company

and public outreach, 53

as Savannah River Site contractor, 1

wetlands protection, Executive Order 11990, 34

wildlife at Savannah River Site, 4

wind rose for Savannah River Site, 112

wood stork, 33

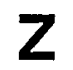

Z-Area, groundwater monitoring results, 175 